\title{
INTEGRALIDADE DA ATENÇÃO À SAÚDE: SUAS EXPRESSÕES NA ORGANIZAÇÃO TECNOLÓGICA DO TRABALHO EM SERVIÇOS LOCAIS DE SAÚDE
}

\author{
RUTH TEREZINHA KEHRIG
}

Tese de Doutorado apresentada ao Departamento de

Prática de Saúde da Faculdade Saúde Pública da Universidade de São Paulo para obtenção do Grau de Doutor em Saúde Pública.

Área de concentração: Serviços de Saúde

Orientador: PROFESSOR DOUTOR JOSÉ CARLOS SEIXAS

São Paulo 
Autorizo, exclusivamente para fins acadêmicos e científicos, a reprodução total ou parcial desta tese, por processos fotocopiadores.

Assinatura do autor:

Data: $10 / 12 / 2001$

e-mail: ruthkehrig@uol.com.br 
À Neca, Toco, Ra e Vi.

In memoriam:

- de meus pais, Ruy Gallotti Kehrig e Albertina Herzmann Kehrig, base primeira da minha vida. 


\section{AGRADECIMENTOS}

Os meus sinceros agradecimentos a cada um e a todos que participaram desta caminhada.

A meus filhos, Antonieta, Victor, Ramon e Vicente, por me cederem espaço em nossas vidas, com sua presença amorosa e desafiadora.

Aos colegas entrevistados, trabalhadores da saúde, legítimos co-autores dos resultados produzidos no estudo empírico da tese.

Ao Prof. Dr. José Carlos Seixas, meu orientador, pela segurança institucinal que sempre me proporcionou e pelo modo atencioso e democrático com o qual conduziu sua orientação.

Ao Prof. Dr. Eurivaldo Sampaio, pelas oportunidades de discussão e importantes sugestões na Banca de Qualificação e fase final de escrita da tese.

À querida mestra e amiga Prof ${ }^{a}$. Dra. Maria Ines Battistella Nemes, por seus ensinamentos, solidariedade e referencial ético-científico, me fazendo sentir bem acompanhada neste processo solitário.

Aos professores da Faculdade de Saúde Pública, em especial às Professoras Évelin Naked de Castro Sá, Carmem Unglert e Maria da Penha, pela acolhida pessoal e institucional, e por estimular sonhos de estudos, pesquisa e prática sobre serviços de saúde.

Ao Departamento de Medicina Preventiva da Faculdade de Medicina da Universidade de São Paulo, pela enriquecedora oportunidade de abrir novos conhecimentos através das disciplinas oferecidas em seu programa de pós-graduação. 
Ao CNPq (Conselho Nacional de Pesquisa), pela bolsa de estudo concedida durante o curso.

À Secretaria de Estado da Saúde de Santa Catarina, por autorizar meu afastamento para cursar o doutorado.

Aos companheiros de caminhada, colegas trabalhadores dos serviços de saúde pública em Santa Catarina.

Aos amigos, âncoras, portos e naves, pelo alento da sua presença, valor soberano em minha vida. 


\section{RESUMO}

Kehrig RT. Integralidade da atenção à saúde: suas expressões na organização tecnológica do trabalho em serviços locais de saúde. São Paulo, 2001. [Tese de Doutorado - Faculdade de Saúde Pública da USP.]

Objetivo. A integralidade das ações, diretriz finalística do Sistema Único de Saúde brasileiro, é mnuito referenciada no plano discursivo, mas pouco estudada. Este trabalho buscou apreender teórica e empiricamente princípios, mecanismos e desenhos organizacionais que possam contribuir para operacionalização dessa diretriz, à luz de proposições de modelos de atenção inseridos em práticas municipais. Essa apreensão se faz nas dimensões política ético-normativa, tecnológica, e sobretudo no plano organizacional-gerencial implicado. A tese defende o espaço organizacional enquanto dimensão privilegiada da condução do processo de transformar as diretrizes políticas do modelo de atenção em conjuntos de processos de trabalho com ações de saúde informadas pela integralidade da atenção.

Recuperação Bibliogrática. Foi realizada uma revisão em publicações especializadas sobre o uso da expressão "integralidade em saúde" ou equivalente (integração assistencial, medicina integral, ações integradas em saúde, atenção integral à saúde, integração sanitária, e similares). Discriminou-se como suas principais modalidades conceituais: dimensão coletiva do objeto de trabalho em saúde; integralidade dos cuidados ao indivíduo; integração sanitária, integralidade da promoção à saúde; e, integralidade da atenção, enquanto prestação integrada das ações de um sistema local de serviços de saúde para resolver problemas de saúde de sua área de abrangência. $O$ movimento historicamente recente da saúde pública brasileira permite afirmar que a integralidade em saúde é um princípio ético que se define no campo filosófico do direito à saúde, o que informa sua tradução em uma diretriz política, e que tem uma proposição organizacional e tecnológica.

Metodologia. Trata-se de uma pesquisa qualitativa desenvolvida em uma secretaria municipal de saúde selecionada entre os maiores municípios do estado de Santa 
Catarina, que mostraram no estudo exploratório possuir um plano de saúde tendo como prioridade a mudança do modelo de atenção de acordo com o princípio e diretriz da integralidade em saúde. Para a apreensão empírica fez-se um estudo de caso organizacional, desenvolvido através de 17 entrevistas abertas realizadas em profundidade. Os entrevistados foram selecionados em razão de sua inserção no movimento de mudança do modelo de atenção no SUS do respectivo município. Para análise do material empírico procedeu-se ao ordenamento dos dados, no seu processamento foram sendo delineadas categorias evidenciadas nos relatos e os resultados se apresentam através da construção de um discurso do sujeito coletivo, com adapações metodológicas próprias.

Resultados. A análise do material empírico, iluminada pelo quadro teórico construído, permite organizar a partir das dimensões política, tecnológica e organizacional teoricamente constatadas, a formulação de um desenho para contribuir em processos de transformação organizacional, referidos à mudança do modelo de atenção em saúde. Trata-se de sete vias organizacionais que, em seu conjunto articulado apresentam potencialidade de operar a integralidade em saúde, quais sejam: um trabalho a partir da rede básica, o processo de planejamento no sistema municipal de saúde, funcionamento da estrutura organizacional, comunicação da estratégia, gerenciamento loco-regional, participação democrático-popular na gestão e a via pedagógica.

Considerações Finais. Por referência às evidências relatadas são enunciados princípios e mecanismos potencialmente construtores de concepções e condições organizacionais na perspectiva da integralidade em saúde. Discute-se, finalmente, a necessidadde de considerar tais concepções enquanto arranjos históricos específicos apontando para a determinação social e histórica da integralidade como conceito e como prática. As implicações para futuras pesquisas são aventadas, recomendando-se estudos adicionais.

Descritores: Modelo de Atenção à Saúde. Integralidade em Saúde. Transformação Organizacional em Serviços de Saúde. Gestão Local em Saúde. Práticas de Saúde. 


\begin{abstract}
Kehrig RT. "Integrality" (comprehensiveness) of health attention: its expressions in the technological organization of the work in health service sites. São Paulo, 2001. [Doutoral Thesis - Faculdade de Saúde Pública da USP.]
\end{abstract}

Objective. The idea of "integrality" has been the most important ethical and normative principle of the Brazilian Health System (Sistema Único de Saúde). Nevertheless it has not been well studied. This work tried to identify the organizational conditions required carrying out activities in such a way as to aim municipal health systems to reach the principle. This thesis advocates the management features as a special dimension in reaching effective "integrality".

Bibliographic review. It was done a review of specialized publications on the use of the expression "integrality of health" or any expression with a similar meaning. The main concepts identified were briefly described. The review also described the ideas and practices on comprehensiveness in the recent history of Brazilian health system.

Methodology. This is a qualitative research developed in one of the major municipal health secretariats located in the state of Santa Catarina, Brazil. Data was collected through open interviews with health professionals. The professionals were selected in terms of their participation in the movement for changing the working model of health services. They were interviewed using open questions. The analysis of the empirical data was carried out through the construction of a collective discourse, using the appropriate methodological adjustments.

Results. The analysis and discussion of the empirical data enabled the organization of seven different ways, which together present the potential for operating "integrality": health attention centered on a primary care net; political-organization, local-regional management, democracy, learning organizations and pedagogy. 
Final considerations. Using the discussion above, it was possible to define the principles and tools that can help to carry out the "integrality" in a right way. Implications of that in future research are discussed, and additional studies are recommended.

Keywords: Health practices. Comprehensive health care. Health service organization. Local management of health systems. 


\section{ÍNDICE}

1. INTRODUÇÃ

1.1. Campo de Estudos e Questão de Pesquisa ................................................02

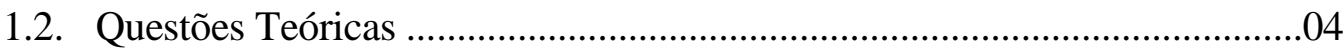

1.3. Da Concepção Integral de Saúde às Respostas Político-Sociais ...............07

1.4. No Espaço da Transformação Organizacional ..........................................18

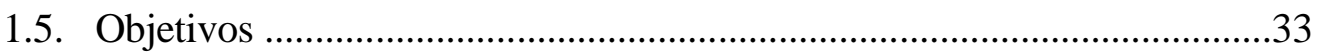

\section{RECUPERAÇÃO BIBLIOGRÁFICA}

DA INTEGRALIDADE EM SAÚDE......................................................................35

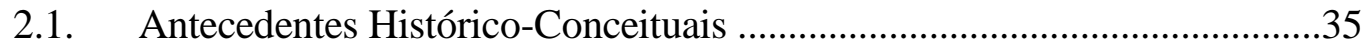

2.1.1. Antecedentes Externos da Integração em Saúde .................................36

2.1.2. No Brasil do Sanitarismo à Integração Assistencial...............................49

2.1.3. Medicina Integral e Comunitária como Alternativa ...............................57

2.1.4. Integração das Ações via Programação Local de Saúde .........................60

2.1.5. Integração nos Sistemas Locais de Saúde ...........................................67

2.1.6. Integração Interinstitucional ............................................................ 72

2.2. A Integralidade da Reforma Sanitária ao SUS..........................................84

2.2.1. No Movimento da Reforma Sanitária ....................................................85

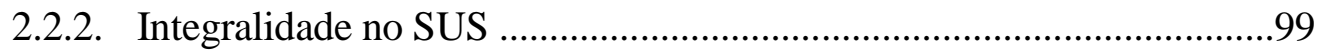

2.3. Modelos de Integralidade da Atenção em Saúde ....................................110

2.3.1. Ação Programática em Saúde ................................................................110

2.3.2. Modelo Tecno-Assistencial em Defesa da Vida ....................................119

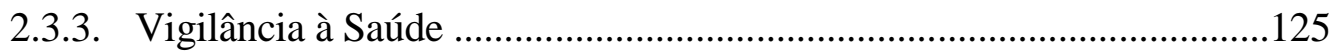

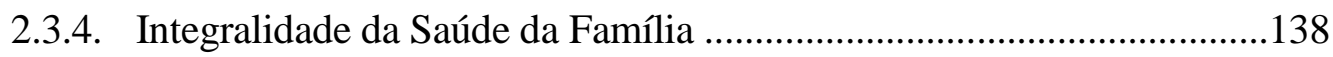

2.3.5. Cidades e Municípios Saudáveis..........................................................144 


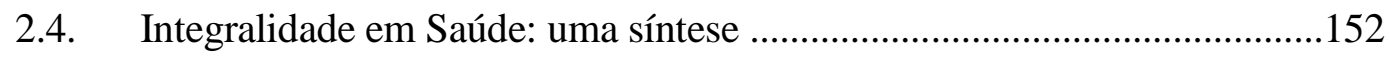

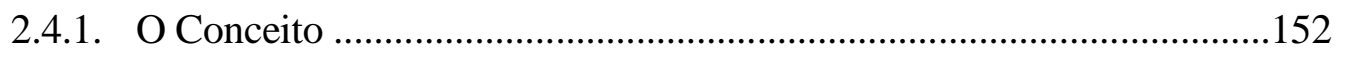

2.4.2. Um Modelo de Integralidade da Atenção em Saúde.............................157

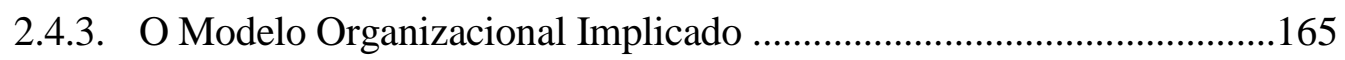

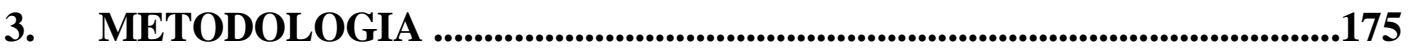

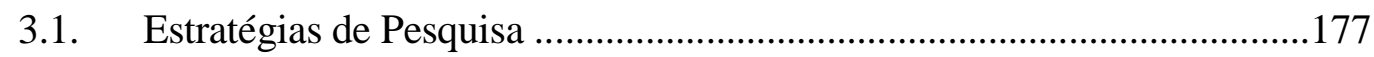

3.1.1. Reconstrução Conceitual do Objeto de Estudo ..................................179

3.1.2. Estudo Exploratório do Empírico.........................................................180

3.1.3. Um Estudo de Caso Organizacional ......................................................185

3.2. Técnicas de Apreensão Empírica ................................................................185

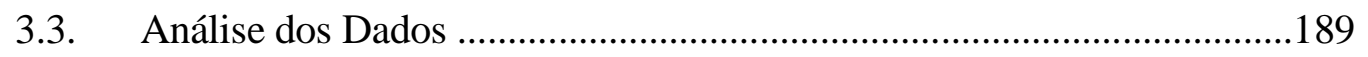

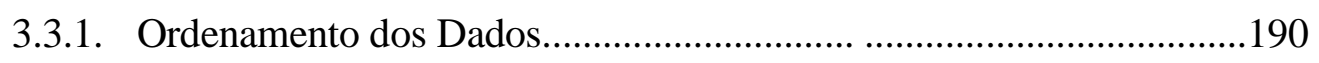

3.3.2. Processamento e Análise dos Dados ................................................191

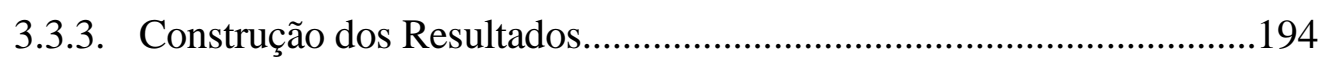

4. ORGANIZAÇÃO DO TRABALHO DE MUDANÇA

DO MODELO DE ATENÇÃO ........................................................197

4.1. Aproximações à Dimensão Política...............................................................207

4.1.1. Período de Transição Política ....................................................................207

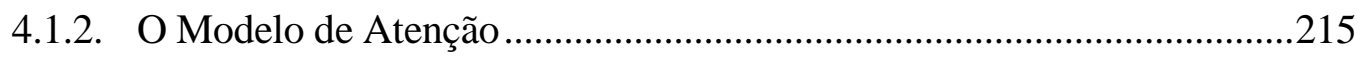

4.1.3. Mudanças Políticas ...................................................................................218

4.2. Aproximações à Dimensão Tecnológica .....................................................227

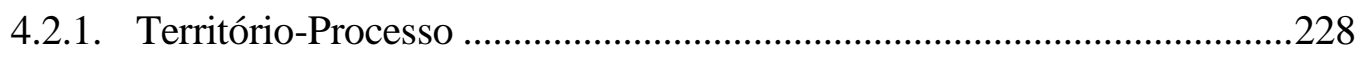

4.2.2. Da Vigilância Epidemiológica à Vigilância à Saúde...............................236

4.2.3. Instrumentos da Atenção Básica Direta ....................................................242 


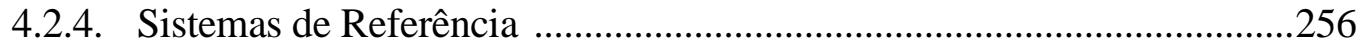

4.2.5. Instrumentos Coletivos de Trabalho ......................................................266

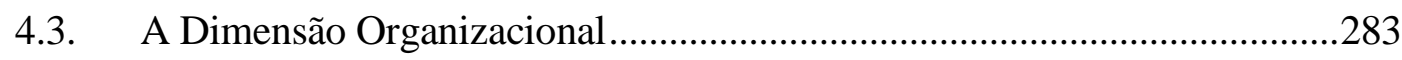

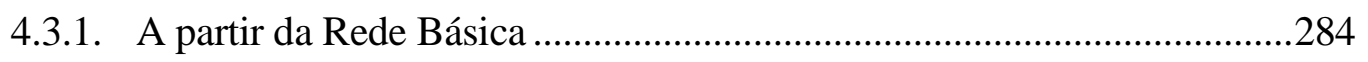

4.3.2. O Planejamento Municipal de Saúde ...................................................287

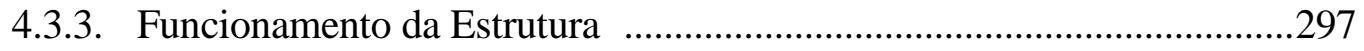

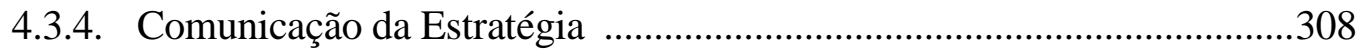

4.3.5. A via do Gerenciamento Loco-Regional .................................................323

4.3.6. Participação Popular na Gestão Local .......................................................348

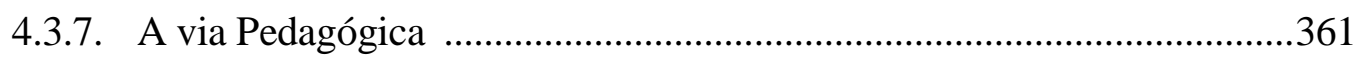

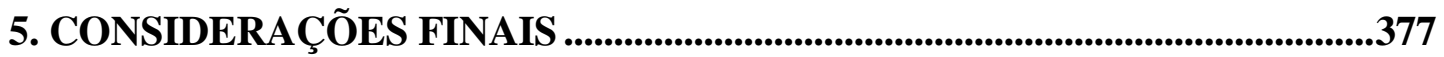

6. REFERÊNCIAS BIBLIOGRÁFICAS .......................................................................381 


\section{LISTA DE ABREVIATURAS, SIGLAS E SÍMBOLOS}

AA - Alcoólicos Anônimos

ABRASCO - Associação Brasileira de Saúde Coletiva

ACD - Acompanhamento do Crescimento e Desenvolvimento

AIH - Autorização de Internação Hospitalar

AIS - Ações Integradas de Saúde

AVC - Acidente Vascular Cerebral

Bipartite - Comissão Intergestores Bipartite (CIB)

CAIC - Centro de Atenção Integral à Criança

CDC - Center for Disease Control

CMS - Conselho Municipal de Saúde

CNS - Conferência Nacional de Saúde

col. - colaboradores

CONASS - Conselho Nacional de Secretários de Saúde

CONASEMS - Conselho Nacional de Secretários Municipais de Saúde

COSEMS - Conselho (Estadual) de Secretários Municipais de Saúde

CPD - Centro de Processamento de Dados

CPI - Comissão Permanente de Inquérito

CSE - Centro de Saúde Escola

CUT - Central Única de Trabalhadores

DIU - Dispositivo Intra-Uterino

DST - Doenças Sexualmente Transmissíveis

et al. - e outros

EIC - Educação, Informação e Comunicação 
FIOCRUZ - Fundação Oswaldo Cruz

FMS - Fundo Municipal de Saúde

GERUS - Gerência de Unidades de Saúde

(Projeto GERUS - de Desenvolvimento Gerencial de Unidades de Saúde)

G.O. - Gineco-Obstetrícia

HU - Hospital Universitário

IBGE - Instituto Brasileiro de Geografia e Estatística

INAMPS - Instituto Nacional de Assistência Médica e Previdência Social

IRA - Infecções Respiratórias Agudas

LAPA - Laboratório de Planejamento e Administração

MARE - Ministério da Administração e Reforma do Aparelho de Estado

NOB - Norma Operacional Básica

OMS - Organização Mundial da Saúde

ONG - Organização Não Governamental

op cit - acima citado

OPS - Organização Panamericana da Saúde

PAB - Piso de Atenção Násica

PACS - Programa de Agentes Comunitários de Saúde

PAIS - Programa das Ações Integradas de Saúde

PAIM - Programa de Atenção Integral à Saúde da Mulher

PAS - Plano de Assistência à Saúde

PES - Planejamento Estratégico de Saúde

PFL - Partido da Frente Liberal

PMS - Plano Municipal de Saúde

POI - Programação Orçamentária Integrada 
PPI - Programação Pactuada Integrada

PSF - Programa de Saúde da Família

PT - Partido dos Trabalhadores

RH - Recursos Humanos

RSD - Revista Saúde em Debate

SES - Secretaria Estadual de Saúde

SIAB - Sistema de Informação da Atenção Básica

SIG - Sistema de Informação Gerencial

SILOS - Sistemas Locais de Saúde

SINASC - Sistema de Informação de Nascidos Vivos

SISVAN - Sistema de Vigilância Alimentar e Nutricional

SMS - Secretaria Municipal de Saúde

SUDS - Sistemas Unificados e Descentralizados de Saúde

SUS - Sistema Único de Saúde

Tripartite - Comissão Intergestores Tripartite (CIT)

UBS - Unidade Básica de Saúde

UFSC - Universidade Federal de Santa Catarina

UNICAMP - Universidade de Campinas

UNICEF - Fundo das Nações Unidas para a Infância

USP - Universidade de São Paulo 


\section{INTRODUÇÃO}

A integralidade em saúde é temática recorrente e atual por sua importância socialmente reconhecida no direito da espécie humana de viver com saúde. Consta como o princípio mais finalístico do Sistema Único de Saúde - SUS, constitucionalmente instituído pela sociedade brasileira em 1988.

Tomando a integralidade por objeto de estudo, no presente trabalho de tese procurou-se captar conceitualmente o seu significado e como se expressa nas proposições de modelos de atenção à saúde e empiricamente o movimento da sua instituição em um sistema municipal de saúde. Neste sentido, procedeu-se ao estudo e análise da organização dos serviços locais de saúde, no âmbito das suas condições para operar o princípio da integralidade em saúde.

A definição do tema de estudo dá-se a partir da inserção profissional da autora, no sistema de saúde do estado de Santa Catarina, fundamentando-se em práticas/reflexão/ação sobre seu objeto de trabalho: o apoio técnico a secretarias municipais de saúde na construção de um novo modelo de atenção à saúde, mais coerente com os princípios e diretrizes do SUS.

O presente documento está organizado em cinco capítulos. Neste primeiro faz-se a apresentação do trabalho, campo de estudos, questão de pesquisa, pressupostos e fundamentação teórica, bem como os objetivos do estudo. No segundo se procede à recuperação bibliográfica do objeto de estudo. O terceiro explicita a metodologia. No quarto são apresentados os resultados empíricos, seguidos das considerações finais no capítulo quinto. 


\subsection{Campo de Estudos e Questão de Pesquisa}

Dentro do campo de conhecimento da Saúde Coletiva brasileira, o estudo situa-se na área de planejamento e gestão em saúde. No campo da administração reporta-se a uma especialização - administração da produção, comumente identificada com a engenharia da produção, ora na perspectiva da sua aplicação setorial em saúde. Pois aqui se trata de dimensionar potencialidades e limites das condições organizacionais dos serviços de saúde para cumprir sua finalidade de "fazer saúde", no caso, com integralidade.

O tema da organização do trabalho em saúde faz pressupor, intrinsecamente, três níveis de abordagem: o sócio-político, o organizacional, e o âmbito tecnológico de realização das ações em relação com a população portadora das necessidades de saúde. Neste estudo se privilegia a dimensão de operacionalização da política, locus do modelo de atenção à saúde. Assim sendo, a articulação com os respectivos níveis supramencionados, dar-se-á privilegiadamente na dimensão da análise do próprio nível recortado. Este nível, a dimensão organizacional - operacional dos serviços, por sua vez, compreende tanto o seu componente das práticas ou ações de saúde prestadas diretamente à população, como a condução da sua organização e funcionamento, especialmente, o campo gerencial, principal foco do estudo.

No contexto atual da sociedade brasileira abordar o modelo de atenção à saúde por assunto, impõe a explicitação de um pressuposto geral do estudo: a implementação dos preceitos constitucionais do SUS como política nacional de saúde e como sistema municipal operante. Portanto, este trabalho está pautado no reconhecimento e defesa dos princípios do SUS, que contém a premissa do direito universal e igualitário à saúde, implicando a consolidação de um sistema democrático-popular e solidário, organizacionalmente estruturado numa lógica de autonomia e descentralização. É neste cenário que se faz a seleção da condução da operacionalização da integralidade em saúde como objeto de estudo.

A integralidade das ações de saúde tem sido genericamente enlevada como uma diretriz consensual no discurso que projeta a saúde e seu sistema organizativo de forma a 
atender as necessidades da população. Ninguém se posiciona explicitamente contra a que todos necessitam e têm direito a ter saúde. Mas cabe perguntar - quanto de saúde, e, qualitativamente, a quê saúde se refere. Integralmente? E para que tais expressões não se reduzam a simples chavões, implica apreender qual o seu significado, objetivamente, na prática dos serviços. Faz-se necessário explicitar em quais bases e condições pode-se encontrar a integralidade em saúde materializada em atos.

Haja vista que na produção especializada sobre serviços de saúde no Brasil, pode-se considerar que com relação aos esforços de institucionalização dos princípios e diretrizes do SUS, tem-se uma ampla reflexão/produção teórico/prática sobre universalidade, equidade, descentralização e controle social, não se pode dizer o mesmo quanto à integralidade.

Para tanto, dado seu entendimento como uma idéia reguladora, genérica e multifacetada, que se coloca em um horizonte ético-político, mas também com conteúdo tecnonormativo, e que vem sendo construída histórica e socialmente no espaço organizacional, faz-se necessário entender mais objetivamente as expressões da integralidade no SUS. Após recuperar como estas questões aparecem na literatura especializada, procura-se captar quais são suas possibilidades no real - como se manifesta e como se operacionaliza.

Mesmo com um recorte de pesquisa definido no âmbito dos serviços locais de saúde, não se pretende entrar na dinâmica interna específica nem de uma unidade básica de saúde, nem tampouco de um processo de trabalho qualquer, mas, na organização do conjunto dos serviços locais de saúde em um território dado, geralmente conformando um objeto de trabalho em princípio privilegiado de uma secretaria municipal de saúde. Ao referir-se à condução da organização dos serviços locais de saúde, no estudo implica ver a articulação/desarticulação dos processos de trabalho realizados, no sentido do acoplamento da organização dos vários tipos de processos de trabalho que conformam o modelo de atenção. 
O problema que a pesquisa se propõe a contribuir na solução é a aparente ausência de condições operacionais dos sistemas de serviços locais de saúde instituírem práticas de integralidade em seu modelo de atenção. A oportunidade do estudo se justifica por esta lacuna. E como utilidade da tese pretende-se oferecer esse tipo de reflexão para aqueles que querem fazer isso, e ajudar as pessoas a encontrar através dos erros os acertos.

A pergunta de partida em que se pauta todo o estudo é: - Como é possível operacionalizar o princípio da integralidade da atenção em saúde? A principal questão de pesquisa formulada está situada nas bases organizacionais de tal possibilidade. Ou seja, como se configura o potencial de organização do trabalho em saúde na perspectiva de uma prática de integralidade da atenção, partindo-se dos serviços básicos de saúde.

Como resultado da pesquisa busca-se contribuir para a implementação de desenhos organizacionais de sistemas de serviços locais de saúde, potencialmente facilitadores da prática de integralidade da atenção à saúde.

\subsection{Questões Teóricas}

Com base na literatura revisada na fase exploratória do projeto de pesquisa, partiu-se de três hipóteses iniciais de trabalho: que as diretrizes políticas são determinantes no processo de fazer a integralidade; que sua implementação é mediada por estratégias organizacionais sendo que a possibilidade pretendida se abre (ou não) a partir da rede básica; e, que a via epidemiológica, enquanto saber orientador das práticas, sustenta tecnologicamente a operacionalização possível da integralidade da atenção à saúde.

Decorrentes do estudo orientado pelos recortes acima, teoricamente se definem como dimensões da instituição de um modelo de atenção orientado pela integralidade em saúde o movimento político da sua configuração ético-normativa, a expressão tecnológica da sua finalidade em ações e instrumentos compatíveis, e entre essas a mediação organizacional. Empiricamente se abrem vários desdobramentos da dimensão organizacional, que em seu conjunto, articuladamente com as outras dimensões 
apresentadas, vieram constituir um arcabouço tecnológico-organizacional que se revela necessário para operação da integralidade em saúde, compreendendo as seguintes vias: a partir da rede de serviços locais de saúde, do planejamento em saúde, do funcionamento da estrutura organizacional de uma secretaria municipal de saúde, da comunicação da estratégia, do gerenciamento loco-regional; a via democrático-popular de sustentação do projeto da integralidade; e, a via de uma prática pedagógica problematizadora, a orientar tanto a relação profissional/usuário como a fundamentação dos processos de capacitação dos trabalhadores de saúde na perspectiva da integralidade e a própria prática organizacional.

A idéia de que os componentes tecnológicos dos processos de trabalho em saúde, assim como a prática gerencial da sua condução em sistemas de serviços locais de saúde, contêm potencialidades e limites da sua mudança para uma prática de integralidade da atenção à saúde informam a hipótese de pesquisa. Assim, pressupõe-se a existência de um eixo político - organizacional - tecnológico, cujas características são condições para a construção de uma organização capaz (ou não) de operacionalizar o princípio da integralidade no modelo de atenção do SUS.

Partindo dos fundamentos teóricos da concepção integral de saúde se constrói um percurso que vai da concepção ética da integralidade às implicações geradas no movimento de suas expressões no espaço organizacional, onde existem aportes a revisar por sua potencialidade em poder estar ajudando a iluminar o espaço existente entre o discurso político de modelo de atenção à saúde e sua operação tecnológica, geralmente a cargo dos profissionais. É na condução da organização dos serviços, um enfoque propriamente mais gerencial de organização das práticas, no elo do planejamento com a ação que está centrado o foco do estudo.

Neste momento é importante esclarecer que, de acordo com o referencial teórico adotado, este estudo se dedica a uma forma particular de existência da tecnologia - a constituída pelo saber (conforme Mendes-Gonçalves 1994) e por seus desdobramentos na produção de serviços locais de saúde, destacando-se aqui o papel privilegiado do 
saber operante das práticas de saúde na dimensão gerencial que opera com a dinâmica própria deste espaço.

Mendes-Gonçalves (1994) redefine tecnologia no desenvolvimento do conceito de organização tecnológica do trabalho. Partindo das conceituações da epidemiologia e da clínica desenvolve a idéia de saberes tecnológicos operantes dos processos de trabalho. Esta concepção é baseada em uma projeção ético-normativa de integração e, simultaneamente, de "superação das características dos modelos tecnológicos polares da clínica e da epidemiologia" (Nemes 1995, p.7).

Ao apresentar seu estudo empírico "Tecnologia do Processo de Trabalho na Rede Estadual de Centros de Saúde de São Paulo", Mendes-Gonçalves (1994, p.125) esclarece sua concepção de tecnologia nos processos de trabalho, como referida aos saberes e equipamentos que o constituem. E isso numa perspectiva totalizante, como arquitetura técnica desses processos, com conexões socialmente determinadas, que ligam seus agentes à dinâmica de reprodução social. Assim entende tecnologia enquanto expressão conjunta de determinações internas e externas, mas que se constitui dentro dos processos. Enfoca o saber em seus desdobramentos materiais, com dimensão técnica e social ao mesmo tempo, privilegiando os aspectos não-materiais da tecnologia. Portanto trata-se da tecnologia própria do processo de trabalho. É uma concepção de tecnologia exposta (p.126), que vai permitir novos alcances à usualmente empregada, tomando por referência a lógica total do processo. Vai tentar captar "por dentro" da tecnologia as suas formas de relacionamento com os processos sociais em que tem significação e procurar compreender a tecnologia como representando o estabelecimento de relações adequadas entre agentes e objetos do trabalho, situando o referencial para essa adequação nas relações sociais de produção.

A questão das necessidades sociais em saúde (Heller 1986), na ótica dos estudos epistemológicos informa a pesquisa de Mendes-Gonçalves (op cit) sobre a construção do pensamento e da teoria da ciência em saúde, o que, seguindo a trilha de Cecília Donnangelo (1976) tem sido uma destacada contribuição inclusive na constituição do campo da Saúde Coletiva. 
Neste estudo procurou-se buscar uma extensão da noção de organização tecnológica do trabalho em saúde (Mendes-Gonçalves 1994) para aplicação deste referencial, de forma articulada com contribuições da teoria organizacional, também no âmbito da organização tecnológica da condução dos processos de conformação de uma prática de saúde comprometida com a diretriz da integralidade. Nessa perspectiva trata-se aqui da organização tecnológica dos serviços locais de saúde.

\subsection{Da Concepção Integral de Saúde às Respostas Político-Sociais}

A necessidade de se considerar cuidadosamente a concepção de saúde em sua articulação com a correspondente organização das práticas de saúde vem sendo cada vez mais reafirmada, ao mesmo tempo em que revela uma dada direcionalidade. Paganini e Chorny (1990, p.424), discutindo os objetivos de um sistema nacional de saúde na última década do século 20, afirmam: 'Se hace hincapié en el concepto integral de la salud'. Essa concepção continua se reafirmando neste início do século 21.

Frente ao aprofundamento das desigualdades sociais e contrastes acentuados de um perfil epidemiológico que evidencia as diferenças regionais, sobretudo em âmbito nacional e latino-americano, refletindo o risco desigual de adoecer e morrer, a construção de resposta social mais efetiva pelos serviços de saúde impõe um enfrentamento mais comprometido dessa questão. Os avanços e possibilidades de contextualidade das abordagens teórico-metodológicas têm que ser construídos quando se quer responder a uma realidade que superpõe atraso e modernidade no seu perfil, tanto social como de saúde, como ocorre na situação de transição epidemiológica, que tem sido identificada em países sul-americanos e especialmente no Brasil (Kehrig 1993).

Com o extraordinário desenvolvimento tecnológico, a atenção médica tem reforçado seu papel curativo. Nos seus marcos conceituais predominantes a saúde pública tem sido restrita basicamente às formas de proporcionar acesso da população a essa atenção e a orientar o controle indispensável de algumas doenças de maior significação epidemiológica. Mas essas práticas de saúde não conseguem responder a necessidades 
de uma população cujo perfil se enquadra em condições de transição epidemiológica conforme ocorre no Brasil (Kehrig 1994). Onde, enquanto ainda não se conseguiu superar os problemas típicos do sub-desenvolvimento, associados a causas infecciosas e parasitológicas de relação ambiental, se convive com os problemas crônicos mais próprios do aumento da expectativa de vida, típicos dos países desenvolvidos, bem como com as chamadas doenças da modernidade relacionadas à violência urbana e novos problemas de causalidade mais elaborada, como as crescentes complicações relacionadas com as infecções hospitalares e aids, por exemplo, sem entrar no efetivo ressurgimento de doenças supostamente controladas anteriormente. Não é com uma concepção predominantemente biológica de saúde/doença e sua correlata organização das práticas de saúde que se pode enfrentar uma problemática de condições de saúde da espécie e gênero existentes na sociedade brasileira atual.

As abordagens conceituais tradicionais de saúde, predominantemente biológicas, são limitadas, segundo Castellanos (1993, p.16-7), tanto em sua capacidade explicativa como em sua utilidade prática para o estudo da situação de saúde, o que impõe a consideração de suas relações com as condições de vida e o planejamento e avaliação de 'ações mais integrais de saúde e bem-estar', o que se tem tornado evidente na medida em que a mortalidade por doenças transmissíveis perde importância relativa, ao mesmo tempo em que a expectativa de vida aumenta e as doenças crônicas e de causas externas vão ganhando força. As condições atuais de transição epidemiológica na situação de saúde coloca a necessidade de: “(....) acciones de caracter más poblacional que, por actuar sobre las 'causas', tendrían un impacto mayor y más duradero”. Mendes (1993a) reproduz uma síntese dessas idéias em periódico da OPS sobre organização de serviços de saúde.

Citando a proposta de Laframboise de uma "estrutura conceitual para análise do campo de saúde", desenvolvida em 1973 no plano do governo canadense para as décadas de 1980 e 1990, posteriormente descrita como o conceito de campo de saúde e que se tornou a "base para a política de saúde daquele país", Dever (1988, p.3) apresenta uma concepção de saúde enquanto "determinada por uma variedade de fatores, agrupados em quatro divisões principais: estilo de vida, ambiente, organização dos cuidados com a 
saúde e biologia humana". Esta proposta conceitual foi publicada por Lalonde ( $A$ New Perspective on the Health of Canadians, como documento oficial do Ministério da Saúde e Bem-Estar do Canadá), sendo em decorrência mais associada ao seu nome. Na mesma perspectiva Blum (apud Dever 1988, p.4-5), em 1974, propôs um modelo de ambiente da saúde, denominado como o campo de força e os paradigmas de bem-estar da saúde. Segundo esse modelo a "amplitude dos quatro grupos de fatores que contribuem para a saúde", enquanto inputs à saúde, indicam "pressupostos sobre sua relativa importância". Assim sendo, os fatores - estilos de vida, ambiente, serviços de assistência médica e hereditariedade - se relacionam entre si e se afetam mutuamente por meio de um círculo abrangente que inclui "população, sistemas culturais, saúde mental, equilíbrio ecológico e recursos naturais", compondo um campo de saúde.

Dever (1988, p.4-6), retomando o modelo de Laframboise e Lalonde, já no ano de 1976 reformulou a proposta de Blum, redesenhando um "modelo epidemiológico para a análise da política de saúde", reconceituando as mesmas quatro dimensões explicativas dos problemas de saúde de uma população: estilo de vida, ambiente (físico, social e psicológico), sistema de organização dos serviços e biologia humana. O conceito de campo de saúde tem uma estrutura abrangente que permite uma ampla análise biopsico-social do binômio saúde-doença, impondo a "investigação por igual de estilo de vida, elementos ambientais e biológicos, assim como de fatores de organização dos serviços de saúde". Dever considera este modelo como "ideal para a elaboração de medidas preventivas". E registra que o mesmo foi adotado pelo governo dos Estados Unidos no "Perfil Preventivo”, anexo ao Health, United States, formulado em 1980.

Dever (1988, p. 2) elabora uma estrutura para os conceitos de saúde, de caráter mais “amplo, abrangente e administrável do ponto de vista estratégico". Para tanto, considera que tal conceituação deve conter dois modelos epidemiológicos - os envolvidos na multicausalidade e os relacionados aos fatores de risco. Segundo Castellanos (1993, p.18-19) essa proposta de Dever destaca-se entre os esforços mais importantes para 'estudar a situação de saúde desde um ponto de vista mais epidemiológico, mais integrador', acrescentando que Dever qualifica essa perspectiva como holística. Esta leitura deve-se a: “(....) su caracter más integrador y por permitir un mejor manejo de 
la salud desde el punto de vista de las políticas públicas y fundamentado en las nuevas necesidades epidemiológicas" (ibid).

De acordo com Castellanos (1993, p.19), os estudos de Blum, Dever e Lalonde sobre a estruturação do conceito de saúde estão motivados basicamente pela intenção de “desenvolver explicações que pudessem orientar as decisões sobre políticas de saúde e ser traduzidas em ações eficazes. Por isso em sua proposta existe uma correspondência entre as dimensões explicativas com os campos de ação para a promoção e defesa da saúde”. Este modelo tem tido grande influência na saúde pública canadense e evidencia a forte tendência naquele país da priorização das ações de promoção da saúde, entendida nos termos colocados pela Carta de Otawa em 1986, de forma vinculada às condições e qualidade de vida, e não simplesmente como ações dirigidas ao estilo de vida pessoal, um "sentido restritivo vinculado somente à educação sanitária e a atenção médica preventiva" (p.20).

Continuando com a linha de pensamento de Castellanos (1993), em suas reflexões sobre concepções de saúde, destaca-se que esse conceito tem evoluído consideravelmente, desde sua maior "vinculação com as doenças e morte - aproximações negativas", até as concepções mais atuais que se relacionam com as "possibilidades de realização pessoal e coletiva das populações - aproximações positivas". Este autor cita a definição adotada pela Constituição da OMS na metade do século 20 como um exemplo destas últimas saúde como um estado de bem-estar físico, mental e social, e, portanto expressão das condições de vida da população (p.13).

\section{Explicação da situação de saúde}

Conforme diz Mendes-Gonçalves (1994, p.56), referindo-se à clássica análise de Canguilhem que entende saúde como expressão dos "modos de andar a vida", estes são campos de normatividade muito mais além do que os limites do corpo anátomofisiológico. "Recorrer, como faz Canguilhem, aos modos de vida como critérios para a normatividade equivale também a ultrapassar a concepção do corpo anátomo-fisiológico como objeto ingênuo de prática médica, principiando a identificar nesse corpo outras 
ordens de determinações" (ibid). Ou, conforme o entendimento de Castellanos (1993, p.13-14): 'saúde e doença são expressão da vida' e conformam fenômenos que 'traduzem os processos de vida', a forma concreta da vida de cada pessoa e grupo de população.

Jorge (1988, p.49) explicita essa idéia assim: “O nível de saúde da população resulta de um conjunto de condições associadas ao trabalho, alimentação, habitação, transporte, educação, renda, meio ambiente, liberdade, lazer, posse da terra e acesso aos serviços de saúde. Desta forma, a saúde de um povo é resultado da forma de organização social da produção e da apropriação de bens e serviços, que, na sociedade brasileira tem gerado grandes desigualdades nos níveis de vida e de saúde".

Castellanos (1993, p.4) reforça que é importante considerar que assim como a saúdeldoença, obviamente, as condições de vida também tem o caráter de processo. Pois, cada estado de saúdeldoença constitui só um instante de tais processos e portanto mudam, se transformam, melhorando ou piorando, em cada momento diferente, de acordo com a "dinâmica reprodutiva dos mesmos e segundo as ações de saúde e bemestar". Em outros termos: “As condições de vida de cada fração de população têm assim a dupla importância de expressar os processos gerais da sociedade e de ser mediadoras das determinações dos problemas de saúde a nível individual e coletivo". Pois, ao mesmo tempo em que as condições de vida constituem a forma particular de inserção de dito grupo na reprodução geral da sociedade formada pelo conjunto da estrutura $e$ dinâmica social, constituem as mediações entre os processos mais gerais da sociedade e os problemas de saúdeldoença peculiares de cada grupo populacional. Segundo esse autor:

Desta forma, a situação de saúde de diferentes grupos de população, é uma das formas de concretização, a nível particular, dos processos mais gerais que caracterizam uma sociedade, sua estrutura e dinâmica, o grau de desenvolvimento de suas forças produtivas, de suas relações sociais, do modelo econômico e de sua forma de inserção internacional, de sua organização estatal e das relações políticas que a caracterizam, em 
cada momento de sua história; assim como das condições naturais onde dita sociedade se desenvolve (Castellanos 1993, p.14-5).

No Brasil, durante a $8^{\mathrm{a}}$ Conferência Nacional de Saúde (1986) é democraticamente instituída, e se poderia dizer "legitimamente legitimada", uma nova concepção de saúde- enquanto qualidade de vida, direito de todos, dever do Estado. A partir de então se encontra essa nova concepção ampliada de saúde (Anais $8^{\mathrm{a}}$ CNS 1986, p.159), sendo freqüentemente apontada por vários autores, em geral indicando "ações e serviços de promoção, proteção, e recuperação de saúde, em todos os seus níveis, a todos habitantes do território nacional" e também se colocando na perspectiva de permitir o ‘desenvolvimento pleno do ser humano em sua individualidade’ (p.382).

No prefácio de importante antologia realizada sobre a promoção em saúde, a OPS (1996) registra: “(....) Nuestra primera obligación debe ser rechazar por completo el concepto mecanístico de la salud, que se remonta al reduccionismo de Descartes y Newton. Debemos hacer hincapié una y otra vez en la búsqueda de la 'salud como un aspecto integral de la eterna lucha por el desarrollo humano' (p.vii)". Tal reconhecimento pela OPS/OMS permite ilustrar, segundo organizações internacionais oficiais no campo, o movimento de mudança do paradigma conceitual sobre saúde.

Nos últimos anos tem se reforçado o aumento da abrangência da concepção de saúde. $\mathrm{Na}$ conjuntura da $8^{\mathrm{a}} \mathrm{CNS}$ se explicitava claramente que as problemáticas do saneamento, a questão de habitação e da educação, fazem parte do entendimento da saúde como uma questão muito mais ampla. Existia então um movimento no sentido de que a 'saúde do trabalhador passasse a ser entendida como parte integrante da saúde' (Anais $8^{\mathrm{a}}$ CNS 1986, p.159). E ainda: "sistema de saúde, não é exclusivamente a promoção da ausência da doença pelo trabalho do técnico específico da área de saúde, mas (....) é trabalho condigno, com remuneração condigna, é alimentação, é moradia, é educação, é liberdade, é direito de optar dentro da própria vida. A saúde passa pelas liberdades constitucionais; a saúde não é privilégio que uma população conquiste exclusivamente através do progresso econômico", caracterizando que a 'saúde faz parte integral e importante do avanço social de uma população' (p.154-5). 
Sob o sub-título 'modelo explicativo integral sobre saúde e condições de vida' Castellanos (1993, p.17) considera que:

\begin{abstract}
"La conciencia creciente sobre las limitaciones de los abordajes conceptuales etiológicos y ecológicos (mais tradicionais) hizo necesarios nuevos 'desarrollos conceptuales más integrales', que redefinieran el espacio de lo individual y pudieran dar cuenta de la complejidad de los procesos determinantes, a la vez que repotenciaran la capacidad de las acciones de salud y bienestar, de impactar sobre los problemas relevantes de salud".
\end{abstract}

Segundo o mesmo autor, em relação à condição de que "cada novo desenvolvimento conceitual sobre saúde/doença incorpora e redefine os conceitos anteriores", pode-se indicar como constatação que, à medida que o desenvolvimento do conhecimento permite e exige uma maior compreensão de sua estrutura e de sua gênese, conformamse 'marcos teóricos mais explicativos e integrais' (Castellanos 1993, p.17).

Castellanos (op cit) incorpora desenvolvimentos conceituais metodológicos e técnicos que contribuem para superar limitações contidas em diferentes modelos conceituais que sofrem uma revisão crítica (o ecológico, o de Morris, o de Blum, de Dever e de Lalonde e outros), propondo um marco conceitual que operacionaliza condições de vida segundo as diferentes dimensões da reprodução social das condições de vida (p.12).

\title{
Problemas de saúde
}

Quanto às condições de vida, Castellanos (1993, p.21) demonstra de forma teóricoprática que as condições de vida, ao ser operacionalizadas em quatro grandes dimensões do processo de reprodução social, cada uma das quais se expressa predominantemente em um grupo de problemas de saúde e corresponde a um campo de serviços ou respostas sociais: processos biológicos (do potencial genético e capacidade imunológica); processos ecológicos (do meio ambiente residencial e de trabalho); processos reprodutivos (das formas de consciência e conduta, determinantes culturais, hábitos e formas de conduta, estilos de vida individuais e coletivos); e, processos 
predominantemente econômicos (as formas de articulação com a produção, distribuição e consumo de bens e serviços).

De forma coerente com sua concepção integral de saúde, Castellanos (op cit, p.22-23) afirma que as condições de vida determinam necessidades de saúde que são socialmente representadas como problemas de saúde. Em assim sendo, na perspectiva da elaboração de um perfil de problemas de saúdeldoença, necessita-se definir procedimentos para identificação de necessidades e problemas, os quais se baseiam em diferentes metodologias e técnicas, que permitam a identificação de problemas prioritários de saúde nos diferentes períodos do processo saúdeldoença e em diferentes espaços organizativos da realidade'.

Com relação aos problemas de saúde, por um lado, admite a dimensão subjetiva dos problemas, onde diversos atores sociais tendem a identificar diferentes problemas e a hierarquizá-los de maneira distinta. Este entendimento de problemas está de acordo com Matus (1993). Por outro lado, os problemas são identificados como produtos finais (mortes, incapacidades e morbidades), como problema potencial (riscos), ou como necessidades no processo reprodutivo. Isto é, identificam-se os problemas como produtos, processos ou insumos. Quanto mais tardia a identificação, menos sensíveis seriam os indicadores às variações das condições de vida. E por referência aos diferentes espaços organizativos da realidade, Castellanos (1993, p.28) considera os atributos individuais e as diferenças entre grupos populacionais segundo condições de vida e no âmbito da sociedade total.

Castellanos (1993, p.29) propõe, no enfrentamento de problemas de alta complexidade e mal estruturados, que sejam introduzidas ferramentas metodológicas para a redução da complexidade (seleção de variáveis estratégicas, segundo modelos explicativos da realidade) e para a articulação de unidades de análise, variáveis e indicadores de diferentes níveis, em um mesmo projeto. Desenvolve ainda o conceito de "sistemas de matrizes de dados" ao proceder a uma revisão da utilização de diferentes tipos de estudos, do ponto de vista epistemológico, conforme propõe Samaja (1993). 
Cabe destacar outro importante esforço no sentido de sistematizar uma concepção mais integral de saúde, realizado por Breilh, Granda e colaboradores (citados por Castellanos 1993, p.20) e outros autores latino-americanos onde se destaca o próprio Castellanos, a partir da categoria reprodução social, enfatizando a importância de um marco explicativo que incorpore o conjunto das condições de vida como mediadoras entre a inserção social e a situação de saúde, e que tenha potência para dar conta do conjunto de problemas de saúde em diferentes grupos populacionais. Sua preocupação básica, portanto, é a vinculação entre saúde e condições de vida. Seguindo a mesma linha de pensamento de Castellanos (op cit), Mendes (1993a, p.12) condensa aquelas idéias ao referir-se à epidemiologia social latino-americana, que "a partir da categoria reprodução social, enfatiza a importância de um marco explicativo do processo saúde/enfermidade que vincule saúde e condições de vida, através da inter-relação entre as dimensões biológica, ecológica, consciência e conduta e processos econômicos”.

\section{Respostas Político-Sociais}

Para seu projeto - Sistemas Nacionales de Vigilancia de la Situación de Salud segun Condiciones de Vida y del Impacto de las Acciones de Salud y Bienestar - Castellanos (1993) considera conveniente utilizar um marco teórico que incorpore três elementos básicos: as condições de vida, os problemas de saúdeldoença, e as respostas sociais dos serviços de saúde e bem-estar. Assim, procura recuperar o conjunto de avanços conceituais referidos, em "um modelo que permita não apenas descrever e explicar os problemas de saúde dos diferentes grupos, mas identificar os campos prioritários de ações de saúde e bem-estar e avaliar o impacto de tais ações” (p.20).

Portanto, o documento-projeto de Castellanos (1993, p.12 e 20) propõe um 'modelo conceitual integrador de condições de vida, problemas de saúde e respostas sociais' (serviços de saúde entre outros), desenhado para abordar o estudo de situação de saúde de grupos populacionais. Este modelo se apóia no já referido marco conceitual que operacionaliza as condições de saúde segundo as respectivas “dimensões da reprodução social das condições de vida (biológicas, ecológicas, formas de consciência e conduta e a dimensão econômica)". Trata-se de um 'modelo integrador de descrição e explicação 
dos problemas por grupos populacionais', compreendendo ainda a identificação de campos prioritários de ação como também a avaliação do impacto dessas ações. Tal desenho é coerente com sua preocupação básica de contribuir no processamento da avaliação e vigilância da situação de saúde em grupos da população segundo suas condições de vida, "de forma a ser útil para o planejamento e avaliação das ações de saúde e bem-estar pelos diferentes atores sociais envolvidos na área” (ibid).

As novas concepções de processo saúde e doença oferecem um referencial conceitual para a reorganização do setor saúde, inclusive nos "países do primeiro mundo onde os sistemas de saúde começam, na metade dos anos 70, a serem fortemente questionados" (Mendes 1993a, p.11). A importância de se recuperar como nível de abordagem o espaço das condições de vida, onde operam ações sociais e serviços de saúde e bemestar coloca-se especialmente para o planejamento e avaliação de tais ações (Castellanos 1993, p.15).

As respostas sociais são organizadas pelos serviços em três grandes grupos de atividades: promoção da saúde, prevenção de doenças e acidentes, e, atenção curativa; trabalhando-se numa proposta de operacionalização por nível de ação e por tipo de determinantes dos problemas de saúde sobre o mesmo, para cuja materialização em atos Castellanos (1993, p.39) propõe "uma 'matriz tridimensional, integradora' do conjunto dos conceitos propostos sobre condições de vida, problemas de saúde e respostas sociais, como apoio para operacionalização dos projetos".

De acordo com Paganini e Chorny (1990, p.438), nas várias vertentes do planejamento estratégico, (....) 'se puede abordar de manera holística el quehacer de salud'. Isto é, o modo de fazer saúde, e "incorporá-lo ao sistema social como um todo".

Pode-se dispor de modelos que permitam uma abstração do movimento de conformação das respostas sociais dos serviços às necessidades de saúde. Assim como se poderia construir um desenho representativo da configuração de um modelo de integralidade da atenção à saúde. Todavia, é somente no campo político que as concepções éticonormativas de práticas e estruturas sociais, como a saúde, podem adquirir viabilidade 
para ser traduzidas em realidade. Assim, a política está presente nas dimensões organizacional e tecnológica apresentadas. Mais precisamente, ao tratar das características tecnológicas de organização e operação dos processos de trabalhos (Mendes-Gonçalves 1994), procurando captar aquelas mais comprometidas com a integralidade da atenção em serviços locais de saúde, ao captá-las enquanto tecnologia, pode-se referi-las à organização social das práticas de saúde.

Ao tratar de possibilidades da mudança de um conjunto tecnológico-organizacional de práticas de saúde vale retomar a reflexão desenvolvida por Mendes-Gonçalves (op cit), que soube "enfrentar a articulação sempre tensa entre o nível de abstração teórica e o de concretude da pesquisa empírica, sobretudo quando se inspira, como é o caso, na concepção dialética do seu objeto (....) e que portanto deve ser compreendido como momento de uma totalidade mais ampla, em fluxo entre determinações objetivas do passado e do futuro" (p.12). Ainda como pressuposto se considera os serviços locais de saúde potencialmente capazes de realizar uma prática mais propriamente de saúde, cujo conteúdo poderá compor a integralidade da atenção no SUS. Nessa perspectiva destacase a centralidade do caráter assumido pelo componente gerencial, também tecnológico.

As perguntas, que se procurou responder no estudo, partiram de uma questão fundamental: qual é a relação entre a integralidade da atenção à saúde politicamente constituída e a correspondente organização do trabalho que a materializa? Existe uma preocupação em apreender possibilidades para transformar-se em base de sustentação de propostas, que, sem renunciar ao nível da crítica no âmbito das questões de saúde e sociedade, possam contribuir com os fazeres dos serviços de saúde. Essa questão inclusive, é abordada por Testa (1995), ao tratar da relação estratégia e programação: “(....) apesar do indubitável avanço do conceito de planejamento estratégico frente ao planejamento normativo, a idéia de planejamento estratégico mantém, subrepticiamente, uma certa separação metodológica (de outro modo impossível - no limite - de se superar) entre a formulação científica e a intervenção política”. Conforme aquele autor o seu "tratamento (....) a este tema avança um passo em direção à integração buscada" (p.12). 
A produção de serviços de saúde aqui estudada é aquela que se desenvolve no interior do espaço institucional da saúde pública enquanto componente do respectivo aparelho de Estado.

\subsection{No Espaço da Transformação Organizacional}

Na formação lato sensu em saúde coletiva sempre se lida, no ensino da programação e gestão em saúde, com a dificuldade acima referida. Pois, a realização de ações de saúde, enquanto serviço prestado à população, dá-se no espaço organizacional. E neste espaço não é possível ignorar a principal referência teórica para o estudo das organizações, a produção do sociólogo Max Weber (Campos, 1978). Inclusive a sua crítica por estudiosos da teoria organizacional, como se pode citar Shon (1971), que ao abordar a questão da "perda do estado estável" se une a outros autores que como Pinchot e Pinchot (1995) se atrevem a falar do fim da burocracia.

Tais questões novamente eclodem na relação teoria e práticas para transformação de realidades do trabalho de produção de bens e serviços, no caso com toda a complexidade que os serviços de saúde carregam. Como também não faria sentido negar a utilidade do instrumental sistêmico para contribuir na apreensão e explicação do movimento da problemática organizacional no setor saúde. Inclusive na perspectiva de sua transformação. O manejo organizacional das intervenções na saúde da população impõe, além da visão político-social, uma compreensão mais instrumental da complexidade administrativa e operacional no setor, pautada em atributos gerenciais de inovação, adaptabilidade e flexibilidade, entre outros a especificar em cada sistema respectivo (Tarride, 1995).

Como destacou Amélia Cohn no Prefácio do livro de Mendes-Gonçalves (1994, p.1213):

Essa dinâmica gera questões nada triviais, tais como a de desvendar as mediações entre o pressuposto da autonomia das esferas de ação - no sentido exato weberiano de legalidade própria - a partir da perspectiva dialética, e, portanto num nível maior de generalização/abstração. Questão, sobretudo, porque se as mediações não estão já dadas, 
quer pelo quadro teórico construído, quer na pesquisa empírica, as instituições, por seu lado, não constituem tão-somente produções em si mesmas e espaços burocraticamente definidos, mas resultam da prática concreta dos atores sociais, e é da trama de suas ações que elas assumem sua configuração. Vale dizer, se as interações humanas são produtos das instituições, estas por sua vez são produtos daquelas.

Partindo da densa elaboração teórica de Mendes Gonçalves (op cit), apresentada por seus editores como um valioso instrumento para se explorar os serviços de saúde da perspectiva de suas práticas, procurou-se produzir e analisar os dados empíricos deste trabalho sob aquele referencial, com mediações construídas em um diálogo com algumas produções com reconhecimento mais recente na teoria organizacional, destacando-se as contribuições da disciplina da transformação organizacional (Motta 1997), por sua afinidade com os desdobramentos da investigação (Shon 1971, Argyris e Shon 1978, Pettigrew 1992, Mintzberg 1985, 1998 e 2000, Chanlat 1996, Pinchot e Pinchot 1995 e Senge 2000).

\section{Planejamento e gestão local}

Em linhas gerais pode-se constatar que na implementação de propostas de mudança do modelo assistencial para sua adequação aos princípios e diretrizes do SUS, tem sido utilizadas abordagens do planejamento estratégico em saúde como principal referência teórico-metodológica para reorientação e operação dos sistemas de serviços locais de saúde. Nesse contexto são destacadas as reflexões de Testa (1995) a respeito do pensamento estratégico em saúde e o uso do Planejamento Estratégico Situacional PES (Matus 1993), com várias experiências no país. Neste método, são os diferentes atores em situação que identificam e analisam os problemas de saúde a abordar. Por outra parte, os saberes operantes (Mendes-Gonçalves 1994) dos trabalhadores de saúde que fundamentam a ação no processo são basicamente os saberes epidemiológicos locais.

Quando o assunto abordado trata da gestão de serviços de saúde, os referenciais do pensamento estratégico em saúde (Testa, op cit), articulados às bases conceituais e 
metodológicas do Planejamento Estratégico Situacional - PES (Matus, op cit), necessariamente são abordados e revisados nas suas respectivas incorporações pelas propostas organizativas estudadas. Especialmente este último, quando sua metodologia desenvolve o denominado momento tático-operacional do processo de planejamento, que informa nesse caso a gestão local em saúde em nível de operacionalização do planejamento. A instituição dessas propostas coloca-se neste estudo, enquanto exercício de uma programação local de saúde, de acordo com a lógica estratégica, geralmente derivada de processos instituintes da descentralização da atenção e do próprio planejamento de saúde ao nível de serviços locais de saúde.

\section{Organizações profissionais}

O setor público, como o setor privado, está cada vez mais interessado nas questões de performance, na capacidade de administrar mudanças de longo prazo, no impacto da economia política sobre as organizações e no papel e natureza da liderança (Pettigrew 1992). Tomando por referência pesquisas realizadas nos sistemas ingleses de assistência à saúde (especialmente no NHS - National Health Service), este autor sugere que procurar saber se a teoria organizacional é teórico-genérica ou setorial-específica, pode ser um debate parcial e talvez inútil. Reconhecendo como principal argumento da diferença entre organizações públicas e privadas o maior grau de politização aparente no setor público, cabe lembrar que um ambiente político complexo também está presente em importantes parcelas do setor privado, como por afinidade de área pode-se citar a indústria farmacêutica e de equipamentos médicos. Pois assim como as categorias setoriais não são estáticas, veja-se o surpreendente crescimento do terceiro setor - de serviços e organizações não governamentais, sequer se pode assumir que organizações de assistência à saúde estarão sempre situadas no setor público.

Importante reter o entendimento dos serviços de saúde como organizações profissionais, sendo o caso mais típico desse modelo os hospitais, cujos segmentos profissionais orgânicos são amplamente autônomos em relação à administração (Pettigrew 1992). Para este autor, dentro de burocracias profissionalizadas, a mudança ocorre através de alterações sucessivas, limitadas e negociadas. Por estas organizações 
serem mais resistentes à inovação e mudança é que as decisões nos modelos de difusão das mudanças devem ser incrementais.

\section{Estratégia organizacional}

Na moderna teoria das organizações, a estas se impõe um movimento contínuo de adaptação e flexibilidade frente a pressões internas e externas.

A estratégia de uma organização expressa como esta enfrenta seus pontos fracos e ameaças e como utiliza os pontos fortes existentes e potenciais (SWOT - strengths, weaknesses, opportunities, threats), na perspectiva de alcançar seus objetivos frente a mudanças do meio ambiente. Kehrig (Acosta 1983), ao utilizar esta metodologia de forma associada à tipologia de organizações autoritárias, paternalistas, permissivas $e$ participativas, desenvolvida por Likert (autor neoclássico das teorias de administração), para analisar as condições de operacionalização da política de saúde desde os centros de saúde estaduais em Santa Catarina, conclui que, mesmo sendo participativos e valorizando oportunidades conjunturais, essas condições organizacionais não foram suficientes para alcançar objetivos pretendidos. De acordo com o referencial teórico adotado no presente estudo, pode-se considerar como limitação daqueles resultados a desconsideração tanto da tecnologia enquanto determinante da materialidade na execução de ações no espaço organizacional, como de princípios e mecanismos de administração em saúde e gestão.

Desde a década de 1960 pode-se identificar uma tendência da literatura especializada em incorporar a noção de estratégia nas organizações, o que na seqüência passa a ser progressivamente incorporado pelo mundo organizacional. A década de 1970 foi marcada pela assunção do planejamento estratégico e após os anos 1980 essa concepção é aperfeiçoada pelas rápidas alterações da relação da organização com seu ambiente (Mintzberg 2000).

O autor acima citado identifica dez escolas de estratégias organizacionais, agrupadas em três segmentos. No primeiro situa três delas, de natureza mais descritiva sobre como 
se formulam as estratégias, como devem ser, ao invés de analisar como elas acontecem. Em um segundo grupo situa seis escolas que consideram aspectos específicos do processo de formulação de estratégias, onde a preocupação é entender como as estratégias têm sido formuladas. Neste segmento inclui a escola do aprendizado, devendo a estratégia emergir gradualmente à medida que a organização aprende; a escola cognitiva; os empreendedores; inclui ainda a escola do poder, onde as estratégias são formuladas via processo de negociação por grupos internos conflitantes, onde genericamente pode-se situar as aplicações do planejamento estratégico situacional (Matus 1993) na área da saúde. Na escola cultural a formulação da estratégia desenvolve-se de forma apoiada na cultura organizacional; identifica também uma escola ambiental, onde as estratégias são formuladas enquanto reação da organização ao seu ambiente externo. E finalmente, no terceiro segmento, a escola da configuração, que propõe uma combinação das anteriores, agrupando as noções de processo de formulação e o conteúdo das estratégias em relação à estrutura organizacional de referência em cada contexto. Nesta proposta com a qual o próprio Mintzberg (2000) se identifica, o processo de formulação é entendido como transformação organizacional, e está informado por toda a literatura de mudança estratégica.

\section{Transformação Organizacional}

Optou-se por incluir neste momento uma rápida recuperação teórica sobre a temática da mudança organizacional, o que ajuda a iluminar a realidade empírica nos seus conteúdos organizacionais. Tal orientação está justificada ao se buscar captar no caso estudado um movimento de mudança do modelo de atenção à saúde, o que se processa via transformação organizacional também. Trata-se aqui de uma fundamentação constituída por um conjunto de conceitos e princípios selecionados ao se considerar que podem informar a leitura da organização dos serviços de saúde no âmbito do estudo realizado.

Como o propósito maior desse estudo é compreender o processo de mudança do modelo de atenção em uma secretaria municipal de saúde, considera-se que conhecer a teoria de mudanças organizacionais, que tem povoado o mundo organizacional nas três últimas 
décadas do século 20 é condição para situar a complexidade do mundo organizacional, contexto do qual as organizações de saúde também fazem parte. As mudanças aceleradas na sociedade impregnam o cotidiano na vida organizacional, sendo as mudanças impostas como questão de sobrevivência.

Não se acredita mais no estado estável e o caminho das organizações é caracterizado pela incerteza. Shon (1971) já há três décadas observou que as organizações perceberam a necessidade de se preparar para os desafios da mudança de uma forma diferente, o que impõe como necessidade aprender a responder a situações de mudança. Existe a necessidade de aprender cotidianamente a lidar com o inesperado. Como as instituições vivem em um processo contínuo de adequação a contingências que lhe são impostas, é preciso entender, guiar, influenciar e gerenciar mudanças. Os adeptos à aprendizagem reúnem melhores condições de inventar e desenvolver organizações como sistemas de aprendizagem, portanto, com capacidade de fazer sua transformação contínua. Sua principal tarefa é aprender sobre a aprendizagem, potencialidades e conseqüências dos sistemas de aprendizagem nas organizações.

Shon (1971) entende a perda do estado estável como imposição de períodos de contínua ruptura no interior das organizações. Nessa condição a sobrevivência organizacional se articula a alguma forma de conservadorismo dinâmico, onde se conjugam as condições dos sistemas de aprendizagem para permitir a mudança do estado estável, sem ameaça a funções essenciais do sistema. Portanto, implica manter a identidade do sistema e a identidade própria dos seus atores, para a organização poder ir se transformando gradativamente nesse processo.

A organização burocrática já não responde adequadamente aos novos valores progressivamente formados na história recente. Se sua lógica era de dominação, controle e exploração dos recursos naturais e humanos, hoje o espaço em construção é de participação, com equipes auto-dirigidas sendo a direcionalidade dos processos amplamente compartilhada, e de desenvolvimentos ecologicamente auto-sustentáveis. É preciso que a nova configuração organizacional seja redesenhada, por aproximações sucessivas, coerentemente com as mudanças de sua realidade externa e necessidades da 
sociedade em que se insere, buscando seus novos valores. Como exemplo nos sistemas de saúde pode-se citar a crescente valorização dos referenciais da promoção.

Segundo Pinchot e Pinchot (1995), a forma burocrática que obteve grande sucesso no passado, enquanto um sistema capaz de gerir a produção de bens e serviços e a divisão do trabalho, tornou-se uma limitação do presente, ao tolher as organizações a uma condição interna focalizada e não criativa. A situação atual das organizações implica em se permitir o aprendizado crítico, consciente e criativo, utilizando novas estratégias de mudança e informação para uma nova base de valores. Portanto, há que se encontrar formas de se chegar a organizações preparadas para aprender via pensamento crítico e ação capaz inclusive de antecipar-se a possíveis alterações futuras.

\section{Gestão humana estratégica}

Considerado o planejamento um momento de formulação estratégica de uma situação desejada e o gerenciamento os movimentos de implementação das ações necessárias, é no espaço dessa relação que são criadas as capacidades organizacionais, tarefa dos agentes do trabalho. Esse é o locus privilegiado das estratégias emergentes, cuja formulação segundo Mintzberg (1998) se dá mais provavelmente pela via da estratégia artesanal. Nessa via o artesão organizacional reúne suas experiências de vida e habilidades do passado, atualizadas em íntima relação com, e conhecimento do, seu objeto de trabalho presente, fazendo uso e criando novas oportunidades a cada momento. A idéia de artesanato é para este autor a que melhor se aproxima do que deve ser o processo de geração de estratégias efetivas.

A administração estratégica de recursos humanos trabalha com a gestão de pessoas e de processos. Nessa perspectiva se colocam as dimensões estratégicas da gestão humana, destacando-se: um foco pró-ativo em resultados, desempenho, produtos e valores agregados; e, um desenvolvimento de capacidades organizacionais voltadas a criar clareza estratégica, fazer que as mudanças aconteçam e gerar competência e comprometimento, o que Klein (1998) denomina de capital intelectual. 
Como instrumentos de tais movimentos destacam-se as redes de equipes de trabalho, a renovação da cultura e valores organizacionais e, sobretudo, a via pedagógica, tendo por fundamento uma metodologia de prática, reflexão sobre essa prática e ação consciente, o que pode ser mais aprofundado conforme propõe Freire (1992). Assim como no mundo empresarial a gestão humana estratégica é fundamental para se alcançar a excelência organizacional, na produção de serviços de saúde é condição para transformação dos seus atores em artesãos de como se pode fazer os princípios e diretrizes do SUS nortearem a prática das suas unidades de trabalho.

Mudanças estratégicas tendem a ser traumáticas e dramáticas, por alterar normas, estruturas, processos e metas. São alterações profundas, que impõem uma reorientação cognitiva da organização, refletindo descontinuidades de percepções, estruturas e contexto, o que ocorre através de alterações nas interações de processos deliberativos e emergentes (Mintzberg e Waters 1985). As estratégias deliberadas são processadas pelo planejamento de mudanças, que é intercortado por estratégias emergentes, mais flexíveis, resultantes de mudanças não planejadas. A organização precisa aprender a partir dos erros cometidos e proceder a uma reorientação organizacional para aprender a aprender com as novas situações.

Chanlat (1996) recupera contribuições da antropologia, em suas preocupações ontológicas, para desenvolver uma nova abordagem do comportamento organizacional. Preocupado com o homem no ambiente de trabalho, adota uma postura compreensiva que procura entender o sentido que as pessoas dão à própria vida. Ao reconhecer a deterioração da vida física, psíquica e cultural dos grupos populacionais e a confusão de valores morais e éticos, propõe reabilitar o ponto de vista do sujeito, o seu desejo referente à sua atividade profissional. Segundo esse autor as modalidades de gestão estão apoiadas numa antropologia das organizações. Ao reconhecer as várias dimensões do ser humano as elabora como sua unidade fundamental, buscando ver a contribuição do trabalho no equilíbrio entre elas: um ser genérico e singular; um ser de desejo e de pulsão (psíquica/afetiva); um ser simbólico; um ser espaço-temporal. 
É preciso estar atento à armadilha da justaposição de disciplinas, o que vai aumentar a impressão de confusão. Isso implica em desenvolver uma compreensão mais profunda do contexto e dos traços únicos das pessoas. As diferentes dimensões do homem impõem um modo interdisciplinar de pensar a sua gestão nas organizações. Na confrontação com a prática cotidiana se coloca as questões éticas como reflexão central sobre os problemas de gestão. Trata-se aqui da ética das relações cotidianas.

Propondo uma teoria antropológica das organizações, Chanlat (1996) analisa cinco níveis que estão respectivamente inseridos um no outro: o nível do indivíduo, da interação entre ritos e afetos ou processos psíquicos nos grupos, da organização, da sociedade (habitus), e do mundo.

\section{Organizações em aprendizagem}

A arte e prática da organização que aprende (Senge 2000) contêm uma concepção inovadora que está revertendo a maneira atual de pensar, gerir e trabalhar nas organizações. Propõe o reconhecimento das pessoas em equipes como o principal meio de alavancagem nos processos de mudança necessários para as organizações se prepararem para os desafios do futuro. Seja na ciência política ou nos movimentos sociais, sempre as transformações são processadas por pessoas.

Nos serviços de saúde, ao se pretender uma formação profissional e educação em saúde comprometida com a mudança das práticas, destaca-se como seu principal fundamento pedagógico o reconhecimento da metodologia da problematização prática/reflexão/ação transformada (Freire 1992). Neste estudo, ao se pretender contribuir para transformações nas organizações de serviços de saúde que impliquem na mudança da prática sanitária, partindo do referencial de uma pedagogia para a transformação conforme desenvolvida por Freire, encontram-se nas obras de Argyris e Shon (1978) e de Senge (2000) importantes ferramentas e métodos específicos que permitem novas formas de pensar e interagir para articular a aprendizagem aos objetivos de mudança organizacional. 
Senge (op cit) define nos contornos da organização que aprende, pessoas se expandindo continuamente na sua capacidade de criar os resultados pretendidos. Para tanto são estimulados novos padrões de pensamento e ação, buscando-se formas de as pessoas entrarem em processos de aprender em conjunto a arte de como aprender. De acordo com uma concepção de que as pessoas são prisioneiras do próprio pensamento e que idéias criam a nossa realidade, através da reflexão sobre as idéias e seus reflexos práticos, esse autor procura ver como pode ser modificada a realidade organizacional.

Existe no mundo organizacional uma consciência de que, entre outras determinações do problema, os esforços de vencer fracassos e as dificuldades das organizações em corresponder às expectativas e necessidades da sociedade, podem estar no próprio sistema de gerência. Essa idéia está articulada com as concepções de qualidade na produção de bens e serviços que têm alimentado o desenvolvimento industrial no último século. Senge (2000, p.11) coloca como tendências organizacionais no novo milênio: maior distribuição do poder decisório, liderança em todos os níveis, pensamento sistêmico substituindo o pensamento reducionista, e habilidades humanas mais sofisticadas. Assim como existe uma perspectiva de que "novos produtos mais eficazes sejam desenvolvidos pelos próprios clientes, trabalhando em íntimas parcerias com as organizações que fornecem tais produtos e serviços" (ibid), podemos pensar nas ações dos serviços de saúde como produtos construídos com ampla participação do usuário e controle social. Portanto, assim como menos fronteiras entre empresa e cliente, menos fronteiras entre serviços de saúde e usuário.

Antes os gerentes estavam orientados a controlar, com nítidas fronteiras autoritárias e decisões hierarquizadas. E hoje se reconhece que talvez a aprendizagem seja mais importante que o controle. Daí a idéia de organizações baseadas no conhecimento, ou seja, organizações que aprendem. Tais organizações são inerentemente mais flexíveis, adaptáveis e aptas a se reinventarem continuamente. Segundo Senge (2000, p.12): "o refrão teórico principal, a emergência da perspectiva sistêmica na administração, era abstrato e desafiador do ponto de vista intelectual". Assim, através de uma crítica à administração tradicional, propõe desafiar a possibilidade dos gerentes poderem: 
controlar de alguma forma um sistema humano complexo, e argumentando que a maioria das intervenções gerenciais piora ainda mais as coisas, em vez de melhorá-las. A solução proposta traz o compromisso fundamental com o desenvolvimento de uma série de sofisticadas habilidades de aprendizagem individuais e coletivas que, em grande parte, estavam quase ausentes nas organizações tradicionais: alimentar a visão pessoal e construir visões genuinamente compartilhadas; o trabalho com uma diversidade de modelos mentais e com os conflitos que inevitavelmente surgem deles; e a compreensão das causas sistêmicas subjacentes a questões complexas e altamente independentes.

Como forma de "influenciar o impacto de longo prazo da organização que aprende" Senge (2000, p.17-8) desenvolve uma base de idéias procurando "fincar ferramentas intelectualmente desafiadoras": a idéia de maestria ou nível especial de proficiência, denominada como a disciplina do domínio pessoal; os modelos mentais a modificar, a visão compartilhada e a aprendizagem em equipe pela via do diálogo, considerando estes elementos como inevitáveis no desenvolvimento das organizações que aprendem. E a quinta disciplina, que nomeia sua obra, seria o pensamento sistêmico, a impor o desenvolvimento conjunto das disciplinas de aprendizagem acima enunciadas, levando a um "processo de aprendizagem progressivo que aumente continuamente a capacidade" acumulada. Esse autor explicita que como "todas as disciplinas são importantes, (....) uma fica limitada sem as outras". É através do pensamento sistêmico que se vai conseguir "ter um impacto significativo e mensurável sobre o desempenho, e (....) saltos na eficácia das equipes de trabalho" (p.25 e 27).

A seguir, apresentam-se alguns aspectos centrais e expressões de possíveis formas de operação das cinco disciplinas da organização que aprende, segundo Senge (2000):

1) Domínio pessoal. Como um perito artesão que "não controla a arte da cerâmica ou da tecelagem, as pessoas com alto nível de domínio pessoal conseguem concretizar os resultados mais importantes para elas". Pois, ao ver "a vida como um artista veria uma obra de arte, fazem isso se comprometendo (sic) com seu próprio aprendizado ao longo da vida". Através desta disciplina continuamente se esclarece e aprofunda a própria visão pessoal, permitindo concentrar as energias, desenvolver paciência e ver a 
realidade mais objetivamente. Essa disciplina é considerada o alicerce espiritual das organizações que aprendem. Através da sua lógica se reconhece que "a capacidade e o comprometimento de uma organização em aprender não podem ser maiores do que seus integrantes" (p.41).

2) Os modelos mentais predominantes são "altamente fragmentados e estáticos. Desde muito cedo as pessoas aprendem a desmembrar os problemas, a fragmentar o mundo". Muitos passam assim a vida inteira, frente a problemas complexos se concentrando na parte que conhecem mais e a "consertar os sintomas do problema, normalmente sem entender as causas mais profundas. É difícil perceber os limites de formas de pensar tão arraigadas" (p.27). Através dos seus modelos mentais as pessoas interagem com o mundo. Assim como "um olho não vê o outro olho", a entrada em um processo de aprendizagem que altere tais modelos desafia, desorienta e assusta, ao confrontar crenças arraigadas. Por isso, "não pode ser feita solitariamente. Só ocorre dentro de uma comunidade de aprendizes". Assim, também os "modelos mentais do que pode ou não ser feito em diferentes contextos gerenciais não são menos arraigados" (p.23). Peter Senge explica que "o trabalho com modelos mentais começa por virar o espelho para dentro, aprender a desenterrar as imagens internas" sobre o mundo, trazendo-as à tona e mantendo-as analisadas. Para isso é preciso estimular a capacidade de conversar sobre formas de aprendizagem, buscando equilibrar indagação e argumentação, criar oportunidades para as pessoas expor seus pensamentos e abrir-se a novas possibilidades derivadas da experiência de outros (p.42).

3) Na construção de uma visão compartilhada busca-se aglutinar as identidades através de projetos de interesse comum. Somente

"quando existe uma visão genuína (em oposição à famosa declaração de missão), as pessoas dão tudo de si e aprendem, não porque são obrigadas, mas porque querem. Porém, muitos líderes têm visões pessoais que nunca se traduzem nas visões compartilhadas que impulsionam uma organização. (....) O que falta é uma disciplina capaz de traduzir a visão individual em uma visão compartilhada - não um livro de receitas, mas um conjunto de princípios e práticas orientadoras" (p.43).

Através dessa prática procura-se desenvolver "habilidades de descobrir imagens de futuro compartilhadas que estimulem o compromisso genuíno e o envolvimento, em 
lugar da mera aceitação. Ao dominar essa disciplina, os líderes aprendem como é contraproducente tentar ditar uma visão" (ibid).

4) A prática do diálogo envolvida na aprendizagem em equipe. Se como costumava dizer Deming (apud Senge 2000, p.28), "sem teoria não há aprendizagem", também sem expressar os pressupostos, de forma que "outros possam entender e construir sobre eles, não haverá um processo maior para testá-los e, assim, construirmos um conhecimento público" (Senge, op cit). Nessa disciplina “(....) o grupo desenvolve capacidades excepcionais de ação coordenada. Quando as equipes realmente estão aprendendo, não só produzem resultados extraordinários como também seus integrantes crescem com maior rapidez do que ocorreria de outra forma" (ibid). Através do diálogo, as equipes de trabalho exercitam a capacidade de rever idéias preconcebidas e participam de um verdadeiro pensar em conjunto (p.43-4). A disciplina da "aprendizagem em equipe é vital, pois as equipes, e não os indivíduos, são a unidade de aprendizagem fundamental nas organizações modernas. Esse é um ponto crucial: se as equipes não tiverem capacidade de aprender, a organização não a terá" (p.44). As equipes excelentes não começaram assim, mas se fizeram assim, por aprender a produzir melhores resultados (p.39). Senge revela o maior interesse "na conexão entre aprendizagem pessoal e aprendizagem organizacional, nos compromissos recíprocos entre indivíduo e organização e no espírito especial de uma empresa composta de pessoas dispostas a aprender" (p.41-2).

5) Em sua representação da disciplina do pensamento sistêmico, Senge usa uma metáfora: "(....) céu escuro, folhas giram (....) vai chover. Pela manhã o céu estará claro outra vez. Todos esses eventos estão distantes no tempo e no espaço, mas estão conectados por um mesmo padrão. Um tem influência sobre o outro, (....) que, em geral, não é aparente. Só poderemos entender o sistema de uma tempestade contemplando o todo, não uma parte individual do padrão" (p.39). Através dessa forma de pensamento se compõe "um quadro de referência conceitual, um conjunto de conhecimentos e ferramentas (....) para esclarecer os padrões como um todo e ajudar a ver como modificá-los efetivamente" (p.40-1). 
$\mathrm{Na}$ ótica do pensamento sistêmico "é vital que as cinco disciplinas se desenvolvam como um conjunto. Isso é desafiador, pois é muito mais difícil integrar novas ferramentas do que simplesmente aplicá-las separadamente". Mas os resultados se têm revelado muito significativos segundo os especialistas. A quinta disciplina é a que "integra as outras, fundindo-as em um corpo coerente de teoria e prática. Impede-as de serem truques separados ou o mais recente modismo para mudança organizacional. Sem uma orientação sistêmica, não há motivação para analisar as inter-relações entre as disciplinas" (Senge 2000, p.45). Para este autor, o pensamento sistêmico existe através do conjunto das disciplinas de visão compartilhada, modelos mentais, aprendizagem em equipe e domínio pessoal:

Construir uma visão compartilhada estimula o compromisso com o longo prazo. Os modelos mentais concentram-se na abertura necessária para revelar as limitações em nossas formas atuais de ver o mundo. A aprendizagem em equipe desenvolve a habilidade dos grupos de buscarem uma visão do quadro como um todo, (o) que está além das perspectivas individuais. E o domínio pessoal estimula a motivação pessoal de aprender continuamente como nossas ações afetam nosso mundo. Sem o domínio pessoal, as pessoas ficam tão envolvidas na mentalidade reativa (alguém/alguma coisa está criando meus problemas) que se sentem profundamente ameaçadas pela perspectiva sistêmica (Senge, p.46).

Poder-se-ia pensar até na possibilidade de uma sexta disciplina, relacionada com a existência da necessidade de um esforço sustentado. Senge (2000) considera relativamente fácil as pessoas se interessarem por novas idéias como pensamento sistêmico e modelos mentais. Todavia, sustentar o esforço na prática das disciplinas é outra questão. Especialmente ao se considerar que a prática é contínua e para sempre. "Na construção de organizações que aprendem não existe lá, não existe um destino final, apenas uma jornada infinita" (p.24). Essa concepção é difícil de ser incorporada pela cultura ocidental, sempre voltada para alcançar objetivos. "Não tanto para as culturas orientais. Em chinês, aprender significa literalmente estudar e praticar constantemente" (p.25). Assim também "praticar uma disciplina é ser um eterno aprendiz. Nunca se chega a um lugar, passa-se a vida aprimorando disciplinas. Jamais podemos dizer somos uma organização que aprende, da mesma forma que não podemos dizer sou uma pessoa iluminada". A idéia é encontrar-se sempre em "estado de praticar as disciplinas de aprendizagem" (p.44). 
As cinco disciplinas das organizações em aprendizagem são consideradas por Senge como novas "tecnologias componentes" (em inglês component technologies, significam as ferramentas que fazem parte da inovação, não sendo necessariamente técnicas), que convergem gradualmente. "Embora desenvolvidas em separado, cada uma delas (....) será essencial para o sucesso das outras, como ocorre em qualquer conjunto. Cada uma proporciona uma dimensão vital na construção de organizações realmente capazes de aprender, de ampliar continuamente sua capacidade de realizar suas mais altas aspirações" (Senge 2000, p.39).

A concepção de organizações que aprendem aplica-se a "organizações nas quais as pessoas expandem continuamente sua capacidade de criar os resultados que realmente desejam, onde se estimulam padrões de pensamento novos e abrangentes, aspiração coletiva ganha liberdade e onde as pessoas aprendem continuamente a aprender juntas" (Senge 2000, p.38). A aprendizagem toca no coração do que significa ser humano. Por essa via a pessoa se torna capaz de fazer algo que antes não fazia e percebe novamente o mundo e sua relação com ele. Amplia-se a própria "capacidade de criar, de fazer parte do processo gerativo da vida" (p.47).

Uma organização que aprende tem por significado básico estar "continuamente expandindo sua capacidade de criar seu futuro", ou seja, "não basta apenas sobreviver". Como também não basta uma aprendizagem adaptativa, mas esta deve somar-se à aprendizagem generativa, através da qual se amplia a capacidade criativa dos participantes do processo (Senge 2000, p.47-8).

Segundo Paulo Freire em sua pedagogia do oprimido (citado por Brandão 1985, p.19), "a realidade deve ser decifrada e reinterpretada a cada momento. Nesse sentido, a verdadeira educação é um ato dinâmico e permanente de conhecimento centrado na descoberta, análise e transformação da realidade pelos que a vivem”. Pois, é no trabalho em estreita ligação com os trabalhadores, que podem ser geradas possibilidades "com vistas a construir com o grupo e a partir da situação vivida pelo grupo, um conhecimento da realidade que conduza à identificação dos meios para superar a situação" (Brandão, op cit, p.20-21). 
A teoria organizacional, desde Weber, é explicativa do espaço organizacional; e, do movimento organizacional desde a incorporação da teoria dos sistemas abertos pela administração. Como decorrência, a sua abertura para o ambiente externo de mudanças informa suas concepções estratégicas de flexibilização e inovação. E prossegue continuamente se renovando através de pesquisas exploratórias sobre a potencialidade de seus próprios achados e formulando normativamente o desenho de novos aportes informados pelas produções teórico-práticas do mundo organizacional. Como ilustração desse fato, no estudo das metas organizacionais, para a prática de sua fixação e implementação, além das contribuições teóricas há que se recorrer ademais, como diz Ansoff (1990, p.28) “a uma espécie de arte de aprender fazendo". Assim como, também, o caráter de dominação da autoridade não é mais adequado ao momento atual, em que a organização democrática da sociedade clama por mais participação e legitimidade (Pinchot e Pinchot 1995).

\subsection{Objetivos}

\subsubsection{Objetivo Geral}

Em relação às concepções de integralidade em saúde, apreender teórica e empiricamente princípios, mecanismos e desenhos organizacionais que possam contribuir para operacionalização dessa diretriz, à luz de proposições de modelos de atenção inseridos em práticas municipais.

\subsubsection{Objetivos Específicos}

1) Reconstruir a noção de integralidade em saúde conforme publicações nacionais especializadas. 
2) Apreender na dimensão política de instituição do modelo de atenção à saúde o conteúdo ético-normativo das proposições de integralidade em saúde.

3) Caracterizar empiricamente objetos e instrumentos de trabalho utilizados na prestação das ações em serviços locais de saúde comprometidos com a integralidade em saúde.

4) Dimensionar o plano organizacional-gerencial implicado no movimento de mudança do modelo de atenção no âmbito de sistemas municipais de saúde.

5) Discutir teoricamente conceitos-chave, princípios organizacionais e categorias da organização local de serviços de saúde, com potencial transformador das suas práticas na perspectiva da integralidade da atenção. 


\title{
2 RECUPERAÇÃO BIBLIOGRÁFICA
}

\section{DA INTEGRALIDADE EM SAÚDE}

\begin{abstract}
As mais diferentes formas de expressão a respeito da noção de integralidade em saúde percebidas nas leituras exploratórias do projeto de tese revelaram quase uma panacéia, o que derivou a necessidade de iniciar a pesquisa por uma sistematização da recuperação secundária do entendimento deste objeto, como aparece na literatura especializada, no sentido da sua reconstrução conceitual.
\end{abstract}

A pesquisa bibliográfica permitiu também identificar, ao trazer contidas em si, as relações implicadas da integralidade com a questão organizacional. Pois, as referências sobre esse objeto geralmente abordam as condições organizacionais necessárias à sua operacionalização.

Segundo a afirmação de Castellanos (1993, p.17), de que, “definitivamente, um marco teórico não é mais que o perfil do objeto de estudo", o presente capítulo pode também ser considerado quadro teórico da tese, que complementa a fundamentação apresentada no capítulo anterior.

\subsection{Antecedentes Histórico-Conceituais}

A concepção de integralidade em saúde não é coisa nova. A primeira noção mais associada à idéia de integralidade é o coletivo, ou seja, a dimensão coletiva das práticas de saúde enquanto objeto de trabalho, pois, as concepções de saúde e da organização da intervenção sobre esse objeto têm uma dimensão coletiva desde a sua origem. 


\subsubsection{Antecedentes Externos da Integração em Saúde}

Por referência à teoria situacional de Matus (1993), e de acordo com sua afirmação apoiada em Ortega \& Gasset de que "a história está viva na situação presente", inclusive reconhecendo que "atua-se apenas no presente", a compreensão dos antecedentes aqui recuperados por referências ao velho e novo mundo no Ocidente, assume maior importância por suas expressões nas práticas atuais de aproximação à noção de integralidade em saúde, conforme apresentado no presente estudo.

\section{No espaço da política médica}

Os antecedentes desta primeira retrospecção remontam a citações referidas ao final do século 18 e início do 19, situadas na Europa dentro dos limites da prática e da teoria da época. Naquele contexto caracterizam-se as origens ocidentais do caráter estatal e coletivo do objeto de intervenção na saúde, assim como uma abrangência da sua atuação sobre a manutenção e o controle das condições de vida e saúde da população. Trata-se das concepções mais antigas identificadas no levantamento bibliográfico, por aproximação à noção pesquisada, explicitamente nomeando uma das expressões da idéia de integralidade.

No século 18 ainda dominavam as antigas “concepções hipocráticas (....) de equilíbrio entre os elementos substanciais (águas, ares e lugares) determinando a saúde ou a doença”, o que caracterizava uma concepção globalizante do processo, apesar da relativa obscuridade dos objetos de intervenção. Desde então acoplada aos acontecimentos econômicos e políticos, no final daquele século a medicina passou por um "processo de rápidas transformações, classificadas por alguns autores como de crises do velho saber" (Novaes 1988, p.86-7).

Segundo Rosen (1994, p.116), nos estados alemães do início do século 19, é divulgado um sistema de uma 'política médica integral' (System einer vollständigen medicinischen Polizey), formulado por Johann Peter Frank (em 1779 a $1^{\text {a }}$ edição e 1817 a $6^{\mathrm{a}}$ e última), basicamente referido à responsabilidade do Estado sobre a saúde coletiva. $\mathrm{Na}$ idéia de uma política médica, nem sempre referida com seu qualificativo de 
“integral”, as vertentes da ação individual e do controle social (*) se manifestam através da "consciência da necessidade da intervenção do governo na saúde pública", encarnada de forma sistemática na Alemanha, por sua ciência da política médica. Esta denominação passa a ser mais utilizada na literatura como "polícia médica", sendo que por referência ao levantamento bibliográfico realizado, somente na obra citada de Rosen é utilizada a expressão "política médica". As raízes do acima referido trabalho de Frank situam-se no sistema político, econômico e social do absolutismo esclarecido. Esse movimento é captado nos estudos de Rosen, revelando que desde os séculos 17 e 18, a partir da questão populacional, se organizava e codificava um saber médico estatal (Mendes-Gonçalves 1994, p.70-71).

Na discussão das idéias e práticas que demonstram a importância da medicina para a política do Estado, conforme consubstanciado na noção de polícia médica, que segundo Donnangelo (1976, p.50) já havia sido enunciada por Thomas Rau em 1764, essa noção trazia como princípios que: “o Estado deve zelar pela saúde da população; os médicos são responsáveis não apenas pelo tratamento dos doentes, mas também pelo controle e manutenção da saúde da população; esse controle deve atingir todos os aspectos da vida dos indivíduos". Assim a polícia médica se configura como uma forma de articulação da prática médica com as estratégias políticas e econômicas da época.

Do interesse pela política médica integral e na tentativa de colocá-la em prática, derivase um 'código integral de leis' instituído para "coordenar todos os aspectos da saúde, destinados não apenas a manter, mas, também, a promover a saúde”. Assim a expressão também contém uma dimensão de integração de ações de prevenção e cura. Este código foi formulado por F. Anton Mai, médico e humanitário, e apresentado ao governo em 1800, o que veio difundir a idéia origem da política médica. Sua proposta não se realizou por causa de condições políticas inadequadas, dos alarmes e incursões de guerras e por ineficiência do governo dos Estados germânicos naquele contexto (Rosen 1994, p.136).

(*) O controle social em suas concepções originais aqui referidas é aquele exercido pelo Estado sobre a população. Diferente, portanto, das concepções assumidas no SUS brasileiro, referentes às instâncias de controle social da população sobre o sistema público de saúde, conforme a Constituição Federal de 1988. 
As idéias de uma política médica integral nos estados alemães tornaram-se bastante conhecidas. Sua influência tem desdobramentos nitidamente na França, o que permite esboçar um movimento europeu da política médica, efetivando-se medidas diferenciadas nas diversas sociedades da época. Fora da Alemanha, esse "conceito é despojado de seu sentido de amplo controle pelo poder político sobre as condições de vida das populações e sobre a própria prática médica", restringindo-se a intervenções de saneamento ambiental e controle de doenças transmissíveis. Inclusive posteriormente, na própria Alemanha de Bismarck em 1880, com a implantação do seguro-social compulsório, generaliza-se o cuidado médico a partir da assistência a algumas categorias de trabalhadores (Donnangelo 1976, p.52).

De todas as maneiras, as noções derivadas da "medicinischen polizey" alemã estavam divulgadas e até hoje são referidas, por sua importância histórica na constituição das práticas de saúde no ocidente. Segundo Donnangelo (1976, p.51), Foucault designa tal modalidade de redefinição social da prática médica na Alemanha por medicina de Estado, assim sintetizada: "O que se encontra antes da grande medicina clínica do século XIX é uma medicina estatizada ao máximo".

As referências à polícia médica alemã, em sua versão francesa constituíram-se na 'medicina do espaço social', segundo aponta Mendes-Gonçalves (1994, p.72) apoiado em indicações de Foucault. No início do século 19 a França pós-revolução estava alinhada com "projetos na direção do mito da sociedade desmedicalizada, porque devolvida à sua saúde de origem”. Havia uma concepção anterior de saúde como um bem original na vida. Partindo da questão populacional, desenvolvera-se uma forma de saber, contido nas prescrições normativas, que Rosen (apud Mendes-Gonçalves) classifica claramente como formulação de uma 'política de saúde coerente e integral'. Em seu contexto de origem essa concepção se colocava no sentido de opor-se ao saber e às práticas anteriores relacionadas à medicina das espécies patológicas.

Observa-se nos enunciados acima que tais práticas de saúde se organizavam então sobre a dimensão coletiva do seu objeto. Como também, caracterizava-se a dimensão política estatal de uma responsabilidade abrangente preocupada com a manutenção e controle da 
saúde e condições de vida da população, principal questão a reter dos antecedentes ora apresentados.

\section{A medicina social}

As idéias de política médica representaram no século 19, “o início de um processo de formulação sistemática das relações entre saúde e condições de vida social (....), ao mesmo tempo em que articulavam as práticas de saúde aos projetos de reorganização social". Todavia, é no desenvolvimento do conceito de medicina social que se expressa de forma mais elaborada essa temática. Agora por referência a uma outra realidade, "relativamente distinta da que fundamenta o desenvolvimento das práticas e conceitos anteriores, na medida em que expressa a forma pela qual se desenvolveu a luta política e a questão social" após a Revolução Francesa (Donnangelo 1976, p.53). Conforme demonstra Mendes-Gonçalves (1994, p.106), foi somente a partir do século 19 que se deram "nas instituições (....) médicas e no aparelho de Estado, uma relação explícita entre saúde e sociedade".

Segundo Donnangelo (op cit), o 'vínculo entre saúde, medicina e sociedade’ é afirmado durante toda a primeira metade do século 19, daí surgindo o termo medicina social, forjado por Jules Guérin, em 1848, condensando todo esse longo processo de elaboração. Naquela concepção de medicina social estão contidos os componentes: "análise dos problemas sociais e de sua relação com a saúde e a doença; determinação de medidas para a promoção da saúde e a prevenção de doenças"; e inclusive, a medicina como "terapia social", através do 'fornecimento de meios médicos e outros meios para tratar com a desintegração social'. Ainda a "politização do campo médico se expressa na temática da medicina social e na incorporação da prática a projetos de reorganização coletiva", articulando-se as idéias de medicina com reforma social (p.57).

As práticas de saúde enquanto práticas voltadas para a sociedade tiveram originalmente seus "modelos de organização (....) estruturados sobre concepções a respeito da natureza da saúde e da doença de alcance supra-individual". É este saber que permite uma reorganização das práticas de saúde decorrente primeiramente da configuração das necessidades identificadas, o que traz um significado inteiramente 
novo assumido pela 'dimensão coletiva de expressão da saúde e da doença'. Foi também a concepção já estruturada sobre o coletivo a respeito da doença, que se constituiu em instrumento tecnológico de estruturação da medicina social européia (Mendes-Gonçalves 1994, p.105-6).

A importância de se analisar mais profundamente as relações que há entre a democracia e a saúde, na história e na política, são apontadas por Berlinguer (1989, p.62), ao evidenciar não ser uma casualidade que a medicina social na Europa, como depois veio ocorrer em outros lugares, tenha nascido em período de grande 'evolução democrática', 1848. Surge assim no seio de uma coalizão de interesses antifeudais; exprimindo a emergência da consciência política do proletariado. É nessa conjuntura que se tem uma relativa reorganização e radicalização de todo aquele movimento anterior da medicina social. Por outro lado é também este momento histórico que vai assinalar, no mesmo tempo, "o seu fim temporário e o nascimento do sanitarismo e da epidemiologia” (Mendes-Gonçalves 1994, p.75).

A medicina social enquanto tal, em qualquer continente, esteve sempre voltada para uma atuação sobre causas sociais, em um movimento contra-hegemônico desde a sua origem. E como já referido na Europa, com a descoberta dos elos epidemiológicobacteriológicos das doenças de massa e pestes, coerentemente com os novos saberes clínicos se desenvolvendo e instituindo, é a epidemiologia que, ao passar a instrumentar tanto a medicina social, virá a suplantá-la rapidamente.

Com a derrota do movimento revolucionário de 1848, primeiro na França e depois na Alemanha, “(....) terminou rapidamente o movimento de reforma médica (....). Nas décadas seguintes, o amplo programa de reforma da saúde transformou-se em um programa mais limitado de reforma sanitária (reduzida ao) que era praticamente viável” (Rosené apud Donnangelo 1976, p.60-1).

\section{Entre o sanitarismo e concepções higienistas}

As novas condições de vida urbana características do industrialismo do início do século 20, traziam a necessidade de outras formas de intervenção, que inicialmente se 
expressaram no que Donnangelo (1976) designa por "medicalização do ambiente", assim entendido o sanitarismo em sentido restrito. $\mathrm{Na}$ Inglaterra, frente a um novo tipo de pobreza caracterizada pelo proletariado industrial de então e que concentrava um aumento efetivo de indivíduos sem assistência, impõe-se a "necessidade de controlar, por razões econômicas e políticas a ação dos fatores que acarretam os elevados índices de enfermidade e de morte", o que assume então a forma predominante do sanitarismo, com a adoção de medidas capazes de atingir coletivamente a população. Nesse contexto o "Estado Inglês, (....) já garantira a presença de uma rede (....) de medicalização" representada, tanto pelo cuidado do pobre, como pela "implantação de medidas gerais de controle do ambiente, (....) das doenças transmissíveis e das epidemias" (p.67-8).

Segundo Mendes (1993a, p.10) o que ele denomina como o paradigma sanitário do sanitarismo (sic) derivou-se do desenvolvimento da microbiologia e sua correspondente concepção mono-causal das doenças.

Independentemente da "ausência de conhecimentos sobre a dimensão individual (....) capazes de instrumentalizar a prática clínica" na época, de forma assentada em técnicas materiais de diagnóstico e de terapêutica capazes de traduzir o conhecimento do corpo anátomo-fisiológico enquanto sede dos processos da doença, segundo MendesGonçalves (1994, p.105), mesmo assim é inegável que a primeira medicina do capitalismo teve um caráter social, pela condição socialmente referida das novas concepções operantes da medicina - de Estado, a "medicina urbana", frente a industrialização da sociedade. Como também, a partir de então o sanitarismo se explica "pela natureza das necessidades a que sua presença respondia, e pela natureza dos conhecimentos anteriores de que partia”. Assim sendo, o coletivo está presente desde as primeiras caracterizações possíveis de uma "medicina” no capitalismo, que tinham um cunho de intervenção social sobre o coletivo. Sua organização, para combater as epidemias, foi capaz de criar condições de salubridade adequadas àquela sociedade européia durante todo o século 19.

Sob as denominações recuperadas por Mendes-Gonçalves (ibid) de 'polícia médica, higiene social, medicina do espaço urbano', estavam contidas as diversas 
particularidades de um "mesmo amplo movimento comum de adaptação do saber e da prática à realidade nova". No capitalismo industrial, a medicina tem uma “especificidade histórica precisa: constituir para a prática um modo de intervenção que atenda às funções renovadas por desempenhar" naquele respectivo contexto econômico e social, onde se carecia de homens e braços aptos às demandas do novo mercado de trabalho.

De acordo com Mendes-Gonçalves (1994, p.73), "à medida que a urbanização, o aprofundamento da divisão social do trabalho, o aumento da dependência entre as nações e entre as diversas esferas da atividade humana caracterizavam a nova estrutura social como apresentando um grau mais complexo de socialização", naquela situação as 'práticas de saúde tornavam-se sociais' na medida em que assumiam objetos "explicitamente sociais como o meio, a cidade, a cultura e os comportamentos, os hábitos".

Após o nascimento da clínica, cujo desenvolvimento muito ajudou - e vai continuar ajudando - a resolver os problemas de doença nos corpos humanos, em sua dimensão individual, impossível pensar qualquer integralidade em saúde sem a participação da clínica. E mais, uma clínica diferenciada, a compô-la. Mas a história marcou seu próprio rumo.

No início do século 20, ao mesmo tempo em que se expressa no novo mundo a imposição das especializações médicas para as mais diversas intervenções sobre o corpo do indivíduo, a dimensão coletiva do lidar com a saúde também encontra ainda alguma expressão revelada em dois movimentos rapidamente secundarizados: a medicina social americana e as concepções higienistas norte-americanas. Segundo Nemes (1995, p.09, citando Ayres 1995), a 'integração médico-sanitária' já era defendida por Winslow, em 1926, cuja produção influenciou o sanitarismo norte-americano.

Foi naquele mesmo contexto histórico que, na Universidade Johns Hopkins, "tendo como base os avanços científicos da higiene e da medicina científica", formulou-se ' $a$ proposta dos centros de saúde' que se articulava com o 'modelo de saúde pública', ocupando-se da "higiene das cidades e do controle das epidemias por meio de obras e 
imunizações" (Silva 1998, p.56). Este mesmo autor cita também “a proposta de Hermann Biggs, comissário de saúde pública do Estado de Nova York, que articulava serviços comunitários de saúde com os demais recursos da comunidade, integrando-se serviços preventivos, curativos e sociais" (p.55).

Após 1910, com o advento da Reforma Flexner nos Estados Unidos da América, quando se criou o hospital de ensino, equivalente ao universitário (HU no Brasil), começa a ganhar corpo uma "abordagem fragmentada e parcial do indivíduo, desvinculado do seu contexto psicossocial" (Rodriguez Neto 1996, p.7). O desenvolvimento precário das atividades preventivas e o crescimento da medicina flexneriana no âmbito privado, atraindo a demanda daqueles que ascendiam economicamente na sociedade, levaram a um esvaziamento da proposta dos centros de saúde nos EUA (Silva 1998, p.55).

$\mathrm{Na}$ Inglaterra, a separação entre a medicina preventiva e curativa era criticada por Dawson, que propunha uma 'atuação coordenada por meio de médicos generalistas', capazes de atuar sobre os indivíduos e sobre as comunidades. Essa proposta foi implantada pelo Plano Beveridge, a partir da década de 1940 (Silva 1998, p.54).

A própria história natural da doença, formulada por Leavell e Clark (1976) na década de 1940, fundamentou a organização de uma medicina preventiva, apoiada na concepção de um sistema articulado e hierarquizado em níveis primário, secundário e terciário da atenção.

\section{Na emergência de projetos alternativos de prática médica}

Após a segunda grande guerra, novamente se estruturam tentativas de "modelos de organização de práticas de saúde (....) voltadas para a sociedade", no sentido de tornálas capaz de responder a necessidades socialmente postas (Mendes-Gonçalves 1994, p.105).

A crítica do caráter especializado e fragmentário assumido pelo ato médico tem praticamente dominado a literatura acerca da organização social da assistência médica 
na segunda metade do século 20, o que segundo Donnangelo (1976, p.77) revela, para além da perspectiva técnica ou doutrinária em que possam se situar os diferentes autores, a penetração do campo médico pelo social, apesar das diferentes concepções desse social.

Segundo Donnangelo (1976, p.79), os projetos da medicina integral, medicina preventiva e medicina comunitária, estão situados entre os "esquemas menos radicais de reforma médica. Correspondendo à busca de racionalização da prática médica por meio da manipulação de aspectos parciais da estrutura de produção de serviços implicam, ao mesmo tempo, uma tentativa de 'integração do social à prática', através de modalidades consistentes com os limites da reforma que se propõe realizar".

Uma compreensão dos movimentos da medicina integral e preventiva permite indicar as estratégias internas à prática médica, em relação às quais se coloca a medicina comunitária. Nas décadas de 40 e 50 esses movimentos adquirem impulso radicando-se nos mesmos processos que deram origem às políticas estatais de saúde. $\mathrm{O}$ foco de inflexão e interferência da medicina integral e preventiva está basicamente situado na recomposição de elementos internos à prática, sendo "o ato médico individual o momento no interior do qual a medicina poderá a um só tempo corrigir deficiências técnicas e incorporar a dimensão social que se manifesta por via da enfermidade". Assim o conceito de 'medicina integral' explicita o confronto existente entre o caráter fragmentário do trabalho médico e a possibilidade de uma "concepção globalizadora do objeto individual da prática - totalidade bio-psico-social”, que não pode ser reduzida a um conjunto de estruturas e funções orgânicas (Donnangelo 1976, p.79).

A autora acima citada caracteriza a fragmentação do ato médico em duas dimensões: a do objeto individual, alvo das interferências parciais do especialista; e outra do processo da doença, recortado em ações terapêuticas e preventivas, que retiram o “caráter de temporalidade e o campo ecológico e social de constituição do processo saúde-doença”. Para uma recomposição do sentido totalizador da prática, vai implicar então no "descentramento do enfoque biológico e na correspondente orientação de cada ato médico no sentido de apreender e interferir com a complexidade do paciente dada por sua inclusão em um campo de relações onde a família aparecerá como unidade 
fundamental". Como também na consideração do 'conjunto de fatores que concorrem para a emergência da enfermidade', e da sua 'interação', para que 'a interferência se oriente para 'momentos precoces do processo saúde-doença', antecipando-se, sempre que possível, à necessidade do recurso a ações curativas” (Donnangelo 1976, p.79-80).

Assim sendo, seus princípios e estratégias dirigidas à recomposição da prática vão se compondo de forma progressiva e envolvem a superposição dos campos da medicina integral e da medicina preventiva. Pois, conforme Donnangelo (1976, p.80):

Incorporando ao processo de trabalho os princípios referentes ao indivíduo e às suas relações com o meio, bem como o correspondente reconhecimento de que a doença constitui o momento de um processo que envolve a interação de um conjunto de agentes naturais e sociais', o médico superará, pelo estabelecimento de 'novas relações com o indivíduo, a família e a comunidade', as deficiências resultantes do caráter fragmentário de sua prática, assegurando que a acumulação dos atos médicos, assim corrigidos, modifique a totalidade da atenção médica e das necessidades de saúde.

Foi no espaço da educação médica americana que desde 1950 "os efeitos da radical separação entre saúde pública e atenção médica, respectivamente a cargo do Estado e do setor privado, começaram a ser questionados, constituindo-se o solo para o desenvolvimento da medicina integral e, conseqüentemente, para a institucionalização do ensino da medicina preventiva nas escolas médicas". Por isso pode-se perceber nesses movimentos uma tendência em reduzir os focos de problematização da assistência a "desequilíbrios na área da educação médica resultantes do crescimento científico muito acelerado" (Donnangelo 1976, p.81).

A emergência da medicina comunitária deu-se nas sociedades capitalistas e seu "significado pode ser apreendido a partir do sentido mais amplo que adquire a política social" frente às dificuldades daquelas sociedades conseguirem responder às crescentes necessidades de saúde da população. Pois, o fato da generalização do consumo médico não se ter efetivado igualmente em todas as sociedades capitalistas se constituiu no ponto de referência inicial para a "delimitação do campo da medicina comunitária, dado que ela deverá tomar como objeto, por excelência, categorias sociais até então excluídas 
do processo de medicalização". Considera, portanto, a extensão da medicina sob a forma de serviço individual como o primeiro elemento característico de seu campo (Donnangelo 1976, p.71). Acompanhando essa autora, retoma-se sua identificação da especificidade da medicina comunitária enquanto "forma de organização de serviços e como dimensão particular da política social", em suas relações com as noções ora pesquisadas como constitutivas parcelares das idéias de integralidade em saúde.

A estruturação de práticas da medicina comunitária vai implicar no "reforço substancial de um elemento que não é estranho à organização geral da prática contemporânea: o uso do trabalho auxiliar de outras categorias profissionais", passando a constituir-se o que se pode designar por 'trabalhador médico coletivo'. Assim sendo, através de um processo de distribuição de tarefas, configura-se que 'o cuidado se resolve através de um conjunto de práticas complementares' (Donnangelo 1976, p.71-2). A medicina comunitária também se caracterizou pela "emergência, de um lado, de uma medicina tecnologicamente simplificada, por referência à prática médica dominante, e ao mesmo tempo ampliada, de respeito às funções sociais a que serve de suporte”. Existe aí um duplo movimento no sentido da simplificação e do 'alargamento do campo de interferência da prática' pela via da constituição do trabalhador coletivo da medicina. Nessa perspectiva específica a medicina comunitária assume um caráter equivalente a uma medicina simplificada, e inclusive a uma modalidade particular de serviço social (ibid).

E ainda em outra dimensão, tais "propostas incidem sobre o princípio da participação comunitária como forma de superação dos problemas sociais identificados e formalizados através desse específico aparato conceitual”. Em decorrência tem-se que a extensão de serviços médicos, através de uma "simplificação-ampliação das técnicas em jogo, com a participação da comunidade, são os termos que compõem basicamente o campo da medicina comunitária" (Donnangelo 1976, p.72-3).

A proposta de medicina comunitária veio na década de 1960, ocupar espaços deixados pelo processo de medicalização. Não se trata de um novo campo conceitual frente a uma nova problemática, mas em uma estratégia de prestação de serviços à população, pautada em "princípios já elaborados no interior das (....) propostas da medicina integral 
e medicina preventiva" (Donnangelo 1976, p.75). Em suas origens estadunidenses a prática da medicina comunitária pode ser confundida "com um movimento que transcendeu os limites da atenção médica e orientou a política social norte-americana, na década de 1960, para programas assistenciais destinados à pobreza” (p.88). Todavia, ainda segundo a mesma autora, os "programas de medicina comunitária norte-americana não chegaram a atingir expressão quantitativa" e já se encontravam em declínio nos meados da década de 1970 (p.91).

Em 1976 Donnangelo já afirmava ser bastante provável, mantendo-se as características de então na estrutura de poder na sociedade americana, que "qualquer interferência no setor saúde só se verifique através de modalidades que não obstaculizem a aplicação e os níveis de rentabilidade dos capitais privados no setor”. Aí se incluem as formas de financiamento da 'assistência médica a grupos sociais suficientemente descaracterizados como consumidores potenciais' pela via da compra direta através de projetos da medicina comunitária ou buscando a 'incorporação da assistência médica individual na estrutura da saúde pública' americana. Nesse contexto a medicina comunitária agrega uma nova dimensão aos projetos anteriores: 'prestação de serviços a categorias excluidas do cuidado médico'. Daí sua característica básica de emergir como forma paralela à organização predominante da assistência médica (p.84-5). Essas idéias vão inspirar práticas inclusive na composição do campo da saúde coletiva.

A crise da medicina flexneriana foi declarada em 1970 nos Estados Unidos pelo chamado Relatório Carnegie, que propunha mudanças no ensino de medicina, como a 'integração docente-assistencial' e outras: “expansão e aceleramento da formação de pessoal auxiliar e técnico, integração de matérias básicas e profissionalizantes, e estruturação de planos nacionais de saúde" (Silva 1998, p.57).

Nesse contexto é que a medicina comunitária enquanto prática e forma de prestação de serviços, antes mesmo de constituir um campo sistematizado de princípios, originou-se nos Estados Unidos e daí se difundiu para as "sociedades dependentes com o suporte das agências internacionais" (especialmente a OMS/OPS - Organização Mundial de Saúde/Organização Panamericana da Saúde). Tais projetos se implementam na década de 1970, derivando programas experimentais de prestação de serviços com o propósito 
de desenvolver "modelos de assistência passíveis de garantir a extensão do cuidado à saúde a populações pobres, urbanas e rurais" (Donnangelo 1976, p.85).

Conforme evidenciou Donnangelo (1976, p.31), os estudos da época sobre a organização da prática médica, sempre se referiam notadamente a uma expansão da produção de serviços, assim como à generalização do consumo por contingentes sempre mais amplos da população. Como também, identificam nessa generalização um "papel central desempenhado pelo Estado, quer o analisem como expressão da representatividade, ao nível do Estado, de interesses comuns à coletividade social, quer o identifiquem com o desempenho da função de reprodução das classes sociais".

As reproduções das propostas da medicina comunitária sempre estiveram marcadas por experiências esparsas, mas também recorrentemente renovadas em diferentes contextos políticos específicos, sendo que inclusive pôde-se recentemente identificar sua revalorização no Canadá. Este fato inclusive ficou constatado em experiências apresentadas durante o $3^{\circ}$ Congresso de Secretários Municipais de Saúde das Américas realizado em Quebec de 13 a 16 de março do ano 2000. Todavia, como já evidenciava Rosen (1994, p. 6-7) estas propostas aparecem sempre vinculadas a um projeto pedagógico na formação médica e não como reforma direta das práticas. Mais recentemente, de forma articulada às proposições relacionadas à saúde da família, essa questão pode estar se modificando, o que será discutido posteriormente (item 2.3.4).

No espaço do projeto da medicina comunitária, Donnangelo (1976, p.86) constata a “inadequação da prática médica para atender às necessidades de saúde das populações, necessidades que devem ser solucionadas tanto como resposta ao princípio do direito à saúde como por sua significação para o processo de desenvolvimento social”. Dado o alcance do campo de problemas sugere a 'subordinação da prática à dimensão social do processo saúde-doença', o que impõe a 'superação do corte entre aspectos orgânicos e psico-sociais, entre condutas preventivas e curativas, entre prática individual e efeitos coletivos da atenção à saúde’. Ao localizar “os elementos responsáveis pela inadequação não apenas nos aspectos internos ao ato médico individual, mas sobretudo em aspectos organizacionais da estrutura de atenção médica”, a autora acima citada propõe que sua superação se dê via novos modelos de organização 
com base no 'cuidado dos grupos sociais, antes que dos individuos'. Pois insuficiente seria voltar-se apenas para a reformulação do ato médico, sem conseguir uma "nova articulação do conjunto de (....) práticas que compõem o campo da atenção à saúde". Nesse sentido indica a permanência do princípio da medicina integral para orientar a prática, mas de forma que suas estratégias se desloquem do ato médico individual e do médico como agente privilegiado de recomposição, para uma busca de 'novos modelos de organização cujo alvo seja a coletividade’. Nessa perspectiva a proposta da medicina comunitária incorpora a "experimentação de modelos, mais do que um modelo organizacional específico", mantendo-se a imposição inicial da "prestação de serviços sob a forma de mais numerosos ou de novos serviços" (Donnangelo 1976, p.87).

Ao sintetizar pontos de referência para análise da medicina comunitária, Donnangelo (1976, p.94) reitera a "especificidade da própria forma de inserção de seu objeto no conjunto das relações de produção. (....) Representando um projeto de extensão da assistência médica a categorias sociais cuja significação é sobretudo política, e cuja produtividade não impõe o recurso a formas determinadas de cuidado, a medicina comunitária" veio configurar uma nova modalidade de organização interna da prática, pretendendo "compatibilizar o aumento do consumo de serviços e a questão dos custos médicos". Coloca-se então "como prática médica alternativa frente a outras modalidades de prática que tomam como objeto distintas categorias sociais, revelando um aspecto da diferenciação interna ao campo médico articulado à estrutura da produção".

\subsubsection{No Brasil do Sanitarismo à Integração Assistencial}

Sob influências do modelo norte-americano, pôde-se identificar indícios de uma concepção inicial de medicina social no Brasil, com a idéia precursora de programas de reforma social, desenvolvidos através de uma consciência mais crítica inicialmente relacionada apenas ao sanitarismo, que se materializava sobretudo em noções de higiene e saneamento. A partir dessa inspiração no século 19, através de discretas aproximações a uma medicina social pretendida, propunha-se então "um conjunto de práticas que, tomando a doença em sua dimensão social, como instrumento de trabalho, 
configurou-se na polícia sanitária, na higiene pública, no controle das doenças epidêmicas" (Mendes-Gonçalves 1994, p.107).

Aqui se trata de outro circuito de referências, situadas no Brasil do início do século 20, através do qual este estudo identifica um contexto em que se configura o que MendesGonçalves (1994) classificou como o primeiro movimento da organização das práticas de saúde em São Paulo, e que ajuda a pensar o movimento correlato no Brasil da época, para informar suas relações embrionárias com componentes parciais necessários para a construção de uma noção da integração das ações de saúde: a 'polícia sanitária' (notificação, vacinação, vigilância sanitária, obras públicas) e as 'campanhas', que revelavam um caráter absolutamente vertical e autoritário da saúde pública no país, onde era coletivo o objeto, mas a atuação era somente corretiva, para evitar o contágio. Apesar da semelhança lingüística não se pode considerar esta polícia sanitária brasileira descendente direta da política ou polícia médica "integral" européia de um século antes. Pois somente manteve aspectos muito reduzidos daquela concepção anterior muito mais abrangente.

Em São Paulo, o estudo de Mendes-Gonçalves (1994) caracteriza como modelo tecnológico de uma primeira fase da saúde pública, que se implanta com a necessária rapidez e já dotado de alta efetividade, 'as campanhas e a polícia sanitária', cujas adaptações temporais foram inspiradoras dos tradicionais programas verticais de controle de doenças no país. "Esse primeiro modelo tecnológico baseia-se na epidemiologia, enquanto saber que permite a apreensão do objeto de trabalho, da qual decorrem instrumentos de trabalho destinados à intervenção sobre o mesmo" (p.110).

Ao situar os modelos de assistência no Brasil do início do século 20, citando Merhy, Silva (1998, p.69) caracteriza este momento histórico como o 'modelo de saúde pública', se expressando em duas vertentes: campanhista e vertical permanente. Esta última baseada na proposta norte-americana de centro de saúde, trazida ao país pela Fundação Rockfeller. Foram essencialmente os saberes que orientavam as práticas higienistas norte-americanas daquele início de século que influenciaram alguns renomados médicos e sanitaristas brasileiros, que, como Paula Souza, por exemplo, vêm defender conceitos de prevenção e promoção para nortear as práticas de saúde, o que 
pode ser identificado na proposta de criação em 1922 de um primeiro 'centro de saúde' em São Paulo, que hoje ainda existe e leva seu nome - o CSE da Faculdade de Saúde Pública da USP. Mas não foi então que tais centros passaram efetivamente a ser implementados, aguardando um momento conjuntural posterior mais propício para conformarem um espaço potencialmente privilegiado para operar alguma integração em saúde.

\section{No modelo médico-sanitário (assistência médica e educação sanitária)}

Ainda é o movimento da saúde pública paulista, em seu segundo grande modelo tecnológico situado por Mendes-Gonçalves (1994, p.112) a partir da reorganização do serviço sanitário do Estado em 1925, sob a liderança de Paula Souza a cuja figura se associa, que ajuda a compreender o panorama nacional. Como sua principal característica tem-se a mudança da concepção do objeto de trabalho em saúde, ao privilegiar a educação sanitária como instrumento destacado da intervenção, mas restrita às noções de higiene privada, de forma articulada a uma prática médica individual em ascensão. Ao diferenciar este modelo, "não se trata de que as campanhas sanitárias ou a polícia sanitária, os principais instrumentos de atuação do modelo anterior tenham sido abandonados. (....) Algumas dessas técnicas perdem a razão de ser inclusive no sentido puramente técnico, outras a têm modificada, outras a mantêm integralmente" (p.113).

Em âmbito nacional esse segundo momento ficou sendo mais genericamente denominado modelo médico-sanitário, situando-se intermediariamente ao sanitarismo e ao surgimento da medicina previdenciária - individual e curativa, espaço próprio da clínica -, enquanto necessidade socialmente colocada, o que vai permitir inclusive configurar objetivamente a saúde como questão social no país. É mais comum encontrar-se referências a somente dois grandes modelos assistenciais no Brasil - o sanitarismo e a medicina previdenciária, sendo que em torno deste último vai sendo construída a hegemonia do modelo médico assistencial privatista. 


\section{Integração assistencial}

Um discreto movimento nesse sentido a partir da saúde pública começa a existir contrahegemonicamente no Brasil. Conforme evidencia Nemes (1995, p.08), os diversos significados conferidos para a integração no Brasil são marcados por diferenças históricas. Em suas primeiras formulações, situadas na metade do século 20, a 'integração centrava-se predominantemente na questão propriamente assistencial'. Defendia-se a "pertinência da assistência médica ao campo de atuação da saúde pública", uma vez reconhecida a necessidade de 'unir as atividades preventivas $e$ curativas sob uma noção de saúde-doença', de acordo com influências do movimento da medicina integral norte-americana. Todavia sua efetivação era insipiente.

Referida por Mendes-Gonçalves (1994), Nemes (1995) e Merhy e Onocko (1997), a tese de livre-docência defendida por Reinaldo Ramos em 1968 junto à Faculdade de Saúde Pública da USP, com o título "A 'integração sanitária': doutrine a prática”, recuperou os movimentos de integração observados anteriormente. A partir da década de 1950 novos elementos iam sendo incorporados nos modelos assistenciais apesar de as estratégias básicas anteriormente instituídas não se terem alterado. Naquele trabalho, Ramos (apud Merhy 1997, p.209) identifica uma convergência no campo da saúde de uma perspectiva de maior 'integração entre a medicina e a saúde pública', sem todavia eliminar-se a "existência dos dois campos, assistencialmente dicotomizados". Tal movimento se referia teoricamente à concepção de história natural da doença, que veio oferecer um marco teórico-prático para viabilizar a união do conjunto das ações de saúde num esforço comum de prevenção e cura.

Durante os anos 1960, ao esgotar-se o modelo de desenvolvimento do país, afirmava-se na política de saúde a consolidação de uma dicotomia institucional entre assistência médica e saúde pública. Segundo aponta Merhy (1997, p.221), “desde o final de 40 já era evidente uma inversão dos gastos públicos, favorecendo a primeira com uma mercantilização da assistência médica e que apresentava uma ação pontual e desordenada das instituições de saúde pública”. E isso apesar de, e em contraste com, um aumento da miséria e também piora das condições de saúde, o que termina gerando, por outro lado, uma contundente crítica ao modelo adotado. 
Por referência à matriz médico-sanitária, nos anos 1950 e 1960 havia uma intensa disputa com outra corrente, que via a necessidade de investir em melhoria das condições gerais de vida para se determinar uma melhora do perfil de saúde dos vários grupos sociais, como conseqüência (Merhy 1997b, p.210). Citando Mário Magalhães que expôs, durante a $3^{\text {a }}$ Conferência Nacional de Saúde realizada em 1963 com o lema "municipalização dos serviços de saúde", a proposta do Ministério da Saúde de um Plano Nacional de Saúde, Merhy sintetiza assim as bases de suas idéias (p.211):

que a doença e a miséria não seriam controladas com maiores gastos em serviços de saúde, mas com o desenvolvimento econômico que levasse à maior independência da sociedade e do trabalho humano, à medida que incorporasse novas tecnologias e maiores controles sobre a natureza; que em vez dos maiores gastos em serviços, o que deveria ser feito seria a busca de um padrão tecnológico próprio de ações de saúde, de maneira mais racionalizadora, com menores custos, com integração dos vários campos de atuação' e sem comércio no setor.

O estudo de Mendes-Gonçalves (1994, p.116), por referência à organização administrativa de uma secretaria estadual de saúde, entre outros aspectos abordados para se compreender as características dos modelos tecnológicos anteriores, ao tomar por diretriz a 'integração dos serviços', destaca a importância da adoção do "centro de saúde como unidade sanitária polivalente, verdadeiro eixo de organização, sob comando único responsável pelos problemas de saúde pública da comunidade a que serve", solução pretendida mas não obtida anteriormente, que no caso de São Paulo veio se efetivar somente após a reforma administrativa da sua secretaria estadual em 1967.

Apesar de na metade do século 20 já se desenvolverem idéias de prevenção da doença, e como sua correlata a promoção de saúde, enquanto conceitos capazes de nortear a prática da medicina (Mendes-Gonçalves 1994, p.114), todavia, a predominância de um discurso da educação sanitária pretensamente transmissor de "bons hábitos" de higiene privada enquanto complemento à atividade médico-assistencial, na sua materialidade e em meio às escassas dimensões do aparato institucional e sua própria estagnação, acaba contribuindo na "substituição das práticas de saúde pública pelas de assistência 
médica individual como (supostamente) capazes de dar conta das dimensões sociais da saúde e da doença” (p.115).

O que se constata é que a "progressiva institucionalização do setor saúde acabou consolidando a divisão entre os sub-setores da saúde pública e o da medicina previdenciária" (Iyda, 1994; Braga e Paula, 1981, apud Nemes 1995, p.08). Inclusive a transição da fase das campanhas e da polícia sanitária para a fase da educação sanitária veio coincidir temporalmente com o que Nemes caracterizou como "o início da institucionalização da assistência médica individual de maneira vinculada à previdência social", cuja instituição pela Lei Eloi Chaves marca esse movimento a partir de 1923.

O próximo movimento das práticas de saúde vem responder a uma necessidade da sociedade brasileira da época: a medicina previdenciária, que rapidamente vai sendo incrementada, primeiramente pelas várias caixas de aposentadorias e pensões, a seguir substituídas por institutos de assistência e previdência social, unificados em 1966 em um Instituto Nacional de Previdência Social, o ex-INPS (Mendes 1993, p.20). Aos excluídos do mercado formal restava a assistência por caridade das instituições filantrópicas de saúde, enquanto as ações de interesse coletivo vão sendo apenas discretamente mantidas. Como as práticas de saúde são socialmente determinadas, já desde a segunda década do século 20, na conjuntura de industrialização dos centros urbanos no Brasil, marcada pelas relações sociais capitalistas da época, havia uma forma específica de reconhecimento da relação entre doença e sociedade e de regulação da força de trabalho, pela imposição do mercado de dispor de uma massa de trabalhadores, ou mão-de-obra constituída de corpos em condições de laborar.

Nos anos 1940 a 1970 houve populismo, trabalhismo e ditadura como pano político de fundo. Herança da clínica já nascida, nesse contexto conforma-se o modelo médico assistencial privatista, considerado como o segundo grande movimento de organização das práticas de saúde no país e que vai construindo sua hegemonia crescentemente debruçada na intervenção sobre o corpo biológico individual. E vão-se consolidando as práticas médicas individuais curativas, especializadas, fragmentadas, hospitalo- 
cêntricas, contraponto das concepções sobre a integralidade em saúde, enquanto objeto coletivo e multidimensional de intervenção.

De acordo com Nemes (1995, citando Ramos 1972; Tanaka 1988; Bodstein e Fonseca 1989), a 'integração de ações médicas e ações coletivas', esteve presente na saúde pública após 1940. Apesar de que sua maior relevância será posterior, quando a organização da assistência médica pública vier somar-se mais objetivamente às tradicionais tarefas sanitárias, tais citações demonstram que a "integração é, portanto, uma questão imediatamente posta pela própria estruturação do sistema de atenção à saúde no Brasil” (p.08).

São vários os esforços realizados em órgãos da saúde pública brasileira para trazer a assistência médica para dentro de serviços públicos. Apesar do seu significado restrito, esta prática é referenciada então como integração assistencial, idéia inicialmente restrita à inclusão da assistência médica na rede pública, ainda que sem articulação com hospitais.

Mesmo reconhecendo a histórica dicotomia entre a assistência médica e a saúde pública no Brasil, Merhy (1997b, p.209-10) indica a existência de elementos presentes já no modelo médico-sanitário, que permitiam a 'introdução dos instrumentais clínicos como componentes das ações coletivas'.

Também na discussão da integração assistencial é a análise apresentada por MendesGonçalves (1994) sobre os modelos tecnológicos da saúde pública paulista, que permite uma melhor compreensão dessa forma particular de aproximação às noções de integração em saúde ora pesquisadas. Foram aqueles antecedentes dos modelos anteriores abordados que permitiram que fosse formatado o momento histórico da saúde caracterizado por aquele autor como terceiro modelo tecnológico da saúde pública paulista, caracterizado na conjuntura da década de 1970, pela 'introdução da assistência médica individual na rede de centros de saúde’ (p.118). Continuam remanescentes as técnicas desenvolvidas em períodos anteriores relacionadas à polícia sanitária e ao campanhismo, como também as práticas sobreviventes do modelo de educação sanitária, e ainda suas antecessoras desenvolvidas no controle da tuberculose e da 
hanseníase. Com o passar do tempo vai ocorrendo “(....) um realinhamento tecnológico, e os sentidos globais das mesmas técnicas aparentes modificam-se” (p.119).

Segundo Merhy (1997b, p.212), houve um momento em que:

(....) colocou-se no limite os elementos que a perspectiva médico-sanitária podia conter, rompendo com a dicotomia entre assistência médica e saúde pública, mas subordinando aquela à lógica desta. Assim, pela primeira vez, de um modo explícito e como produto da análise crítica dos modelos anteriores e das políticas até então instaladas apareceu nitidamente a discussão de um 'modelo tecnoassistencial baseado na integração das ações coletivas e individuais de saúde' cujo ponto de apoio seriam os serviços permanentes planejadamente elaborados.

Ressalvando o peso da filiação histórica aos governos militares, entre os anos 60 e 70, o mesmo autor observa que então se incorporam dois novos elementos nas políticas de saúde: a valorização do planejamento das ações e dos serviços de saúde e a 'incorporação da assistência médica como instrumental de saúde pública'. E considera possível a absorção destes elementos no "modelo médico-sanitário sem grandes traumas em sua estrutura básica” (p.218).

\section{Políticas de extensão da cobertura dos serviços de saúde}

Ao admitir a grave crise social brasileira a partir da segunda metade da década de 1970 e visando manter a estabilidade política, o governo passa a investir em políticas sociais como as políticas de extensão de cobertura dos serviços de saúde (Brasil/MS, 1975, 1977, 1980, apud Nemes 1995). Essas políticas são estimuladas pela OPS, vindo a implicar em noções de práticas diferenciadas, que assumem diferentes expressões pelo Brasil afora. As idéias de política social neste país, originalmente não se definem como “intervenção compensatória ou re-distributiva e de organização do mercado de trabalho". De acordo com a conjuntura político-social da época dos governos militares, se inseriam em um "movimento de construção nacional e de 'integração social' com inúmeras especificidades” próprias daquele contexto (Almeida 2000, p.10).

Talvez as primeiras experiências no Brasil explicitamente comprometidas com a cobertura assistencial dos serviços de saúde se possam situar no âmbito do PIASS Programa de Interiorização das Ações de Saúde e Saneamento, veiculado pelo 
Ministério da Saúde no final dos anos 1970. Em São Paulo somente na região do Vale do Ribeira, se implanta um programa de extensão de cobertura subordinado àquele programa, que tinha como "população-alvo prioritária (....) segmentos relativamente marginalizados dos centros urbanos. Esta característica está nacontinuidade, aparentemente, da que demarcava as práticas educativas de saúde pública na vigência do modelo anterior" (Mendes-Gonçalves 1994, p.119). Ao situar como parte intrínseca do modelo proposto as dimensões derivadas de uma opção pela extensão de cobertura apresentam como modificação aparentemente mais importante a generalização de 'ações a todos os níveis de atenção à saúde' da população coberta (ibid).

No contexto dos programas de assistência à criança e à gestante, iniciados pelo Ministério da Saúde na segunda metade dos anos 70, "permanece o espaço para a utilização da educação sanitária, mas agora subordinado à idéia de conjunto", associada ao termo "integração sanitária", por referência à já citada tese de Reinaldo Ramos. Naquelas propostas programáticas procurava-se instituir alguma forma de 'execução simultânea de ações de promoção, proteção e recuperação da saúde', ficando neste outro momento histórico redefinida sua oportunidade e relevância (Mendes-Gonçalves 1994, p.119). Esse mesmo autor situa o "processo de incorporação da assistência médica individual, ainda que como meio - o que certamente a redefine como orientada para o coletivo - no quadro mais geral da política de extensão da cobertura de serviços de saúde implantada no Brasil em meados da década de 1970”. Essa política se inseria como esforço de implementação de uma política social frente à conjuntura de crise no fim do "milagre econômico" (p.118).

\subsubsection{Medicina Integral e Comunitária como Alternativa}

Este item permite discutir a relação entre espaços alternativos e hegemônicos. Para os interesses deste estudo destacam-se dois movimentos reformadores da assistência médica, a medicina comunitária e a medicina integral, que também passam a ser conhecidas no Brasil a partir da metade do século 20. Através desses modelos alternativos tem-se a emergência de um projeto preventivista portador das idéias do movimento da medicina preventiva e social, que se expressa em tentativas de reforma do modelo hegemônico da medicina científica. 
Pode-se considerar o Chile como precursor deste movimento no continente SulAmericano, pois ao sistema de saúde que lá foi se formatando desde a metade do século 20, coube velar pela efetiva prestação da atenção, segundo a concepção de 'medicina socializada ou integral'. Sua execução teve por base a integração docente-assistencial, informada pela doutrina da medicina integral. Tal orientação esteve presente naquele sistema de saúde até que com a intervenção no setor resultante da ditadura militar a partir de 1973, as consideradas "modernizações na esfera da saúde pública e seguidamente, as inovações privatizantes na previdência e saúde", vieram substituir os “consagrados parâmetros de necessidades, eficácia e qualidade da medicina integral pelo de rentabilidade quantitativa de atos curativos" (Labra 1988, p.20-1).

Em seu "plano político-ideológico, o projeto preventivista se expressa na chamada "medicina comunitária" e seus desdobramentos nos programas extra-muros" (Nunes 1994, p.7-8), referidos a algumas universidades brasileiras em suas faculdades de medicina. No espaço universitário brasileiro, a partir de 1962, se desenvolvem alternativas à prática dominante nos serviços de saúde, enquanto projetos de medicina comunitária, veiculados através de programas de residência médica voltados a uma formação profissional baseada na 'integração das ações preventiva e curativa' (ibid); o que no plano técnico, procura abolir a separação entre medicina preventiva e medicina curativa (Novaes 1988, p.86).

A partir do final dos anos 1970 obtém maior espaço os programas de medicina comunitária, identificados com programas de atenção primária (Noronha 1996, p.94). Então são constituídos os núcleos de desenvolvimento de modelos alternativos de assistência, com financiamento da OPS e outras instituições americanas, passando a ser estimulada a 'integração entre as instituições de ensino e os serviços de saúde' (Silva 1998, p.73).

Segundo Silva (1998, p.58), o modelo teórico e operacional da medicina comunitária se confirma graças ao que considera a 'interação de um conjunto de elementos estruturais', referindo-se em primeiro lugar ao coletivismo restrito, segundo o qual a "medicina comunitária resgata a característica coletiva do objeto de práticas médicas, individualizado pela medicina flexneriana", passando a preocupar-se com a saúde de 
grupos populacionais, idéia restrita aos "limites da comunidade local, vista como o espaço em que se estabelecem fortes ligações integrativas e consensos de interesses". Em segundo lugar, entre os elementos estruturais refere-se também à 'integração de atividades promocionais, preventivas e curativas', segundo a qual a medicina comunitária procura reintegrar o ato médico para torná-lo mais eficaz e eficiente. Todavia, na recomposição do processo da doença é reconhecido "apenas seu caráter natural, a-histórico, desarticulando-se a prática médica da sociedade em que ela se insere". Enquanto intervenção social sobre grupos marginalizados, a medicina comunitária manifesta-se por meio de uma pretensa "função "integradora" à sociedade', que é reprodutora da ideologia dominante. E enquanto prática, a 'integração preventivo-curativa' fica centrada no ato médico e em suas tecnologias (p.60-1).

Uma primeira concepção que até hoje se mantém como uma dimensão genericamente reconhecida por referência às idéias de integralidade dos cuidados à saúde surge no Brasil com o movimento da 'medicina integral', uma apropriação da expressão "comprehensive medicine", recuperando a perspectiva de tratar o indivíduo em sua totalidade, portanto de uma forma abrangente, portadora da idéia de 'integração biopsico-social' assumida pela proposta (Nunes 1994, p.6-7). Em outros termos, o objeto de intervenção da prática médica passa a ser a unidade bio-psico-social da pessoa humana. A medicina integral implicava na reformulação pedagógica para capacitar os futuros médicos para um 'exercício “integral” da medicina' (Novaes 1988, p.85).

Importa reter neste momento que o movimento da medicina integral na América Latina aparece colocando ênfase na 'medicina de família integrada' enquanto prática de saúde, munindo-se de "conceitos sociológicos, antropológicos, demográficos, epidemiológicos e ecológicos" (Nunes 1994, p.6). Apesar da abrangência das intenções, a prática da medicina integral tem se pautado no ato médico individual de promoção e educação em saúde e de prevenção, cura e reabilitação de doenças. Um exemplo que pode inicialmente reportar-se àquela proposta, são as concepções mais abrangentes de puericultura.

Berlinguer (1988, p.63) defende a idéia de que, em países como o Brasil, de "forte tradição de cultura popular, de atenção médica espontânea, de experiências que não 
sejam da medicina ocidental, mas que têm um valor intrínseco, cultural”, torna-se oportuno 'integrar as duas medicinas', considerando benéfica tal socialização. Em suas palavras, parece que 'o pensamento médico mais moderno trabalha por uma integração' entre a medicina ocidental e alternativa. Na homeopatia, em sua condição de ser uma teoria, com um corpo conceitual explicativo da realidade, a cura "é algo de global, de integral, é 'a cura do homem como um todo' e de acordo com certos princípios básicos, e não somente a eliminação da totalidade sintomática" (Novaes 1988, p.92-3).

Como referencial normativo das práticas clínicas e de atenção individual à saúde por diferentes profissões, a abordagem da pessoa em seu todo bio-psico-social é até hoje reforçada especialmente nas abordagens mais holísticas do atendimento de saúde. O individual pode ser integral, mas em si é insuficiente para representar a idéia de integralidade em saúde, apesar de fazer parte dela.

\subsubsection{Integração das Ações via Programação Local de Saúde}

Num contexto de valorização da expansão dos serviços básicos entre as estratégias de reorganização do setor saúde, realiza-se em Alma-Ata na URSS de então, através do UNICEF (Fundo das Nações Unidas para a Infância) e da OMS (1978), a Conferência Internacional sobre Atenção Primária à Saúde, que se torna um importante marco político dessa tendência. No bojo da proclamação da meta de Saúde Para Todos no ano 2000 (SPT/2000), definida pela OMS na 30ª Assembléia Mundial de Saúde (1977) para os seus países membros, transitam discussões entre o caráter integral dos serviços de saúde para grupos prioritários e/ou somente serviços limitados para todos. A partir deste cenário, nas discussões sobre atenção primária de saúde articulada com os pressupostos da meta SPT/2000, ganham espaço as idéias de atendimento integral para toda a população. Mas muito timidamente são encontradas qualificações sobre quê saúde se pretende nesse atendimento integral. De qualquer forma, para alcançar a meta de saúde para todos terem uma vida social e economicamente produtiva, entendendo a saúde como parte do desenvolvimento geral, foi definida no ano seguinte em Alma-Ata a atenção primária de saúde como estratégia para aquela pretensão (OPS 1980). Conseqüentemente, a Assembléia Mundial da Saúde em 1979, segundo Castellanos 
(1993, p.06): “... instó a los Estados miembros a definir y poner en práctica estrategias nacionales, regionales y globales tendientes a alcanzar la meta de SPT2000”.

A conjuntura nacional de crise política e da previdência social no final da década de 1970, alimentada pelas diretrizes de atenção primária de saúde formuladas na Conferência de Alma-Ata (OPS 1978), coloca novamente na agenda política setorial a valorização da assistência médica básica enquanto responsabilidade institucional da saúde pública.

Inicia-se ainda no Brasil dos anos 1970, "um movimento que resultaria na necessidade de articular a assistência médica à saúde pública, tanto na direção de admitir a assistência médica como tarefa sanitária, como na direção de organizar essa assistência com base nas orientações tecnológicas da saúde pública" (Nemes 1995, p.20). É partindo destas linhas que se constrói uma proposta de integração sanitária desde então.

Em São Paulo durante a década de 1970 situa-se uma política, designada como "programação", que foi implementada na rede estadual de centros de saúde, apoiada em tecnologia de base epidemiológica e que marca o desenvolvimento de uma concepção importante na organização de serviços de atenção primária de saúde: “que a assistência médica fosse um dos meios de um trabalho definido a partir de objetivos epidemiológicos". Foi o enfoque da problemática da integração na proposta da programação, que segundo Nemes (1995, p.22), autorizou seu entendimento enquanto uma organização de trabalho, situada no contexto subseqüente aos modelos de organização da saúde pública em São Paulo anteriormente abordados. Pois, ao tratar da assistência médica enquanto um instrumento de trabalho, que de forma articulada a outros, pretende inclusive obter impacto em coletivos, se impunha uma organização capaz de colocar a assistência médica operando numa lógica epidemiológica.

As idéias de programação em saúde advindas da década de 1960 foram sendo totalmente reformuladas a partir do final dos anos 1970 e cada vez mais têm ocupado "o centro de um debate (....) sobre a forma mais adequada de se organizar os serviços de assistência à saúde" (Schraiber e col. 1993, p.11). 
Segundo Nemes (1995), em São Paulo, “a proposta da programação mobilizou intensamente os centros de saúde estaduais e teve boa parte de seus instrumentos implantados nos anos 1975 a 1978. (....) Assim, embora a programação tenha alterado profundamente a organização do trabalho nos centros de saúde, não logrou, como era a intenção política original de seus proponentes, alterar a conjuntura dos serviços de saúde". Naquela oportunidade já se impunha "analisar as repercussões dos princípios da prática programática na estruturação e dinâmica do trabalho gerencial” (p.22-3). Influências das idéias de planejamento em saúde num contexto político setorial de políticas de expansão da cobertura, e especialmente dos movimentos da medicina integral e comunitária, se fazem presente na formulação daquela política de programação (p.20-1).

Os Centros de Saúde Escola - CSE em São Paulo além de sua função de formação de pessoal também “abriam possibilidades de testar 'práticas assistenciais integradas' para os novos centros de saúde" da secretaria estadual (Cyrino, 1993, apud Nemes 1995, p.77). As idéias de 'cuidado integral das questões da saúde' foram orientadoras da proposição do trabalho no CSE Butantã desde sua fundação (Nemes 1995, p.93). Segundo essa autora (p.81-2) em documento de 1979 daquele CSE, intitulado "Enfoques alternativos para 'ações integradas de saúde' em medicina de primeira linha - simplificação e participação" já se encontrava uma proposta de organização do trabalho apoiada na noção de 'integração de ações'.

Com a contribuição da programação enquanto instrumento tecnológico do trabalho em saúde, estudos de Schraiber e colegas (1993, p.12) passaram a "argüir da competência e adequação de tal ou qual conjunto estruturado de processos de trabalho para a intervenção sobre a saúde/doença de uma maneira global, tratando-se pois dos modelos operatórios das práticas médica e sanitária e dos 'modelos de sua integração' ". Com esse enfoque, ao considerar a programação na ótica do modelo assistencial, a experiência paulista consegue fazê-la emergir com maior vigor pragmático, ao situá-la como modelo operatório das práticas em saúde. Esses autores indicam algumas bases conceituais e os aspectos histórico-políticos mais importantes daquele movimento (p.18). Na experiência citada revelava-se a programação em saúde como ferramenta adequada para abordar as questões objetivas dos serviços que carecem de uma 
'integração das práticas clínica e sanitária', frente a oposições existentes entre a prática clínica e a prática sanitária, entendidas como modelos assistenciais diversos: de "consultação" e de "controle sobre a doença/saúde" (p.19).

A programação passa a "articular a proteção e a promoção da saúde com a recuperação do doente, desfazendo a tradicional dicotomia prevenção X cura, como também (....) as fragmentações e a independência das ações de planos assistenciais similares, paralelos e verticalizados". Nessa perspectiva passa a ser construído o "princípio da integração sanitária' (Schraiber e col. 1993, p.21). Na noção de ação programática a assistência médica vai ressurgir "como meio de realização de objetivos definidos epidemiologicamente sobre o coletivo" (Mendes-Gonçalves 1994, p.118), o que contribui para, contempladas as idéias de integração assistencial, iniciar-se o movimento de construção da integração sanitária, enfoque que será discutido posteriormente (item 2.3.1).

Apesar de fundado no planejamento o discurso da programação-modelo assistencial, na perspectiva da incorporação das noções de integração e de hierarquia do cuidado, implica também na "construção de um saber técnico que se pretende como fiel apreendedor de uma problemática social (....) e política” (Schraiber e col. 1993, p.23). De acordo com esses autores a pesquisa de um modelo assistencial baseado em uma “tecnologia de coletivo”, implica em uma prática de apreensão do objeto da intervenção e esta mesma se processando "por meio de instrumental de caráter coletivo, como o saber epidemiológico e as técnicas dele derivadas". Para tanto, há que se buscar no interior da "abordagem epidemiológica da realidade em saúde aproximações progressivamente totalizantes de realidades que sempre serão apenas partes da vida em sociedade", a exemplo do adoecer (p.32).

A histórica divergência entre o objeto de explicação e intervenção da medicina e da saúde pública, desde o século 18, quase sempre foi dividir o problema em partes e instituições separadas. A proposta de ação programática em saúde (item 2.3.1), ao se constituir em aplicação tecnológica da ciência epidemiológica, representa uma forma potencial de resolver essa contradição (Schraiber e col. 1993, p.44). 
De acordo com a lógica acima apresentada, a atenção à demanda articula-se com ações coletivas programáticas, entendidas como uma horizontalização para superação dos diversos programas verticais de controle de agravos à saúde, centralmente coordenados e desarticulados das realidades locais. No nível da prática se requer sintetizar os conhecimentos e ações analiticamente desagregadas nas especializações. Pois, conforme aponta Paim (1995, citado por Silva 1998, p.81), os 'programas verticais de saúde pública contrariam a lógica da distritalização e da integralidade’.

Uma referência importante utilizada nas expressões assistenciais da política de programação paulista foi o modelo da comprehensive medicine e sua correlata concepção de homem bio-psico-social. Essa questão diz respeito à 'integração da assistência individual dentro de um conjunto mais amplo orientado para o coletivo'. Nessa perspectiva a abordagem clínica inspirada na medicina integral ofereceu um certo padrão clínico como modelo para a prática dos sanitaristas. Todavia, limitado pela carência de indicadores para caracterizar "sua subordinação ao contexto mais inclusivo de um saber epidemiológico como estruturante do trabalho" (MendesGonçalves 1994, p.171-2).

Em estudo que trata da "avaliação do trabalho em serviços assistenciais de atenção primária à saúde organizados tecnologicamente mediante a lógica da prática programática em saúde”, Nemes (1995) identifica que na prática da assistência oferecida no CSE do Butantã no período da política de programação viabilizava-se uma 'compreensão global do paciente, na perspectiva da abordagem integral' (p.79). O 'atendimento médico individual do tipo integral', foi o principal instrumento do trabalho no período (p.84). Havia um pressuposto de que houvesse "no atendimento individual 'uma compreensão integral' que, de fato, transcendesse a abordagem clínica informada pela noção de risco". Mas que, 'baseada na noção de integralidade, pudesse disputar com o saber clínico o recorte do objeto de trabalho' (p.96-7). Naquele empírico estudado fica bem caracterizado o atendimento integral na expressão instituída como: o "trabalhar com o doente e não com a doença"; onde se inclui o social e o emocional "ao apreender o doente" (p.93). A pesquisa referida detecta um primeiro movimento de reformulação fundado na "busca de uma concepção de objeto para o trabalho que (superasse) o referencial biológico de doença, tal como pretendido pelas 
concepções integrais”. A alternativa que se coloca então para tanto é a epidemiologia, por seu manejo de instrumentos fundados em apreensões coletivas (p.111).

O problema era a incapacidade dos instrumentos existentes para impor ao atendimento uma apreensão mais social, propondo 'formas operacionais para tentar uma relação mais articulada entre a norma integral e o padrão de atendimento', onde prevalecesse uma apreensão estratégica de tipo epidemiológico. "Neste sentido, este projeto representou um reconhecimento da necessidade de 'discriminar os elementos tecnológicos da abordagem integral de modo a introduzir uma normatização mais capaz de ir produzindo um padrão tecnológico' claro e controlável, para além da atitude compreensiva do agente" (Nemes 1995, p.114-5).

O recurso à programação trouxe a necessidade de priorização para o plano éticonormativo. Por referência a documento institucional do CSE, Nemes (1995, p.112) destaca a característica de priorização dos eventos quanto ao impacto das ações, a ser incorporada no gerenciamento do serviço sob o enfoque coletivo. Ao se orientar por um “diagnóstico de saúde da população, propondo intervenções e avaliando resultados a partir da análise do coletivo", é que o trabalho programático pode ser uma estratégia orientadora do conjunto das ações. Naquele momento a prática programática para o CSE representava, "muito mais uma aposta ética do que uma construção tecnonormativa. (....) O plano ético-normativo assume uma priorização fundada sobretudo em uma 'oposição genérica e abstrata ao integral', através de uma expectativa de normatização e padronização também abstratamente epidemiológicas” (p.116).

Destaca-se naquele momento o "ressurgimento das técnicas de grupo como instrumentos privilegiados de trabalho". Anteriormente "essas técnicas estavam desacreditadas quanto à sua efetividade em obter uma abordagem mais social do objeto". Assim sendo, a tentativa de abordagem integral se tornara predominantemente psicológica dos grupos. A necessidade então recente de "delimitar objetos e intervenções coletivas desacredita na abordagem individual e confia na obtenção de elementos de vivência social compartilhada, para delimitar intervenções de fato sociais (porque coletivas) e não apenas psicológicas” (Nemes 1995, p. 123-4). 
Em decorrência passa a existir um 'descrédito na abordagem individual integral', concomitante ao aumento da "confiança na positividade do caráter coletivo do grupo", o que se pode explicar "também pela ausência, neste momento, de uma alternativa de normatização para o atendimento individual que também discriminasse elementos mais sociais de instrumentalização. Com isso, o padrão esperado para 'o atendimento individual permaneceu orientado por uma normatização ainda integral"' (Nemes 1995, p.114). Todavia, "o deslocamento pretendido da terapêutica das 'outras questões da saúde' para os grupos de discussão, (....) diminuiu muito 'a força da abordagem integral', mesmo no plano normativo". Observe-se que na realidade dos serviços esta prática é remanescente. Naquele caso do CSE, “o conjunto de diagnóstico-terapêutica já estava comprometido pela cisão entre 'um diagnóstico integral no atendimento' e uma terapêutica a ser feita fora dele" (p.125). Isso dificultava a proposta, ao mesmo tempo em que não se dispunha de instrumentais tecnológicos para tal.

Em 1989 uma nova proposição articulada com a epidemiologia se materializa de forma coerente com as 'assunções mais gerais da reformulação do trabalho - rompe com a (considerada) integralidade e aspira uma normatização estratégica necessariamente apreendida e manipulada no coletivo' (Nemes 1995, p.140).

A pretensão de "também se investigar outras questões de saúde, em um atendimento tão dependente de uma decisão clínica, relativamente pequeno de elementos de raciocínio diagnóstico (anamnese e exame físico dirigidos pela queixa), parece uma aspiração muito descolada das outras funções tecnológicas” de um serviço de P.A. (prontoatendimento). "Sua inclusão no padrão de atendimento do P.A. parece mais uma decorrência da dificuldade de se assumir uma normatização diversa para 'um processo de trabalho de finalidade diversa do trabalho integral', uma tentativa de 'preservar uma "janela“ integral' em uma situação tecnológica evidentemente dominada pela apreensão clínica" (Nemes 1995, p.158). Essa situação, em parte, “decorreu da dificuldade em implementar extensivamente o novo instrumento devido à carência de recursos. A falta de clareza do papel do cadastro para a 'passagem da abordagem integral para uma abordagem estratégica' (epidemiológica), foi, entretanto, o principal determinante dessa situação" (p.166). 
Frente à necessidade de cobertura de serviços de saúde manifestada pela população local, buscou-se "simultaneamente, (....) 'orientar a prática pelos princípios de uma assistência integral' e que permitisse maior participação da população no interior dessa assistência. Portanto nesse aspecto a trajetória de organização do serviço vinculou-se às propostas inovadoras da medicina integral, medicina comunitária e da programação em saúde” (Schraiber, Nemes e Mendes-Gonçalves 1996, p.24).

De maneira articulada ao movimento dos sistemas locais de saúde a seguir discutidos fundamenta-se a necessidade de enfocar a 'programação local na perspectiva da flexibilidade, integralidade' e adequação constante (Paganini e Chorny 1990, p.438). Quanto à abrangência do seu objeto, se admite que na programação procurar-se-á integrar os aspectos da promoção à saúde, prevenção e tratamento das doenças $e$ reabilitação (OPS 1990, p.616). Assim sendo, a integração passa a constituir um componente conceitual intrínseco às noções vigentes de programação em saúde durante a última década do século 20 .

\subsubsection{Integração nos Sistemas Locais de Saúde}

É no espaço dos SILOS que a atenção primária à saúde se materializa efetivamente, como também é onde se manifestam princípios integradores de organização deste âmbito. No apoio internacional da OPS à implementação de SILOS constata-se um esforço no sentido de reforçar os sistemas de saúde com base na: 'atención primaria como parte integrante del desarrollo sanitario' (OPS 1990, p.601). Paganini e Chorny (1990, p.443) apontam entre as bases dos SILOS as seguintes: “(....) programación local, coordinación intersectorial, participación social, los sistemas locales de información-decisión, y otros que se estimen convenientes”. Abordando a noção de 'integridad de las acciones' estes dois autores (p.441-2) caracterizam os SILOS como espaço privilegiado para a integração de ações preventivas e de promoção, recuperação e rehabilitação'. Neste espaço os programas verticais deverão 'integrar suas ações para resolver o conjunto de problemas da população'.

O XXVII Conselho Diretor da OPS aprovou em 1980 as chamadas "Estrategias Básicas para la Región” (das Américas), oportunidade em que aquela entidade, segundo 
Castellanos (1993, p. 8): “(....) especifica la necesidad de 'acciones intersectoriales de caracter integral', y orientadas hacia los 'grupos humanos prioritarios', considerados estos últimos, sobre todo, los habitantes marginados del medio rural y del medio urbano". No trabalho intersetorial impõe-se construir capacidade de negociação para mediar acordos que permitam 'integrar os diversos setores' orientando-os de acordo com objetivos específicos de saúde (OPS 1990, p.619). Em uma concepção de saúdedoença como resultante das interações sociais, impõe-se colocar da mesma forma as intervenções. Assim sendo, "a estratégia dos SILOS propõe duas modalidades de intervenções em saúde: intersetoriais e intra-setoriais” (Mantilla 1990, p.519).

Após dez anos da formulação da meta de saúde para todos, já em 1986 na XXII Conferência Sanitária, os ministros de saúde das Américas decidem priorizar as ações sobre os principais problemas de saúde da população. E, em 1990, na XXIII Conferência Sanitária, partindo da análise da desigual distribuição de renda existente sobretudo em países latino-americanos e da decorrente falta de 'integração de uma parte substancial da população aos níveis mais elementares de bem-estar social', são definidos os indicadores mínimos para acompanhamento daquelas estratégias por adaptação das metas regionais à meta global de SPT/2000. Em tais documentos fica claramente estabelecida a necessidade de relacionar as ações de saúde com o desenvolvimento social e bem-estar das populações. Aquele documento enfatiza que apenas a elevação da qualidade de vida e a diminuição da pobreza extrema e das desigualdades entre grupos humanos, permitirão alcançar as metas de saúde para todos (Castellanos 1993, p.07-8).

Considerando-se os SILOS como instrumentos dos processos de transformação setorial, eles representam uma possibilidade de 'integração dos sistemas de saúde com as comunidades a que servem'. Neste âmbito a saúde é considerada “uma das formas de realização do ser humano em liberdade” (Paganini e Chorny 1990, p.444-5).

Como trabalho intersetorial no âmbito dos SILOS destaca-se as Organizações Não Governamentais - ONG, por haverem desenvolvido uma 'concepção integral de seus programas e projetos', citando-se como exemplo os 'centros infantis integrais'. Suas concepções de 'desenvolvimento social integral' produzem na prática maior impacto 
que as ações isoladas setorialmente. Esta modalidade de trabalho intersetorial é quase uma constante nas ONG, cujo conceito de 'desenvolvimento local costuma ser integral' (Mantilla 1990, p.515-8). Em sua perspectiva de ação intersetorial, ainda segundo o mesmo autor, nos SILOS se procura "concentrar esforços de articulação dos setores sociais e produtivos para realização conjunta de diagnósticos e intervenções". Nesse sentido destaca o trabalho das ONG, por sua "ação intersetorial, de promoção da participação social e sua experiência de integração do trabalho setorial para o desenvolvimento local integral',' (p.519).

Já em 1987 (*) se postulava que: “(....) la intensificación eficaz de la atención primaria depende de 'acciones integradas basadas en distritos de salud' adecuadamente organizados", como se havia definido na Assembléia Mundial de Saúde de 1986. A preocupação com equidade e situação econômica desperta a convicção de que o distrito dispõe de melhores oportunidades para identificar a população com maiores necessidades (OPS 1990, p.607). A responsabilidade por um espaço territorial abrange tanto a saúde das pessoas como 'los aspectos integrales del medio que influyen sobre la salud de la población’ (p.589). Os SILOS são mais conhecidos no Brasil como distritos sanitários, definidos como 'unidades programáticas básicas na prestação de serviços integrais de saúde’ (Mantilla 1990, p.521). Para a consecução de ações integradas implica de fato integrar todas as intervenções em saúde necessárias para melhorar a saúde da população.

Ainda no contexto da avaliação regional entre os países da América, após dez anos do compromisso dos governos com a meta de SPT/2000, foram definidos os Sistemas Locais de Saúde (SILOS) como estratégia privilegiada daquela política (OPS 1986). Daí se veicula, especialmente na década de 80, novas concepções de forma associada ao movimento de saúde para todos, onde, por referência às noções constituintes da idéia da integralidade em saúde, destaca-se que: ‘(....) Debe hacerse hincapié en la atención primaria integrada o total' (OPS 1990, p.601). A abrangência dessa noção pressupõe a (*) Conforme - Declaración sobre el Fortalecimiento de ... Distritos Basados en la Atención Primaria -
Reunión de Harare - Zimbabwe (07/08/1987). 
articulação dos serviços de saúde com outros recursos da comunidade. Um trabalho de comparação internacional situa a 'integralidade do cuidado' entre onze características que definem um escore da atenção primária como orientação de sistemas de saúde (Mendes 1996, p.274).

Paganini e Chorny (1990) apontando os desafios operacionais para a implementação da estratégia dos SILOS, na perspectiva da integração programática necessária à promoção da saúde, destacam como importante que, desde a formulação inicial dos princípios dos SILOS, se vinculava o 'enfoque integral' à exigência de uma convergência das ações dos 'diferentes programas nos indivíduos, famílias e comunidades ou ambiente' (p.437). Ou seja, consideram como imperativo que: '(....) las acciones de salud amalgamen los programas tradicionales en acciones integradas que tomen como unidad la persona, la familia o la comunidad'. De acordo com essa premissa os autores citados explicitam: 'En vez de considerar por separado las necesidades de cada uno de estos segmentos de la población, todos los elementos de la intervención deben integrarse' (p.442).

Em noções derivadas das produções latino-americanas sobre os sistemas locais de saúde, reafirma-se que um processo de programação em bases epidemiológicas mais abrangentes permitirá 'integrar los enfoques parciales que disgregan la realidad' (Paganini e Chorny 1990, p.437). Nos modelos de atenção de base epidemiológica e sensíveis aos riscos sociais, como se propõem os SILOS, há que se evoluir da avaliação de coberturas derivadas de 'programas verticais e desintegrados' para a medição de 'coberturas de atenção integral de populações definidas', por coerência. Poder-se-ia começar a medi-las em função da 'atenção integral em prevenção e acessibilidade de grupos populacionais expostos a diferentes riscos' (OPS 1990, p.591).

$\mathrm{Na}$ abordagem do desenvolvimento de um novo modelo de atenção, Silva (1998, p.63) considera que os SILOS devem se constituir em um importante processo de mudança tanto na 'integração dos conhecimentos', como na utilização dos recursos e na forma de concretizar-se a participação social. 
Nos serviços de saúde, a falta de um efetivo apoio dos níveis de maior complexidade ao nível de distrito, como também a ausência de uma relação mais efetiva com as demais atividades de nível comunitário, são deficiências identificadas em sistemas de saúde dos países considerados como de "terceiro mundo"; sendo que, a centralização das decisões desestimula as iniciativas locais, ao mesmo tempo em que o interesse pela sofisticação da atenção médica limita o apoio ao nível básico. Neste contexto, a 'integração deve ser algo mais que simples elucubração', no sentido de que vai implicar, necessariamente, "tanto em um sistema de referência como na integração com a comunidade" (Paganini e Chorny 1990, p.602).

Segundo a OPS (1990, p.603), por referência aos SILOS, faz-se necessário um imediato conhecimento dos problemas nas comunidades como também a 'interação entre epidemiologia e gestão'. Pois, os SILOS devem responder a necessidades da população e à estrutura da rede de serviços de saúde, organizando-se de forma a facilitar a 'condução integral de ações' (OPS 1990, apud Silva 1998, p.62).

Refletindo um movimento internacional, o Brasil, aos poucos, consegue se integrar e reformular parcialmente a lógica global de funcionamento do sistema, na medida em que se desloca o eixo da assistência antes centrada nos hospitais, possibilitando uma 'maior integração entre ações preventivas e curativas' (Vasconcelos 1999, p.15).

As experiências com sistemas locais de saúde no Brasil, quer sejam denominados distrito sanitário ou não, vieram a ser a principal característica da organização do setor saúde nos municípios, após a Nova República constituída em 1984. Ainda sem essa diretriz política da OPS formalmente instituída (o que ocorreu em 1986), os movimentos de integração das ações de saúde no Brasil foram seus antecessores.

O debate sobre a reorganização descentralizada do sistema de saúde brasileiro, que já havia sido explicitado na $3^{\text {a }}$ Conferência Nacional de Saúde realizada em 1963, tem ocorrido, conforme registram Noronha e colegas (1990, p.529), de forma paralela a diversas iniciativas concretas de organização de sistemas locais de saúde. Isso antes mesmo da sua denominação enquanto tal, como ocorreu com a implantação das AIS, 
precursoras da instituição dos SILOS no Brasil e marco das grandes transformações pelas quais passa a organização dos serviços de saúde no Brasil a partir de 1983 -1984.

Esse debate ganha novos contornos reais, no bojo das mudanças preconizadas pelo movimento da reforma sanitária, especialmente na junção das idéias descentralizadoras, visando municipalizar os serviços, mantendo-se as diretrizes de integração interinstitucional, conforme se discute adiante.

\subsubsection{Integração Interinstitucional}

Até meados dos anos 1970, de acordo com autores referenciados por Nemes (1995: Donnangelo 1975, Oliveira e Teixeira 1986, Cohn 1981), "havia um grande grau de separação entre as instituições da saúde pública e da assistência médica previdenciária que foi a forma institucional principal assumida pela assistência médica no Brasil" (p. 7). Já na segunda metade da década de 1970, em um contexto de absoluta dicotomia cognominada por Mendes (1993), como um verdadeiro "Tratado de Tordesilhas" na saúde, estão consolidadas, de um lado as instituições de saúde pública e de outro a assistência médica previdenciária. Esse panorama ficou explicitamente retratado na Lei 6229 (Brasil 1975), formulada com base nas diretrizes do II Plano Nacional de Desenvolvimento (PND), tomando por referencial doutrinário a teoria dos sistemas. Institucionaliza-se então em lei o modelo médico-assistencial privatista, ficando definidas as 'competências das instituições públicas e privadas e propondo mecanismos de integração e coordenação'. Nestes termos, ainda, a integração é proposta como forma de manutenção do modelo hegemônico (Mendes, op cit).

E, prosseguindo com a análise de Nemes (1995, p.19-20, citando Teixeira), tem-se:

Somente com a chamada crise da previdência brasileira, cujos contornos começaram a se desenhar nos anos 70, iniciou-se um movimento que resultaria na 'necessidade de articular a assistência médica à saúde pública' tanto na direção de admitir a assistência médica como tarefa sanitária, como na direção de organizar essa assistência com base nas orientações tecnológicas da saúde pública. 
Com o fim do chamado "milagre econômico", a crise econômica brasileira que se explicita após 1978, levou a uma drástica diminuição dos recursos financeiros da previdência social, cuja visibilidade se explicitava em dados do ex-INAMPS (Instituto Nacional de Assistência Médica e Previdência Social), o que era amplamente divulgado na imprensa ao redor dos anos 1980. Eis que o sistema de saúde explicita sua crise, tanto econômica quanto em suas condições de atender adequadamente às crescentes demandas e necessidades da população, estas inevitavelmente relacionadas com aquele contexto de crise econômico-social.

A crise evidenciada no sistema de assistência à saúde no Brasil ao final da década de 1970 impõe um reordenamento do sistema para os anos 1980, cujas iniciativas surgem nos primeiros anos daquela década, dentro das próprias instituições previdenciárias. Derivam-se daí os primeiros esforços institucionais na busca de uma racionalização do então pluralista sistema nacional de saúde. A continuação desse período foi palco de importantes transformações na organização dos sistemas de saúde no Brasil.

A solução pensada gira em torno das idéias de 'integração interinstitucional entre saúde e previdência'. Nesse contexto começaram a germinar projetos, que pretendiam uma 'ação mais integralizadora' entre o então Ministério da Previdência e Assistência Social (ex-MPAS) e outros serviços públicos, em nome de um "maior controle sobre o setor privado - tanto conveniado, quanto contratado - e um maior investimento na rede pública” (Merhy 1997b, p.216).

O apoio às políticas de implantação e expansão de ações básicas de saúde, colocava-se em uma perspectiva progressiva de "apoderar-se" do sistema como um todo, com o que, segundo Merhy (1997b, p.220), pretendia-se que pudesse desembocar uma "lógica de funcionamento de acordo com um sistema único de serviços, ilusão que contaminou realmente" as primeiras propostas apresentadas.

Aquelas iniciativas representavam uma proposta racionalizadora, cujo modelo vinha sendo objeto de diversas proposições oficiais e não-oficiais, em várias versões, naqueles anos. O Plano de Reorientação da Assistência à Saúde no Âmbito da Previdência Social foi elaborado pelo então Conselho Consultivo de Administração de Saúde 
Previdenciária e aprovado em agosto de 1982 pelo Governo Federal, contendo teoricamente alguns elementos racionalizadores. Trata-se aqui do projeto denominado Prev-Saúde, mais conhecido como o "Plano do CONASP" - Conselho Nacional de Saúde e Previdência, cujas subseqüentes versões ocuparam o cenário políticoinstitucional dos setores saúde e previdência nos dois primeiros anos daquela década, procurando instituir uma proposta de atuação conjunta entre Ministério da Saúde e Ministério da Previdência e Assistência Social, o que não vinga, mas do qual derivam outras medidas.

De acordo com Mendes-Gonçalves (1994, p.120), “como decorrência dos antecedentes referidos, uma nova e ponderável força passa a atuar sobre o campo de práticas a partir de 1983-1984. (....) Trata-se dos 'projetos de integração regionalizada das ações de saúde', com a participação do Instituto de Assistência Médica de Previdência Social (INAMPS) e das instituições públicas" voltadas à saúde, no caso destacando a SES de São Paulo. Essa linha de articulação política era desencadeada pelo ex-INAMPS especialmente com algumas secretarias estaduais e as secretarias municipais da saúde das grandes capitais e de municípios de maior porte.

Segundo Cecílio (1997, p.91-2), também “o município de Campinas tinha uma tradição de ampliação da rede básica que o colocava ao lado dos municípios que mais avançaram no compromisso com a assistência à saúde", desde a década de 1980. Destaca-se sua “importante experiência de integração interinstitucional, através do chamado PróAssistência, que foi anterior ao CONASP (....), enquanto 'experimentação de gestão colegiada e integrada dos serviços públicos' ligados a diferentes instituições”. Esse convênio, datado de 1982, recebe, ao final de 1984, o nome de AIS (Santos 1988, p.09). Por referência àquela iniciativa, Cecílio (1997, p.107) destaca alguns 'problemas relativos à integração interinstitucional', referidos ao gerenciamento no âmbito de uma região administrativa da SES de São Paulo (DRS-5), discutindo os programas de saúde enquanto contraponto das ações de integração.

Como desdobramento mais depurado daquelas intenções, no começo de 1984 instituíram-se as Ações Integradas de Saúde (AIS), uma proposta oriunda do Plano de Reorientação da Previdência e Assistência Médica no Brasil, através das quais se 
viabiliza o apoio financeiro do Ministério da Previdência e Assistência Social aos municípios pela via convenial, destinada basicamente para apoiar a estruturação de uma rede de serviços básicos de saúde. Nas palavras de Mendes (1996, p.61) fica mais claro esse movimento:

O plano do CONASP colocou 'como alvo a integração das ações de saúde' mas desdobrou-se, na prática, em vários projetos racionalizadores, como o Plano de Racionalização Ambulatorial, que levou à proposição das 'Ações Integradas de Saúde’. As AIS, implantadas em 1983 como um programa de atenção médica, adquiriram, (....) na Nova República, um desenho estratégico de co-gestão, desconcentração e universalização da atenção à saúde. Importa salientar que as AIS modificaram-se, qualitativamente, a partir de ações intestinais dentro da instituição propositadamente preparada para sustentar o modelo médico-assistencial privatista, o INAMPS.

As AIS foram criadas após vários estudos, atrasos e mudanças de nomenclatura. Tratava-se de uma primeira tentativa de incorporar os princípios defendidos pelo movimento sanitário a respeito da organização dos serviços, através de uma via convenial entre o ministério, os governos estaduais e os municípios. Na época considerou-se um grande avanço, haja vista não existir, até então, qualquer diálogo, integração ou entendimento entre tais serviços (Pupo Filho 1997, p. 89-90).

Aprovadas como política de reorientação setorial entre os ministérios da Saúde, Previdência e Educação - MS/MPAS/MEC (Rodriguez 1984, p.14), as AIS surgem como uma ação, uma atividade, um programa, inicialmente através de um convênio trilateral e depois, como um programa de ações integradas. Desde o seu início, assume o caráter de proposta intergovernamental, a chamada 'estratégia de ações integradas de saúde' (Rodriguez Neto 1988, p.34).

Na sua formatação inicial, as AIS se constituíram enquanto um programa, conhecido na época como PAIS, base da sua constituição. "Enfim, as AIS eram os ex-PAIS" (Felipe 1988, p.68). Ambos tinham um caráter reformista. Segundo Vasconcelos (1988, p.73), a partir do conceito de co-participação, havia duas formas de financiamento: a listagem de gastos potenciais de um pacote de programas verticais, realizados pelas unidades 
conveniadas, enquanto totalidade de suas atividades, sendo a soma desses gastos rateada entre as instituições envolvidas. Para esse autor "o exemplo marcante desse tipo de financiamento foi o PAIS de Santa Catarina", cujas distorções (rede paralela, compra de serviços auxiliares de diagnose e terapia no setor privado, hospitais públicos privatizados), se somavam ao fato de não conseguir 'avançar nas questões de produtividade e de integralidade das ações' (ibid).

De acordo com o modelo racionalizador havia uma concepção de organização do setor através da 'integração interinstitucional entre as instituições públicas do nível federal e as de nível estadual e municipal' (Rodriguez 1988, p.14). Através das AIS se institui, pela via de atos normativos, a 'estratégia de integração inter-institucional' do setor saúde a partir de 1983, pretendendo-se também que se integrem ações preventivas $e$ curativas', de forma articulada a um sistema de serviços de assistência médica secundária e terciária (p.16 e 19).

Para além da sua condição de uma bela idéia, existem dificuldades para se conseguir efetivar a 'integração intersetorial e integração interinstitucional'. Conforme Arouca (1988, p.41) denunciava, nota-se que 'na integração setorial existem verdadeiras ações 'intrigadas' e não integradas'. Caracterizava-se a necessidade do seu aprofundamento na coordenação dos diversos serviços, para se 'intensificar a integração das diferentes instituições de saúde’' (Felipe 1988, p.67).

A perspectiva da "incorporação dos serviços de saúde estaduais e municipais à rede de serviços da previdência social, através das AIS, fez com que as secretarias estaduais de saúde tivessem que dar maior atenção a seus serviços de saúde” (Nicz 1989, p.54). Por outra parte, a instituição das AIS pelos estados e municípios brasileiros, veio propiciar uma significativa ampliação da rede municipal de unidades básicas de saúde, inicialmente aumentando a oferta de assistência médica. Segundo Rodriguez Neto (1988, p.14), no decorrer de todo o ano de 1985 algumas experiências de natureza racionalizadora e integradora começam a ser divulgadas e replicadas. Durante os primeiros anos da Nova República, as 'propostas de integração entre as instituições que mantinham serviços de saúde ganharam forças' na oportunidade de sua prática. As AIS trouxeram contornos realistas à instituição de sistemas locais de saúde no Brasil e 
seus desdobramentos passaram gradativamente a discutir a incorporação dos princípios que faziam parte da proposição dos SILOS. As idéias associadas às AIS, por referência de aproximação às noções de integralidade ora pesquisadas, são apresentadas a seguir, segundo o contexto da sua formulação.

Efetivamente, após três anos da sua existência no país, predominava na conjuntura constatada na $8^{\mathrm{a}}$ CNS (Anais 1986), uma avaliação positiva: as ações integradas já estão deixando de ser relação de compras de serviços (p.147); têm caracter de conjugação e de integração das ações com as entidades filantrópicas beneficentes e com o setor privado de caracter lucrativo (p.148); implicam na definição de um programa de saúde integrado (p.155); contém propostas recentes de fusão e integrações de instituições (p.235); viabilizam a inserção dos setores filantrópico e privado em 'sistemas modularizados e integralizados' (p.287); permitem a antevisão de 'um novo sistema de saúde, pluriinstitucional, mais unificado nas suas diretrizes de integração' (p.314); representam uma 'alternativa de integração descentralizada' (p.21); portam propostas integradoras com os municípios de um modo geral (p.315); tem-se como meta a integração (p.316); as AIS constituem os primeiros passos para a integração (p.317); ofereceram a oportunidade para a integração possível (p.68); apontam para um 'sistema único de saúde - integral' (p.352); deve-se preservar as AIS (p.360); foi considerado um avanço as AIS (p.361); e se sugeria a avaliação de um funcionamento integrado das AIS (p.366).

Nas demais referências revisadas destacam-se ainda outros argumentos positivos sobre as AIS: "é incontestável que foi um grande passo para a reorganização do setor da saúde, em função de uma cobertura integral” (Scalco 1988, p.48 e Felipe 1988, p.65); destaca-se a idéia de integração e universalização da assistência médico-sanitária; as AIS defendiam propostas históricas como "a integração e participação, num enfoque mais preciso de controle social sobre os serviços, (....) constituindo-se em um importante instrumento (ou momento) pedagógico de 'planejamento descentralizado $e$ integrado"' (Felipe 1988, p.68); as instâncias das AIS eram 'responsáveis pela gerência dos serviços públicos em processo de integração' (Gadelha 1988, p.80). 
Como também, ao assumir sua responsabilidade para com a saúde da população, o próprio poder público vai identificando limites na implantação das AIS, fundamentalmente derivados da "impossibilidade de garantir o acesso universal pela própria forma como está organizado o sistema, com redes diferentes; as dificuldades de integração entre as várias instituições públicas, o que dificultou que se conseguisse que a rede pública pudesse trabalhar com a sua capacidade total; as dificuldades de financiamento das próprias AIS, não só pelo orçamento que foi destinado a elas como pelos próprios mecanismos de co-participação que foram instituídos" (Anais $8^{\mathrm{a}} \mathrm{CNS}$ 1986, p.370). Como avaliação final, o relatório da $8^{\mathrm{a}} \mathrm{CNS}$, ao traduzir as diretrizes predominantes sobre as AIS, conclui pela sua reformulação imediata (Gadelha 1988, p.82).

\section{SUDS como travessia ao SUS}

No momento imediatamente posterior à $8^{\mathrm{a}} \mathrm{CNS}$, segundo o Conselho Nacional de Secretários de Saúde - CONASS (1985, p.22), considerou-se que aquela forma de organização sanitária brasileira devesse se modificar através da estruturação de um sistema unificado de saúde tendo entre suas principais diretrizes a "eliminação da artificial dicotomia entre a saúde das pessoas e saúde coletiva, através da incorporação do (ex-)INAMPS pelo Ministério da Saúde, sendo o sistema de saúde coordenado pelo Ministério da Saúde". Foi somente quase no momento da exoneração de um representante do movimento sanitário da Presidência do ex-INAMPS (Hésio Cordeiro) e no rumo das conclusões aprovadas na histórica $8^{\text {a }}$ CNS (1986), que aquela gestão ainda conseguiu deixar como produto "a elaboração e institucionalização politicamente, ao nível da própria Presidência da República (via decreto), o Sistema Unificado e Descentralizado de Saúde - SUDS" (CEBES 1988, p. 5).

No contexto pós $8^{\mathrm{a}}$ CNS ainda persistem expressões do movimento de integração interinstitucional com o qual se finaliza a apresentação dos antecedentes históricoconceituais que informam a presente investigação. Derivada da íntima relação existente entre as propostas das AIS e do seu sucedâneo, os SUDS, após aquele período em que se reorientaram os equipamentos públicos com as AIS, na seguinte conjuntura era o SUDS que vinha anteceder a perspectiva de um sistema único pela via constitucional. 
Como desdobramento da $8^{\mathrm{a}} \mathrm{CNS}$, pretendendo dar encaminhamentos institucionais para as diretrizes ali consagradas, foi criada a Comissão Nacional de Reforma Sanitária, no interior da qual foi formulada a proposta do SUDS que se institucionalizou via decreto presidencial. Apesar desta sua característica, o SUDS foi considerado naquela conjuntura específica um importante passo para se chegar a um sistema único de saúde. A idéia era partir de uma unificação, com vistas a um novo sistema a ser conquistado em outros fóruns políticos, especialmente a Assembléia Constituinte em vias de instituição.

Conforme registrou Silva (1998, p.24), entre 1987 e 1990, “este processo enfrentou sérios obstáculos, como o agravamento da crise econômica e a turbulência política provocada pela elaboração da Constituição e pelas eleições municipais (1986), presidenciais (1989) e estaduais (1990)". Considera que o "ápice da crise deu-se no período entre 1991 e 1992, com o tumultuado processo de municipalização da saúde e os severos cortes orçamentários no setor social". Segundo Paim (1988, p.40) menciona ao discutir esta problemática, após lembrar que "enquanto em 1986 a polêmica era se as AIS atrapalhavam ou não a reforma sanitária”, no contexto dos anos seguintes, “diversos autores e estudos têm destacado o significado das AIS e do SUDS no projeto da reforma sanitária. (....) Mas apesar de todo o esforço concentrado sobre a Constituição pelos militantes da saúde, as vitórias conseguidas apontam mais para mudanças setoriais, possivelmente redutíveis a uma reforma administrativa” (p.41).

No âmbito ministerial "permaneciam 'dificuldades de integração nas entidades supervisionadas', na SUCAM, na Vigilância Sanitária, nas Campanhas e nos investimentos realizados com os recursos do Banco Mundial". No âmbito estadual, ainda através do INAMPS, com a implementação dos SUDS defendia-se uma "proposta de radicalização da descentralização e do fortalecimento de uma autoridade sanitária estadual única, o secretário de saúde" (Vasconcelos 1988, p.74). Desde o contexto da $8^{\mathrm{a}}$ CNS persistia um sistema apresentando ainda características como a "multiplicidade de órgãos nas diversas esferas de governo, com 'insatisfatório grau de integração programática e operacional'; excessiva centralização política e financeira no nível federal de governo", entre outras (Anais 8 a CNS 1986, p.143). 
Neste panorama nacional, apesar das SES começarem a se preocupar com a rede de serviços como um todo, entre suas dificuldades, não se conseguia obter "grandes avanços na 'integralidade horizontal dos diversos programas' do Ministério da Saúde, que as SES eram e continuam sendo as principais executoras" (Vasconcelos 1988, p.74).

Noronha e col. (1990, p.532) identificam duas correntes estratégicas na configuração do modelo institucional do SUDS no Rio de Janeiro, centrado na municipalização: uma de natureza política, tratando de sua consolidação como abertura de caminho para o SUS pela via de um processo radical de descentralização; e outra, de natureza técnica, que concebe o caráter dos SILOS como uma 'integração entre os setores público e privado', buscando aplicar o conceito de rede assistencial.

Em âmbito nacional, pode-se considerar que as "novas formulações unificaram os subsetores institucionais da saúde pública e da assistência médica previdenciária e estabeleceram a rede de unidades básicas da saúde pública como principal porta-deentrada do sistema de atenção à saúde" (Nemes 1995, p.23).

Via estratégia da 'Programação Orçamentária Integrada' - POI, “buscava-se, a partir de um locus privilegiado, a Secretaria de Planejamento do INAMPS, contribuir para a criação de uma metodologia de planejamento, que aproximasse as práticas dos serviços de saúde das características epidemiológicas locais" (Vasconcelos 1988, p.71). Diretrizes integradoras encontravam sustentação político-administrativa nas POI, por seu caráter de dar materialidade à 'integração nos SUDS' (Silva 1998, p.73).

Como antecedente havia a estratégia AIS, redirecionando recursos para o setor público e se ampliando as bases sociais para as mudanças na saúde, e assim segundo Paim (1988, p.39-40), se "construía de forma ascendente e participativa (tijolo-por-tijolo num desenho lógico) o novo sistema de saúde dentro do velho, que se articulava com as campanhas dos governadores, deputados estaduais e constituintes e, simultaneamente, elaborava a Programação Orçamentária Integrada (POI-87) para não faltarem recursos aos novos governantes". 
A POI configurava-se enquanto tecnologia de planejamento participativo, pelo menos por referência aos técnicos das secretarias estaduais de saúde (SES). No desdobramento das ações setoriais, dentro das secretarias estaduais de saúde havia a dificuldade de se conseguir 'integrar, duas estruturas' (Mendes 1996, p.122), por referência ao INAMPS e às próprias SES.

Com a POI se factibilizavam ações antes inviáveis no sistema público, como por exemplo, a implementação de um Programa Integrado de Imagenologia, buscando “adequar esse poderoso instrumento de diagnose, a um padrão ótimo de utilização e não a um padrão ótimo de lucratividade" (Vasconcelos, 1988, p.75). A POI era o instrumento para esse repensar e sua abrangência e complexidade diferia em cada conjuntura estadual. Os procedimentos previstos definiam uma tecnologia interdependente, que se entrelaçava (p.75-6).

Desde a $8^{\mathrm{a}}$ CNS (Anais 1986, p.158), já havia uma clara preocupação com o financiamento público como forma de "considerar a saúde num universo mais amplo e, fora da lógica de seguro" com pré-pagamento específico, sendo proposta uma visão que vem permitir 'a apreensão da saúde de forma mais integral', sem privilegiar as "ações assistenciais em detrimento das de proteção e promoção da saúde, quase sempre de efeito mais extenso e significativo". Efetivamente a "universalização da utilização dos recursos previdenciários se deu na prática, contrariando o meridiano artificial que separa as ações curativas (médico-individuais) e preventivas (de alcance coletivo). Nos níveis estadual e municipal os recursos serviram à compra de medicamentos e insumos, pagamento de pessoal etc., para a rede ambulatorial e de hospitais públicos, abertas ao conjunto da população". Importa reter que 'a questão da integralidade da atenção devida veio à tona, com a atualização ampliada dos recursos previdenciários' (Felipe 1988, p.68).

\section{Sistema integrado}

As condições da reforma sanitária haviam sido construídas em anos anteriores pelo movimento sanitário, "consolidando um projeto técnico-político claramente formulado em torno de um conjunto de diretrizes e princípios organizativos" propondo 'um sistema 
público, universal e integral de atenção a saúde’ (Teixeira 1989, p.49). Já vinha do contexto das políticas dos sistemas locais de saúde a compreensão da importância de se dispor de um 'sistema integral de serviços de saúde acessível para todos' (Carlson 1990, p.552). Em momento preparatório da $8^{\mathrm{a}} \mathrm{CNS}$, havia no âmbito estadual, em contextos de Pré-Conferência Estadual de Saúde o entendimento da fundamental importância de se desenvolver uma profunda mudança na estrutura vigente no "sistema nacional de saúde, no sentido de criação de um novo sistema, (....) em condições de propiciar a todos os brasileiros 'assistência de saúde integral' e de boa qualidade, com 'integração institucional entre os vários órgãos e os vários níveis de atenção' e prioridade para os serviços públicos em relação à área privada" (Anais 1986, p.357).

Nessa perspectiva, havia uma clara consciência na área da saúde pública, dentro da conjuntura iniciada com a Nova República, de que era primordial se promover a efetiva mudança institucional na sua composição setorial, o que consumia o debate sobre as reformulações da assistência à saúde - a discussão da reformulação institucional do setor. Assim como começava a marcar presença a "questão de adequar a gestão do setor saúde à perspectiva de implantação de um regime democrático no país" (CEBES 1985, p.11).

$\mathrm{Na} 8^{\mathrm{a}}$ CNS (Anais 1986, p.152) colocava-se claramente como uma meta a ser alcançada, um compromisso no sentido de que 'o estado assumia integralmente a responsabilidade com a garantia de saúde para a população', assim como a política de medicamentos, de tecnologia e assistencial. Na seguinte conjuntura imediata, de um ano em processo constituinte (1987), reforçava-se a defesa da idéia de um sistema integrado, integralizado e resolutivo', além de condições efetivas de ser gerido colegiadamente com participação da população (Goulart 1988, p.62). Era então reconhecida como também necessária tanto a 'integração intersetorial', ora referida ao saneamento, habitação, colonização, viação, abastecimento e educação, como a 'integralidade de ação setorial', para se superar "progressivamente as dicotomias entre individual/coletivo e preventivo/curativo" (Anais $8^{\text {a }}$ CNS 1986, p.158-9).

Na perspectiva do aprofundamento da implementação da estratégia AIS, foi formulado de forma articulada aos Núcleos de Estudos em Saúde Coletiva ou Comunitária junto a 
universidades, uma proposta de cursos de capacitação pretendendo contribuir na institucionalização das propostas da reforma sanitária. Nesse sentido destaca-se a proposta do CAPSIS - 'Curso de Aperfeiçoamento em Planejamento de Sistemas Integrados de Saúde’. Estes cursos foram ministrados em todo o país, especialmente direcionados a técnicos das secretarias estaduais de saúde, e eram financiados com recursos da previdência. Consta no programa do CAPSIS, por referência ao módulo que tratava da reorganização dos serviços de saúde: "Análise do processo de construção de um modelo assistencial como orientador da programação e da execução de políticas de saúde"; e, por referência ao módulo o sistema de avaliação e a 'programação/ orçamentação integrada no planejamento estratégico': "análise do sistema de avaliação e da POI - como instrumento do planejamento estratégico" (NESCOM 1988, p. 40).

Defendia-se a proposta do SUDS como um sistema unificado de saúde que vinha responder basicamente a uma 'integração administrativa e burocrática', mas ficava exposta a consciência da necessidade de outro sistema de saúde, não se resumindo somente à 'integração do INAMPS com o Ministério da Saúde', e sim 'um sistema de saúde que integre além desses órgãos' (Anais $8^{\mathrm{a}}$ CNS 1986, p.159). Nos sistemas municipais precursores da organização dos seus serviços na lógica da reforma sanitária, a exemplo de Santos no litoral paulista, pretendia-se, inicialmente, "montar o sistema municipal e organizar a atenção básica à saúde que, até então, era atribuição quase que exclusiva do estado". Assim sendo, 'a principal diretriz do movimento sanitarista era a descentralização e a organização do sistema integrado’ (Freire e Ghanem 1997, p.42). Mesmo nesse caso concreto Pupo Filho (1997, p.91) explicita que no período do SUDS a 'articulação entre os serviços, se processava mediante a busca da descentralização e integração'.

O fato de que a descentralização e a 'integração/unificação interinstitucional' acabaram ocupando o maior espaço de concretização das propostas, gerou, ao mesmo tempo, críticas a esses dois princípios, onde se pode destacar a posição de Campos (1988, p.09), fazendo uma tréplica nesse debate. De todas as maneiras

a redução a uma dimensão mais burocratizada é uma possibilidade real. Tanto é que esses eram os princípios que mais visivelmente continuavam sendo implementados e de certa forma tendiam a se restringir a uma 'integração significando somente unificação interinstitucional'. Daí a existência da crítica frente à sua hegemonia discursiva no 
contexto da reforma sanitária brasileira. Pois ambos podem estar referidos somente mesmo à lógica burocrática, se não houver uma vigilância nesse sentido (ibid).

Foi a percepção do peso centrado nas diretrizes de descentralização e integração do sistema que levou a retomar deliberadamente as questões da finalidade desse sistema como condição de dar efetividade aos princípios mais finalísticos da reforma sanitária.

\subsection{A Integralidade da Reforma Sanitária ao SUS}

A década de 1980, considerada "perdida" para a economia na sociedade brasileira, foi marco de profundas transformações no sistema de saúde ao mesmo tempo em que na redemocratização do país, contexto em que se insere o movimento da reforma sanitária, referência central da dimensão política de formulação ético-normativa da diretriz da integralidade em saúde.

A constituição do próprio campo da saúde coletiva brasileira pode ser situada como um dos fundamentos daquele movimento tupiniquim. Em uma análise que Silva (1998, p.13) desenvolve, partindo da crise do modelo assistencial de saúde nos anos 70, considera que "em seus desdobramentos no contexto mais amplo da ofensiva neoliberal contra o estado de bem-estar social, a partir do fim da década", a crise tenha estimulado também o que situa como a gênese de um campo científico e político novo - o da saúde coletiva enquanto outro paradigma, onde novas propostas de modelos de atenção à saúde passam a ser formuladas.

Segundo Donnangelo e Campos (1981, citados por Silva 1998, p.22-3), a conformação do campo da saúde coletiva no Brasil se define "(....) no esforço de superação do projeto da medicina preventiva em sua imediata subordinação ao objeto da clínica", processando-se enquanto a "reorientação possível do coletivo, não mais reduzido necessariamente ao conjunto de influências sociais que incidem sobre o indivíduo". Desloca-se a "ênfase posta na questão saúde/doença para a questão da prática de saúde sob distintas perspectivas (da administração de serviços à análise das práticas sanitárias em suas articulações políticas e ideológicas)”. 


\subsubsection{No Movimento da Reforma Sanitária}

Com o advento da Nova República na metade dos anos 80, num contexto de redemocratização da sociedade brasileira, o movimento sanitário consegue articular um claro posicionamento dos setores da sociedade com uma nova política de saúde que é amplamente formulada durante a $8^{\mathrm{a}}$ Conferência Nacional de Saúde (Anais $8^{\mathrm{a}}$ CNS 1986), marco histórico que sacramenta o processo nacional de reforma sanitária, destacando-se neste contexto a idéia do direito à saúde. A Conferência, convocada pelo Chefe do Poder Executivo e pelo ministro da saúde, oportunidade em que se constatou a integração entre pessoas e instituições com responsabilidades no setor saúde, foi um amplo fórum que legitimou os princípios e diretrizes de um novo modelo assistencial em saúde, além da própria expressão reforma sanitária (Cordoni 1989, p.58).

Uma característica que lhe acrescenta maior importância pode ser atribuída ao fato da reforma sanitária colocar a saúde como uma questão central na vida nacional. A isso se associa a idéia de que, "um país que se queira democrático tem que ter como objetivos de governo a promoção, a proteção e a recuperação da saúde de todos e de cada um de seus cidadãos" (Scalco 1988, p.47). Essa expressão, legitimada naquele contexto, já aponta para idéias de integralidade em saúde.

\section{1) Integralidade como princípio da reforma sanitária}

A conquista de uma universalização do acesso aos serviços de saúde parecia uma questão de honra do projeto da reforma na saúde. Tratava-se do 'direito de assistência à saúde’. Significando, segundo Jorge (1988, p.50), o acesso igualitário de toda a população às 'ações e serviços de promoção, proteção e recuperação da saúde em todos os níveis'. Conseqüentemente, passa a ser dever do Estado assumir uma política econômica para assegurar à população - o 'acesso aos bens e serviços necessários à saúde integral'. Como também, 'que as ações de saúde passem a ser implementadas de uma forma integral', para 'superação do paralelismo de ações e da dicotomia entre as dimensões preventivas e curativas' (Anais $8^{\text {a }}$ CNS 1986, p.364-5). 
Por ocasião da $8^{\mathrm{a}} \mathrm{CNS}$ havia uma clara consciência que entendia assim: "que 'o direito à saúde integre e ao mesmo tempo interdependa dos direitos sociais básicos'. Portanto, a todo indivíduo deverá se resguardar o direito à alimentação, habitação, saneamento básico, educação, pleno emprego, salário justo, lazer, condições de salubridade do meio ambiente incluindo o ambiente de trabalho, 'assistência integral à saúde', com maior ênfase à prevenção" (Anais $8^{\mathrm{a}}$ CNS 1986, p.362).

Para a concretização de todo esse ideário se preconizava ainda a implantação de um modelo participativo de saúde comunitária, apesar das linguagens ainda se lapidando, que compreendia a aplicação dos seguistes princípios: "unificação do sistema, universalização, equidade, dignidade, resolutividade, regionalização" e ainda 'integrações das ações de saúde' (Anais $8^{\mathrm{a}}$ CNS 1986, p.369). Em um contexto bastante anterior à formulação da Agenda 21 (1992), já se reconhecia publicamente que é a força da sociedade civil organizada que faz os governos se comprometerem com os direitos da população: "Na promoção de saúde, deve participar, e participam realmente se o programa se propõe ser efetivo, toda a comunidade e todos os segmentos da sociedade". Propunha-se um direcionamento da saúde, no sentido da real promoção à saúde e não do tratamento da doença. Nessa perspectiva colocava-se a importância de haver uma diferenciação muito grande entre promoção de saúde e tratamento de doença (Anais $8^{\mathrm{a}}$ CNS 1986, p.153).

O caráter processual da reforma sanitária brasileira se expressava sobretudo na necessidade de transformações institucionais, que demandavam novos princípios da política econômica para a saúde, mas, segundo Berlinguer (1988), especialmente na imposição de "uma reforma cultural, porque a participação democrática, necessária para a promoção da saúde, pode ser uma palavra sem significado, se não há informação e cultura" (p.64).

A idéia de modelo de atenção à saúde tem um conteúdo técnico, organizacional e político. Um novo modelo assistencial era então anunciado. Mesmo ainda sem ter uma noção mais clara da sua formatação tecnológica, isso viria ocorrer no processo. Havia princípios e clareza política. A crise institucional tinha que ser resolvida e a dívida 
social paga. O movimento da reforma sanitária brasileira expressou-se por um leque de significados. Dentre estes se destaca especialmente, o princípio do direito democrático.

O Brasil de então era, antes que nada, de abertura democrática. Precisava afirmar-se enquanto tal. Naquele contexto se defendiam alguns preceitos como os seguintes (Scalco 1988, p.48): “concepção da saúde como fruto do desenvolvimento econômicosocial, e não apenas uma ação setorial e de assistência médica; direito universal à saúde (....); dever do Estado quanto à promoção, proteção e recuperação da saúde; criação do orçamento social (....); criação de um sistema único de saúde”, destacando-se aqui, entre os seus princípios, a 'integração institucional' e a 'integralidade do cuidado e das ações'.

Os contextos das idéias de integralidade continuaram sendo formatados nos anos de 1987 e 1988, nos campos de luta pela reforma sanitária, estando centrados especialmente em duas instâncias: na primeira institucionalmente, através da criação de uma comissão nacional de reforma sanitária e na segunda politicamente, onde se articula os segmentos da sociedade civil organizada, mais comprometidos com o projeto, através de uma plenária da saúde para defender a sua proposta no processo constituinte, destacando-se, sob o pressuposto de um sistema único de saúde, a lógica de defesa do direito integral à saúde.

Durante a $8^{\mathrm{a}} \mathrm{CNS}$, o desenvolvimento do tema 'saúde, direito de todos e dever do Estado', entre outras contribuições, destacava: "Para que isso seja assegurado, entendemos que seja necessário, em primeiro lugar, 'que se considere saúde em sua plenitude' e priorizá-la nas políticas governamentais, através de maciços e contínuos investimentos nas áreas de saneamento básico e de defesa do meio ambiente; na produção de alimentos para consumo interno; na prestação de serviços de saúde, de educação, habitação; garantia de trabalho e condições de lazer, imprescindíveis para a valorização do homem" (Anais $8^{\mathrm{a}}$ CNS 1986, p.124). A amplitude do direito está contida na concepção assumida de saúde e doença.

A $8^{\mathrm{a}}$ CNS (1986), consolidando o ideário que foi construído pelo movimento sanitário e sociedade civil organizada, deflagra e consagra uma reforma sanitária informada 
genericamente por princípios de organização dos serviços de saúde de forma universal, com equidade, descentralização, mando único em cada esfera de governo, gestão colegiada e participação da comunidade, pressupondo para tal um sistema integral. A questão da integralidade por vezes aparece ou não neste rol, às vezes como princípio finalístico, outras mais predominantemente como princípio de organização do sistema.

Ante a crise financeira da seguridade social evidenciada no início da década de 1980, e no interior dela, a crise do modelo privatizante do setor saúde - incapaz de expandir-se nas mesmas bases -, o movimento sanitário foi o único grupo capaz de oferecer uma alternativa concreta para reformulação do sistema de saúde. Essa condição foi construída

pouco a pouco, consolidando um projeto técnico-político claramente formulado em torno de um conjunto de diretrizes e princípios organizativos de um 'sistema público, universal e integral de atenção à saúde'. Como também, concomitantemente, fora tecida uma complexa teia de relações políticas que, embora estivesse situada externamente ao órgão principal na condução da política de saúde, a seguridade social, cada vez mais dava mostras de que não poderia continuar por muito tempo a ser desconsiderado no processo de formulação e implementação dessa política (Teixeira 1989, p.49).

Em um sentido mais restrito, o entendimento do direito à saúde ficava centrado no problema da expansão dos serviços assistenciais à doença, o que, segundo Nemes (1994, p.24-5, citando Dalmaso 1993; Nemes 1992; Campos 1992), se materializava por referência à:

expansão do acesso à assistência médica individual e, sobretudo, a um tipo especial de assistência: o atendimento médico do tipo pronto-atendimento, cujas características tecnológicas (atendimento organizado pela procura espontânea, centrado na queixa principal, com baixo grau de utilização de técnicas de investigação clínicolaboratoriais e de referenciação a especialidades médicas e alto grau de utilização de terapêuticas medicamentosas) permitem aumentar rapidamente a 'cobertura populacional da assistência' sem investimentos maiores. 
Foram adotadas três vias para viabilizar a reforma sanitária - a legislativo-parlamentar fixando as bases jurídicas; a sociopolitica, agregando as organizações da sociedade civil em torno da necessidade de reorientação dos serviços e no controle dessas políticas; e a institucional, de maior interesse para os fins deste estudo, que esteve concentrada "na organização, (....) implantação e (....) desenvolvimento de um novo sistema de saúde, mais identificado com os ideais de universalidade, equidade, 'integralidade na atenção da saúde', e sob comando único” (Silva 1998, p.23-4).

Pode-se extrair como um pressuposto daquele movimento a necessidade de se implantar um sistema único de saúde que garanta 'atendimento gratuito e integral' (CEBES 1989, p.08). Considerando que, da

crítica ao modelo assistencial, excludente, privatista, hospitalizante, curativista, medicalizante, incentivador das práticas especializadas e consumidor de tecnologia médico-hospitalar sofisticada começa a nascer a proposta de um novo modelo que propugna pela equidade, participação, descentralização, integralidade e universalização dos serviços".

Assim tem-se a enunciação da 'integralidade' entre os 'princípios finalísticos' da $8^{\mathrm{a}}$ Conferencia Nacional de Saúde (Cordoni 1989, p.58).

Observa-se que, em linhas gerais, todas as formas de expressão da integralidade até então levantadas, são enunciadas em nome dos princípios da reforma sanitária. Inclusive, no contexto da campanha presidencial de 1989, as propostas dos partidos políticos procuravam contemplar os princípios constitucionais para reger a política de saúde (CEBES 1989, p.13).

A dimensão política da integralidade em saúde se expressa também na concepção tecnológica das formas de fazer saúde implicadas nos princípios enunciados éticonormativamente. $\mathrm{Na}$ revisão das referências indicativas das concepções de integralidade, publicadas no contexto da reforma sanitária, foi possível dimensionar alguns âmbitos de sua expressão, como o cuidado da saúde das pessoas, as possibilidades de sua organização a partir da rede básica, ficando enunciada a perspectiva da sua conformação como caráter do modelo de atenção e sua configuração nas políticas públicas. 


\section{2) Integralidade do cuidado à saúde da pessoa}

Desde a $8^{\mathrm{a}}$ CNS houve consciência de que a possibilidade de operacionalização do princípio da integralidade das ações de saúde implicava em uma reformulação do sistema nacional de saúde, buscando superar, na prática de seus serviços, a falsa dicotomia entre ações preventivas, ou de saúde pública, saúde coletiva, ou de atenção médica, ou saúde das pessoas. Destacando, porém que a integralidade da atenção, entretanto, só encontra seu sentido ao obter serviços mais resolutivos (Anais 1986, p.283-4).

Conforme identificou o estudo de Mendes-Gonçalves (1994), a resolutividade é genericamente entendida pelos profissionais na perspectiva clínica restrita associada à idéia. Assim, sua associação mais freqüente é tanto com a disponibilidade da medicação necessária ao tratamento do caso e a existência de suficientes opções terapêuticas para sua resolução de continuidade, como também com a necessidade de integração dos serviços ambulatoriais do centro de saúde com os serviços de internação de um hospital'. Ou, no caso de unidades básicas de saúde de menor porte, especialmente a sua articulação com serviços ambulatoriais de maior complexidade como retaguarda. Segundo esse autor, a carência de retaguarda percebida pelos profissionais "não coloca em questão as dificuldades, classicamente apontadas, de integração entre ações de saúde pública e ações estritamente clínicas, por se tratar de ações tecnologicamente incongruentes, mas só lamenta a falta de articulação formalizada e automática, como se não houvesse problema de integração entre instituições com objetivos diferentes" (ibid, p.190).

A concepção de uma 'atenção integral à saúde', no sentido da incorporação da assistência médica individual nessa linha de atuação "significava abrir mão de trabalhar, por exemplo, com grupos de risco a partir do saber produzido pela epidemiologia”. Cabe sim "adequar os programas aos problemas de saúde epidemiologicamente significativos”, de acordo com a 'filosofia de atenção integral à saúde' (Cecílio 1997, p.109). 
Os saberes das diferentes disciplinas "podem enriquecer a prática dos trabalhadores da saúde, habilitando-os a 'abordarem o ser humano de modo integral' em sua dimensão biológica, sociocultural, psicológica e de cidadão com direitos” (Merhy 1997, p.332). Intrinsecamente às práticas alternativas em saúde busca-se inclusive "situar o homem no cosmos, como unidade inseparável de corpo, sentidos, mente e alma, e na qual o homem é visto como parte da unidade cósmica, incorporando e refletindo o todo" (Seravalle 1996, p.84-5). Na proposta culturalista formulada por Mendes em 1980 (citado por Silva 1998, p.51), reforça-se o "movimento de saúde totalizante que pretende resgatar a unidade dos indivíduos, integrando corpo, mente e espírito, mediante práticas que superem a dualidade corpo-mente e reintroduzam elementos de espiritualidade na medicina". Nessa perspectiva, caberia a cada equipe de saúde fazer uma 'abordagem mais integral e holística de cada caso', ao assumir como critério valorativo o restabelecimento integral do paciente (Cecílio 1997, p.50-3).

Coerentemente com a percepção mais ampla do homem são estimuladas reflexões sobre a diversidade pressuposta nos sistemas de atenção à saúde para possibilitar uma apreensão e intervenção fundamentada na 'visão de totalidade holística do ser humano' (Seravalle 1996, p.87).

As equipes de saúde transitam entre a especialização e a polivalência. Tanto em universidades como em serviços de saúde, supondo um 'cuidado integral ao paciente', tem sido imposta aos profissionais e paciente a consulta com vários profissionais distintos que intervêm de maneira excessivamente focal. Nesta situação, por conseqüência, “perde-se a 'visão integral do caso' e as decisões são tomadas de maneira mecânica, a partir do diagnóstico inicial e de protocolos considerados adequados". Como exemplo, um 'programa de atenção integral à saúde da mulher', em que cabe ao médico exclusivamente o diagnóstico e tratamento clínico de patologias (Campos 1997, p.246-9).

Através de políticas ministeriais para a saúde no Brasil, geralmente informadas por diretrizes assumidas pela OPS, os 'serviços básicos de atenção integral à saúde', têm sido gradativamente propostos e estimulados nas secretarias estaduais e municipais de saúde, privilegiando propostas a grupos populacionais ou nosológicos como o exemplo 
da atenção integral à saúde da mulher e da criança. Assim sendo, “(....) ao ser circunscrito a uma proposta assistencial, o PAISM não se consubstanciou como projeto de saúde de âmbito multisetorial para as mulheres" (Costa 1997, p.225).

Havia uma 'integralidade pensada na formulação do PAISM', que além da 'integração das distintas modalidades e níveis de assistência', incluía a 'perspectiva da integralidade dos sujeitos sociais'. Naquele contexto podia-se identificar a 'integralidade como principal estratégia de reorganização dos serviços de saúde’. A assistência no PAISM tinha por características a cobertura universal e a finalidade de 'consolidar o projeto de uma assistência integral com qualidade'. O discurso da 'integralidade da assistência à saúde das mulheres' trouxe o "reconhecimento de que o PAISM representou um espaço de criação de tecnologias para os serviços de saúde, com grande potencial de transformação das práticas" (Costa 1997, p.226-8). Já na 8 a CNS se defendia um sistema universal de 'assistência integral à saúde da mulher' (Anais 1986, p.17). Mas entre os avanços do seu desenvolvimento observe-se a mudança da sua denominação para 'ações de atenção integral à saúde da mulher', que implicavam em dotar os serviços com recursos materiais e humanos para tal (RSD 26, 1989, p.18).

Não sendo assim, permanecem os profissionais sendo responsáveis por procedimentos e não pelos doentes, "fragmentando o processo terapêutico e dificultando a definição do responsável pelo 'acompanhamento integral do doente', bem como da articulação das várias ações necessárias para a recuperação deste". A redução da responsabilidade aos procedimentos gera alienação do profissional em relação ao caso atendido além da separação entre os membros da equipe de trabalho, ficando cada um ocupado com as próprias tarefas, sem maior 'preocupação com a integração das várias atividades assistenciais' (Rollo 1997, p.324).

Inclusive o desenho organizacional das unidades de saúde, especialmente as hospitalares, cria barreiras de comunicação entre os vários corpos profissionais. Tais características têm que ser cuidadosamente consideradas frente ao propósito de se implantar uma nova lógica de funcionamento, voltada para a 'integração de equipes centradas no paciente' (Cecílio 1997b, p.304). Nas produções dos professores do LAPA - Laboratório de Planejamento em Saúde da UNICAMP, existe uma aposta nessa 
possibilidade ao considerar que os 'hospitais são importantes equipamentos na garantia da equidade, integralidade da assistência e na defesa da vida' (Rollo 1997, p.321).

Em nome da 'integralidade da atenção' são identificadas experiências de se trabalhar com a responsabilização das equipes sobre os cuidados prestados, "aliados ao núcleo específico de incumbência tecnológica de cada unidade". Por referência a um hospital psiquiátrico Onoko e Amaral (1997, p.370) afirmam que “os doentes mentais também têm corpos e pretende-se que as equipes responsabilizem-se integralmente pela assistência".

$\mathrm{Na}$ relação convenial de compra de serviços hospitalares, apesar da necessidade expressa como exigência no texto de um contrato-padrão, os hospitais relutam em assinar e se comprometer, enquanto instituição contratada, com a 'integralidade da atenção prestada a cada doente' (Felipe 1988, p.69).

Na primeira metade da década iniciada em 1980, começa a defender-se a proposta de uma 'rede pública capaz de fornecer um cuidado integral, das medidas preventivas às intervenções cirúrgicas complexas'; assim como "a montagem de um sistema de referência e contra-referência entre as diferentes unidades; utilização dos instrumentos do planejamento na administração dos serviços e, finalmente a criação de formas de participação da população e dos profissionais na gestão dos serviços de saúde" (Teixeira 1989, p.48).

\section{3) Da rede básica à discussão do modelo assistencial}

Entre os subsídios apresentados pelo movimento sanitário para o governo de transição democrática (CEBES 1985, p.11), se reconhecia como "forma importante de intervenção do Estado no sentido de reorientar a organização da assistência à saúde no país, a sua atuação como executor de atividades de saúde”. Daí se derivaram 'planos de expansão dos serviços públicos e melhoria do seu desempenho via regionalização, hierarquização e integração das ações'. Como essas iniciativas tendiam a ficar no nível mais "discursivo, seja por falta de recursos, seja pela ausência de uma efetiva vontade política de mudança", naquele momento histórico se reconhecia que uma reversão da 
situação levando o Estado a assumir sua 'responsabilidade de garantir os serviços que atendam às necessidades de saúde de toda a população', somente se viabilizaria enquanto compromisso político de um governo democrático, ou seja, mudanças fundamentalmente de natureza política. E nesse contexto assume importância uma dimensão técnica nas propostas de mudanças, buscando-se encontrar formas de por em prática as intenções politicamente definidas.

De um lado, já existiam os primeiros esboços de uma proposta de médico de família no Brasil, que continha uma centralização do serviço na figura do médico. De outro lado, havia a proposta trazida das experiências alternativas de saúde comunitária, aquelas gestadas durante as décadas de 1970 e 1980. Segundo (Vasconcelos 1999, p.15), um dos “debates políticos importantes que polarizou, na época, os profissionais envolvidos no processo de mudança do sistema de saúde foi sobre que modelo de atenção primária à saúde deveria ser expandido".

Conforme constata Nemes (1995, p.09), a "experiência da reforma sanitária forçou a convivência das estruturas e ações da saúde pública e da assistência médica individual, até então relativamente autônomas, acabando por recolocar em debate a questão da 'integração em bases novamente mais assistenciais'. Deixando de centrar-se nas necessidades político-institucionais imediatas, ao menos parcialmente já "resolvidas", 'a integração passa a ser discutida enquanto proposta de "modelo assistencial" (Schraiber e col. 1993). Dessa renovada perspectiva, a 'proposição assistencial da integração' funda-se na possibilidade de potencializar a efetividade das técnicas de intervenção clínicas e epidemiológicas sobre os processos de saúde-doença.

Por referência à experiência de uma regional de saúde, Cecílio (1997) discute a formulação de uma proposta de gestão democrática do setor público, onde se pode perceber o conteúdo tecnológico implicado: buscava-se a construção do 'centro de saúde integrado, regionalizado e hierarquizado', sendo estes os "princípios que a rede básica devia adotar para fazer face às necessidades da população", com valorização da 'atenção integral a todos os grupos etários'. A operação dessas propostas se processava pela via de um "planejamento anual elaborado pela equipe local, em consonância com um diagnóstico de saúde". Como também se identifica o pressuposto político de que a 
'assistência integral à saúde é um dever do Estado', que se cumpre pela via de um sistema público e democrático de saúde. Para tanto, a organização da rede básica se coloca como 'porta de entrada de alta resolutividade deste sistema' (p.110). O referido autor considera que na organização do processo de trabalho ao nível dos centros de saúde tais indicações vieram significar "uma virada na forma de se pensar as unidades básicas que era dominante até então". Pois, além de qualificar o primeiro atendimento na unidade de saúde como 'atenção integral ao indivíduo', enquanto mecanismo de detecção eficiente de riscos à saúde havia um início de discussão do 'atendimento integral ao grupo familiar e não apenas do indivíduo', inclusive sendo a 'atenção integral à saúde garantida pela equipe' (p.112-3).

Recomendava-se em diferentes fóruns políticos do setor, a exemplo do III Encontro de Secretarias e Departamentos Municipais de Saúde do Estado de São Paulo (1989, p.86), que a 'atenção básica à saúde fosse organizada numa perspectiva ampla, a da integralidade das ações'; implicando que "conforme as características de cada região, se consiga equilibrar a assistência médica individual - organizada segundo a lógica do ambulatório, com seguimento de pacientes, etc. e a do atendimento de emergência, a assistência odontológica, a vigilância epidemiológica e sanitária, bem como outras ações de abrangência coletiva". Persistiam em contextos específicos, como também por referência a Bahia, os esforços de associação do pronto-atendimento, com a ‘integralidade do cuidado’ (Paim 1988, p.43).

O papel dos municípios com a implementação dos princípios era cada vez mais ampliado, pois, segundo Goulart (1988, p.62), muitos deles reuniam "melhores condições que os estados de bancar e assumir a 'construção de um modelo assistencial' distritalizado, hierarquizado, de acesso amplo à clientela, integrado, integralizado e resolutivo', além de condições efetivas de ser gerido colegiadamente com participação da população".

Através da materialização do princípio da integralidade em saúde buscava-se desde então a adesão da população à reforma sanitária, que se pretendia fosse traduzida concretamente pelo serviço prestado. Tal condição impunha "uma revisão das práticas de saúde mediante a organização de conselhos técnicos e comunitários junto às unidades 
e o estímulo às atividades de ensino/serviço", de acordo com uma concepção estratégica que priorizava "o nível local, a ponta-da-linha da rede de serviços", onde se destacava, entre as exigências de mudanças qualitativas nos serviços prestados, as questões do pronto-atendimento e da 'integralidade do cuidado’ (Paim 1988, p.43).

Paim (apud Silva 1998, p.73) destaca que desde a proposição do SUDS, tendo por eixo diretor as recomendações da $8^{\mathrm{a}} \mathrm{CNS}$, indicava-se "um processo de regionalização das ações de saúde por meio de distritos sanitários como uma forma de descentralizar decisões, compreender os problemas locais e permitir maior acesso da população aos serviços de saúde. (....) A distritalização era entendida como processo político institucional, organizativo e operacional, voltado para a construção da base do SUS ".

A hierarquização dos serviços exigia a criação de uma 'rede articulada e integrada' de serviços de saúde de complexidade crescente onde cada unidade tivesse suas funções definidas. Todavia, a intenção de 'integrar práticas' antes separadas na atenção de saúde, enquanto 'ações preventivas e ações curativas, ações individuais e ações coletivas', colocava como diretriz uma abertura às necessidades sociais de saúde, ultrapassando a simples "implementação de ações restritas apenas a uma reorganização da atenção médica e a mudança de elementos internos ao ato médico individual”. Pois segundo Vasconcelos (1989a, p.53), “ao se abrir para as dimensões ecológicas, sociais e psicológicas de saúde, o faz com uma série de novas ações preventivas, curativas, coletivas e individuais de caráter eminentemente técnico, de uma forma que acaba por mascarar a necessidade de outras formas de atuação".

\section{4) Integração de políticas públicas}

A concepção integral de saúde impõe que, além dos cuidados integrais ao indivíduo, a ação seja referida a problemas de saúde dos grupos populacionais, o que se pode estender a segmentos mais amplos da população, geralmente implicando na ação intersetorial. A partir de 1986, no momento em que se adotou a Carta de Ottawa, subscrita por 38 países (Mendes 1993a, p.12), e que entre os requisitos fundamentais para a saúde postula-se o entendimento do autocuidado como uma parte integral da 
promoção à saúde (OPS 1996, p.xi), as referências de concepção e práticas de promoção à saúde passam a ser sistematicamente revisadas.

A Carta de Otawa esteve informada pela preocupação com as desigualdades em saúde segundo condições de vida que, conforme Castellanos (1993, p.8-10) se traduz em numerosos estudos internacionais, destacando no contexto sul-americano o trabalho da CEPAL (Comissão Econômica para a América Latina, órgão da ONU) sobre a magnitude da pobreza nos anos 80, assim como estava amparada na já existência, definitivamente, de suficiente convicção nos governos e instituições, comunidade científica e organismos internacionais especializados, sobre a estreita relação entre a situação de saúde e as condições de vida dos diferentes grupos populacionais. E portanto, "sobre la necesidad de desarrollar 'acciones integrales, multisectoriales', que no se limiten a la atención médica, para transformar las condiciones de vida y la situación de salud”. Porisso, na Carta de Ottawa sobre promoção à saúde se enfatizou que: "la paz, la educación, la vivienda, la alimentación, el ingreso, un ecosistema estable, la conservación de los recursos, la justicia social y la equidad, son requisitos fundamentales para la salud" (Castellanos 1993, p.10).

A preocupação dos governos com os problemas de alimentação e nutrição impõe a garantia de uma 'integração entre as políticas' - "agrárias, agrícola, de abastecimento, de comercialização, de emprego, salarial, de habitação, educacional, de saúde, etc., de forma a garantir a estabilidade nutricional de todos os brasileiros" (Valente 1988, p.53).

Como ilustração de respostas sociais pode-se citar o movimento preocupado com a 'proteção integral da saúde dos trabalhadores', traduzida em "programas e ações executadas dentro de um modelo que privilegie a participação dos mesmos na identificação e no controle dos riscos e dos danos à saúde. O objetivo colimado é proporcionar uma atenção eficaz em caso de doença ou acidente do trabalho e simultaneamente intervir nas condições laborais de risco" (CEBES 1989, p.18). Inclusive, pretendendo efetivar na saúde a integração dos trabalhadores rurais no atendimento' (Anais $8^{\text {a }}$ CNS 1986, p.156-7). A nova política de saúde então vinha se formatando, pela organização e pressão dos trabalhadores em cada comunidade e/ou estado, sem o que não se haveria garantido tais direitos. "A sociedade igualitária 
almejada pelos brasileiros ainda está distante. Mas pelo menos, uma política mais distributiva onde os trabalhadores, os segmentos da sociedade, tenham acesso aos serviços de saúde, à educação, à casa, à moradia, ao trabalho, à alimentação" (ibid).

A saúde do índio traz elementos novos na discussão de uma proposta de diretrizes sobre a sua problemática. No caso da saúde indígena o conceito de saúde da OMS vai implicar reconhecer a cidadania plena e respectivos direitos constitucionais, como determinantes do seu estado de saúde; assegurar a integridade dos ecossistemas especificos' onde vive a população indígena; garantir 'a autonomia, a posse territorial e o uso exclusivo pelas nações indígenas dos recursos naturais do solo e subsolo, de acordo com as necessidades e especificidades etno-culturais próprias de cada nação" (Krenak e colegas 1988, p.60-1). Coerentemente com essas idéias, nas moções da Conferência Nacional Proteção à Saúde do Índio, aquela plenária se posicionava pela "paralisação imediata da política de criação dos centros de vivificação em áreas indígenas e pela participação da comunidade nacional na discussão dos projetos de desenvolvimento da Amazônia, garantindo a sobrevivência e integridade das Nações Indígenas" (ibid). Como qualquer cidadão, também o "índio necessita do seu equilíbrio psico-biológico, enfim, de uma saúde global no seu todo' (Cunha 1988, p.46-7). Inclusive como exemplo claro dessas concepções, a criação do Parque do Xingu teve como objetivo científico a 'saúde integral dos povos' daquela região, situada na própria sobrevivência integral do povo xinguaro (ibid).

A saúde é considerada como "uma das necessidades individuais e coletivas manifestas, às quais é preciso dar respostas sociais. Nas sociedades contemporâneas esse desafio é grande e tem se tornado assunto cotidiano". Este cenário possibilitou conceituar "um sistema único de saúde pautado na universalidade, integralidade e descentralizações das ações sanitárias assim como no controle social' (Lafoz 1996, p. 2). Articuladamente aos princípios e concepções apresentadas, como uma resposta da sociedade brasileira à situação de saúde enfrentada pelo movimento da reforma sanitária, vai ser instituído em 1988 seu novo modelo de sistema de saúde conforme consta no próximo item. 


\subsubsection{Integralidade no SUS}

\section{1) Preceitos constitucionais-legais}

O Sistema Único de Saúde instituído pela Constituição Federal de 1988 é sustentáculo da organização do sistema público de saúde no Brasil e genericamente referido em um quase consenso cívico do direito à saúde.

De acordo com o Artigo 194 da Constituição (Brasil 1988), 'a saúde integra a seguridade social', juntamente com a previdência e a assistência social (NOB 1996, p.16). Essa condição é importante e foi uma das conquistas do movimento sanitário dentro do processo de reforma sanitária brasileira, por entender-se a seguridade social como 'um conjunto integrado de ações' próprias da 'iniciativa dos poderes públicos e da sociedade destinadas a assegurar os direitos relativos à saúde, à previdência e à assistência social" (Rodriguez Neto 1988, p.35). Acreditava-se que tal concepção poderia contribuir na viabilização do financiamento necessário à execução das ações decorrentes da garantia do direito à saúde enquanto dever do Estado.

A consagração da saúde na Carta Magna como direito universal sendo dever do Estado garanti-lo, foi produto de intensa luta social pelo direito à saúde, desenvolvida no contexto de democratização do país praticamente durante toda a década iniciada em 1980 (Giovanella e col. 1995-6, p.13). Segundo esses autores, “a concepção de saúde afirmada na Constituição considera o processo saúde/enfermidade nas suas determinações econômicas, sociais e políticas", sendo considerado como o caráter mais acentuado contido na proposta do SUS o dever do Estado em relação à saúde, que tem sido "traduzido pelos organismos governamentais como a necessidade de ampliação do acesso à atenção, provendo a um maior número de pessoas um leque mais amplo e diversificado de ações e serviços de saúde, através da unificação e descentralização da atenção à saúde" (ibid). Assim vai se construindo o SUS.

O arcabouço legal do SUS finalmente expresso na Carta Magna é sustentáculo do conceito ampliado de saúde e da organização do sistema público de saúde no Brasil, 
conforme os seus dois artigos mais centrais e portadores de concepções integrais para a saúde:

Artigo 196 - Saúde como direito de todos, garantido pelo Estado, mediante políticas públicas que visem a redução do risco (....) para sua promoção, proteção e recuperação. Artigo 198 - Ações e serviços (....) de saúde integram uma rede regionalizada e hierarquizada (....) e constituem um sistema único organizado de acordo com as seguintes diretrizes: I - descentralização (....); II - 'atendimento integral' com prioridade para as atividades preventivas, sem prejuízo dos serviços assistenciais; III participação da comunidade.

A palavra da lei isolada na sua expressão lingüística não permite interpretar o significado subjacente à noção de integralidade aí contida. Mas na relação entre os dois artigos pode-se perceber que no compromisso do Estado de garantia de políticas públicas para responder ao direito instituído de promoção, proteção e recuperação da saúde existe pressuposta uma integralidade da atenção à saúde, cuja expressão nos cuidados se explicita na diretriz do atendimento integral a pautar a organização do sistema, integrando uma rede de ações e serviços de saúde.

Em 1990, com a Lei Orgânica de Saúde representada pelas leis 8080 e 8142, a integralidade encontra sua existência formalmente instituída pela primeira vez com esta denominação específica, formulada como segue. "As ações e serviços (....) devem obedecer, (entre outros), ao(s) seguinte(s) princípio(s): 'integralidade de assistência', entendida como um conjunto articulado e contínuo das ações e serviços preventivos e curativos, individuais e coletivos" (Lei 8080/90, Cap II, art 7, item II). Melhor dito, seria a integralidade de atenção à saúde, por romper com a idéia assistencial que o vocábulo da lei pode conter de forma implícita e que convém superar.

Como se pode perceber, em um primeiro momento se reconhece, constitucionalmente, a concepção do pressuposto de um conceito ampliado de saúde implicando em uma adequada resposta integrada nos correspondentes níveis de atenção, num segundo como diretriz de organização do sistema de atendimento à saúde e num terceiro, legalmente, enquanto princípio do SUS. 
Nessa última definição em Lei, é explicitado o caráter qualitativo da integralidade ações e serviços preventivos e curativos; sua abrangência - individuais e coletivos; e, sua lógica de funcionamento - um conjunto articulado e contínuo. Importa reter aqui o seu reconhecimento como princípio das ações e serviços de saúde conforme pressuposto e diretriz constitucionalmente sacramentados.

A aprovação das leis orgânicas da seguridade social e da saúde deu-se em 1990, já com quase dois anos de atraso em relação à Constituição, e estas deveriam produzir como conseqüência, uma 'política social integrada' (Rodriguez Neto 1996, p.11), cuja implementação a rigor continua em pauta.

Não é somente no capítulo da saúde que se pode encontrar a especificação dos direitos relacionados à saúde da população brasileira. Em capítulo anterior, quando preceitua “(....) que à criança e ao adolescente são assegurados como dever da família, da sociedade e do Estado, o direito à vida, à saúde, alimentação, educação etc.”, lá está “dito que o Estado promoverá, com entidades não governamentais", projetos de 'assistência integral a saúde da criança' (ABRASCO 1988, p.27).

\section{2) Leituras do SUS constitucional-legal}

Mendes (1993, p.62) sintetiza em somente um parágrafo que "a saúde na Constituição está definida como resultante de políticas sociais e econômicas, como direito de cidadania e dever do Estado, como parte da seguridade social e cujas ações e serviços devem ser providos por um Sistema Único de Saúde, organizado segundo as seguintes diretrizes: descentralização, mando único em cada esfera de governo, atendimento integral e participação comunitária". E lembra também que, "ao mesmo tempo, o Art. 199 consagra a liberdade da iniciativa privada".

No texto aprovado ficava como idéia geral que embora o setor privado também tivesse comemorado as suas conquistas, havia sido preservada a essência da proposta articulada através do movimento sanitário. Além da garantia "do direito universal e igualitário às ações de promoção, proteção e recuperação da saúde (não questionado), o 
importante era um Sistema Único que incorporasse todas as ações e serviços de saúde financiados pelos recursos públicos” (Rodriguez Neto 1988, p.22).

Da luta por dar consecução prática aos preceitos constitucionais resultam conquistas importantes para a saúde da população. Tomando por "referência os limites da nova Constituição Federal, coloca-se como horizonte, avançar rumo a serviços mais eficazes, com mais democracia, mais descentralização, 'mais integração', mais participação popular" (Almeida 1988, p.13). Segundo Mendes tem-se que:

o SUS inscreveu, na agenda sanitária nacional, um novo objeto, expresso nas suas diretrizes e princípios: universalidade, integralidade da assistência, preservação da autonomia das pessoas, igualdade da assistência à saúde, direito à informação, utilização da epidemiologia para estabelecimento de prioridades, alocação de recursos e orientação programática, participação da comunidade, descentralização políticoadministrativa com direção única em cada esfera de governo, descentralização dos serviços para os municípios, regionalização e hierarquização da rede de serviços e intersetorialidade.

No novo contexto, "mesmo que o setor privado fosse contratado pelo poder público, o seria sob as normas do SUS; só estariam fora do SUS os serviços privados que não se utilizassem de recursos públicos, isto é, os privados propriamente ditos. (....) E por fim, para falar em essência, 'um conteúdo mínimo de atribuições que conferisse ao SUS um alto grau de integralidade', com a inclusão indispensável da saúde ocupacional" (Rodriguez Neto 1988, p.34). Como se pode ir observando é a diretriz da integralidade que vai atribuindo uma característica central para qualificar o novo sistema. Assim entre os princípios que regem o sistema se enuncia, através da 'integralidade' que o 'SUS é responsável por todo o espectro de ações capazes de interferir nos diferentes momentos do processo saúde-doença' (Henriques 1997, p.25).

Através da constituição do Sistema Único de Saúde, que vem 'integrando todos os serviços públicos em uma rede hierarquizada, regionalizada, descentralizada (....) $e$ atenção integral com participação da comunidade', Teixeira $(1989$, p.51) relembra que “(....) todas as conquistas alcançadas ao nível do texto constitucional deverão ser então 
traduzidas em práticas institucionais correspondentes, para que realmente sejam assegurados os direitos ali afirmados".

Uma vez contida na Constituição Federal e na Lei Orgânica da Saúde a base doutrinária e instrumentos necessários para equacionar a problemática de saúde do país, a posição assumida por sociedade civil, governo, instituições de saúde e trabalhadores é que vai implicar na sua tradução em atos e fatos.

Sendo no espaço dos municípios que as ações de saúde se concretizam, e fortemente condicionadas por recursos de gestão financeira, a sua regulamentação pela Norma Operacional Básica do SUS (NOB 1996), permite iniciar uma visualização, ainda no plano normativo, de como a integralidade pode se expressar na prática do SUS. O pleno exercício da função de gestor municipal, segundo essa NOB (1996, p. 6) se viabiliza mediante "a imprescindível cooperação técnica e financeira dos poderes públicos estadual e federal", sendo atribuída ao poder municipal não só a responsabilidade direta pela prestação de serviços de saúde (Artigo 30, inciso VII), como, da mesma forma, a 'responsabilidade pela gestão de um sistema que atenda, com integralidade, à demanda das pessoas pela assistência à saúde e às exigências sanitárias ambientais' (inciso V). Segundo aquela NOB (p.7) a 'totalidade das ações e de serviços de atenção à saúde', no âmbito do 'SUS-Municipal - voltado ao atendimento integral de sua própria população', devem ser organizadas e coordenadas de forma que o gestor possa 'garantir à população o acesso aos serviços e a disponibilidade das ações e dos meios para o atendimento integral'.

Em função dos diferentes níveis de complexidade nos vários municípios, as negociações entre os gestores quando um município atende usuários vindos de outro, tem como instrumento de garantia, de forma mediada pelo estado, a 'programação pactuada e integrada' - PPI (NOB 1996, p.09). Em seu processo de elaboração configura-se como uma 'programação pactuada entre gestores e integrada entre esferas de governo'. Como também, 'o pacto e a integração das programações constituem, fundamentalmente, a conseqüência prática da relação entre os gestores do SUS' (p.18). 
Abrangendo "as atividades de assistência ambulatorial e hospitalar, de vigilância sanitária e de epidemiologia e controle de doenças", a PPI constitui um "instrumento essencial de reorganização do modelo de atenção e da gestão do SUS, de alocação dos recursos e de explicitação do pacto estabelecido entre as três esferas de governo" (NOB 1996, p.18). Explicitamente, a 'PPI observa os princípios da integralidade das ações de saúde' (ibid).

Frente à ameaça da ocorrência de gastos exagerados, decorrentes de uma incorporação tecnológica acrítica e desregulada, a NOB (1996, p.15) reconhece no SUS 'um sistema regido pelo interesse público e balizado, por um lado, pela exigência da universalização e integralidade com eqüidade', como também por uma intrínseca limitação de recursos a ser programaticamente respeitada.

\section{3) Integralidade na instituição do SUS na prática}

Conforme afirma Laurell (1997, p.36), sabe-se que os países latino-americanos não dispõem de recursos ilimitados, porém, ao considerar que o problema principal dos chamados países de renda média é a distribuição dos recursos e não sua escassez absoluta, essa autora refere várias evidências para afirmar que em muitos desses países poder-se-ia 'garantir serviços integrais de saúde a toda a população se isso fosse assumido como uma alta prioridade social'.

\section{Resistências e limites}

Assim como "na conjuntura de definição da política do SUS, o clima de democratização contaminou e serviu de ponto de identificação para grande parte da população brasileira e profissionais", na metade da última década do século 20 já se constatava que a efetivação daquela política vinha assumindo um direcionamento oposto aos princípios definidos na Constituição Brasileira (Pedrosa 1996, p.29).

Em artigo que propõe moralizar as relações entre o SUS e o setor privado, Rodriguez (1990, p.10) constata que, além de não se enquadrar nas 'normas de universalidade, equidade e integralidade e da ética', o setor privado contratado ou conveniado pelo 
SUS, tem ignorado "olimpicamente a sua subordinação ao interesse e relevância pública definidos pela Constituição". Perde-se assim a perspectiva do mandato público para a defesa dos cidadãos. É lamentável que para tal situação sejam “apontadas como responsáveis duas ordens de favores: a descentralização e a má gestão pública dos recursos, através dos quais se há tentado imputar ao SUS - Sistema Único de Saúde, a culpa por tamanho descalabro" (ibid).

Ainda por referência às relações do SUS com o setor privado, Rodriguez Neto (1996, p.12) considera necessário denunciar o 'afastamento do SUS do seu princípio doutrinário mais central que é a integralidade', entendida como a indissociabilidade entre prevenção e atenção curativa. Pois, ao constatar que a "prioridade orçamentária federal é nitidamente representada pela assistência médico-hospitalar", o mesmo autor denuncia um "detrimento criminoso das ações de promoção e proteção à saúde". Nesse contexto situa-se a proposta de reforma do aparelho de Estado formulada pelo Ministério da Administração e Reforma do Estado (MARE 1995), que insiste em separar logisticamente prevenção e cura (ibid).

A mesma situação pode ser encontrada na proposta das Organizações Mantenedoras de Saúde, que, segundo Mendes (1996, p.88), seriam criadas com finalidade exclusiva de prestar atenção integral à saúde', ao lhes ser vetado transformar-se em ramo das seguradoras ou entidades do sistema financeiro. Por referência a uma proposta política que defende que os serviços estatais sejam transformados nessas organizações, "onde a captação de recursos se faz através de vouchers mediante competição de qualidade no mercado, sendo vedado qualquer subsídio às instituições estatais", aquela proposta técnica foi assumida, com assessoria de seus propositores, pelo Instituto Liberal (do PFL) que, assumindo a mesma base conceptual e justificativas, propunha a criação do sistema nacional de assistência à saúde de forma integrada entre os dois subsistemas “o sistema integrado de assistência à saúde e o sistema assistencial e de saúde preventiva".

Mendes (1996) considera o Plano de Ação do Ministério da Saúde para o período 1995/99 como emblemático de uma esquizofrenia institucional, cuja análise revela a descoordenação ministerial. Ilustra sua constatação pela frequiência com que o 
Ministério da Saúde resolve em suas próprias ações e estratégias, 'autoconvocar-se para um trabalho integrado'. Assim tem-se como parte do plano mencionado a proposição de sua "adequada integração com outros programas" da mesma instituição (p.114-5).

Ainda persistem "programas de saúde pública, resquício do sanitarismo, situados como enclaves nas secretarias estaduais, gerando atividades verticais, em nítido 'confronto com a proposta de integração das ações' contida nas temáticas do SUS" (Mendes 1996, p.123).

$\mathrm{Na}$ realidade, "em meio ao conflito de duas fortes tendências no cenário nacional, o SUS oscila entre a manutenção dos compromissos constitucionais do Estado, simbolizados pelo 'caráter universal e integral da atenção á saúde', além do pleno desenvolvimento dos mecanismos de participação social e, por outro lado, de impulsos poderosos voltados à reforma do pacto estabelecido em 1988” (CEBES 1996, p.03).

Nas propostas dirigidas aos países latino-americanos por agências de financiamento internacional, existem muitas iniciativas para se instituir a chamada "cesta básica de benefícios". Em função de tais orientações, 'a integralidade das ações também está constantemente na berlinda', ao se entender que o "direito à saúde não pode ser reduzido à prestação de cuidados básicos - por mais importantes que eles sejam. $\mathrm{O}$ sofrimento, decorrente de qualquer uma das formas de adoecimento, tem que ser considerado e a sua atenção garantida". De acordo com essa presunção, as tentativas de diferenciar os tipos de serviços de saúde assumidos pelo Estado daqueles existentes no mercado adquiridos por seguro privado representa a 'quebra do princípio da integralidade' (Costa 1997, p.11).

Quando se reduz o "conteúdo de um pacote de ações essenciais de saúde a um número restrito de ações de saúde pública e serviços clínicos ambulatoriais" com custo préfixado, sendo os demais serviços discriminados segundo a sua forma de pagamento pela população, conforme proposta do Banco Mundial (1993 apud Laurell 1997, p.28), essa proposição se afasta tanto da noção do direito à proteção da saúde como do 'conceito integral de atenção primária' ao optar por ações de uma seletividade radical, sendo sua 
validade questionada por muitos autores como os citados por Laurell (Berman, 1982; Gish, 1982; Unger y Killingsworth, 1986).

Outro exemplo questionado frente à defesa da 'saúde, entendida no seu sentido integral', pode ser encontrado na experiência de São Paulo com o Plano de Atendimento à Saúde-PAS (de 1997 a 2000). Autorizado por lei a prestar atendimento à saúde, colocava em risco a "manutenção das ações próprias e indeclináveis de autoridade sanitária" (Sá et.al. 1997). Entre as principais preocupações situou-se "a identificação de como se dariam técnica e financeiramente os encaminhamentos para atendimentos especializados ou ações mais complexas dos pacientes" derivados da cooperativa e como compatibilizar ações coletivas e de aderência aos programas de saúde ao pronto atendimento massivo assumido. $\mathrm{O}$ mesmo estudo ainda revela a dificuldade intrínseca do PAS em "absorver demandas de saúde coletiva, uma vez que o seu objetivo definido em Lei restringe-se à prestação de atendimento médico, sendo bastante difícil a definição do sistema de referência e contra-referência para os serviços públicos de saúde" (p.151-2).

Merhy (1997, p.193-4) considera a NOB 96 de forma submetida "ao projeto de cunho neoliberal proposto pelo Ministério da Saúde e MARE em seu documento - Sistema de Atendimento de Saúde do SUS" que prevê a transformação dos hospitais estatais em organizações sociais, assim consideradas as entidades públicas não estatais. Naquela proposta existe uma clara "separação dos hospitais estatais (....) do subsistema de distritos de saúde", considerando que a este cabe credenciar e contratar serviços dos hospitais estatais, que passam a competir em qualidade e custo dos serviços, com os demais hospitais. $\mathrm{O}$ autor acima entende que essa "atitude, aliada à fragmentação do financiamento, 'fragmenta a integralidade da atenção', criando uma cesta básica financiada com recursos do (....) PAB, (....) PSF e (....) PACS - para os cidadãos mínimos e dando liberdade para o setor privado crescer na ausência do público como prestador de assistência hospitalar especializada”.

O resumo do texto "Sete tópicos sobre as reformas do Estado e do SUS" de David Capistrano propugna que, "sem abandonar a crítica à gestão pública e identificar necessidades de mudanças para melhorá-la”, há que se defender "o SUS, tal qual está 
previsto em seu ordenamento legal, para fazer frente às propostas do Ministério da Administração e Reforma do Estado (MARE), que transformam a gestão pública dos hospitais em organizações sociais autônomas, 'inviabilizando o modelo de atenção integral à saúde', tornando precárias as relações de trabalho, transferindo patrimônio público para o setor privado, em nome de maior eficácia gerencial” (Heimann 1997, p.276-7).

\section{Dos limites às possibilidades}

Apesar das dificuldades reais, após uma década de SUS, já se pode entender que existe uma retórica discursiva da integralidade em saúde no Brasil. Como também existem várias experiências que confirmam sua possibilidade, podendo-se recuperar a referência à cidade de Santos/SP (de 1989 a 1996) como “o SUS que dá certo" (Costa Filho e col. 1997, p.21-4). Naquele como em outros lugares pode-se constatar a construção da integralidade no SUS a partir dos municípios.

São os gestores municipais com vontade política de cumprir com o princípio da integralidade da assistência que conhecem as dificuldades concretas da sua implementação.

Por conta da "progressiva municipalização que acompanha a implantação do SUS, os temas vêm impondo-se pelo 'compromisso com a garantia do acesso universal $e$ integralidade das ações' e pela necessidade de qualificar os atendimentos que mantêm a vida em momentos críticos, evidenciando o papel do governo local em relação à crise do setor" (Henriques 1997, p.199).

Por referência ao papel das SES, reforçando a lógica constitucional, uma das responsabilidades nucleares que cabe ao poder público estadual trata-se de mediar a relação entre os sistemas municipais, como também, quando ou enquanto um município não assumir a gestão do sistema municipal, responder, provisoriamente, pela gestão dos serviços capazes de 'dar atenção integral àquela população que necessita de um sistema que lhe é próprio' (NOB 1996, p.08). 
No plano estadual de saúde, contendo as estratégias, prioridades e respectivas metas de ações e serviços, deve sobretudo constar a 'integração das programações dos sistemas municipais'. Para os interesses deste estudo há que se destacar ainda o papel das SES na 'implementação de mecanismos visando a integração das políticas e das ações' consideradas "de relevância para a saúde da população, de que são exemplos aquelas relativas a saneamento, recursos hídricos, habitação e meio ambiente" (NOB 1996, p.10).

Por parte do gestor federal em saúde, através de "negociações com os diversos atores envolvidos e da ratificação das programações e decisões", derivadas sobretudo dos planos estaduais de atuação na prestação de serviços no setor saúde, implica definir no Plano Nacional de Saúde as estratégias, prioridades e metas da 'programação integrada nacional' (NOB 1996, p.13).

A organização das instituições se abre à participação da população através de conselhos de saúde, sendo possível, segundo Pedrosa (1995-6, p.31), "por meio de um processo de educação para a cidadania, de promoção da consciência sanitária e da constituição de sujeitos sociais, reconhecer 'pontos de interação entre as necessidades de saúde' emergentes da população e as necessidades que os conselhos, por força até mesmo da Lei, devem materializar em práticas nos serviços de saúde”.

Na potencialização das possibilidades frente aos limites, por referência a uma análise da trajetória da saúde coletiva pode-se evidenciar que a continuação do movimento pela reforma sanitária, faz-se necessária para corrigir os descaminhos da universalização elitista se implementando no país, e resgatar possibilidades abandonadas voltando a “agregar valores como equidade, participação e controle popular”. Nesse contexto, ' $a$ integralidade da atenção também é posta, mas com grande ênfase na racionalização gerencial' (Costa 1997, p.226). Todavia, enquanto princípio, contém o sentido de incorporação de um direito social - o de viver com saúde, em seu sentido integral. 


\subsection{Modelos de Integralidade da Atenção em Saúde}

A formatação de um modelo de atenção que venha materializar os princípios e diretrizes constitucionais do SUS tem sido o maior desafio setorial na última década do século 20 e continua sendo.

A conformação do campo da saúde coletiva no Brasil (segundo Donnangelo e Campos, apud Silva 1998, p.22-3) foi definida "(....) no esforço de superação do projeto da medicina preventiva em sua imediata subordinação ao objeto da clínica. Para tanto, impõe-se uma reorientação possível do coletivo, não mais reduzido necessariamente ao conjunto de influências sociais que incidem sobre o indivíduo. O 'deslocamento da ênfase posta na questão saúde/doença para a questão da prática de saúde' dá-se sob distintas perspectivas, que vão da administração de serviços à análise das práticas sanitárias em suas articulações políticas e ideológicas." O modelo de atenção representa a conformação das práticas na organização da prestação dos serviços de saúde.

A integralidade em saúde, aqui toma a forma de modelo. São identificados movimentos de produção teórico-prática que revelam proposições de integralidade para o SUS, entre os quais destaca-se a ação programática em saúde, defesa da vida, vigilância à saúde, saúde da família e municípios saudáveis.

\subsubsection{Ação Programática em Saúde}

O Departamento de Medicina Preventiva da Faculdade de Medicina da Universidade de São Paulo, através da equipe de pesquisadores de seu Centro de Saúde Escola realizou uma importante produção teórico-prática no campo, desenvolvida através da proposição denominada ação programática em saúde. Trata-se do conceito de integração sanitária.

Para os fins do presente estudo aquela produção assume maior relevância na perspectiva do planejamento, gestão e avaliação local de saúde, articuladamente à organização tecnológica do processo de trabalho em saúde e práticas de integração sanitária (Schraiber e col. 1993, Mendes-Gonçalves 1994, Nemes 1995 e Schraiber, Nemes, Mendes-Gonçalves 1996). 
O estudo que fundamentou a referida produção foi o de Mendes-Gonçalves (1994), orientado para um conjunto de questões voltadas ao esclarecimento dessa temática nuclear, que ele explicita 'do ponto de vista epidemiológico', segundo o qual 'a integração sanitária é não apenas razoável e racional, mas quase impositiva'. Sua pesquisa empírica procura identificar para qual tipo de integração sanitária tendem as práticas observadas nos centros estaduais de saúde em São Paulo (p.128). A partir do universo estudado, a pesquisa de Mendes Gonçalves revela que não tem existido efetivamente uma 'integração entre práticas de finalidades e objetos distintos', por referência à clínica e à epidemiologia, havendo apenas 'uma integração em que os centros de saúde se subordinam à lógica que organiza a estrutura de produção de serviços de assistência médica individual' (p.169).

Essas ordens de questões, segundo Merhy (1997b, p.221-2), inicialmente eram "estudadas somente em algumas políticas estaduais", como ocorreu em São Paulo, passam progressivamente a ter sua discussão generalizada em âmbito nacional, relacionadas ao enfoque do papel de uma rede de serviços de saúde em sua porta de entrada. No "modelo de rede da perspectiva médico-sanitária", segundo o mesmo autor, também existe a "incorporação da assistência médica (....) como um mero instrumento de um programa de saúde pública". Nas propostas vigentes de mudança do modelo de atenção, a assistência médica vem sendo recolocada como parte intrínseca da saúde pública. Mas de qualquer maneira, sem a devida articulação com necessidades identificadas em bases epidemiológicas. A situação acima indicada situa o processo dicotômico das práticas médico-sanitárias como sendo construído em parte pela medicina em sua forma de intervenção sobre a doença e riscos manifestos, e em parte pela saúde pública em sua atuação por meio de tecnologias para "impactar os processos de exposição e/ou as articulações entre as práticas de saúde, enquanto serviços”. Nessa encruzilhada, conforme este autor, "o modelo vive o seu dilema e facilmente acaba por reproduzir ou a dicotomia ou o predomínio e subordinação" entre estas 'distintas, mas necessariamente articuladas, racionalidades tecnológicas' (ibid).

A forma dessa articulação é o desafio posto pela realidade. A história recente da saúde no Brasil persiste na manutenção de uma prática clínica hegemonicamente se superpondo aos movimentos da saúde pública e contra-hegemonicamente alguns 
esforços de subordinação da clínica à racionalidade epidemiológica, matriz própria da saúde coletiva, como se há evidenciado no modelo tecnológico da ação programática em saúde. De todas as maneiras essa proposição está voltada para a formatação tecnológica daquela possibilidade de integração.

Tais produções têm ocupado um papel importante dentro do projeto de reforma sanitária, enquanto alternativa tecnológica de construção do novo modelo assistencial a partir de unidades básicas de saúde, para finalmente renascerem objetivadas em práticas históricas comprometidas com a construção do SUS no país. Ou, nas palavras de Schraiber (apud Nemes 1995, p.24): “(....) ambas as vertentes às quais filiamos nossa proposição de Ação Programática (programação em saúde e reforma sanitária) já se objetivaram em práticas históricas; tendo sido concretamente (....) operadas em relação aos projetos tecno-políticos de que se fizeram porta-vozes”. Em virtude da construção da proposta denominada ação programática em saúde haver nascido justamente naquelas conjunturas, Nemes (ibid) afirma que: "ela é filha da Programação dos anos 70 na Secretaria de Saúde de São Paulo mas é também filha da reforma sanitária no Brasil". Assim sendo, suas "raízes passam pela possibilidade histórica de um projeto sanitário novo" onde, entre outras questões, se expressa visivelmente o "reconhecimento ético e legitimidade sócio-política da necessidade de universalização da assistência médica individual".

A proposição da ação programática em saúde é abordada no presente tópico por permanecer como alternativa concreta de 'operar a integralidade na prática dos serviços de atenção primária de saúde', mais propriamente em unidades básicas de saúde, âmbito no qual obteve reconhecimento consensual no discurso da comunidade científica da saúde coletiva; e, neste trabalho, especificamente, em virtude de seu potencial em revestir-se da condição de modelo tecnológico de organização das práticas em serviços locais de saúde.

No estudo de Nemes (1995) foram examinadas formas históricas que o trabalho em saúde tem assumido no Brasil e em São Paulo, o que orientou sua análise das raízes históricas de 'uma especial proposição de integração', denominada 'ação programática em saúde' (p.19). Com esta citação se está chamando a atenção para o 
fato da idéia de integração sanitária ser conteúdo intrínseco da proposta de ação programática. Para esta autora, a "prática programática em serviços de atenção à saúde (....) pode ser conceituada como uma forma de organizar o trabalho coletivo no interior de um serviço de assistência à saúde". Sua lógica está baseada em uma 'projeção éticonormativa de integração', pretendendo a "superação das características dos modelos tecnológicos polares da clínica e da epidemiologia". Fundamentada no 'ideal da integração’ e inspirada em tecnologias de base epidemiológica, a racionalidade de intervenção na ação programática em saúde se processa através da 'integração de ações médicas e ações coletivas' o que tem ocupado lugar de destaque no debate sobre propostas de organização técnica dos serviços (p.7).

O modelo tecnológico da ação programática em saúde representa o conjunto de como se transformaria o objeto recortado (processo de saúde e doença) em uma necessidade social posta para o trabalho. O técnico é a base material das ações e a finalidade do trabalho, que se realiza tecnologicamente, onde estão contidas determinações do plano político-organizacional.

Dentro desta prática integrada se organiza também a atenção à demanda individualcurativa articulada com ações coletivas programáticas de proteção à saúde, o que se destaca neste estudo por conter uma possibilidade objetiva de se operar simultaneamente com o individual-coletivo e a proteção-cura, ao integrar os enfoques parciais da epidemiologia e da clínica. Em sua operação, segundo Paim (1993) citado por Nemes (1995, p.7), “a prática programática em saúde tem a mesma raiz tecnológica da oferta organizada de ações nos serviços de saúde", referida ao conjunto de pacientes captados na demanda espontânea aos quais se propicia 'além do atendimento médico individual, triagem ativa para necessidades de saúde epidemiologicamente identificadas'. Nessa perspectiva se incluem nas "ações voltadas para essas necessidades, a totalidade da demanda e os (....) segmentos da população submetidos a (....) estudos epidemiológicos ou mesmo às técnicas de busca ativa de casos ou grupos de risco".

Cabe destacar enquanto característica tecnológica importante da integração de ações, que, além de reafirmar a 'necessidade de articulação entre serviços de complexidade 
diferente', discute esta 'articulação no âmbito interno do trabalho entre os diversos profissionais' (Nemes 1995, p.82-3).

$\mathrm{Na}$ "ambição maior da proposta da ação programática em saúde”, segundo Ayres (apud Nemes 1995, p.28), ela compreende "um projeto de 'organização do trabalho assistencial que busca realizar a integração médico-sanitária', isto é, um tratamento articulado e mutuamente enriquecedor das necessidades assistenciais objetivadas no plano individual e aquelas objetivadas no plano coletivo no qual as primeiras estão consubstanciadas". A denominação deste projeto como ação programática é assim explicada por Nemes (op cit):

(....) suas proposições se originaram no 'reconhecimento da fecundidade $d a$ organização tecnológica dos programas de saúde’ para a realização destas 'apostas em novas práxis sanitárias e sociais, cujo movimento se ancora profundamente nas relações sociais reproduzidas e modificadas pelo trabalho'. Por outro lado, a forte 'conexão de nosso objeto com a vida social' exige que as propostas tecnológicas articulem-se o mais estreita e dinamicamente possível ao conjunto de 'necessidades concretamente vividas' pelos diversos sujeitos envolvidos nas demandas e respostas por assistência à saúde (p.29).

De acordo com Testa (1997, p.44), a disponibilidade está relacionada com as necessidades das pessoas, o que se precisa para poder viver e que define as condições de vida digna no cotidiano. Dessa forma, a possibilidade de decidir dá-se na constituição da cidadania, o que possibilita a construção do seu sentido. Ou, nas palavras de Agnes Heller (1986), as primeiras seriam necessidades necessárias e as últimas necessidades radicais.

A "idéia reguladora" de uma apreensão integral indica a construção de uma 'possibilidade tecnológica de atingir recortes de objetos tendencialmente mais sociais, embora de instrumentação ainda insuficiente' (Nemes 1995, p.115).

Em seu estudo, Nemes (1995) ressalta "a natureza genericamente instrutora que veio assumir o projeto tecnológico da ação programática em saúde. Esta pode ser definida como uma proposição de corte tecno-normativo, apoiada na busca de um horizonte ético 
claro e intersubjetivamente aberto, voltada para a contínua construção de uma ‘ntegração emancipadoramente orientada das diversas práticas de saúde’” (p.29).

Schraiber, Nemes e Mendes-Gonçalves (1996), em livro que trata da questão saúde do adulto, segundo as "elaborações já contidas na proposição da ação programática em saúde", aprofundam o 'conhecimento das ações integradas' via 'apreensão totalizante do cuidado primário', cuja "produção é resultante da composição de ações de distintas naturezas e perspectivas técnicas"; como também da 'tecnologia de organização do trabalho' via aproximação das 'relações interativas e também intersubjetivas (....) na estrutura produtiva, buscando articular (....) profissionais e usuários', o que permite "observar as tensões da organização da prática na produção dos serviços" (p.1 a orelha).

Em sua pesquisa, Nemes (1995), analisando a história tecnológica do CSE Butantã, identifica um movimento que transita do plano normativo na direção de uma "maior especificação de objetos, acoplamento entre atividades, acessibilidade e coerência dos focos de avaliação”. Considera também existir no discurso dos agentes que entrevistou, um claro chamamento ético na sua valorização das potencialidades do modelo programático. E ainda afirma que, as dificuldades encontradas "na apreensão concreta deste valor durante o trabalho", os fizeram "não encontrar mais 'resposta na integralidade', nem apenas no impacto epidemiológico e sim na possibilidade da convivência, sabidamente conflituosa, da racionalidade estratégica epidemiológica e clínica com a racionalidade comunicativa" (p.221). Contribuições como as derivadas da pesquisa acima citada vinculam, necessariamente, às propostas de integração em saúde, que sejam acoplados preceitos de sua viabilização operacional, o que se processa basicamente pela via organizacional, ou mais propriamente gerencial dos serviços. Este é o espaço da interatividade dos agentes.

No espaço das UBS, por referência à integração entre ações de promoção, prevenção e recuperação da saúde nos seus diferentes níveis de complexidade, colocam-se questões fundamentais a respeito da interface entre a dimensão organizacional e tecnológica, conforme indicado por Schraiber e col. (1999, p.222). "São elas: 'integralidade das ações', para a intervenção médico-sanitária articulada e conformando modelo de assistência de natureza técnica interdisciplinar específica; 'interação entre 
multiprofissionais' no trabalho em equipe; qualidade resolutiva da assistência muito mais da perspectiva da produção direta das ações do que do modelo de assistência genérico, gerando outras questões como: eficácia técnico-científica na resolução de casos, adesão e intercomunicação na relação direta de sujeitos (profissionais-usuários, profissionais-profissionais e profissionais-gerentes) e delimitação do alcance e limites dos cuidados".

As problemáticas existentes no espaço da unidade básica de saúde relacionadas com a "necessidade de definir e requalificar a assistência e o trabalho", de modo análogo, também podem contribuir para outras situações, pela "similitude de questões que terão de tratar os gestores locais na administração pública, mesmo quando em nível mais amplo tal como os distritos sanitários". Schraiber e col. (1999, p.223) fundamentam esta constatação no fato de que "gestores de vários níveis sempre se envolvem com a implementação de uma dada política assistencial, implantando uma certa organização da produção dos serviços em acordo com as diretrizes do SUS”, mas também buscando, ao mesmo tempo, produzir a 'integralidade das ações e as interações que produzem cuidados diretos à população'. Tais objetos - a 'integralidade das ações e as interações entre indivíduos e atores resultantes' - compõe uma linha atual de pesquisa do Departamento de Medicina Preventiva da USP, que há mais tempo vem "investigando as possibilidades e os limites da 'integração entre a assistência clínica e aquela dos programas de prevenção e promoção da saúde na assistência da unidade básica', através da proposição da ação programática em saúde" (ibid).

Ao lidar com essa renovada problemática, novas questões são colocadas enquanto problemas que necessitam "vir a ser tomados pelo trabalho gestor: 'a integralidade das ações com interdisciplinaridade das técnicas e interação entre multi-profissionais no trabalho em equipe', ou a garantia de qualidade resolutiva da assistência, tanto como eficácia técnico-científica quanto adesão e intercomunicação na relação direta entre os diversos profissionais e destes com os usuários dos serviços" (Schraiber e col. 1999, p.221).

De acordo com Schraiber e col. (1999, p.223): 
(....) tal modo de trabalhar e assistir propiciou o 'estudo da integração entre práticas realizadoras de trabalho em saúde': possibilidades e limites da interação entre os profissionais da prática clínica, e seu agir assentado na aproximação individual dos problemas de saúde, e aquele da prática sanitária, de aproximação populacional ou seus segmentos, sendo esta 'interação propiciadora de questões tanto da interdisciplinaridade dos saberes especializados', quanto da 'interatividade na relação entre os usuários e o próprio serviço'. Dessa experiência procuram extrair o conhecimento técnico-científico que possa contribuir para o planejamento e gestão de serviços de saúde.

Nas perspectivas acima abordadas existe uma concepção de 'trabalho como processo produtivo e como interação', que considera as 'articulações entre as ações em saúde, pelo que representam de ações estratégicas para a produção de cuidados e assistência, bem como as relações intersubjetivas, pelo que representam de ações comunicativas e partilhas de decisão" (Schraiber e col. 1999, p.221).

Ao enfrentar a difícil tarefa de traduzir os postulados políticos da reforma sanitária em protocolos assistenciais, estes se configuram como novas práticas, pois estão "sob novas bases técnicas no interior das ações. Assim sendo, (....) as práticas de saúde (compreendem) o momento social último de realização do conhecimento científico e de suas tecnologias, e representam também, e simultaneamente, o momento social último da política e do planejamento, a dimensão mais concreta e específica de suas realizações na vida social". Estas últimas funções são derivadas do movimento de colocar a técnica em ação. "E uma vez que (....) o ético-político está também no processo técnico, isto possibilita indagar: no interior da técnica, qual o seu lugar? Em outros termos, 'em que momento da ação se expressa e de onde interage a dimensão ético-política com o técnico-científico"? Ou ainda, como atingir o núcleo duro da técnica? (Schraiber 1995, p.30-1).

Segundo Schraiber (1995), na relação médico-paciente, o domínio tecnológico expressa a autoridade técnica, e o seu modo de aplicação "expressa a autoridade moral. (....) Em síntese, trata-se de relação intersubjetiva em que a interação se dá pela exclusividade da 
autoridade técnica do médico, com prioridade deste sujeito na autoridade moral" (p.32). Portanto, reconhecer "ambas as qualificações desta técnica, sem desqualificar qualquer delas e sobretudo sem rejeitar suas articulações e consubstancialidade", permite compreender as naturezas polares da 'interação dialética que representa sua síntese em uma só realidade, a prática de saúde’. O fato de "problematizar isto não significa rejeitar/desqualificar a dimensão tecnológica, mas o reconhecimento de seus limites e alcances relativos. Desconsiderar isto, por outro lado, absolutizando a técnicatecnológica como única dimensão e modo exclusivo de operar é tornar a conduta moral tecnológico-dependente e a dimensão humana, escrava da técnica”. A mesma autora ainda situa "no centro dessa tensão, (....) a 'interação entre o ético-político e o técnicocientífico', assim como será da propriedade de parte desta técnica que podemos retomar valores como a justiça, a solidariedade, a democracia e a autonomia do sujeito" (ibid).

A implementação objetiva da técnica concretamente exercitada, além de seus fundamentos científicos, faz-se acompanhar também de "juízos e decisões quanto ao melhor modo de aplicar a ciência", o que se insere participando da técnica. É este "último aspecto o que certamente lhe introduz uma face relacional e que vem tornar tão peculiar esta técnica da ação em saúde". Assim, pode-se reafirmar os dois momentos interligados, que se definem na interação de sujeitos e gestão do projeto tecnoassistencial' (Schraiber 1995, p.30).

Nemes (1995), estudando a relação de "coerência tecnológica da avaliação com o trabalho programático, desenvolve um conceito analítico a respeito do processo de trabalho na prática programática, informado pela necessidade de 'articulação entre os movimentos de estabelecimento das prioridades para o trabalho, das normatizações das ações e das padronizações das práticas dos agentes". Identifica tal articulação "como uma cristalização permanentemente tencionada" em função das "características tecnológicas concretas atuais das práticas assistenciais de saúde” (p.-1). Com o objetivo de "testar um quadro conceitual de orientação para a 'avaliação do trabalho em práticas assistenciais' baseadas nesta projeção” (ético-normativa de integração), Nemes (1995) defendeu em sua tese que, "quanto mais evidenciável e dinâmica esta articulação" do conjunto das práticas sob avaliação, 'mais produtivo é seu movimento na direção da integração' (ibid). 
Os dispositivos tecnológicos criados a partir do modelo programático devem ter, portanto, grande flexibilidade técnica e política. Como projeto de organização do trabalho, a ação programática em saúde busca expressar o projeto histórico da saúde coletiva. Assim sendo, "não pode renunciar, sob pena de banalização, burocratização, alienação, aos compromissos históricos da saúde coletiva com a mudança social; neste plano é um modelo aberto, não esgotado, que pode (e deve) se cristalizar em organizações efetivas do trabalho aqui e ali” (Nemes 1995, p.29).

\subsubsection{Modelo Tecno-assistencial em Defesa da Vida}

Em sua discussão da 'integralidade na oferta de ações' Silva (1998) aborda especialmente o referencial das produções do grupo do LAPA - Laboratório de Administração e Planejamento em Saúde da Universidade de Campinas. A produção deste Grupo segundo Cecílio (1997, p.23), está baseada na região de Campinas, desde o início da década de 1980, sendo também referida em outros municípios onde seus integrantes prestam assessoria ou participam de projetos. Ao explicitar sua adesão a uma ruptura com certos paradigmas herdados, propondo "superar os modelos de intervenções estatais, profundamente restritivos e burocratizados", considerando "muitos dos quais devedores uma longa tradição médico-sanitária”, Merhy e Onocko (1997, p.15) identificam a obra que organizam como sendo voltada para a busca do que chamam "uma verdadeira 'integração do que há de melhor na medicina e na saúde pública' no Brasil, na construção de um modo de se fazer saúde, de forma pública e para o público".

Sob o título 'defesa da vida como eixo estruturante das práticas de saúde', Campos (1997, p.250-2), discutindo particularidades dessa prática profissional na sua relação com outras subjetividades, sugere que na avaliação da eficácia das práticas de saúde seja considerada "toda a potência sanitária da clínica e da saúde pública. (....) Desejar a potência máxima de reabilitação, de prevenção e de promoção, não seria condição sine qua non para se pensar a utopia da saúde para todos?’. Sem dúvidas uma proposta ambiciosa, sendo necessário por razões éticas responder afirmativamente à questão colocada. Mas convém lembrar a reflexão de Schraiber e col. (1993, p.44) reconhecendo a insuficiência das apropriadas contribuições da clínica e da epidemiologia "como parte 
das práticas de defesa da vida, dado o modo pelo qual se constituem na conjuntura brasileira". E à questão "qual é a intervenção mais competente para lidar com tal gama de necessidades?", se nem a clínica médica nem a assistência sanitária já postas, os últimos autores defendem que na direção de uma vida mais solidária, existe o dever moral de acolher a construção de tais possibilidades.

Discutindo a reforma dos modelos de atenção, Campos (1996, p.62-3) faz sua crítica à tradicional divisão piramidal dos sistemas de saúde em atenção primária, secundária e hospitalar informada por um planejamento pouco sensível à realidade social, por suas implicações para um 'projeto de modelo assistencial mais globalizante'. Identifica efeitos adversos desta postura, de uma forma mais expressiva nos cuidados clínicos, em função de que "um certo estilo muito estrito de programação dificulta o acatamento de algumas outras diretrizes (....) fundamentais para assegurar a qualidade do cuidado e a legitimação dos serviços públicos pelos usuários". Refere-se aqui às "noções de 'vínculo e acolhida e de responsabilizar-se a equipe pelo cuidado integral da saúde coletiva e individual', diretrizes que deveriam sobre-determinar todo desenho de modelo e assegurar os contornos e o ritmo de desenvolvimento" da nova estruturação proposta segundo sua metáfora com a forma de um redemoinho. Prossegue Campos, afirmando que um "sistema público organizado tendo em conta as diretrizes do vínculo e de uma 'acolhida integral aos problemas de saúde', será sempre um modelo tendente à instituição de um processo radical de descentralização, de produção de modos heterogêneos de cuidado, que exigiria a presença de serviços e de equipes de trabalhadores com um razoável grau de autonomia e responsabilidade técnicoprofissional-gerencial. Ou seja, o sucesso deste modelo depende de um razoável equilíbrio dialético entre a autonomia e responsabilidades dos trabalhadores de saúde" (ibid, p.64).

Conforme Merhy (1997c, p.139), a ação resolutiva vai para além de assumir uma conduta, mas impõe colocar a "possibilidade de usar tudo que se dispõe para eliminar o sofrimento e as causas reais do problema do paciente". Isso é extremamente abrangente, ao significar "colocar à disposição do paciente toda a tecnologia disponível a fím de se conseguir o diagnóstico e o tratamento adequado a cada caso", implicando inclusive em 'abordar a dimensão individual e coletiva dos problemas de saúde'. Para tanto há que 
se "criar um processo que tenha como desdobramento uma efetiva alteração do quadro do usuário" e sua conseqüente satisfação.

E prossegue o mesmo autor afirmando que tudo isso “(....) permite construir uma intervenção efetiva, que implica numa 'abordagem mais integral dos problemas', pois como a clínica sozinha não é suficiente para dar todas as respostas para as várias dimensões que adquirem os problemas, muito para além do sofrimento individual", coloca-se então como 'fundamental se trabalhar associadamente com as ações coletivas'. Em conseqüência, a atenção nas unidades básicas, "implica em responsabilidade na atuação da área de abrangência", o que se traduz em: "estabelecer a vigilância à saúde, construir redes de petição e compromissos com os outros equipamentos, identificar os problemas de saúde da área, fazer a vigilância de alimentos, medicamentos, epidemias" (Merhy 1997c, p.139).

Com a questão da resolutividade, implica defender "que todo cidadão tenha à sua disposição, nos casos de doença, o 'acesso a toda tecnologia que a humanidade acumulou em defesa da vida', ou seja, o hospital deve ter a capacidade de dar respostas efetivas aos agravos de saúde de seus usuários com resolutividade diagnóstica e terapêutica no tempo ótimo que o caso exija, eliminando ou diminuindo o sofrimento, os riscos, e promovendo a recuperação e cura". Evidentemente "a maioria dos hospitais não tem capacidade tecnológica instalada para resolver todos os casos que (....) chegam. Impõe-se que estes se articulem em parceria e complementaridade com outras unidades de saúde, de modo a garantir a continuidade da assistência, compatibilizando a gravidade dos casos com os recursos tecnológicos disponíveis definidos pela missão de cada hospital no sistema de saúde" (Rollo 1997, p.332-3).

Em texto de Cecílio (1997), portador da sua "contribuição para uma teoria da mudança do setor público", este autor diz que 'o plano tem que ser integrado, transetorial $e$ transdisciplinário', o que implica em instâncias técnicas que estejam 'bem articuladas às de decisão político-administrativa". E, discutindo esta idéia, propõe, "em vez de planos, trabalhar com programas ou projetos que atuam em processos presentes, cujos outputs são problemas". Logo, a intervenção é feita para modificar estes outputs/problemas (p.241). 
Por referência às formulações a respeito da gestão em empresa pública, feitas por Campos (apud Cecílio 1997, p.269-72), cabe registrar sua constatação de que "este tipo de gestão dos serviços tenderia a atenuar a alienação dos profissionais do seu objeto (o paciente, a saúde) e de seu instrumento de trabalho (o hospital, centro de saúde e o próprio sistema), na medida em que os "critérios de avaliação de desempenho teriam obrigatoriamente que se referenciar a metas qualitativas de cobertura, de 'integralidade das ações', de atendimento de intercorrências individuais e de adoção de medidas de prevenção".

Abordando questões da avaliação da qualidade e a gestão descentralizada em uma rede básica de saúde, por referência à experiência da SMS de Piracicaba, Cecílio (1997a, p.163-4) explicita que através da estratégia de desenvolvimento de um programa de formação de gerentes voltado à implantação do 'projeto em defesa da vida a nível local', se constrói uma concepção de organizar a gerência para a ação”.

A 'divisão de trabalho entre diferentes categorias profissionais e suas especialidades para que o somatório dessas práticas garantisse a integralidade', como forma de contornar a dificuldade de 'inserção dos médicos em programas de atenção integral à saúde', em virtude de características próprias da medicina científica é reconhecida por Campos (1992, apud Silva 1998, p.104). Na perspectiva proposta, alguns profissionais trabalhariam a demanda clínica, outros atuariam na promoção e prevenção com maior ênfase, e outros arranjos seriam possíveis conforme a natureza dos problemas apresentados à responsabilidade das unidades de saúde; ficando a 'articulação interna a cargo da gerência'. Convém explicitar que tal entendimento impõe como requisito que as unidades de saúde disponham efetivamente da coordenação de uma gerência, preparada e voltada para a mudança das práticas de saúde ali histórica e culturalmente instituídas no sentido da consecução dos princípios e diretrizes do SUS. Por coerência.

Cecílio (1997) relata a integração nas decisões derivadas da instituição de um colegiado de gerência na administração de um hospital. Nessa nova condição, por exemplo, em uma decisão temporária de suspensão de cirurgias eletivas em função de obras, articuladamente a ações de controle de infecção hospitalar, “(....) o problema deixa de ser só médico ou, quando muito, da clínica cirúrgica e passa a ser visto, de uma maneira 
integral, por todas as áreas do hospital” (p.211). Como também, uma direção descentralizada do hospital, não é incompatível com o controle e 'acompanhamento do hospital como organismo, em sua integralidade'. Pois, a autonomia não é incompatível com instâncias que devam ser coordenadas de forma mais centralizada, a exemplo da questão orçamentária e financeira (p.229-30).

Discutindo a 'relação entre o planejamento local e os modelos assistenciais', para enfrentar resistências por parte do quadro dirigente às mudanças, Bueno (1997, p.186-7) propõe uma "quebra da solidão do gerente na condução do processo nas unidades, desenhando-se uma operação estratégica: a configuração dos Grupos de Apoio à Gestão (....) que participam do processo de planejamento local, dando suporte político e metodológico aos gerentes na disputa de projetos". A importância de iniciativas dessa natureza vai além da aproximação derivada do nível central com aquele fórum de nível local, conforme revelado na experiência citada, mas contém possibilidades de construir uma visão compartilhada sobre 'a saúde integral do usuários'.

Em produção de 1994, Campos (citado por Silva, p.106), acrescenta a esta problemática:

"Um sistema público organizado tendo em conta as diretrizes do vínculo e de uma 'acolhida integral aos problemas de saúde', será sempre 'um modelo tendente à instituição de um processo radical de descentralização', de produção de modos heterogêneos de cuidado, que exigiria a presença de serviços e de equipes de trabalhadores com um razoável grau de autonomia e de responsabilidade tecnoprofissional-gerencial".

Por referência a Machado (1991, citado por Silva 1998, p.35), este autor "aponta as dificuldades geradas pela minimização das importantes diferenças entre os agentes historicamente envolvidos no processo de produção, em relação ao processo de trabalho, ao elemento desencadeador das ações, aos principais insumos utilizados e ao local de produção das ações, o que leva à 'ênfase na articulação entre diferentes equipes conforme o objeto e o processo de trabalho para conseguir a atenção integral'. 
Na experiência de Betim/MG, com a assessoria do LAPA procedeu-se "a discussão de quais modelos assistencial e de gestão seriam os mais adequados" naquele contexto. Então foi decidido manter seu "hospital na administração direta, vinculado à secretaria municipal de saúde (....) e não constituir uma fundação para gerenciar o hospital. Porque se desejava que ele fizesse parte da rede de serviços de saúde, entendendo que não poderia ser uma unidade isolada", mas inserida na rede como 'uma unidade que estaria vindo complementar a assistência integral, no seu nível maior de complexidade' (Oliveira 1997, p.342).

Ao discutir a inserção do serviço hospitalar no sistema de saúde mental local, Onocko e Amaral (1997, p. 357) apontam 'dificuldades de integração efetiva' apesar de ser uma unidade que cumpre o "papel de principal referência local e regional para internações de pacientes em crise e de gerenciar o único hospital-dia e projeto de reabilitação profissional em saúde mental". O processo de planejamento da gerência, ao refletir sobre tal preocupação, tem permitido a emergência de estratégias para enfrentar esse problema. Todavia, constata-se que a "iniciativa de inserção e subordinação às necessidades do sistema de saúde local tem sido tomada mais pelas equipes do serviço do que pelos gestores do SUS".

Os textos de Merhy (1997b, p.220) também estão identificados com posições que procuram "romper a dicotomia expressa em certos dilemas, (....) como por exemplo a possibilidade de 'operar integralizadamente com a racionalidade médica e sanitária' ". Outro autor que tem se revelado preocupado com a problemática do 'papel da clínica e da saúde pública, sobre como integrá-las na prática', ao mesmo tempo em que se volta às idéias de gestão participativa, é Campos (1997, p.265). Nessa perspectiva trata da delimitação dos objetos de trabalho das equipes, discutindo as conseqüências na prática e formação dos profissionais, do fato de que a doença envolve dimensões sociais, subjetivas e biológicas.

$\mathrm{Na}$ busca de situar algumas ênfases que configuram singularidade ao "modelo tecnoassistencial em defesa da vida, se confrontado com formulações de outras vertentes do modelo sanitário", e explicitando particularmente o enfoque da visão programática, Cecílio (1997, p.23) reconhece que essa proposição é "apontada ainda hoje como a 
forma mais adequada de se abordar os problemas de saúde da população". Ao considerar que "em tal modelo a atenção médica individual é vista como, necessariamente, subordinada à epidemiologia”, destaca que na proposição do Grupo LAPA, a defesa de que 'a medicina pode atuar sobre um indivíduo como um instrumento pertencente a um projeto integrado de ações de saúde' pretende colocar a ação individual de forma mais articulada com as coletivas. As demais caracterizações apresentadas por esse autor estão genericamente presentes em todas as proposições aqui abordadas de modelos de atenção comprometidos com a integralidade. Como seria o caso de considerar "que um não atendimento à demanda espontânea é uma maneira de não incorporar o modo como o coletivo construiu a relação entre o usuário e os serviços de saúde, entre um dado cidadão e seu acesso a determinados serviços de saúde, mesmo identificando a parcialidade deste momento" (ibid).

\subsubsection{Vigilância à Saúde}

No movimento setorial de organização dos sistemas de serviços locais de saúde, a partir de 1988, têm ocorrido no Brasil as oficinas de distritalização, realizadas com apoio técnico de consultorias da OPS, nas quais foi sendo construído um referencial teóricometodológico específico. Nesse processo instituinte de distritos sanitários, na perspectiva da mudança da prática sanitária, destacou-se a inserção de um conceitochave denominado vigilância à saúde.

\section{No espaço do distrito sanitário}

Os antecedentes de organização dos serviços de saúde na lógica de distritos sanitários se encontram na "estratégia de transformação dos sistemas nacionais de saúde através dos sistemas locais de saúde”, formulada pela OPS e que chega no Brasil através do seu Programa de Desenvolvimento de Serviços de Saúde. Nesse contexto, a estratégia adotada para implantação de distritos sanitários no país admite diversos momentos. Durante os anos de 1987 e 1988 procedeu-se à "difusão da idéia de distritos sanitários enquanto processos sociais de mudança das práticas sanitárias", através de reuniões, seminários e distribuição de material bibliográfico em articulação com círculos acadêmicos e de serviços, em vários municípios do país (Mendes 1993, p.11-2). A 
proposta de distritalização, originalmente era entendida como "processo político institucional, organizativo e operacional, voltado para a construção da base do SUS" (Silva 1998, p.73).

No processo instituinte dos distritos sanitários no Brasil, onde está contida a proposta da vigilância à saúde, pode-se destacar também a importância do apoio da Cooperação Italiana que se expandiu em alguns estados brasileiros, destacando-se especialmente em alguns municípios da Bahia e São Paulo, no final dos anos 1980 e por toda a década de 1990.

Politicamente, pode-se constatar, nas produções de Mendes (1993, p.97-8), uma interpretação da proposta de distrito sanitário, que nas suas palavras enquadra-se perfeitamente com a chamada terceira via, assim demarcada por este autor: "A terceira via busca equilíbrios dinâmicos entre interesses coletivos e individuais, entre local e o central, entre os diferentes atores sociais de um sistema de atenção, entre a equidade e a eficiência, entre os controles e as liberdades dos profissionais, entre o hospital e o ambulatório, entre o sanitário e o social etc.”.

Mendes (1996) propõe um entendimento do "distrito sanitário como projeto estruturante dos serviços de saúde" (p.264-70). Inclusive, considerando que "dessa forma, o distrito sanitário concilia os ideais municipalistas, estimula o espírito colaborativo entre as cidades, fortalece o federalismo cooperativo, 'viabiliza os princípios da universalidade do acesso e da integralidade da atenção' e garante a economicidade do sistema de saúde".

O distrito sanitário, tomado inicialmente como unidade operacional administrativa do sistema de saúde, caracterizava-se pela existência de recursos públicos e privados, que se articulavam por mecanismos institucionais para 'desenvolver ações integradas de saúde' e resolver os principais problemas da respectiva área de abrangência, com a participação da população envolvida (Silva 1998, p.73). Referindo-se ao documento "distritos sanitários - conceituações/princípios básicos", este autor (p.74) define o distrito sanitário como "unidade mínima do sistema de saúde com base territorialpopulacional e um conjunto de equipamentos de saúde", destinados a corporificar a 
resolutividade das práticas. Segundo Flores (1991, apud Silva 1998, p.75), a tais equipamentos são atribuídas 'ações básicas de promoção, prevenção e recuperação, garantindo-se referência e contra referência aos níveis hierárquicos mais complexos'.

Por referência à proposta baiana de SILOS, Silva (1998, p.75) cita seus 18 'princípios orientadores para a distritalização', entre os quais consta: 'integralidade de atenção', adequação tecnológica; podendo-se nessa expressão constatar o conteúdo tecnológico associado ao princípio.

Para a conformação da proposta dos distritos sanitários no Brasil, foram condensadas contribuições teóricas de autores e campos diferenciados: partindo-se de uma visão de território-processo derivado das concepções de Milton Santos sobre uma nova geografia; utiliza-se uma adaptação do "planejamento estratégico situacional de Carlos Matus; a teoria de problemas de Mitroff; as concepções de processo de saúde/doença e do processo de trabalho em saúde da medicina social latino - americana. O objetivo fundamental deste momento foi o de iniciar o processo de construção de uma teoria e de uma metodologia, referidas à cena brasileira, no campo dos sistemas locais de saúde" (Mendes 1993, p.11).

\section{Concepção e definição da vigilância à saúde}

Uma concepção sintética dos preceitos orientadores dessa lógica pode ser condensada nas seguintes características da vigilância à saúde: organização das ações nos sistemas de serviços locais de saúde referida a todos os momentos do processo saúde/doença; partindo da análise participativa das causas dos problemas identificados; que numa postura de vigilância organizam a intervenção, desde a promoção e proteção à saúde, passando articuladamente pelos diversos níveis de prevenção dos problemas, até a atenção curativa e reabilitação.

A proposição da vigilância à saúde tem por objetivo desenhar alternativas de modificação do modelo de atenção vigente, tomando a epidemiologia como mola mestra para a conformação do campo de necessidades de saúde. Na vigilância à saúde faz-se a micro-localização de grupos de risco, com vistas ao seu controle e prevenção. Para tanto 
se organiza um diagnóstico local dos problemas em cada território de abrangência dos respectivos serviços de saúde, realizado de forma participativa por todos os atores envolvidos com aqueles problemas, especialmente profissionais e população.

Enquanto dimensões da vigilância à saúde pode-se destacar: o campo das necessidades de saúde é desvendado por saberes técnicos dos serviços em articulação com a compreensão pela população da sua área de abrangência e responsabilidade; as intervenções são singularmente planejadas, de forma participativa e ascendente; e, são os diferentes atores em situação que identificam e analisam os problemas de saúde a abordar, sendo os saberes operatórios desse trabalho os saberes epidemiológicos locais. A concepção de vigilância à saúde extrapola as noções próprias da vigilância epidemiológica (servillance), não se reduzindo também a uma simples produção de informação, mas fundamentalmente se refere à 'intervenção sobre determinantes $e$ condicionantes de problemas de enfrentamento contínuo', destaca-se, e incorpora também, ações de caracter individual. Daí seu interesse direto na conceituação da noção de integralidade em saúde. Enquanto estratégia de intervenção, os "problemas são escolhidos pelo alto impacto que têm nas condições de existência de grupos populacionais em micro-áreas específicas e pela possibilidade de intervir sobre eles" (Mendes 1993, p.177).

Conforme registrou Silva (1998, p.80), existe uma ênfase na prática da vigilância à saúde, conceituada como: "(....) uma prática sanitária que organiza os processos de trabalho em saúde, sob a forma de operações, para comportar problemas de enfrentamento contínuo, num território determinado. Fá-lo através de 'operações montadas sobre os problemas em seus diferentes períodos do processo saúdelenfermidade', quais sejam, sobre produtos, os processos e os insumos dos problemas".

A prática de 'vigilância à saúde', atuando sobre o meio ambiente, condições de risco e doenças, tem sido 'considerada um bom instrumento', ao mesmo tempo didático e assistencial, para envolvimento da equipe multiprofissional na 'execução de ações integradas de saúde' (Castanheira e Sader 1997, p.249). Observa-se no contexto da Oficina que produz tal declaração durante o $5^{\circ}$ Congresso Brasileiro de Saúde Coletiva 
(Anais 1997), que a concepção de integração referida coloca-se como potencialidade do modelo assistencial de vigilância à saúde.

A operação da vigilância à saúde pode dar-se tanto diretamente através da rede básica local, como através de estratégias de mudança do modelo de atenção, a exemplo da estratégia da saúde da família discutida no item seguinte (2.3.4).

Quando Mendes (1993 e 1993a) definiu os quatro conceitos chaves para abordar os distritos sanitários como sendo território, problemas, prática sanitária e processo de trabalho, trazia nos dois primeiros importantes referências para operacionalização da vigilância à saúde enquanto nova prática sanitária proposta. E finalmente indica o espaço do processo de trabalho como locus da mudança potencialmente em condições de responder ou não à finalidade da ação.

\section{Territorialização}

A implementação da prática de vigilância à saúde dá-se por um processo que se inicia pela estratégia da territorialização, que, além de sensibilizar, responsabilizar e instrumentalizar os trabalhadores de saúde para a proposta, os leva a reconhecer e desvendar o seu território de responsabilidade do trabalho promovendo uma análise do acesso geográfico, funcional, econômico e cultural aos serviços.

Uma importante contribuição, com este momento operacional da vigilância à saúde, pode ser encontrada na proposta de estudos de situação de saúde segundo condições de vida elaborada por Castellanos (1993, p.44), quando propõe, em suas considerações técnicas para operacionalizar o projeto, após dimensionar a intervenção sobre produtos, processos e insumos dos problemas, a recuperação de um conjunto de técnicas que poderiam permitir superar dificuldades e facilitar o desenho das ações, através da utilização de recursos epidemiológicos direcionados a realidades onde não é operacional o uso tradicional da "epidemiologia dos grandes números". Trata-se do uso de: unidades geográfico-populacionais, como base para a estratificação da população segundo condições de vida; populações sentinela, adaptando essa técnica às necessidades de cada projeto, visando reduzir os custos e aumentar a sensibilidade do 
sistema; e, traçadores, adaptando este conceito às necessidades do projeto, como via para a redução de indicadores, conforme o marco conceitual respectivo.

A utilização do sistema de informação gerencial denominado SIG-Blade Runner, utilizado na experiência pioneira de um distrito sanitário na Bahia (DS Pau de Lima), "possibilitou a sistematização de dados referentes a vários setores que interagem no território trabalhado, facilitando a percepção dos fatores extra-setoriais que determinavam saúde ou doença" (Silva 1998, p.88).

Tais recursos informacionais permitem melhor representar a dinâmica do territórioprocesso através de "uma configuração gráfica interativa com os problemas que se distribuem, no território, segundo as condições de vida dos diferentes conjuntos sociais, isto é, através de mapas inteligentes" (Mendes 1993a, p.14).

\section{Enfoque por problemas}

O desvendamento da realidade de vida, saúde e recursos do território, permite, ademais:

(....) uma leitura, com forte enraizamento social, porque compartilhada, no interior de um território, por técnicos e população. Nesse sentido, o enfoque por problemas facilita o desenvolvimento da consciência sanitária da população (....). No âmbito do distrito sanitário, trabalhar por problemas exige, ainda, a sua micro-localização por reconhecer que a sua distribuição dá-se assimetricamente no território, discriminando negativamente grupos sociais, de condições de vida semelhantes, que tendem a concentrar-se em determinados espaços de existência. Isso é fundamental porque as operações relativas ao enfrentamento das causas dos problemas serão desenvolvidas com discriminação positiva em relação àqueles conjuntos sociais postergados (Mendes 1993a, p.15).

Na perspectiva da "vigilância do recém-nascido", segundo Palma e Rufián (1990, p. 449-61), ao levar em conta o que significa um comitê de investigação de óbitos infantis na tomada de decisões sobre saúde, pode-se "ver até que ponto um profissional considerado central como é o médico", passa a renunciar de certa maneira sua verdade 
hegemônica para se recolocar em 'uma trama que exige a articulação de todos os pontos de vista comprometidos com o problema'.

Também em Curitiba, de acordo com Silva (1998, p.95), havia, na concepção de integralidade apoiada em texto de Raggio (1992a apud), a idéia de 'compatibilização da clínica e do pronto-atendimento (....), com a epidemiologia e a atenção programada como formas de organização da vigilância à saúde' sobre o território e 'como instrumentos de racionalização da atenção coletiva sobre problemas contínuos'.

É no enfoque por problemas que, para os fins deste estudo, se encontra a maior contribuição da proposta de vigilância à saúde. E é onde se consegue perceber mais explicitamente sintetizadas as diferentes contribuições que fundamentaram sua concepção teórica. Tal abordagem, segundo Mendes (1993a, p.15):

apresenta uma perspectiva de organização bastante distinta. Parte do reconhecimento de um território para, sem posições apriorísticas, identificar, descrever e explicar os macro-problemas de saúde ali contidos, referidos por atores portadores de um dado projeto de saúde, para depois, 'articular através de práticas sanitárias, as diferentes disciplinas e setores, num conjunto de operações' interdisciplinares, destinadas a solucioná-los, tendo presente a disponibilidade real de recursos existentes naquele território.

\section{A integralidade na prática sanitária da vigilância à saúde}

Em uma perspectiva voltada para orientar a "organização do enfrentamento dos problemas de saúde no espaço territorial dos distritos sanitários”, Mendes (1993a, p.156) reconceitua prática sanitária como "o conjunto de processos de trabalho articulados em operações que impõe uma 'estratégia de ação integral sobre os nós críticos de um problema', num território determinado".

A formatação de um modelo que dê conta da "prática sanitária da vigilância à saúde, num território singular, envolve a definição de um problema de enfrentamento contínuo, sua descrição, sua explicação em diferentes espaços, a identificação dos nós críticos nos diferentes períodos do processo saúde/enfermidade", e a partir daí a montagem de 
'operações integradas de promoção da saúde, prevenção de enfermidades e acidentes e de atenção curativa' (Mendes 1993a, p.17). Assim sendo, implica utilizar e 'integrar o estoque de saberes e fazeres' compreendidos na atenção médico-hospitalar, nos "programas de saúde pública", na vigilância epidemiológica, na vigilância sanitária, e educação para a saúde, e outras propostas de "ações extra-setoriais em distintos campos como água, lixo, esgoto, drenagem, educação, habitação, alimentação, etc.” (ibid).

Sua importância neste estudo deve-se à assertiva indicada por Mendes (1993a, p.17), seguindo a proposta de Terris (apud), de que na vigilância à saúde, a estratégia de intervenção, seja diante de um problema de saúde, ou seja, "enquanto resposta social a problemas de enfrentamento contínuo, vai articular operações que compreendem três grandes grupos de atividades: promoção da saúde, prevenção de enfermidades e acidentes e atenção curativa". Conforme reafirma Mendes (1996, p.247-8), ao tratar "de combinar, de forma ótima, em eficácia e eficiência sociais", esses tipos de ação, pode-se afirmar que a 'vigilância à saúde implica ação integral sobre os diferentes momentos ou dimensões do processo de saúde-doença' (p.244).

A perspectiva de um modelo de intervenção sobre problemas não incide apenas, sobre os produtos finais do processo de saúde-doença, "como mortes, seqüelas, doenças e agravos, mas também indícios de danos (assintomáticos), indícios de exposição (suspeitos), situação de exposição (expostos), grupos de risco e necessidades sociais de saúde" (Mendes 1993a, p.16). E ainda, coerentemente com a afirmação anterior, esse mesmo autor, citando Paim e Teixeira, explicita também que a vigilância à saúde admite diferentes níveis de controle: de danos, de riscos e de "causas", relativas estas últimas aos condicionantes e determinantes dos problemas de saúde.

A mudança da prática sanitária tem sido enfocada por Mendes (1996, p.241-3), através da proposição de vigilância da saúde, que representa "uma nova forma de resposta social organizada aos problemas de saúde, referenciada pelo conceito positivo de saúde", como também sob o 'paradigma da produção social da saúde’.

A concepção ampliada de processo saúdelenfermidade é o que veio originar um movimento de formação de um novo paradigma assistencial denominado por Mendes 
(1993a, p.12) como o 'paradigma da promoção da saúde'. Tal paradigma reorienta as respostas sociais aos problemas de saúde organizando-as em uma nova lógica de estruturação: 'a prática sanitária da vigilância à saúde'.

Mendes (1993a, p.16) diferencia duas práticas sanitárias na operação dos serviços presentes no espaço do distrito sanitário - a prática da atenção à demanda e a prática da vigilância à saúde. E considera que, ainda que contraditórias entre si, tais práticas devam, dialeticamente, conviver no mesmo espaço, apesar de partir, para sua estruturação, de lógicas distintas. Fundamenta sua posição no reconhecimento de que a “prática da atenção à demanda estrutura-se pela lógica do paradigma flexneriano, enquanto a prática da vigilância à saúde, organiza-se segundo o paradigma da promoção à saúde". Então propõe que em "um processo de distritalização, ambas as práticas devem ser organizadas, obedecidas suas lógicas próprias, com hegemonia da vigilância à saúde".

A problemática da articulação entre a clínica e a epidemiologia, em novos termos, é, de alguma forma, retomada aqui, se a prática de atenção à demanda for entendida como equivalente à assistência clínica e a prática da vigilância à saúde como equivalente de proposição epidemiologicamente informada, ou até mais especificamente, da ação programática em saúde.

Mendes (1993a, p.16) considera a tematização da vigilância à saúde em sua inserção na perspectiva de uma resposta social, situada como modelo de intervenção sobre problemas, num território dado, mas diferenciando-se "da proposta da vigilância da situação de saúde que se articula mais como unidade de análise para avaliar e monitorar a situação de saúde segundo condições de vida de diferentes conjuntos sociais. Este autor a considera ainda mais ampla que as ações programáticas de saúde por envolver operações sobre fatores condicionantes e determinantes dos problemas de saúde, através de intervenções intersetoriais organizadas". Mas nada impede que a ação programática tenha esse alcance.

Utilizando as elaborações de Mendes (op cit), em sua construção conceitual da integralidade, Silva (1998, p.34) menciona as duas dimensões em que a integralidade 
se manifesta de forma mais operacional, "do ponto de vista das práticas sanitárias: na 'integração, definida por um problema a enfrentar através de um conjunto de operações' articuladas pela prática da vigilância à saúde", como também, complementarmente, na 'integração entre vigilância à saúde, dentro de cada unidade de saúde, e as práticas sanitárias de atenção à demanda'.

Interessante a interpretação de Schramm e Schramm (1995, p.53) ao propor que o "sistema de vigilância, paradoxalmente, deva ser diferenciado funcionalmente dentro do contexto mais amplo da saúde pública, e integrado informativamente no seu ambiente de qualidade em saúde". Ao considerar esse sistema do ponto de vista da complexidade, identificam nele dois subsistemas: um "autopoiético - fechado autorreferencialmente sobre a estrutura que constitui o seu saber-fazer próprio" - e outro "alopoiético - aberto heterorreferencialmente sobre o seu ambiente constituído pelas informações sobre a qualidade em saúde". E ainda acrescentam que "a auto-referência pode ser tida como condição da sua abertura, ao passo que a heterorreferência constituiria a condição para a sua compreensão", o que está de acordo com a premissa ecológica de se pensar globalmente e agir localmente.

Assim sendo, a bipolaridade entre auto-referência e heterorreferência representa de fato um vínculo. Os autores acima citados propõem então pensar "a questão da vigilância em seus vínculos com a questão da cidadania, inserida na articulação complexa das várias dimensões da condição humana, do ponto de vista da qualidade de vida e saúde", ou seja, com a questão da 'integração generalizada das pessoas nos sistemas sociais', coerentemente com as 'diretrizes da integralidade da atenção', a descentralização e a participação do SUS (Schramm e Schramm 1995, p.53).

Ao identificar a existência de um "esforço teórico que tem contribuído para a investigação das relações entre saúde e sociedade com base na compreensão do conjunto articulado de práticas econômicas, políticas e ideológicas”, Mendes (1993, p.201), destaca nesse particular, as análises empreendidas por Mendes-Gonçalves 'indicando as vinculações das práticas de saúde com a totalidade social', o que permite "uma necessária contextualização no tempo e no espaço de projetos de redefinição dessas práticas tal como parece ocorrer com a proposta do distrito sanitário”. Então 
recomenda que, por concordância com a referência indicada, que antes sejam revisitados certos "momentos" do processo de trabalho em saúde. Esta última noção, embora reconhecida como um conceito-chave da distritalização em saúde, é a menos desenvolvida, explicitamente, na proposição da vigilância à saúde, sendo efetivamente abordada somente na proposição da ação programática em saúde.

\section{Vigilância à saúde, ética, prática e organização dos serviços}

Schramm e Schramm (1995, p. 53-4) desenvolvem uma analogia entre as diretrizes da integralidade, descentralização e participação, mais reconhecidas pela legislação e leituras do SUS, acrescentando a equidade introduzida mais recentemente no debate, com os quatro princípios da autonomia, beneficência, propriedade e autoridade sintetizados por Engelhardt como norteadores da bioética, referidos estes aos seus princípios correlatos mais recorrentes: a sacralidade da vida e o princípio de qualidade de vida; a autonomia da pessoa e o principio de propriedade; o principio de beneficência além da não-maleficência, a justiça ou equidade e o principio de autoridade; e, a solidariedade com o princípio de responsabilidade; que, em seu conjunto, "tecem uma rede de direitos e deveres constitutivos do ethos das sociedades laicas e pluralistas modernas e, portanto, inevitavelmente atravessadas por conflitos entre valores e por crises estruturais e de identidade".

Os mesmos autores consideram ainda que 'a integralidade na atenção parte do pressuposto holístico da pessoa' entendida 'como um todo (....) não divisível em partes ou funções, justificando tal assertiva na definição de saúde da OMS (o completo bemestar físico, psíquico e social)" considerando-a de "certa forma, 'expressão de uma concepção que considera o ser humano na sua integridade de unidade indivisível' que, ao ser dividida em partes ou funções, contradiz a própria noção de pessoa e, em particular, o principio de autonomia". Este princípio "funda a possibilidade do respeito recíproco entre seres, por princípios autônomos e iguais em deveres e direitos, portanto, integralmente considerados possuir, em principio, a cidadania plena" (Schramm e Schramm 1995, p.54). Para esses autores "tanto as diretrizes propostas pelo SUS (integralidade, descentralização, participação e equidade) quanto os princípios bioéticos referidos, (....) estão em geral em conflito entre si, ou pelo menos em tensão, pois 
resultam de uma realidade complexa que, embora seja modelizável, não pode ser reduzida sem prejudicar seu dinamismo e, sobretudo, sem comprometer a emergência do novo e do sentido, indispensáveis para construir soluções relevantes para os problemas vigentes" (ibid).

Segundo os mesmos autores, tanto as diretrizes do SUS como os princípios básicos da bioética, se consideram ferramentas para a qualidade de vida, resguardada sua sacralidade, integradamente. Todavia, na concretude do viver, diretrizes e princípios se revelam imperfeitos, às vezes contraditórios, submetidos que estão "aos azares da condição humana. Ou seja, na medida em que se incorporam na vida concreta, os princípios se dinamizam, evoluem, decaem e são substituídos por outros, que as sociedades históricas constroem, desconstroem e reconstroem na precariedade da existência” (Schramm e Schramm 1995, p.55-6).

As idéias mais diretamente relacionadas ao modelo organizacional implicado na proposição da vigilância à saúde têm sido apreendidas em vários municípios brasileiros através da contribuição mais sistematizada das produções teóricas, metodológicas e práticas do Projeto GERUS - de gerenciamento de unidades básicas de saúde (Brasil 1995). Pode-se perceber a complexidade própria da gestão de unidades locais de saúde na citação de Bertussi e col. (1996a, p.52), referenciada pelo Projeto GERUS para capacitação gerencial no âmbito de unidades de saúde, que inclui como principais atributos de um "novo perfil gerencial desejável para gestão" de UBS, o desencadear dos três momentos que organizam teoricamente a proposta do GERUS: "avaliação do quadro de necessidades de saúde, reorganização do processo de produção e condução das operações". E, do ponto de vista da produção conceitual, acrescentam uma reflexão sobre a vinculação de tais atributos com a 'problematização da realidade e a facilitação do processo de abstração (vinculado à totalidade) permitindo a gradual interação com o objeto e o desenvolvimento de generalização e abstração'.

Bertussi e col. (1996, p.26) atribuem à "perpetuação da concepção cultural centralizadora", observada nas organizações de saúde, o fato do 'discurso de caráter integral e intersetorial', não haver conseguido, ainda, "produzir alterações substanciais na sua prática". Ao constatar que "a reflexão do processo de trabalho não é do cotidiano 
na produção de serviços", esses autores (Bertussi e col. 1996a, p.56) interpretam que as relações do sistema municipal com a UBS têm se dado de forma fragmentada, com prioridades não relevantes para as práticas de cada uma delas. Daí se deriva a necessidade de "desenvolvimento da capacitação em gerência de unidades básicas de saúde, enquanto instrumento de alavancagem do processo de reorganização da prática sanitária" para produzir os efeitos institucionais pretendidos.

As posições tradicionais de gerência local em saúde têm que ser revisadas sob a lógica da transformação organizacional, o que por referência às proposições de vigilância à saúde, pode contribuir no sentido de ajustar suas "propostas às realidades institucionais, com a preocupação de mobilizar e constituir atores sociais no processo de discussão e realização de ações de saúde", para que assim possam ser alcançadas as respostas desejadas. Do ponto de vista metodológico, em tal processo procura-se "(des)construir a compreensão de saúde (entre trabalhadores de saúde e usuários dos serviços) no que se refere a todos os aparatos técnicos, organizacionais e operacionais que a justificam, para uma visão no sentido positivo que ultrapasse os limites medicalizantes, racionais e burocráticos". Para tanto se procura 'romper com a dicotômica relação: ações promocionais e preventivas $X$ ações curativas e hospitalo-cêntricas', para que se possa “construir/ (re)construir/ (des)construir uma prática de saúde individual e coletiva, na conformação de uma totalidade, que englobe os sujeitos inseridos nos espaços sociais (intra e extra-institucional) e suas inter-relações com os ambientes físicos, cultural e social” (Assis e col. 1996, p.59).

Em estudo que aborda o "processo de territorialização em saúde, tomando-o enquanto uma estratégia gerencial de intervenção nas práticas sanitárias, fundamentada na concepção de distrito sanitário", Assis e colegas (1996) colocam, enquanto finalidade desse processo, desenvolver uma 'articulação colegiada e compartilhada entre os atores inseridos no processo', destacando-se a participação dos gerentes, equipes e usuários, para construir nos diversos momentos da prática gerencial, formas de "ultrapassar a separação entre informação, decisão, execução e controle das ações desenvolvidas no espaço territorial local” (p.59-60). Em meio a um processo dessa natureza é possível que se anule "a organicidade e especificidade dos atores sociais reais, que disputam interesses e projetos nos espaços institucionais, por simplificar o 
modelo a determinações mais gerais do contexto social (....) por não 'intervir de uma forma mais integralizada na defesa do sofrer/adoecer/individual e da saúde coletiva'. Nesse espaço se constroem proposições, como os referidos autores vêm desenvolvendo, através de "um modelo estratégico de planejamento e gestão que combina ações tecnológicas mais consolidadas e avançadas no campo da saúde pública, com a atenção às demandas por assistência médica por parte da clientela". Em meio a tais processos, os autores acima destacam "a necessidade do trabalho em equipe, reconhecendo a autonomia e legitimidade da clínica (....), procurando descentralizar a figura do médico" (Assis e col. 1996, p.61-2).

As noções de vigilância à saúde contêm aspectos que "configuram de fato um sistema complexo que inclui a integralidade do subsistema representado pelo processo produtivo' (produção - distribuição - consumo), o subsistema do processo comunicativo (produção - reprodução e transformação de informações e valores numa comunidade determinada e na relação com outras comunidades) e aquele do 'processo interativo' (relações de poder tanto micropolítico como macropolítico)" (Schramm e Schramm 1995, p.52).

\subsubsection{Integralidade da Saúde da Família}

De acordo com Vasconcelos (1999), a "priorização da intervenção no nível da família como forma de integração e dinamização das diversas políticas sociais vem ganhando força em vários países" (p. 6). Assim sendo, "o ano de 1994 foi definido pela ONU como Ano Internacional da Família". A incorporação da 'tendência de valorização da família na agenda das politicas sociais brasileiras' (p.11) é incorporada pelo Ministério da Saúde, através do surgimento do PSF - Programa de Saúde da Família, uma estratégia de modelo cuja dimensão política é destacada.

O município de Niterói foi precursor desse modelo alternativo de organização da atenção primária através do médico de família. Aquela proposta, inspirada no sistema cubano, foi inovadora especialmente por anteceder as políticas nacionais definidas na sua continuidade. 
Por ocasião de uma exposição de importante autor* na produção teórica sobre a prática da vigilância à saúde, inclusive organizador do referenciado livro intitulado Distrito Sanitário (Mendes 1993), ao apresentar a proposta do PSF, o mesmo usa como referências aquelas desenvolvidas na sua obra citada, mas sem referir-se à proposição de distritalização ou vigilância à saúde. E quando inquirido sobre as causas dessa mudança de nomenclatura, declarou tratar-se da mesma proposta, mas sob uma denominação de maior aderência política, ou seja, saúde da família. Acrescentando numa tentativa simplificadora - "É a mesma proposta, só muda o nome".

Segundo Carvalho (1994, citado por Vasconcelos 1999, p.11-2) a 'priorização da família na agenda da política social' assume "três modalidades de ação: programas de geração de renda e emprego (....); programas de complementação da renda familiar (....) integrados a serviços locais que acompanhem a família (....); e, uma rede de serviços comunitários de apoio", sendo considerada esta como a modalidade de ação mais importante na dinâmica da atenção à saúde. É neste contexto que se inscrevem as políticas de atenção à saúde da família no Brasil.

O PSF potencialmente pode desenvolver uma prática de integralidade na atenção à saúde ao reorganizar o serviço pela atuação sobre os problemas do seu território de responsabilidade. E na literatura encontram-se várias referências sobre essa 'integralidade do PSF'. A aplicação do referido princípio impõe que os serviços de atenção primária envolvam 'ações promocionais, preventivas e curativo-reabilitadoras, providas de forma integrada, por meio da vigilância da saúde' (visão sistêmica) e também que 'as intervenções da saúde da família conformam uma totalidade que engloba os sujeitos do sistema e suas inter-relações com os ambientes natural e social' (Mendes 1996, p.276-9).

As ações da proposição saúde da família incidem sobre o indivíduo, sua família e sua comunidade, podendo partir de cada um destes âmbitos simultaneamente. Conforme

(*) Palestra proferida no Seminário de Regionalização da Secretaria de Estado da Saúde de Santa Catarina (Florianópolis/SC, agosto/1995), tendo como participantes a equipe de técnicos e dirigentes da SES/SC, para a qual foi convidado em função de sua destacada reflexão conceitual sobre esta problemática. 
Mendes (1996), tal área de atuação situa-se em diferentes espaços sociais de reprodução da vida, como sendo domicílio, microáreas homogêneas de risco sócioeconômico e sanitário, e espaços da vida social (creche, escola e local de trabalho). Nessa concepção se insere a 'integralidade - como um dos princípios organizativos da estratégia da saúde da família' (p.276).

A concepção mais generalizada de intervenções no PSF, revela uma 'incompreensão da integralidade da saúde da família', ao considerar a saúde da família, estratégia de organização da atenção primária como reduzida a um programa a mais. Portanto, constitui-se "um grave equívoco das propostas oficiais, enunciar a prioridade da saúde da família, ao lado de tantos outros (programas) de igual hierarquia", a exemplo do Programa de Agentes Comunitários de Saúde (Mendes 1996, p.278-9). Essa postura caracteriza-se como uma negação do princípio da integralidade, que "exige a superação da organização da atenção primária por meio de programas verticais, desenhados aprioristicamente e impostos, de cima para baixo, às unidades de saúde”. Ao contrário, 'a saúde da família é a forma de horizontalização dos programas' que passam a ser definidos em espaços temáticos para englobar o conjunto de ações prestadas no campo da atenção primária frente aos problemas priorizados no âmbito de determinado território, de forma a 'englobar o conjunto de ações relativas à atenção integral à saúde da mulher, da criança e do adolescente e a outros conteúdos' (alimentação e nutrição, hanseníase, tuberculose, controle de DST, de doenças crônicas - hipertensão e diabete, etc.), que passam a ser "incorporados à rotina de trabalho dos generalistas que compõem a equipe de saúde da família" (ibid).

Em geral, segundo Mendes (1996, p.72), “(...) a mídia não noticia as excelentes experiências desenvolvidas em vários municípios brasileiros", em que pretensamente 'a crise da saúde foi substituída por atenção integral à família', considerada como "humanizada, contínua, feita nas casas, resolutiva, com satisfação de usuários e profissionais de saúde e que impacta favoravelmente os níveis de saúde, especialmente os de mortalidade infantil e materna". Citando vários municípios com experiências exitosas em saúde da família, de Santa Catarina esse autor destaca Joinville entre os “exemplos dessa nova forma de prestar serviços de saúde que se vai espalhando pelo país". 
Por referência ao estudo exploratório realizado para composição do empírico da tese (capítulo 4) também se destacam neste enfoque Florianópolis, Blumenau e Criciúma, mas sabe-se a cada dia de novas adesões bem sucedidas à política nacional de priorização da saúde da família, podendo-se enunciar ainda os municípios de Chapecó e Jaraguá do Sul. Todavia, uma organização dos serviços sob a estratégia de saúde integral da família, mesmo que bem sucedida não significa a solução da crise da saúde. Faltam avaliações científicas fazendo essa relação. Como também a avaliação da integralidade da estratégia de saúde da família é um indicativo de prosseguimento dos estudos ora derivados.

Vasconcelos (1999, p.18-9) explicita como um desafio central do PSF, conseguir realizar sua 'capacidade de integração com serviços locais de saúde bem-estruturados, redefinindo qualitativamente seu modelo de atuação'. Pois, assim como em um primeiro momento havia uma "atenção primária seletiva que priorizava sua ação sobre doenças de fácil tratamento e grande mortalidade, como a diarréia e a pneumonia, no conjunto da população", num momento mais recente, teria sido encontrada "uma nova forma de economia de recursos ao concentrar sua intervenção basicamente sobre as famílias mais vulneráveis ao adoecimento e à morte", o que tem implicado num distanciamento da perspectiva de uma 'atenção integral a toda população'. O autor acima situa bem o desafio implicado em se encontrar formas de abordagem dos problemas familiares integradas em outras dimensões' presentes na luta política dos diversos movimentos sociais (p.13).

Continuando com Vasconcelos (op cit, p.13), percebe-se a importância dos serviços públicos comunitários, que necessitam centrar suas ações no próprio fortalecimento enquanto espaços de apoio à "recomposição dos vínculos afetivos internos ameaçados e a sua 'reintegração na rede de solidariedade social local'”. Nessa perspectiva a "metodologia da educação popular inova na medida em que não separa as dimensões materiais dos problemas sociais da cultura e do saber ao buscar relacionar problemas específicos com o contexto político e econômico geral”. Importante acrescentar seu posicionamento que não nega "a importância de suportes materiais (....) que podem potencializar a intervenção educativa, enquanto eixo da metodologia de abordagem dos problemas familiares". Efetivamente tem sido constatado que as especificidades do 
trabalho social com famílias em situação de risco reúnem condições de poder contribuir na 'reorientação das políticas sociais em direção a práticas mais integradas às iniciativas da sociedade civil', todavia sem pretender "utilizá-las para justificar a diminuição da responsabilidade estatal com os problemas sociais” (p.14).

Em Santos, a partir de 1993, segunda gestão da Administração Democrática Popular, as 'secretarias da área social passaram a trabalhar de maneira mais integrada', visando assim potencializar suas ações ampliando os resultados. Nessa perspectiva é implementado um 'programa de apoio às famílias com dependentes em situação de risco, exemplo maior de integração de ações', através do qual a estruturação familiar é trabalhada como elemento básico na garantia dos direitos da criança e do adolescente (Bertuol, Campos e Silveira 1997, p.142).

Para os mesmos autores acima, em nome de uma 'interação crítica das práticas' entre os profissionais da saúde e da educação, a consolidação desse novo olhar impõe uma aprendizagem de desacostumar-se com as precariedades das unidades de saúde e das escolas. E (....) mais que isso: quantas oportunidades para o desenvolvimento de uma articulada e complexa noção de saúde e de seus determinantes surgem, quando o trabalho da policlínica e da escola se volta para os problemas do cotidiano dos homens, das mulheres, dos jovens, das crianças e dos velhos do bairro, às voltas com as questões do emprego, do salário, da alimentação, da habitação, do lazer, do transporte, da sexualidade e da solidão? (Bertuol, Campos e Silveira 1997, p.147).

Segundo Mendes (1996, p.147), a estratégia de saúde da família:

(....) do ponto de vista da assistência, rompe com a lógica convencional do centro de saúde prestador de atenção médica simplificada e de programas de saúde pública, quando vincula um número determinado de famílias a uma equipe composta por um médico generalista e um auxiliar de enfermagem, com base logística num módulo físico com dois consultórios médicos e serviços de apoio e preventivos. As equipes cadastram todas as famílias, a elas adstritas, e mantêm, com elas, 'relação interativa'. Essa 'equipe desenvolve, equilibradamente, ações promocionais, preventivas, curativas $e$ reabilitadoras, com forte componente intersetorial', seja no âmbito da unidade de saúde, seja no hábitat das famílias. 
Do ponto de vista do Programa de Agentes Comunitários de Saúde - PACS, este se coloca aqui de acordo com o pressuposto da sua inserção dentro da estratégia de saúde da família e não se constituindo em outro programa. Desde as proposições iniciais, a forma indireta de incorporação do agente comunitário de saúde ao sistema público de saúde tem-se mostrado polêmica. A questão foi sendo adequada através de um “discurso oficial sobre a emergência, papéis e funções do 'agente comunitário como integrante de um sistema de saúde', e sobre o envolvimento da categoria de enfermeiros nessa questão" (Martins e col. 1996, p.39). De acordo com Solla, Medina e Dantas (1996, p.13), este supervisor deve ser também o sujeito facilitador da 'integração do agente com os serviços de saúde', por seu papel de “elemento orientador e coordenador das decisões importantes a serem tomadas pelo programa no nível municipal, adequando-as".

O resultado final do trabalho do agente comunitário, "por definição relacionado à resolução de determinados problemas de saúde", estabelece-se na medida em que os serviços elou instituições consigam responder prontamente às suas demandas, criando “condições de trabalho adequadas. É importante lembrar que ao agente cabe um papel bem definido no desenvolvimento de certas ações básicas de saúde, mas que o cuidado à saúde, de uma maneira geral, requer também o desenvolvimento de ações em outros níveis mais complexos, aos quais o trabalho do agente precisa estar articulado", de forma a obter respostas a, "pelo menos, duas necessidades básicas: a garantia de continuidade das ações e do adequado apoio técnico e operacional ao desenvolvimento das ações” (Solla, Medina e Dantas 1996, p.14).

Segundo Nogueira (1993, apud Martins e col. 1995, p.40), em "um momento onde 'conceitos como a totalidade e a integração na abordagem da qualidade do trabalho em saúde' se fazem presentes, uma proposta que privilegia a utilização aleatória de trabalhadores sem qualificação específica, ainda que de forma emergencial, afetaria a qualidade da assistência oferecida pela categoria de enfermagem a qual se integrariam esses trabalhadores". Como também, afeta ao trabalho coletivo dos profissionais, pela 'natureza integrada e complexa da produção de serviços de saúde' (Goulart 1994, apud Martins e col. 1995, p.41). 
A última NOB (1996, p.21) coloca o PSF e PACS como 'estratégias de garantia da integralidade da assistência', atribuindo-lhes, em nome deste objetivo, o incentivo aos programas de saúde da família e de agentes comunitários de saúde, na forma de um acréscimo percentual ao montante de recursos repassados através do PAB - Piso de Atenção Básica, sempre que tais equipes e agentes, ou 'estratégias similares de garantia da integralidade da assistência', estejam atuando 'integradamente à rede municipal'.

\subsubsection{Cidades e Municípios Saudáveis}

Segundo Terris (1992, apud OPS 1996, p.38), a expressão "promoção da saúde” foi utilizada pela primeira vez em 1945, quando Henry E. Sigerist, reconhecido historiador da medicina, definiu suas quatro tarefas essenciais como sendo: promoção da saúde, prevenção da doença, cura e reabilitação dos doentes, acrescentando ainda que "a promoção da saúde se faz proporcionando condições de vida decentes, boas condições de trabalho, educação, cultura, formas de lazer e descanso", impondo-se para tal o esforço coordenado de políticos, sindicatos de empregados e patronais, educadores e médicos. Decorridas quatro décadas, sua proposição se repete na Carta de Otawa para a Promoção da Saúde (ibid), onde a mesma ordem lógica é reafirmada. Na primeira Conferência Internacional sobre Promoção da Saúde realizada em 1986 na cidade canadense de Otawa, se renova através de uma carta o compromisso com a consecução da meta Saúde para Todos no ano 2000. Então se entende que "promover a saúde consiste em proporcionar aos povos os meios necessários para melhorar sua saúde e exercer um maior controle sobre esta” (OPS 1996, p.367).

Segundo a Carta de Otawa "a participação ativa na promoção da saúde implica em: a elaboração de uma política pública saudável, a criação de ambientes favoráveis, o reforço da ação comunitária, o desenvolvimento de posturas pessoais, a reorientação dos serviços de saúde” (OPS 1996, p.368-70). Quanto a esta última questão, o papel do setor saúde na promoção ultrapassa em muito à simples oferta de serviços de saúde e assistência médica. Mas deve reorientar-se sensivelmente às necessidades culturais dos grupos populacionais. Os serviços “deverão voltar-se à necessidade das comunidades de 
levar uma vida mais sadia e criar vias de comunicação entre o setor saúde e os setores sociais, políticos e econômicos" (ibid).

Já desde as propostas de modelos de SILOS veiculadas pela OPS a partir de 1986, havia uma clara concepção de que: "La integración de las acciones preventivas y curativas, individuales y comunitarias, destinadas a las personas y al medio', requieren la concertación de los diversos sectores relacionados con el de la salud tales como el de educación, vivienda, economía, etc.” (Palma e Rufián 1990, p.463).

A proposição dos municípios/cidades saudáveis se desenvolve através de uma dimensão essencialmente política e organizacional, sem haver elaborado mais propriamente uma proposta de operacionalização das suas diretrizes, o que vem sendo enfrentado por vários municípios no Brasil com muita criatividade e buscando construir soluções locais no dimensionamento dos conteúdos tecnológicos de operação implicados.

Segundo Costa Filho (1997, p.19) uma das "experiências mais marcantes na administração santista" foi a construção de um movimento que fosse integrando diversos setores em torno de politicas sociais prioritárias'. Tratava-se de um 'trabalho integrado à comunidade', estimulando inclusive sua organização e participação. Este autor situa tais iniciativas, como articuladas ao movimento de Cidades Saudáveis, que em torno de 1995 começa a constituir uma rede no país, e ainda de acordo com a "Agenda 21", firmada em 1992 (na Eco-Rio) e coordenada pelo International Council of Local Environmental Iniciatives (ICLEI), "entidade do sistema das Nações Unidas, que tem como princípios genéricos a intersetorialidade e a participação ativa da comunidade, tanto na tomada de decisões como na ação propriamente dita" (ibid).

Costa Filho (1997, p.18) ao discutir a perspectiva de ser governo municipal, distingue três modelos de administrações, umas preocupadas somente com a "zeladoria" das cidades, outras voltadas para as grandes obras de engenharia, e aquelas dedicadas a políticas sociais. Tais "modelos" não são considerados "excludentes e podem ser concebidos como dimensões de uma 'política urbana integrada', harmoniosa, capaz de melhorar a qualidade de vida da população e reduzir as desigualdades na apropriação do espaço e das vantagens da vida urbana". 
Segundo Gianini e Manfredini (1997, p.110), em texto integrante do Caderno Preparatório para a IV Conferência Municipal de Saúde de Santos, realizada em 1996, um fator diferencial na implantação do Programa Cidades Saudáveis foi o fato de contemplar a manutenção de uma 'política integral de assistência à saúde', para assegurar "o acesso da população à rede de policlínicas, serviços de urgências e especialidades, (....) e hospitais. Não sendo negada a importância da assistência, ao mesmo tempo, eram concentrados esforços para viabilizá-la e incrementá-la.

O fato mais importante considerado durante a IV Conferência Municipal de Saúde de Santos (1996) foi incorporar a filosofia do movimento de cidades saudáveis, proveniente da experiência de cidades canadenses, desde a década de 1980. Tal programa prevê a existência de uma comunidade forte, organizada e com alto grau de participação nas decisões do governo, o qual, por sua vez, tem de desenvolver 'políticas integradas nas áreas que afetam de perto a saúde', como emprego, habitação, transporte, lazer e outras (Pupo Filho 1997, p.98).

Sob o marco da promoção da saúde é possível definir as formas mais adequadas para se enfrentar os problemas cotidianos de saúde. Trata-se de um referencial que une distintos conceitos, propiciando "uma forma especial de pensar e de atuar no sentido de alcançar o objetivo de saúde" para a cidadania. A 'promoção da saúde é um enfoque que pode ser desenvolvido progressivamente e integrado em sofisticados sistemas de atenção de saúde’ (Epp 1986, apud OPS 1996, p.36).

Na discussão da promoção novamente se coloca o problema da prioridade entre a mudança individual e do ambiente. "A idéia é que os programas de promoção da saúde possam ser assumidos (....) por organizações universitárias, governamentais ou comunitárias, onde se 'enfoque a saúde de uma forma integradora' e se estude a totalidade de exposições da pessoa no trabalho e na comunidade, as tensões ocupacionais e na família, a situação econômica, os problemas de saúde existentes, o estilo de vida e herança genética". Pois, vai ser este 'enfoque integrador que conseguirá os resultados mais saudáveis' para a população (Milio 1988, apud OPS 1996, p.55). Um exemplo citado da 'integração de critérios de saúde com os de outros setores da política pública' é a Lei do Meio Ambiente Ocupacional da Suécia (p.54). 
Abordando o tema do autocuidado na promoção da saúde, Kickbusch (1989, apud OPS 1996, p.237) discorre sobre o "autocuidado como parte de um conceito de estilo de vida, que segundo ela, tem a OMS como catalisadora. Seu principal argumento coloca o sistema social como ponto de partida da análise do autocuidado, com suas estruturas próprias da vida cotidiana, onde as pessoas são consideradas agentes ativos". Assim sendo, 'as atitudes e as condutas relacionadas com a saúde se entendem como parte integral do estilo de vida global da sociedade', onde se insere o grupo social e o indivíduo.

Na seguinte citação de Celentano (1991, apud OPS 1996, p.263), novamente aparece a diretriz da integração dos enfoques da clínica e da epidemiologia, aqui referida à promoção da saúde, mesmo sendo do ponto de vista de seu potencial de influência em agravos individuais:

En algunos aspectos, hemos utilizado un enfoque globalizador para demostrar la utilidad de la aplicación de los métodos epidemiológicos para comprender los factores de la conducta propios del estilo de vida (....) y aspectos tales como la personalidad o el estilo con que se afronta la situación. La 'valoración del método epidemiológico y del paradigma de la salud pública' demuestra las notables diferencias que existen con respecto al enfoque clínico tradicional. Ambos enfoques son esenciales para comprender la dinâmica de la conducta de los pacientes y de sus riesgos de cáncer (por exemplo). Además, 'ambas perspectivas deben integrarse' simultáneamente con los paradigmas psicosociales (estrés) en cuyo marco se consideran los recursos personales y sociales.

Reveste-se da maior importância o fato da promoção da saúde, articuladamente ao chamado novo movimento da saúde pública (Frenk 1992), haver-se constituído em uma base integrada de ação para os anos 1990. Assim, o conceito de "promoção da saúde permanece centrado na promoção geral da saúde pública, (....) para defender de novo as mudanças sociais e do meio ambiente" enquanto estratégias para se 'alcançar estilos de vida saudáveis: encontrar um equilíbrio entre as medidas dirigidas ao indivíduo e a ação coletiva para promover a saúde'. Situam-se no núcleo desse conceito "a defesa das potencialidades da pessoa e a ação coletiva, dirigidas a resolver as ameaças para a 
saúde, tanto imediatas como subjacentes" (Nutbeam e Blakey 1990, apud OPS 1996, p.339). Assim como os diferentes momentos do processo saúde e doença.

Numa perspectiva de 'complexificação da questão da vigilância', esta se coloca 'estritamente vinculada à questão do exercício pleno da cidadania integrada numa concepção holística de cada humano - que só se torna pessoa pela integração com seus pares - numa visão ecológica' - "que considera o humano como parte do mundo em que vive - e tecnocientífica - que o considera também como um ser criador de novos mundos". Nesse enfoque complexo e contextualizado, não se pode pensar a vigilância como separável da epidemiologia, assumindo uma dimensão do conjunto mais amplo da saúde pública. Seu funcionamento vai implicar em "uma certa independência tanto política com financeira, ou seja, não excessivamente regulamentado nem burocratizado, mas sim bastante descentralizado" (Schramm e Schramm 1995, p.53).

\section{Políticas públicas saudáveis}

No Brasil pode-se identificar diversos 'movimentos setoriais de racionalização integradora das políticas sociais', entre os quais destacou-se a criação em 1966 do Instituto Nacional de Previdência Social (ex-INPS), que substituiu os antigos institutos de aposentadoria e pensão organizados por categoria profissional e, em 1988, do Sistema Único de Saúde, apesar do que, as políticas sociais continuam fragmentadas (Vasconcelos 1999, p.07). Considerando que o indivíduo foi fragmentado em carências, constata-se que os direitos passaram a ser consumidos e fornecidos de forma separada. E como agravante, "neste contexto de individualismo, assiste-se a um espantoso crescimento da importância do discurso centrado na subjetividade como explicador dos problemas sociais" (ibid).

Considerando que a percepção da fragmentação das políticas sociais vem proporcionando o surgimento de propostas e tentativas de 'integração das várias ações estatais no campo social', Vasconcelos (1999, p.07) questiona: mas como fazer essa integração das várias ações do Estado, 'transformando-as em um todo articulado'? O movimento de priorização política da família, identificado por Carvalho (1994, apud 
Vasconcelos 1999, p. 8), tem contribuído no reconhecimento da saúde da família como estratégia para tão pretendida integração. Assim sendo, segundo este último autor, vem “crescendo internacionalmente a visão de que as unidades de atuação família e comunidade são pontos importantes da 'estratégia de integração das diversas políticas sociais"". Todavia, a resposta ao como fazer para transformar a integração das ações em um todo articulado exige especificar melhor tecnologicamente a forma de atuação nas unidades família e comunidade para que produzam a efetividade desejada.

É sabido que desde a definição de saúde como direito, na $8^{\mathrm{a}} \mathrm{CNS}$ já se percebia uma estética, segundo a qual o Estado deve assumir explicitamente uma 'política de saúde conseqüente e integrada às demais políticas sociais e econômicas' (Silva, Egydio e Souza 1999, p.39). Frente às desigualdades de saúde entre grupos sociais elou regiões, as análises setoriais "têm enfocado principalmente iniqüidades na distribuição e consumo de serviços de saúde, embora 'políticas econômicas e sociais integradas com o objetivo de redução das iniqüidades' diagnosticadas" sejam freqüentemente sugeridas (Giovanella e col. 1995-6, p.16-7).

Pretendendo ser rigorosamente conseqüente com o discurso da promoção da saúde através de políticas públicas saudáveis, há que se aliar ao princípio da integralidade o da equidade enquanto direitos de cidadania. De acordo com Travassos (1995, citada por Giovanella e col. 1995-6, p.17), pode-se relacionar equidade em saúde com justiça social. "A equidade refere-se às necessidades em saúde que são socialmente determinadas (....), e a utilização dos serviços de saúde está determinada, tanto pelas necessidades de saúde da população, como pelas características da oferta de serviços de saúde". Assim como na equidade, embora a "ação isolada dos serviços de saúde não seja suficiente para resolver o conjunto das iniqüidades em saúde, mas certamente pode contribuir para reduzi-las", no caso da integralidade em saúde, além do esforço setorial, as políticas econômicas e sociais podem ser determinantes para materializá-la.

Considerando a solidariedade um valor intrínseco à constituição da nação, que assume o caráter de força aglutinadora dos indivíduos em um “nós” inclusivo, Giovanella e col. (1995-6, p.21) propõem o enfrentamento das desigualdades em saúde como uma “situação que não pode ser resolvida apenas através de ações emergenciais ou setoriais. 
A consolidação dos direitos de cidadania no país supõe uma nova articulação entre políticas econômicas e sociais promotoras de uma efetiva redistribuição de renda". Trata-se aqui de um "modelo de desenvolvimento (....) no qual as políticas econômicas assumam também a dimensão de políticas sociais".

Ao considerar a intersetorialidade, enquanto 'articulação intersetorial', uma dimensão de análise que lhe permite aprofundar o conceito de modelos tecnoassistenciais em saúde, através de uma abordagem que vem reconstruir o conhecimento da causalidade e incorporar visões interdisciplinares, Silva (1998, p.37) se referencia ao paradigma ecológico e holístico (citando Capra 1982, Weil 1988 e Coelho 1992). Segundo aquele autor, 'repensar as políticas públicas segundo uma nova concepção de desenvolvimento' se constitui em um desafio urbano, que propõe, em última instância, uma nova cultura político-institucional e social: "Uma política de reversão de prioridades - descentralizando o poder e democratizando a gestão, 'integrando ambiente construído e natural', potencializando os recursos locais, utilizando técnicas adequadas para a região, desenvolvendo projetos de renda para população, ampliando a infra-estrutura básica e melhorando a qualidade de serviços nos bairros mais carentes que signifique a materialização de uma nova cultura de gestão baseada na construção de cidadania, na garantia do direito à vida, e não na cultura do favorecimento e do clientelismo" (Silva 1998, p.37).

\section{Planejamento integrado}

Problematizando o aspecto inovação, Malik (apud Westphal 1997, p.259) demonstra que o que aparece nos documentos como princípios orientadores e estratégias de ação da proposição de cidades/municípios saudáveis apresenta pouco de novo. Por referência à proposta do planejamento, a seu ver, muito utilizada e até desgastada, considera que 'o caráter novo está na perspectiva integrada que os defensores da idéia indicam como característica do planejamento'. Em relação à intersetorialidade, comentou a dificuldade político-corporativa, que muitas vezes torna esses projetos uma guerra fratricida. No mesmo sentido, a apresentação de Keinert (apud Westphal 1997, p.262), identifica ainda “(....) um déja $v u$ em relação a muitos aspectos da proposta, sendo o 
inovador o planejamento intersetorial, ou seja, a 'abordagem da questão de saúde por diferentes setores da sociedade de forma integrada".

Também em Curitiba, através de 'um 'planejamento municipal integrado', solidário, no qual as políticas e técnicas dos vários setores se articulam no atendimento das necessidades da população", se materializa a proposta que Raggio (1992, citado por Silva 1998, p.91-2) denominou como "saudicidade, para repensar o papel do setor saúde", enquanto alternativa à sua crítica à "capacidade limitada dos modelos sanitários em atuar na problemática gerada no processo de urbanização acelerado de regiões metropolitanas". Seu conceito de "saudicidade" significa: 'saúde para a cidade, saúde para os cidadãos que nela possam potencializar a plenitude da vida', colocando-se como o oposto da patogenicidade.

Segundo Mendes (1994, apud Silva 1998, p.88), “a (...) complexidade ... dos problemas de saúde impõe (....) uma abordagem matricial no seu enfrentamento", sobretudo por envolver setores fora do setor saúde. Considerando 'que essa articulação se deva dar nos níveis superiores de governo para melhor integração de atividades', por sua vez, podem ser 'coordenadas, no nível distrital, pela autoridade sanitária local'.

Para a OPS (1996, p.389) os 'programas direcionados à promoção do bem-estar total deveriam reconhecer a natureza multidimensional e integradora da saúde', centrando mais sua atuação nos estilos de vida, do que sobre as condutas e fatores de risco. No glossário de sua antologia sobre a promoção de saúde, entende-se por 'bem-estar total um novo conceito de saúde basicamente relacionado com a qualidade de vida destacando as dimensões da vida' humana relativas à experiência e conduta.

Um primeiro desdobramento da abordagem da promoção da saúde de uma forma ampliada é a própria reestruturação do sistema de saúde para assumir a responsabilidade pela coordenação de todos os níveis de ação de saúde, sejam realizadas diretamente intra ou indiretamente extra setor. Entre as várias proposições a esse respeito já se destacou neste estudo a de Castelhanos (1993) sobre "estudos de situação de saúde segundo condições de vida" onde propõe, através de uma matriz 
multidimensional de saúde, uma atuação nos diversos momentos do processo saúde e doença. Seu projeto pressupõe ação desde a promoção e proteção à saúde, passando articuladamente pelos diversos níveis de atenção, inclusive oferta organizada, assistência e referência aos demais níveis de complexidade crescente.

\subsection{Integralidade em Saúde: Uma Síntese}

Recupera-se o conceito, que informa o modelo de atenção em que se realiza e as questões organizacionais implicadas.

\subsubsection{O Conceito}

Os antecedentes de aproximação a um conceito de integralidade em saúde se inserem no movimento histórico das concepções do processo de saúde e doença. E este, por sua vez, representa o objeto de trabalho do campo da saúde coletiva, que se situa de forma intrinsecamente articulada com a correspondente organização das práticas de atenção à saúde. Assim, a existência de uma concepção de integralidade da atenção define-se em uma concepção integral da saúde.

Nos antecedentes históricos de aproximação à noção de integralidade em saúde, identificou-se o coletivo como sua primeira dimensão conceitual, indicando a apreensão do coletivo enquanto objeto de trabalho das práticas de saúde como práticas sociais. Nesse espaço nasce a medicina social.

Por contingências históricas, as práticas de saúde adentram no século 20, balizadas por conhecimentos clínicos que produzem a hegemonia da atenção individual na saúde, cada vez mais especializada, e, por conhecimentos epidemiológicos a princípio predominantemente orientados pelos elos bacteriológicos da doença. Nesse contexto houve uma retração da dimensão coletiva a um enfoque individual e curativo da doença. Por sua concepção mono-causal naquela época, os esforços sanitários de base coletivo- 
populacional se restringiam ao controle de epidemias e higiene das cidades, berço do sanitarismo.

No Brasil, esse momento histórico se expressa nas campanhas e polícia sanitárias inauguradas nas primeiras décadas do século 20. Com o espaço aberto para a medicina previdenciária e o grande desenvolvimento das especialidades médicas, na continuidade se configura o modelo médico-sanitário em que convivem essas duas racionalidades atravessando praticamente todo o século 20. Em seus primeiros desdobramentos, esse modelo propõe uma noção de integração assistencial originariamente restrita à inclusão da assistência médica na rede pública de atenção à saúde.

Os elos perdidos com o coletivo e social ressurgem em práticas alternativas da formação médica informada por um projeto preventivista traduzido especialmente na medicina comunitária e medicina integral. Derivada desta última pode-se apreender uma segunda dimensão a compor o conceito de integralidade em saúde - a concepção de abordagem da totalidade bio-psico-social do indivíduo, enquanto objeto de apreensão do trabalho em saúde impondo uma recomposição totalizadora de suas práticas.

As concepções de cuidado integral à saúde das pessoas têm sido continuamente renovadas, seja no sentido da integralidade das ações pressupondo o acesso articulado a todos os níveis de complexidade da assistência médica, seja atualmente também identificada com abordagens mais holísticas do atendimento de saúde. Por mais integral que possa ser a atenção integral à saúde individual, esta se constitui em somente uma das dimensões do conceito de integralidade em saúde.

A integração sanitária constitui uma terceira dimensão que é central e, portanto imprescindível à noção em construção, haja vista debruçar-se teoricamente sobre possibilidades de superação das dicotomias entre a racionalidade do atendimento individual de saúde e da epidemiologia, através de uma abordagem articulada na apreensão das necessidades individuais e coletivas e na organização da intervenção simultaneamente operando cura e proteção. 
Mais recentemente pode-se identificar um movimento de ampliação do sentido das várias concepções das práticas de saúde: da atenção curativa individual, onde a ação é sobre o sintoma ou queixa, à atenção integral à saúde, onde cada processo mórbido é visto em várias fases (promoção/prevenção/cura), atuando-se sobre a totalidade biopsico-social do indivíduo; e, avançando para uma noção de integralidade na atenção à saúde, que impõe mexer não só com a sintomatologia da doença e outras manifestações dos problemas de saúde, mas tentar, também, remover causas expressas coletivamente.

Assim sendo, em uma quarta dimensão conceitual, situa-se a integralidade da atenção em uma concepção referida à apreensão do conjunto de problemas de saúde de uma população definida. Nessa perspectiva pode-se referir a definição de Silva (1998, p.34), que entende a integralidade como a 'capacidade de oferecer ações que satisfaçam às várias demandas ligadas à promoção e recuperação da saúde'. E por isso trabalha com a dimensão de 'integralidade da oferta de ações', referindo-se à 'integralidade na prestação de serviços'.

De acordo com Mendes (1994, citado por Silva 1998, p.34), 'a integralidade exige, exatamente, uma intervenção integradora, no seu âmbito tecnológico, sobre indivíduos, familias, ambientes coletivos, grupos sociais e o meio ambiente'. Também a NOB 96 (p.15) reconhece explicitamente que 'o enfoque epidemiológico atende ao compromisso da integralidade da atenção', ao assumir "como objeto das ações, a pessoa, o meio ambiente e os comportamentos interpessoais". E acrescenta que, "nessa circunstância, o método para conhecimento da realidade complexa e para a realização da intervenção necessária fundamenta-se mais na síntese do que nas análises, agregando, mais do que isolando, diferentes fatores e variáveis". Nessa perspectiva os conhecimentos "mais particularizados e (....) com grande sofisticação e detalhamento analítico devem possibilitar, igualmente, um grande 'esforço de visibilidade e entendimento integrador e globalizante, com o aprimoramento dos processos de síntese', sejam lineares, sistêmicos ou dialéticos".

Cada vez mais existe o reconhecimento pela comunidade científica de que a separação entre a medicina exclusivamente curativa e as ações essencialmente preventivas sobre o ambiente e hábitos de vida parece não ter mais fundamentação. "O ambiente social pode 
exercer uma papel curativo importante, assim como a existência do sistema de saúde pode exercer uma função preventiva pelo sentimento de confiança que ele cria no seio da população. A melhoria da saúde da população depende assim, em proporções desconhecidas, da qualidade do ambiente, da prosperidade geral do país e dos serviços de saúde realizados pelo sistema de tratamento" (House, Landis \& Umberson, 1988, citados por Contandriopoulos 1996, p.58).

Segundo Schraiber (1997, p.226), na trajetória da saúde coletiva e no movimento da reforma sanitária, a 'integralidade da atenção se inseriu com grande ênfase na racionalização gerencial'. E as "outras maneiras de pensar a integralidade envolviam: a perspectiva de 'integrar formas assistenciais de caráter coletivo e individual'; a 'integração do ato médico', como crítica à super especialização; a 'integração biopsicossocial dos indivíduos'. Historicamente, esses distintos olhares têm sido privilegiados e abandonados como, por exemplo, a proposta da medicina integral". De acordo com essa autora, "de qualquer modo, pensar a integração na saúde pressupõe: o reconhecimento de que cada segmento (sic) tem racionalidades e culturas próprias; e, que esse processo requer um permanente estranhamento de práticas familiares no sentido de 'verificar possibilidades concretas de integração'. Como o produto das práticas de saúde responde a necessidades da sociedade, a escolha de alternativas se dará no confronto político de interesses sociais" (ibid).

Uma conseqüente atenção integral ao indivíduo impõe considerar uma concepção mais integral desde a visão da pessoa até as políticas públicas; portanto, a intervenção se subordina à lógica em que os problemas são apreendidos. Inclusive, o problema individual pode ser apreendido coletivamente e o problema coletivo pode ser aprendido no indivíduo. Conforme diz Schraiber (1997, p.226), "é necessário descobrir quais as 'chances históricas, científicas e tecnológicas de que a integração se processe', identificando, por exemplo, as brechas que permitam tornar o individual coletivo e viceversa". Por referência ao feminismo essa autora coloca "que talvez o social e o individual não constituam antinomia e que se deva pensar em indivíduos sociais cujo agrupamento não resulta em homogeneidade, mas, ao contrário, em pluralidade e diversidade". 
E finalmente, a explicação integral dos processos de saúde e doença incorpora aos problemas de saúde as condições de vida, o que permite explicitar como uma quinta dimensão da integralidade em saúde, aquela comprometida com a intervenção sobre os determinantes dos processos de saúde e doença, especialmente através da promoção da saúde. Trabalhar com o conceito de processo saúde-doença no atendimento às pessoas implica ir até a sua determinação social e ver como o serviço de saúde pode responder também a isso: seja encaminhando ações no próprio setor, seja desenvolvendo estratégias conjuntas para organizar demandas e acompanhar a ação dos demais setores objetiva ou potencialmente envolvidos. Isso implica para o setor assumir uma tarefa a mais - sem deixar de ter sua política interna atuando no seu papel intrínseco e indelegável de recuperar e proteger a saúde da população, fazer o possível em todos os níveis, mesmo que inicialmente desde o lugar dos serviços locais, para que as ações intersetoriais aconteçam no sentido da promoção e proteção da saúde.

Assim impõe-se a articulação entre sistemas de serviços de saúde e políticas públicas. A integralidade situa-se dentro da competência do setor saúde, e neste, especialmente, na sua articulação intersetorial, portanto acrescido basicamente da responsabilidade de privilegiar a reflexão e intervenção na interseção com as políticas públicas de interesse da saúde da população, pois, é no espaço próprio da saúde que melhor pode ser criada tal condição de integração. Essa interseção entre o papel do setor e das demais políticas públicas cabe ao setor saúde acionar e operacionalizar, contribuindo para a operação da intersetorialidade na saúde e estabelecendo vínculos objetivos do ponto de vista da saúde.

O coletivo não elimina o individual, agrega. Assim a integralidade em saúde compreende a atenção integral à saúde das pessoas em seu habitat, um territórioprocesso, de forma articulada com uma ação integral sobre os problemas de saúde e suas causas. A ampliação da concepção não diminui a concepção do cuidado curativo individual, pois as dimensões apresentadas são acumulativas, coletiva e individual, de prevenção e cura, ou seja, proteção e recuperação da saúde, implicando na apreensão e atuação sobre os vários momentos dos processos de saúde e doença. 
Portanto, um quase-conceito de integralidade em saúde, ancorado em uma concepção integral da saúde, pode ser formatado através das seguintes sub-dimensões: dimensão coletiva do objeto de trabalho em saúde; integralidade dos cuidados ao indivíduo; integração sanitária, integralidade da atenção enquanto organização e prestação integrada das ações de uma unidade ou sistema local de serviços de saúde para resolver problemas de saúde de sua área de abrangência; e integralidade da promoção à saúde. Cabe lembrar aqui que, "além de essencialmente dinâmicas, as práticas de saúde são também concebidas como estruturadas em uma totalidade, daí que cada locus de sua realização contenha necessariamente o conjunto das determinações dessa estruturação, diversificado no concreto singular” (Mendes-Gonçalves 1994, p.48).

\subsubsection{Um Modelo de Integralidade da Atenção em Saúde}

A diretriz da integralidade se projeta na caracterização do modelo de atenção pretendido. Nas diversas proposições historicamente recuperadas na sua expressão em diferentes contextos nacionais, lugares, tempos e espaços politicamente instituídos, existem vários componentes que em seu conjunto possuem atributos que contêm a possibilidade de estar formatando um modelo de atenção, que se pode considerar como aproximações à perspectiva de um modelo de integralidade da atenção à saúde. Essa assunção teórico-prática se constitui através das três dimensões que compõe um eixo de apreensão da integralidade enquanto modelo de atenção à saúde - o político, tecnológico e organizacional.

Em decorrência, há que se reconstruir a recuperação histórico-conceitual do objeto, através de um quadro teórico informado pelas hipóteses iniciais de trabalho que afirmavam que a integralidade se faz pela política, organização e tecnologia e iluminado pela fundamentação teórica do estudo. Essa mesma construção teórica vai orientar a leitura do empírico, ao mesmo tempo em que será enriquecida por referência à realidade apreendida empiricamente.

No contexto da crise do estado de bem-estar social, assim como a equidade tem sido 'uma das questões centrais do debate sobre politicas públicas de saúde', também se coloca que “(....) uma segunda questão central ao debate se relaciona com a 
'integralidade', a qual também constitui um dos princípios básicos da reforma sanitária brasileira e ainda permanece um desafio como estratégia de reorientação do modelo assistencial". Tal reconhecimento orientou a organização da oficina "políticas de saúde, equidade e gênero" no V Congresso Brasileiro de Saúde Coletiva, partindo destas duas abordagens para anteceder a discussão de gênero (Costa 1997, p.223).

Segundo Mendes (1993, p.119), “a mudança do modelo assistencial hegemônico, é que vai qualificar e diferencia, fundamentalmente, os projetos alternativos, inseridos na arena política da saúde". Nessa perspectiva, coloca como principal alternativa a municipalização, na sua condição de fenômeno de natureza político-administrativa, que se efetiva em um espaço de transformação institucional, tendo sua densidade marcada por estar desenhada para provocar uma mudança no paradigma assistencial hegemônico, fazendo-o migrar da hegemonia de um modelo clínico para um 'modelo sanitário', o que viabiliza a atenção à saúde enquanto sistema. Assim sendo, as decorrentes modificações no espaço operativo que são acopladas às transformações no espaço institucional, é que vêm configurar efetivamente a mudança do modelo.

Obviamente há que se reconhecer 'a importância e a dificuldade do paradigma de saúde', por condicionar a possibilidade de mudanças efetivas na ponta enquanto exigência das concepções definidas na reforma sanitária, visando construir 'uma nova cultura da saúde e de novas práticas que atendam às necessidades sociais $e$ epidemiológicas' o que implica construir “condições de pleno exercício e realização profissionais" (Garrafa e Rodriguez Neto 1995-6, p.03-4).

Assim como o "processo de desenvolvimento dos sistemas locais de saúde não tem fim", o mesmo também se pode dizer a respeito do desenho de um modelo de atenção em saúde. E, num paralelo, ambos começam "com o estabelecimento de suas bases fundacionais e, como consequiência da sua dinâmica inerente, (cada um) continuará com aperfeiçoamentos e ajustes permanentes colocados pela própria dinâmica e pelas condições internas e externas do âmbito local”, que são impostas para atender seus objetivos (OPS 1990, p.443). 
Também na concepção da integralidade enquanto modelo de atenção as suas dimensões são tomadas como uma totalidade. Cada vez mais vai se abrindo o espaço organizacional de realização da dimensão política e de apoio à execução tecnológica das finalidades pretendidas. Como ilustração dessa perspectiva pode-se tomar o instrumento da avaliação em saúde. Indicando o propósito de "assessorar a decisão política", Mendes (1996, p.218-9), apresenta algumas características que considera fundamentais na 'avaliação tecnológica', como o fato de que ela 'envolve o trabalho integrado de diferentes disciplinas' (citando a epidemiologia, engenharia biomédica, bioestatística, economia, sociologia, antropologia, bioética, direito, medicina, biofísica etc.); “exige o uso da melhor informação disponível sobre o (....) uso da tecnologia médica; e requer a disseminação dessa informação para distintas clientelas (decisores políticos, associações profissionais, instituições de saúde, profissionais de saúde, organizações de usuários etc.)".

Outra ilustração da expressão simultânea das três dimensões da integralidade em saúde pode-se encontrar no estabelecimento de critérios para a alocação de recursos escassos em um sistema de saúde, onde ressurgem os 'conceitos de coordenação, integralidade e negociação, correspondentes aos sistemas locais de saúde, havendo que estar igualmente presentes (por exemplo) na estruturação de um comitê de ética'. Assim se percebe que problemas deste tipo não podem ser concebidos de outra forma que contemplando uma 'hierarquização normativa de opções, integrando ação $e$ negociando propostas', em função da multiplicidade disciplinar que caracteriza tais comitês (Tealdi 1990, p.464).

Até a NOB (1996, p.15) propõe, essencialmente, que 'o novo modelo de atenção deve resultar na ampliação do enfoque do modelo atual', entendendo que assim se pode alcançar a 'efetiva integralidade das ações'. Como primeira condição propõe a defesa e investimento no modelo atual, havendo que se entender aí a proposta do SUS. Então ainda explicita como instrumento para tal ampliação a "incorporação, ao modelo clínico dominante (centrado na doença), do modelo epidemiológico, o qual requer o estabelecimento de vínculos e processos mais abrangentes", inclusive também organizacionais, conforme já discutido neste estudo. 
Assim, na NOB 96, “além da ampliação do objeto e da mudança no método, 'o modelo adota novas tecnologias', em que os processos de educação e de comunicação social constituem parte essencial em qualquer nível ou ação, na medida que permitem a 'compreensão globalizadora a ser perseguida', e fundamentam a negociação necessária à mudança e à associação de interesses conscientes", âmbito em que se destaca a importância da valorização da informação informatizada. Nessa perspectiva cada pessoa passa a ser estimulada enquanto 'agente da sua própria saúde e da saúde da comunidade que integra'. Assim, também na intervenção ambiental, o SUS assume algumas ações específicas e busca a 'articulação necessária com outros setores', para a criação das condições indispensáveis à promoção, à proteção e à recuperação da saúde" (p.15-6). Essas presunções impõem uma cuidadosa comunicação da estratégia no espaço organizacional da saúde.

É possível afirmar que a integralidade em saúde é um princípio ético que se define no campo filosófico do direito à saúde, que informa sua tradução em uma diretriz política, e que tem uma proposição organizacional e tecnológica. Em torno da noção de integralidade em saúde, tem se configurado concepções de renovação do modelo de atenção, que acompanham um movimento que desde a reforma sanitária veio sendo construído no âmbito do SUS, sobremaneira pelos próprios municípios. Em todas as proposições abordadas de conformação das práticas de saúde enquanto modelo de atenção - ação programática em saúde, defesa da vida, distritalização com vigilância à saúde, PSF e municípios saudáveis -, pode-se identificar a presença sutil ou explícita das três dimensões, que compõem o eixo da política, organização e tecnologia, expressadas sob diferentes ênfases e concepções.

\section{A integralidade enquanto princípio político}

Em sua dimensão política, a integralidade em saúde assume um corpo de valores sociais e ideológicos, que estão representados nos seus princípios ético-normativos. Na medida em que a integralidade avançar dos discursos oficiais e declarações públicas, passando a ser um valor compartilhado pela sociedade, então, conseguir-se-á dar um passo decisivo em direção à sua efetivação. Assim como a equidade, a integralidade também pode ser entendida como uma mudança filosófica colocada pelas ciências da saúde, em um 
horizonte ético, ao mesmo tempo em que conceitual e prático, que impõe "o desenvolvimento de uma ética institucional e social, obviamente mais complexa que a individual" (OPS 1990, p.440).

Este horizonte ético é construído com base em valores existentes: Schraiber (1997, p.226), expondo o tema 'integralidade: possibilidade ou utopia na construção dos modelos assistenciais no SUS, inicia "pela constatação da proximidade entre possibilidade e utopia, pois não há utopia que se coloque se não estiver inscrita como possível, assim como não há possibilidade concreta que não se oriente por projetos. Há que se ter em conta que, na vida social, ao se adotar uma certa direção, outras estão sendo abandonadas ou preteridas e que a realização de uma dada utopia, provavelmente, implica a impossibilidade histórica de outras".

O segundo momento da dimensão política se conforma na tradução do princípio ético em uma questão de direito. Assim já se expressam mais claramente as relações saúde e sociedade, em cujo conjunto emerge as concepções de integralidade em saúde.

Existem muitos argumentos a favor da 'relativização do direito integral à saúde', que segundo Schramm (1997, p.52-3) se apóiam no fato dos recursos serem limitados e precisarem "ser otimizados; (....) das necessidades de assistência sanitária estarem crescendo devido à transição epidemiológica", o que implica no aumento dos custos dos serviços, defendendo que, nestas condições, as 'demandas sanitárias não poderiam ser razoavelmente satisfeitas integralmente'; em nome do " argumento de que (....) existem também outras prioridades, sendo a saúde, embora importante, (....) só um dos direitos fundamentais a ser protegido, dentre outros". Na perspectiva da "alocação eqüitativa dos recursos disponíveis no contexto de vigência de uma cultura dos limites", Schramm identifica um dilema moral colocado para a saúde pública, ao situar-se no conflito entre duas concepções: uma primeira que entende "que a saúde seja um direito não só do indivíduo entendido como pessoa, titular de direitos e deveres (de primeira geração) mas, em princípio, de todos os cidadãos (direitos de segunda geração), e que deve ser protegido sempre, e na sua integralidade, pelo Estado"; e, outra que procura relativizar esse direito em nome dos limites da realidade. Tal postura "emerge, paradoxalmente, no mesmo momento em que se afirma também uma cultura que defende várias concepções 
legítimas de qualidade da vida; que afirma a legitimidade de uma medicina dos desejos; em suma, que promove a centralidade de uma figura que poderíamos chamar de consumidor de qualidades em saúde" (ibid).

No conflito dessas duas posições situa-se a "saúde entendida como possibilidade de acesso aos meios financeiros, tecnológicos, educacionais e informacionais, capazes de prevenir, cuidar e curar as situações mórbidas e agudas, fato moralmente relevante porque coloca a delicada questão da justiça sanitária em termos de equidade e no contexto dos recursos efetivamente disponíveis em cada situação concreta”. Este talvez seja, do "ponto de vista da ética sanitária, o conflito moral mais agudo (....), pois diz respeito à espinhosa questão pública da alocação eqüitativa dos recursos disponíveis" (Schramm 1997, p.56).

Um terceiro momento da dimensão política diz respeito à realização da integralidade enquanto instituição pública. Desde sua origem situada na Europa do final do século 18, as noções de integralidade em saúde nas mais diversas denominações se expressavam através de um caráter estatal do objeto de intervenção na saúde, basicamente referido à responsabilidade do Estado sobre a saúde da população.

Em sua estética castelhana, Testa (1997, p.31) assim se refere à construção do espaço público para a saúde: "Desde la lejana ágora donde el pueblo se reunía para discutir sus problemas, 'una larga historia construyó para la salud el espacio de lo público'. Esa construcción nació privilegiada por la visión prevaleciente en el momento de su fundación, dada la formulación hipocrática sobre 'Aires, Aguas y Lugares' ". Testa considera ainda como consolidação do espaço público o movimento de transformação da saúde em saúde pública, por abrigar em suas práticas, “o espaço da política, do diálogo, da discussão, da criação de consenso, do fortalecimento da sociedade civil, da solidariedade possível". Considera que foi este o movimento que ocupou a época de configuração da medicina social, relacionada com as lutas populares dos mais diversos países (p.32-3). Assim como também se fez presente no movimento brasileiro de reforma sanitária. E a perspectiva de construção de um modelo de integralidade da atenção à saúde ainda continua colocada no espaço público. 
Laurell (1997, p.37) considera economicamente factível e eticamente imperativo que reformas de saúde, comprometidas com cobertura universal, possam contar com financiamento e prestação de serviços assumidos como responsabilidade pública. A tradução desta proposição geral em medidas concretas passa inicialmente pelo problema crucial de "reestruturação do financiamento para garantir os recursos necessários e sua distribuição eqüitativa". Um segundo problema refere-se ao modelo de atenção pretendido. De acordo com essa autora, uma 'prestação de serviços integrais de saúde' que tenha "ênfase na promoção e prevenção é mais factível quando os serviços públicos ocupam o lugar dominante no sistema de saúde". Seria muito mais complicado sob domínio de interesses privados. Nesta perspectiva, o fortalecimento dos serviços públicos torna-se "uma opção muito melhor que a desestruturação institucional que tem sido promovida", especialmente em países onde exista ou tenha existido um setor público forte mesmo sendo freqüentemente deteriorado.

\section{Integralidade do sistema de saúde}

Cabe aqui destacar a definição da integralidade por referência a Mendes (1994, apud Silva 1998, p.34): “(....) A aplicação deste princípio implica reconhecer a unicidade institucional dos serviços de saúde para o conjunto de ações promocionais, preventivas, curativas e reabilitadores e que 'as intervenções de um sistema de saúde sobre o processo saúde/doença conformam uma totalidade que engloba os sujeitos do sistema e suas inter-relações com os ambientes natural e social"'.

A concepção da organização de serviços enquanto sistema é informada pelo pressuposto da racionalidade interna e externa do seu objeto. "A racionalização em saúde é a procura sistemática de formas mais eficientes de produção e da eliminação de consumo desnecessário e a seleção de bens e serviços de maior utilidade para a sociedade. $\mathrm{O}$ objetivo da racionalização é diminuir os custos sem impactos negativos nos níveis de saúde (coletiva e individual) e aumentar a eficiência sem prejuízo da eficácia e da efetividade das ações desenvolvidas” (Mendes 1996, p.19).

Não somente as proposições de modelo de atenção no SUS, mas "todas as tendências internacionais propugnam 'um outro paradigma, mais holístico', tanto em termos de 
compreensão da determinação do nível de saúde individual e coletivo, quanto em relação a uma abordagem mais racional, representada pelo planejamento de ações e serviços e acesso da população, de acordo com as suas necessidades, o que significa a oferta da assistência desde o nível primário até o mais especializado, num sistema hierarquizado, de maneira a que todos possam se beneficiar do sistema, sabidamente carente de recursos" (Rodriguez Neto 1996, p.08).

A integração necessária no próprio sistema de saúde se impõe para uma efetiva integração das ações de saúde na perspectiva de viabilizar referências de acesso a qualquer nível de complexidade da assistência, sem descontinuidades. Essa noção de integralidade da assistência existe atualmente em países capitalistas desenvolvidos como o Canadá, e também em Cuba, um país socialista.

De acordo com Silva (1998, p.128-9), através da "regionalização (técnica) e hierarquização, a saúde coletiva oferece alternativas mais criativas, flexibilizando a concepção de níveis de assistência, procurando oferecer opções mais resolutivas no plano local. Incorpora criticamente tecnologias, procurando oferecer universalmente as opções necessárias à proteção e à recuperação da saúde (integralidade)". Reforçando essa concepção, o autor acima explicita que "a noção de regionalização (....) no setor saúde (....) leva em conta o acúmulo de técnicas e tecnologias necessárias à manutenção de saúde que, dado seu custo crescente, precisam ser racionalizadas para oferecer a 'integralidade de opções' a populações circunscritas a territórios" (p.36). Na idéia do atendimento integral à saúde dos doentes está presente o pressuposto da garantia da referência a qualquer e a todos os níveis de complexidade crescente tecnologicamente disponíveis, com os respectivos mecanismos de referência e contra-referência. Tal integração do sistema começa com a idéia de uma rede básica, com garantia de atendimento em uma rede de maior complexidade.

Não é somente no Brasil que a 'integração das ações clínicas e epidemiológicas' vem sendo "apontada, como forma potencialmente mais efetiva para a organização da atenção à saúde". Isso também acontece em outros países, embora seus arranjos institucionais particulares possam contar "com graus maiores de autonomia 
organizacional entre a saúde pública e a assistência médica" (Buss e Labra, 1995; Evans, Hall, Warford, 1981; OPAS-OMS, 1989 e 1990, citados por Nemes 1995).

Na perspectiva do funcionamento de um sistema integrado de saúde, Nogueira (1995) discute o conceito ampliado de razão formulado por Habermas, que veio criticar e superar o "cunho meramente cognitivo-instrumental associado com as ciências clássicas". Baseando-se na "capacidade que têm as pessoas de argumentar, de mudar de opinião e de alcançar livremente um entendimento ou um consenso, atesta a existência de outra forma de racionalidade, ligada à ação comunicativa”. A capacidade de poder contribuir com a opinião do outro e inclusive modificá-la pela 'interação dialógica', faz parte da formação mesma de cada um na sociedade, portanto não sendo algo pertinente apenas aos técnicos e cientistas. (....) “A transição de uma fala autocentrada a uma fala centrada no outro pressupõe uma inversão de papéis" (p.39).

Operar por problemas parece uma boa alternativa, onde não interessa isolar a ação setorial, como também não interessa uma concepção que trabalhe somente com o âmbito intersetorial, sem a especificidade do setor saúde em si, e também voltado para fora de si.

Partindo do conceito de integralidade em saúde enquanto conformação de um objeto constituído por coletivos e pessoas, as considerações a seguir buscam elaborar uma síntese que toma o modelo tecnológico de atenção, que implica na operação da técnica realizando o político, portanto finalidade e começo do processo, determinada e determinante, em sua dimensão mais propriamente organizacional.

\subsubsection{Um Modelo Organizacional Implicado}

Aqui se discutem percepções das proposições apresentadas na perspectiva de um modelo de atenção comprometido com a integralidade em saúde, à luz de contribuições produzidas no campo das organizações. Assim agregam-se à compreensão apreendida na revisão de como a integralidade em saúde é entendida e se expressa historicamente, aportes da moderna teoria organizacional, selecionados especificamente sobre o objeto de pesquisa, haja vista o caráter intrínseco de mudança do modelo de atenção assumido 
pela possibilidade de materialização do princípio da integralidade no SUS. Essa diretriz exige a sua operacionalização em espaços de transformação organizacional, o que explicita a articulação imprescindível entre as três dimensões contidas no modelo de atenção. Tal complexidade tem colocado em pauta a necessidade de recuperar das práticas instituídas nos mais diversos sistemas de saúde referidos a perspectiva da articulação das dimensões política e tecnológica mediadas pela problemática organizacional.

A diretriz da integralidade também se projeta na caracterização do modelo organizacional pretendido. Das referências históricas tomadas, as que se referem explicitamente à dimensão organizacional se restringem a alguns usos de adaptações da metodologia do planejamento estratégico situacional (PES) na saúde, ao desenvolvimento gerencial da rede básica veiculado pelo Projeto GERUS e à proposta também referida como gestão local estratégica pelo Grupo LAPA da UNICAMP. Esta última aborda mais especificamente a rede de serviços locais, enfatizando a constituição política de sujeitos nos espaços de disputa do micro-poder institucional. Embora existam proposições historicamente construídas em relação à dimensão organizacional da integralidade, fundamentadas na importância da gestão para um modelo organizacional, esta aparece imediatamente conectada a somente alguns componentes do modelo de atenção.

As proposições e experiências referidas permitem explicitar um enunciado de instrumentos gerenciais que reiteradamente se recomenda utilizar no setor saúde, entre os quais se destacam:

- organização a partir da rede básica, com integração das unidades do sistema local na rede municipal de saúde, articulação aos níveis de complexidade crescente e operação da integração das ações básicas coletivas e políticas públicas;

- planejamento local estratégico na perspectiva da integralidade, através de metodologia participativa de análise da situação, programação e avaliação do conjunto de operações para resolver problemas locais de saúde;

- gestão estratégica de unidades locais de saúde, voltada para a reorientação dos seus processos de trabalho em saúde, enquanto espaço de operar a integralidade das ações; 
- conselhos de gestão por unidade de saúde e ampliação da participação popular no controle social da gestão em saúde.

\section{A partir da rede básica}

No plano organizacional dos serviços de saúde, a caracterização mais importante no sentido de definir o locus privilegiado do trabalho comprometido com a integralidade é: a partir da rede básica. Nessa sub-dimensão se conforma a organização de uma rede de serviços ancorada na rede básica, em uma concepção de grande valor para a atenção primária. A busca de proposições referidas como estratégias privilegiadas para conformação de um modelo de integralidade da atenção à saúde tem encontrado, no âmbito da rede básica de saúde, locus de organização da porta de entrada aos serviços de saúde, um espaço privilegiado a partir do qual se constroem possibilidades concretas de integralidade da atenção no SUS.

Ao refletir sobre a posição transformadora atribuída à rede básica do sistema de saúde, Merhy (1997b, p.223-4) a concebe como uma rede mais complexa, que além de porta de entrada do sistema de saúde seja 'o lugar essencial a realizar a 'integralidade das ações individuais e coletivas de saúde'. Como tal, “ao mesmo tempo contém a linha de contato entre as práticas de saúde e o conjunto das práticas sociais que determinam a qualidade de vida, provocando a mudança no sentido das práticas". Para tanto, "a rede básica teria de ser inventada tecnologicamente, não bastando incorporar o que já se acumulou em outras experiências, simplesmente agregando assistência médica à saúde pública ou combinando-as no mesmo espaço institucional". Ao considerar que tais medidas, frente à hegemonia do modelo clínico, tendem a desembocar em uma medicalização do modelo, o autor acima propõe "um repensar mais radical sobre a publicização da gestão do processo de trabalho em saúde e sobre a natureza e o sentido das tecnologias em saúde, além do tipo de incorporação tecnológica”.

É no espaço operacional, apesar dos melhores preceitos constantes na legislação e das várias tentativas de adequação institucional, que as mudanças não estão garantidas. Para a população o que conta é a 'concretude dos serviços prestados em resposta às necessidades e representações dos seus usuários'. É nesse espaço operativo que um 
sistema de saúde adquire materialidade através das ações realizadas no cotidiano dos hospitais e dos centros de saúde, ao se estabelecer "num território determinado, através de uma relação direta e recíproca entre suas unidades produtoras de serviços, geridas por uma autoridade sanitária” e sua população de referência (Mendes 1993, p.139).

Desde sua origem, a integralidade em saúde tem um objeto coletivo de apreensão e intervenção. A abrangência de sua atuação compreende ações de promoção, recuperação manutenção e controle das condições de saúde da população. Seu conteúdo tecnológico se processa na integração dessas ações, informadas pelos saberes que as operam. $\mathrm{O}$ saber contido nos protocolos normativos é uma abstração da racionalidade dominante no processo de trabalho, portanto, o saber é sempre tecnológico e está contido nos instrumentos prescritivos da ação. Logo, é possível abstrair instrumentos prescritivos do saber.

No âmbito da rede básica, nos limites de contato deste estudo com a dimensão mais propriamente tecnológica da integralidade, destacam-se somente alguns instrumentos historicamente colocados nas proposições discutidas. Estes são instrumentos tecnogerenciais locais, aqui situados por serem epidemiologicamente definidos:

- acolhimento à demanda garantindo o acesso universal aos serviços de saúde e viabilizando o cuidado integral à saúde da pessoa;

- organização da demanda em bases epidemiológicas;

- territorialização com definição populacional da área de responsabilidade dos serviç̧os;

- captação mais precoce das necessidades de saúde;

- equipes movendo-se em torno das necessidades do paciente;

- retaguarda de assistência integral assegurada através de um sistema de referências até o nível de maior complexidade existente;

- $\quad$ apreensão das necessidades da população enquanto problemas de saúde;

- análise de causas dos problemas para organizar a intervenção;

- atuação nos diversos momentos do processo saúde e doença;

- vigilância de problemas de saúde;

- capacidade de intervenção contínua sobre os problemas de saúde; 
- assunção dos conteúdos tecnológicos da integralidade do PSF na prática das equipes;

- $\quad$ articulação do conjunto de ações da UBS via integração sanitária.

Para afastar chavões, através da expressão vigilância de problemas de saúde, estão sendo referidos componentes das proposições tecnológicas da vigilância à saúde, da estratégia de saúde da família e de municípios saudáveis.

Não faz sentido falar de integralidade em saúde onde não houver condições de resolutividade das ações realizadas, o que implica tanto uma atenção primária forte como garantia de retaguarda através de um sistema de referência e contra-referência. No âmbito operacional dos serviços dá-se a relação com a população, ampliando os significados da atenção propriamente oferecida.

\section{Planejamento em saúde e estratégia}

Um dos princípios organizacionais que é possível captar das proposições de modelo de atenção é que em todas elas existe uma preocupação com a participação dos sujeitos envolvidos, seja entre os trabalhadores de saúde ou destes com a clientela dos serviços. O trabalho em saúde se realiza no que pode ser entendido como uma interação entre sujeitos, isso inclusive no próprio processo de trabalho em saúde, uma vez que o produto se constrói durante e dentro da relação profissional/usuário. O que propõe a literatura sobre transformação organizacional é um referencial muito rico para ajudar a realizar potencialmente este estatuto de sujeitos. A esse respeito também há pouca coisa incorporada pelas proposições de modelo de atenção em saúde. Derivados da teoria organizacional existem princípios e instrumentos que podem iluminar o olhar para essa problemática. São contribuições advindas de outras disciplinas, especialmente como a antropologia, psicologia social e sociologia, que a teoria organizacional tem incorporado.

Corneta, Maia e Costa (1996, p.49) propõem "considerar os recursos humanos como componente tecnológico de maior valor e estruturá-los em novas bases, considerando-se a complexidade do processo saúde-doença e a necessidade de intervenção integral e 
multisetorial, o que exige a incorporação de novos perfis profissionais para responder de maneira oportuna e satisfatória às demandas e problemas identificados”.

\section{Gerenciamento loco-regional e avaliação do trabalho}

A instituição da mudança da organização do modelo de atenção à saúde implica um processo de descentralização e planejamento local em saúde, de caráter estratégico e participativo ascendente. A implementação das propostas organizativas dá-se enquanto exercício de uma programação e gestão local de saúde, geralmente derivada de processos instituintes da descentralização da atenção e do próprio planejamento de saúde, no nível de serviços locais de saúde.

Existe um reconhecimento da importância de se 'resgatar o papel que o acompanhamento e a avaliação podem ter na recuperação da integralidade dos procedimentos' nos serviços prestados à população, composto de trabalhos parcelados, mas que devem "constituir um resultado dotado de unicidade" (Mendes Gonçalves 1992, citado por Corneta, Maia e Costa 1996, p.48), realizado por perfis profissionais específicos integrantes da equipe de trabalho em cada unidade. Além do conteúdo tecnológico dessa assunção, a sua instituição enquanto prática dos serviços de saúde é construída na dimensão organizacional, integrando os processos locais de planejamento e gestão do modelo de atenção à saúde.

Somente cada unidade sanitária local sendo "inteiramente responsável pela organização e gestão de seu sistema local de saúde" pode-se considerar a gestão dos sistemas locais de saúde como efetivamente descentralizada. Assim no "nível local seriam discutidas e regulamentadas, de uma maneira adequada a cada contexto, as questões relativas (....) às arbitragens entre as ações sanitárias e sociais, 'a questão do grau de integração do sistema de saúde e as relações entre o setor sanitário e os outros setores' cujas ações influenciam a saúde" (Contandriopoulos 1995-6, p.61-2).

Pela via do seu objeto e metodologia, o trabalho em saúde pode ser 'um trabalho permanente de produção de subjetividades por meio da vigilância contínua aos problemas de saúde', como forma de superar as rotinas, "buscando saídas que não 
precisam necessariamente estar instituídas (na prática ou no pensamento) nos modelos, na cabeça dos técnicos de boa vontade ou mesmo nas diretrizes político-partidárias. Trabalhar com saúde é um trabalho que se reconstrói, à medida que se descobre que ser humano é diferente de ser máquina e isso, exige uma nova ética diante da vida" (Pedrosa 1996, p.32).

É reconhecida "a necessidade de se adotarem 'estratégias de comunicação, de modo a retraduzir os princípios fundamentais da equidade, universalidade e integralidade em categorias mais facilmente apreensíveis' pelo senso comum e a permitir uma interlocução efetiva entre profissionais e gestores de saúde e os movimentos sociais" (Costa 1997, p.227).

\section{Participação popular na gestão}

É importante ressaltar que 'experiências isoladas de organização de serviços locais de saúde bastante integradas aos movimentos sociais locais', têm ocorrido durante as três últimas décadas do século, acompanhando a instituição da ordem democrática no Brasil, através das quais tem surgido iniciativas muito criativas (Vasconcelos 1999, p.19).

Discutindo a descentralização, Henriques (1997, p.26) refere-se aos municípios como “os únicos entes federativos com identidade material, ao contrário dos estados e da Federação", que expressam uma organização política formal e legal. A essa idéia se associa a possibilidade do efetivo controle social articulado à visibilidade e facilidades de acesso inerentes ao poder local. Em decorrência, assim 'facilita-se a integralidade e suas correspondentes atividades de vigilância, a saúde do trabalhador e os vários programas compondo uma malha inseparável da assistência individual'. É no âmbito municipal que "tais avanços aliam-se à coordenação intersetorial, tão natural dentro de uma mesma prefeitura, à abertura de espaço para a eclosão de soluções mais criativas, à velocidade de circulação de informações, à eficiência muito maior na utilização de recursos e à agilidade na tomada de decisões”.

A participação democrático-popular faz parte da gestão local em saúde. Mas, para que os trabalhadores sejam também atores sociais deste processo, a própria organização da 
dinâmica interna dos serviços tem que ser democratizada; como condição de diálogo com a população usuária, inclusive no âmbito da autonomia da prática profissional de saúde. Quais outras condições participativas é preciso desenvolver além de todos reconhecerem a importância do controle social no SUS é o espaço a derivar novos aportes para ajudar a entender melhor essa possibilidade de efetivar-se uma sustentação popular da proposição da integralidade em saúde.

\section{A via pedagógica}

$\mathrm{Na}$ organização do trabalho comprometido com a integralidade encontra-se, nas proposições revisadas, o que se pode associar com um primeiro nível da contribuição das noções de aprendizagem na gestão, através de propostas interativas entre os sujeitos do trabalho em saúde. Na recuperação existem indícios para reafirmar a hipótese de que o pedagógico é importante e trouxe elementos de como o pedagógico pode se realizar historicamente na gestão em saúde. O trabalho com a interação entre os sujeitos da saúde, para ser conseqüente, necessita de uma fundamentação pedagógica coerente. Além do uso da pedagogia da problematização ser bastante desenvolvido em serviços de saúde, e também especificamente na perspectiva da gestão, a exemplo da capacitação pedagógica do Projeto GERUS, a teoria organizacional pode ajudar a construir uma proposição.

Nesse sentido, os aportes das disciplinas da organização em aprendizagem (Senge 2000) apresentam afinidades com a problemática de mudança do modelo de atenção em saúde: há que se ter maestria tecnológica sobre o conteúdo do trabalho, os modelos mentais sobre o que é saúde e serviço público de saúde têm que ser abertos e revisados, a construção continuada de uma visão compartilhada sobre a integralidade referencia o processo de mudança de modelo, as equipes autodirigidas e seus profissionais autônomos precisam aprender a aprender em equipe e o pensamento sistêmico sobre todos os processos em movimento faz parte inclusive do significado lingüístico da integralidade.

A direcionalidade do trabalho de equipes autodirigidas é construída pela visão compartilhada e pela dinâmica de aprender a aprender em equipe, o que redireciona a 
formação e capacitação dos agentes do trabalho. Nesse sentido, conforme apontam Bertussi e col. (1996, p.55), é importante refletir sobre "como a integração ensinoserviço tem sido abordada neste processo de implantação/implementação no SUS. É relevante lembrar que sua característica principal é o ensino ativo em serviços, isto é, tendo como concepção básica o trabalho como eixo pedagógico e transformador da própria prática”. Na mesma linha, "os programas de educação continuada, integração docente-assistencial em todos os graus de formação e mecanismos de difusão de conhecimentos sobre os problemas da população são estratégicos para a capacitação da força de trabalho" (Silva 1998, p.64).

\section{Um enlace de propostas organizacionais}

A teoria organizacional tem acompanhado o ritmo de mudanças e novas demandas implicadas para o mundo das organizações. Também os serviços de saúde podem buscar enriquecimento na condução de suas estratégias e práticas no espaço organizacional refletindo sobre os fundamentos teóricos e acompanhando as produções atualizadas do campo.

Um modelo de atenção à saúde, portador da finalidade do trabalho em saúde, somente se sustenta com um correspondente modelo de organização dos serviços voltados a essa atenção. E quando se trata de um modelo de integralidade da atenção à saúde, o modelo organizacional capaz de dar-lhe sustentação tem que estar baseado em princípios e tecnologia compatível. Ou, por referência a Testa (1995), dentro de um postulado de coerência entre objeto da política, métodos e organização.

Mendes (1993, p.109-10) identifica alguns exemplos que ilustram a desobediência ao postulado da coerência formulado por Testa (1995), resignificando-o por referência a um objeto institucional, ao qual devem corresponder estruturas e métodos organizacionais coerentes. Considera que o "caos da saúde no seu componente institucional tem sua raiz nesta incoerência entre objeto, métodos e estruturas" identificados nos primeiros anos de implantação do SUS. Pois, frente à defesa de um 'sistema com mando único, descentralizado, com integralidade da atenção', eram mantidas "estruturas federais com capacidade decisória nos estados, sistemas de 
financiamento e de controle centralizados, pagamentos por procedimentos médicos de acordo com a densidade tecnológica etc.”.

Ao se assumir uma concepção de gestão local em saúde comprometida com a mudança do modelo de atenção, utiliza-se a expressão gestão com o significado de processo de gerenciamento, portanto, indistintamente de gerência, e por extensão gerente como a representação da coordenação formal dos processos gerenciados. Apesar da NOB 96 ter consagrado setorialmente a expressão gestor do SUS para a titularidade de cada nível do sistema (municipal, estadual e federal), por simples convenção exclusiva da área da saúde, a expressão gerente é mais utilizada para o âmbito de unidades e serviços.

Articuladamente ao movimento de formulação da diretriz política, faz-se necessário entender qual é o papel de processos de planejamento instituídos pelos sistemas municipais de saúde na perspectiva de mudança do modelo de atenção do SUS. O plano, que não se transforma em instrumento de gestão e fica na abstração, não faz sentido. As experiências reafirmam a condição de que os planos sejam discutidos, revalidados, submetidos à apreciação de diferentes fóruns, enfim, mecanismos para desdobrar-se em estratégias de gestão. Sem uma administração estratégica participativa em todos os níveis da organização não existe PES que se implemente. Assim sendo, a operação de processos de planejamento dá-se pela via da gestão. 


\section{METODOLOGIA}

O presente trabalho buscou refletir sobre possibilidades de transformação de uma situação constatada. Mais que se propor a explicação de práticas organizacionais existentes nos serviços de saúde, a idéia era buscar compreender a possibilidade de novas práticas no contexto estudado. Ao considerar ainda que "o estudo e o conhecimento da realidade são também necessidades imperativas do ponto de vista dos que querem transformá-la" (Brandão 1985, p.19), foi somente nesta perspectiva que se faz a abordagem empírica.

A complexidade do objeto trouxe a necessidade de uma revisão teórica da conformação de práticas instituídas em sistemas de serviços locais de saúde, o que indicou a articulação das dimensões política, organizacional e tecnológica, enquanto expressão da diretriz da integralidade nos modelos de atenção no SUS. Neste estudo, a integralidade em saúde foi recuperada em sua conformação de modelo de atenção, através das três dimensões indicadas, o que veio constituir o eixo da análise realizada.

Ao se pretender a observação de um objeto que se insere em uma realidade social, com apreensão do real no seu movimento setorial-organizacional na perspectiva de transição e mudança, aceitou-se o desafio de utilizar algumas referências do método dialético na abordagem e análise em uma pesquisa referida à perspectiva de articular o entendimento de que "práticas e programas de saúde expressam os conflitos e diferenças que existem no setor", o que se relaciona com as contradições mais gerais da sociedade (Minayo 1996, p.157). Conforme adverte essa autora, o campo da saúde refere-se a uma realidade complexa e que coloca de imediato o problema da intervenção, o que "requer como essencial uma abordagem dialética que compreende para transformar e cuja teoria, desafiada pela prática, a repense permanentemente" (p.13). O princípio dialético da coexistência de elementos positivos e negativos, no caso potencializadores e 
negadores de uma prática de integralidade na atenção à saúde, são apreendidos buscando compreender a sua inserção teórico-prática, em uma perspectiva histórica e empírica.

Brandão (1985, p.25), em sua produção especializada sobre educação popular, contribui nessas formulações desde sua argumentação de que "o pesquisador, como o educador, (....) também precisam ser educados e esta educação só pode vir no bojo de sua prática dentro de uma realidade social", no caso articuladas ao processo de pesquisa. Esta opção deverá permitir apreender melhor sobre a rede de implicações e conflitos de interesses derivados das relações sociais se expressando nos serviços de saúde, procurando "captar os conflitos e contradições que lhe imprimem um dinamismo permanente, (e possivelmente) explorar as brechas e contradições que abrem caminho para as rupturas e mudanças".

Entre as várias articulações estabelecidas pelo investigador para a realização do trabalho de campo, destaca-se inicialmente a importância de assimilar a "relação entre a fundamentação teórica do objeto a ser pesquisado e o campo que se pretendeu explorar. A compreensão desse espaço da pesquisa não se resolve apenas por meio de um domínio técnico" (Minayo 1994, p.69). Somente após recuperar a base teórica foi possível compreender os dados de forma a conseguir ver além do que estava simplesmente sendo mostrado. O quadro de referências construído permitiu superar a simples descrição dos fatos relatados, pois conforme diz a mesma autora, "por melhor que seja a captação da realidade vivida, faz-se necessário um compromisso teóricometodológico (....) que nos permite fugir do que podemos denominar mito da técnica" (ibid).

Pretendeu-se "captar a lógica dinâmica e contraditória do discurso de cada ator social e de seu relacionamento com os outros atores, visando a despertar (....) o desejo de mudança e a elaborar, com eles, os meios de sua realização". Essa formulação parte de uma premissa de que a forma "da organização social atual não esgota toda a realidade nem constitui o único real possível. Debaixo de todo ordenamento social aparentemente imutável, fermentam, por vezes lenta e silenciosamente, alternativas, amadurecem 
rupturas. Muitas vezes, o que existe hoje pode e deve ser mudado". Por isso é preciso interrogar constantemente a realidade (Brandão 1985, p.25-6).

A oportunidade de durante o processo solitário de elaboração da tese, desde o seu projeto e em meio a sua execução, poder discutir em diferentes fóruns (*) os fragmentos da produção em processo de construção, foi determinante na consolidação do trabalho ora apresentado, do qual certamente vai derivar novas reelaborações após sua argüição.

\subsection{Estratégias de Pesquisa}

Iniciou-se a execução do projeto de tese com sua fundamentação teórica, informada pela formação da pesquisadora em administração e sua inserção no campo dos serviços de saúde pública, com prática pedagogicamente pautada na metodologia da problematização, que se desenvolve através da reflexão sobre a própria prática para produção de ação consciente renovada sobre o processo de trabalho, no caso tendo por objeto a dimensão tecno-organizacional da mudança do modelo de atenção no SUS e cuja finalidade se constrói como resposta a necessidades socialmente postas.

A pesquisa é de natureza qualitativa, que de acordo com Merrian (1998), coloca como preocupação central o entendimento do empírico a partir da perspectiva dos participantes, sendo o pesquisador o instrumento da coleta e análise de dados, faz-se através de um estudo de campo in loco, e enfoca o processo, o significado e o entendimento, tendo como produto inicial uma rica descrição. O seu design é emergente

(*) Dentre esses cabe registrar: discussão do projeto de tese na disciplina Fundamentos da Investigação Científica (FSP, junho/1997), apreciações do projeto no Exame de Qualificação (FSP, setembro/1998), assim como a apresentação da recuperação bibliográfica sobre a integralidade em saúde no Congresso de Secretários Municipais de Saúde das Américas (Quebec, março/2000), apreciação dos resultados empíricos no Conselho Municipal de Saúde do município-sede da pesquisa de campo (maio/2000), painel sobre os resultados do estudo de caso no VI Congresso Brasileiro de Saúde Coletiva (Salvador, agosto/2000), apresentação preliminar dos resultados teórico-práticos da pesquisa na Secretaria de Estado da Saúde de Santa Catarina (outubro/2000), e finalmente sua fundamental re-elaboração com a colaboração de professores na pré-banca (FSP e FAMEUSP, outubro/2001). 
e flexível conforme as condições do estudo desenvolvido e a seleção amostral é proposital e pequena. No tempo de campo existe um intenso contato com os entrevistados.

Segundo Godoy (1995), “o estudo de caso é um tipo de pesquisa referida a um objeto que se analisa profundamente", através de um exame detalhado de uma situação na qual o pesquisador se insere para observar o seu contexto. Como a principal questão a responder na presente pesquisa é "como se faz" e também procurar entender possibilidades de superação das dificuldades identificadas, o estudo de caso tem se revelado como a estratégia metodológica mais adequada a essa ordem de problemática. No dizer de Godoy (op cit, p.25), trata-se de situações em que "há pouca possibilidade de controle sobre os eventos estudados", estando o foco de interesse voltado a fenômenos atuais ainda em processo. Portanto, partindo-se de um enfoque exploratório e descritivo, na medida em que o estudo se abre às descobertas que a realidade revela, novos elementos e dimensões vão surgindo no decorrer do trabalho. Importante destacar também que o estilo mais informal de apresentação dos resultados é permitido nos estudos de caso (p.26).

A natureza dos dados compreende descrições detalhadas de situações e se usam as citações literais do que as pessoas falam sobre suas experiências, atitudes, crenças e pensamentos. Segundo Patton (1986), quando se faz essa abordagem o pesquisador parte de observações mais livres não tendo que, necessariamente, dispor de uma definiçãa a priori das dimensões e categorias que emergem durante o processo de coleta e análise dos dados. Em uma visão holística do estudo qualitativo, conforme ocorreu no presente estudo, a compreensão dos processos estudados se dá conforme sua inserção no contexto em que ocorrem. Por sua abordagem interpretativa, não existe uma preocupação subjacente com a generalização; o que se procurou foi a elucidação dos processos na perspectiva da sua modificação.

Referenciados pela construção teórica de um eixo que dimensiona a expressão da integralidade nos serviços de saúde, os resultados da pesquisa empírica vêm reafirmar potencialidades e dar alguns passos pelas vias que se abrem. Não vai infirmar nem comprovar hipóteses, mas enriquecer e reconstruir o quadro teórico, procurando localizar 
articulações possíveis com a integralidade, em cada momento do processo de gestão, o que informa a construção de algumas vias instituintes de um modelo organizacional comprometido com um modelo de integralidade da atenção em saúde.

\subsubsection{Reconstrução Conceitual do Objeto de Estudo}

Acumulando leituras do material bibliográfico que foi possível, nos limites de tempo e espaço do pesquisador, acessar na literatura nacional especializada sobre modelo de atenção em saúde, inicialmente levantado através dos descritores - práticas de saúde, atenção integral à saúde, integração sanitária e integralidade em saúde, gradativamente foi sendo reconstruído o perfil do objeto de estudo. Como também, referências indicadas no material bibliográfico acessado forneciam novas fontes de produções sobre o objeto de estudo para complementar sua recuperação teórico-prática.

Na elaboração teórica de suporte da tese, que se constrói em todo o processo de pesquisa, procurou-se inicialmente estabelecer um diálogo entre a teoria referida ao objeto da integralidade em saúde e o problema investigado, a sua operação expressada na organização dos serviços locais de saúde, informada por aportes da teoria organizacional. Pois, como bem pondera Samaja (1987, p.50-55):

Un paso primordial del trabajo teórico consiste em delimitar el objeto de estudio, estabelecer sus atributos relevantes, necesarios de observar, para hacer un perfil formal del objeto que queremos conocer a fondo y transformar. Sin una sólida teoria, el trabajo consistente en observar, describir y clasificar las manifestaciones o cualidades del objeto, y el de establecer criterios para apreciar sus modificaciones en intensidad o amplitud serían muy poco promisorios.

Com a entrada em campo, a recuperação dos antecedentes histórico-conceituais das noções aproximadas à integralidade em saúde até a sua instituição no SUS, que constitui a primeira parte da revisão bibliográfica, adquire maior significado ao revelar a presença de seus componentes conceituais no presente pesquisado. Os atributos do objeto que vieram compor o quadro teórico necessário para guiar a interpretação dos achados empíricos são mais diretamente derivados da segunda parte recuperada, os modelos de atenção à saúde vigentes no cenário nacional de forma comprometida com a 
diretriz da integralidade da atenção em saúde. A delimitação teórica do objeto é sintetizada em uma elaboração conceitual, através do eixo condutor da sua compreensão enquanto modelo de atenção configurado nas dimensões política, organizacional e tecnológica.

A recuperação histórica da evolução de modelos de atenção e da correspondente organização dos serviços de saúde tem sido amplamente divulgada na literatura especializada em anos recentes, e no Brasil especialmente após a instituição do SUS em 1988. A amplitude do levantamento efetuado na recuperação bibliográfica sobre a integralidade em saúde (capítulo 2) é ilustrativa deste fato.

Somente as citações literais estão entre aspas, sendo que nas citações indiretas são mantidas em itálico algumas denominações e núcleos significativos de conteúdo ao se estar utilizando palavras dos autores referidos. Optou-se por sua grafia diferenciada em itálico porque são expressões que tem autoria identificáveis no estudo (como no destaque acima, que é uma expressão de Mendes-Gonçalves 1994). Portanto, além de partes das citações indiretas, mesmo em frases ou parágrafos produzidos neste estudo, o uso de expressões e núcleos de trechos mais significativos que têm autoria(s), também aparecem em itálico (como exemplos, a reforma sanitária ou a vigilância à saúde).

Ainda citações mais específicas das diferentes aproximações ao conceito, significados ou expressões correspondentes, referidas às noções de integralidade em saúde são destacadas 'em itálico entre aspas simples', simplesmente assim se inseridas em uma referência indireta, mas podendo constar também dentro das referências diretas devidamente identificadas. Trata-se de destaques da autora, por serem mais diretamente utilizados na reconstrução do objeto.

\subsubsection{Estudo Exploratório do Empírico}

Entre os sistemas municipais de saúde em Santa Catarina que têm se destacado pela reorganização dos seus respectivos modelos de atenção, através de medidas pautadas basicamente em propostas organizativas, relacionadas com a vigilância à saúde, saúde da família, estudos de situação de saúde segundo condições de vida, planejamento local 
estratégico e desenvolvimento gerencial de unidades básicas de saúde, procurou-se identificar em quais havia uma orientação na perspectiva da integralidade.

Iniciou-se então uma pesquisa exploratória em algumas secretarias municipais de saúde pertencentes a um universo de 18 municípios que são sede de regional de saúde no Estado de Santa Catarina (após 1989). A atual regionalização é desdobramento de uma divisão anterior do Estado em 7 centros administrativos regionais (1973-1988), e que atualmente está sendo reestruturada em 8 macro-regiões de saúde. Os municípios foram afinal selecionados somente entre aqueles que foram sede de regional de saúde em todas as divisões já havidas, por reunirem serviços de maior complexidade, o que aumenta a abrangência da discussão sobre a operacionalização da diretriz da integralidade. Esses também estão entre os maiores municípios do Estado.

A partir desse universo, conciliando as condições de mobilidade do pesquisador para os municípios, associada a seu conhecimento anterior sobre aqueles sistemas municipais de saúde, com constatações em que os mesmos se destacavam pela adequação do modelo de atenção instituído de acordo com os princípios e diretrizes do SUS, foram selecionados os municípios a compor um universo empírico exploratório - Blumenau, Criciúma, Florianópolis e Lages. A nominata de municípios apresentada é produto de um trabalho preliminar executado mediante entrevistas focais informais com técnicos dos níveis central e regional das áreas de planejamento e epidemiologia da Secretaria de Estado da Saúde de Santa Catarina, complementadas com uma leitura dirigida dos respectivos planos municipais de saúde.

Foram previamente selecionados esses quatro sistemas municipais de saúde em função de sua maior proximidade do objeto da tese, por se haverem destacado na reorganização dos seus respectivos serviços locais de saúde, através de medidas pautadas genericamente em estratégias organizativas relacionadas com as proposições acima indicadas, de forma que suas práticas de saúde estivessem comprometidas com a integralidade.

Assim sendo, somente em uma etapa exploratória desenvolvida para definição do universo empírico da pesquisa, foram preliminarmente selecionados esses quatro 
municípios - Blumenau, Criciúma, Florianópolis e Lages. Trata-se de quatro secretarias municipais de saúde que na gestão atual (1997-2000), por ocasião da coleta dos dados, vinham desenvolvendo um projeto comprometido com a integralidade em seu modelo de atenção à saúde e ainda com antecedentes derivados da gestão anterior (1993-1996), numa mesma linha. Além de todos os quatro municípios terem passado por experiências de planejamento local estratégico, ainda pode-se registrar: 1) Blumenau - na gestão anterior, executando um plano amplo de extensão da cobertura da rede básica, informado pelas diretrizes da vigilância à saúde e estratégia da saúde da família; e na atual um modelo de atenção integral como sua prioridade política. 2) Criciúma - com uma rede básica forte e concentração de esforços na gestão anterior para desenvolvimento de um estudo da situação de saúde segundo condições de vida e trabalho da população e um aperfeiçoamento da equipe de técnicos em vigilância à saúde, o que gera um plano prático nesse sentido; e a gestão atual interessada na implementação daquelas diretrizes através de um ampliado programa de saúde da família. 3) Florianópolis - com uma rede básica e de referência ampliada, tendo passado por um processo de descentralização de forma articulada ao desenvolvimento gerencial da rede básica, informado por uma proposta de distritos sanitários e vigilância à saúde; e na gestão atual, além de desdobramentos daquelas propostas, alguns projetos de atenção integral a exemplo do "Capital Criança", com prioridade aos cuidados a sadios. 4) Lages - município pioneiro na implementação do Programa de Ações Integradas de Saúde (PAIS/SC), com uma experiência histórica de participação de comissões locais de saúde na elaboração de um estudo de situação de saúde segundo condições de vida e na gestão do sistema municipal; e uma administração atual empenhada em dar consecução aos princípios do SUS com ênfase na integralidade do atendimento, sem vinculação a propostas e modelos específicos.

A explicitação da integralidade como prioridade política pode ser recuperada como proposta oficial em alguns planos de saúde daqueles municípios vigentes no momento da pesquisa exploratória. Como ilustração desse fato, veja-se o caso de um plano cuja proposta central é a "inversão do sistema de atenção à saúde (centrado em ações curativas) para um modelo de atenção centrado na integralidade das ações". E que explicita como sua finalidade: "reorientar as práticas locais de saúde, a partir da reorganização da estrutura e do funcionamento, redirecionando os setores e serviços 
para o caminho que aponta a atenção integral em saúde". E como objetivo específico: "implantar o modelo de atenção integral e de vigilância à saúde, hierarquizado e regionalizado, com ênfase à ampliação do programa saúde da família" (Blumenau 1997).

No mesmo caso, destaca-se ainda como explicitação mais diretamente relacionada com a diretriz da integralidade na saúde, o plano municipal assim se auto-definir: "um processo permanente de criatividade, de vigilância e de controle social efetivo que utilizará, como referência, a defesa apaixonada e radical dos princípios e diretrizes do SUS, buscando a universalidade e equidade, assegurando com resolutividade a integralidade da atenção à saúde, priorizando as ações de promoção e proteção, com hierarquização e regionalização dos serviços". Entre seus objetivos específicos destacase: "(....) reorientar as práticas locais de saúde, direcionando-as efetivamente aos princípios e diretrizes do SUS, em particular à universalidade, integralidade e intersetorialidade das ações" (ibid).

Cabe ainda registrar que se encontrou um estudo realizado em Santa Catarina tomando por objeto a integralidade enquanto efeito da municipalização. Foi realizado em Blumenau por Ortiga (1999), sendo sua análise feita somente através do incremento de programas preventivos (imunização, prevenção do câncer e saúde bucal) e da relação entre os níveis de complexidade do sistema.

A entrada em campo iniciou-se preliminarmente através de uma pesquisa exploratória nas quatro secretarias municipais de saúde mencionadas. Após as entrevistas exploratórias realizadas nesses municípios pré-selecionados, iniciou-se o estudo em um primeiro município. A continuidade desse processo impunha o seu aprofundamento e isso a ponto de se chegar, em um determinado momento, a fazer uma opção por suspender o projeto nos demais e concluir a pesquisa somente naquele município. A complexidade do objeto e nível de aprofundamento exigido pelos objetivos da sua apreensão empírica inviabilizava a pesquisa em mais de um município. Por isso, o processo de observação em profundidade se realiza somente em um município, segundo as condições objetivas de interesse do estudo, que levaram a situações de 
impossibilidade operacional de fazer um estudo de caso em cada um dos municípios previamente selecionados.

Ao considerar que os processos apreendidos ainda estão em curso (*), que os mesmos atores continuam em cena e que os agentes do trabalho são os mesmos, optou-se por não explicitar nesse momento o nome do município-sede do estudo. Assim não se autoriza o uso dessa referência para objetivos alheios à sua característica de material empírico de uma tese, por razões éticas e politicamente óbvias, apesar dos fatos serem próprios, dada a amplitude dos relatos e interpretações.

No estudo exploratório nas quatro secretarias municipais de saúde que integraram o estudo preliminar foram realizadas 11 entrevistas ( 2 em Blumenau, 2 em Florianópolis, 3 em Criciúma e 4 em Lages), que serviram como experiência da técnica de entrevista. No momento que se faz a opção por fazer o estudo empírico em somente um dos municípios, não foi incluído no estudo o resultado dessas entrevistas exploratórias realizadas nas demais secretarias municipais. O material obtido na pesquisa exploratória, considerando que a primeira entrevista sempre foi com o gestor municipal, para apresentar os objetivos do estudo e solicitar sua autorização para entrada no campo - em dois municípios tratava-se do mesmo secretário em uma segunda gestão - e que a segunda entrevista era geralmente com um assessor mais diretamente ligado às questões relacionadas com a mudança do modelo de atenção, constitui-se em um importante acervo que consta dos arquivos da pesquisadora para estudos futuros.

Lembrando que a amostragem boa é aquela que possibilita abranger a totalidade do problema investigado em suas múltiplas dimensões (Minayo 1992, apud Gomes 1994), no caso procurou-se ver quais "indivíduos" tinham uma vinculação mais significativa para o problema a investigar. Esse raciocínio inicialmente guiou a escolha dos municípios a compor a fase exploratória do estudo, e uma vez selecionado o município,

(*) Por referência ao momento da defesa da tese (10/12/2001), após o qual, aceitando recomendação da Banca, somente na edição final da via entregue à Biblioteca da Faculdade de Saúde Pública da USP, optou-se por registrar que se trata do município de Blumenau/SC. 
como unidade de pesquisa por suas características diferenciadas em relação ao objeto de estudo, a mesma lógica também informou na continuidade a seleção dos entrevistados no caso estudado, como se apresenta nas técnicas de coleta dos dados.

\subsubsection{Um Estudo de Caso Organizacional}

Usualmente, nos estudos de caso, as técnicas utilizadas são a pesquisa documental, observação direta e entrevistas. E quando a unidade de estudo é uma empresa ou instituição, também é esperado que se faça um estudo de caso histórico-organizacional, assim como no estudo de uma personalidade se faria um estudo de caso por história de vida. Apesar de no presente estudo haver sido feita uma pesquisa documental exploratória e que, durante todo o desenvolvimento da pesquisa empírica tenham aparecido importantes documentos nas falas dos entrevistados que os entregavam nas mãos da pesquisadora, dada a opção de não identificar mais explicitamente qual foi o município estudado e os objetivos perseguidos, não se considerou necessário incluir a informação documental nos resultados.

\subsection{Técnicas de Apreensão Empírica}

Encontrei hoje em ruas, separadamente dois amigos meus que se haviam zangado um com o outro. Cada um me contou a narrativa de porque se haviam zangado. Cada um me disse a verdade. Cada um me contou as suas razões. Ambos tinham razão. Ambos tinham toda a razão. Não era que um via uma coisa e outro outra, ou que um via um lado das coisas e outro um lado diferente. Não: cada um via as coisas exatamente como se haviam passado, cada um via uma coisa diferente, e cada um, portanto, tinha razão. Fiquei confuso desta dupla existência da verdade

(Fernando Pessoa, manuscrito solto - versão da língua portuguesa de Portugal).

Os fatos são apreendidos pela sua descrição e representação captada na fala dos entrevistados. Mesmo que simplesmente um dos entrevistados tenha entendido daquela forma expressada, metodologicamente se reveste de conteúdo hábil para integrar o 
material empírico analisado. Não se tratando de uma avaliação de serviços, não existe a preocupação em averiguar a veracidade da descrição dos processos relatados através de observação direta. No caso, basta um sujeito dizer algo para que o dito exista enquanto representação do entrevistado sobre a organização do trabalho em sua inserção no movimento de mudança do modelo de atenção à saúde no município. Não é objetivo do estudo conhecer a representação dos entrevistados sobre a integralidade, mas através de sua representação sobre o próprio trabalho, captar os movimentos deste processo em relação à conceituação elaborada da integralidade em saúde, especialmente em sua expressão operacional na organização dos serviços.

Para apreensão empírica fez-se um estudo de caso organizacional, desenvolvido através de 17 entrevistas realizadas em profundidade. Logo, se processou e estruturou a análise exclusivamente sobre a informação derivada dessas entrevistas, todas pertencentes ao caso estudado. A seleção das áreas e quantidade dos agentes a entrevistar deu-se em função da característica das atividades por eles desenvolvidas e dos diferentes níveis de interação estabelecidos.

\section{Seleção dos sujeitos - fontes de dados}

Ao se proceder, no trabalho de campo, à priorização dos agentes do trabalho a observar, inicialmente foram contatados e entrevistados o secretário municipal de saúde da gestão atual e o imediatamente anterior. Então era exposto o plano de pesquisa e ao final se solicitava indicação de profissionais que pudessem contribuir com informações por estarem mais diretamente envolvidos no movimento de mudança do modelo de atenção. E os demais entrevistados iam sendo escolhidos pela pesquisadora, a partir da sua leitura decorrente do processo de pesquisa, selecionando aqueles mais envolvidos nos processos estudados.

Portanto, a seleção dos sujeitos a entrevistar era intencional, em função da relevância identificada dos respectivos processos de trabalho na perspectiva da integralidade, assim como da sua caracterização enquanto "informante chave" e, às vezes, possibilidade operacional de coleta da informação. A seleção dos profissionais atores sociais, enquanto sujeitos-objeto da pesquisa, dava-se em função da sua vivência de 
determinada realidade que estivesse sendo investigada. Ao final, a amplitude horizontal (número de entrevistados) e vertical (aprofundamento da entrevista) apreendida sobre o universo empírico acabou sendo a que melhor conseguiu embasar o estudo do objeto, nos limites de tempo e mobilidade ao alcance da pesquisadora.

Assim sendo, o material empírico está baseado nas representações de uma amostra intencional constituída de sujeitos: 17 profissionais de saúde mais diretamente envolvidos nos movimentos locais de mudança do modelo de atenção daquele SUSmunicipal. Este número foi fechado quando as três últimas entrevistas realizadas revelaram que suas abordagens praticamente já estavam contempladas no corpo amostral.

A coleta dos dados realizou-se durante um ano - de junho de 1999 a maio de 2000, sendo que o estudo exploratório havia sido realizado nos seis meses imediatamente anteriores.

\section{Método de observação - entrevista e representação social}

De acordo com o propósito da pesquisa, esta era referida aos entrevistados como interessada em captar o movimento de mudança do modelo de atenção em curso no município. A cada entrevistado apenas se solicitava que discorresse sobre sua inserção e percepção deste movimento, que continuava em processo. Ao não referir a integralidade como objeto e sim a organização do modelo de atenção naquele SUS-municipal, pretendeu-se eliminar qualquer indução ao tema, ampliar a abertura dos resultados e ao mesmo tempo poder perceber como a integralidade aparecia nas representações expressadas, haja vista constituir-se esta diretriz na maior prioridade política da Secretaria Municipal de Saúde estudada.

A observação do empírico deu-se através de entrevista aberta, em profundidade, como principal técnica de coleta de dados. Os entrevistados faziam a representação do próprio trabalho, situando-o no movimento pesquisado de mudança do modelo de atenção. Os entrevistados eram estimulados a avançar em profundidade quando apresentavam um maior acúmulo de informações sobre os processos de trabalho em observação. 
Entre as diversas formas de abordagem da representação social de profissionais do universo empírico sobre o seu trabalho, destaca-se na literatura a entrevista como base de apreensão da realidade observada, no caso para a caracterização dos serviços na perspectiva da sua mudança para um modelo de integralidade da atenção. Na sua representação social, o que se pretende investigar dos trabalhadores de saúde, realmente é o seu pensamento-linguagem relacionado à sua prática de trabalho no contexto da sua realidade de serviço, ou seja, os níveis de sua percepção dessa realidade.

A técnica de entrevistas não-estruturadas, onde o informante aborda livremente o tema proposto, foi complementada pela observação ocasional de práticas, inclusive a pesquisadora participando de reuniões de serviço quando houve oportunidade e interesse. Algumas discussões de grupo foram ocasionalmente observadas no sentido de aprofundar as informações. Portanto, somente de forma complementar utilizou-se outros recursos de pesquisa qualitativa, como a revisão de documentos (planos, protocolos e relatórios) e ocasionalmente, alguma observação direta assistemática dos locais de trabalho, assistindo oportunamente a reuniões e discussões de trabalho, somente visando esclarecer algum entendimento colocado nas entrevistas ou o seu contexto de inserção. Não se inclui nos resultados a informação documental ou de observação, pois se consideraram os resultados exclusivamente apreendidos nas entrevistas suficientes para os objetivos do estudo.

A entrevista em profundidade foi um procedimento metodológico que propiciou a possibilidade de se efetivar um diálogo entre a pesquisadora e cada entrevistado, deixando uma sensação de intensamente correspondido, sobre os respectivos processos de trabalho, apesar de somente o entrevistado colocar suas representações. A postura de escuta e interesse na fala, que pode ser comparável à prática de psicoterapia analítica como o fez Castoriadis (1987), auxiliou a estimular o entrevistado a discorrer sobre os processos vivenciados.

A gravação das entrevistas sempre foi autorizada sem dificuldades e se justificava pela possibilidade de captar mais corretamente as falas, ao mesmo tempo em que havia o compromisso do pesquisador de manter seu registro nos arquivos pessoais do mesmo, preservando o anonimato na apresentação dos resultados. O registro das entrevistas, por 
gravação consentida, teve suas transcrições e observações anotadas pela própria pesquisadora. As informações obtidas - descrições de serviços, processos e atividades, objetivos da ação e interpretação subjetiva dos fatos, em suas representações conceituais, organizacionais e opinativas - vão permitir imputar a caracterização do conjunto de atividades, identificando seus conteúdos político, organizacional e tecnológico a partir das evidências empíricas.

\subsection{Análise dos Dados}

Como indicativos da construção do método de análise, destaca-se que, durante o processo de coleta de dados, o pesquisador já inicia o trabalho de análise da realidade observada, o que vai sendo mais bem configurado durante a transcrição das entrevistas e em cada releitura.

A análise é um processo de dar sentido aos dados, o que envolve a consolidação, redução e interpretação daquilo que as pessoas falaram - é o processo de dar significado. A análise dos dados é um processo complexo realizado em movimentos contínuos de ir $e$ vir entre dados e conceitos, raciocínio dedutivo e indutivo, descrição e interpretação. Esses significados ou compreensão constituem as descobertas do estudo. As descobertas podem estar na forma de considerações descritivas organizadas, temas ou categorias que recortam os dados ou na forma de modelos e teorias que explicam os dados. Essas formas refletem os diferentes níveis analíticos desde uma simples descrição até altos níveis de abstração na construção da teoria (Merrian 1998).

Merriam (op cit) adverte para a importância de variação imaginativa na apreensão do objeto de pesquisa, o que implica vê-lo sob vários ângulos e perspectivas diferentes. Durante a descrição da realidade observada na busca dos seus significados, procurou-se entender a estrutura dos serviços, seu funcionamento e características do movimento organizacional observado, sempre procurando pensá-los em relação à diretriz da integralidade no modelo de atenção. 
Utilizou-se uma metodologia qualitativa do tipo interpretativa, por considerar que o estudo da mudança organizacional tem um conteúdo histórico, cultural, político, ideológico e tecno-normativo. A abordagem interpretativa permitiu a compreensão do processo de mudança do modelo de atenção e organizacional a partir da interpretação dos próprios atores, seguida da interpretação da pesquisadora, buscando-se captar como eles fizeram esse movimento. Existiu um componente de pesquisa heurística na opção metodológica uma vez que a experiência pessoal no processo de investigar se constituiu em parte dos resultados, ao orientar o estabelecimento de conexões conceituais.

Cronologicamente, podem-se recuperar no processo de análise dos registros das entrevistas as seguintes fases ou passos adotados para sua operacionalização: ordenamento dos dados, seu processamento e análise e a construção dos resultados.

\subsubsection{Ordenamento dos Dados}

Em um primeiro momento (1), procedeu-se à transcrição das entrevistas gerando um arquivo individualizado para cada entrevistado [nome]. Então era ouvida mais uma vez a entrevista inteira. Preliminarmente ao uso da informação capturada, procedeu-se inicialmente uma análise longitudinal de cada entrevista, genericamente informada por uma pré-análise dos seus conteúdos com atenção focada na coerência interna. Congregando um conjunto de técnicas, procurava-se captar inclusive significados subjacentes subjetivamente expressados. Na prática esta é uma função complementar à busca mais objetiva de tendências, ideologias, posturas, atitudes e práticas, no caso referidas ao próprio trabalho e ao conjunto em que se inseriam, buscando-se uma caracterização de condutas e práticas organizacionais próprias do contexto estudado.

Em um segundo momento operacional (2), realizou-se a seleção das informações mais pertinentes ao objeto do estudo, procedendo-se à exclusão em cada entrevista das falas ou partes delas não selecionadas para análise, por serem consideradas alheias aos objetivos da pesquisa. Então era gerado um arquivo da transcrição mantida por entrevista, entrecortada por reticências nos trechos deletados [nome2]. 
Sendo as entrevistas absolutamente abertas, em torno de 50\% do material transcrito foi retirado por extrapolar a temática e finalidade do estudo. Assim, partindo-se de mais de 500 páginas transcritas, referentes a aproximadamente 50 horas de gravação de entrevistas, que na maioria tinham uma duração superior a duas ou três horas cada, procurou-se ter sempre presente na análise o contexto de referência das falas, normalmente relacionado com a sua inserção na estrutura dos serviços em sua representação temporal. Em outras palavras, houve um cuidado de preservar as indicações do contexto do qual faziam parte as mensagens.

\subsubsection{Processamento e Análise dos Dados}

Até certo ponto, a análise de conteúdo é implicitamente utilizada em qualquer análise de dados qualitativos, pois em um sentido, toda a análise de dados qualitativos é análise de conteúdo, uma vez que é o conteúdo das entrevistas, notas de campo e o conteúdo escrito da redação de documentos que compõem o material empírico analisado.

Em um terceiro momento (3), passando da organização preliminar ao início do processamento, com base no que foi considerado relevante nas falas dos entrevistados, na seqüência se procedia a uma revisão redacional do material empírico, definindo unidades de registro e destacando núcleos temáticos de significado [nome 3].

Para Merriam (1998) a construção de categorias como análise de dados começa com a primeira leitura da primeira transcrição de entrevista, mediante anotações de observações e comentários e dúvidas nas margens dos textos. É o início de uma "conversa" do pesquisador com os dados.

Entre as várias formas possíveis de se definir as unidades de registro para facilitar a análise do conteúdo de uma mensagem, optou-se pela sua organização em parágrafos lógicos por assuntos (as "falas" de cada entrevistado), iniciando-se sua classificação em sub-temas que se definiam pelo desdobramento dos conteúdos apreendidos. Tomar por unidade as falas que freqüentemente se explicitavam como um parágrafo extenso, em torno da qual extrair as interpretações, foi aqui considerada a técnica mais adequada ao caso. Preferiu-se utilizar como unidade de análise as partes dos textos referidas aos 
núcleos temáticos de significado, definidos a partir do próprio processamento qualitativo do conjunto da fala tomado para análise.

Os dados eram construídos através de questionamentos aos seus significados, informados pela fundamentação teórica da pesquisa e processados por leituras repetidas e exaustivas dos conteúdos apreendidos em cada entrevista, buscando seus nexos e relações. A obtenção e organização das informações consideradas relevantes para o estudo em questão iam sendo processadas concomitantemente.

Neste momento (4), procedeu-se a uma primeira tentativa de organização dos resultados do conjunto das entrevistas através de uma esquematização prévia somente dos sub-temas ou pré-categorias apreendidas em todas as entrevistas. Entre muitos movimentos e interrogações que conduziam a um ir e vir nos próprios dados, produziam-se interrogações que permitiam identificar aspectos mais relevantes e estruturar estes itens inicialmente em uma ordem lógica e mais cronológica de ocorrência dos relatos. Então se voltou às entrevistas, reordenando seus conteúdos de acordo com esta esquematização [nome 4], finalmente habilitadas para gerarem arquivos por tema e não mais por entrevistado.

A partir daí emerge a elaboração de pré-categorias como uma técnica privilegiada para se trabalhar os conteúdos observados, que acabam configurando sub-dimensões identificadas em relação ao eixo de análise teórica.

Os dados neste momento (5) foram reeditados através de sua estruturação de acordo com as três dimensões teoricamente derivadas da recuperação bibliográfica sobre os modelos de atenção - as questões mais propriamente políticas, organizacionais e tecnológicas. Considerando as inter-relações implicadas entre as mesmas e a riqueza de aportes na dimensão organizacional privilegiada na apreensão do empírico, esta se desdobrava em aproximações a algumas categorias específicas do campo organizacional, nos resultados apresentadas como "vias" de se contribuir organizacionalmente na transformação de um modelo de atenção informado pela diretriz da integralidade em saúde. As várias sub-dimensões colocadas pela realidade estudada é que permitiram organizar o material nas vias propostas. 
A divergência e conflitos próprios da situação real estudada são relatados como foram representados, procurando-se somente resguardar a explicitação de questões de ordem mais pessoal. Até este momento, o corpo empírico estava disposto com as falas identificadas por entrevistado e página na transcrição original. Ao se fazer então a opção metodológica de não identificar, na apresentação dos resultados, as falas por entrevistado e sim em uma seqüência numérica atribuída por aproximação cronológica, cuja correspondência de origem está devidamente registrada nos arquivos do pesquisador, faz-se então uma utilização genérica dos instrumentos desenvolvidos por Lefèvre, Lefèvre e Teixeira (2000) para análise do conteúdo das entrevistas. Por referência ao método proposto por estes autores, realizou-se um processo de desparticularização dos discursos, o que contribui ao resgate do sujeito coletivo profissionais de saúde mais diretamente envolvidos em um processo de mudança do modelo de atenção no município estudado.

Como no original da escrita optou-se por digitar a fala de cada entrevistado em uma cor diferente, na análise da informação, a qualquer momento, foi possível diferenciar as representações por sujeito entrevistado. Mas também não existe interesse do estudo nessa identificação na apresentação dos resultados empíricos, para evitar possíveis personalizações inoportunas. O método utilizado permitiu captar a realidade de forma muito crua e disponibilizar pistas que pudessem identificar os entrevistados poderia gerar, naquele contexto, discussões alheias aos objetivos do estudo. Além do que, houve um compromisso do pesquisador com o anonimato das falas reproduzidas, em nome do qual sequer se atribuiu a cada entrevistado um número, para evitar que o conjunto das representações de cada um pudesse revelar a respectiva identidade. Por isso optou-se por atribuir somente uma seqüência numérica às falas citadas, em uma ordem cronologicamente orientada dos fatos apreendidos. Esses cuidados não prejudicaram em nada os resultados obtidos, mas ao contrário, permitiram um trânsito mais livre para revelar abertamente as representações dos sujeitos ouvidos.

Após a reconstituição aproximada de um discurso do sujeito coletivo, assim considerado o conjunto dos relatos processados, o pesquisador apresenta este resultado preliminar em reunião extraordinária do respectivo Conselho Municipal de Saúde agendada exclusivamente para a apresentação do estudo de caso realizado. Houve "certo tipo de 
validação" dos resultados obtidos por parte de conselheiros e entrevistados, tendo todos esses últimos sido convidados para a referida reunião e aqueles que se fizeram presentes também manifestaram na oportunidade que efetivamente os dados conseguiram uma fiel apreensão da realidade. Aquele foi um momento de devolução dos dados, agradecimento e despedida do campo.

\subsubsection{Construção dos Resultados}

Também contribuiu o método de elaboração de um discurso do sujeito coletivo (Lefèvre, Lefèvre e Teixeira 2000) para a organização do material através de idéias centrais e na interpretação das falas por meio das ancoragens conceituais expressas pelos entrevistados e/ou teoricamente agregadas. Houve uma adaptação do referencial metodológico acima citado sobre o discurso do sujeito coletivo, de forma a não impor, necessariamente, reunir em cada parágrafo a representação de vários entrevistados. Pode ter sido de um só, ou dois, ou mais, sendo inclusive possível diferenciá-los pela sinalização (...), sendo que as reticências simples ... indicam a omissão de trechos da fala de um mesmo entrevistado. Na presente pesquisa entende-se como discurso do sujeito coletivo o conjunto das representações coletivamente construído por todas as falas incluídas no capítulo.

Apresenta-se em itálico o discurso dos sujeitos entrevistados, seguido da indicação numérica das falas (Fn), sendo que as demais anotações são produzidas pelo esforço de ordenamento e discussão das questões abordadas. Pode-se considerar a autora como parte do grupo cuja representação é apreendida, ao organizar e interpretar as falas dos demais. Mas suas esporádicas intervenções estão graficamente diferenciadas, pois somente as palavras dos entrevistados constam em itálico. A grafia padrão (sem itálico) também é usada quando, na fala de um entrevistado, o autor reescreve a idéia transmitida, mas sem reproduzir literalmente suas palavras, e sim procedendo a um resumo do conteúdo ou a adequações de linguagem. É nesse espaço que se insere o estilo do tex to final produzido.

As idéias centrais estão agrupadas em subtítulos com conteúdo imediatamente especificado e na seqüência se procede a sua interpretação, constando a ancoragem 
conceitual identificada na representação dos entrevistados. Assim, em muitas situações se constata uma representação auto-ancorada, pelo menos aparentemente. Em muitas expressões utilizadas pelos entrevistados se dispensa a explicitação de referências de ancoragem por ter sido suficientemente discutida aquela expressão anteriormente (capítulos 1 e 2). Após a citação das falas, por interesse do estudo, em sua leitura interpretativa e análise, são utilizadas as demais referências teóricas da tese, nas quais o texto também encontra sua ancoragem conceitual. Considerando que uma grande parte das falas são auto-explicativas, contendo comentários que estão de acordo com a lógica de análise, essa não é novamente explicitada para evitar ser repetitiva.

Segundo Gomes (1994, p.77), na análise final dos resultados empíricos são estabelecidas articulações diversas "entre os dados e os referenciais teóricos da pesquisa, respondendo às questões da pesquisa com base em seus objetivos". Dessa forma se produzem "relações entre o concreto e o abstrato, o geral e o particular, a teoria e a prática" (o saber e o fazer). Para esse autor, o nível do encontro do pesquisador com os fatos surgidos se constitui como: "ao mesmo tempo, ponto de partida e ponto de chegada da análise. As comunicações individuais, (....) a análise das instituições (....) são aspectos a serem considerados nesse nível de interpretação" (p.789).

Assim finalmente teve-se um último momento (6) de tratamento dos resultados e interpretação. Conforme Minayo (1992, citada por Gomes, 1994, p.69), pode-se "apontar três finalidades para essa etapa: estabelecer uma compreensão dos dados coletados, (....) responder às questões formuladas, e ampliar o conhecimento sobre o assunto pesquisado, articulando-o ao contexto cultural do qual faz parte". Da análise do material empírico foram derivadas algumas vias que, devidamente ancoradas no quadro teórico, podem ser consideradas categorias organizacionais, entendidas como instrumentos para análise e reflexão sobre a realidade, portanto mais como uma forma de pensar do que um referencial acabado e definido.

Todas as etapas exigiram muitos movimentos de ir e vir entre os dados empíricos e a literatura pesquisada, como também uma boa dose de imaginação criativa e muita dedicação, rigor durante o processamento dos dados e organização para conseguir 
dispô-los de forma inteligível, para poderem ser sistematizados de acordo com o quadro teórico construído. Somente na fase final da análise se realiza a integração dos dados de que deriva a escrita do texto apresentado no capítulo de resultados.

Nesse tipo de metodologia, necessariamente, nos resultados se consolidam os comentários e a análise ao mesmo tempo. O que está apresentado nos resultados já é uma síntese dos dados realizada através de um eixo que, partindo da dimensão política do objeto, centra-se nas questões organizacionais, na perspectiva da finalidade tecnológica de um trabalho que operacionaliza a diretriz da integralidade em saúde.

É sabido que "o processo de campo nos leva à reformulação dos caminhos da pesquisa, através das descobertas de novas pistas. Nessa dinâmica investigativa, podemos nos tornar agentes de mediação entre a análise e a produção de informações, entendidas como elos fundamentais. Essa mediação pode reduzir um possível desencontro entre as bases teóricas e a apresentação do material de pesquisa" (Minayo 1994, p.69).

Para Merriam (1998), nos resultados de pesquisas qualitativas não há uma só resposta, mas várias pistas. Como resultados da pesquisa obteve-se um conjunto de vias que permitem categorizar um modelo organizacional aproximado referido à integralidade na atenção de saúde no SUS, projetando-se num cenário de municípios brasileiros. A proposta resultante compreende princípios e instrumentos derivados basicamente da pesquisa bibliográfica e empírica, iluminados por referenciais teóricos de transformação organizacional, na perspectiva da sua incorporação no espaço organizacional de produção setorial de serviços públicos de saúde. A perspectiva de utilização dos indicativos apresentados requer a sua adequação ao contexto em que se pretenda sua aplicação.

Esta é uma pesquisa que se processa em um movimento permanente de maior aproximação ao objeto, pela integração das partes no todo e de um sucessivo recomeçar. 


\author{
Capítulo 4
}

\title{
4 ORGANIZAÇÃO DO TRABALHO DE MUDANÇA DO MODELO DE ATENÇÃO
}

Neste capítulo se expõe os resultados no sentido de captar como opera no empírico o movimento de introdução da integralidade em saúde, e mais especificamente, a condução desse processo. Os componentes e características de organização do trabalho estudado, de finalidade comprometida com a integralidade enquanto princípio e diretriz do SUS são desenvolvidos conforme apreendido a partir do material coletado. Como o quadro teórico construído informa basicamente as dimensões de análise, sem uma categorização prévia dos seus desdobramentos a pesquisar, a ordem lógica se constrói sobre os resultados obtidos, obviamente ancorados na fundamentação teórica da tese.

A linha condutora que determina a apreensão finalmente havida da realidade corresponde às três hipóteses de trabalho derivadas da fundamentação teórica do estudo: 1) As proposições de integralidade da atenção à saúde têm uma dimensão política de conteúdo ético-normativo, cuja constituição empírica, primeiramente apreendida na organização do material levantado, implica na existência de atores para viabilização e sustentação do projeto. 2) A política se realiza no espaço organizacional dos serviços. Nas propostas de integralidade sempre se encontra o âmbito dos serviços locais de saúde como sendo o locus privilegiado de sua implementação. Os arranjos institucionais desencadeados no movimento de condução do projeto constituem a via organizacional privilegiada no estudo. 3) As referências a uma caracterização genérica das ações desenvolvidas no âmbito dos serviços locais e a alguns instrumentos utilizados informam aspectos da dimensão tecnológica da integralidade indiretamente apreensíveis na representação de profissionais sobre o conjunto do trabalho realizado. 
Por referência a essas três dimensões de apreensão da realidade - política, organizacional e tecnológica -, o estudo empírico vem revelar como a sua sucessão e articulação ocorrem no movimento relatado de mudança do modelo de atenção no município estudado. Obviamente as dimensões destacadas não se expressam separadamente na realidade; apenas são assim apresentadas por motivos didáticos, no sentido de facilitar sua abordagem. É o mesmo eixo, partindo da política, passando pelo organizacional até sua expressão tecnológica percebida que informa também a análise do material coletado.

A recuperação do movimento de como se faz a integralidade no empírico restringe-se ao período estudado - a gestão atual (1997-2000). Todavia, existe uma retração deste período na referência ao último ano da gestão, em razão do período de coleta da informação haver sido encerrado em maio de 2000, ainda durante um ano de estudo. Por outro lado, o último ano da gestão anterior é especialmente recuperado nas representações dos entrevistados. Assim sendo, em função dos resultados obtidos, o período de referência do estudo poderia ser corrigido para 1996-1999, incluindo-se então o último ano da gestão anterior ao mesmo tempo em que não se desenvolve o último da gestão propriamente estudada. Também antecedentes relatados da gestão anterior são recuperados por sua condição de facilitar a análise do período estudado.

\section{Os entrevistados - quem somos}

Os 17 entrevistados eram agentes do trabalho de mudança do modelo de atenção na secretaria municipal de saúde estudada, incluindo-se: 3 gestores; 6 membros de equipes dirigentes ou chefias técnico-finalísticas, 4 gerentes regionais ou chefias de unidades de saúde; 3 "profissionais-chave", sendo um técnico de nível central e 2 trabalhadores de ponta e, ainda 1 conselheiro representante de usuário. Em relação à formação profissional eram: 5 médicos, 4 assistentes sociais, 3 dentistas, 3 enfermeiros, 1 psicólogo e 1 sindicalista.

Os trabalhadores de saúde são seres humanos. Vivem e sonham. Seu trabalho em saúde é um trabalho humano em geral. Os sujeitos da saúde pública são sujeitos do mundo social. As pessoas que constituem o universo empírico, em sua subjetividade são seres 
multidimensionais (Chanlat 1996 e Ramos 1984), e segundo os próprios entrevistados assim se auto-apresentam: Meu pai é médico; (...) tenho dois livros de poesia e dois de crônica prontos para editar; (...) minha vida na cidade começou em um sítio, onde sonhávamos fazer uma ... comunidade alternativa; (...) eu participava de um movimento da igreja católica (cursilhos); (...) sou sindicalista (...); ... tenho um passado de política, fui vereador; (...) eu tinha muito ... conteúdo, prática nenhuma a não ser a coisa do voluntariado e muita discussão ... ideológico-humanitária; (...) Eu já tenho um pouco de história política, ... alguma experiência com administração pública ... em outra secretaria, onde fazia a captação de recursos (F01-8). Eram mães, pais, jovens profissionais, professores, militantes políticos de esquerda, centro ou direita, como também alguns sem partido, eram cidadãos brasileiros, agentes do trabalho em saúde no município. O reconhecimento das diferentes dimensões da pessoa humana faz parte de novas abordagens do seu comportamento no ambiente de trabalho, especialmente articulado com seus objetivos em relação ao trabalho. Em uma postura mais compreensiva dessa multi-dimensionalidade se recuperam os sentidos que as pessoas dão à própria vida, visando reabilitar o ponto de vista do sujeito, ou como diz Chanlat (op cit), as dimensões esquecidas do ser humano nas organizações.

Enquanto trabalhadores de saúde se profissionalizam. E explicam sua opção por saúde pública ou área afim (oito profissionais com especialização), para o que se revelou determinante a importância de um preparo para a saúde coletiva a partir da graduação: Fiz estágio em saúde pública, ... era diagnóstico de saúde, mapeamento e cadastramento; isso despertou meu interesse ... pelo trabalho comunitário. ... Trabalhava em cima dos conceitos do que é família e comunidade, aí comecei a me interessar pela saúde. (...) Entrei na saúde pública desde a época da graduação em medicina, trabalhava com organização comunitária. (...) Existem diferentes motivadores pela opção por essa especialização: fui fazer saúde pública para subir como funcionária, precisava ter uma titulação melhor, só que eu me encantei. (...) Eu gostava da área de odontologia social, aquilo me seduzia. (...) Para instrumentalizar uma prática coletiva, ... percebi que precisava uma formação que me desse a bagagem técnica necessária para trabalhar com comunidade, e fui fazer residência geral e comunitária (F09-13). 
Como derivações da especialização na área de saúde tem-se: A minha estrada na saúde pública, é muito assim - antes insatisfeita com aquele trabalho e depois do curso de saúde pública, com a cabeça muito mexida, aí as coisas que aconteciam ... não coincidiam mais com o que havia mudado em mim, ... tanto que me tiraram do nível central. (...) Quando eu cheguei aqui não havia ninguém com especialização em saúde pública na cidade. Então eu ofereci isso pro meu setor, ... eu pretendia trabalhar mais na área de pesquisa ou planejamento. Mas não permitiram, não quiseram aproveitar nada, aí fui para a clínica (F14-5). Apesar de, no nível da assistência clínica, na rede pública, também poder se fazer um trabalho de sanitarista, não é novidade no contexto de municípios e estados brasileiros que os cursos de especialização em saúde pública, realizados sem inserção em um projeto institucional dos serviços da região, formem profissionais críticos geralmente não aproveitados como sanitaristas pelos respectivos serviços.

Por uma opção pela cidade, profissionais vindos de fora traziam sua experiência anterior de trabalho em saúde: Eu preferi vir trabalhar nesta cidade porque aqui, na verdade, eu também poderia dar aula na universidade; era uma oportunidade de poder trabalhar com aulas práticas, em projetos de ensino-serviço. (...) Isso daqui é o paraíso para qualquer médico geral comunitário, ... porque aqui eu pude ensinar, pude praticar no PSF, pude administrar. (...) Tem condições de fazer o que quiser dentro da área da saúde desse município (F16-8).

A experiência anterior de trabalho em saúde era bastante diversificada no grupo entrevistado: Comecei a trabalhar no setor público numa comunidade muito carente; (...) trabalhei com alguma coisa de pastoral da saúde, e foi onde eu me interessei pelo trabalho comunitário. (...) Tive um emprego em hospital, foi assim que eu comecei meu trabalho como profissional de saúde. (...) Antes eu sempre só clinicava, tanto na prefeitura de uma cidade grande, como no consultório particular. (...) Eu trabalhava numa secretaria municipal de saúde em outro Estado, de onde eu saí quando estava se iniciando um processo de descentralização; então vendo por onde estava caminhando aquele processo de mudança de modelo assistencial, eu comecei a trazer isso, na gestão passada quando aqui se começou. (...) Como é que eu entro nisto ai?... Através de uma 
proposta política do movimento sindical na saúde, eu trabalhava articuladamente com a proposta de saúde dos sindicatos ligados a CUT no Brasil (F19-24).

De acordo com o ano de ingresso na secretaria municipal de saúde, os entrevistados se distribuem da seguinte forma: somente um profissional com mais de 10 anos naquela inserção, 4 admitidos em 1992, 5 nos dois primeiros anos da gestão anterior, 5 em 1996 e dois admitidos na gestão atual para o período estudado. As maiores safras anuais de novas admissões se deram em 1996 e, anteriormente, em 1992, tratando-se ambas dos últimos anos de uma gestão.

Coincidentemente, todos os funcionários da SMS entrevistados já haviam tido alguma experiência de nível local naquela relação de emprego. O nível central tem sido geralmente constituído a partir de profissionais oriundos da rede: Fiquei uns 4 ou 5 anos trabalhando como dentista de escola, até que um coordenador me convidou para trabalhar no nível central. (...) Na gestão passada eu trabalhava mais exclusivamente com clínica na rede e a gente já estava, de certa forma, discutindo essa questão de modelo assistencial em vários fóruns aqui. (...) Antes de vir pro nível central nesta gestão, eu não tinha noção nenhuma de metodologia, do que era federal, o que era lei, o que a gente tinha que seguir, qual era o método, lá na rede eu não sabia de nada (F25-7).

\section{Organização do setor saúde no município}

À guisa de apresentação do empírico, por referência à cidade sede do estudo de caso, com uma população na faixa de 250 mil habitantes, um gestor considera que: É uma constatação que o desenvolvimento de uma cidade que tem universidade, ... faz melhorar a qualificação das pessoas, que passam a ter ... uma visão melhor das coisas, dos problemas gerais, e isso melhora o seu senso crítico. ... E passam a ter um melhor julgamento político das ações, o que ajuda muito, ... fazendo com que o município cresça muito. Até há pouco tempo atrás, ... todo mundo estava assim meio negativista, achando que a cidade estava em decadência e agora você vê que outra vez se está dando a volta por cima, chamam a atenção algumas melhorias urbanas, uma nova rua central, inaugura uma nova ponte, moderniza a cidade. ... Quer dizer, a gente está 
realmente conseguindo levantar, ... o que faz parte de um todo que está ocorrendo no município, não é só saúde (F28).

A história dos serviços de saúde no município mudou muito, especialmente na última década. Em 1989 a secretaria da saúde estava saneada e já tinha feito o convênio de municipalização, com uma gestão muito incipiente. Aí começou o grande desenvolvimento ambulatorial da saúde na cidade (F29). Em 1990, com a Lei Orgânica da Saúde reforçando essa descentralização, tivemos o município entrando no SUS. (...) Com a esfera federal, por convênio passando à gestão do município, o secretário até tentava aventuras, como trazer ginecologistas e pediatras para a periferia. Havia alguma intenção precursora de descentralizar, começando pelos profissionais (F30-1).

No começo da década era visível a ainda remanescente herança das campanhas sanitárias. Havia alguma coisa nesse nível ... feita regularmente pela secretaria estadual e pelo ministério da saúde. E aqui, como foi outrora região endêmica de malária, tinha uma delegacia da antiga SUCAM (Superintendência de Campanhas), bastante atuante e fazendo alguma coisa na captura de larvas de "aedes". Mas basicamente era isso que se fazia (F32).

É muito mais presente a herança do modelo médico-assistencial privatista ainda hegemônico, tendo-se então, como antecedentes dos serviços de saúde, uma situação da rede no início dos anos 90 que em termos gerais pode ser assim descrita: Já havia na época 3 ou 4 ambulatórios gerais; (...) cada um comporta em torno de 60 profissionais ... e ali se concentravam as atividades de ginecologia, pediatria e clínica, de maneira geral num só período. Tinha também o posto do antigo INAMPS, um centro de saúde do Estado e quatro hospitais. (...) Tudo absolutamente desarticulado. Um fato que ilustra essa situação é que: ... antigamente era assim, a primeira unidade de saúde bucal que teve era separado do posto de saúde (F33-5).

Antes o modelo assistencial era voltado só para um binômio - doença/cura. Aí ... a medicina era muito mais o bate-volta assistencial. A pessoa ia no posto porque estava sentindo alguma coisa. Não havia um trabalho de base, de descentralização. ... E era 
melhor que as pessoas não ficassem doentes, porque na hora de recuperar a saúde era complicado, complicado no ambulatório, no posto do antigo INAMPS, nos exames, no medicamento e ... na área hospitalar também era muito difícil a coisa (F36).

Antes de haver o sistema público, no modelo do município, o pessoal só vinha ao hospital. Cada qual era cliente de um dos existentes, ia lá resolver o seu problema, porque vai ter alguém no pronto-socorro que vai indicar um especialista. Para complicar, ... a cabeça do povo aqui é consulta com especialista. (...) A fundação hospitalar municipal dizia que não precisava de hospital público, a cidade era bastante rica (F37-8).

No espaço da saúde coletiva um contexto de crise assistencial: Era muito importante ... coibir a internação, até porque aí a gente vai estar trabalhando no viés ideal que seria realmente promover a saúde e proteger. ... Então nós estávamos numa situação algo parecida com como ficou Cuba depois da revolução, era muito importante que as pessoas não ficassem doentes, porque se ficasse doente ia ser um trabalho pra curar. Isso foi uma coisa que ... motivou muito pra esse lado da promoção e da proteção (F39).

Em 1992 já havia um trabalho da faculdade de serviço social daqui, em termos de atividades com grupos nosológicos específicos. Então eles acompanhavam os hipertensos e os diabéticos - era o que havia assim em termos de trabalho coletivo.... Inclusive, havia um serviço da área de assistência social que fazia busca ativa a pé. (...) Aquele secretário também começou ... a experiência mais interessante em termos de saúde pública na odontologia - um projeto chamado "sorriso" (F40-1).

Despontam referências remotas de atenção integral: Muito incipiente era a questão de uma 'atenção integral à saúde do cidadão', como um ser com saúde onde a atenção tem que servir para que ele mantenha ou preserve esta saúde. (...) A outra intenção na gestão passada era realmente mudar o modelo da dicotomia cura-doença, para proteção, promoção e recuperação da saúde (F42-3). 


\section{Estruturação da rede municipal}

Na gestão anterior (1993-1996) houve uma forte expansão da rede básica: A gente bolou pulverizar o modelo assistencial e surgiram as unidades básicas de saúde, que nós chamamos de "unidades avançadas", por uma questão geográfica. Como a cidade se estende ao longo dos afluentes de um rio, que são verdadeiros corredores, a gente chamava assim porque estava avançando dentro desses braços do rio, ou então em alguns desses morros que tenham sido habitados. A idéia era permitir uma rede capilar onde o cidadão pudesse ter sua primeira atenção à saúde próximo do seu ambiente. (...) As unidades avançadas ficam fora do centro. É uma unidade pequena, são 94m2, com um ... ou dois consultórios médicos sendo um ginecológico e um clínico-pediátrico. Tem sala de enfermagem, sala de vacina, sala de espera e mais uma pequena cozinha. Algumas têm consultório odontológico. No geral é isso que comporta. Ali agora na maioria atende o médico da família, o enfermeiro e os dois auxiliares (F44-5).

Como não havia muitos recursos humanos na secretaria, fizemos um convênio com a universidade ... na fundação do curso de medicina, visando atingir uma fatia de mercado com menos acesso, pois se tentava mudar a filosofia dos cursos de medicina para assistência básica. O sistema chamava UNISIS - 'Unidade do Sistema Integralizado de Saúde' (sic), a gente fez um ... convênio que botava a saúde coletiva na periferia (F46).

Conseguiu-se capilarizar a rede, porque desde o começo era inaugurada ... mais de uma unidade por mês. O critério foi um levantamento sócio-econômico feito a cada dois anos pela universidade. Era baseado em moradia, educação, origem do cidadão, salário, quem é o cabeça do casal, e alguns dados sociais; com isso se fazia o mapa das carências do município. E o número de unidades de saúde saiu por causa disso, porque esse documento trabalhava com 37 áreas que viviam na mais absoluta ausência de qualquer serviço público. Nessas áreas a gente imaginou uma unidade de saúde, já integrando com prefeitura e outros órgãos. A idéia era pegar um terreninho pequeno e ter uma estrutura mínima para fornecer informações, fazer carteira de identidade, um postinho de coleta de correio, alguma coisa assim. Acabou não dando certo isto, deu certo em alguns ambulatórios. A idéia era aproximar o governo da comunidade. (...) A 
partir de então, de dia o povo começou a ir ao ambulatório antes de ir pro hospital. (...) Era essa a intenção - absorver a demanda ambulatorial: Na verdade nós conseguiríamos resolver tudo se tivéssemos implantado todas as equipes do programa de saúde da família, ... dando uma continuidade (F47-9).

No início da atual gestão conviviam aspectos próprios de uma rede de atenção primária no modelo tradicional, com movimentos de sua mudança na perspectiva dos princípios do SUS. Na primeira concepção registraram-se as seguintes referências a rotinas estabelecidas: A unidade onde eu estou ... é uma unidade bem daquele modelo antigo. Um médico só consulta, fica uma horinha, ... outro só pede exame e encaminha. A população quer mais o exame e o encaminhamento. E ficam naquela rotina. Então o que eu poderia fazer lá? (...) Eu fiquei no centro de saúde. Lá ... eu não podia dar entrevista, nada, entregava vacina com um ônibus do Canadá, era o que eu fazia. ... Era assim, pega vacina, carrega vacina, pega vacina; eu não agüentava mais (F50-1).

Quanto à estrutura da rede: A gente tem uma atenção de ponta boa, ... hoje são 42 unidades básicas de saúde, onde tem um bom funcionamento, uma boa funcionabilidade (sic) e uma boa resolutividade. A gente tem uma atenção de medicina básica, que é boa de um modo geral (F52).

O que a gente vê é que houve um aumento muito grande do número de pessoas, duplicou em algumas categorias profissionais. Hoje a secretaria está com mais de 800 funcionários. É, ... a gente vê, claro, como isso aí está atrapalhando a gestão (F53). A complexidade, acompanhando o crescimento das organizações e informada mais pelo objeto de trabalho que por seu quantitativo, exige métodos mais complexos, inclusive para descomplexificar seu manejo (Tarride 1995 e 1998). 


\section{Como se faz a integralidade no empírico - o fio do modelo de atenção à saúde}

O material empírico está estruturado em três dimensões que, em seu conjunto, potencialmente reúnem as condições necessárias à organização do trabalho de forma a se obter a consecução de um modelo de integralidade na atenção à saúde: o político; o tecnológico, ora basicamente referido a instrumentos que mesmo expressados na sua natureza organizativa dos serviços locais, aqui se inserem por sua fundamentação epidemiológica; e, o organizacional. $\mathrm{Na}$ dimensão organizacional se abrem sete vias: a partir da rede básica, o plano municipal de saúde, estrutura e funcionamento, comunicação da estratégia, gerenciamento loco-regional; participação popular na gestão local; e a via pedagógica.

Nas seguintes falas sobre o espaço da integralidade no contexto da realidade pesquisada pode-se perceber uma referência a cada uma das dimensões abordadas: Falar em planejamento, agenda de secretário, na conjuntura atual, deve ser piada, porque isso não se faz. ... Então aí fica difícil de você cumprir a integralidade. (...) Porque para mim ela tem que ter três coisas: 1) Tem que ter o cara central, que é o secretário, que queira fazer (decisão política). 2) Tem que ter o pessoal da ponta disposto a trabalhar dentro dessa integralidade, e eles estão (os agentes do trabalho podem ser tomados como participantes da tecnologia). Eles ficam só loucos para pedirem para eles fazerem, porque eles querem fazer. Aquele papo antigo dizendo que servidor público era tudo vagabundo que não quer trabalhar, já não é mais assim. 3) E também entra nisso aí o controle social, e a avaliação também. (...) Agora esse projeto só vai entrar em execução quando lá dentro da secretaria resolverem que querem continuar a manter essa linha. Porque falta um pouquinho de abertura mesmo pra se avançar (F54-6). As últimas referências são ilustrativas da dimensão organizacional. Os aspectos parcelares indicados somente apontam uma percepção empírica da abrangência da abordagem da problemática de mudança do modelo de atenção nas três dimensões pesquisadas. 


\subsection{Aproximações à Dimensão Política}

Por essa via apreende-se uma concepção de que a possibilidade de mudança do modelo de atenção na perspectiva da integralidade em saúde começa a existir com uma definição política de tal diretriz a se materializar no espaço organizacional dos serviços de saúde. O caso estudado revela que em tempos de transição política essa condição é determinante. E tudo isso sujeito às intercorrências político-institucionais que a realidade coloca.

\subsubsection{Período de Transição Política}

O ano denominado "eleitoral" equivale ao último de uma determinada gestão, ao mesmo tempo em que se articula a próxima. Neste estudo, o movimento de transição começa no último ano da gestão anterior ao período estudado e continua no primeiro da atual. E por essa condição de transição política, algumas práticas mudam.

Como antecedentes das noções de transição política, constatou-se que no início de 1993, ao assumir uma nova gestão, como ... oposição ao governo que estava antes, ... não houve conflito nenhum na transição de cargo. ... O secretário que saía então, era considerado uma pessoa muito ética e de capacidade de consulta às bases muito grande. Sem contar com ... muito apoio no governo municipal que achava que saúde tinha de deixar como estava, aquele secretário espertamente se fortaleceu com as entidades de base, associações de moradores e sindicatos (F57). Como também, aquela transição sem rupturas poderia explicar-se pela identificação política de ambas equipes com posturas mais propriamente de centro, que de esquerda ou direita (Bobbio 1995).

Já no final da última gestão, 1996, o clima político-institucional estava agitado. Aquele ano foi bem interessante, porque, era quando nós tínhamos a maturidade. ... Até passamos por uma CPI da saúde, ... que não deu em nada, ... só um processo administrativo; ... a repercussão foi política. (...) Nos últimos meses, ... enquanto uns tocavam o hospital, outros tocavam o PSF e a rede. Lógico que tínhamos conflitos 
decisórios. Então um ... dizia assim: Pelo amor de deus, tem que parar de construir unidade de saúde, porque não ia dar mais tempo pra terminar a construção antes da mudança de governo. (...) Infelizmente essa mudança ... deu-se no momento mais delicado: pós euforia de implantação do PSF. As equipes estavam precisando mais ... de um apoio continuado, mais efetivo. Depois da primeira oficina de sensibilização, que nós fizemos com todo o pessoal da rede e PSF juntos, eles precisavam assim saber ... como continuar na prática, com um planejamento e avaliação local (F58-60). Não havia mais tempo hábil.

Do ponto de vista de agentes do trabalho local o compasso era de espera: Quando eu entrei, em 96 quase na virada da gestão pra esse governo, ... era um ano político, em que poucas coisas ocorrem. ... A gente não fez absolutamente nada, a não ser cumprir um papel muito restrito da própria profissão (F61).

Houve ainda uma decisão política no final daquela gestão, que tende a ser prevalente no município, de fazer novas admissões para aumentar a força de trabalho antes de mudanças de governo: Então a gente foi tocar, basicamente, ... um levantamento das unidades ... sem enfermeira, para que fossem contratadas. E também colocar mais assistente social nos ambulatórios, e ... psicólogos. E ainda tentar montar a equipe do nível central. ... Não dava pra deixar só cargo de confiança. ... Quanto mais pessoas nós colocássemos no nível central, melhor (F62). Enfim, tratava-se de novas admissões. A maior safra de 1996 se reflete no corpo de entrevistados; assim como havia ocorrido em 1992, ambos últimos anos de gestão concentrando novas admissões.

Em suas relações políticas externas também o final de uma gestão traz novos embates político-partidários, como esse que se expressa em discussões na câmara de vereadores: Daí o que nós fizemos de mais errado e certo ao mesmo tempo, foi ... um projeto de lei, ... uma emenda ao plano de cargos e salários, criando todos os cargos de chefia ... que se precisava. ... Alguém entrou no sindicato com uma ação contra, que não podia aprovar essa lei. E fomos brigar na câmara, mobilizamos ... e fomos todos de camiseta amarela, ... pressionar os vereadores. E ali, foi um grande erro político nosso, o enfrentamento. Nós brigamos porque eles estavam contra, e ia ser uma coisa muito 
boa, pois hoje o que tem de remuneração é graças àquela lei. (...) Com tantos embates ... o próprio partido se mata. Isso aconteceu no final da gestão anterior. Como agora também podem estar se matando (F63-4).

Nas representações dos entrevistados se percebe uma preocupação com as implicações na definição e implementação da política municipal de saúde derivada da situação de cada ano eleitoral, o presumível último ano de uma determinada gestão. E, por esta condição, intenções não suficientemente amadurecidas são abandonadas: Algumas práticas mudam, e tem "intenções verdes fritas", como com aquele objetivo de implantarmos o projeto de município saudável, conforme proposta do ministério. Mas não conseguimos (F65).

\section{Plano de campanha e eleição}

Por referência a campanhas eleitorais: Faz-se muito o uso da máquina nessa época. ... A gente já estava esgotado, e era mais porque sabia que ia perder a eleição mesmo. E se começou a pedir voto, voto pra cá, voto pra lá, ... mas já não dava mais. ... Nós não queríamos que ... ganhasse o partido que defendia o PAS (Plano de Assistência à Saúde) de São Paulo (F66). Não era um modelo para essa cidade.

Na visão dos que assumem o governo municipal da saúde na gestão estudada: Na época da campanha ... tinha muita gente decepcionada, havia um clima tipo assim - a gente achou que podia ser diferente. Os funcionários não se sentiam à vontade de fazer esse tipo de política partidária ... no serviço, mas havia pressão. Eu percebi também que foram forçados a isso pelas circunstâncias. Mas não pode ser assim. E a gente talvez até como equipe geral do PSF não ... se posicionava, não tinha ninguém pra questionar, isso é omissão. Havia espaço de discussão política, para esse embate, ... mas a gente se acuou, sentiu que aquilo ... podia ser uma mentira. A gente deveria ter se envolvido mais no debate político. Era muita discussão, desgastes e enfrentamentos isolados. Eu acho que isso influenciou bastante o próprio conjunto como um todo (F67). 
Assim como no início deste ano 2000, a perspectiva de uma nova transição já se iniciou: Agora esse ano é outro ano político, é um ano difícil, delicado. Não sei como as coisas vão continuar. A gente não sabe o que vai acontecer. Esse mês de março é decisivo, e o mês de maio também, quando se escolhe o candidato a vice-prefeito, que são não sei quantos candidatos, o secretário atual inclusive. ... Então a idéia agora já é pensar mais em mudança de governo, querendo ou não (F68).

O plano setorial de campanha, reassumido como política da gestão, é um instrumento importante no sentido de aglutinar as equipes através de uma visão compartilhada em torno de um compromisso político. Isso se reforça quando, conforme identificado na campanha da gestão anterior: Saúde era a preocupação número um da população, a segunda era educação. E a coisa que o pessoal mais reclamava era não ter acesso aos postos (F69).

Como antecedentes, entre os posicionamentos na época daquele plano de campanha (1992), destacou-se uma estratégia de apoio político do prefeito ao plano do setor saúde: Como já havia essa intenção, ... conseguimos que o prefeito assinasse publicamente um compromisso com o plano de governo, num programa de TV. Então a gente se ateve simplesmente a seguir o plano de governo à risca. ... Nós prevíamos a construção de 40 unidades básicas de saúde, ... acho que até fomos mais além ... em um ano e pouco inauguramos 32 unidades (F70).

Nos casos de primeira ascensão de governos populares de oposição ao poder instituído, especialmente em cidades de cultura mais conservadora, observa-se uma postura de resguardo aos posicionamentos partidários, mesmo com afinidades ao compromisso com valores de igualdade mais identificados com a esquerda (Bobbio 1995). Então são comuns expressões do tipo: Não sou uma pessoa que, politicamente, é de política partidária. (...) Eu não tinha praticamente nenhum envolvimento partidário. (...) No plano de campanha, eu não trabalhei "com eles". Eu estava lá na minha unidade, só que claro, todo o tempo dizia: A gente tem que mudar, tem que pensar de uma maneira diferente (F71-3). 
A definição de política de saúde no plano de campanha do governo popular teve seu encaminhamento de formulação assim referido: Durante a campanha do PT eles faziam seminários sobre saúde ... e ninguém queria ir, ninguém queria se envolver. Aí eu fiquei meio sem graça de ninguém ir ... e acabei indo. (...) No seminário foram convidados todos candidatos a prefeito e os candidatos a vereadores pela Frente Popular. Aí no "discurso deles" era uma fala muito de pronto socorro e hospital. Isso não estava de acordo com as deliberações das conferências de saúde, onde a ênfase era atenção primária (F74-5). Não existe uma identificação compartilhada com o discurso, mais referido como "deles", mas existe um consenso no discurso coletivo de defesa das resoluções das conferências municipais de saúde já realizadas (1994, 96 e 98).

Como desdobramento, ... quando terminou aquele seminário, juntou um grupinho que resolveu se reunir pra fazer as propostas do plano de campanha, para que os candidatos falassem dentro da política do SUS, enfatizando a atenção primária. Então o nosso objetivo era esse. (...) Na época eram $5 \%$ das intenções de voto, e faltando três meses para as eleições, $7 \%$... pra Frente Popular. Então não tinha perspectiva nenhuma. Mas a gente se reuniu e fizemos as propostas. (...) Então pensamos: Vamos fazer um negócio bem bonito no papel de oposição, que nós temos que formar um governo paralelo, ... ter um modelo o mais bonito possível, pra espelho. Vamos nos embasar bem, pra gente cobrar de quem assumir (76-8).

Algumas referências à primeira eleição da Frente Popular: Apesar das poucas intenções de voto divulgadas, veio a eleição e o governo popular ganhou. (...) Aí deu a zebra, ... é, foi totalmente inesperado. E agora, como colocar em prática aquele sonho do modelo? (...) Enquanto para uns ... foi um susto, porque ninguém esperava (...) ou, foi super, ... foi assim ... um vendaval, um furacão que passou. (...) Para outros era assim: ... tudo bem, não tem problema. (...) Ou, mais especificamente, ... quando entrou o PT pensei, agora é uma chance de finalmente eu pôr em prática, daqui pra frente, aquilo que aprendi no curso de saúde pública e que ideologicamente está mais dentro daquilo que eu acredito (F79-84). 


\section{Primeiras dificuldades na formação da equipe}

Se, por um lado, foi na formação da equipe em um governo novo que assumia que se revelava uma grande dificuldade de condução do projeto político pelas contradições e conflitos colocados, é também nesta dinâmica que novos agentes vão progressivamente aderindo e querendo ajudar na construção das mudanças propostas: Estou envolvido, por compromisso profissional (F85). Tal envolvimento, segundo Freire (1992) trata-se sempre de um compromisso do profissional com a sociedade, em uma ética social, que pode ser caracterizada como uma ética da convicção (Ramos 1989).

Ao assumir o novo governo popular, surgem várias dificuldades e orientações politicamente influindo na gestão da saúde. No primeiro mês, janeiro de 97: Era aquele alvoroço, ninguém sabia direito o que fazer. ... A primeira dificuldade: nós sem experiência de gestão e com falta de quadros. ... Então, quem é que vai ocupar os postos-chave? O pessoal da saúde da família e algumas pessoas que já tinham história. (...) A equipe que assumia tinha consciência das suas limitações: Todo o movimento que tinha dentro da saúde da família em 96 era a gente que encabeçava, foi onde a gente se encontrou. ... Então, na verdade, quase toda a equipe que entrou naquela época era a equipe que fazia a saúde da família. (...) Foi o grupo que havia feito as propostas do plano de campanha, o pessoal que tinha militado na campanha eleitoral, que foi chamado ... para o nível central. (...) Aí quem veio mais aqui pra dentro era o pessoal mais novo na secretaria, que estava no PSF no máximo há dois anos. Então, conheciam mais saúde da família, a questão epidemiológica, a questão da atenção primária. (...) Ou seja, o pessoal não tinha nenhuma noção do que era o restante do serviço. Nós éramos todos novatos em administração pública (F86-90). Havia somente um ideário e a experiência de trabalho na ponta do sistema.

Era difícil iniciar um trabalho em condição de isolamento: Quando a gente entrou na secretaria, tinha assim pouquíssima gente pra trabalhar. E o pessoal todo apavorado, ih, governo do PT. Não devia ser assim, o que é que tem demais? É, não sei, mas a gente fica apreensivo, não tinha ninguém. Eram três gatos pingados pra assumir a secretaria. (...) Eu sabia que o PT tinha uma proposta. ... Pensei, vamos sentar com o pessoal e fazer umas reuniões. ... Mas na equipe que estava aí, não havia nada de 
ninguém que queria trabalhar. Hoje eu acho que nossa crença foi inocência. Baita decepção (F91-2).

Com as rupturas políticas internas, a segunda dificuldade: o que fazer com as chefias anteriores? (...) A gente teve que definir o destino de algumas dessas pessoas. Elas tiveram que ficar lá. E a gente tentou respeitar o máximo, sem colocá-las em situação complicada, eu acho isso. ... Não sei se as pessoas que estavam lá no nível central sabem disso, mas a gente teve uma dificuldade muito grande pra poder reciclar o espaço, pra poder colocar as pessoas onde fosse, sem estar necessariamente, ocasionalmente prejudicando ninguém. Era gente que trabalhou junto com a gente. E todos também estão sujeitos a isso. Vê o que está acontecendo comigo agora, quer dizer, as coisas viram rapidamente e você não está mais dentro da história e sem nem saber porquê. (...) Eu tenho uma plena confiança de que quem estava antes lá,... continua na luta, que sempre tivera essa luta do SUS. ... Mas estavam com outros compromissos. ... Só que inclusive utilizaram o material da saúde para a propaganda política, eu achei que isso foi uma coisa que queimou um pouco (F93-5).

Na perspectiva dos que saem, a interpretação é diferente: Quando mudou de governo ... eles tiraram todo o andar (11 pessoas). Era assim: uma salinha com 3 pessoas, como uma redoma de vidro, onde tu entravas, te atendiam e ali eles decidiam tua vida na instituição. ... Demitiram ... quem ainda estava em experiência. (...) E, onde você quer ficar? Acontece que tinha um diretor administrativo ... que teve que ser afastado. Ali, talvez. Mas como mudou de governo, não me quiseram. ... A gente não sabe bem direito, quem que não quis nós no nível central. ... Eu não sabia o quê fazer. ... Ninguém me queria, porque eu incomodava. Daí, o ... secretário me ofereceu pra eu ir lá na unidade tal, mas chegando lá, os funcionários fizeram um motim pra eu não ir pra lá. (...) Aí depois acontece uma coisa interessante - alguém que foi dispensado se posiciona influenciando desde fora a política municipal de saúde (F96-8). No caso, pela via da relação interinstitucional, a exemplo de uma coordenação de um núcleo de capacitação. São as "voltas da ciranda" em uma mesma cidade de porte médio, onde técnicos especializados em saúde coletiva não são muitos. 
Existe muita diferença entre o serviço local e o de nível central: Trazendo a experiência de médico de ponta, eu assumi uma superintendência, e foi onde eu vi que aquele ... não era o meu meio, não exatamente trabalhar com planejamento central. Ainda mais se sou médico geral comunitário e não sanitarista. (...) Entrei nessa história ... meio de inocente. Eu achava que podia contribuir, ... se eu consigo fazer planejamento local, a questão da cidade não deve ser muito diferente. Só que aí eu não contava com outras forças, com outras habilidades que você tem que desenvolver, pra trabalhar no nível central. Não é assim tão simples. E para estabelecer parceiros, uma discussão horrível. Então, isso eu não esperava (F99-100). Constata-se um clima de relações de desconfiança. Dejours (1992), caracteriza dificuldades desta ordem como o tipo de doença ocupacional mais típico de organizações do terceiro setor sobretudo em serviços de escritório, onde se podem incluir as administrações centrais de instituições públicas, especialmente em situações de disputas de espaços de micro-poder técnico, administrativo ou político institucional.

\section{Começar de novo}

Como iniciar o trabalho (?), se ... também não teve transição, não tinha nada. A gente não recebeu nenhuma orientação e chegando lá não se sabia o que tinha para fazer, não sei porquê. (...) Aí foi feito um questionário (de levantamento) enorme, umas 150 páginas, tudo sobre a secretaria (F101-2).

Repete-se a cada novo governo, um novo recomeçar: Foi uma ruptura muito grande. Parece que tinha uma preocupação em termos de partido, de ser uma coisa muito diferente. Porque imediatamente eles entraram numa situação muito de querer apagar qualquer vestígio da gestão anterior. ... Não só mudar o nome, o logotipo, mas como zerar tudo, alguma coisa assim. ... Impressionante. Não tem cabimento. (...) Pegavam os materiais, botavam em caixas, e devolviam aos que estavam sendo substituídos. Mas, isso é documento da secretaria, não é meu e também não vai ser de vocês. Vocês vão ter que deixar, vão precisar disso. ... Mas era assim, uma coisa mesmo de não deixar vestígio. ... Alguns meses depois estavam atrás de um tal documento. (...) Foi a coisa mais estranha do mundo, inclusive o material da coordenação do PSF, ... quase iam jogar no lixo (F103-5). 
É sempre assim: Cada novo secretário que chega aqui, aí os caras mudam tudo. Mas não mudam porque as pessoas tem deficiências, e sim por causa da questão política. Na saúde não pode ser assim. ... Pois nós temos ... bons técnicos na frente dos programas, que se amanhã forem tirados faz falta. E não são valorizados, ... porque muitas vezes não são afinados política ou ideologicamente com este ou aquele. Isso é um absurdo tremendo - ... vamos trocar as pessoas também, porque mudou. (...) Têm pessoas que devem ser valorizadas e permanecer. Só deviam ser substituídas a partir do momento que esgotassem seus potenciais, ou porque ... precisam se reciclar, ter outra visão, participar de outra proposta, ... ou pelo menos ... ter uma oportunidade. (...) Recentemente fomos participar de uma mostra do PSF em Brasília, mas como nosso trabalho não foi nem apresentado, não foi qualificado. Eu não acho que era um dos piores, mas também sei que não era dos melhores, podia ser melhor. Mas nós permitimos que fosse assim. ... Porque mudam as pessoas e se trocasse seis por meia dúzia, tudo bem, mas trocaram seis por menos de meia dúzia. Então, por que não deixaram como estava? Aífica difícil (F106-8).

Falta clareza do rumo político: E por conta da história da transição, ficou todo o primeiro ano desse governo, sem ter mais nem reunião das equipes do PSF, ... e daí veio muita rotatividade. Foi a partir daí que mudou muito e como não estava acontecendo a educação continuada, ficou meio solta a coisa. Tiraram imediatamente a equipe de supervisão, e só mais de um ano depois ... entra a figura das gerentes regionais, quer dizer, era pra tirar aquelas pessoas e botar outras lá. (...) Então a secretaria ficou uns 8 meses dando uma ré (F109-10).

\subsubsection{O Modelo de Atenção}

Agora, ao nível de modelo, de projeto, ... é uma coisa que tem muita pressão econômica também, do momento que a gente está, até se está dizendo que é o fim do mundo (F111).

Assim foi referida a origem da proposição de saúde da família assimilada pelo município: Na verdade, a questão do PSF nasceu de uma amarração em um congresso que fomos a Cuba, ... tinha uma turma do ministério da saúde, e a gente quase que se 
comprometeu na gestão passada a fazer uma coisa mais ou menos seguindo alguns critérios, para não ter de criar de repente mais guetos, como tinha no programa de assistência de saúde da mulher, por exemplo (F112).

A partir da metade da gestão anterior, a prioridade política já era o PSF. (...) Como aquele secretário não gostava de nada piloto, ... tinha que ser 19 equipes de uma vez só, 3000 e poucos agentes de saúde, tudo grande, ... um monte de dinheiro. (...) O dinheiro foi tirado do hospital, porque tinha que investir menos em hospital, e mais na rede básica. ... Fizemos isso (F113-5).

Na gestão atual, houve, na secretaria municipal de saúde estudada, uma clara opção política: a implementação de sua rede de atenção primária em uma concepção integral, através da estratégia de saúde da família e de forma articulada com um sólido sistema de referência aos demais níveis de complexidade. Como também um plano municipal de saúde voltado para a construção de um modelo de integralidade da atenção. De todas as maneiras, nos pressupostos do modelo de atenção anunciado, aflora a perspectiva de formação de um novo referencial em saúde - da promoção e atenção integral.

Havia algumas "imagens-objetivo", que segundo o pensamento estratégico de Testa (1995) informa o diagnóstico da realidade, a orientar a definição de políticas de ação: Desde o começo ... tinha aquela proposta - nós temos que modificar este modelo hospitalo-cêntrico. (...) Começamos dentro desta visão - 'modelo de vigilância à saúde e atenção integral'. (...) A gente sabia o quê que era o objetivo nosso, a gente queria ser diferente da gestão anterior, queria ser mais democrático e descentralizado e ... fazer uma forma de gerenciamento diferente. Institui-se o gerenciamento na secretaria, que até então não existia. (...) Na verdade a gente tentou, era o papel primordial, estar trabalhando de uma forma democrática, com equipe multidisciplinar, nada mais do que isso. Em alguns locais ofereceram resistência e outros nem tanto, então a gente conseguiu quebrar umas cercas e algumas barreiras (F116-9). 
O sonho na época ... era exatamente trabalhar em cima desse novo modelo: 'vigilância à saúde e atenção integral'. E fundamentado na estratégia da saúde da família. A idéia era ampliar essa equipe mínima, trazendo assistente social, psicólogo, nutricionista e quem mais der; e trazer para o quadro da prefeitura, abrindo concurso. Vamos fazer 40 equipes, e cobrir a maior área possível do município, vamos tentar superar essa questão de saúde da família focalizado em área de risco. Essa era a idéia. A gente começou a fazer o trabalho dentro desta visão. É ótimo de discurso, na prática não é bem assim (F120).

Desde o início deste governo foi definido no conselho que o PSF seria o modelo que se queria para a cidade (F121). Havia também a clareza de que a realização das diretrizes ético-normativas sobre o modelo passava pela decisão política: $O$ que é que levou o secretário a implantar as oficinas, enquanto estratégia de encaminhamento da proposta, ... isso tudo eu não sei. ... A definição se é isso ou aquilo que vai acontecer, faz-se por critério político, ... é estratégico, é ideológico (F122).

Frente à perspectiva de encaminhamento de uma proposta de mudança do modelo de atenção havia também muitos questionamentos: Bom, 'modelo de vigilância e atenção integral', mas o que isso implica? Em educação continuada, em trabalho dia a dia com a comunidade, ... em ter uma cultura de solidariedade entre o trabalhador de saúde e sua comunidade. Para se descobrir um caminho é muito em cima da experiência de cada um. Isso é difícil, pelas nossas limitações, aspirações diferentes da comunidade, conflitos entre a equipe, questões que não se consegue trabalhar bem (F123). As implicações e dificuldades enunciadas mais uma vez revelam o reconhecimento empírico de que a possibilidade da transformação pretendida se processa através da relação entre as dimensões estudadas. Nessa perspectiva coloca-se a necessidade de desenvolver aportes da teoria da transformação organizacional por sua afinidade aos atributos desta problemática.

Mas essas percepções eram individualizadas, não compartilhadas. Assim como expressa a fala: Que modelo é esse? O discurso estava desgastando. ... 'Atenção integral, ... atenção integral é ... quer dizer, é didático', não é? (F124). Isto é, de quê modelo se 
falava não estava suficientemente claro nem sequer para a equipe de condução do processo. Na própria representação do entrevistado sua reflexão lhe parecia insuficiente.

\subsubsection{Mudanças Políticas}

As questões políticas são a principal característica dos contextos de mudança organizacional. Existe um evidente caráter político nos movimentos ora recuperados por referência a uma secretaria municipal de saúde - a transição, assunção do novo modelo de atenção e novas mudanças a partir do presente item.

\section{Relação política entre conselho e gestor}

Um conselho municipal de saúde politicamente forte, onde o secretário não é o presidente, mas uma representação de usuários, além das suas melhores condições em efetivar o controle social, pode fazer muitos arranjos, em geral concentrando poder suficiente para tal. No caso o conselho demandava insistentemente uma maior participação na gestão.

Por referência à relação do conselho com a secretaria, as seguintes expressões são ilustrativas dessa representação: Em 99, o ano inteirinho nós ficamos brigando. (...) Foi sempre embate. ... É que a gente manteve controle social. ... Depois que veio o conselho, a cobrança em cima do secretário também veio. (...) E como complicador, havia dificuldades de relações com o presidente do conselho, ... que exigia do secretário da saúde uma posição de enfrentamento com o prefeito. Um posicionamento que não dava pra ter de forma nenhuma (F125-7).

Relação de política externa do CMS: Bom, no conselho nós apresentamos pro prefeito onze pontos para enfrentar a crise da secretaria: Tem resposta sim, enquanto trabalhadores, queríamos a efetivação do programa da saúde dos trabalhadores que estava parado; a moralização, complementação do PSF, era o segundo ponto; a implementação do laboratório numa farmácia de manipulação que era uma reivindicação da comunidade; uma reestruturação das gerências, acabar com as 
gerências locais implementando os conselhos gestores de unidades, certo? Era implementação de um sistema de controle de interligação de todas as unidades de saúde pra saber o que ... estão fazendo ou produzindo e assim por diante. ... Pelo descredenciamento de vários prestadores de serviço que não tinham mais necessidade de estar credenciados, então tem uma série de coisas e de economias pra viabilizar muitas coisas que estavam lá dentro. ... Quer dizer, nós tínhamos propostas, aonde que tinha que cortar, aonde tinha de economizar, quando se fala que tem déficit, está aqui, tem tantos mil de déficit, e de onde que os caras vão tirar dinheiro se a prefeitura não bota dinheiro? Então nós temos propostas (F128).

As críticas do conselho àquela gestão tornam-se mais agudas, independentemente do mérito: Qualquer plano que se faça, pra mim ele deixa de atingir seu objetivo principal a partir do momento em que a direção maior da secretaria começa a se locupletar, ... eu não estou inventando nada ... isso tem registrado aqui, dizendo que o secretário não respeitou o conselho, o regimento interno, aonde diz o conceito ou a lei, que o conselho precisa ser ouvido inclusive nos aspectos econômicos (F129).

Apesar de também haver enfrentamentos, ... pode surpreender, mas dentro do conselho nós temos pessoas da iniciativa privada que vem aqui defender essa priorização da atenção primária. Os conselheiros, ... por incrível que pareça, eles não vem fazer enfrentamento aqui dentro, mas vem sempre discutir uma política de saúde dentro do município (F130). E ainda assim, radicalizando a crítica e interpretando sem fundamentar, houve um conselheiro afirmando que, pressupostamente: Esse governo é que não teve capacidade para avançar, porque achavam que todo mundo é de direita, não é bem assim (F131).

\section{Mudanças de gestor}

Nós tivemos mudança de secretário por três momentos nesta gestão. ... E entram pessoas que pensam totalmente diferente. E pior quando não sabem sequer o que é o SUS e o modelo que se está gerando no município. Então vem desconhecendo tudo e a gente tem que parar tudo que está fazendo pra ensinar. ... Vem secretário e vai embora 
e não se integra com o todo, ou seja, não se integra na nossa realidade, em termos de saúde pública (F132).

Na metade da gestão, inclusive, tem um detalhe importante aí, o prefeito pediu desculpa pra nós do movimento sindical, pelos erros que nós dizíamos que era do secretário e ele dizia que não, ele disse: "Eu assumo os erros." ... Foi no dia tal, o prefeito ... disse assim: Quero pedir desculpa a todos vocês pelos erros do secretário e assumir seus erros. ... E aí foi nomeada uma comissão para ajudar o secretário e diante disso ele tinha mais era que ir embora. O prefeito até agora lamenta. (...) É óbvio que o secretário começou a sentir que tinha perdido, porque as propostas que estavam vindo ali eram de mudanças e aí ele sai. (...) Houve uma mudança de gestor, e isso deu uma quebra na continuidade da proposta do modelo e do plano municipal de saúde (F1335).

Com a saída do primeiro secretário da gestão é nomeado um interino: Nós gostaríamos que o secretário interino, da primeira mudança, ... que ficou aqui quase 2 meses, ficasse por mais tempo. Nesses 2 meses ele fez um estrago danado aqui no bom sentido, porque nos chamava e, o que é isso aqui ? Por que isso? E nós colocamos pra ele, olha isso aqui não dá e tal. (...) No conselho nós queríamos que esse novo secretário ficasse aqui por uns 6 meses pra botar as coisas no trilho, dar uma linha. ... Mas ele não quis, ... tinha suas razões derivadas de sua corrente política, aquelas facções no partido. Então ficou meio complicado, mas a gente queria ... pelo menos continuar a sonhar, é sério, pelo menos a gente vai ... acreditando que pode mudar (F136-7). Ao lhe ser aberto maior espaço de influência na administração, o conselho apóia politicamente aquele secretário.

Posições do conselho na escolha de um novo secretário: Nós temos o nosso candidato pra secretário. ... É que falta só um ano e pouco desta gestão e ... nós tínhamos de reforçar alguma coisa, que era ... o sistema de controle e avaliação, valorizando essa área e o controle social, que é de fundamental importância. (...) Então a gente vê que, ... para ser secretário da saúde não pode ser médico - como o foram todos até então. ... Eu acho que tem de botar é um usuário. A pior coisa que tem é botar uma pessoa que não sabe de saúde e ... médico entende muito de doença mas de saúde não entende 
bulhufas nenhuma, ... porque o normal é a pessoa ter saúde. Tem que trabalhar pra isso (F138-9).

E mais, ainda penso ... que dentro do sistema único, o secretário seria eleito ou destituído nas conferências. ... E que não fosse cargo de confiança de prefeito nenhum, mas ... um cargo de confiança dado pelo povo. ... Esse negócio da escolha do secretário de saúde, ele tinha que ser eleito. Apesar de aqui ter algo muito solidificado dentro de outra lógica, é claro, até teve um secretário ... que ficou 11 anos. É um agravante ter essa facilidade aqui e ter essa ... história, que é cultural. (...) Agora você imagina a população ter um serviço onde se possa avaliar e ver um todo. A população dizer se vai continuar e se vai eleger um outro, sem passar por essas indicações. ... Mas nós estamos aí (F140-1).

A figura do secretário: Agora, com o novo secretário, ... não se sabe como fica. Está tudo na dependência do novo gestor. (...) Eu acho que se a gente vai conseguir ... manter a coisa sempre depende do secretário que vá vir. ... Vai depender de quem entrar, ... depende do ator principal que é o secretário. ... Como também externamente, a probabilidade de manter a nossa proposta de trabalho com o prefeito é muito pequena (F142-3). Não havia viabilidade política suficiente para as propostas assumidas. O mais difícil é perceber se a inviabilidade situa-se mais no conteúdo das propostas ou nos atores que a têm representado.

A nomeação de um novo gestor, com perfil alheio ao SUS: Então o prefeito toma a decisão sozinho, não ouve ninguém e escolhe alguém pra aumentar seu leque de alianças e sustentação política. A situação complica novamente a partir do momento que entra um secretário, que nunca participa de uma conferência municipal de saúde e também não deve participar de nenhuma associação médica, ... que tem representantes no conselho. Se pelo menos fosse uma dessas pessoas que participassem. ... Vem uma pessoa que não tem o mínimo conhecimento disso aqui. ... No mínimo um tanto para evitar, que quando venha alguém de um ... hospital dizendo - ó, tira isso daqui secretário -, ele vai ali e tira, sem saber e nem perguntar. Então assim, pra onde é que se vai? (F144). 
Um novo secretário no meio de uma gestão: Quando esse último secretário entrou, eu reuni todas minhas gerentes e falei: Nós vamos receber quem quer que seja, com o maior braço aberto, ... para introduzi-lo na equipe, pra gente não ter ruptura ruim de filosofia, de trabalho, de tudo mais. Mesmo assim tivemos muitas quebras, ... sempre tem. Eu grudei nesse secretário, até a gerência se queixa, ... pra que ele pudesse ter conhecimento, ficar por dentro das coisas, precisava ensinar para ele as coisas que a gente já tinha construído para ele não destruir. Então, primei por isso. (...) Quanto às mudanças políticas: Eu percebo que a secretaria da saúde sofreu muito com a mudança de secretário, teve perdas enormes, porque o secretário que nós tínhamos, tinha um perfil, uma condução filosófica $X$, e o que nós temos hoje é Y. Não é bom nem ruim, simplesmente é diferente (F145-6).

\section{Priorizações políticas}

A concepção de modelo assistencial limitada na representação do novo gestor: A visão geral, global, é muito difícil de dizer, porque a saúde hoje, ela não é totalmente pública, nem totalmente privada, ... é um misto de privado e público. ... O gestor público, na verdade, ficou com ... a fatia da população pobre. ... No SUS, a nós compete atender exatamente essas pessoas mais carentes, que normalmente são as pessoas que têm menos poder de representatividade. E talvez por isso não consigam clamar tanto por suas necessidades. E aí eu acho que é onde aumenta a nossa responsabilidade. Porque você tem que tentar escutar, sem às vezes eles falarem, você tem que ir lá na base do problema e tentar ... descobrir o problema (F147).

Novas prioridades políticas após a mudança de gestor: Outra coisa que a gente está fazendo, é ir equipando e melhorando as unidades básicas. ... Nós estamos ampliando a rede, ... realmente há uma grande preocupação em melhorias. Nós temos hoje um (outro) plano, dentro da própria secretaria, em que estamos aumentando oito unidades, que serão melhoradas. Em algumas ... poderia ser só re-equipamento e deslocamento do pessoal, para um local mais adequado (F148). Como se pode constatar, aqui outras prioridades políticas foram sendo colocadas. E bem fundamentadas na leitura do gestor atual: Quando a gente assumiu, ... tinham certas áreas ... deficitárias, que não estavam bem cobertas. Talvez até por uma questão financeira. As zonas carentes que 
mereciam ter ambulatório, um posto mais avançado, com mais recursos, ... não estavam sendo assistidas. Na atenção básica, embora tendo vários PSF, às vezes onde precisa não tem. (...) Veja o exemplo do morro tal: É uma das zonas mais carentes do município e não tem um ambulatório. ... É uma zona ... extremamente pobre, favela, que a gente imagina que quase não exista, mas existe isso aqui. Então nós vamos construir lá primeiro $(\mathrm{F} 149-50)$.

Um secretário não pode ter tanta autonomia para desconsiderar o plano, CMS, equipe técnica e fazer pela sua cabeça o que quiser. Até a filosofia do SUS lhe é desconhecida. ... Constatava-se uma diferença de referencial teórico, biológico (sic), e de práticas, experiência e tal. É a gente que vai sempre estar ... aqui dentro. Mas eu tive um problema, eu nem briguei, ... não fui mal educada, despeitada, nada. Só ... não conseguia me comunicar, fiquei bloqueada. Agora está meio confuso, mas na realidade são referenciais e projetos diferentes. (...) Mudou muito o estilo: $O$ nosso processo interno de trabalho também mudou muito. Antes era participativo, interativo. E agora, o interesse atual está em reformar ou construir unidades e outras obras (F151-2).

A divulgação do governo está sendo muito em cima de hospital ultimamente, parece que não estão muito preocupados com a questão do modelo. ... O governo comprou um discurso assim da população, ... a reforma do hospital, um projeto antigo. ... Isso no planejamento interno do governo municipal, mas os nossos projetos a gente tem conseguido manter, ... e talvez com mais oportunidade (F153).

Após três meses e meio da entrada do secretário nomeado para concluir aquela gestão, este assume, como bandeira de mudança interna da administração, seu propósito de acabar com a chamada "gratificação dos cargos de dedicação plena" geradora de um aumento salarial em torno de $150 \%$. ... Então quem é que ficou com a "plena" dentro da secretaria? Quem faz parte do saúde da família, e, você pode não acreditar, os funcionários de primeiro escalão dentro da própria secretaria. (...) Sabe, isso é muita injustiça. ... Inclusive aqui dentro nós temos funcionários que ganham ... mais que o próprio secretário. Não por antigüidade, mas por questões de má gerenciamento ... As pessoas que tomam as decisões, dentro da secretaria, todos eles recebem a gratificação 
"plena", a colocaram para si (F154-5). Isso gerou muita polêmica dentro do conselho. O que permite supor que a expressão "locupletar", anteriormente referida, possa ter sido derivada desta situação.

Na seguinte referência - Porque eu acho que quando você faz um plano e dentro do plano existem injustiças (F156), o problema é anterior. O novo gestor nega o plano municipal de saúde ao fazer sua crítica por referência à "gratificação plena" como se fosse um produto daquele plano, sem que o tenha sido. Conseqüentemente, pode-se atribuir a esta fala uma crítica ao plano sem conhecimento do seu conteúdo; portanto, deduz-se que através dela se coloca uma posição contrária à equipe anterior responsável por sua feitura e defesa.

A partir da crítica sobre a situação encontrada, na representação do novo gestor referida à sua proposta, ... a gente está tentando montar um esquema novo, para tirar muito dessas coisas. E já se está conseguindo mudar. (...) Então, a gente está ... procurando soluções para isso, porque, é demais esse disparate, não é? (F157-8). Apesar do discurso, as questões levantadas não são enfrentadas durante o período do estudo. Ao contrário, a situação se mantém e fica aparentemente estabilizada. O discurso de um gestor não é suficiente para garantir sua transformação em atos.

Um equacionamento parcial da relação entre o conselho e a secretaria: Quanto à participação do conselho, ... quando eu entrei aqui, ... havia uma brigaceira entre a secretaria e o conselho, que não se conseguia entender o que era. Eu não me metia naquilo e aprendi a observar, antes de me meter a besta e dar palpite furado. (...) Fui me aproximando do conselho, freqüentando as reuniões e percebi ... que tinha ali um grande potencial de amigos, que nunca foram aproveitados. Então comecei a ficar mais à vontade para me colocar em grupo lá no conselho. Hoje fico ... super à vontade nas reuniões e falo nem que seja pra falar abobrinha, se eu falar alguma coisa errada, eu digo, vocês me desculpem mas estou precisando de ajuda nisso e nisso. Então eles constroem junto comigo, a coisa fica leve, eu peço ajuda deles, porque tem ... gente ali que não trabalha e tem tempo disponível. Aí eu falo, olha vocês vão com a gerente regional lá, ver pra mim qual é o melhor lugar, onde é que tem bolsão de pobreza, onde é que tem loteamento novo, ... vocês façam isso e depois "já me tragam” isso tudo 
mastigado. Porque eu não tenho tempo de ir. Eles se sentem importantes, eles são meus amigos hoje, muito amigos mesmo. Eu sinto assim uma parceria legal hoje ali dentro. ... É legal, tem que tirar proveito disso (F159-60). Faz-se necessário tanto na secretaria, como também no âmbito do conselho, ficar mais claro o papel do controle social sobre a secretaria municipal de saúde, para não se confundir com a responsabilidade executiva do governo local.

Persistem algumas visões incoerentes, assim como a representação acima, quanto à participação no CMS: Mesmo que tenham representantes ali no conselho que são de setores privados, que não têm nada a ver com o SUS, mas fazem parte do conselho, ... todo palpite ou ... opinião é bem vindo ali, porque tem coisa que a gente não enxerga. E com ... um toque, meu deus, como é que eu não pensei nisso ainda? (...) As coisas hoje estão mais fáceis. ... Às vezes a gente fica ... até com certas vergonhas, perante esse grupo que eu considero um grupo amigo, os conselheiros, perante algumas entidades $e$ tudo mais; ... vergonha por promessas feitas e que ... não podem ser cumpridas (F1612).

Uma administração municipal se abre à participação democrático-popular à medida que renova internamente seus valores e princípios de forma coerente com essa diretriz.

\section{Outros componentes políticos}

Nas relações externas da secretaria municipal tem-se alguns indicativos que revelam dificuldades políticas com a secretaria estadual de saúde: Quando o centro de saúde tinha sido municipalizado, a secretaria veio acabar com o laboratório equipado que tinha, maluquice que aconteceu lá no Estado, é sempre assim, sem critérios transparentes. Agora, esses dias atrás, prenderam uma ambulância de um município que vinha com renais crônicos para fazer hemodiálise na referência estadual porque no município de origem o aparelho tinha pifado. ... O município numa situação plena tem a obrigação de resolver o problema do seu usuário no próprio município, é, mas ... se prendeu por que? Por causa de briga política. Isso é um absurdo contra o SUS. ... Eu participei de uma reunião esses dias, do programa de saúde da família e disse pra eles, 
não venho mais nesse troço assim não. Pois o pior é que o funcionário da secretaria de saúde do Estado incorpora as brigas políticas, estão todos eles tocando o pau no pessoal daquele município (F163).

Eu critico muito a atuação da secretaria estadual, o seu papel maior que é apoiar os municípios, não faz; quer fazer aquele papel antigo de ... execução e comando. $\mathrm{O}$ governo do Estado representar 50\% da Bipartite é muito forte, não é verdade? Pelo menos pra dar mais satisfação, porque eles vêm aqui e mandam retirar um item $X, \ldots$ por uma decisão da secretaria estadual, tomada pelo conselho lá e tal, não pode mas faz. (...) Então, nesse sentido, nós temos uma distância, até porque o Estado ... enquanto governo, também ... vive as mesmas indefinições que existem no mundo enquanto modelo. A confusão que nós temos na cabeça, ... do que será o Estado, ... no resto do mundo está assim, a mesma confusão. ... E ao mesmo tempo em que se quer gestão plena, não se luta por isso, ... e no município não tem aquele apoio que deveria ter do Estado (F164-5).

A troca de experiências nos colegiados de secretários ajuda a consolidar e abre o leque de projetos de uma gestão: Com um trânsito fácil ... em Brasília, fui apresentado ao ministro da saúde ... e toda a equipe. Aí em poucos meses já fui guindado a situação de vice no CONASEMS na região. ... Esse contato abre muito e enriquece o trabalho do gestor municipal, porque a gente vê que de fato há experiências realizando ... aquilo que a gente idealizou como um projeto ideológico. Nos vários contatos que tivemos, ... a troca de experiências enriqueceu muito o processo. O fato de você estar sempre lá em reuniões, ... sendo alimentado, é praticamente comparável a um processo de lavagem cerebral, porque quase todo mundo entra numa ... mesma onda, e você vai caminhando junto. Acho que ... foi esse cunho ideológico, que consolidou muitas coisas. A gente traz muitas idéias de lá ... em várias questões, porque realmente, a coisa está dando certo em outros lugares. (...) A necessidade de estar no nível nacional e também estadual, assumindo cargos no CONASEMS e/ou COSEMS, que por causa da representatividade política era importante pra ter pontos aqui, me deixou compelido a abrir o leque da coisa (F166-7). Naquele contexto maior também havia sonhos compartilhados para o SUS no município. 


\subsection{Aproximações à Dimensão Tecnológica}

No próprio título da tese, já consta como pressuposto que a organização de um serviço de saúde para fazer a integralidade da atenção dá-se a partir da rede básica, nos serviços locais de saúde. Como componentes estratégicos desta formulação tem-se a concepção de modelo de atenção que informa a organização das ações, o qual está contido na prática dos agentes do trabalho e nos instrumentos e ações desenvolvidas, mesmo que sua configuração tecnológica não seja explicitada. Como o encaminhamento das entrevistas não era sobre as formas de operação do próprio trabalho e tampouco houve qualquer pergunta dirigida à dimensão tecnológica das práticas, os resultados aqui apresentados representam somente uma captura de partes dos conteúdos espontaneamente relatados, que possam estar relacionadas com caracterizações tecnologicamente apreensíveis.

Por referência aos níveis que analiticamente se espera venham compor a dimensão tecnológica das práticas de saúde, de acordo com o quadro teórico elaborado por Mendes-Gonçalves (1992 e 1994), cabe considerar antecipadamente as seguintes limitações dos resultados apresentados nessas aproximações à dimensão tecnológica: 1) As possíveis identificações realizadas pelos profissionais sobre seu objeto de trabalho, devem ser tomadas somente como indicativos de um objeto que certamente poderia ser muito melhor delineado se a pesquisa houvesse se orientado para captar diretamente sua caracterização, modificando-se o desenho metodológico. 2) A elaboração das finalidades referidas ao trabalho se condicionava ao olhar da inserção dos entrevistados em um processo de mudança do modelo de atenção delimitado na sua percepção. Nesse sentido, havia mais a indicação do nível técnico de condução da proposta do modelo de atenção, referida no uso de instrumentos de base epidemiológica na ação local, a exemplo da territorialização, do que a reflexão dos agentes das ações de saúde sobre a finalidade destas. 3) É justamente no nível da apreensão dos processos de articulação de instrumentos e ações do trabalho sobre o objeto conduzindo à objetivação das finalidades, que a presente pesquisa não adentrou diretamente. Apenas são apontados alguns instrumentos como os de condução, controle e supervisão dos conjuntos de processos de trabalho realizados por unidades locais e/ou regionais de saúde, sem 
avançar na caracterização tecnológica dos fluxos delimitadores dos processos instituídos.

Considerando que a opção metodológica da coleta dos dados foi restrita ao relato dos entrevistados, sem observação do trabalho operando, enquanto está sendo efetuado, só se recupera a epidemiologia no âmbito das referências ao uso de instrumentos por ela informados. Seu enfoque aqui se restringe, sobretudo ao uso de instrumentos de trabalho baseados na assistência direta de fundamento epidemiológico mais tradicional como a busca ativa e prevenção de riscos, ou atividades coletivas tipo trabalho de grupos. Instrumentos de organização, baseados na tecnologia epidemiológica, como a territorialização e ações de vigilância à saúde, são incluídos em função do uso da epidemiologia estar colocado como saber central organizativo daqueles trabalhos.

Percebe-se um maior reconhecimento da importância das bases epidemiológicas para informar o trabalho desenvolvido, mais que referências explícitas da utilização objetiva deste instrumental, inclusive faltando clareza dos usos da epidemiologia nos serviços, como se percebe na seguinte expressão: Da epidemiológica, é, eu acho difícil dizer alguma coisa. Eu não estou muito ligado assim em ... tomar uma decisão epidemiológica (F168).

\subsubsection{Território-Processo}

Através da proposta do PSF como estratégia de mudança do modelo de atenção, começa a delinear-se o caráter tecnológico do modelo pretendido. Na história do modelo, ... o nosso grande desafio, se entendeu que ele entrava com a territorialização, enquanto instrumento da proposta. Muito puxado, porque aí era o momento de você romper com aquela coisa do PSF enquanto programa e 'passar para o modelo integral'. Era o momento decisivo. E muita gente não sacou ainda. Está em ebulição esta questão das pessoas perceberem que o modelo é viável, técnica e economicamente viável, em termos de assistência e prevenção (F169). 


\section{As oficinas de territorialização}

A primeira característica do trabalho epidemiológico - sua base populacional, é contemplada em todo um processo de territorialização da população potencialmente usuária dos serviços de saúde no município. Do ponto de vista do PSF isso é mais claro porque ... tudo começa com o cadastro, aí você tem a sua população (F170).

Objetivo da oficina: A idéia da territorialização surgiu já na época da elaboração do plano municipal de saúde, pela necessidade de tentar fazer o modelo avançar. A gente chegou num impasse - olha a (estratégia da) saúde da família, só o (programa de) saúde da família não é suficiente, temos que integrar o saúde da família com a rede, essa foi uma preocupação nossa desde o primeiro momento. A territorialização entrava como estratégia para isso. Então ... as oficinas, surgiram também com esse intuito, de tentar unificar o saúde da família e a rede. Era essa a dicotomia que existia na nossa assistência básica. (...) Porque o propósito da oficina era e continua sendo, territorializar todos os serviços de saúde (F171-2). Assim eram definidas as bases populacionais de responsabilidade dos serviços em relação às necessidades de saúde da população.

Metodologia da oficina: A primeira oficina teve a duração de 2 dias numa semana, 2 na seguinte, e mais 2 dias numa terceira semana (6 dias alternados durante 3 semanas). ... A gente fez isso até porque entre uma semana e outra ... ficavam exercícios práticos pras pessoas fazer. Era o tempo necessário para que as pessoas pudessem trazer todos os dados epidemiológicos ... da região, para fazer um mapeamento melhor. Na hora de fazer um exercício de estimativa rápida, ali estavam os dados (F173).

Em 99 foram feitas 3 oficinas, ... quer dizer, a mesma oficina em 3 regiões diferentes. $\mathrm{Na}$ última delas ... teve uma carga um pouco menor, já foram de 2 dias numa semana e mais 2 dias numa segunda e depois só mais uma reunião, onde a gente fechou as avaliações e tudo. Mas aí já não foi com a participação de todo o mundo (F174). Essa prática de ir diminuindo o aprofundamento dos conteúdos trabalhados e sendo mais restrita a participação dos atores pode trazer repercussões negativas no processo. 
A oficina é toda por partes articuladas. Num primeiro momento, é preciso assimilar conceitos, que são novos pra maioria dos funcionários. Trabalhamos muitos textos, basicamente sobre: ... o que é e porquê a vigilância em saúde, ... o conceito de território, a questão de território-processo, área de abrangência dos serviços, toda essa questão de dinâmica de funcionamento entre as unidades, a referência e contrareferência na região, a questão das áreas de risco, e como ... levantar dados epidemiológicos dentro da própria região. Enfim, como trabalhar dentro da visão de saúde que esses conceitos acabam trazendo pras pessoas (F175). A oficina se propõe a construção de um saber epidemiologicamente informado e estrategicamente colocado na perspectiva de mudança das práticas dos serviços locais de saúde.

Em seu preparo, antes da oficina, procuramos ... encontrar e montar o material disponível, textos e dados necessários. ... Conseguimos os dados de todos os setores censitários do IBGE, essa informação a prefeitura daqui tentava há bastante tempo $e$ não havia conseguido ainda. ... Ali tem muita informação, nível de educação, emprego, uma série de outras coisas (F176). O IBGE dispõe de todos os dados levantados nos censos computados por setor censitário, a área de cada recenseador.

Trabalhando com mapas: Os agentes das equipes do PSF têm mapa de sua área de abrangência. Todos dizem que têm. Só que nem todos dizem que tem território definido. ... E todas as unidades que foram para a territorialização, tinham os mapas da sua região, para, ... dentro dum trabalho que iniciou na oficina, eles fazerem o mapeamento da sua área de abrangência, na sua atuação, dentro dos conceitos trabalhados. Então hoje, os que já fizeram territorialização, que são a maioria, já têm isso (F177). Com o mapa por setor censitário e suas informações, pode-se montar vários mapas, que sendo superpostos permitem visualizar o cruzamento de informações.

A oficina de territorialização, ... eu achei muito importante. Foi muito interessante porque tinha dados que a gente ignora no dia a dia e ampliaram-se vários conhecimentos que a gente até então não se apercebia (sic). (...) E ao final, sempre das 
oficinas de terrritorialização sai um relatório lindo. São ricos e tem as avaliações de cada participante, que a gente documentou, ... é um relatório criativo deles (F178-9).

\section{Desdobramentos da oficina de territorizalização}

Desvendando o território: A partir da oficina o pessoal das unidades ... pode fazer um trabalho já em conseqüência da concepção de região, conforme eles a trabalharam na oficina. No caso aqui eles continuam fazendo visita domiciliar, identificando áreas de risco, em suas regiões, vendo onde, epidemiologicamente, tem algum componente diferente ou um problema mais grave. Então, ... além de trabalhar com mapas, é estar indo na região e tal (F180). Trata-se de uma forma de apreensão de necessidades de saúde através de instrumentos simples, utilizáveis no nível local, apoiados por técnicas derivadas de uma epidemiologia adaptada para situações sem grandes números ou indicadores tradicionais, como as técnicas de estimativa rápida.

Após a oficina fizemos, inclusive ... um mapa de riscos à saúde na cidade. Mas o risco baseado só no nível de renda dentro de cada setor censitário; com esse índice, ... já se tem condição de mapear riscos por aproximação. ... Então com isso que a gente faz empiricamente, desenhando na mão, dá pra ver que as áreas vermelhas são de risco. ... Elas se concentram nos morros. Aqui não é o paraíso. Só que fica escondido, ... aqui no centro não se vê, mas morro ... tem em tudo que é lugar e ali fica bem escondida a pobreza na cidade. Mas tem bastante. (...) Esse mapeamento serve inclusive como orientação, para ver onde se criar uma unidade de saúde, baseado em quê. ... Tem algumas áreas de riscos tiradas dentro desse mapeamento e que ainda estão descobertas do PSF (F181-2).

Começando a trabalhar com geo-processamento, ... a gente viu que isso é um trabalho complicado, ... conseguir ter dados disponíveis - amplos e rápidos. Mas que facilitaria e facilita muito a ... atuação das equipes, sobretudo na identificação de focos ... de riscos, para a gente trabalhar mais na questão da promoção e menos preso na assistência. (...) O médico responsável pela vigilância epidemiológica do município é um epidemiologista da rede, que ... mesmo sem todos os critérios que são necessários 
para fazer um geo-processamento, está trabalhando com isso. Já tem todos os mapas digitalizados. ... E tem os dados disponíveis dentro desse mapeamento: população, casas, ... foto aérea, pra digitalizar todas as informações de saúde, e daí conseguir identificar e localizar. ... Seria assim: bateu uma notificação de determinada doença, ... vai no computador e identifica na hora onde é que estão ... os focos de infecção, se localiza de imediato. Isso facilita demais o trabalho de vigilância dentro da região e mesmo dentro da unidade local. ... Já conseguimos colocar ao nível regional informações que só tínhamos no nível central. E já se está inclusive conseguindo colocar isso nos mapas digitalizados (F183-4).

Na primeira oficina a gente fez a territorialização por área das unidades. Então estou querendo ... conseguir todos os mapas, ... que é uma coisa que todos não fizeram ainda, cada um faz o seu mapa. Com esse material vamos fazer um mapa ... de todo o município, identificando a área de abrangência de cada unidade. (...) Preciso das gerentes regionais para isso, para cada uma ... identificar a sua área pra depois a gente juntar tudo. Quer dizer, vem de baixo pra cima. Cada uma vai ter que ter todas as suas unidades com a área de abrangência identificada (F185-6).

Entre os vários mapas já elaborados, é preciso condensar um bem identificado por área. Porque isso inclusive é importante pra população poder localizar na própria região, conforme a área de abrangência, que quem toma conta dela é tal unidade. ... Então a gente vai respeitar, principalmente ... em campanhas e uma série de ações preventivas e de promoção. Nessas horas dá pra respeitar cada um a sua área, na questão de vigilância dá. ... Na assistência a gente sabe que não funciona assim, a pessoa quer procurar o médico em outra região e acaba tendo o respaldo legal. No PSF já é mais fácil, porque eles até têm as metas da sua equipe por áreas, porque fizeram o cadastro (F187).

Algumas unidades conseguem se orientar pela territorialização: A gente trabalhava muito em cima de mapa, era construir o mapa, fazer tudo aquilo e colocar vários botais, para trabalhar um por um os pontos. ... O quê que acontece, o pessoal sabe fazer isso, sabe localizar, e não é só o pessoal do PSF, o pessoal do ambulatório também está se 
saindo bem nessa parte. Porque depois que "regularizou o negócio" melhorou bem para eles (F188). Estavam conseguindo trabalhar com demanda organizada.

Então teve aí o início de um processo que eu acho que na prática é o início de um processo da mudança de modelo, mesmo, porque é onde as equipes começam a trabalhar diferenciado. (...) Apesar de que o processo de trabalhar na prática rompeu muito pouco a questão da assistência, mas permitiu mesclar um pouco essa questão da assistência com o trabalho de vigilância e ... promoção à saúde, dentro das áreas de risco e tudo isso; é um trabalho a ser construído. (...) A territorialização é construída quando ... as pessoas identificam que elas fazem parte do território, que existe uma autoridade sanitária ... responsável e que está ali perto. Não aqui na secretaria, porque daí volta o centralismo. Mas, para elas entender isso ... (F189-91).

As coisas andaram, como sempre acontece, de forma heterogênea. ... Quer dizer, o avanço se dá entre idas e vindas, em algumas equipes mais que em outras. Mas a gente viu que nas equipes com ... um comprometimento maior, onde já havia uma discussão, uma opção dentro das pessoas, ... uma formação e discussão anterior mais aprofundada, aí o trabalho avança mais. E outras ficaram mais na teoria, no discurso (F192).

Mudança da prática sanitária: Na verdade, pra se ter um trabalho neste sentido, as unidades de uma forma geral, ou em forma de rodízio, de diversas formas, mas elas vão ter que, em algum momento algumas pessoas vão ter que sair de aonde estão, pra fora. Não ficar só dentro da unidade, para poder fazer um reconhecimento de área, um levantamento. Enfim, é aí que fica o grande $X$ da questão, o grande problema - o pessoal fica sobrecarregado pela demanda e não consegue sair, quer dizer, essa é a questão a romper, porque esse negócio sempre vai existir, a gente sabe disso. ... Então, é muito mais uma questão de postura mesmo. A demanda às vezes acaba sendo uma boa desculpa, pra não assumir uma ... mudança de atitude, o que é sempre a dificuldade no sentido de transformação. Toda mudança gera uma reação imediata e toda essa questão. É, então em alguns lugares avança assim, uns mais que outros (F193). 
Unglert (1993) faz uma reflexão sobre a importância de existir uma base territorial em processos de mudança de práticas sanitárias, por possibilitar e integrar a concepção de saúde-doença, a orientação para problemas da população, a consideração do impacto das ações no nível de saúde, o planejamento local feito por profissionais e população da área, uma relação de responsabilidade entre usuários e população e a implantação de um modelo assistencial regionalizado. Essa concepção ajuda a compreender a territorialização desde suas primeiras proposições, como instrumento de um processo de articulação do trabalho visando a construção de um modelo de atenção com base territorial-populacional.

\section{Do sistema local de informação aos estudos de situação de saúde}

Antecedentes da gestão anterior: A gente começou a ver, ... que tinha que ir trabalhar com o pessoal lá do ... sistema de informação, do CPD - centro de processamento de dados. Porque metade mandava relatório, metade não mandava, e como é que ia ser isso? ... Então se começou a pensar em sistema local de informação. Daí começamos nossas oficinas de territorialização no PSF. Queríamos implantar mais efetivamente o SIAB (sistema de informações da atenção básica), porque até então era só a ficha de cadastro, e metade das unidades, as que tinham computador faziam e as que não tinham não faziam. E vinha a unidade dizendo: Ih, é uma tristeza, o nosso computador na unidade é de mil novecentos e não sei quanto. ... A gente começou a pensar um jeito de ter essa informação de alguma forma, ... mas paramos por aí, porque veio a eleição. (...) Isso é interessante, ficava claro que era nisso que precisava investir, no SIAB, e no planejamento local. ... E se começou a querer fazer ... este tipo de trabalho. Só que a gente não tinha ainda um sistema de informação, porque no nível central, a estrutura da secretaria não conseguia dar conta disso. ... Então eles continuam trabalhando nisso (F194-5).

Desvendados os territórios, os profissionais já preparados trabalham com mapas $e$ constroem com os dados epidemiológicos, para mapear melhor. ... Fundamental a questão de levantar os dados dentro da própria região. Mas depois da oficina ficou só um diagnóstico de saúde, onde foram identificados os pontos críticos, ... e não se 
retomou aquela discussão. Até aprendemos a trabalhar com estimativa rápida e evento sentinela (F196). Era o momento de organizar e disponibilizar um sistema local de informação.

Hoje nós temos: mortalidade, morbidade, SISVAN (sistema de vigilância alimentar e nutricional) e SINASC (sistema de informação de nascidos vivos), tudo isso já disponibilizado por região dentro do município. ... São dados para eles estudar dentro da própria região. O caminho ... é cada vez mais descentralizado, daqui a pouco vamos ter toda essa informação dentro da área de abrangência de cada unidade. ... Agora o pessoal da vigilância está organizando esse dados de forma mapeada e ... então a gente consegue visualizar de uma forma melhor. Aos poucos está avançando. ... Através do campo endereço, que a gente sempre está brigando para ser bem preenchido nas unidades e hospitais, pode-se ter qualquer coisa, ... porque notifica isso para a vigilância poder fazer o levantamento. Está sendo montado o nosso próprio banco de dados, que até então não tínhamos (F197). Para qualquer informação sobre o município antes havia muita dependência dos bancos de dados operados pela secretaria estadual.

Na verdade a gente deveria estar fazendo mais levantamento, com estudos sobre os problemas de saúde em cada território. Por exemplo, ... identificamos uma área que chamamos de micro-área de risco. Lá a gente detectou bastante casos de DSTs (doenças sexualmente transmitidas ) e na verdade a gente só foi uma vez lá, depois fomos chamados pra falar sobre DST, sei que a gente fez muito pouco (F198).

Quanto aos estudos de situação de saúde, um uso potencialmente privilegiado da epidemiologia nos serviços de saúde (Kehrig 1994), além de sua afinidade tecnológica com o momento explicativo do planejamento estratégico situacional (Matus 1993), apesar da descentralização da informação e do processo de territorialização havidos no caso terem uma característica de desvendar o território, não existia uma preocupação maior em elaborar nas regiões e no âmbito municipal, sequer para informar o processo de planejamento, o desenvolvimento de um estudo mais explicativo da realidade de saúde dos grupos populacionais, para além do rápido enunciado de alguns problemas conforme ocorrido durante algumas oficinas. 


\subsubsection{Da Vigilância Epidemiológica à Vigilância à Saúde}

As ações de vigilância epidemiológica no município, herança das competências antes exclusivas dos centros de saúde do Estado, na gestão anterior estavam concentradas no centro de saúde da cidade. Inclusive na reorganização administrativa da administração passada, ... nós tínhamos colocado ... que aquele passaria a ser um centro de vigilância à saúde (F199).

A vigilância de problemas de saúde refere-se a problemas potenciais e epidemiologicamente colocados. Trata-se de detectar o mais precocemente possível os problemas para acompanhar sua evolução e intervir mais eficazmente. Nessa linha, já existe um trabalho com a vigilância do recém-nascido, como também com vigilância da morte infantil e da morte materna, para, a partir da análise de mortes evitáveis, encontrar o que poderia ser modificado nos serviços para melhorar a atuação do sistema de saúde, reduzindo novas mortes evitáveis ao menos nesse âmbito de ação.

Antecedentes das ações de vigilância do recém-nascido na gestão anterior: Nós criamos ... uma caderneta do cidadão; a idéia era baseada naquela história da caderneta do médico de saúde da China. ... Nós transformamos o cartão de saúde em caderneta do cidadão, que a mãe recebia, a idéia era ... acompanhar o cidadão por toda a vida. Era entregue na maternidade, junto com um "Manual do Bebê", ... vinha em uma pasta onde tinha todas as orientações, começando com os dados de medição e peso. E ainda recebia um diploma assinado pelo prefeito. O primeiro bebê que teve isso era de um município vizinho. E quando a televisão foi filmar, a mãe falou assim: - Ainda bem que vim ter meu filho aqui; tem que levar isso pra minha cidade também. ... Eu acho assim, ... que a pessoa pobre, humilde, quando é bem tratada, dá muito valor para aquilo a que tem acesso, ... eles são muito mais solidários, se solidarizam com o pouco que tem. Então, ... dificilmente a mãe vai deixar de ter aquilo em um lugar especial, com o maior cuidado, ... é que esse filho é especial (F200). E as anotações de saúde acabam sendo mais valorizadas e bem guardadas. 
Foi engraçado que o hospital municipal adorou a coisa, foi uma coisa ... muito interessante e ... positiva a aproximação do hospital nessa história. Porque eles não tinham pensado nisso mas se sentiam orgulhosos que as mães saíssem tão satisfeitas. ... Depois nos hospitais particulares, ... acabaram criando um sistema de orientação própria, mas mesmo assim, em nome da saúde pública também entregávamos o nosso (F201).

Nessa cartilha ... vinha onde a mãe morava e transmitiam aquelas informações à equipe ou unidade. $\mathrm{O}$ pessoal fazia visita domiciliar, ... o registro no SINASC e $o$ encaminhamento. E passava os dados para a unidade, que provavelmente ... já estava acompanhando o recém-nascido. Era importante ... estar controlando os nascidos vivos, vendo sempre o risco; então se tinha anotado no caderno o tipo de risco e o quê que podia ser trabalhado pelo profissional de saúde. Quando é identificado como de risco, continua sempre fazendo visita. (...) Uma ação importante na parte preventiva é a vigilância de todos os recém-nascidos. Quando vem pra vacinação e pro teste do pezinho, já é agendado com pediatra para controle e se ... orienta sobre os grupos. Isso para todos os recém-nascidos da área de abrangência. (...) A partir daí são formados os grupos, eles vão e gostam. ... Alguns têm problemas de saúde e precisam receber a assistência adequada. ... A vigilância de recém-nascido continua sendo ... feita em todo o município. É um controle feito pela vigilância. (...) Também no ambulatório se faz visita domiciliar para busca dos faltosos da vacina e o trabalho do SINASC, que de acordo com uns 4 ou 5 itens ... o recém-nascido é avaliado, e ... conforme a situação ali, se considera de risco, risco social ou biológico. Daí a gente faz a busca pra passar orientações, através da visita, para lidar com os problemas de saúde na casa (F202-5).

Vigilância da morte infantil: Aconteceu uma morte infantil evitável, a princípio, por problema da atenção de saúde. Não dá pra admitir ... esse tipo de coisa aqui. Ah, mas é um só. Um só já é muito. Eu era assim muito perfeccionista, baixei um pouco a bola depois (F206). Ações de saúde e de vigilância, especialmente no sentido daquelas que podem exigir um acompanhamento contínuo, precisam ser reforçadas por estratégias de gestão capazes de evitar problemas de solução de continuidade e qualidade. 
$\mathrm{Na}$ atenção da criança, a imunização só não é realizada em algumas unidades. Mas a cobertura está boa, as crianças estão imunizadas. ... Só com a vacina antitetânica houve um problema, porque a epidemiologia não ... tinha vacina pra liberar pra todas as equipes do PSF fazer. Porque se todas as equipes resolvessem vacinar os adultos, não tinha vacina suficiente. Então começou ... só 3 equipes fazendo. (...) A maioria das equipes do PSF agenda a vacina. Eles não mandam a pessoa vacinar noutro lugar. Eles agendam tudo ... pra um dia, pegam um isopor uma vez por mês e vão buscar as vacinas, trazem tudo no dia e vacinam. ... Eles agendam as gestantes, as crianças, todos, ... e eles mesmo aplicam, não querem mandar a população deles pra outro vacinar. ... Isso que é o diferencial pra mim, porque a equipe dá um jeito nisso, ... tem coisas que eles não conseguem (F207-8).

Tuberculose e hanseníase está descentralizando, aí além dos ambulatórios gerais, quase metade das equipes do PSF já fazem o diagnóstico e tratamento (F209).

Com a denominação de vigilância domiciliar, na apreensão da necessidade da ação de visita na casa, percebe-se uma abertura nas concepções de vigilância: Hoje de manhã tinha um caso que eu observei lá no ambulatório, uma senhora com três crianças, aí perguntei pra enfermeira se as crianças precisavam de uma vigilância domiciliar. ... Porque enquanto o pediatra atende, a gente vê o que mais pode ser feito, se já encaixa também pra odontologia, se precisa outro atendimento, porque eu notei que elas estavam cheias de piolho, se a mãe foi bem orientada e tal. ... Quando a gente identifica um problema que ali no ambulatório não é suficiente pra dar conta, daí o pessoal vai e faz visita (F210).

No PSF todas as ... unidades trabalham com vigilância epidemiológica. E a vigilância epidemiológica se deu muito bem tendo as equipes do PSF, porque a pior coisa ... era quando tinha que fazer alguma visita ou fazer alguma vigilância ... de algum caso notificado e não tinha quem fizesse. Isso modificou com o PSF, porque o pessoal da rede trabalhava aquele número de horas e estava condicionado a não fazer nada mais do que aquilo, sair para fazer visita e tudo o mais. ... Então como eram 21 unidades no município, com o PSF aumentou muito a faixa de vigilância, e o suporte é a própria vigilância epidemiológica (F211). 
Antecedentes da vigilância sanitária: Na gestão anterior ... nós municipalizamos a vigilância sanitária, ... a idéia era fazer funcionar. ... Quando nós chegamos no município a sanitária tinha dois veículos, um fusca com o motor fundido e outro que estava no cavalete, não tinha como. O pessoal ia fazer a vigilância a pé. Agora tem uma boa estrutura. ... Criamos o selo de qualidade, uma idéia que copiamos de São José dos Campos (SP), ... o secretário de lá na época nos mostrou um dia ... como era. Criamos a lei e daí restaurantes, produtos alimentícios em geral, supermercado, feira, etc, ... estando OK recebia o selo. ... Embutido criamos um serviço de inspeção municipal. ... O grande problema que tivemos foi ... que após conseguir equacionar aqui, ... o nosso produto não entrava em outras cidades maiores que ... não aceitavam a inspeção municipal (F212).

Para um adequado desdobramento das ações de vigilância sanitária na rede básica, ... essa área era orientada pelo faisqueiro (agente comunitário do Projeto Faísca), que também era preparado para acompanhar os estabelecimentos em geral. (...) No PSF tem a vigilância sanitária trabalhando com controle de alimentos já em algumas equipes, com medicamentos, dejetos e destino de lixo. Só que controle aqui não é controle, ... eles não tem ... nem a autorização, ... não estão legalmente aptos para fazer a inspeção, fiscalizar e autuar. ... É só um trabalho ... mais preliminar, ... é concentrado em orientação, porque a questão da inspeção mesmo, reconhecida, ... na maioria eles chamam o pessoal da vigilância do município pra fazer (F213-4). Na prevenção de riscos e vigilância à saúde tem muito de vigilância sanitária que pode ser feito na rede básica.

Os fiscais da vigilância sanitária passaram por um curso de capacitação agora. ... Pela primeira vez eles estão tendo contato com uma visão um pouquinho menos policial da coisa, com uma proposta de modelo diferente. (...) Tem uns que participaram, outros que se negaram a participar, a gente deu acesso para todos. ... Tem muita diferença no discurso, de ... quem está fazendo o curso e quem não está. E não só no discurso, na ação também. Porque com esse pessoal, antes mesmo de fazer o curso, ... a gente fez uma proposta de trabalhar com aqueles grupos de pessoas que não tem higiene, pelo menos vai dar uma noção mais adequada para elas, educar, fazer palestras. Só que é 
um trabalho que não aparece, porque já atenderam não sei quantas mil pessoas, deu pra aumentar bastante ... a postura educativa também, não só fiscal (F215-6).

Nós estamos tratando de melhorar cada vez mais ... o setor de vigilâncias. Investiu-se bastante na vigilância sanitária, para que eles possam realmente fazer o trabalho nas indústrias e tudo o mais. (...) É uma idéia melhorar a atenção à saúde do trabalhador, nós temos a CEREST (central de referência de saúde do trabalhador), que é o órgão que cuida exatamente da atenção ... das doenças e acidentes de trabalho. ... Estamos tentando chamar a atenção para a situação, levantar as firmas que têm mais problemas, ver o que está ocorrendo, aumentar a fiscalização, quer dizer fazer então uma prevenção de riscos, pra tentar diminuir ... a incidência das doenças ocupacionais (F217-8). A idéia é chegar a fazer a vigilância da saúde do trabalhador, ainda não se avançou muito nesse sentido.

É de praxe definir a linha de ação dos agentes comunitários em reunião técnica dentro da equipe do PSF. Assim: O que a gente precisa fazer agora, o que se observa como profissional de saúde, que está mais assim problemático? É a questão do lixo. Por que apareceu o lixo? Apareceu um rapaz no posto, com uma mordida de rato no dedo. Ele achava que era uma picada de aranha. Então assim, essas coisas a gente precisa ter mais claro. E se procura o apoio da comunidade, para trabalhar aquilo ... que é mais emergente, ... evitando constranger ou humilhar a pessoa, ... fazendo com que se sinta diminuída. ... É, o profissional de saúde precisa ter um baita preparo para esse tipo de trabalho, como conseguir orientar a captação mais precoce de necessidades epidemiológicas através da demanda espontânea. ... Então nós trabalhamos também com lixo (F219).

Nas ações do PSF, ... como enfermeira eu procurei trabalhar sempre com bastante contato com a comunidade. Participei do orçamento participativo, ... na escola com palestras, e caminhando pela comunidade inteira junto com os agentes de saúde, para conhecer toda a região, saber de onde vem a água, onde ficava a caixa coletora, qual era o tipo de água que a comunidade estava usando; para, a partir daí, poder trabalhar os problemas de saúde. E ... trabalhando nos grupos também se identificava qual era o problema que estava incomodando mais (F220). 
A prática sanitária da vigilância à saúde ... depende de uma infra-estrutura; o cara tem que ter tempo para sentar, fazer uma estatística, por exemplo, anotar no mapa onde estão os casos de notificação, ... para fazer a vigilância. E outra coisa é fazer o controle daquilo no tempo, a tempo; o pessoal ... ainda não entrou nesse ritmo não. Eles estão muito ainda dentro da atenção à demanda espontânea (F221).

Na sua organização de atendimento à demanda, em geral as unidades do PSF fazem ... de manhã atendimento às pessoas que têm problema emergente. Nós pegamos uma planilha, onde o médico anota todo dia o nome do paciente, idade e o tipo de queixa. E por ali ... então nós fizemos um levantamento desses problemas. O quê que nós tivemos de atendimento no mês passado - março de 2000? Então, o maior problema foram as infecções das vias aéreas superiores, e depois as leucorréias (sic), que é um problema que tu podes amenizar com a questão da informação, tem palestras, grupos, para trabalhar mais em cima disso, o que vai reduzir essa demanda específica. E a dor, tem pessoas que vão lá só porque estão com dor, nevralgia, ou qualquer outro tipo de dor. Então tudo coisas que nós podemos tratar na prevenção para diminuir essa demanda de manhã. E assim a gente vai organizando melhor o serviço. (...) É muito 'importante fazer a captação do risco na demanda espontânea curativa, é só ficar atenta' (F222-3).

A integralidade no PSF: Eu acho que ao nível de ponta o que dá o caráter integral que $o$ PSF trouxe, a integralidade que o PSF trouxe, foi a questão de suporte epidemiológico, porque a unidade por fazer de tudo, faz a vigilância em saúde mesmo (F224).

No âmbito do conjunto da apreensão empírica da vigilância à saúde foi possível obterse uma nuance de como se recortam alguns objetos em um trabalho com a integralidade.

Nos próximos sub-itens (4.2.3-5) são enunciados os objetos do trabalho referidos pelos entrevistados e quando explicitadas são esboçadas algumas de suas características. 


\subsubsection{Instrumentos da Atenção Básica Direta}

São apresentadas algumas ações e instrumentos de trabalho na rede e no PSF (*), conforme referido pelos entrevistados. Ao não se penetrar no campo propriamente técnico das formas de operação das ações, são apontados somente alguns instrumentos e princípios orientadores da ação, pretendendo assimilar como se situam na perspectiva de mudança do modelo de atenção.

\section{O trabalho de alguns agentes}

Bem poucos profissionais de nível local em operação foram ouvidos. Algumas falas sobre o próprio trabalho são apresentadas descritivamente, como também aquelas referências feitas ao trabalho de outras categorias, sendo muitas auto-explicativas. $\mathrm{Na}$ representação dos entrevistados, os principais agentes do trabalho na rede básica de saúde são os agentes comunitários de saúde, auxiliar de enfermagem, médico, enfermeiro, assistente social e dentista, entre outros profissionais mais esporadicamente referidos como os técnicos de vigilância sanitária, psicólogos e nutricionistas.

Os agentes comunitários juniores de saúde eram o pessoal do Projeto Faísca, que fazia um trabalho muito bom. ... No cadastro identificavam gestantes, casos de hipertensão, quem estava hospitalizado, aquele trabalho do agente. Eles só não faziam procedimentos de nenhum tipo, nem verificar temperatura, conforme ensinado pela gente. (...) A principal atividade do agente é a visita domiciliar. ... O agente de saúde é o contato da comunidade com o serviço. ... A gente procurou sempre mostrar para eles ... a importância de buscar as coisas para a comunidade. Porque eles já são moradores dali, ... eles tinham essa característica. Um tipo de ação que a gente insistia: Nós temos que nos relacionar melhor com a comunidade (F225-6).

(*) Apesar da rede básica incluir tanto as unidades com equipes do PSF como as demais que prestam serviços de atenção primária à população, durante o texto manteve-se a forma de expressão empírica de referir-se à rede somente para o conjunto de unidades excluído o PSF. 
No PSF atendimento clínico, só quem faz é o médico, ... que atende também pediatria e ginecologia. Esse mesmo clínico que só atendia adulto em geral, veio atender mulher, criança, o avô, a grávida, o homem e a mulher. (...) Havia que ser um bom “consultador" (F227-8).

A consulta do médico de família é generalista e na rede é só clínica médica ou ginecoobstetrícia ou pediatria. Como eu sou médico generalista, atendo todas as faixas etárias, então para mim, ao sair do PSF, era melhor continuar numa unidade em que pudesse fazer esse atendimento. Porque o clínico normal que seria meu trabalho, só atende adulto, a clínica médica. (...) A única unidade que sei que vai trabalhar com isso tudo é a minha. Porque sou só eu, de médico comunitário, que se predispõe a fazer isso. ... Aí como eu posso fazer 6 horas, assim posso continuar meu trabalho geral comunitário, na verdade não sei fazer outra coisa a não ser isso. (...) Antes eu atendia uma área, vamos dizer assim, uma área dobrada em relação a essa unidade onde estou agora. Tinha uma área mais carente e outra menos carente. A menos carente tinha mais estrutura no serviço, essa área ficou comigo - como médico da rede. Ali eu faço todo o atendimento de todas as faixas etárias. Porque ali não precisa de uma equipe e tudo mais. ... E a outra área mais acima, onde era mais necessária uma equipe do PSF, eles alugaram uma casa, para colocar uma unidade lá. Aí vai ter o médico de família, com 8 horas, que é a necessidade de todo mundo. Essa que é a diferença com a rede, no geral os clínicos que só trabalham em ambulatórios gerais ou unidades básicas que não estão no trabalho do PSF, eles fazem 3 horas e atendem só clínica (F229-31).

No PSF havia um trabalho médico além de consulta, que era basicamente trabalhar também com grupos e ... com a comunidade, não ia muito além disso. Porque a gente não tinha estrutura pra mais, a secretaria não estava organizada pra fazer muito mais. Mas isso tinha que ficar claro pra equipe, que o trabalho se diferenciava pelo menos nesse sentido (F232).

Características da prática médica representada: $O$ cartão de visitas pro médico é a consulta. E nisso eu me excedi. Então era o meu trabalho, apesar de também trabalhar em grupo, visita domiciliar, fim de semana, não importava o dia, sempre mantendo o 
acompanhamento dos pacientes internados. E então isso aí me desgastou bastante, porque tinha uma demanda muito grande para consulta, eu atendia bastante. Mas nesse meio tempo a minha bateria arriou. Fiquei muito cansado e desgastado até. (...) Geralmente todo meu paciente tem o seu retorno vigiado; seja de exame, seja de tratamento antibiótico, qualquer coisa. Qualquer tratamento que eu inicie, depois eu tenho que ver no final o que o tratamento está tendo de volta. $E$ as gurias se adaptavam. Eu acabo atendendo a mais. Mas pelo menos eu sei se aquilo foi efetivo ou não. Só não tenho feito muito mais a parte de grupo, de informação, porque a demanda chegava a ser muito grande. (...) A gente só reduz alguma coisa, normalmente reduz o número de visita domiciliar e tudo mais. Porque você já não tem mais aquela disposição de tempo, mas o restante continua (F233-5).

As referências havidas sobre a prática médica revelam uma efetiva mudança do atendimento médico com o PSF: Eu lembro que quando eu entrei em 94 o médico era aquele um que entrava no consultório, atendia e ia embora sem falar com ninguém. Hoje em dia ele conversa com uma equipe multiprofissional, se envolve com grupos $e$ hoje já tem, ás vezes, ... até uma leve disputa, vamos dizer assim, entre aquele profissional que trabalha com grupo e o outro ficando enciumado (F236).

Por outro lado, no conjunto do PSF, do ponto de vista do gestor atual, a coisa não estava funcionando, considerava que o posto estava exatamente com essa imagem. A comunidade sabia que ali tinha um programa específico - o saúde da família. E o pior de tudo isso é que o programa estava incompleto, quer dizer, os programas estavam com as enfermeiras, estavam com tudo, mas não havia o essencial que era o médico. ... Até pode receber um curativo da enfermeira, que pode ajudar também, mas quem vem no posto quer o atendimento da pessoa que, digamos assim, é qualificada pra isso - o médico. ... Porque quem está doente quer o médico, ... é o médico que resolve mesmo (F237). A idéia explicitamente aqui colocada era uma concepção do serviço centrado no médico, tudo girando em torno dele. 
Por referência ao papel do médico especialista: Não é comum a gente ter cirurgião na gestão pública, não é? Eu não me lembro de ninguém. (...) Um cirurgião atende a pessoa, é um problema muito específico (F238). Mas essa ação poderia estar respondendo a um problema coletivo.

Quanto ao enfermeiro no PSF, além das outras atividades relacionadas com o profissional de enfermagem, a gente procurava fazer o preventivo e o curativo; visita domiciliar se fazia bastante. Na casa, procurava sempre estimular o autocuidado, não deixar que o paciente achasse que a gente ia estar ali para fazer tudo. ... Deixava-se material para eles poderem fazer curativos em casa, e a gente ia fazer avaliação para ver se estavam fazendo de maneira correta. Por exemplo: Oh, sua esposa precisa de curativos todos os dias, ela está magra, pode vir a ter feridas e tal. Então orientar tudo o que pode ser feito para prevenir escaras e outros problemas que uma pessoa acamada tem, o risco de pneumonia, então tudo que podia ser orientado era orientado. ... Havia pacientes com problemas respiratórios, que precisavam de visita. E curativos, vacinas, exame preventivo, pré-natal, puericultura. Tudo igual à atividade do enfermeiro dentro de uma unidade de saúde. A parte administrativa fazia também, o planejamento (F239).

Ano passado se avançou um pouco no sentido do acolhimento, porque segundo o acolhimento de Betim (MG), a enfermeira tem atribuições diferenciadas, ... que ela realmente exerce e aqui isto não é ... (permitido), não está acontecendo. Não podem estar exercendo mais ações como estar resolvendo alguma coisa no caso de ... DST, por exemplo. Tem consulta de enfermagem? Tem, mas elas não podem prescrever nem medicação e nem exames. ... Até tinha uma comissão ... vendo isso, mas não avançou muito, esbarra em várias coisas. Então a gente procurou outra alternativa que foi conversar com os médicos, para ao atender uma pessoa que toma medicação contínua, em vez de tirar uma consulta pra só passar uma receita, então que ele atenda mais um e só passe a receita. ... Na verdade essa vaga se daria sempre para o acolhimento. No ambulatório tem 4 clínicos e 3 estavam fazendo isto, mas ainda esbarrando em algumas resistências. (...) Veja só, falando do acolhimento teve um médico que disse: "mas tem outros profissionais que não são enfermeiras e estão fazendo isso"; ... e aí eu culpo as 
enfermeiras por deixarem este espaço pra outros profissionais que não deveriam estar fazendo aquilo (F240-1).

A atividade de supervisão, quem faz é o enfermeiro, pois pelas capacitações que eles participam ficam mais bem preparados. (...) A supervisão, muita enfermeira desistiu, porque não recebia adicional para fazer a supervisão. Mas um grupo fez questão de continuar, justamente para manter essa visão. Quer dizer, tem a questão econômica e tudo, mas se a gente está lá fazendo um horário de trabalho, pode estar ajudando também nessas atividades. Então eu acho que dá pra conciliar bem, se a gente quer mudar alguma coisa. Não tem outra maneira (F242-3).

Antes enfermeiro era só cuidar da área administrativa, e ... agora tem vezes que, além das suas atividades da profissão, faz as duas coisas. (...) No nível central ou regional, ... aquela parte de coordenação da categoria que a enfermagem fazia, hoje não tem mais na secretaria; isso significa que não tem ninguém que escute uma auxiliar de enfermagem que brigou com o marido, ou ... tem que sair mais cedo porque está estudando à noite. Não tem mais uma representação da enfermagem (F244-5).

O trabalho do assistente social fez um percurso da triagem econômica às atividades com grupos: Em 94 entraram 5 ou 6 assistentes sociais que a gente pensava que era para fazer um trabalho de educação em saúde nos ambulatórios gerais, sendo o histórico do serviço social na secretaria já anterior a isto. (...) Mas acontece que com aquela demanda de alto custo e de medicação que não havia na rede básica, as assistentes sociais foram fazer vários trabalhos de ... triagem, com avaliação sócio-econômica. (...) E algumas ... não aceitavam isso porque entendiam a universalidade do SUS. É aquela coisa de ficar triando quem vai receber e quem não. ... A gente batalhava muito para mudar isso, já que a idéia da administração anterior era esta - ou fazia isto porque precisava, ou, ... não precisa assistente social na rede (F246-8).

Mesmo fazendo aquela avaliação sócio-econômica de triagem pros exames de alto custo, se conseguia fazer algumas atividades coletivas. ... Então depois de muita batalha e luta, conseguiu-se aos poucos começar a trabalhar com grupos. ... Sabe-se 
que ainda é feito pouco em relação ao SUS. (...) Só que naquela época não tinha tanta demanda, e agora elas têm pouco tempo para essa demanda dos grupos, ... porque a assistente social está envolvida no planejamento e avaliação, ficando mais a frente desse trabalho. Os outros profissionais só vêm depois que ela chama, principalmente para avaliação (F249-50).

Outra característica a registrar é que as assistentes sociais trabalham muito intersetorialmente, com a secretaria do meio ambiente e outras, ... elas sempre estão fazendo ações inter-setoriais, pode ser pela formação (F251).

A estruturação dos serviços de odontologia sanitária no município foi precursora da mudança do modelo de atenção: $O$ trabalho que eles vêm desenvolvendo é muito interessante. ... No bairro tal, falando da parte preventiva da odontologia, atendem todas as escolas, uma vez por semana vão pros colégios, dão todas as orientações, é feito exame do pré até a $4^{a}$ série e é encaminhado sem passar por fila para o ambulatório (F252).

Existe um trabalho de acolhimento na odontologia: Conforme a necessidade, ... faz-se orientação antes de entrar pro tratamento, eles mostram, como se faz a escovação, o uso do fio dental e aplicação de flúor. (...) A reclamação é que tinha filas enormes, muitas pessoas sempre pra marcação, aí se estipulou um dia fixo pra marcação, uma vez por mês. E se utilizou um método que é a manutenção como a gente chama, é assim, a pessoa que fez todo tratamento e teve alta, se ela voltar em menos de um ano ela não entra na fila, só vai lá e marca. E com isso a gente está conseguindo acabar com a fila. (...) Tanto é assim que outro dia uma gerente ... colocou carro de som em duas localidades bastante carentes. Eu fiquei apavorada pensando que no outro dia de manhã ia ter fila quilométrica e tinham só 140 pessoas, ... quer dizer, como se está conseguindo o atendimento com mais facilidade, então está reduzindo a fila e o método da manutenção também está propiciando isso (F253-5).

No trabalho da odontologia na saúde pública constatou-se, na representação social dos profissionais dentistas entrevistados, de forma associada à sua opção pela saúde pública, a busca de uma solução para a angústia derivada do seu desejo em ampliar o 
conteúdo específico da profissão, ao mesmo tempo em que parece haver uma sensação de que está tudo desenhado para afunilar. Manifestava-se um desejo do cirurgiãodentista de ir além da boca: Quando fui trabalhar em consultórios dentro de escolas, era um ambiente onde eu podia interferir em outros setores, ... $a$ educação era meu ponto de partida. ... Então, ali nas escolas, ... eu pude me expandir um pouco nesse sentido, sair mais do consultório e fazer essa parte de ações coletivas. Eu vi assim, ... mas por intuição mesmo, que sem envolver o professorado eu não ia chegar a lugar nenhum, pelo menos naquele ambiente. Então eu ficava ... disponível para trabalhar em sala de aula, ... participava nas atividades da escola e festas de fim de semana, e aí entrava com $o$ trabalho educativo da odontologia preventiva. ... Aqui, por ser uma cidade menor $e$ a família estar mais próxima, dá pra você chamar pai e mãe para fazer a atividade junto. Eu falava pai e mãe não tem que mandar filho escovar dente não, deixa teu filho escovar teu dente um dia. Ou, tira tua dentadura e dá na mão do teu filho para ele escovar (F256).

Na visita domiciliar o maior trabalho quem faz é o agente de saúde. Depois o auxiliar, depois o enfermeiro, depois o médico. E na reunião de comunidade não é muito diferente. São mais ou menos os mesmos profissionais, como também nas reuniões de equipe, ... ou em grupos educativos (F257). Isso com relação aos profissionais ora referidos, porque essa relação muda com a entrada de outras categorias como as assistentes sociais nos grupos, especialmente.

\section{Instrumentos das ações - na rede básica \& PSF}

Como antecedentes da localização e estruturação das equipes tem-se: todos os PSF foram criados em cima de um trabalho de bolsões de pobreza feito na cidade pela secretaria de assistência social em 1994. No início a gente elegeu ... critérios pra escolha dos lugares das equipes. ... E fizemos as duas primeiras equipes - uma em um ... CAIC (Centro de Atenção Integral da Criança) de maior capacidade, e ... tendo um espaço pra unidade, e ... a localização da outra foi por pressão política da comunidade, uma reivindicação já antiga, era em um ambulatório novo ... que estava sendo construído. (...) Hoje tem 21 equipes de PSF, sendo que são 19 lugares, tem dois que 
tem equipe dupla. ... Talvez 3 ou 4 destes 19 não são os lugares mais prioritários, é que agora através do conhecimento maior que a gente tem da própria região se saberia disponibilizar melhor esses equipamentos em regiões mais necessitadas. Como também, ... hoje para criar um novo PSF é muito mais fácil ou se você quiser remover uma equipe de um lugar pra outro, por se ter as regiões já mapeadas (F258-9).

No âmbito das unidades avançadas já havia uma ... territorialização do PSF, e dentro deste território eram escolhidos os agentes comunitários. ... Eram 16 agentes por equipe do PSF. A gente fez um cálculo na época, era pra ... ficar 100 a 200 famílias por agente, na média era 150 famílias pra cada um supervisionar. (...) Com esses agentes comunitários juniores fez-se o Projeto Faísca. ... Os agentes comunitários começaram a trabalhar na época das duas primeiras equipes, ... que em outubro de 93 já estavam formadas. E tudo isto ajudou a diminuir aquele impacto da demanda no hospital (F260-1).

Cadastro e demanda: O trabalho do PSF começa com o cadastro. Tinha algumas equipes que não concluíam, estava muito devagar, porque a demanda do serviço era muito grande. ... E o cadastro ia ficando incompleto, ... por não conseguir acabar, não chegavam nas 1000 famílias, era muito trabalho, muita coisa. ... Quando abria um PSF, ao começar uma equipe, a demanda aumentava, ia lá em cima. Primeiro porque todo mundo queria ver como era, e segundo que se achava mais demanda, porque pelo cadastro fazia um rastreamento e encontrava quem era diabético e não sabia, quem era hipertenso e não sabia, quem era ... tudo aquilo, captava grávidas de vez em quando, e assim ... achava trabalho. (...) O cadastro estava sendo feito ... mais ou menos no tempo determinado, mas a maioria não tinha terminado, então fomos ver o que estava acontecendo. Ao fazer uma análise, vimos que a demanda muito grande era mais em cima da demanda espontânea, e eles estavam meio loucos, atendendo todo mundo. (...) O pessoal da saúde da família está treinado pra agir e agiram. A partir daí, ... as ações foram $50 \%$ pra orientar e divulgar, organizando a demanda e busca ativa. Então está muito em cima disso ainda (F262-4). 
Em uma avaliação feita este ano (1999) constatou-se: Só 85\% das equipes cumpria o cadastro. ... Como é que eles não terminaram o cadastro se em dezembro de 98 foi feito o recadastramento de todas as equipes, era uma exigência do ministério da saúde. Quer dizer, eu interpreto aqui, é uma hipótese, que essas equipes que responderam que ainda não tem o cadastro, ... eles entendem assim por uma questão do processo de cadastro. ... Todas as equipes fazem assim, quando ... muda uma família, retira do cadastro e se entra uma família nova, acrescenta no cadastro. E isso é processo, sempre é assim. Ao terminarem o cadastro daquela área deles, essa é a área e a população. ... Agora, se nesta equipe, esta família for embora, claro que tem bastante migração, tem que tirar do cadastro, se eles interpretaram isso, faltava mais era uma atualização do cadastro (F265).

O isolamento de um profissional frente a esse movimento da demanda: Então é assim, é coisa do meu mundo. Na verdade é uma área de muita migração e a gente pega esse pessoal que vem mesmo para essas áreas de risco, área de coisa. Então assim, você tem que acabar reorganizando o serviço todo com essa demanda nova (F266). Mas esse problema se repetia em praticamente todas as equipes. Era um problema a partilhar para no conjunto buscar encontrar soluções possíveis.

Em uma ilustração da avaliação de impacto do PSF na gestão anterior: Tem muita equipe que a gente implantou mas nós tivemos contato com os profissionais contratados em 1996 durante 6 meses, não deu pra arrumar a casa. .. Nas duas primeiras equipes que foram equipes piloto, ... conseguiram uma média de ... redução em torno de 120 AIHs (autorizações de internação hospitalar) por mês num bairro. Isto é o equivalente a mais ou menos 6 a 7\% do volume total das AIHs do município. Então é aquela história, por exemplo, do controle do diabético instável, isto diminuiu muito o número de internações. ... Embora não seja a situação de Cuba, que começou tudo só com 5 médicos, nós tínhamos esta visão, de resolver o problema o mais precocemente possível (F267).

Ao iniciar o atendimento pelo PSF a gente fez uma priorização, que no primeiro momento era a atenção materno-infantil. Na agenda, de cada dez consultas seis era 
materno-infantil, tinha que ser. Sabia de outros trabalhos que, se investisse em materno-infantil bastante coisa teria cobertura (F268).

Atividades de prevenção na atenção médica: Aumentou muito o tipo e o número de atividade, especialmente as de promoção e prevenção, as de cura também aumentou bastante, até umas coisas que não eram feitas antes. ... Por exemplo: Fazia pré-natal? Fazia, 30\% das unidades faziam o pré-natal. Só que dentro desse pré-natal, ... só fazia consulta médica. Não usava o protocolo, onde tem tudo especificado. ... Mesmo fazendo o pré-natal, na consulta médica o profissional não usava o cartão da gestante, não fazia antitetânica, não fazia avaliação nutricional, e não tinha o sulfato ferroso. Quer dizer, naquela atividade, era aquilo, concentrado na consulta médica e sem continuidade. (...) Na saúde da criança, também só fazia a consulta, nem a avaliação nutricional era feita. Já o prontuário familiar todos usam (F269-70). Isso ajuda a organizar o trabalho.

Somente não é realizado pelas equipes do PSF: consulta ginecológica nas equipes que não tem um médico ... da saúde da família; aí ficava um médico clínico da secretaria, marcando ... e atendendo no SUS os pacientes de maior emergência. DIU? Só 3 ou 4 equipes colocam o DIU. Isso é só falta de capacitação do profissional. Já receberam o material, porque tem DIU em quantidade suficiente ali no nível central, onde era referência antes. O Papanicolau feito por médico é uma pendência, porque $100 \%$ dos enfermeiros das unidades fazem o Papanicolau. E só a metade dos médicos faz. Mas a atividade não está deixando de ser feita (F271).

A rede faz todas as ações anteriores menos o cadastro: $\mathrm{O}$ atendimento no PSF era $a$ mesma coisa ... que atender num posto com a mesma carga horária, e às vezes alguém precisava de um ambulatório com seus ... programas específicos, aí encaminha. (...) No ambulatório geral, a gente está vendo ... uma vontade muito grande de ... estar desenvolvendo mais ações preventivas. ... Essa sim é uma meta importante, de um grande grupo, praticamente ... $80 \%$ da equipe tem essa visão de trabalhar a prevenção. O PSF deveria fazer mais prevenção que nós. Será que faz? A única diferença é ... porque no PSF tem os agentes comunitários que fazem ... o cadastro. (...) Porque assim se tem a realidade de todas as famílias, e aí pode trabalhar essa 
realidade; nós não temos isso. Nós temos aquilo que vem na nossa demanda. $\mathrm{O}$ diferencial está no cadastro, onde tem todas as informações necessárias para fazer um trabalho maior, mais preventivo. ... Então nós não sabemos de toda a nossa área, a gente não conhece. E a gente espera que agora em algumas partes vai poder estar desenvolvendo outros tipos de ações. Agora, se vier o agente para a rede, me diz qual é a diferença? Tem diferença? Não tem (F272-4).

Acolhimento à demanda espontânea: A proposta de acolhimento partiu da equipe de um ambulatório geral. (...) Desde o ano passado a gente passou a se reunir uma vez por semana para discutir o acolhimento a partir de relatos sobre a experiência do Projeto Acolhimento de Betim/MG. Realmente temos intenção de estar aplicando este acolhimento. ... A gente estudou e esbarrou só na falta de profissionais. ... Volta e meia se quer avançar e tem de dar uma recuada. Esse começo do ano 2000 tem que deixar assim, até engrenar leva um tempinho. ... Só se retomou a questão da marcação, tentando organizar melhor a demanda (F275-6).

Eu entendo que o acolhimento é toda aquela forma de conversar com o usuário, como nós estamos fazendo agora. É assim, o usuário vem pra fila, os que não conseguem consulta vão conversar com a enfermeira. Então é explicado a situação, ... ou de repente dá pra esperar, ou se vê o que pode estar sendo feito até conseguir a consulta. ... Orienta-se que cada região tem sua área de abrangência, que deveria procurar lá, mas se realmente precisa é lógico que a gente dá a atenção. ... E conforme o caso, se foi ali só por ir, ou falta de informação, e topou numa boa voltar e procurar uma unidade próxima da sua casa, aí tudo bem (F277).

Demanda versus vigilância: Que se reportam a esse ambulatório geral tem ... cinco equipes do PSF. Mesmo assim, ... até por sinal, o pessoal da comunidade nem estava mais indo lá no PSF, diziam que lá não conseguiam consulta e aí vinham direto pro ambulatório. (...) A gente até recrimina este procedimento, porque assim se deixa de atender nossa área de abrangência pra atender quem tem PSF. E nem é só isso, mas é que não se faz vigilância, porque se o prontuário está aqui, como é que vão saber que a pessoa veio no médico daqui, se foi medicada ou ... teve tal intercorrência. (...) A gente 
não está fazendo assistência por assistência, mas fazendo vigilância. ... Então se argumentava desta forma com o usuário, sempre procurando organizar a demanda. (...) Aí a gerente fez uma determinação por escrito, final do ano passado (1999), que a partir de tal data o usuário do PSF só seria atendido no ambulatório com encaminhamento do PSF. Alguns resistiram e ... conforme a situação, é lógico, a gente até atende e diz que da próxima vez ... tem de trazer o encaminhamento (F278-81). Assim não tem mesmo a livre escolha do profissional, por via de regra ficando a opção restrita ao médico do PSF ou ao especialista encaminhado pela unidade.

Um exemplo de acolhimento foi com o exame preventivo. Como ... a gente só tem uma enfermeira fazendo a coleta lá no ambulatório, as vagas são limitadas e tem uma demanda de umas 7 a 10 pessoas além das vagas. ... Então foi conversado uma a uma pra ver quem estava com problema, para ... passar pelo ginecologista e depois fazer o preventivo. Fez-se um trabalho de orientação e realmente se conseguiu agendar todas que precisavam naquele momento e encaminhar pra outros serviços as demais. Todo trabalho de orientação foi muito importante porque também é uma forma de prevenção (F282).

No ano passado o que se teve de maior dificuldade foi a falta de material. E se discutia a proposta do acolhimento, ... aí vem aquela jogadinha do funcionário dizer: "Olha, se não tem nem material pra trabalhar, o que é que vocês querem mais de nós?" ... E realmente paralisamos 3 ou 4 vezes a clínica odontológica por falta de material, é um absurdo, ter que mandar o usuário voltar, ir embora. (...) Isso até poderia ser uma razão a mais para se solidarizar com o usuário e ver o que se pode fazer. ... Pra avançar é uma coisa muito lenta, ... não sei se já é hora, é tudo um amadurecimento (F283-4). Este dado empírico refere ao entendimento de que em organizações profissionais a mudança é incremental.

Isso tudo varia demais de unidade pra unidade. ... Na nossa experiência, ... desde quando se criou o PSF naquela unidade, o pessoal fez o treinamento do acolhimento e assim todo mundo que chega lá tem que ser atendido. E essa era a ordem do secretário, principalmente pro PSF. O cara tem que ter o problema dele ouvido, tentado solucionar. Você pode não resolver, mas vai encaminhar para uma resolução. O PSF 
não podia nunca deixar de dar uma referência para algum problema de alguém que chegasse. Mas a demanda era sempre espontânea. Fora quando fazia alguma visita e encaminhava ou agendava. (...) Então, por exemplo, a minha dinâmica é assim, a gente tem os casos agendados, tem um horário que atende agendados e retornos, e tem um horário do dia que é o pessoal que vem na demanda, ... é um pronto-atendimento com consulta o mais rápido possível (F285-6).

Avaliação da satisfação das expectativas do usuário: Entre alguns profissionais falamos sobre a possibilidade de estar retomando o acolhimento. Em uma pesquisa interna do ambulatório constatamos que estava tudo muito pro lado assistencial. ... Foi uma pesquisa ... informativa, para saber se as pessoas já conheciam os nossos grupos preventivos, aceitando sugestões, se na sala de espera eles queriam falar sobre algum tema e qual, e como estava a marcação. Realmente a questão é a marcação, é o horário do médico, que muda horário e tal. Apresentamos os resultados para os funcionários, ainda vou passar a limpo porque só coloquei num cartaz pra apresentar. Foi ouvida uma amostra de mais de 100 usuários, achei muito pouco (F287).

Resultados do PSF na organização da demanda: Agora eu te digo uma coisa, se tu quiser ver o resultado, pergunta pro pessoal lá no pronto-socorro - quando o PSF está de folga, o que acontece? Ou, quarta-feira, quando tem reunião do PSF, o que acontece? Pergunta aqui no ambulatório geral, ... agora neste momento enquanto estamos conversando, que está sem médico do PSF, pode perguntar ali na portaria. Então as pessoas assim, falam tão mal, ... mas o PSF está se reunindo de novo, não é? ... Sem perceber as pessoas dizem da necessidade. ... Em vários lugares, aqui no ambulatório geral, pode perguntar, ou no pronto-socorro, ... pra quem está ali no diaa-dia, atendendo o balcão. As pessoas percebem a diferença. Até elas te dizem o dia que o PSF se reúne - $4^{a}$ feira, porque é o dia que fica mais cheio. É interessante pegar o discurso das pessoas neste sentido, não é? (F288) Estas expressões confirmam a absorção pelo PSF de uma importante demanda potencial dos serviços de prontoatendimento. 
Quanto à dispensação de medicamentos: Ainda há muita reclamação de falta de medicamentos. Se tu falas que vais comprar um medicamento no mês que vem, e chega o mês que vem e não tem o medicamento, o pessoal vira e fala: Voltou tudo à gestão anterior. (...) Em muitas unidades é freqüente não ter o medicamento pra hipertensão, ... nem pra diabetes em outras tantas (F289-90).

Dentro da policlínica de referência tem uma farmácia básica, é a grande farmácia popular do município. Cada unidade básica tem uma farmácia, mas o montante do medicamento está aqui. E os controlados também, porque aqui fica uma farmacêuticabioquímica. ... Pelo número de habitantes, teria que ter 57 itens; nós temos 117. E ainda não conseguimos suprir a necessidade. ... Antes as pessoas faziam aquelas filas na secretaria de saúde, pra falar com o secretário, com o financeiro; aquilo pra mim é degradante, então eu via isso e me incomodava. E comecei a trabalhar em cima de uma proposta que levei ao secretário, houve alguma resistência, mas depois aceitaram. E eu gerei, aqui dentro da policlínica, também um serviço de atendimento àquela receita que não tem o medicamento na farmácia. Conseguimos uma verba da secretaria e o serviço social ajuda a lidar com essa demanda. Então aquele caso da criança febril, que chegava aqui em estado grave, precisando de um antibiótico que não tinha, e que não tendo pra onde ir, a mãe com o filho no braço vai pra secretaria, pra ação social, isso não existe mais. (...) Vem pra assistente social do ambulatório e aqui a gente usa a universalidade, não é feito o sócio-econômico, apenas é um caminho pra também não ficar tão fácil pra qualquer BMW. Você entendeu? E pra ter alguém também controlando essa verba da farmácia. O usuário recebe aqui o medicamento na mão, a farmácia nos traz (F291-2).

A gente só não atende medicamento de uso contínuo acima de 3 meses. Por que?Porque se fizer isso tem uma lista de 100 na espera. Então a gente atende assim: os casos agudos, ou auxilia até 3 meses, ou um mês sim, um mês não; quando é 6 meses. Isso tem contribuído para essa população não fazer mais fila na secretaria; e diminuiu aquela demanda lá, que era extremamente inadequada; um uso indevido de verba, porque o gabinete do secretário não é lugar para isso. E a gente gerou um serviço novo e com isso está construindo o quê? O que parece que não está acontecendo - nós 
começamos a mudar a lista de medicamentos da farmácia. ... A gente fez uma pesquisa dos mais procurados que não havia. Então na verdade é uma nova política local de medicamentos. (...) É, a gente gera toda uma história com um movimento que parece pouco significativo. ... Este também foi um serviço gerado com alguma resistência, ... num primeiro momento, mas que ... valeu a pena (F293-4).

\subsubsection{Sistemas de Referência}

As ações locais de recuperação e proteção da saúde, sobre os indivíduos e coletivos, tem implicado numa expansão também qualitativa da rede de serviços locais, o que por coerência com o cuidado integral à saúde das pessoas, impõe referências programadas. Fica clara a indispensabilidade de sistemas de referência, como contingência de toda rede básica de saúde: Nesta gestão começamos um processo de organização da rede, não só a atenção primária, mas o que vinha depois, em atenção secundária. Tentamos acertar os serviços de referência (F295).

A rede básica e especialmente o PSF têm uma relação diferenciada de suporte aos ambulatórios de referência: Isso é que é diferente com as outras áreas da própria secretaria. Se você ... está encaminhando para os ambulatórios de referência ... de saúde da mulher, saúde da criança, do escolar, esses ambulatórios tinham no PSF uma equipe melhor de suporte também. Porque era lá que era feita puericultura correta, era lá que era acompanhado o baixo peso corretamente, era lá que era feita a vacina, que era controlado, o que faltou de vacina ia atrás. Então a unidade do PSF dá muito suporte para isso, ... por esse lado melhorou a referência, por causa de tudo isso (F296).

$\mathrm{Na}$ rede de atenção secundária há uma estrutura considerada boa. Como um serviço novo, criamos o CAPS (Centro de Apoio Psico-Social). Só a questão de saúde do trabalhador ainda não avançou, ... por seu suporte implicar várias coisas. Você tinha o trabalhador encaminhado, cobrava da saúde do trabalhador o retorno desse paciente e ficava sem resposta (F297). 
No centro de especialidades desde a gestão anterior, frente à dificuldade de acesso, procura-se uma organização da demanda na marcação de consulta especializada: Pra pegar ficha, antes tinha que ir pro ambulatório de madrugada enfrentar uma fila enorme ... pra marcar uma consulta com especialista. ... No final daquela gestão o pessoal da policlínica começou um trabalho para acabar com a fila no centro, fazendo com que as pessoas fossem ... obrigadas a ir primeiro na sua unidade mais próxima e de lá agendar a consulta ... por telefone. A idéia era sair da unidade básica para o ambulatório já com a consulta marcada. Isso funcionou razoavelmente bem no começo, ... depois a demanda foi crescendo e não se manteve por muito tempo. Todos os municípios da região, as nossas unidades e os nossos ambulatórios tinham acesso ao centro de especialidade (F298).

A gente conseguiu começar a dar essa guinada mesmo na fila, a partir de março de 97; aquela fila ela foi até metade do ano ainda. ... O usuário que morava num bairro era consultado pelo clínico geral ou ginecologista lá na UBS, e se ele precisava de um cardiologista, ele vinha às 3 ou 4 horas da manhã pro PAM (Policlínica de Assistência Médica do ex-INAMPS) e tinha umas 300 pessoas na fila de espera. ... Não dava para continuar vendo aquilo, isso foi quando ... a gente teve um clique assim de querer gerar alguma mudança. Então nós começamos a "fazer a fila de espera", pra entender. Nós íamos pra fila, tanto eu como a ... administradora da unidade e outra assistente social, éramos pessoas com vontade de fazer alguma mudança e fizemos. ... A gente chegava lá às 7 da manhã, eu me benzia, porque às vezes a gente era ameaçado mesmo, imagina, era uma multidão querendo vaga. E dizia: seja o que deus quiser. E aí conversava com cada um na fila, até chegar no último. ... Um por um: porquê ele vinha, de onde, como é que foi encaminhado. Era como uma pesquisa com o usuário, boca a boca, se gostou e o quê que estava faltando. Para entender o processo que levava à essa fila e ver se a gente descobria o nó. (...) Com isso a gente foi percebendo o que estava acontecendo. Ao falar com todo esse povo, a gente começou a se antenar pra algumas propostas. Resolvemos gerar a consulta por telefone. Foi um caos no início, ninguém aceitava, achavam que não ia dar certo. E a gente foi e foi e foi, ... até fazer o convencimento. Porque não tinha gerenciamento, não tinha descentralização, não tinha nada. Tinha lá uma policlínica, como um apêndice dessa secretaria, sem vínculos. ... 
Até convencer todas aquelas coordenações locais, de que podia dar certo, foi o maior trabalho. ... Então o usuário passou a ser agendado por telefone e é assim até hoje. Ele é atendido lá no bairro, ... a própria enfermeira da unidade liga pra cá, e nós temos uma equipe com vários telefones, que já marcam a consulta dele. ... Ele recebe um cartãozinho lá na unidade dele, e já vem aqui com hora marcada. Hoje funciona super bem (F299-300). Depois que organiza parece simples.

Pode escolher profissional? Até pode. Em alguns casos pode. Se você é paciente do dr. tal, você continua sendo paciente dele, não tem problema. ... Para as especialidades que tem muita demanda, se não consegue suprir mensalmente todas as esperas, a gente tem um dia de marcação e se distribui nas unidades um número de vagas. Aí eles pegam lá por prioridades, nos dão os nomes por telefone e avisam o usuário, que só vem aqui no dia da consulta. ... Demora no máximo 10 dias ou 15 dias. (...) Nós temos problemas hoje com uma fila de espera somente na oftalmologia e ... ortopedia, que chega a esperar 3, 4, até 5 meses na fila. (...) Mas a questão da falta desses profissionais é um problema de categoria mesmo. A oftalmologia não tem interessados, eu até já botei na rádio, TV e jornal, já procurei até em Curitiba, pra você ter uma idéia. Agora nós conseguimos contratar 2 pra trabalhar nos sábados. E a ortopedia da mesma forma. São categorias que não tem profissional que queira, porque são poucos na região, que têm uma boa clientela particular ou de convênios, e não tem esse profissional no SUS (F301-3).

A contra-referência é sempre a maior dificuldade. E a dinâmica dos centros de especialidades é muito diferente e ainda desarticulada da rede básica: A única área que não modificou muito o perfil foi a questão da especialidade. O nosso encaminhamento ainda continua, mas a especialidade se fecha dentro da própria ... policlínica e não abre realmente. Você manda um paciente para lá e é como se você perdesse o paciente. Eles não encaminham de volta, não dão o retorno. (...) Nós estamos tentando trabalhar com contra-referência. Difícil. Difícil. ... Não tem um sistema de informação; pra você ter uma idéia até o papel do prontuário a secretaria passou muito tempo sem poder nos dar. Então a gente botava preguinha no envelope pra colocar dentro, pra botar no arquivo, a gente colava. Então tem uma série de dificuldades também (F304-5). 
Quanto a uma certa forma de avaliação da satisfação dos usuários, ... eu li no jornal de ontem, se você pegar está lá assim: "Como é que está a saúde no município?" Tem algumas reclamações e tem alguns casos dizendo: "Ah, eu acho que está ótimo, a policlínica parece um consultório particular." ... Então tem pessoas dizendo: "Meu deus, isso aqui é uma maravilha, eu cheguei a doar 100 reais para uma instituição de caridade, porque eu tinha que pagar 3000 para fazer uma cirurgia, vim aqui e fizeram tudo pelo SUS". E tem outras pessoas que vão pra rádio e reclamam porque esperaram uma hora para ser consultado. Então, é o de sempre. (...) Fizemos uma pesquisa com os usuários da policlínica, ... tem bastante coisa escrita. A gente tem tão pouco tempo, se você soubesse, a corrida é maluca. Mas a gente vai parar ainda e quem sabe sistematizar aquela análise e escrever os resultados (F306-7).

Sistema de referência implica informatização: Nós tínhamos um problema seriíssimo de informações, informações falhas e furadas. ... Na questão da hierarquização, com referência e contra-referência, tinha que estar toda a rede informatizada. A gente teve dificuldade, quer dizer, nós temos dificuldades ainda, de entender essa idéia. (...) Agora estamos pra informatizar toda a rede, isso deve estar acontecendo em questão de dois meses no máximo. ... Aí as coisas realmente tendem a melhorar. (...) E no nível central foi muito complicado, ficou comprometido porque a gente não conseguiu implantar o sistema de informação. Então isso ... faz falta porque a atenção especializada fica muito na questão do exame e medicamento (F308-10).

A organização do acolhimento na equipe de referência para problemas de distúrbio de comportamento e déficit na aprendizagem: os adolescentes que são encaminhados pra cá pelas escolas, ... nós chamamos eles em grupo. Já trabalhamos antes com os pais e a escola que encaminhou. Muitos casos precisam ser atendidos individualmente, outros em grupo, outros acompanhamento de um mês ou dois e já podem ser liberados. Casos que realmente têm um acompanhamento que chega a 6 meses são raríssimos. (...) Se atende problemas de distúrbio de comportamento e déficit na aprendizagem, geralmente com distúrbio de fala. ... Antes a pessoa ficava 9 meses na fila de espera, e o profissional que ia trabalhar com essa criança ou esse adolescente não sabia o que o estava esperando lá na fila. E quando chegava a hora do atendimento a situação já era 
outra. Hoje, a fila de espera já é conhecida, ... porque enquanto espera, o estudante já foi visto e já passou por alguns profissionais, ... a gente chama isso de acolhimento. ... A família também já foi orientada sobre como nós trabalhamos e discutimos suas expectativas ... Então a pessoa já está num processo de atendimento. A escola já foi visitada, pra já começar a trabalhar em sala essa criança, o profissional começa a ser capacitado (F311-2).

Essa equipe em revezamento se desloca semanalmente pra rede básica de saúde do município; para promover ... processos de educação continuada nas unidades. Assim como a gente está trabalhando com UBS, professores, pais, também se recebe muitas solicitações ... do pessoal da educação, que liga: Por favor, a gente vai ter uma reunião e gostaria de vocês aqui. Como é que chegam as demandas para atendimento aqui? ... No caso da fonoaudiologia, se aceita demanda encaminhada direto da escola, porque distúrbio de linguagem dá pra detectar pela pedagoga e professores. Já com a psicologia, agora estamos contratando um psiquiatra infanto-juvenil, é uma questão que a gente sabe que vai gerar uma série de outros compromissos, ... outros caminhos que vem por aí. ... Então no caso encaminhado pro psiquiatra, precisa passar antes pela avaliação do psicólogo da rede básica que fica em ambulatório geral. ... Como a gente não quer que o usuário perca o vínculo com o local onde ele vive, porque está super definido, a gente fez territorialização, então tem todo um estudo e trabalho em cima daquela população ... da área de abrangência dos serviços. Com base nesse estudo, a gente sempre recomenda devolver o adolescente para a rede básica (F313).

Numa avaliação a partir dos dados do SIAB eu observei que tem algumas contradições brabas. ... Por um lado, com o PSF, melhorou demais a referência. Quer dizer, o acesso dos pacientes na referência secundária e terciária, melhorou muito. Consegue-se fazer tomografia, cintilografia, assim ... numa média boa, $75 \%$ das equipes disse que consegue. Nos outros exames fazem tudo, 100\%, esses comuns de patologia clínica (F314).

Pequenas cirurgias: Para ter uma idéia de como são os profissionais do ambulatório geral, ... eu acho que aquele é um dos, ou o único ambulatório, que tem pequenas 
cirurgias, tanto pediátrica como de adulto. Então eles têm um envolvimento de até chegar a ir na casa do usuário sim, isso é raro (F315).

\section{Referência hospitalar}

Como antecedentes, no início dos anos $90, \ldots$ na parte hospitalar era realmente aquele caos, nós tínhamos um hospital privado fora do SUS, outro querendo sair, ... e a fundação hospitalar municipal eternamente em crise. Os salários geralmente atrasados, tudo muito mau situado. E era aquilo, ... um modelo hospitalo-cêntrico. Achava-se que o poder público não precisava se meter na questão hospitalar, quem tinha que se meter era a AIH (F316).

No equacionamento do nível hospitalar da atenção, aqui apresentado sob o ponto de vista da sua gestão político-organizacional, não são abordados fluxos e instrumentos do trabalho interno aos hospitais, mas somente sua relação com a organização da demanda, o que justifica sua inclusão neste momento.

$\mathrm{Na}$ atenção de urgência durante a gestão passada, ... pelo menos conseguiu-se quebrar um pouсо ... uma prática de preencher a fichinha verde e o paciente ser pré-atendido pra saber se era particular ou não. Então era aquela coisa de condicionar assim: eu vou te atender, mas se não for urgência tu vais pagar. ... Muito mais em função da capilarização da saúde a gente conseguiu quebrar bem mais, porque o povo começou a ir ao ambulatório primeiro e só depois pro hospital. (...) Nós temos um sistema no mercado de trabalho completamente diferente de outras cidades, porque tem turmas que começam meio-dia e terminam às 10 da noite, aí a mãe chega em casa encontra a criança com febre, pensa que tem alguma coisa e leva pro hospital (F317-8).

$\mathrm{Na}$ gestão anterior o equacionamento da demanda regional: $O$ sistema era muito limitado, porque as vagas hospitalares eram relativas. Na verdade ... 35\% dos leitos na cidade eram ocupados por gente de fora. Nós tínhamos na época 550 leitos públicos, ... tínhamos umas 1200 AIHs. Na verdade os hospitais tinham que rejeitar gente. ... Embora essa é a região do Estado com maior concentração de leitos hospitalares por cidade, eram 14 municípios ... correndo para cá. Os municípios da região geralmente 
têm um pequeno hospital geral, ... que resolve apenas parte do problema - G.O. (gineco-obstetrícia), pediatria, clínica geral e alguma coisa de cirurgia geral; trauma não resolve. ... Final de semana geralmente mandava o paciente para o hospital daqui (F319).

No começo daquela gestão (1993) era um inferno, de vez em quando tinha paciente que o bombeiro trazia, mais acidente e trauma, que vinham bater na secretaria na hora de pagar. O hospital tentava cobrar do paciente, o paciente ia pra prefeitura, normalmente pro gabinete do prefeito. E de lá vinha pra gente fazer a negociação, ... porque teoricamente, dentro do SUS o paciente tem direito à assistência. Se foi atendido num hospital privado, a gente conseguia, quando muito, pagar submúltiplos da tabela AMB (Associação Médica Brasileira) ou múltiplos da tabela SUS, ... vergonhosa naqueles valores, para ... um atendimento particular com alto equipamento; mas, também não pagava particular. ... Era uma dificuldade muito grande embora fosse ... relativa, porque havia um abuso grande na filtragem, era muito fácil para o prefeito, pro vereador, pros secretários de saúde dos municípios mandar para cá, não havia ... coresponsabilidade (F320).

Essa história começou a reverter ... quando se criou o colegiado dos secretários municipais de saúde, que depois virou associação, porque nós começamos a mostrar ... que eles iam perder dinheiro no futuro, porque naquela época já se pensava em fazer a série histórica. ... No momento que deixam uma hérnia inguinal ser operada fora, essa hérnia vai somar lá 260 reais, no município de vocês seria 180, mas ela vai entrar na nossa série histórica ... e sair da série histórica de vocês. Isso por referência à ... gestão semi-plena, que já se falava desde o começo de 1993 (F321).

Na questão hospitalar houve um avanço quando nós criamos, através da primeira associação dos secretários municipais de saúde, ... o banco de compensação das AIHs. Era só deixar para o secretário ... autorizar ou não a internação fora. Isto foi bem interessante, todos os secretários se comprometeram de não pagar AIH quando o procedimento pudesse ser realizado no município de origem. Então, ao receber do hospital as AIHs no final do mês, ... nós não negávamos o atendimento, eu mostrava 
para o secretário do lugar de origem do paciente e ele dizia: ... Não vou te pagar essa AIH; é, tem razão porque realmente o hospital não deveria ter atendido aquele caso. Nós não chegamos a ameaçar o hospital de não pagar, não tinha como, ... o hospital entrava com uma ação, eles tinham uma associação forte. Então ... nós baixamos uma norma assinada por todos os secretários municipais de saúde e prefeitos da região, dizendo que a partir de então todo e qualquer procedimento eletivo que fosse internado no município, seria de responsabilidade desse município. ... Tinha aquela história da ... família pedir AIH, era um transtorno miserável. Aí passava a ser responsabilidade do município que internava e o município de origem não tinha obrigação de pagar. $O$ que acontece com isso? Quando o hospital daqui pedia pra mim a AIH de paciente de fora, eles mandavam o laudo e se era eletiva eu negava e voltava ... pro município de origem. ... Então o hospital começou a não ter como cobrar a coisa, eu não pagava e a origem não mandava a AIH. Então fizemos uma reunião com os nossos hospitais e colocamos pra eles: vocês não podem fazer o que é eletivo, expliquem pra família e mandem de volta. Espalhamos isto pra todos os ambulatórios, pra toda a população, foi um trabalho bastante intenso das secretarias de saúde ... e com isso melhorou muito. Nós reduzimos em torno de 20 a $22 \%$ o índice de internação do paciente de fora aqui, ou seja, passamos a internar aquele que realmente precisava (F322).

Como proposta assistencial, segundo a gestão anterior, ... a intenção era manter o hospital infantil e fazer uma maternidade nova ali no lado direito. Na outra parte do prédio que ia sair, seria um hospital geral. ... Mas com as forças políticas da época não se conseguiu. E poderia ... ter resolvido todo problema de hospital geral, a um custo que ... àquela altura se conseguiria cobrir com o próprio Fundo Municipal de Saúde. ... Então continuamos com o hospital enforcado nas suas funções, ele é maternidade $e$ hospital geral tendo pouco leito pra maternidade, muito pouco leito pra hospital geral e a parte infantil também muito pequena (F323).

Para o conselho, a inserção da atenção hospitalar no SUS era um grande problema: E não adianta querer PSF se não tem um hospital de referência. Tudo isso aí tinha que 
mudar. ... Nós definimos o perfil da fundação hospitalar municipal, ... isso é deliberação da conferência e ainda não aconteceu. ... Mas tem que mudar porque da forma como está, não dá mais. ... E isso nós estamos dizendo desde 1992, que tem de mudar o perfil deste hospital, que ele só pode ser pronto-socorro e maternidade. Se a prefeitura continuar administrando e ela quer continuar a administrar, então, é só maternidade e pronto-socorro, mais nada, o resto tem de acabar com isso. Então quer dizer, tinha uma direção em todo aquele processo e aí o que é que acontece? Perde o rumo outra vez e privatiza mais definitivamente (F324).

Existe uma tendência mundial de diminuir internações: Na verdade eu tenho uma visão, particularmente, eu não investiria ... mais hoje em número de leito. ... Na questão hospitalar eu partiria para o que é mais moderno em medicina, para uma estrutura de ambulatório com hospital-dia e deixaria os leitos como estão. Porque a tendência da medicina, no mundo inteiro, vai ser internar bem menos do que se interna hoje em dia. ... Então não adianta você estar construindo novos leitos, ou ... querer fazer um hospital universitário. ... Isto é a maior burrice, porque a faculdade hoje, com os hospitais que tem na cidade, ela consegue tranqüilamente dar a parte hospitalar pros alunos, bastaria fazer só um hospital-dia. ... Nas cirurgias feitas no hospital da Unimed ... uma boa parte na verdade passa só uma noite lá, ... isso porque tem uma estrutura "home care”, o paciente conta com uma assistência ... que chama de urgência pré e pós hospitalar. ... Essa é a tendência no mundo, sabe, a Austrália hoje em dia interna $60 \%$ do que internava há 10 anos atrás (F325).

Mais que número de leitos totais disponíveis, o problema no município é leitos para o SUS, dada a inexistência de qualquer hospital efetivamente público no município. Isso ocorre em todo o Estado de Santa Catarina onde o único hospital que atende exclusivamente usuário do SUS é o HU da UFSC em Florianópolis. Os hospitais próprios desse Estado e dos municípios atendem em geral a todas formas de convênios, clientela particular e reservem uma parcela dos leitos para o SUS. Assim como em geral também o fazem os hospitais privados existentes em Santa Catarina. 
Aqui nesta cidade tem outra vantagem, ... na hora de internar, não interna pelo SUS, ... porque o hospital público, por ser fundação, ... tinha uma característica "privada", aí o médico da Unimed internava lá pelo seguro. Então a fundação tinha uma fatia de faturamento muito pequena. ... A internação por seguro privado ... hoje até é maior, ... porque tem um continente grande de seguro saúde. Em nível de Brasil não, que hoje $11 \%$ são segurados, mas tem muita cidade da nossa região que ... tem aumentado este índice. A gente acompanha isso dia-a-dia na Unimed, no início da gestão anterior era mais ou menos um quarto da população do município segurada. Então 3/4 dependendo do SUS, por não ter seguro, ... isso é um grande volume. Na verdade ... hoje, por causa das fábricas o seguro está em tudo quanto é canto (F326).

No caso estudado, a fundação hospitalar municipal mudou muito para o SUS na gestão anterior. Antigamente era igual outro hospital privado, a fundação tinha esse comportamento. ... Não conseguimos resolver grandes coisas, mas o atendimento hospitalar havia melhorado por causa da melhorada na rede em geral (F327).

Bem, na verdade na gestão atual não avançamos muito também nessa questão da referência. Eu tive uma dificuldade enorme em garantir a referência hospitalar para os pacientes do SUS, mesmo do (programa de) saúde da família. Dificuldades enormes, porque a fundação hospitalar é independente (F328).

Hoje estamos também envolvidos com o SAMU - o serviço de atenção à medicina de urgência. O município vai ser uma área de referência, o Estado terá seis áreas em seis cidades - pólos e aqui será uma delas. ... O importante nisso é centralizar o atendimento das pessoas que sofreram qualquer tipo de mal de urgência, o acidente doméstico, ou ... de trânsito, ... uma queimadura, um acidente grave qualquer. ... É uma central que vai poder ajudar a pessoa ... a receber o atendimento rápido, e também ... ter o transporte adequado e chegar no local certo. Pra não ir de repente pra um hospital não qualificado. Nós vamos melhorar também esse tipo de atendimento de saúde na cidade (F329). 
$\mathrm{Na}$ concepção do gestor atual, por referência à diversidade dos serviços de saúde: Inclusive, ... nós também estaremos inaugurando em breve um centro de imagens, também novo, na fundação hospitalar. ... É, por isso que eu pensei no município saudável (sic). Aqui poderia ser um ... município saudável (F330).

\subsubsection{Instrumentos Coletivos de Trabalho}

Caracterizam-se as ações coletivas e os instrumentos de trabalho referidos, geralmente informados por bases epidemiológicas quando explicitamente orientadores da integralidade da atenção. E outras ações são tomadas como objeto, por princípio.

Nas equipes do PSF se começou a construir o trabalho coletivo, porque, quando a gente entrou, não tinha nem um diagnóstico de saúde. E precisava. (...) Agora fazem grupo; ... visita domiciliar tem bastante; e uma coisa que é bem pouco ainda é a internação domiciliar, algumas equipes fazem mais, outras quase não fazem (F331-2).

Tanto no ambulatório geral como no PSF, eu acho que se o pessoal souber organizar bem, aí as atividades coletivas aumentam em número e grau, muitas já são feitas, principalmente nos ambulatórios gerais, que antes quase não faziam, todos passaram a fazer. Porque na questão da disputa entre modelo, de que vocês não fazem o que a gente faz, eles começaram a fazer grupo e ... visitas domiciliares. Lógico que não é o geral, mas tem pessoas dentro do ambulatório que fazem, o importante é que alguns começaram a fazer tudo isso. São psicólogos fazendo atividade coletiva, dentistas fazendo atividades coletivas, auxiliares de enfermagem saindo para fazer visitas de SINASC e vigilância do recém-nascido, enfermeiras fazendo grupo de tudo quanto é coisa que elas podiam imaginar. ... Isso aumentou com o estímulo do PSF. As unidades da rede também são impulsionadas pela proposta do PSF de estimular intervenções mais coletivas sobre o objeto de trabalho. Porque na verdade, na rede eles têm que ser modelo também (F333).

Observações referidas à disputa 'ações coletivas versus demanda': O pessoal me questiona e fala que se começa a fazer atividade coletiva para diminuir demanda. Aí eu 
viro e falo que não, nunca se vai conseguir diminuir demanda com atividade coletiva, vai é aumentar a demanda. ... A atividade coletiva tem que ser feita com o intuito de um desenvolvimento de cidadania, de participação grupal e tudo mais. E não é igual a você diminuir a demanda espontânea. Porque se você vai fazer a atividade coletiva e chega a identificar ali um usuário, você vai trazer ele e mais 3 para uma demanda organizada dentro de seu posto. Você organiza a demanda e não diminui. Se vocês querem fazer, então estejam preparados. (...) Por outra parte, atualmente não tenho mais feito ação coletiva ao nível de ambulatório. Por que? Porque na verdade, como a área era muito grande, eu acabei quase atendendo sozinha ... uma grande demanda para consultas. Agora, com a chegada de outro médico, se minha demanda reduzir, aí a 'captação mais precoce dos problemas' acontece (F334-5).

\section{Grupos}

O trabalho com grupos vem sendo feito nas unidades da rede e no PSF desde a gestão anterior. As diversas modalidades e dinâmicas adotadas na atividade grupal com usuários (puericultura, mulher, adolescentes, diabetes e hipertensão, alcoolismo, e terceira idade), explicitam uma apreensão mais coletiva do objeto de trabalho, sendo relatados mais os requisitos e dificuldades para sua organização na rede básica, com algumas indicações da finalidade destes processos de trabalho.

Grupo de gestante e puérpera: Faz-se o trabalho de grupo com gestantes ... em algumas unidades. (...) A amamentação é orientada através dos grupos com puérperas. ... A gente abordava ... a pega correta, os problemas que podem acontecer durante a amamentação, a questão da cólica que a mãe se preocupa muito, enfim, ... todos esses temas sobre maternagem são trabalhados (F336-7).

Grupo da criança e puericultura: No PSF a gente faz ... um trabalho de grupo com crianças. ... No ambulatório também tem grupos de puericultura funcionando com assistente social, pediatra, enfermeira e psicóloga. Esse trabalho começou por solicitação da pediatra na época - 94. ... O grupo de puericultura ... para ter um 
melhor resultado tem que ser de ... 8 a 10 pessoas no máximo. ... É uma sala que tem brinquedos, onde já vivencia também o trato com a criança. (...) No primeiro ano do bebê eles vêm uma vez por mês e de 1 a 2 anos é trimestral. Sempre aquelas mães se encontram no mesmo grupo. Tem vários grupos, mas cada grupo é aquele, sempre o mesmo, a não ser que haja muita desistência. (...) No encontro anterior o grupo escolhe um tema. ... E as mães expõem aos profissionais (deveria ser ao grupo) como sentem a coisa, e vai havendo uma troca de informações. Depois de discutido o tema faz-se a consulta coletiva, ... onde o médico pergunta pra cada mãe ... como está a criança, ela vê também os dados que consta ali na ficha do ACD (acompanhamento do crescimento e desenvolvimento), e se quiser consulta individual no final do grupo o médico faz. (...) $\mathrm{Na}$ avaliação de resultados desses grupos, não sei agora a porcentagem, mas se constata que a grande maioria, próximo de $100 \%$, amamentam por mais tempo que anteriormente era visto, e se observa menos reincidência de doenças. Tem mães e profissionais que são mais resistentes, outros mais acessíveis (F338-41).

Grupo de adolescentes: Na experiência do ambulatório geral, ... fizemos muito superficialmente grupos de adolescente, porque era só a assistente social, e quando dava, uma vez ou outra a enfermeira e uma vez ou outra o médico. Não era um trabalho planejado por uma equipe multiprofissional. O adolescente é difícil. Precisa cobrar sua participação, porque é complicado fazer com que esse grupo se reúna. (...) $\mathrm{Na}$ experiência do PSF, ... também trabalhamos com grupo de adolescentes. ... É um trabalho difícil de começar e emplacar. ... Foi o mais difícil de todos para conseguir adesão, porque eles não vêm. Então fizemos o seguinte: Oh, pode trazer salgadinho, pipoca, o que quiser. E vamos passar um filme e depois discutir a respeito do filme. Aí começou a vir e veio bastante. Até nós comentamos: o que será que ia pensar uma pessoa de nível central, um dos coordenadores, se entrasse no posto naquela hora comendo pipoca, vendo um filme, ... deitado na maca. Mas é o único jeito. Porque tem que conquistar a confiança, trazer eles para nós, e depois começar a trabalhar as ações; e até fazer com que eles trabalhem com os amigos (F342-3).

Grupos de diabetes e hipertensão: No ambulatório geral começou em 94 o trabalho de grupo com hipertensos e diabéticos. ... A gente nem se envolveu muito porque é uma 
coisa que já vinha há anos, era coisa do ministério e é muito aquela história de palestrinha. (...) Mas mesmo assim, ... eram muitos, tinha 90 hipertensos numa UBS. (...) No PSF, quando esse grupo ... estava chegando em 40, já não era nem grupo mais, era reunião, era palestra. Com razão tem gente que diz que isso não é grupo. ... Hoje ainda continua assim praticamente em todo o PSF. Mas na equipe se procurava que não ficasse assim, pra todas as pessoas poder se conhecer. (...) Por outra parte, há dois anos que não tem registro de eventos cardiovasculares ou um AVC (acidente vascular cerebral), o que era bem freqüente na época. Esse resultado do acompanhamento no grupo é evidente (F344-7).

Grupo de alcoolismo, na experiência de uma equipe do PSF: Nós trabalhamos a questão do alcoolismo, porque tinha bastante queixa das mulheres que faziam o preventivo. ... Quando a gente perguntava se ela tinha algum problema, mas com relação à parte ginecológica, sempre vinha a queixa emocional do marido que bebia, dizia que apanhava, e toda aquela questão do alcoolismo. Então se resolveu fazer um grupo à noite. ... Eles nem queriam colocar esse nome, era um grupo de apoio que não tinha nome. ... No início a enfermeira e a médica trabalham juntas nesse grupo. ... Primeiro, desenvolvemos temas e às vezes se levava um filme pra discutir com eles. ... Conseguimos manter o trabalho uns sete ou oito meses. Depois a médica saiu e fica a enfermeira, mas é uma questão muito difícil para trabalhar sozinha. Não tem apoio ... e precisa preparo $(\mathrm{F} 348)$.

Até se tentou buscar apoio junto com o AA para ver se dava para montar um núcleo lá. ... Fizemos uma pesquisa pra ver quantas pessoas tinham o mesmo problema. Fomos na reunião do AA mais próximo e eles se interessaram, o coordenador veio aqui conhecer, esteve na secretaria conversando com o secretário e tudo. ... Mas não conseguiram montar. Precisavam de uma pessoa da comunidade já participando ... de AA, para iniciar o grupo com eles e ... continuar mantendo. Não tinha ninguém disponível para ir. ... Foi difícil, ... estava tudo praticamente organizado, já tinha local, a creche tinha cedido uma sala à noite. Só não conseguiram uma pessoa com força bastante para dizer - eu vou, eu assumo. Porque tem toda dificuldade de acesso e era difícil mesmo, precisava de 2 ônibus para ir e 2 pra voltar, isso pesa no orçamento deles. (...) Aquele grupo foi se desfazendo aos poucos, até que ... o trabalho de grupo mesmo ... acabou, 
ficou mais um atendimento de apoio para eles, porque apesar de toda orientação, ter o CAPS, ter o AA, eles se acomodavam muito. É muito difícil mudar, principalmente esse tipo de hábito (F349-50).

Grupo da $3^{\mathrm{a}}$ idade: No ambulatório geral tinha também um grupo de qualidade de vida na terceira idade, que no momento não tem mais, porque é começo de ano, o serviço está se reestruturando e está um pouco difícil agora. (...) A partir do fato de que as pessoas têm uma maior perspectiva de vida, temos a possibilidade de desenvolver um projeto pra discutir o envelhecimento saudável (F351-2). E nesse sentido o trabalho de grupo é fundamental.

Somente nesta gestão ... se passou a planejar em equipe o trabalho de grupos. Faz-se $o$ projeto e aí se montam os grupos. Por todas as questões implicadas, ... é preciso fazer esse planejamento em cada unidade. (...) O importante da abordagem de grupo é constituir esse grupo enquanto grupo. Você precisa dessa relação para trazer as pessoas para o grupo. Sobre como fazer isso, entra muito a visão de mundo do profissional (F353-4). Existe problema de local para atividade em grupo: Meu problema lá é só esse, eu não tenho espaço para atividade coletiva. Nas duas unidades precisa fazer uma reforma, ... então se usa espaço de igreja e escola. Mas mesmo assim as ações mais coletivas, ainda são bem reduzidas. Isso é um ponto fraco nosso (F355).

Os agentes do trabalho em grupo no ambulatório: Antes quem fazia educação em saúde, que é o que mais se faz nos grupos, era a enfermeira, ... depois entrou a assistente social, mas ainda era uma coisa meio isolada. E passou-se a trabalhar então também com médico na equipe. Onde tem psicólogo ou nutricionista eles também participam. $\mathrm{O}$ trabalho de grupo exige a organização de equipe multiprofissional. É, o que falta mesmo é mais profissionais pra trabalhar com grupos. (...) Agora o enfermeiro e o médico, ... não estou criticando, mas é difícil sua adesão. ... Então a gente acaba tendo poucos grupos, pela falta de profissionais (F356-7).

O PSF tem uma organização melhor com relação aos grupos, nós lá trabalhamos assim, no período da tarde: grupo de hipertensos tem toda $2^{a}$ feira, puericultura toda $3^{a}$ 
feira, visita $4^{a}$ feira, $5^{a}$ feira é só pré-natal, e $6^{a}$ feira é só retorno de consultas, ... porque é só um médico à tarde. (...) Nos ambulatórios ... também se faz grupos. Foi a enfermeira que começou a organizar esse trabalho. ... Ela já conseguiu fazer em todas unidades da região. Então daí se constata que não precisa ter um PSF para atuar assim. ... É só mobilizar a equipe e conseguir adequar as condições de trabalho (F358-9).

O usuário enquanto participante de grupo amplia seu acesso aos serviços. Havia bastante dificuldade pela falta do médico, porque muitos usuários não vêm só para o grupo, eles vêm se tem alguma coisa vinculada, a medicação ou a consulta médica, aí se aproveita o momento e faz o grupo. Não é essa a intenção, mas a gente faz isso pra iniciar, pelo menos enquanto eles não entraram em um processo grupal. A gente tenta motivar, até conquistar a confiança, um trabalho difícil de manter, principalmente os grupos de adultos. (...) Quando tem algum problema, se no momento ali dá alguma intercorrência, passa pela consulta. Então, a gente vinculava. Isso é uma coisa assim, não muito democrática, mas que em um momento entrou bem. Quem ia no grupo, tinha medicamento. Pelo fato de ter a medicação e acesso médico quando fosse necessário, o paciente se sentia seguro (F360-1).

Os grupos têm por objetivo ... trabalhar com a saúde das pessoas. E não trabalhar tanto assim com doentes, como o grupo tem a tendência de fazer; falar de doença, já se toma remédio todo dia, tem que fazer exame, isso ou aquilo. E a saúde? Então, o grupo teve essa perspectiva. A gente procurava trabalhar com grupo e não com doenças, tanto que na nossa equipe os grupos eram abertos, não era só hipertenso, tinham jovens, era um trabalho de educação à saúde. (...) Reunir as pessoas, não tinha muito mistério. ... Era difícil começar, mas a gente sempre procurou vincular o grupo à equipe, isso ajuda. ... Legal o fato do grupo não estar vinculado a uma pessoa, porque quando a equipe mudou, o trabalho continuou. ... Lá onde eu trabalhei saiu praticamente toda a equipe e continua o grupo. ... O grupo é dono dele, dono de si mesmo (F362-3). No seu funcionamento os grupos constituem uma dinâmica própria.

$\mathrm{Na}$ avaliação do trabalho com grupos, ... a gente se questiona entre os profissionais. E eles dizem: "O que vocês querem com esse trabalho?". ... Vocês acham que isso é realmente produtivo, fazer atendimento coletivo, sem ver a pessoa? Nós estamos 
colaborando pra acabar com a doença ou é uma coisa paliativa, ou simplesmente se atende por atender?". Então é interessante, me surpreendeu esse questionamento de um médico que, ... apesar de atender grupos dava impressão que não estava nem aí, mas veja bem, com essa reflexão ele está se importando com a prevenção sim. (...) A gente sempre busca avaliar o trabalho que faz, é uma preocupação que se tem. ... É muito lindo dizer que tem grupos, mas precisa estar avaliando os avanços desses grupos. ... Parâmetros exatos não tem, mesmo porque não existe, mas estamos desenvolvendo alguns, que a gente chama de protocolo pra estar depois comparando e ver se a gente está alcançando os objetivos. Isso se faz desde 96, ... para que se possa realmente avaliar e ter medidas de avanços. ... A avaliação dos profissionais ... sobre o trabalho do grupo é positiva. ... Não adianta estar fazendo uma coisa por fazer, a gente tem que avaliar se os resultados são positivos ou não. (...) É feito avaliação também com os usuários, por exemplo, no ano passado a gente quis avaliar o ano todo. Daí foi feito uma avaliação ao final de cada grupo, ... não vou te dizer que é sempre, mas constantemente. Na minha época ... tudo o que acontecia no grupo ... era relatado e discutido entre os profissionais e com o próprio grupo (F364-6).

\section{Salas de espera, discussão de temas e palestras}

Existe um trabalho de sala de espera. Tem unidade, como a nossa, onde na verdade nem é uma sala de espera, ... é um corredor de espera. ... Os usuários estão ali e a gente vai lá na frente e fala. (...) Nas reuniões, mesmo na sala de espera, a gente discute os casos. Na verdade eu trabalho mais com eles a coisa da auto-estima, e se estimula o acompanhamento e desenvolvimento. ... Também são desenvolvidos temas, como TB, AIDS, ... o funcionamento do ambulatório, ... direitos na saúde e o SUS, porque pouquíssimas pessoas conhecem, depois de tantos anos, muitos poucos sabem sobre o conselho de saúde. (...) No ambulatório geral a gente faz a sala de espera ... só na parte da manhã, que ... tem mais demanda, e a equipe é mais completa (F367-8)

$\mathrm{Na}$ atividade de sala de espera não existe um conteúdo tecnológico mais elaborado, passando a se constituir em uma opção simplificada, como se pode depreender da fala de uma enfermeira em unidade tradicional: Eu poderia tentar fazer grupos pensei, ... e 
fui numa comunidade para começar a fazer. Chegou lá, tinha o presidente da associação de moradores, ... que quer ser candidato a vereador e usar "o meu grupo", ... aí eu não quis. Não, grupo ali não dá, vou fazer a sala de espera, ... porque não sei trabalhar na assistência, não consigo ser aquela enfermeira de trabalhar junto com médico. ... Naquela unidade, ninguém sabe muito que fazer comigo e me deixaram lá. Sei que estou devendo um trabalho pra unidade. ... Só que não posso ser a chefe da unidade, eles não querem, ... mas preciso fazer um trabalho lá, ... é, tem a sala de espera (F369).

A escola também é um espaço de educação em saúde. A gente ... fazia palestras para todas as idades. ... Para cada faixa se abordava um tema, de acordo com a idade: na préescola, higiene; da $1^{\mathrm{a}}$ a $3^{\mathrm{a}}$ série, acidentes na infância, leis do trânsito, ensinar a atravessar a rua e tal; a partir da $4^{\mathrm{a}}$ série se trabalhava a sexualidade e reprodução; e, nas $6^{\mathrm{a}}, 7^{\mathrm{a}}$ e $8^{\mathrm{a}}$, trabalhava mais com sexualidade e drogas. Esse trabalho quem fazia era a enfermeira junto com os agentes de saúde, todos adolescentes. ... Outra coisa que a gente também trabalha com comunidade é quando eles nos solicitam para fazer alguma palestra $(F 370)$.

\section{Visita domiciliar}

$\mathrm{Na}$ visita domiciliar, além da vigilância do recém-nascido, os trabalhos mais explicitamente comprometidos com a idéia de cuidados integrais à saúde eram a internação domiciliar e o acompanhamento de pacientes terminais. $A$ atividade de visita domiciliar impõe uma primeira condição ... o conhecimento técnico. Porque, aqui aparece muito forte a questão da orientação (F371).

$\mathrm{Na}$ visita tem que ser profissional, mas tem que ver também o lado humano. Eu vou na casa da pessoa, vejo como ela vive, onde dorme, as condições de moradia e higiene dentro e fora da casa. ... A gente observa fiação elétrica, encanamento de água, esgoto, lixo, tudo. (...) Ao entrar na casa, tu vais olhar e ver o que tem de bom e de ruim, vais te colocar no lugar daquela pessoa; e no primeiro momento tu não vais falar ou 
comentar nada, vais fazer uma visita, conhecer o mundo dela. Depois de ver de que maneira ... trabalhar é que se começa o trabalho. ... Então foi uma coisa assim, que abriu o conceito de saúde, muda muito. E depois que se conhece esse conceito, não tem mais como limitar (F372-3).

A visita domiciliar exige uma estrutura para a ação, transporte, por exemplo. No ambulatório o carro vem duas vezes por semana e duas vezes por mês vem uma vez por semana. ... O carro é pra enfermeira, auxiliar e assistente social, sempre que precisar estar fazendo estas visitas. Apesar de ser usado pra outras coisas (F374).

Quanto aos agentes da visita domiciliar, no PSF quem faz mais é o agente, depois o auxiliar de enfermagem, depois o enfermeiro, depois o médico. (...) Na dinâmica de uma equipe, o enfermeiro, o auxiliar e os agentes de saúde fazem visita semanal e $o$ médico faz uma vez por mês, para fazer uma avaliação. (...) O ambulatório geral pode fazer praticamente tudo o que o PSF faz, e os profissionais vão fazer as visitas. ... Conforme a situação, sai o enfermeiro, o auxiliar de enfermagem, já saiu psicólogo, mas isso quem faz rotineiramente é a assistência social. (...) Só o médico que não vai, não se propõe a ir ... e diz: Não, espera aí, eu não sou médico do PSF. Já o auxiliar de enfermagem não, sempre vai lá fazer o curativo em casa. Mas eu não ganho conforme ganha a auxiliar do PSF, ... isso nos chamou a todos de vagabundo. Mas nem por isso deixamos de fazer a nossa parte. ... Então, tem espaço. Os profissionais da rede, ... gostariam de fazer um trabalho mais completo, mais próximo da comunidade. Essas visitas elas iriam, ... as auxiliares, têm muita vontade (F375-8).

As equipes do PSF fazem todo o acompanhamento dos pacientes em casa, pré e pós internação hospitalar. (...) Está sendo muito comum a gente ouvir, até seguro de saúde falando de internação domiciliar (F379-80).

Atendimento domiciliar de pacientes terminais: As pessoas se conheciam bastante, porque a gente fazia muita visita domiciliar. Uma parte muito bonita ... foi 'cuidar de pacientes terminais', pessoas que vão morrer mesmo. Todos os casos morreram super bem, uma morte bonita e a família bem segura. Isso faz 'parte da atenção integral à saúde’. ... Pessoas que não conseguiam internação iam morrer a mingua lá, a gente 
não faz muita coisa, talvez dar um suporte pra família e isso faz muita diferença. ... Eu sempre deixava o telefone da minha casa para quando tinha algum problema e dizia: só não liga na hora do almoço, está bem? Pode ligar domingo, de tal a tal hora. Se precisar, eles ligam, mas nunca ... alguém utilizou mal, nunca abusaram. ... Por que as pessoas têm que se privar do que é correto, com a sua equipe? Às vezes a gente se acha muito superior e se surpreende com a grandeza dos demais. ... São pessoas aparentemente carentes, ... que têm respeito. ... Doutor, morreu a minha mãe, morreu o meu pai. É uma vinculação que tu tens com a comunidade. Então assim, se a pessoa está com alguém para morrer em casa, ... porque não tem mesmo o que fazer, em processo de luto, vou ligar pra quem? Para conseguir um atestado de óbito tem que pagar, e não é barato. ... Quer dizer, nem tem (F381).

\section{Reuniões na comunidade e parcerias}

A participação dos profissionais em reuniões na comunidade, geralmente associação de moradores e escola, também se destaca como um importante instrumento do trabalho coletivo na rede básica de saúde.

O pessoal precisa melhorar a interação com a comunidade, tem que participar mais das associações de moradores; alguns funcionários da saúde hoje estão em diretoria da associação, se integraram. (...) Sempre tem reunião de comunidade, com associação de moradores. ... Todas as gerentes regionais fazem reuniões na comunidade, e as coordenadoras de unidade também vão. Na função delas sempre se reforça ... a importância delas ir, ... e quando não podem, ... é bom sempre ter outro representante da unidade. Fundamentalmente, o trabalho com a comunidade é divulgar ... os nossos serviços: o que é o PSF, ... que serviços têm, como a gente trabalha, o que é saúde, ... e por aí. Não estou fazendo grande coisa. (...) Só que é assim, tu falas e ali tem vereador no meio, e tem cabo eleitoral, que aproveitam aquelas informações que tu dás, e ... aí mistura tudo, quer dizer, faz parte (F382-4).

Relações primárias com a associação de moradores e suas formas de parcerias entendidas como "participação da comunidade": Quando entrei no PSF, tinha só uma 
equipe, quase sem equipamento. Então, pela formação, a gente começou a buscar alternativas dentro da própria comunidade. Como o CAIC (Centro de Atenção Integral à Criança), ... tinha verba para compra de equipamentos, compraram mesa ginecológica, espéculo e uma série de outras coisas que a saúde não tinha como fornecer. (...) Na comunidade tal é diferente porque ... tem 5 associações ... bastante organizadas. Quando nós entramos, já colocamos toda dificuldade que tinha na unidade, e eles se dispuseram a nos ajudar e fazer uma promoção para arrecadar recursos financeiros para comprar o que estava faltando. ... Arrecadaram quase 1000 reais em uma galinha com polenta ... e doaram pra unidade comprar material. Então não tinha sonar, hoje tem, com a participação da comunidade. Não é comum isso, eu acho que foi uma conquista ... interessante. Foi tudo feito com nota, e depois reunião para apresentar onde foi gasto o dinheiro, tudo certinho, pra comunidade ver como valeu a pena o esforço. (...) Colocamos murais na parede para cartazes, até na sala de espera que era uma coisa mais fria, ... cada um trazia uma coisa, flor por exemplo. ... Não tinha cortina na janela e quem passava lá fora via ... dentro, então a gente comprou a cortina. (...) A comunidade foi vendo que era em benefício deles, e que valia a pena participar porque voltava para eles. É claro que facilita o nosso trabalho, melhora a qualidade do trabalho, mas o trabalho é para eles, foi uma coisa muito boa (F385-8).

Em cada contexto a relação com a comunidade organizada é um trabalho bem diferente. Em outra localidade, por um tempo nós conseguimos trabalhar bem com a associação de moradores, depois já foi mais difícil. No começo nem tinha associação, a gente até pediu para eles formarem uma, ... assumiu um presidente que trabalhava na prefeitura, e que tinha uma noção, uma idéia diferente de como trabalhar a saúde. A gente conseguiu um apoio legal, ele sempre convidava a equipe pras ... reuniões. E se precisava divulgar as reuniões de comunidade ele pedia ... ajuda aos agentes de saúde. ... Na última gestão, com a nova presidência da associação de moradores do bairro, eles não tinham essa rotina de reuniões mensais. A pessoa trabalhava muito sozinha. Tinha muita queixa da comunidade, até ... pessoas que faziam parte da diretoria se queixavam que havia reunião e ninguém ficava sabendo. Assim era mais difícil de trabalhar. Mas isso era com a associação, o contato com a comunidade a gente não perdeu. Então 'a comunidade continuou integrada', trabalhando junto com o serviço de saúde (F389). 


\section{Datas comemorativas da saúde}

Como única referência às ações coletivas realizadas no município, o novo gestor menciona as datas comemorativas de cuidados da saúde: Nós temos uma equipe que faz muito a divulgação em todos esses momentos, sempre que tem dia de combate ao câncer, dia da prevenção ... de tuberculose, dia do portador de deficiência, das pessoas hipertensas e assim por diante. ... Tem todos esses movimentos coletivos, digamos de atenção para a medicina preventiva, ... quer dizer, os cuidados e conscientização da população. Esse trabalho ... é bastante forte na secretaria. Existe uma grande preocupação na prevenção, em chamar a atenção das pessoas pra realidade (F390). E a própria ação assim referida fica despida de maior significado, ao não se caracterizar propriamente uma atenção para a saúde.

A gente tem um cartaz com todas as datas comemorativas da saúde e como tem um terminal de ônibus perto do ambulatório, faz-se a atividade nos terminais, com trabalho de informação. Sempre se está procurando trazer o adolescente, porque a gente percebe muito a coisa da baixa auto-estima, eles não têm um objetivo de vida, não vêem nada além daquilo ali, e também por isso não vão buscar. Então a gente tem que mostrar outros lados e procurar trabalhar em cima disso. (...) No PSF trabalhamos assim, sempre que tem algum momento dentro da saúde, como o dia de combate ao fumo, dia mundial de prevenção à AIDS, e outros, ... a gente entra com alguma atividade. ... Fizemos algumas passeatas com o grupo de adolescentes, um ano saímos de bicicleta lá do bairro para vir até a prainha no centro. Aí no final do percurso, sorteio de camisetas. Mas foi assim, escoltado, com polícia e tudo, então eles se sentiam super valorizados (F391-2).

\section{Participação em promoções da comunidade}

Em diversas comemorações da comunidade pode-se identificar a importante participação da equipe de saúde, mas chama a atenção especialmente quando a comemoração é promovida pela própria equipe, o que se articula enquanto sua resposta mais sensível à captação de carências da comunidade. 
Um exemplo nesse sentido foi a organização de uma festa de natal promovida por uma equipe de agentes comunitários de saúde: No primeiro ano de trabalho da equipe do PSF questionávamos com os agentes juniores: $O$ que a gente vai fazer? Era setembro $e$ se começava a falar em natal. Então eu disse: Alguma vez vocês já tiveram festa de natal?Ah, não. Não faziam, não tinham aquela coisa que todo mundo tem, de fazer o seu pinheirinho. Então eu falo: Quem sabe a gente organiza uma festa de natal? ... Ah, mas ninguém nunca fez isso. É simples, uma árvore de natal, e a gente canta uma música. ... E eles começaram a se mobilizar, foi muito bom. A gente conseguiu brindes, eles iam batendo de casa em casa e vinham felizes da vida porque tinham conseguido alguma coisa. Eu achei interessante porque estimulou a busca e eles podem conseguir. Nunca ninguém fez, por quê? E por que vocês não fizeram? Então eles foram atrás, ... essa era a intenção, primeiro mostrar que eles tinham condição, para incentivados por esse estímulo, incentivarem outras pessoas da comunidade. A festa foi muito boa, todos fizeram gorro de Papai Noel, cantaram uma música, teve bala e brinquedo. ... Foi muito legal (F393).

O profissional de saúde participando nas festas da comunidade: Na nossa área do PSF havia uma boa ... organização da comunidade. Eles fazem festas populares na comunidade e nós procuramos participar. Até porque é um momento de ficar entendendo as coisas ... de outra forma. Na hora que a pessoa está descontraída na festa, fala coisas que dentro do posto não vai falar. Porque lá tem aquela coisa da saúde, tu és o enfermeiro. E ali na festa eles te vêem como alguém mais próximo, estás no ambiente deles, vais sentar-te à mesa para comer o mesmo churrasco, e isso traz as pessoas para a gente (F394). Assim se abre mais a interação do profissional com a população usuária dos serviços.

É importante a presença do serviço em promoções organizadas pela comunidade, como quando ... nos convidam para participar de alguma ação comunitária. Uma vez a gente foi com todo material informativo e eles queriam uma coisa mais completa, aí então foi o pessoal de medição de pressão arterial e também a parte de prevenção odontológica, para falar sobre escovação, aplicação de flúor, e todo seu trabalho informativo. Eles pedem muito o trabalho da odontologia, ... a questão informativa mesmo, eu acho interessante, porque tem tantos outros assuntos. (...) Na nossa micro-área, estamos 
sempre em contato com o presidente da associação de moradores, tanto que agora vai ter uma ação ... chamada de Vila Saúde e já solicitaram nossos serviços e da universidade, vai ser um sábado só de orientação sobre saúde (F395-6).

\section{Ação local da saúde no saneamento básico}

No trabalho dos agentes pode-se identificar muitas soluções locais criativas e participativas para problemas relacionados com lixo, água, esgoto e condições gerais do ambiente em que vivem. A idéia de ações intersetoriais de caráter mais coletivo, numa área de risco em que o problema é saneamento, a saúde faz o que? Aí as gerências têm um papel fundamental, ali na prática do dia-a-dia. Não é nem como eu planejo, ... eu não tenho isso planejado (F397), mas é a relação estabelecida com quem vive o problema.

A questão do lixo: Esse é um problema ... que a gente tem observado bastante no bairro, ... e é mais factível de trabalhar do que água e esgoto. Então, vamos trabalhar isso antes. (...) Os agentes comunitários fizeram o projeto do lixo, eles mesmos fizeram o folder para distribuir, ... pesquisando ou copiando do material que a gente tinha no posto, ... eles mesmos desenharam, tinham aqueles que sabiam desenhar bem, e ... faziam o desenho de todo mundo. Foi um trabalho muito bom. ... Na comunidade arrecadaram madeira, ... confeccionaram as caixas coletoras de lixo, e foram colocando nos pontos onde o pessoal costumava jogar o lixo. Não dá pra ficar esperando vir alguém fazer, ou esperar o setor da prefeitura responsável por cavar o buraco, a gente procurou trabalhar isso. ... Estamos vendo a coisa acontecer e vamos fazer alguma coisa. Eles fizeram, cavaram, cortaram a madeira, pregaram tudo, e ao final cada caixa tinha a identificação do agente comunitário de saúde júnior responsável. Era assim, um orgulho para eles, passar naquela caixa de lixo e ver o nome deles ali e saber que foram eles que fizeram. E para a comunidade também, porque eram filhos de pessoas da comunidade ... trabalhando a favor disso (F398-9).

Ao nível local, ... com relação à água, então eles iam de casa em casa, orientando sobre o filtro, para ferver a água, manter a caixa coberta, fazer a limpeza da caixa d'água. Esse era o início do trabalho da água. (...) Na nossa comunidade tem aquelas 
caixas coletoras que a gente achou no meio do mato, onde tem muita fonte eles constroem as caixas, a água cai ali dentro e dali saem vários canos de água. Só que aquela água ali, aquela caixa coletora não era coberta, estava cheia de barro, de folha, de tudo quanto é coisa que vinha com a chuva. Então foi conversado com a comunidade para fazer um trabalho ali. Os agentes cobriram essas caixas, orientavam as pessoas, mostravam a qualidade da água, porque as pessoas precisam ver. Era muito bom o trabalho deles (F400-1).

A gente fazendo a supervisão e orientando, esse é o trabalho do enfermeiro. ... Os agentes confiam na minha opinião, e eu acho assim que ... a gente tem que ter uma visão pra poder até perceber o que é mais conveniente num momento. Porque tem coisas que não se consegue resolver. O esgoto, por exemplo, precisa canalizar toda a rede de esgoto e as ruas não têm nem calçamento. Então como é que tu vais fazer isso? Se bem que eu acho que se for atrás, pode-se encontrar soluções inclusive para o esgoto em pequenas áreas. Tu podes não conseguir uma rede, mas se consegue resolver $o$ problema do bairro. A comunidade está fazendo sua parte, eles assumiram fazer toda essa questão da canalização (F402).

Na questão da água e esgoto, as renovadas referências a já considerada máxima ecológica "pensar globalmente e agir localmente" também se aplicam: Eu acho que é importante saber o que depende de ti, porque não adianta querer fazer tudo. Essa semana o presidente da associação, que trabalha na vigilância, esteve lá e disse: Ah, eu vou fazer um trabalho com ... a água e o esgoto. Aí eu perguntei para ele: Mas, nesse teu trabalho e tal, tu queres resolver o problema da água e do esgoto? Ele diz que quer melhorar essa situação. Está bem, então se tu queres escolher um trabalho, para resolver o problema, tens que procurar uma coisa que dependa mais de ti, que tu possas fazer. Porque água e esgoto dependem da comunidade, depende do serviço municipal de água e meio ambiente, depende do departamento de serviços urbanos da prefeitura, depende de muita gente. Então, claro que vamos direcionar a ação para isso, organizando as demandas necessárias. Mas tens que saber que não depende só de ti o resultado. (...) Para trabalhar com água e esgoto a gente tem que se organizar na comunidade. Tem que juntar mais gente para reivindicar (F403-4). Isso conforme as aplicações do PES em nível local 
(Matus 1993 e Brasil 1995), para organizar demandas aos setores mais diretamente responsáveis por essa ação.

\section{Promoção da saúde e intersetorialidade}

A promoção da saúde tem sido uma preocupação crescente das equipes de saúde, encontrando dificuldades e ao mesmo tempo inventando novas possibilidade para um trabalho intersetorial articulado.

A integração com outras instituições no Projeto Faísca: Esse trabalho foi concomitante ... ao lançamento do PSF, era um projeto interinstitucional, entre várias secretarias; mas, a secretaria da saúde é que foi o carro chefe, que executava mesmo. ... Foram várias reuniões para preparação desse projeto na área da criança e do adolescente. (...) O Projeto Faísca, entendido na perspectiva dos próprios agentes, é 'um fórum de atenção integrada à saúde da criança e do adolescente', eram vários programas e ações articuladas dentro da sua proposta. Havia ... uma atuação intersetorial $\mathrm{d} a$ secretaria de ação comunitária e do Promenor com a secretaria da saúde. ... O grande problema do Faísca é que se ... tentava integrar, só que o secretário da saúde aparecia demais (F405-6).

As atividades de promoção à saúde incluem: Educação, moradia, trabalho, geração de renda e agricultura, alimentação, desenvolvimento social, ... pequenos moradores de escolas de creche e o orçamento participativo. ... No PSF só 3 equipes relatam que estão trabalhando com o projeto da renda mínima, um pequeno projeto de promoção, ... e com o projeto de geração de emprego também. Eu acho que é pouco, ... por causa da questão do compromisso de um governo popular. (...) No PSF a gente vê que se está trabalhando também com outros setores, a intersetorialidade. ... A maioria empresta a escola pra fazer reuniões de saúde com a associação dos moradores, aí se articulam com a educação e com a associação de moradores, já é um começo (F407-8).

Articulação com outras áreas sociais em algum trabalho integrado: Nós temos ... um exemplo com a área de educação - a prevenção das crianças com deficiência visual e 
com a assistência social também tem vários programas, ... são programas conjuntos. (...) Outra articulação intersetorial que a gente teve foi no desenvolvimento ... do índice de cidadania. ... É um projeto com a universidade, que capacita as pessoas, ... e constrói uma consciência. ... Eu fui lá e falei da nossa população. ... Quando eu vi, eu também estava toda envolvida ali. Era uma atuação intersetorial (F409-10).

A articulação do profissional dentista com escolas básicas: Por pura intuição, eu fazia atitudes educativas de culinária, pra colocar a promoção em odontologia. (...) Na matemática também, eu falava pro professor me avisar quando fosse ensinar sistema métrico, ... para eu trazer um tubo de pasta de dente. Porque eu queria que esses vocábulos fossem mais rotineiros, ... para a criança aprender um centímetro de pasta de dente, porque aí fica mais familiar. ... Matemática é uma linguagem universal, é o mesmo instrumento de comunicação, que se pode usar também como veículo de educação em saúde. Por que toda criança aprende que a mãe foi na quitanda comprar 3 laranjas e 2 maçãs? Por que ... não comprou uma pasta de dente e 2 escovas, ou um fio dental? Até o vocabulário enriquece, aprende matemática e mexe com saúde. Porque com tudo sempre igual fica tão limitado, sem poder dar vazão e expandir a criatividade. ... Outros setores agora estão fazendo isso que intuitivamente se fazia, ao levar essas possibilidades para o professorado. Poderia ser o nosso papel na articulação intersetorial, na promoção. É que eu sempre penso - o que nós podemos fazer? (F411-2). As iniciativas criativas dos agentes do trabalho podem e devem ser avaliadas e renovadas pela via da interação entre profissionais.

$\mathrm{Na}$ integração interinstitucional destaca-se a intersetorialidade da promoção nas políticas públicas. Com a questão do orçamento participativo, o pessoal da unidade participava bastante junto com o presidente da associação (F413). Participar do orçamento participativo aqui está configurado como ação de saúde, uma forma de fazer promoção.

A relação com as outras secretarias foi muito aberta nos contatos ... pra essa questão intersetorial da regionalização, ... principalmente com aquelas secretarias que se trabalha bastante - educação, ação social e obras. ... É o grupo de gerentes regionais 
que tem trabalhado mais nisso. Essa integração começou a partir da secretaria de saúde. Nós sentimos essa necessidade no processo de territorialização e descentralização do gerenciamento. ... Tornou-se necessário conhecer mais a estrutura da região, saber o que tem. E pra ter acesso aos serviços, a gente sentiu que tinha que realmente estar interagindo com outras secretarias, então se propôs uma reunião intersetorial. No início foi uma dificuldade daquelas secretarias entender, mas quando entenderam ficaram ouriçados. ... Construímos com eles um mapa dos recursos sociais de todo o município. Cada secretaria levou esse mapa e está mapeando ... o serviço que possui em cada região. Esse mapa vai girar entre todas as secretarias e no final vai sair um mapa completo. E cada região vai poder visualizar, tendo mapeado todos os serviços que possui; isso é intersetorialidade. A gente descobriu que não pode viver uma sem as outras, tanto que a secretaria da ação social, já está com a proposta quase finalizada, descentralizando a ação social num projeto piloto na região tal. Vão deslocar uma equipe deles pra lá, e o usuário não vai precisar mais vir ao centro pra ter os benefícios da renda mínima, por exemplo (F414).

Nós estamos vivendo um momento realmente muito importante pra cidade, em termos de serviço público e saúde pública. Eu acho que 'saúde tem a ver com tudo isso, saúde engloba todas as outras políticas públicas', não é? (F415).

As informações apresentadas, sobretudo as descritivas, tiveram a utilidade de possibilitar um reconhecimento geral das atividades referidas como mais diretamente implicadas na mudança do modelo de atenção de acordo com a concepção dos entrevistados.

\subsection{A Dimensão Organizacional}

O que se apresenta a seguir já é uma síntese de conceitos, princípios e mecanismos subjacentes aos relatos apreendidos, por referência aos processos de condução das medidas necessárias para organização dos serviços, de modo a operarem ações de forma comprometida com um modelo de integralidade da atenção à saúde. 


\subsubsection{A partir da Rede Básica}

Constituída pelas unidades executoras de um conjunto de ações de saúde que potencialmente contêm as condições de operar o princípio e diretriz da integralidade no SUS, a rede básica é o espaço onde os aportes da teoria organizacional, coerentes com essa proposta de mudança do modelo de atenção à saúde, adquirem sua materialidade. Como o foi, da realização tecnológica das ações, e também é, locus de expressão da dimensão política apreensível nas práticas de saúde. Os mesmos aportes organizacionais não são aplicáveis a qualquer tipo de serviço de saúde, porque o trabalho se diferencia nos vários âmbitos do sistema de saúde. Aqui importa reter a caracterização dessas unidades como organizações profissionais, integrantes de uma rede inserida em um sistema local de serviços de saúde e articuladas aos demais níveis do sistema, como também o serviço mais próximo do usuário e instalado dentro de e em relação direta com sua comunidade de vida. Nessa perspectiva há que se considerar as contribuições da disciplina da transformação organizacional no contexto da formatação de uma rede básica renovada em relação à sua finalidade de mudança do modelo de atenção, eticamente desenhado no campo filosófico do direito à saúde integral e tecnologicamente operado de forma que contém a política consubstanciada na técnica. E por extensão, como não poderia deixar de ser, também nas técnicas de gestão abordadas.

$\mathrm{Na}$ gestão anterior iniciava-se o PSF com ... cada unidade avançada construída passando a ser um projeto de unidade de saúde da família (F416). Ou seja, cada unidade da rede é um projeto do mesmo modelo de atenção pretendido. Como exemplo da sua estruturação tem-se: no bairro tal nós fizemos um laboratório, que seria o primeiro laboratório municipal de saúde coletiva, para absorver o atendimento de 4 equipes do PSF. Eram unidades onde podia haver um sistema de tratamento odontológico, e de repente ter até um encaminhamento mais privilegiado em termos de especialidade. ... Bom, assim só se instalou duas (F417). Na rede básica se estruturam os serviços potencialmente em condições de atender as necessidades da sua população de referência. 
A formatação da área do PSF: Havia uma equipe ... numa comunidade mais concentrada, onde era mais fácil de trabalhar, porque a unidade ficava no meio e a comunidade em volta. ... Era uma comunidade mais fechada, então eles não saíam para procurar outros serviços, ... dependiam daquela unidade e a procuravam. (...) No local que eu estou trabalhando agora, já é um pessoal que tem um poder aquisitivo melhor, ... tem plano de saúde ... e buscam atendimento fora. ... Esse é mais o pessoal local, ou de cidades vizinhas que veio pra cá, tem a cultura da região. E a estrutura de vida é melhor, mas é diferente trabalhar ali, a área é bem mais extensa, e não dá pra trabalhar como em área concentrada (F418-9). A unidade "tem que ir onde o povo está”.

Dificilmente fecha uma unidade, normalmente abre outro PSF ou uma UBS. ... Lá onde queriam fechar o que precisa mesmo é de uma linha fina, para a população do morro ter acesso à unidade, por isso que havia pouca demanda. Eu conversei com a comunidade $e$ com associações de lá, para ... ver as ações da saúde que podem ser desenvolvidas. São essas e essas, a gente pode ampliar (F420). E assim vão se adaptando as decisões do serviço a necessidades locais.

Com o que aconteceu em outro local, onde se pretendia fechar um PSF, pode-se ilustrar que também as decisões têm múltiplas determinações e implicações: Aí eu fui trabalhar na ponta ... e fiquei lá. Só que eu fui pra essa equipe com uma tarefa - ... acabar com a equipe. Porque ... era para realmente comprovar que lá não precisava. ... E foi dito isso, literalmente, não estou interpretando: Vai trabalhar lá, porque daí tu vais ficar só um tempo, e o pessoal aqui te esquece, porque era pra eu sumir do nível central. ... É que a gente não vê necessidade de ter PSF lá; naquela comunidade já tem o ambulatório geral que atende. Depois a gente vê o que tu vais fazer. ... Mas havia ... todo um envolvimento, nesse ambulatório especialmente; lá é um foco bastante grande de adesão da população. Lá também ... tem uma ligação bem forte com o prefeito, e especialmente com a articuladora política do setor no município. ... Não sei se tecnicamente se achava alguma coisa de ter que acabar com a equipe lá. Mas aí não conseguiram, por resistências dos funcionários, da equipe e da comunidade, que souberam da intenção e reagiram (F421). 
Número e composição das equipes: Apesar do nosso sonho, o (programa de) saúde da família continua sendo focalizado nas mesmas 21 equipes iniciais. Não conseguimos avançar no aumento do número de equipes. Não havia quadros, a nossa equipe era a equipe da gestão anterior; na realidade era uma falácia, porque não eram equipes completas. Às vezes tinha o enfermeiro e não tinha o médico. Às vezes tinha o enfermeiro e o médico e não tinha o auxiliar de enfermagem, ou não tinha enfermeiro. Então a primeira preocupação foi tentar completar as equipes. (...) Mas não conseguimos ampliar, mesmo fazendo parte do plano. Continuaram as mesmas equipes do início da gestão e inclusive com grandes dificuldades pra mantê-las (F422-3).

Dinâmica e inserção da equipe no PSF: A equipe lá é boa de trabalhar, está completa. (...) A equipe do PSF recebia bastante apoio da instituição, eu sentia segurança com a proposta e a gente ia a reunião periódica. Eu me sentia como um parceiro da política de PSF. O apoio que eu recebi, que todo mundo recebeu, foi uma coisa fantástica, ... eu me senti à vontade de fazer perguntas e mandava bastante relatório (F424-5). Se na rede básica estão as bases que fundam o modelo de atenção, a sua dinâmica tem que estar continuamente sendo objeto de reflexão entre os agentes para definição de ajustes e melhorias contínuas. $\mathrm{E}$ isso de forma intimamente articulada com a comunicação da estratégia política de toda a organização, no caso uma secretaria municipal de saúde.

Atualmente os serviços da rede básica municipal, inclusive os de saúde da família, se reportam normativamente a uma coordenação central situada na superintendência de vigilância e atenção integral (F426). Apesar da sua referência enquanto rede, os serviços não estavam estruturados como sistemas locais de atenção básica.

Antecedentes da gestão anterior: No último ano a gente já estava assim, calejado, ... meio pronto, e tínhamos ... altos planos: o saúde da família, ... muitas 'capacitações com o fim de integralização', fazendo encontros semanais e tudo. E tocando a rede em paralelo, ... mas com sincronia. ... Nós estávamos chegando no momento em que íamos convergir e ... fazer 'uma integração entre a rede e o (programa de) saúde da familia', mas de uma maneira mais leve, da forma mais harmoniosa possível (F427). 
Essa diferenciação entre o PSF e a rede é complicada ... pro município. O PSF vai ficando muito caro, ... e o médico trabalhar 8 horas, com dedicação exclusiva, geralmente ele não fica, sai. (...) E as unidades da rede, o quê que elas tem de diferente do PSF? Se a enfermeira é gerente e fica na unidade, dá pra fazer todas as ações que são feitas no PSF. O ambulatório geral pode fazer praticamente tudo que o PSF faz. ... E todos os serviços giram em torno do ambulatório geral, ... em sua relação com as demais unidades e equipes do PSF (F428-9).

Se fôssemos analisar comparativamente o trabalho do ambulatório e de um PSF, ... que a gente está atenta à isso, não tem diferença nenhuma. ... Aqui temos uma unidade do PSF dentro do ambulatório, para uma área que é da nossa demanda. ... Tem até um que é dentro do mesmo espaço físico do ambulatório. (...) Volta e meia, a gente está fazendo ... um trabalho com um usuário, e dali a pouco a gente percebe que é de lá da área do PSF. (...) Atendendo no ambulatório geral ... a gente pega um monte de furo ali no PSF, porque acaba em nós. É complicado, eu já tive vários conflitos aí (F430-2).

A integração do PSF dentro de um ambulatório geral: O PSF só tem a ganhar com os ambulatórios gerais, porque fica aquela disputa. O PSF está aqui dentro e o ambulatório geral ainda é responsável por toda essa área. Então o pessoal ainda acabava escapando do PSF e indo ao ambulatório geral, ... que mandava subir de volta pro PSF. Briga de comadre eu chamo isso. Mas que se tem alguém de pulso na administração da unidade ou na administração do ambulatório geral, as relações ficam ótimas. Só nos locais onde não tinha bom gerenciamento que a coisa pegava (F433).

Havia uma clareza na equipe dirigente que a mudança do modelo de atenção à saúde teria que partir da rede básica e que a forma de gerá-la teria que ser construída.

\subsubsection{O Plano Municipal de Saúde}

Por referência à gestão anterior: Do plano municipal de saúde de 94, ... o que deu mais certo foi a construção das unidades de saúde, capacitação de recursos humanos e a implementação do PSF, quando iniciou. ... Aquele plano serviu mais porque era o único 
documento escrito que se tinha, em que alunos da faculdade e de colégios, como outros secretários da saúde da região consultavam. Ele era mais diagnóstico, muito extenso. Só que o plano ... desse governo atual foi ainda maior do que o anterior, criticado num primeiro momento porque achavam muito grande, era muita coisa, debocharam (F434).

\section{Definições preliminares}

No início do governo, quando a gente na verdade resolveu achar as diretrizes dessa administração na área da saúde, então ficou a meu cargo fazer a ... definição de por onde a gente ia começar (F435). Neste tipo de expressão transparece uma idéia muito do tipo "eu sou o dono do processo". Essas questões também precisam ser trabalhadas na organização e condução dos processos de trabalho em saúde.

Havia que fazer um plano. Todo mundo dizia: o nível central não tem uma estrutura, ... é uma teia assim. (...) Era o ... início da discussão de reforma administrativa, geralmente a primeira coisa que novas gestões procuram fazer. ... E felizmente por isso começou a se falar do plano. (...) Então nós resolvemos fazer primeiro um processo de planejamento, para poder ter um plano municipal de saúde de referência (...) e inclusive poder executar o plano já em 97. ... Claro, eu nunca tinha trabalhado tanto (F436-9).

Quanto ao plano municipal de saúde: Em primeiro lugar, ao se dizer que a secretaria tinha que fazer um plano, até como exigência da NOB/96, nós no conselho municipal de saúde definimos primeiro que pra fazer esse planejamento tinha que fazer através do método de planejamento do Carlos Matus (1993), o PES. ... Então se resolveu fazer o Planejamento Estratégico Situacional. (...) Nós sabíamos que com essa proposta, de ... fazer um PES, era o quê? Quem planeja executa e tal (F440-1). Importante aqui destacar a clareza dos atores sociais sobre seu papel estratégico no processo de planejamento implicando no compromisso com a execução do planejado. 
Quanto à inserção do plano na gestão: O plano realmente é todo dentro da metodologia do PES, ... que foi a base do nosso plano municipal. (...) A gente fez um plano tradicional que o Estado exige e incorporou o PES. Ele é uma mistura (F442-3).

A busca de consultoria: Vamos ter que fazer um planejamento estratégico. E nos lançamos a procurar propostas. (...) Então nós resolvemos, na verdade eu e uma outra profissional, ... entrar em contato com vários organismos de reconhecido valor, pra nos assessorar a, num primeiro momento, fazer um planejamento estratégico. ... Entre as várias propostas ... contratamos a assessoria selecionada (F444-5).

Praticamente toda a equipe de condução no nível central se auto-atribui a seleção da consultoria. E outros também. Muitos e cada um, como autores no processo. No conselho definimos que quem iria orientar como fazer o PES era a Fundação Oswaldo Cruz. (...) Eu digo: eu acho que a assessoria ideal realmente é a Fiocruz. Eu não conhecia outra. Então eu tive assim até uma influência muito grande nisso. Eu batalhei bastante pra que fosse a Fiocruz. (...) Veio a Fiocruz. E saiu o plano municipal de saúde, plurianual (1997-2000), para toda a gestão. ... Fantástico o tipo de processo da consultoria (F446-8). Sob diferentes relatos, os trabalhadores de saúde pública no município fizeram sua própria história.

\section{A oficina do PES}

Para introdução do processo de planejamento realiza-se uma oficina com consultoria de experts no assunto. ... E foi fantástico todo o processo, foi muito interessante, teve a participação dos funcionários, de conselheiros, um negócio muito bonito, muito bem definido, muito bem pensado (F449).

A definição dos aproximadamente 50 participantes da oficina gera sua adesão. Pode-se considerar que um processo de gerenciamento inicia pela inserção da equipe no mesmo processo. No caso estudado constatou-se uma vontade de participar muito clara e expressiva, desvelando-se o desejo de pertinência, de inserção: E eu ali. ... Eu ali naquele meio assim, às vezes dando umas bolas fora, assim, ... falo uma coisa que não 
devia falar, ... mas enfim, eu estou lá dentro. (...) Enfim a gente pôde participar do plano, do planejamento estratégico (F450-1).

Quanto aos participantes da oficina, enquanto uns dizem que ao final ... foram $40 e$ tantas pessoas, (...) outros especificam que foram 50 pessoas, 52 ou 54, na primeira oficina. (...) Eram: os gerentes maiores, na verdade assim era mais ao nível dos técnicos que representavam de uma maneira geral todas as divisões e setores da secretaria. ... O conselho teve dois participantes, não houve muita receptividade nesse momento. ... E mais dois representantes da ponta, o que já era compromisso. (...) A gente conseguiu envolver uma série de pessoas pra ter representatividade, tanto que hoje o conselho diz: Ó, está lá no Plano. ... Estão sempre voltando a uma coisa que a gente nem imaginava a dimensão disso daí. Era impressionante como ... pessoas completamente contra nossa gestão, tipo conselho, que era sempre embate, e nessa história entrando já como parceiro, participando do processo. Incrível. Apesar de que eu nunca vi o conselho como contrário (F452-5).

O auto-reconhecimento como autoria do processo tem o seu lado positivo no sentido do envolvimento e compromisso, mas no caso continha também uma idéia de apropriar-se como autores proprietários da proposta, o que afastava a adesão de outros no processo, inclusive gerando resistências desnecessárias.

A duração da oficina avançou no percurso de três meses: Na primeira oficina trabalhamos dois finais de semana, um em abril e um em maio de 97. ... E depois de um mês, veio mais um consultor para dar continuidade, aí teve mais uma semana em junho. (...) Então foram três finais de semana, $6^{a}$ feira, sábado e domingo, em semanas alternadas. ... Praticamente ficamos as três semanas trabalhando exclusivamente com o planejamento estratégico (F456-7).

\section{Metodologia do PES}

Por referência aos quatro momentos da metodologia do PES (Matus 1993), o momento explicativo aqui se expressa inicialmente em um diagnóstico situacional seguido de uma definição de prioridades. Com relação ao momento estratégico, alguns indicativos 
desse pensamento, que por sua importância ajuda a denominar a metodologia como PES, aqui estão contidos na descrição da metodologia da oficina. O momento normativo, sob o qual aqui se consideraram algumas referências em que, partindo da análise dos problemas, são colocados muito vagamente alguns esboços de idéias de formulação de ações. Retorna outras considerações estratégicas em um próximo movimento referido aos desdobramentos da oficina. E finalmente, o momento táticooperacional não é abordado imediatamente, mas no próximo subitem (Pós-PES), porque não fez parte da metodologia da oficina de planejamento realizada. Assim sendo, o processo da oficina de planejamento, conforme representado por vários de seus participantes, tem sua metodologia aqui adaptada nos movimentos a seguir relatados.

Inicialmente um momento de diagnóstico situacional: Fizemos uma seleção de problemas, o planejamento estratégico trabalha a partir de problemas. ... Elencamos uma série de problemas que nos afetavam enquanto técnicos. (...) A gente procurou ser bastante completo, ... até pormenorizado demais, ... poderíamos até ter simplificado em alguns momentos, mas pecamos mais por excesso do que por falta, tentando ser o mais abrangente possível. (...) Nos dividimos em grupos e subgrupos para discutir os vários problemas. ... Então grupos que tinham mais afinidades com alguns problemas acabaram entrando nos subgrupos respectivos para poder trabalhá-los melhor. Em um grupo, a gente tinha uma equipe pequena, que se dividiu em duplas e trios, aí uma pessoa podia fazer parte de mais que um sub-grupo. No grupo que era eu e o fulano tocando esse trabalho, muito lindo, a gente ficou quase doente, de tanto se envolver, a ponto de sentir assim: A força motriz do plano, foi eu, o fulano e tal (F458-60). Apesar desta última expressão também conter o sentido de poder considerar o problema trabalhado pelo sub-grupo como o mais fundamental para todo o plano, sua força motriz portanto, como poderia ser o caso do modelo de atenção, mesmo assim não pode passar desapercebido na expressão sua caracterização predominante como pretensa apropriação do processo. E também, por seu caráter muito centralizador, a partir dessa expressão associada a várias outras falas, pode-se pressupor que um planejamento local, participativo e ascendente, não estava colocado como preocupação. Era mais o envolvimento total de uma equipe reunida para esse fim. 
Um momento de definição de prioridade - todo o plano gira em torno dessa mudança de modelo: Eu particularmente, com outras pessoas que tinham essa mesma intenção ou interesse, entro num subgrupo chamado de modelo assistencial. Então esse passou a ser o primeiro problema, o maior de todos. Era um modelo de como a gente vai atuar na rede, pensando na integralidade. Então dentro dessa discussão começou a aparecer a questão de modelo, quer dizer, pra onde a gente vai, na verdade (F461).

A metodologia da oficina, em dois tempos: Eu não participei tanto da escritura do plano, ... mas, em todo o processo de sua formulação na oficina eu participei. (...) Na segunda etapa, já se trabalhou só com um grupo bem pequeno, era pra enxugar e revisar o plano. Então aí a gente processou rapidinho, ... não no grande grupo, ficou só no grupinho (F462-3). Essa prática se pode situar como descolada dos pressupostos conceituais do PES, quanto à participação dos atores sociais durante todo o processo de elaboração do plano.

Mas aquelas etapas todas, de análise de cenário, foram feitas. A análise de cenário só não está escrita ali no plano (F464). Essa postura está de acordo com o princípio da opacidade necessária às estratégias, pois, o importante nesta técnica é a abertura de alternativas para construir a viabilidade política do plano.

Era impressionante ver as coisas acontecer, esse negócio aqui existe, ... é possível, é viável, e alguém consegue essa organização desse caos todo, dessa loucura toda. ... Por outra parte, ... é uma pena, eu fico triste, porque ... depois parece que fica assim relegado ao segundo plano. Parece que as pessoas, que cada um tem um plano na cabeça, e aquele foi muito legal porque foi costurado em várias mãos. Foi bem democrático o processo (F465). Os desdobramentos do processo havidos revelaram que este envolve e compromete (só) quem participa.

Um momento de análise dos problemas para orientar a definição de ações: $E$, a gente conseguiu reunir 8 grandes problemas, depois esses 8 problemas básicos iniciais a gente enxugou em 6 grandes macro-problemas selecionados para compor o plano. E que acabaram sendo extremamente estruturais, eram problemas administrativos, 
gerenciais: recursos humanos, hierarquização, regionalização, modelo, comunicação, a área financeira, administrativa, aquisição e distribuição de materiais, as equipes, tudo é organizacional. Isso é só de interesse do funcionalismo, de melhorar o funcionamento da secretaria (F466). O que não lhe diminui a importância estratégica.

Todavia, a equipe sentiu aquele encaminhamento como uma falha do seu processo de planejamento: Mas isso não é ... a coisa fim, que é o que bate pra população: do quê adoecem, morrem e como vivem as pessoas. Esse é o diagnóstico epidemiológico. (...) Aí no segundo tempo o consultor se tocou, que a gente não trabalhou, ... na verdade, os problemas terminais. ... Bom, agora nós vamos ter que ver os problemas de saúde - o que é de interesse pra população. ... Aí a gente começou a refletir. Por que a gente fez assim? Porque a gente não tem um pensamento, um olhar, uma visão epidemiológica, o que a gente fez foi muito pensar só administrativamente, mas faltou pensar também epidemiologicamente. Aí nós teríamos enxergado (F467-8).

A concepção de um modelo de atenção tem que ser desenhada como a mais adequada para responder aos problemas de saúde que afetam sua população de referência. E mais precisamente, a partir da construção de uma rede explicativa dos problemas, com suas causalidades fenomênicas mais imediatas, explicadas por sistemas vigentes de regras e normas e estas pelas determinações mais estruturais da sociedade, o que segundo Matus (1993) pode ser esquematizado na forma de um fluxograma situacional, ou como também se encontra em suas derivações (Brasil 1995), em forma de árvore cujas ramificações relacionam as causas referidas a cada problema; é sobre a visualização destes diferentes níveis de problemas resolvidos que são definidas as soluções necessárias. Ou, simplificando, como diz um entrevistado: Foi através da análise dos problemas orientadora da definição dos objetivos a cumprir, que se passou a ter então as ações e operações, conforme esta metodologia (F469).

Assim sendo, quando por referência à metodologia da oficina do PES, tem-se a seguinte constatação - Nós só não fizemos a árvore de causas (F470), aí fica colocada uma grande questão, metodológica inclusive. Porque pensar nas causas dos problemas é pensar epidemiologicamente, ao considerar seus determinantes e condicionantes. E pensar a integralidade como resposta social aos problemas de saúde carece disso. 
Todavia problemas de serviços de saúde também devem ser trabalhados como problemas de saúde.

Movimento de algumas considerações estratégicas adicionais: Uma coordenação específica como a odontologia, dentro do planejamento estratégico, é uma coisa fragmentada, que não tem muito a ver ... com mudança de modelo, de tudo, essa coordenação fica meio ... fora. Então eu não estava gostando muito, ... aquele era um trabalho legal, mas não estava fechando ... com o plano, na verdade, não estava (F471). Ou seja, não se conseguia ver as possíveis relações do trabalho da odontologia entre outros, com o processo de planejamento, assim como, mais setores e membros da secretaria iam se sentindo excluídos do processo.

A busca de possíveis explicações para um processo envolvente a princípio mas que acabou frustrando expectativas: $O$ planejamento tinha toda uma informação de toda a secretaria, tudo - é mexer muito, não é? E, os gestores ali da secretaria, meus superiores, ... eles tinham medo na verdade, porque ainda estavam inseguros, dá sempre uma insegurança grande, num sentido assim: Bom, tão radical. ... Eu escutei tanto isso. E tem muitas forças que contém e mantém esse "status quo". Será que nós vamos mexer nisso ou não vamos? Então o que eu senti assim, foi na verdade, que o secretário na época, ele ia tentando mudar aos poucos. (...) Passos estratégicos, só o pessoal de saúde e tal. Foi muito legal. Só que o ideal teria sido, ter dado continuidade, e isso não aconteceu. (...) Nós também aprovamos no conselho que teria um acompanhamento da execução desse plano, através da mesma consultoria, mas não deu (F472-4).

\section{Pós-PES: primeiros resultados do processo}

Finalizada a oficina, esse é o momento da construção da viabilidade estratégica da ação planejada, onde os fatos são predominantemente políticos e a materialidade da ação é tecnológica, seja trabalho de saúde, seja sua condução gerencial. Após a oficina, por referência à derivação de ações de um PES no início do seu momento tático-operacional (Matus 1993) tem-se uma primeira constatação: Dois meses depois, aí a gente perdeu o 
fôlego. Faltou lenha (F475). Para uma mudança desse porte precisa combustível continuado.

Observou-se nos atores entrevistados uma sensação de que o plano não se realizou; da teoria, referida como sua formulação, não se passava para a sua prática. Mas por quê não dava mais certo? São muitas respostas possíveis na tentativa de explicar: Porque no PES havia aquele negócio, quem planeja executa, mas quando as pessoas não querem executar, querem planejar e executar de forma diferente, aí não funciona. É, e aí foi tudo de água abaixo. ... Fizeram o plano, mostraram e todo mundo vem aqui, olha, e diz: Meu deus que coisa bonita! Mas só isso não basta. (...) E a partir do momento em que as pessoas passaram a não respeitar o plano, ... a coisa se complicou. Embora muito daquilo ali foi executado, ... pelo menos eu acho que uns 50\%. Eu não sei se esse é um índice bom. (...) Olha, o plano, eu acho assim que foi um dos avanços que a gente teve aqui em termos de conteúdo, o teórico estava extraordinário. A prática dele não se deu. Isso em função da própria secretaria ter uma visão atrasada do SUS, o plano estava muito longe da realidade. Se nós aceitarmos que ... a prática é o critério da verdade, ... a coisa fica preta. (...) Mas também era um plano com muita coisa fora da realidade, na estratosfera, com os pés fora do chão. A questão financeira principalmente. ... O quê que aconteceu com o plano? O plano em si é bom, o modelo é aquele. A questão é a execução do plano (F476-9).

Não havia uma estrutura de implementação e avaliação, especialmente no sentido de impulsionar a execução do planejado: Porque se você fez um planejamento estratégico, você tem que ter uma equipe de acompanhamento e monitorização; nós nunca tivemos. Isso aí nós pecamos também. Até que teve uma equipe no início da gestão, mas eles também não conseguiram, naquele negócio de apagar incêndio, e o secretário também não deu respaldo à equipe de planejamento. De fato ... faltou respaldo político ao plano. (...) E a nossa briga com o secretário foi toda vida esta, porque nós fizemos o plano e ele sempre foi contra o plano, mas ao mesmo tempo assinou o plano. Eu passei a ser hostilizado, ... porque eu assinei o plano também, o prefeito assinou e o secretário também. E no conselho ficamos cobrando o plano constantemente (F480-1). 
O acompanhamento e avaliação fizeram falta àquele plano municipal de saúde: Quando chegou na hora de trabalhar mecanismos e indicadores de acompanhamento, na hora de pensar ou fazer a avaliação, ninguém tem mais tempo de escrever. ... Quando era pra investir nos indicadores a gente não tinha mais tempo. (...) E não houve acompanhamento. Porque não teve mais transparência, nos diversos sentidos daquilo que estava se produzindo, daquilo que estava se executando, entende? ... Então as próprias pessoas que estão realizando alguma coisa nem elas sabem o que estão fazendo. (...) Se a sua prática não se deu ... foi por erros administrativos, inclusive pela dificuldade de efetivar o controle social ou especialmente por isso (F482-4).

Eram apontadas atitudes próximas ao amadorismo gerencial pesando na condução das relações funcionais internas: $O$ pessoal consegue ser tão displicente, quando eu fui atrás do plano municipal, me pareceu ninguém mais querer saber muito dele. ... Eu trabalho em cima dele na minha pós-graduação, fazendo sua monitorização. ... Do ponto de vista da avaliação do planejamento, então a gente queria estabelecer outros indicadores, pois aqueles indicadores referidos no plano ... são muito quantitativos. (...) Só me recuso trabalhar com a parte administrativa, que não conseguiu tirar do papel pra prática, ... porque aquilo pra mim é incompetência, não foi má administração. Bom, à parte dessa avaliação tem o problema da falta de equipe nessa área $(\mathrm{F} 485-6)$.

Era perceptível a ausência de atores com a determinação de levar o plano à prática e querendo descobrir como fazer para conseguir isto. Ao mesmo tempo, nunca se havia estado tão próximo de se poder fazer a mudança do modelo, porque aquele plano estava praticamente pronto para ser implementado. São surpreendentes algumas compreensões expressas na crítica da própria experiência vivida: As coisas foram assim, estava bonito no papel, só que no meu modo de ver, porque a gente está de fora, a questão é: as pessoas não faziam ligação, entende? Ligar, eu quero dizer assim: o quê que a unidade de saúde tem a ver com o PSF, o quê que o PSF tem a ver com o hospital, o quê que isto tem a ver com o povo, o que é que isso tem a ver com o plano administrativo na formação do pessoal. Era tudo uma cadeia. O que é que isso tem a ver com a vigilância? Por que é que tem que ter mais controle, controle social e discussão da forma de participação? ... Era tudo uma cadeia (F487). Esta leitura traz, 
empiricamente, uma compreensão da necessidade de um pensamento sistêmico na organização de um modelo de atenção à saúde. Tal pensamento representa a quinta disciplina que nomeia a obra de Senge (2000) sobre as organizações em aprendizagem.

A reflexão sobre quais ações e resultados permite concretizar a materialidade do plano, encontra importantes subsídios na concepção de Matus (1993) sobre o arco direcional do plano, quando propõe que, no processo de avaliação; se busque a congruência entre a situação inicial, os projetos intermediários e a situação - objetivo.

E depois do PES, algum plano de trabalho, sobre como fazer o processo acontecer? ... Nada, tudo continua numa lógica de reforma administrativa, só (F488). Sem ninguém se questionar mais para quê. Efetivamente, nos primeiros contatos da pesquisadora com a equipe dirigente, em sua entrada exploratória no campo, objetivando inicialmente conhecer a situação mais geral, quando procurava falar do plano, considerado um importante instrumento para a mudança do modelo, constatou-se que não havia claramente essa linha diretriz, não era esse o interesse. A percepção era efetivamente como diz a fala: Só queriam saber de reforma administrativa (F489). Observou-se naquele contexto, quando já iniciado o segundo ano da gestão, que havia uma leitura político-institucional pressupondo que pela via da reforma administrativa se resolveriam os problemas enfrentados.

\subsubsection{Funcionamento da Estrutura}

Assim como o plano municipal de saúde é um instrumento privilegiado para a instituição do processo organizacional, a estrutura e o funcionamento da organização têm que estar voltados ao propósito assumido. As questões organizacionais aqui relacionadas constituem um outro importante bloco de reflexões elaboradas, ao mesmo tempo em que ocupam o interesse da gestão pós-euforia da oficina do PES. Trata-se de um movimento de definição e gestão organizacional, o funcionamento da estrutura. 


\section{Reforma administrativa para quê? - seu fundamento e concepção}

No início da gestão anterior, já havia uma preocupação com a integração interinstitucional: Na época nós já lutávamos muito em mudar o modelo administrativo municipal, tentando integrar a área social, para ... acabar com essa idéia que tem que ter um dono pra cada ovo, como a gente vê nas prefeituras, de acordo com as tendências do prefeito, mais na área social, econômica, ou obras (F490). Conforme Capistrano, seriam as administrações voltadas à zeladoria, políticas sociais ou engenharia (Campos e Henriques 1997).

Era então constatada uma duplicação de funções: A gente vê uma série de órgãos fazendo a mesma coisa. Eu achava que deveria ter uma concentração das atividades da área social, com as áreas de desenvolvimento urbano, administrativo, enfim, uma coordenação que imbricasse todos esses trabalhos comuns. (...) Só atuando na área da saúde nós tínhamos a secretaria da criança e adolescente, secretaria de saúde, do meio ambiente e ação comunitária, o saneamento ambiental trabalhando com a água fluoretada, os transportes urbanos fazendo ações da saúde no que tange a acidentes $e$ óbito no trânsito, com uma falsa visão da coisa, considerado óbito ocorrido na via pública. ... Então era uma bagunça, ... um modelo vencido, e a gente acabou não conseguindo mudar. (...) Mas foi uma ajuda muito grande ... começar a discutir com Curitiba a história de tentar colocar em prática a idéia que tínhamos aqui, que coincidia com aquilo que estavam fazendo lá. A idéia era 'junto com o prefeito montar um modelo administrativo integrado', e por coincidência a gente queria fazer a mesma coisa aqui sem que a gente tivesse tido contato com eles. Às vezes acontece isto ... e ao mesmo tempo. Eu acho até que de repente e não é muito difícil isso. É que se você começar a filtrar, com um senso crítico o que está errado, acaba encontrando uma solução, que é muito parecida com aquilo que outro está fazendo (F491-3). Aqui existe uma referência ancorada em Capra (1995, p.259), no sentido de que a construção de uma "nova visão da realidade (....) baseia-se na consciência do estado de inter-relação e interdependência essencial de todos os fenômenos", o que indica a "formulação gradual de uma rede de conceitos e modelos interligados e, ao mesmo tempo, o desenvolvimento de organizações sociais correspondentes". 
E internamente na secretaria havia guetos por categoria profissional como antecedentes: Bom, no início da gestão anterior, era assim, tinham alguns guetos de poder lá dentro: ... divisão de odontologia, onde se achavam no direito de indicar quem seria o diretor, mesmo que não fosse de confiança do secretário, ... eram os mais impetuosos; ... tinha o grupo dos médicos e suas facções - do município, do Estado, ou federal; e o grupo de enfermagem, entre outros. E se a gente quer realmente 'trabalhar a idéia de saúde como um todo, ver o ser como um cidadão', tem que ter ... 'ações da saúde voltadas para esse cidadão como um todo' (bio-psico-social). Tem que parar de dividir a pessoa em olhos, ouvidos, cabeça, perna, braço, então tem que 'olhar o ser como um cidadão saudável num ambiente saudável'. Nós vamos ter de mudar isso. E dava briga porque um se metia na esfera do outro (F494).

Aí analisando o organograma, ficava claro que precisávamos mudar aquele negócio, ... e a partir de uma discussão bolamos como poderia ser a coisa. E quando eu cheguei na secretaria, disse de supetão: Vamos mudar tudo isso aí, a partir de hoje não tem mais divisão de nada. ... Nós vamos 'trabalhar baseado no ser humano'. ... A gente não sabia como encaixar as pessoas porque era uma idéia muito incipiente. Então criamos um departamento de saúde. Mas como para cada categoria com mais de dois profissionais já reivindicavam uma divisão, então criamos um departamento de serviços especiais de saúde (F495). A integração somente pela via da estrutura organizacional é sempre muito limitada, não se consolidando efetivamente.

Se no último plano aprovado existe um consenso forte em cima da idéia de integralidade como diretriz do modelo de atenção, de onde veio essa idéia? Foi uma coisa definida pelos técnicos e que nasceu de um processo participativo. E que no fundo recupera uma proposta historicamente colocada naquele SUS a nível municipal. O que se queria entender melhor é de onde veio essa idéia e o que ela significava, pensando desde o final da gestão anterior, como é que se pode perceber essa idéia, e depois, como as coisas evoluem.

Em meio ao processo de fazer um plano municipal de saúde e uma proposta de reforma administrativa (1994-95) por contingências daquela gestão anterior, com a contribuição 
de uma curta assessoria de profissional especializado (*), teve-se: Aí fizemos uma coisa interessante, ... eram alguns projetos de reunir o pessoal pra começar a discutir isto, aqueles grupos que se encontravam lá na universidade, eu acho que ali é que começou, ... ali deflagrou. ... Na verdade eu acho que ali o pessoal começou a dar sentido a uma coisa que eu tinha ainda fosfórica na cabeça, mas que não sabia como é que faria pra acontecer, te confesso. Eu sabia que não podia mais as coisas continuar a ser assim separadas, 'nós tínhamos que realmente integrar, mas eu não sabia como fazer pra isso'. (...) Todo aquele trabalho acabou criando consciência. Eu lembro que uma vez um dentista, o representante do setor, ... ao apresentar umas questões discutidas em grupo, disse: "Eu estava vendo uma possibilidade interessante com a área de enfermagem, a gente pode trabalhar junto". Então isso significa que ... eles deixaram de ver a sua profissão isolada na maneira de fazer saúde e passaram a ver o cidadão, com uma maneira de ajudar este cidadão a ter saúde. E foi aí que surgiu a vigilância em saúde, acho que foi ali o estopim e aconteceu. Aí aquele dentista falou: "No bairro tal vamos fazer uma 'unidade integrada de saúde bucal' lá junto, integrado com o pessoal dos serviços, aí o usuário vai lá e pra nós é melhor até porque usamos a mesma pessoa pra cadastrar." Quer dizer então, aí o pessoal já começou a pensar em vigilância à saúde (F496-7). Portanto, a vigilância à saúde surgia como eixo da discussão de mudança do modelo na perspectiva da integralidade da atenção.

\section{Um novo processo de reforma administrativa}

No início da atual gestão coloca-se o processo geral de reforma: Ninguém mais conhecia a parte de estrutura, mas tinha de mexer com isso. Então eu fiquei muito nesse lugar, de coordenar esse trabalho de repensar a estrutura da secretaria. A gente aproveitou um pouco o que tinham discutido em 94-95, ... e que, talvez pela luta de interesses, retrocediam em alguns momentos. (...) Queriam então fazer uma reforma administrativa em 30 dias, uma coisa super difícil de articular. Em dezembro de 97 a prefeitura aprovava a reforma. Depois de um ano de discussão e vai e volta.

(*) Trata-se da autora da tese. 
O que o secretário queria em um mês levou um ano. ... A prefeitura ainda vivia com o organograma de 1990 (F498-9). Não é difícil justificar a suposta necessidade de reformas de estrutura organizacional, especialmente nos serviços públicos em mudança de administração. A experiência empírica tem confirmado isso, argumentos não faltam.

A crítica das relações externas com a estrutura executiva municipal: A saúde não pode fazer sua reforma administrativa de forma isolada. ... Havia um pensamento de uma ou duas pessoas da equipe de reforma administrativa da prefeitura, ... que não admitiam área de planejamento nas secretarias, por entender que devia ser centralizado na prefeitura. E como fica a saúde com suas contingências setoriais a impor um planejamento local participativo, elaborado conforme o ponto de vista das unidades de saúde, ... que acabam mostrando a real? (...) Será que aquele planejamento da prefeitura não tem autocrítica? E não nos apóia ou assessora. E assim passou o ano de 1997 e em 98 a gente começou a implantar. ... Quem? Como? É, nesse segundo passo, me faltaram dados (F500-1). Interessante ressaltar que, como argumento, o planejamento local participativo aqui é defendido; mas sua prática não se identifica no período estudado. Ao contrário, observam-se movimentos em torno de reformas administrativas reduzidas a um novo desenho de estrutura organizacional, sem configurar-se um processo de mudança planejada.

Internamente, de gestão em gestão, por referências às três últimas, um mesmo discurso em diferentes expressões se repete: Como é que (também) a gente pensou: Vamos acabar com os guetos aqui na secretaria. Não tem mais o setor de enfermagem, do médico, do dentista, não tem coordenação disso ou daquilo. Vamos trabalhar multidisciplinarmente, ... vamos ousar na proposta. E a gente conseguiu, de fato, romper com isso. (...) A gente procurou fazer um organograma mais horizontal, mais moderno ... Era difícil explicar pras pessoas, ... porque romper com aquelas divisões por categoria profissional. ... O pessoal não consegue entender se a sua unidade não "virar um quadradinho". Isso ... mexe com o lugar que todo mundo quer ocupar, e ... ninguém entende ficar fora dum quadradinho (F502-3). Não lhes basta pertencer a uma área, a necessidade posta é ser um setor da secretaria. 
No desenho da estrutura organizacional, ... a gente seguiu um pouquinho também a estrutura de ministério e de estado na busca de soluções para as mudanças aqui, pois, se olhar as outras, a gente consegue ir se ajeitando. ... Então se fez muita pesquisa de organograma, em municípios que já tinham conseguido fazer reforma numa tendência mais atual, com área de planejamento, recursos humanos, ... com descentralização e distritalização. ... A gente não teve que manter tanto as estruturas aqui dentro, porque as estruturas hoje estão mais nas gerências regionais. A regionalização faz com que enxugue o nível central (F504). Refere-se a trabalhar por região, com responsabilidade sobre as unidades de um território ou distrito.

Criam-se algumas superintendências, ou melhor, renomeiam-se duas e cria-se uma nova. Mas continuam sendo superintendências, uma terminologia de poder institucionalizado que se mantém. Duas áreas ganham destaque na nova estrutura: Foi criada uma superintendência de desenvolvimento pessoal (recursos humanos), que era uma coisa que não se trabalhava antes. Incluiu a parte de comunicação, junto com educação em saúde e informações (EIC), que antes nem tinha sistemas computadorizados, foi colocado tudo a disposição. (...) A unidade de políticas de saúde foi extinta ... e se transformou na ... 'superintendência de integralidade', (...) onde se faria o 'desenvolvimento da vigilância à saúde e atenção integral', com 'todos os serviços integrados em um fluxo de relações' (F505-7). Observa-se que somente nas referências ao titular desta unidade usava-se a expressão "o superintendente" (da secretaria), sem adjetivos. E a denominação dessa superintendência vai ser referida por muitas expressões diferentes. Seu nome e conteúdo não são assimilados de forma consensual. Aquele órgão ainda continha a idéia de promover uma integração organizacional, pensando "o inteiro" da estrutura da secretaria: Quando entrou a proposta da reforma administrativa, entrava essa superintendência com interesse em pegar a saúde (área fim), e organizar internamente todos os serviços de forma hierárquica, 'que prevalecesse uma integração mesmo', com um fluxo de relações bem estabelecidas entre todos os serviços (F508).

Naqueles dois encaminhamentos de caracterização do organograma constatou-se que havia uma intenção de adequar a estrutura ao PES. Isso representa uma clareza política sobre a necessidade de implementar a diretriz da integralidade no modelo de atenção, 
tanto que se privilegia essa intenção na estrutura organizacional. Essa foi uma das raras tentativas de adaptação da estrutura aos objetivos do plano.

Havia naquelas representações dos entrevistados, sobre a organização da estrutura da secretaria, uma importante questão implicitamente colocada, que coincide praticamente com o objeto desta pesquisa: Em que modelo organizacional e com quais características tecnológicas se estrutura o funcionamento de uma organização para dar consecução a um modelo de atenção integral e vigilância à saúde?

O espaço da estruturação organizacional se revelava insuficiente: Em 1998, um ano depois, se conseguiu mexer mais no organograma - a superintendência de vigilância e atenção integral, onde primeiro não se quis separar a vigilância da assistência, ... acabamos separando. Aí hoje tem a superintendência das vigilâncias e a superintendência da assistência integral que é a rede própria e o PSF. (...) A idéia era fundir, mas não se fundiu, segmentaram e ficou segmentado. ... Tanto estava incompatível que a gente acabou separando. (...) Aí, passado ... o tempo de implementação da reforma administrativa, no final do ano veio uma discussão sobre virar fundação. De novo (F509-11). Pois essa intenção já havia mobilizado a secretaria por mais de um ano na gestão anterior - tornar-se uma fundação municipal de saúde. Mas novamente sem viabilidade.

Parecia haver algum nível de fixação na idéia de querer resolver tudo via reforma administrativa. Sem levar em conta que esses movimentos, não devidamente articulados à um processo mais abrangente com clara direcionalidade de mudança organizacional, tendem a deixar todo mundo muito alvoroçado com os novos cargos $\mathrm{e}$ redimensionamentos das inserções dos membros das equipes.

\section{Antecedentes de funcionamento das relações internas}

Atitudes personalistas na condução do último ano da gestão anterior (1996): Naquele período, as avaliações de todos os médicos, passava tudo por mim. ... Na expansão da rede, para inaugurar todas aquelas unidades de saúde, tinha que negociar com cada 
médico, para se predispor a estar trabalhando longe. Eu ... ajeitava de uma tal maneira, e, selecionava as pessoas pra fazer treinamento, ... uma loucura. Só que tinha que discutir em equipe e no estilo gerencial do nível central não havia muito isso (F512). Caberia questionar aqui com qual referencial tecnológico se processavam aquelas ações. Quando não há sistema as soluções são personalizadas.

$\mathrm{Na}$ apropriação de espaços de micro-poder: A questão do poder, ... eu nunca vi um carimbo, que a gente manda fazer à vontade, um raio de um carimbo, te dar tanto poder que eu nem sabia que tinha. Tanto que só descobri que tive todo esse poder depois que saí. (...) Então um dizia: $O$ dr. tal não trabalha, a dra. tal não trabalha, ... ficava-se dizendo os furos para o gestor, dedando mesmo, porque não dava para ver aquilo. E ... o secretário viajando, era o Conass, Conasems, Bipartite, Tripartite, governo (F513-4).

O estilo centralizado de gestores anteriores é constatado: No início da última gestão, a secretaria ... ainda ocupava só a metade do primeiro andar da prefeitura e ali ainda tinha a perícia e o ambulatório. O secretário que nos antecedeu era um maluco, porque era só ele e dois diretores ao seu lado, tudo centralizado neles. Comparativamente então, na nossa gestão passada, até podemos dizer que fomos ... um pouquinho mais descentralizadores. (...) $O$ gestor anterior veio com uma proposta diferenciada, embora não tão descentralizada como seu antecessor, porque foi mais centralizador de decisões. É que ele participava de muitas coisas, se envolvia muito e aí centralizava. (...) Na verdade o secretário da última gestão anterior tinha muito a fama de ele mesmo planejar, era muito centralizador. Então não existia uma equipe de trabalho (F515-7).

A expressão nada rara quando eu peguei a secretaria (F518) tem um conteúdo implícito de apropriação. São questões que deixam passar desapercebido o que está por trás do explicitado. Em tais posturas existe uma armadilha ética, quando se fica anestesiado e não se percebe o que está acontecendo no dia-a-dia. É preciso estar atento para questões que se expressam sem perceber o significado que contém. 
Antecedentes da relação nível central versus pessoal de ponta: Eu entrei na secretaria em março de 96 e então, sem o aspecto crítico negativo, estou colocando a situação real, era um órgão centralizador, com secretário, diretor e algumas pessoas que gerenciavam toda essa estrutura sem sair de dentro do nível central. Lembro muito bem que se em 6 meses, alguém recebesse uma dessas pessoas no nosso local de trabalho por uma horinha, a gente achava o máximo, porque tinham nos ouvido. E com certeza o retorno não existia (F519). Mas após o processo de constituição de um grupo de gerentes regionais, ... hoje o retorno é imediato. Eu recebo uma correspondência hoje, amanhã minha coordenação está recebendo a resposta. Mas aquelas pessoas, não tinham uma estrutura pra realmente estar dando esse retorno. Então, as pessoas na ponta se sentiam largadas, como apêndices (F520).

\section{O nó administrativo}

Na cronologia já se iam 2 anos desde o plano, havia um grande espaço de tempo a rever, procurando entender: É, do planejamento estratégico até a oficina de territorialização, também tem uma lacuna de tempo ali. ... Mas isso foi rápido, por incrível que pareça. Legal falar sobre isso, aconteceu o seguinte: todo o plano não cabia mais num caderno enorme. (...) E como cuidar do dia-a-dia? As coisas do dia-a-dia começaram a atropelar. Isso eu acho que é um teste, da vida, da realidade (F521-2).

Por referência a mais alguns antecedentes da gestão anterior, fica uma imagem de como ir resolvendo os problemas cotidianos no caminho, ao mesmo tempo sendo gerenciadas as atividades meio e fim: Mas quem ficava com os problemas assim do dia-a-dia? Tinha que ter alguém. ... E eu, continuava sempre no papel de estar dando atenção pro pessoal da rede. ... Eu cuidava desde o motorista, a servente, a telefonista, todos tinham que ser bem tratados e respeitados, pra que funcionasse o serviço. Eu fazia esse meio de campo, ... não sei explicar. ... Dei muita atenção pros médicos também, ... estava fazendo amizade, consegui me relacionar bem com os problemáticos da rede. ... Eu descia e falava com um e outro no dia-a-dia e subia para acompanhar as ações técnicas do modelo. ... A parte de cima do andar, onde era o modelo, alguém dava conta (F523). Havia técnicos preparados para isso e existia uma mesma direcionalidade. 
Nessa gestão os avanços técnicos eram reconhecidos e o mesmo não ocorria no administrativo: O pessoal técnico consegue avançar bastante. Avança porque o próprio planejamento impulsiona, agora vem a capacitação para o desenvolvimento gerencial da rede, ... então permanece a proposta. (...) A parte técnica, de saúde, o nosso pessoal, em dois anos passou a dominar, adquiriu experiência. A área técnica se transformou. E onde é que continuou o nó crítico? Na administração financeira e de materiais (almoxarifado, suprimentos, medicamentos). Isso aí nos matou, ... eram muitos problemas na área financeira, na questão de suprimentos, contratos e convênios e serviços gerais (...) Como a gente chama aquelas coisas que queimam no dia-a-dia, era isso o que estava afogando a gente, ... afogando o secretário e mesmo a gestão. E era aquela coisa, não se conseguia fazer o plano acontecer, como se tinha direcionado, ... porque a cada dia você tinha que estar apagando um incêndio (F524-6).

A secretaria precisava de pessoas capacitadas na área de administração, porque técnicos na área de saúde tinha. ... Na parte de controle e avaliação, almoxarifado, não tem um técnico preparado a partir da forma como a saúde funciona, da dinâmica da saúde. (...) O pessoal administrativo, ou são pessoas que, se estão preparadas para aquela função, não conhecem nada de saúde, ou, se sabem algo de saúde, não estão preparados para aquela função. ... Então, isso ajudou a ser fatal para impedir um maior avanço na proposta. (...) Quem conhece um pouquinho dessa área ... tem muito espaço. Falta capacitar gente nessas questões, precisa. Para um contador de repente não decidir e ter mais poder que o secretário, às vezes, por saber o funcionamento dessa área (F527-9).

Conseqüentemente, e como cada superintendência partiu para apagar seus incêndios, aí desgastou e separou. E ... começaram as brigas pelo poder e separou mais. Isso já desde o final do primeiro ano de governo. Foi quando a gente teve uma pauleira danada com o pessoal da administração, o administrativo estava fazendo um erro atrás do outro e a gente não admitia. E ficava aquela cobrança, a gente acerta daqui, convence o pessoal daqui, e vocês de lá não acertam o que tem que fazer. O processo de licitação é sempre onde peca a secretaria, no administrativo, e agora tem aparecido problemas no controle e avaliação. (...) Apesar de que no controle e auditoria, a parte 
mesmo do controle, funcionou muito mais efetivamente depois que a gente entrou. ... Controle, avaliação e auditoria, a gente até se virava (F530-1).

Observa-se que a ordem de problemas levantados no momento estratégico do PES, efetivamente era onde haveriam que ter sido enfrentadas as dificuldades advindas.

\section{Gestão financeira dos recursos pelo FMS}

Sobre a política municipal de investimentos em saúde: Em 1994, com a gestão semiplena aumentaram os recursos da saúde no município, e foram pra atenção primária. ... E agora o Fundo Municipal de Saúde (FMS) não recebe um tostão da prefeitura, que só paga o funcionário. Então aqui nós demos um passo atrás, lamentavelmente. (...) Aí se você vai ver os investimentos da prefeitura na saúde, são todos em hospital. Nas outras administrações não era assim. ... No duodécimo da prefeitura, o que tem de contrapartida aí é só dinheiro da parte de medicamento (F532-3). E a contrapartida só entra porque é pré-requisito de vários financiamentos. Como se pode ver, aqui tem uma ação contra a SMS por falta de atendimento, aí paga, porque foi decisão judicial. Dinheiro mesmo, o único dinheiro da prefeitura que entrou aqui no Fundo foi em 1997, dezembro, tantos mil reais. O resto é tudo dinheiro de repasse. (...) Por causa disso o berreiro que teve no conselho, quando naquela policlínica ali ... de referência de especialidades, eles gastaram tantos mil reais com divisórias. ... Isso porque eles começaram a ignorar tudo aquilo que a gente construiu e ajudou a planejar, por referência à participação no PES (F534-5).

Definição política de aplicação dos recursos: Nós necessitamos aqui, e já discutimos isso com os vereadores e com o prefeito, é ... reorientar os recursos que recebemos do ministério da saúde. Aí melhora, porque dentro deste processo nós temos recursos para alta complexidade - ressonância magnética e implantação de marca-passo -, mas falta ainda lá o exame de sangue e outros procedimentos básicos. Nós temos que reorientar pra quem necessita mesmo de garantias de acesso, o que lamentavelmente, nos tínhamos que estar fazendo já há mais tempo. Não sei se vai ser neste governo, mas vai ter que fazer; só não sei quem vai fazer. Até porque as nossas prefeituras e os governos 
estaduais estão falidos. E não é querer fazer uma medicina pra pobre, não é isso aí, mas é repartir melhor os recursos que tem. (...) Nós gostaríamos de que 60\% dos recursos fossem para a periferia na atenção básica, $30 \%$ intermediário e $10 \%$ no centro para os serviços de referência, aquela coisa de medicina mais avançada, de exames mais complexos (F536-7). Na realidade é tudo ao contrário, apesar do quantitativo de ações ser naquela ordem. E a equação é mais complexa.

Sobre o pagamento dos serviços comprados de prestadores privados: Nós temos uma briga aqui dos laboratórios que querem fatias iguais, ... você já viu isto? Aqui existe isso e é claro que no conselho não vamos interferir neste processo. Se o laboratório tem capacidade de colocar um posto de coleta lá perto da unidade de saúde e o trabalhador não ter de se deslocar de lá pro centro, tem que deixar fazer lá mesmo. Ainda mais quando ... tem outro que faz. O usuário tem o direito de escolher onde ele quer fazer o exame. (...) Aqui tem isso porque as pessoas querem trabalhar, mas também querem algumas coisas. Na oftalmologia, por exemplo, não tem ninguém que se pré dispõe a trabalhar pela tabela SUS (F538-9).

\subsubsection{Comunicação da estratégia}

Existe uma relação continuada entre as condições de apoio administrativo e o encaminhamento das estratégias organizacionais. Por exemplo, a diretriz da vigilância à saúde impõe a integração intra-institucional: Na época fizemos várias propostas pra viabilizar internamente, com mudanças de gerência, cargos diferenciados, estruturas diferenciadas, mudanças na vigilância sanitária, epidemiológica e tal. (...) A gente não consegue admitir a situação seguinte: secretaria daqui, vigilância sanitária dali e vigilância epidemiológica de lá, em três endereços de quarteirões diferentes. Quer dizer, ... o conselho vai tomar quê decisões sobre vigilância à saúde tendo essa distância da vigilância sanitária e epidemiológica lá em baixo? (F540-1).

Apesar dos esforços de descentralização na estrutura organizacional, o estilo centralizado continua a transparecer no início da gestão atual. Mas se diferencia da anterior centrada em uns poucos atores, para a atual centralização sobre um processo de 
gestão através de uma equipe de nível central desarticulada dos níveis de execução das ações de saúde.

Observe-se o sentimento de quem se insere na equipe da gestão atual sem haver participado da oficina do PES, ao referir-se ao documento do plano: Aí eu tive que aprender o que é um plano de saúde, e peguei aquela bíblia, o PMS, porque não participei de nada naquele processo de fazer o plano. Enquanto aqui se planejava eu estava lá na unidade clinicando. E lá nem se ouviu falar. Tudo aquilo estava acontecendo só aqui. Não chegava lá na ponta, a estratégia (F542). No quadro interno de relações do nível central com as unidades locais, a ponta do sistema, as visões não eram compartilhadas e isso faz falta para querer mudança de prática sanitária - uma adequada comunicação da estratégia. Não existe mudança estratégica se seu planejamento e execução não estiverem amplamente disseminados entre aqueles que realizam o trabalho, ficando todos os integrantes da organização envolvidos no processo. O novo conhecimento que está sendo construído precisa circular por toda a organização, sendo coletivamente compartilhado e não pretensa propriedade de poucos.

Era tudo muito centralizado, não havia uma visão compartilhada nos vários níveis de serviços. E continuou não havendo. Ou seja, era um processo restrito às estruturas centrais. Como também, não se pode dizer que houvesse uma condução do processo de trabalho segundo o modelo de atenção pretendido. Conforme as representações até aqui apresentadas, a arquitetura interna derivada e implicada também não havia sido sequer pensada.

O isolamento emerge: $O$ que eu sabia de SUS, para você ter uma idéia, era o que eu aprendi em 88, naquela época ainda era SUDS. Entendeu como é que eu estava atrasada? Até ser convidada para o nível central, ... eu ficava totalmente a margem disso, não entendia, não sabia o quê que era isso (F543). Essa situação mostra uma organização no nível central, que não entregava nada para o "profissional de ponta", que ficava sem qualquer engajamento no processo. E pelo quanto depende dele a prática do processo de trabalho e a sua organização interna, é fundamental a sua inserção mais 
objetivada em processos de mudança organizacional que pretendam atribuir um novo caráter ao serviço prestado à população.

Inserção sistêmica: A gente nem conseguia visualizar o todo. ... Qual era realmente o meu papel na estrutura total da secretaria? Eu me via só no ambulatório ou policlínica, tentando melhorar aquilo lá, daí mandava um projeto e nunca era respondido. (...). Com uma assistente social, assumindo ... aquele comando da policlínica, ... porque se ajudou a elaborar o PES, a gente também ficou mais atuante dentro da secretaria. ... Então, aos poucos já se conseguia ter algum envolvimento e se foi fazendo essa construção de um novo modelo (F544-5). A diferença se marcava pela participação no PES.

\section{Liderança de condução da estratégia}

Em posicionamentos da área finalística que centraliza a estratégia identificam-se disfunções: Na época não tinha a central de exames. ... Então começou a vir uma demanda muito grande pra assistência batendo direto aqui no nível central. (...) Naquela situação o superintendente técnico era o grande autorizador de exames. Isso acabou com a função dele de superintendente. Isso engole a pessoa (F546-7).

Na perspectiva de reforços na equipe central da SMS, um convite pessoal para o nível central é destacado com o sentido de "privilégio de sair da ponta": Pensei: ai que delícia parar de clinicar. Porque nessas alturas do campeonato, eu já estava sacuda de clinicar na rede pública, eu não tinha mais o que aprender, eu não tinha mais o que fazer, abria e fechava o lugar. Eu já estava ficando assim, não ligava pro serviço. E aquele foi o oxigênio que eu precisava, aí eu vim pro nível central (F548).

Critérios de remanejamento na equipe dirigente: Aí, um belo dia, eu ainda nem tinha visto o resultado do meu teste de aptidão psicológica, o secretário me chamou e disse: Eu quero te oferecer a superintendência (técnica) da secretaria, no lugar do fulano. Difícil captar a lógica do quê leva um gestor a uma opção assim. Mesmo que houvesse uma explicitação tipo: O seu teste veio muito bom e eu quero que você assuma (F549). Essa forma de seleção de ocupante de postos-chave via testes psicológicos, é mais 
própria de empresa privada, surpreendendo no contexto político-organizacional do caso estudado. Apesar de cada vez mais haver uma unificação da teoria organizacional de aplicação na administração pública e empresarial (Pettigrew 1992).

Aparentemente, o conhecimento técnico não tem feito parte dos critérios de escolha dos ocupantes dos cargos dirigentes dos diferentes órgãos internos de condução técnicopolítica da mudança do modelo de atenção. Existem muitas questões colocadas que seria necessário entender ainda. Como exemplo, a relação cargo comissionado e projeto político enquanto produto de um processo democrático, portanto participativo apesar de restrito ao nível central (o PES).

Dentro da superintendência de atenção à saúde existia, naquele mesmo órgão, ainda, $a$ coordenação do PSF, passando o novo superintendente a acumular as duas funções. ... Segundo este, as gerentes regionais solicitaram ao secretário, que o mesmo também viesse a coordenar o PSF, para não ter duas coordenações, uma para rede e uma PSF. (...) Mas eu não entendo de PSF. Não, mas vai entender. Aí o secretário ... falou, está bom, vocês querem, vai ser assim. Na ocasião, quem era o coordenador do PSF, entende de PSF que é um espetáculo, ... tem muita prática de PSF, ... sabe tudo, já trouxe essa experiência de outro município. (...) Mas meu deus do céu, vou ter que estudar isso também. Aí eu falei para o secretário pedir pro coordenador anterior pensar um pouco em mim, para me ensinar e passar as coisas. Mas isso foi muito pouco. ... Então nesse setor PSF me sinto muito perdida e desamparada. E fui buscar coisas para aprender, para ler, para saber, mesmo assim, até hoje não me sinto muito legitimada perante as equipes do PSF. (...) E então eu fui nesse vai/vem de ir aprendendo, ... muito mais eu aprendendo com elas, porque elas eram muito mais bem preparadas, muito mais inseridas no contexto do que eu. Eu era um peixe totalmente fora d'água (F5503).

Muitas organizações se tornam "proficientes na aprendizagem de circuito único, desenvolvendo a habilidade de perscrutar o ambiente, de colocar objetivos e de monitorar o desempenho geral do sistema (....) para manter a organização em curso. (....) Curiosamente, uma função de memória é também freqüentemente construída por esses controles de mão simples". Todavia, somente "a habilidade de atingir proficiência em 
termos de uma aprendizagem de circuito duplo, (....) encorajando o debate contínuo e a inovação", podem levar à construção de uma organização em aprendizagem ao invés de processos de aprendizagem individual (Morgan 1996, p.93).

É preciso aprender a aprender: Eu não aprendi com ninguém, mas quero aprender aqui. E vou aplicar. ... Eu gosto de preparar as coisas para minha ausência e não para minha presença (F554). Essa concepção está ancorada em princípios de gestão de qualidade.

A explicitação de um conflito de relações entre as superintendências meio e fim: Como superintendente - fim, ... eu precisava ter as outras superintendências mais atuantes. Tenho uma dificuldade grande aqui dentro da casa, por causa da superintendência de recursos humanos. Quando a superintendência administrativo - financeira me bloqueia o trabalho ... é um pouco mais fácil entender. Se faltou dinheiro ... é mais concreto, mais objetivo e claro - não dá para fazer e pronto. Agora, recursos humanos, ... sinto muito, ou funciona ou não funciona. (...) Como eu aplico a política de saúde, se eu não tenho recursos humanos, e se para ter esses recursos ... basta fazer um papel e assinar, é o fim do mundo ficar nessa carência. Aqui não é uma cidade lá no sertão que ninguém quer ir lá trabalhar. Aqui está tudo na minha mão. (...) Eu vou te contar um segredo, o negócio não está no ... modelo teórico. ... Mas em quem é que toca esse modelo - o recurso humano. (...) Eu sinto dificuldades graves, a morosidade em especial, porque quando um setor-fim anda a mil por hora, e outro que é meio vai a 10 por hora, não atende as necessidades, que são fins. As gerentes regionais estão enlouquecendo por causa disso, está todo mundo estressadíssimo. Essa história aí compromete tudo e é nós que estamos perante os funcionários e enfrentando o público usuário (F555-8).

O estilo gerencial da "administração principal representada pelos executivos de primeira linha" é questionado na lógica do princípio da qualidade, segundo o qual é preciso "insistir na noção de que o processo seguinte é o cliente, dando garantia para cada processo sucessivo", independentemente de sua natureza (Ishikawa 1993, p.132). Foi em uma discussão sobre serviço meio e serviço fim, que percebemos que não se tem $a$ visão de cliente e fornecedor interno. Porque o serviço fim é o atendimento direto ao usuário - a 'superintendência de assistência integral'; as vigilâncias, também fazem 
parte. Só que na superintendência de RH também tem serviços diretos com o usuário. E tem o usuário interno. ... Quando tu estás em parte do processo, estás num serviço meio, mas se tem um processo de trabalho, que tu planejas, executas do começo ao fim, e avalias inclusive, então é um serviço fim. ... Esse discurso a gente não tinha. Nós não tínhamos ainda discutido mais a fundo esses conceitos, isso ajuda muito. (...) Porque com essas deturpações conceituais e falta de estudo, ou de abrir mais essas discussões, e poder aprofundar, pois eles só repetem um discurso, isso foi acabando com tudo. ... Essa coisa de papagaio assim e vai discursando; fazem isso com uma propriedade impressionante, parece assim que são os mentores da reforma sanitária. Isso foi acabando com nosso projeto (F559-60).

Do ponto de vista do colega de trabalho se criticava como forma de autoritarismo uma concepção assim autocentrada: Eu sou o serviço fim, tudo deve girar em torno de mim. Diferente da questão do respeito com a pessoa do gerente $e$ o respeito às outras equipes. É uma visão de superioridade e aí ... o espírito de equipe acabou. Se antes a gente fazia reunião ... que se achava uma droga, então imagina agora que 'não tem mais integração, não tem mais articulação interna'. (...) Romper com isso não condiz com um perfil de superintendente que ... acha que todas as atenções têm que ser pra si, no sentido de ser servido pelos outros setores. (...) Eu também acho que coordenador com autoritarismo, não dá, porque as pessoas rendem mais quando se sentem livres (F5613). Não dá para um gerente de serviço-fim considerar-se o epicentro do funcionamento organizacional. Ao mesmo tempo em que a relação entre colegas é prejudicada por um estilo gerencial autoritário, nessa condição a criatividade da equipe tende a estar sendo tolhida.

A expressão de relações hierárquicas com o primeiro escalão: Fico respondendo ao secretário que é o meu chefe, e respondendo ao prefeito, que ao final de contas quer saber das políticas de saúde. E, respondendo ao conselho municipal de saúde, que eu prezo muito. (...) Por outra parte, então agora a situação como ... eu me encontro inserida aqui nesse contexto é a seguinte: eu tenho domínio hoje, de toda a situação da secretaria da saúde, de toda situação de políticas de saúde, do que o município precisa, eu não tenho é a caneta na mão pra fazer. Claro, ... eu sou subordinada às instâncias 
que tem a caneta (F564-5). Essa visão tradicional de domínio hierárquico desrespeita a diretriz de controle social democrático-popular no SUS e aos princípios da transformação organizacional.

\section{Gestão participativa}

A relação entre participação e dominação está colocada no espaço organizacional: Vai ser difícil reverter ... essa fantasia que tem em relação ao nível central, vai continuar. Muito autoritarismo, que ... aparece em situações assim, quando a gente permite. Democracia não é tão fácil de fazer. Por um lado a discussão começa a surgir, e por outro começa a aparecer novas ditaduras. Isso dá medo, dá pavor, porque, tu sabes da nossa história. Então no momento eu não estou com forças para trabalhar com isso, contra isso (F566).

É preocupante constatar a individualização do ato de planejar e conduzir o processo de gestão: O fulano sempre esteve comigo, ... e me ajudou a organizar a oficina do planejamento estratégico, dali fomos pro plano municipal e depois fazer as oficinas de territorialização. O fulano faz a parte de planejamento (F567). As forças de expressões são reveladoras, no caso de micro-alianças de poder institucional.

Concepções culturais de organização burocrática versus uma gestão colegiada: A gente tem muita dificuldade aqui de construir um colegiado dentro da casa, ... com todos juntos, ... remando para um mesmo local. Essa é a grande dificuldade, ... um colegiado, onde estariam quase todos no mesmo rumo. Até teve momentos que isso existiu, com o secretário mais no início da gestão. (...) Era uma coisa que nessa cidade não se aceitava: a gente procurava resolver as coisas de forma colegiada. É diziam - é fraqueza, falta de pulso (F568-9). Então aparece como uma questão cultural essa necessidade de uma figura forte, o "paisão", remanescente do modelo burocrático paternalista de Weber (Campos 1978, p.25), onde se reconhece somente uma "autoridade legal, racional ou burocrática", sob a qual os subordinados aceitam as ordens como justificadas por ser de seu superior, cujo comando consideram legítimo. 
Um colegiado já começa a romper com esta pressuposta "estabilidade da estrutura de autoridade". Para Weber os "órgãos colegiados representativos" fazem parte das "muitas formas que podem existir que não se aproximam do modelo". Todavia, "seria ilusão imaginar que o trabalho administrativo contínuo pudesse ser executado, em qualquer setor, sem a presença de funcionários trabalhando em seus cargos. Todo modelo de vida cotidiana é talhado para se adequar a esta estrutura. Porque a administração burocrática é sempre, (....) o tipo mais racional". Nos tempos atuais, em que pelo menos como princípio, o modelo burocrático está em declínio, é bom considerar as possibilidades dos modelos de transformação organizacional, especialmente veiculados por Pinchot e Pinchot (1995). No caso estudado este empírico está a exigi-lo.

Por referência aos superintendentes que fazem parte do estudo cabe registrar que mesmo nas mais modernas teorias de mudança organizacional, a estrutura hierárquica não desaparece, mas se transforma. A liderança cada vez mais se insere em um contexto de redes de aprendizagem e autogestão (Menegasso 1998, p.164). Isso além da presença do controle social por parte da população sobre os serviços de saúde. Nessa perspectiva há que se concordar com a seguinte representação: Esses diretores autoritários é tudo uma espécie em extinção. Porque a partir do momento em que a população começa a cercar e ... exigir, começa a ter essa consciência de que o Estado não é dono dela, mas tem de cuidar bem do cidadão e da saúde dele, todo esse processo, então o gestor vai pensar duas vezes se ele ... quer fazer política partidária e ganhar votos (F570).

A dinâmica nas disputas de espaços de micro-poder se expressa em diferentes circunstâncias: É, aqui também não tem mais ninguém batendo o pé. ... Eles só pontuam mesmo é o lado pessoal - Ah, aquela fulana não vai enquanto gerente, aquele fulano não vai bem, ah, o secretário é centralizador. Mas mesmo assim acho que o pessoal ainda teve uma pitada de democratização e de participação. (...) Tem gente boa pra queimar o nome dos outros. ... Eu não agüentei assim, foi demais. Também é um lugar de muita fofoca, muito desgaste até. (...) No momento que você tem injustiças, ... já começa a ver discórdias, dissabores internamente, então o funcionário não vai corresponder àquilo que seria necessário. (...) Conseguir resultados é um processo 
dolorido. ... Então está sendo dolorido, mas tem dia que a gente se pergunta - Por quê que eu estou aqui ainda? É porque eu acredito (F571-4). O sofrimento e dor continuada no trabalho desgastam muito.

\section{Uma área crítica na condução da estratégia - o planejamento}

Na área finalística que assume a consecução da definição política de modelo de atenção, essa função se confunde com a área de planejamento: Até um pouquinho antes da primeira "superintendente da integralidade" sair, ela pensou em montar uma superintendência de planejamento, porque não estava conseguindo resolutividade, não estava satisfeita com aquela estrutura. E começou a pensar nisso para implantar, só que esta proposta foi ... barrada. (...) Na realidade tinha uma grande área que foi acumulando essas funções, a 'superintendência de vigilância e atenção integral à saúde'. À sua frente ficou um técnico responsável, que estava meio sozinho, ficou tudo meio que com esse técnico. (...) Então eu acho que o grande articulador, pra sair e ... acontecer esse movimento de mudança do modelo, foi este técnico, ele ... teve uma participação importante. Porque sempre foi ele quem mais defendeu o modelo integral. ... O tempo todo era ele, vamos dizer assim, ... foi uma pessoa que batalhou muito em relação a isso (F575-7). Mas para levar uma proposta que é técnica, política e ideológica, precisa-se mais que um técnico encarregado.

A idéia de uma 'superintendência com vigilâncias e atenção integral, eu acho que é uma loucura. É um modelo teórico que não funciona. ... pelo menos aqui não. ... Vigilância à saúde é coisa pra posto de saúde; não pra modelo de administração central. É uma coisa que ... tem que ser de baixo pra cima (F578). Claro, não se integra nada via estrutura organizacional. É a partir da estrutura velha que tem que começar a construir uma nova. E se não se integra via estrutura central, há que se saber o que este nível teria de fazer para viabilizar essa integração. Revela-se insuficiente fundir órgãos como pressuposta solução.

Como estratégia organizacional, para responder pela área de planejamento se estrutura no nível central uma "equipe técnica". Em uma segunda substituição do titular da 
chamada "superintendência de integralidade", segundo essa nova chefia, diz o gestor por referência ao titular substituído: A gente vai compor uma equipe técnica. A gente vai colocar lá uns 4 ou 5 profissionais que vão se reportar diretamente ao secretário e que vão fazer o planejamento e ... supervisionar o andamento disso (F579).

Neste processo todo, então a superintendência ficou só com a assistência integral. A vigilância à saúde passou a ser pensada e articulada na equipe técnica. 'A atenção integral era parte da idéia de vigilância à saúde'. A equipe era de assessoramento técnico, assessoramento da secretaria. (...) Assim então estava ... dividida a superintendência - uma de atenção integral e uma de vigilância. Essa última já vinha de um bom tempo. As partes das vigilâncias sanitária e epidemiológica são diferentes. Até a história foi diferente. Esse é o modelo teórico, é perfeito, bonito. (...) 'Atenção integral basicamente é coordenar as gerentes regionais e os postos', inclusive a coordenação do PSF, quer dizer, a assistência mesmo, rede própria e PSF. E a vigilância à saúde coordena as vigilâncias. Burocraticamente definidas como se vê (F580-2). Ao mesmo tempo em que a discussão entre as concepções da relação entre modelo e plano, como também entre atenção integral e vigilância, tem um conteúdo intrínseco, esse transversalmente passa a ser invadido pelo movimento de disputas de espaços de poder institucional. Assim, a suposta subordinação da vigilância à atenção integral ou vice-versa, trazia embutido um posicionamento político da equipe técnica em relação à superintendência finalística da secretaria. Além da incerteza derivada da característica de equipe ou comissão em relação a um setor instituído formalmente na estrutura organizacional, gerando disputas típicas entre órgãos de linha e assessoria.

A condição de não haver uma estrutura de planejamento colocava uma problemática: $O$ secretário me convidou para trabalhar com a questão do modelo, no setor de planejamento de saúde, que depois acabou se fundindo com outros elementos e outras funções, o que veio até formar a equipe técnica. (...) A idéia de formar uma equipe técnica surgiu no plano, era a idéia de ter uma equipe multidisciplinar pra trabalhar com acompanhamento do plano e outros projetos que se fizessem necessários. Nem precisaria estar trabalhando esta questão do modelo de uma forma direta assim mais intensa, mas em um âmbito de assessoria (F583-4). 
No planejamento estratégico ficou muito forte a importância de se ter uma superintendência de planejamento ou alguma coisa nesse nível, um setor ou uma unidade de planejamento dentro da secretaria, que então planejassem, que pensassem, ... para fazer acontecer. E só o quê que aconteceu? A coisa meio que não aconteceu. Assim está meio complicado nesse ... setor. (...) Agora compuseram uma equipe de assessoria técnica pro secretário. Antes, eles não souberam como lidar com isso, não souberam. ... E o planejamento mesmo fica mais nessa equipe técnica. (...) Então, ficou essa área aí, que era pra ser um setor de planejamento, uma assessoria de planejamento ligada direto ao secretário, que depois virou a equipe técnica. ... Tem uma certa superposição de coisas aí, é uma coisa meio confusa. Na verdade, de repente a equipe técnica devia ser a equipe de uma superintendência de planejamento, alguma coisa assim. Que seria um grupo responsável em monitorar, acompanhar, fazer implementar o plano (F585-7). Assim se constituiu a equipe técnica, sua função fazia falta. Parece que essa equipe não conhecia tecnologicamente como fazer isso, ou, politicamente, não conseguiu articular e manter tal espaço, para garantir que o planejado fosse implementado.

Quando se formou aquela equipe técnica, ali ... eu não acompanhei muito bem, embora eu fizesse parte dessa equipe técnica. ... Só que essa equipe técnica ... na verdade não deslanchou (F588). Mitroff (apud Menegasso 1998, p.165-6) afirma ser necessário ir além da proposta weberiana da burocracia para fazer frente às grandes mudanças da sociedade e, por extensão, do mundo organizacional, cujas transformações são uma constante: "As adequações, de natureza estratégica, tática e operacional, criam oportunidades de mudança com sedimentação pragmática, devendo, no entanto, levar em conta a transformação dos atores humanos da organização". Em geral colocam-se como "aspectos críticos de implementação" de propostas de mudança, um foco "apenas nos resultados em detrimento dos fatores humanos", por conseqüência, "nessa hipótese não haverá transformação organizacional".

E a parte de planejamento, de acompanhamento e avaliação, ficou com a equipe técnica. Só que eles acabam, apesar de ter dado certo o relacionamento, eles trabalham muito em conjunto, mas ficou uma coisa meio estranha. ... Era uma equipe também 
receptiva, mas bastante confusa. (...) É, mas a proposta foi que a equipe começasse seu trabalho internamente, com cada técnico da equipe. ... Não era coisa de um gerente só, com as informações técnicas balizadas não, era toda uma equipe, a gente estava multidisciplinar lá. Mas ... na verdade também era assim, uma coisa muito controlada. Isso só foi sendo percebido aos poucos. (...) Eu acho também que a equipe técnica teve dificuldades. ... Parece que o secretário não quer que mude, ou ele tem medo de mudança. Eu acho que começou a ter atritos, ... entre a superintendência técnica e o secretário. Ou o secretário não estava satisfeito (F589-91).

E isso tudo de forma absolutamente independente de outra superintendência de planejamento, controle e avaliação e auditoria em saúde, que ainda se mexeu o ano passado, para tirar a palavra planejamento, porque não fazia (F592). Este órgão tinha só as funções de controle, avaliação e auditoria, herdadas do ex-INAMPS em relação aos serviços contratados. Portanto, não se envolvendo com o planejamento da prestação direta das ações de saúde.

Na equipe técnica não se conseguiu manter uma estruturação mais efetiva. E isso mesmo quando a gente conseguiu uma inserção maior com outras secretarias - a intersetorialidade. (...) A gente tinha uma necessidade de conseguir dinheiro e aquela era uma oportunidade de se buscar apoio externo, porque com o que havia, a gente não estava conseguindo tocar. ... A prova disso é que ... com as ações que se implementam, é possível conseguir recursos pro município, a propósito, a gente conseguiu bastante coisa. ... A nossa preocupação era com disponibilidade de materiais, inclusive não só parecer técnico e avaliação dos projetos. (...) Desde abril (1999) a gente conseguiu um milhão e tantos mil, no projeto e de economia, com a entrada de recursos externos. A gente desenvolve uma série de projetos com outras secretarias. E $90 \%$ das propostas conseguiu-se cumprir. Então, fomos uma equipe resolutiva, mas que, eu agora não lembro muito assim, tem que ser noutra oportunidade (F593-5).

Na sua relação com a rede, do ponto de vista da policlínica de referência regional, a equipe central buscava alternativas: A gente sentia que nossas demandas ao nível central não tinham retorno, porque eles não conseguiam visualizar o todo. Mas era uma equipe com conhecimento do SUS, em que a gente conseguia buscar idéias novas. ... Eles 
sabiam o que era um projeto de saúde da família, eles sabiam o significado de trabalhar prevenção, eles conheciam ... o que estavam fazendo. A equipe técnica era uma equipe pequena e sem técnica. Essa equipe ... começou a gerar a proposta da descentralização e do gerenciamento, a partir do planejamento estratégico, porque sentiu que não tinha pernas para cobrir o retorno (F596). Essa foi uma opção de como encaminhar tecnologicamente a mudança do modelo, evidentemente articulada no espaço político.

\section{Retomada do plano}

Mesmo na seguinte expressão não se pode atribuir-lhe um significado de apoio político ao plano: Nós estamos retomando o plano municipal de saúde, ... nós temos o prefeito pressionando (F597).

Em meio a muita incerteza como característica mais evidente do ambiente interno, finalmente são precisados pelos atores interessados, dois sub-projetos do PES, cuja defesa passa a ser assumida, explícita ou implicitamente, como a retomada do plano: As oficinas de territorialização e o Projeto GERUS - de gerenciamento de unidades básicas de saúde (Brasil 1995). Estas propostas passam a ser incorporadas como soluções para se conseguir a mudança do modelo de atenção conforme previa o plano, na perspectiva da integralidade da atenção em saúde. Na continuação se discutem somente as representações sobre o movimento político interno para viabilização dessas propostas. $\mathrm{O}$ seu conteúdo tecnológico está abordado nos itens que tratam das vias em que se incluem: via epidemiológica para a territorialização (item 4.2.1) e as vias do gerenciamento loco-regional e pedagógica para o Projeto GERUS (itens 4.3.5. e 4.3.7).

E ainda ressurge o PSF como outra questão emergente adicional, com desdobramentos que extrapolam sua proposta, tipo gratificações salariais, que passam a ser associadas com a retomada do plano pelos respectivos atores envolvidos. Assim, na semana anterior a uma reunião estratégica do CMS para redefinição e direcionamento do PSF, coloca-se: Desde a entrada de um novo secretário estamos tentando uma retomada do plano - fazer a territorialização, levar o Projeto GERUS para as unidades locais e tirar 
um posicionamento em relação ao PSF. Recoloca-se a regra das 8 horas no PSF. E está se querendo cortar a "gratificação dos cargos de dedicação plena". (...) A idéia é essa e ... o momento certo já era pra ter sido há um ano atrás, seria primeiro a equipe técnica, depois as oficinas de territorialização, as gerências regionais e na seqüência, o GERUS. ... Parece sabonete, primeiro começa com o verde, depois vem com o roxo e esse aqui é melhor. Difícil, não? (F598-9).

Aquelas estratégias passam a ser representadas muito pontualmente apenas, como se cada qual contivesse potencialmente as condições necessárias e suficientes para garantir o processo de mudança do modelo. Se efetivamente assumirem esse caráter e passando a ser trabalhadas como estratégias emergentes é possível, organizacionalmente, uma construção desse tipo. Mintzberg (1973) propõe três combinações em que se operam as orientações das estratégias: as deliberadas que são pretendidas e realizadas; as não realizadas, mas pretendidas; e as emergentes, que não eram pretendidas mas são realizadas e assumiram sua condição estratégica durante o processo. Na prática as estratégias pretendidas, em sua realização, mudam de forma e se tornam em parte emergentes e as emergentes passam a ser formalizadas como deliberadas.

E foi até iniciar a territorialização; daí em diante que não deslanchou mais, a conjuntura não permitia. Apesar de só ter iniciado. (...) Nesse processo de territorialização, percebe-se que ... aí existe também aquela coisa assim de vaidade pessoal, ... foi uma coisa do fulano, ele que batalhou (F600-1). A disputa de paternidade da idéia, novamente se faz presente aqui. Mesmo quando a ação era só cumprir a própria função e disponibilizar as informações reunidas a respeito. O plano já determinava isso claramente, era desdobramento técnico ir atrás. Por outro lado, ... eu vejo que somente um técnico que acompanha tudo, está sempre atento às coisas, ... entra em tudo e transita nas superintendências. (...) Às vezes um técnico consegue resultados importantes. Como nesse processo todo de territorialização, o que levou o secretário a fazer isso, eu não sei. Acho que alguém o convenceu. ... Na verdade, eu acho que foi esse técnico que convenceu (F602-3). 
As alianças de micro-poder vão ficando mais explicitadas: Porque assim, o fulano é como uma raposa, muito hábil, esperto, age muito na surdina e não se expõe de jeito nenhum. ... Ele está onde as coisas acontecem, é muito assim. Eu acho que ali na secretaria ele está tendo espaço, está perto das decisões ... e está conseguindo levar. (...) Nos meus valores e sensibilidade, na minha equipe, ... então tem horas que a postura de fulano ... é útil. Nós temos uma relação muito assim: quando é conveniente para um ou pra outro, a gente se amiga, se é pra defender alguma coisa. Na verdade é assim, tem momentos que estamos afinadíssimos, tem vezes que não. Tem horas que a gente não fecha (F604-5).

Posicionamento político interno do grupo: Com a territorialização, ... eu pensei - por que a gente está defendendo tanto isso? Quando se começou a querer retomar o plano, nós defendemos o plano o tempo todo, é, deve ser por isso. Então, estou pensando melhor agora nisso, ... tu me questionaste. E na verdade, eu estou tão envolvida nisso, ... defender, defender ... e batalhar por isso, até que ... a gente pára pra pensar (F606). $\mathrm{Na}$ medida em que aquela proposta era colocada como retomada do plano, aquele plano com o qual seus formuladores estavam comprometidos, ficava uma nova aliança implicitamente aceita.

Metodologia de condução do processo: Foi fantástico o trabalho com as oficinas. E não teve continuidade, só ... não conseguimos completar as oficinas, elas pararam. Por que não terminar primeiro o processo nas regiões que já fizeram a primeira oficina? A gente está tentando fechar ... a continuidade das oficinas e as equipes. Mas as equipes já sentiram ... o que é que era, quem participou percebeu. Uma pena, que foi pouco tempo, pouco conteúdo, as pessoas queriam avançar mais. Então agora eu vou conseguir conhecer a minha comunidade, isso está acontecendo, porque as equipes, elas podem fazer contato com as outras equipes, ... e trabalhar em parceria. Está funcionando assim, esse é um negócio que está acontecendo sem as pessoas de fora perceber: não tem vaga de consulta aqui, tem grupo ali, no dia-a-dia da comunidade. (...) Na verdade essas últimas oficinas de territorialização, nas duas regiões que faltam, já era para ter acontecido. Aí houve uma série de coisas e mudanças, o que fez atrasar o 
processo (F607-8). Complicou-se mais a continuidade do plano frente às novas decisões políticas derivadas da última mudança de secretário.

Finalmente, no ano passado as gurias começaram a fazer o treinamento do GERUS. Então assim eram as coisas que se instituíam a partir do momento que o primeiro secretário dessa gestão esteve lá. ... A manutenção do GERUS agora com o secretário atual, foi a maior pauleira lá dentro para convencer de que era necessário terminar o curso e continuar. (...) Mas a grande preocupação ainda é recursos humanos. Está comprometido, mas não completamente, é, isso pode comprometer o modelo. ... Agora fechar algumas coisas como a implementação do GERUS, claro que está sob risco (F609-10).

\subsubsection{A via do Gerenciamento Loco-Regional}

No final da gestão anterior, a gente ainda compôs uma equipe de supervisão e nos dividimos por região - éramos 3 enfermeiras, uma assistente social e uma nutricionista. ... A idéia era fazer disso um processo de supervisão ... através de uma equipe técnica que ia toda semana em cada unidade, isso vinha acontecendo. Já se estava até discutindo o termo supervisão; a gente chamava equipe de apoio do PSF (F611). Essa figura depois se substitui pela do gerente regional.

A condução gerencial é aqui abordada do ponto de vista da via local, da gestão da rede básica de atenção à saúde. Após discutir os problemas derivados da gestão do PSF, enfoca-se a constituição de gerências regionais criadas para orientar a gestão da rede, a questão do gerenciamento de unidades locais de saúde e ainda como instrumentos privilegiados do trabalho de gerência loco-regional, a programação e avaliação local em saúde. Por esta via se processa o saber gerencial operante nos serviços locais de saúde. A via gerencial penetra nos âmbitos da construção e condução de um modelo organizacional que permita a concretização do modelo de atenção desejado. 


\section{Gestão do PSF}

Sobre a seleção interna das primeiras equipes: Os profissionais do PSF são pessoas raras, por causa do perfil. A gente resolveu primeiro tentar achar esses profissionais na rede. E isso foi mais pela intuição, ... porque já se conhecia os profissionais, ... havia um contato direto com quase todos. A gente mapeou algumas pessoas e chamamos para uma entrevista, já meio direcionado. ... Para formar as duas primeiras equipes não abrimos, ... praticamente se escolheu esses profissionais - dois médicos e duas enfermeiras. ... De uma forma geral, com essas duas equipes deu certo. Só que depois aqui também não tinha mais gente na rede como eles (F612).

$\mathrm{Na}$ constituição das primeiras equipes também entraram ... duas auxiliares de enfermagem pra cada equipe, e 16 agentes juniores de saúde, os menores do Projeto Faísca, já iniciado. ... Com as auxiliares de enfermagem, fizemos o mesmo processo de recrutamento na rede, ... chamamos e entrevistamos. Colocamos quais os objetivos, o que seria o trabalho, ... o que a gente queria que eles fizessem, ... e qual era a proposta naquela época, para ver como é que eles se sentiam. Tinha que ficar claro a questão da classificação, da jornada de trabalho, que era bem maior - o dia inteiro, e o tipo de atividade. ... E durante a seleção dos agentes de saúde, ia se pensando na seleção das próximas equipes. Isso foi em meados de 95 (F613).

Seleção geral do PSF: Chegou o final do ano e a gente já estava fazendo seleção para mais 17 ou 18 equipes. Nós não conseguimos colocar na cabeça do secretário, que tinha que ser mais devagar. Sinceramente, agora ... eu dou razão pra ele, acho que tinha que ser assim, senão ia ficar só as duas equipes até hoje (F614).

Enquanto as duas primeiras equipes estavam trabalhando, nós fizemos a seleção dos outros - abrimos inscrição e foram feitas uma prova escrita, entrevista e análise de currículo. Daí nós colocamos em jornais, ... pra trazer mesmo pessoal de fora, porque aqui era complicado. E apareceram alguns médicos daqui da rede, outros que não eram da rede e alguns avulsos vindos de outros estados, da medicina geral comunitária. ... Nós montamos e fizemos todo o processo seletivo no começo de dezembro de 95, 
para assumirem no início de 96, fevereiro ... alguns, e outros em março. E foram 17 equipes, ... uma ficou pra mais tarde porque não se conseguiu médico suficiente. Contando com as duas primeiras, ... deu 19 equipes. (...) Só que ... já nessa época tinha demanda, mesmo com um trabalho bem insipiente, mas já havia ... pedido de duas comunidades, ... para uma segunda equipe. Isso era só porque eram atendidos e bem atendidos, e visitados (F615-6). Ao final chegou-se nas 21 equipes.

Com o treinamento introdutório pôde-se começar tudo certinho, ... com sistema de informação, quer dizer, organizar o trabalho. ... Aí eu comecei a treinar a primeira turma de agentes, para uma equipe do PSF. ... E junto treinando alguns enfermeiros, especificamente pra eles ... treinarem a sua equipe, cada enfermeiro treinava os seus 16 agentes. (...) Fizemos esse treinamento pensando assim, no mínimo é melhor a gente treinar os médicos e enfermeiros, porque daí o enfermeiro pode orientar $e$ supervisionar o trabalho dos auxiliares. (...) E o auxiliar ficou meio esquecido. Quer dizer, não tinha como, não tinha perna, não tinha jeito de fazer. Então a gente optou por deixar assim. A gente não tinha nem acabado a seleção ainda dos auxiliares de enfermagem (F617-9).

Constituição das equipes do PSF: Não fomos nós que escolhemos ou colocamos o profissional para montar cada equipe. Nós fizemos o treinamento e não sabíamos quem ia ficar onde, a não ser aquelas duas primeiras que já ficavam impulsionando. ... A gente colocou pra eles assim, agora vamos visitar os lugares que estão planejados pra se colocar as equipes, naqueles critérios, e ... vocês podem escolher com quem querem trabalhar, ... compor a equipe entre vocês, e escolher os lugares. Se não der certo, se tiver dois num mesmo lugar, aí a gente ... ajuda a desempatar. A princípio não tem porquê, vocês se sintam à vontade. E daí eles se arranjaram, os que se identificavam no treinamento, vários escolheram em função da proximidade da casa, e foram compondo. ... No final deu tudo certo, eu não tenho assim lembrança de alguma complicação que tenha dado naquela ocasião. ... Depois tiveram várias, no decorrer do trabalho, porque daí a gente se conhece melhor, ... como em um casamento (F620). 
Características da safra do PSF de 96: De uma forma geral, tinha alguma coisa especial com esse ... primeiro grupo, como também nas duas equipes que iniciaram. ... Acho que o treinamento ajudou bastante pra isso, ... era um grupo apaixonado, era um time, tinha essa idéia, essa sensação de sentimento de time. (...) Nós que somos do mesmo grupo, estamos começando uma coisa nova e vamos mostrar que isso dá certo. E, muita, muita paixão, assim, todo mundo muito apaixonado, com muita vontade, muito disponível pra isso (F621-2).

O horário do PSF como característica da força de trabalho: Um detalhe que foi muito discutido ... no início era o horário. A gente teve bastante dificuldade de definir que eram as 8 horas mesmo. Então se abriu mão da dedicação exclusiva, não precisava fazer só aquilo, o que precisava era 8 horas. Depois ficou difícil e voltamos a discutir. A gente não queria, mas o secretário era aquela história, e a gente acabou concordando ou obedecendo. E tentamos, então o médico passou a fazer 6 horas. Porque o próprio mercado de trabalho era assim e daí ninguém vem aqui essa hora. ... Mas já está diferente hoje, esse mesmo mercado de trabalho já está diferente hoje no município. Ficou mais fácil ... estar chegando e já preencher todo o tempo e receber aquele salário assim. Aí naquela época eles passaram a fazer 6 horas. ... E os enfermeiros também, ... não me lembro se desde o início junto com os médicos, ou um pouco depois, ... mas é meio isso. Eram 6 horas, e agora esse ano voltou a ser 8 . ... Todos não estão fazendo, mas é pra fazer; ... a maioria está cumprindo. E assim, no decorrer do tempo a gente teve vários problemas (F623).

Gestão do horário no PSF: $O$ médico, a enfermeira e o auxiliar ter jornada de trabalho de 6 horas, eu não acho justo. ... No PSF precisa das 8 horas. ... Aí vem o secretário ... dizer que o PSF teria também que ser 6 horas, até pra ficar igual à rede. Não sou contra isso aí, ... o problema é que o cara disse assim: "Todas as administrações do PT no Brasil têm implantado 6 horas de serviço público e não somos nós agora que vamos criar 8 horas". E eu disse tudo bem, então vamos duplicar as equipes numa mesma região, ... uma parte atende de manhã e a outra de tarde, das 7 às 13 e das 13 às 19. ... Se cada PSF tem duas equipes eu acho excelente, os profissionais não precisam se estressar, mas será que nós temos recursos financeiros pra fazer isso? Claro que não. 
(...) A sacanagem que eu vejo é assim, o médico trabalha 6 horas no PSF mais 6 horas de plantão e mais 6 horas ele vai dar aula, e ainda atende no consultório, quer dizer ele vai trabalhar de 18 a 24 horas, é um cara que tem chance de fazer isso. ... Na fundação hospitalar não tem uma enfermeira ali que não tenha 2 ou 3 empregos, quer dizer, que enfermeira é essa? A gente batalha pra ter uma redução da jornada de trabalho, pra ter mais empregos e essas pessoas continuam com três empregos. ... Não é justo uma pessoa que ganha diferenciado no PSF ainda ganhar mais lá e cá (F624-5).

O problema do salário no PSF, ... a principal queixa era essa, sempre foi e continua sendo. ... Tanto é que a maioria dos profissionais, até mesmo do PSF, ... na época se manifestavam e não entendiam porquê a diferença salarial se eles faziam a mesma coisa, ... que era atender num posto, com a mesma carga horária. Às vezes alguém precisava de um ambulatório, ... às vezes fazer uma visita, ... já estava sendo implantado o SINASC e os auxiliares de enfermagem dos ambulatórios e assistentes sociais já faziam algumas visitas, em ... programas específicos, mas faziam. Então, por que no PSF ganha o dobro? (F626).

Eu acho complicada essa diferença salarial de PSF, porque como se diz na rede, aí passam a trabalhar menos pra ganhar menos. ... O que se pensava no PSF era em ... incentivar esse profissional pra morar lá na comunidade, ... porque você quer implementar um outro conceito e aí sim. ... A gente quer um PSF com o modelo de Cuba e com o salário do Canadá. (...) Isso aí ... o Fundo tem que pagar, o conselho tem que opinar nisso aí e não é o prefeito que vai ... criar diferenciações lá, isso é uma espécie de gratificação. ... Mas também que não seja trabalhar 6 horas e abrir um consultório particular na comunidade, como ... está acontecendo em algumas cidades. ... Nós queremos um outro conceito, não esse conceito mercantilista aí: "Eu vou estar 24 horas à disposição, vou trabalhar 6 aqui, ... e cada vez que você vai no consultório paga sessentinha” (F627-8).

Nesta gestão ... colocamos o PSF dentro da prefeitura. Hoje todo mundo que é da rede, já deve ter feito prova para militar no PSF, não tem mais aquela antipatia que tinha antigamente, daqueles que ganham mais e daqueles que ganham menos. ... É lógico que tem diferença de ... salário, mas não tem aquela antipatia que existia antes. E o 
gerenciamento é que vai cuidar disso cada vez mais. (...) Com o pessoal do PSF no quadro da secretaria, ... aí 'com a integralidade o objetivo nosso era ... trazer o PSF para dentro da prefeitura', como funcionário da saúde. Esse era o nosso objetivo e 'a integralidade passava por isso', ... juntar PSF e rede integrando toda a atenção de saúde. ... Apesar de ter mudado a equipe na comunidade tal, dá pra perceber que a proposta continua, e que ... as pessoas têm um desempenho bom (F629-30).

Rotatividade no PSF: Nós tivemos outro problema grande, que foi a rotatividade do profissional. Era difícil ter e manter uma equipe completa. Ainda em 1996 eu fiz um levantamento e ... havia só 3 equipes que não tinham médico. Mas o que eu vi é que tem muita rotatividade de profissional. (...) A troca de profissionais é ruim pra comunidade, porque ela se habitua a ter um tipo de serviços e de repente acaba. E é ruim pra gente também porque assim, 3 anos trabalhando, e tudo que foi feito ... de repente acaba. Isso não é problema do profissional, na verdade ... é problema da estrutura. A gente sente muito quando sai, ... é difícil de se desvincular, e, tem os agentes de saúde, há um vínculo muito forte com a equipe mesmo, então fica difícil sair (F631-2).

Outras dificuldades apontadas pelas equipes segundo sua coordenação: Falta transporte pra equipe se deslocar, ... a capacitação é insuficiente para o trabalho comunitário; tem atrasos de salário, ... porque o PSF ganha mais, então atrasa mais. ... Quanto à questão mais de infra-estrutura, material é o mais grave dos problemas, ... horrível. E ainda o mais crucial é o medicamento, medicamento básico. Em equipamentos a situação está bem (F633).

Nas seleções para o PSF: Deram a chance pro pessoal da rede trabalhar no PSF, ... se tiver perfil. A maioria não sabe nem o que é SUS, depois de todos esses anos. ... SUS é uma proposta de modelo de Estado, ... participativo e democrático. Quem não tem essa visão, ... também não tem paixão por aquilo que exerce. ... Se perguntar pra enfermeira ou médico da rede, se ele participou da última conferência? Ih, ninguém me avisou nada (F634). 
Perfil para seleção de profissional do PSF: Lá no item da seleção do médico do PSF consta que tem que ter paixão, ... quer dizer, para incorporar-se. ... Se não tiver por parte dessas pessoas uma sensibilidade, se não souberem porque tem programas de saúde da família e que as pessoas não podem estar lá só porque o salário é atrativo, então não tem perfil (F635).

A respeito dos processos mais recentes de admissão do agente comunitário: $O$ conselho participou do processo seletivo do médico, da enfermeira e do auxiliar de enfermagem. E aí a nossa bronca agora é com o PACS, que vem o prefeito e nomeia lá. Nem foi feito um novo processo seletivo no PACS. A assistência social da prefeitura é que manda, mas não pode ser assim, pelo amor de deus. ... Tem que ver se a pessoa tem perfil ou não, mesmo os indicados. ... Com isso a gente fica triste, ... o conselho participou do algo mais, mas aquilo que é da base, não temos participação. Isso é contradição. ... Estamos dando aval pro médico, pra enfermeira e pra auxiliar no PSF. E ... a equipe tem pensado com cabeça de SUS, há respeito entre as pessoas, elas querem que se efetive realmente esse modelo, mas não está saindo ainda, e por que está só nesse grupo? Porque no todo a gente encontra barreiras, agora ... isso aí é que está pegando. Que bom se a gente puder agora, nesses embriões de conselho gestor que estão surgindo, ir lá pra comunidade incentivar. E nós incentivamos e dissemos pra eles que é assim e se não for assim, eles não tem que aceitar os serviços deste agente de saúde, se não for escolhido pela comunidade, a não ser que a comunidade não tiver ninguém pra oferecer (F636).

$\mathrm{Na}$ nova seleção do PSF, quem seriam as pessoas que iam entrar? ... Vamos montar uma equipe de seleção aqui na secretaria. ... Nada disso, ... a secretaria tem que ter uma participação mínima, tem que colocar a comunidade, que conhece esse tipo de serviço do PSF, que sabe o que é que é. E também ... colocar médicos, enfermeiras e auxiliares de enfermagem que já trabalham no PSF pra definir quem vai trabalhar com eles. Esses, com certeza vão saber quem é que trabalha nesse modelo. Eles já sabem, ... provaram mostrando lá no conselho o quê e como é a proposta da saúde da família. Não deixou sombra de dúvida sobre o programa (F637). 
PSF - a crítica pelo novo gestor: Dos 21 postos de PSF, ... apenas 12 tinham o médico de família, ou seja, 09 não tinham, isso é a crua ... verdade. Fala-se tão bem do programa de saúde da família e a sua execução aqui ... era uma grande mentira. Pois o modelo é bom quando você o tem funcionando. Agora se você tem um modelo onde $40 \%$ não tem um médico, que modelo é esse? ... Eu notei que exatamente era a zona da periferia, onde estavam as equipes do PSF, em zona de carentes, ... que na verdade não estava sendo bem atendido nada. (...) E essa foi uma das primeiras queixas, quando houve a mudança de gestor (F638-9).

Em nome do questionamento de salário, mais especificamente da gratificação plena, por seu uso extensivo ao nível central, correu-se o risco de comprometer o próprio PSF. Na sua defesa houve uma mobilização das equipes da saúde da família: Agora eles vieram defender sua proposta no conselho, eu nunca vi tanta alegria, uma coisa maravilhosa o que foi apresentado pelas equipes do PSF. ... Então muita gente ficou enciumada quando o profissional foi lá começou a filmar tudo o que fazia e depois vai lá no conselho e apresenta - O PSF é isso, é o que a gente quer. Mas era um momento que estava bem (F640).

A gente só lamenta que mesmo com ... essa oportunidade, toda a proposta também está sendo bloqueada pelo secretário, então, por exemplo, tem um médico aí que não tem nenhuma condição de trabalhar no PSF, mas o secretário está dizendo que tem (F641).

Participação nas decisões sobre prioridades, segundo um médico do PSF: Eu precisava estabelecer os parceiros localmente, lá na rua, na comunidade, tinha que ter uma aproximação com o pessoal. ... Porque teve uma divergência, que quando a equipe foi pra lá se dizia: ... Prometeram, a equipe que vem pra cá é pra atender a escola. E eu argumentava que a escola faz parte da comunidade. No PSF a prioridade é para esta comunidade. Então, essa negociação foi muito interessante, pelo conteúdo da proposta de trabalhar assim junto, ... foi impressionante. E a gente conseguiu uma coisa, ... até colocou pra eles: Olha, não é prioridade nesse momento trabalhar com o escolar, a gente precisa trabalhar com o (grupo) materno-infantil, essa área está muito carente, está muito deficiente a atenção. (...) E se fazia exames de saúde, ginecológicos e 
preventivos. Eu pesquisava, peguei trabalhos, estudava, tentava aprender e estabelecer um fluxo. ... Com todo o gás; então as pessoas compreenderam a proposta, pra comunidade toda, e a equipe colocava materno-infantil. E, pra escola no momento nós vamos começar com atuação na questão da sexualidade (F642-3).

Ficou bem claro ... essa abrangência do trabalho no PSF: Então a gente conseguiu estabelecer esses três momentos, que ... seria trabalhar com materno-infantil, adulto e com o coletivo. Somente depois eu consegui enxergar bem isso aí. ... Eu não tinha tanta preocupação em mostrar o nosso trabalho porque tinha segurança que os usuários iriam entender, era bem o que eles queriam. E precisava arrumar parceiros na comunidade. ... A gente conseguiu um bom resultado, conseguiu uma boa aceitação (F644).

Perfil de seleção dos novos agentes comunitários de saúde: A minha grande esperança é fazer um bom processo pra escolha dos agentes de saúde, já que está aprovado pelo ministério, ... fazer uma formação com essas pessoas pra discutir cidadania, direito, ... são mais de 300 agentes. Olha se a coisa sair como a gente imagina, tem uma possibilidade muito grande de fazer um bom processo de seleção dos agentes de saúde (F645).

E as pessoas brincam que tem que baixar o salário do PSF. Assim não é possível, tem é que aumentar o dos outros. E botar as pessoas pra trabalhar de uma forma semelhante ao que é o modelo do (programa de) saúde da família. Só que tem que ter uma referência técnica, não é improvisar (F646).

Avaliação do PSF: Passar a brigar pelo PSF, ... então é assim, porque se quiser fazer dá, se quiser. Hoje se gasta $5 \%$ dos recursos do Fundo com a equipe do PSF. ... E os médicos produzem pelo PSF $30 \%$ das consultas médicas de toda a rede. As enfermeiras produzem no PSF $40 \%$ de todas as consultas de enfermagem. ... Além disso, na mortalidade infantil, o componente infantil tardio (após 28 dias) caiu e vem caindo regulamente, ... são essas as crianças ... atendidas pelo (programa de) saúde da família. (...) $\mathrm{Na}$ avaliação pela comunidade, entre as dificuldades apontadas pelas equipes, destaca-se que: A população desconhece o PSF. ... Mas se todos trabalham 
com associação de moradores, como é que o pessoal desconhece o PSF? Na realidade a população que mais reclama por não conhecer é a população que não está no PSF. Tem mais isso do que reclamação dos que estão no PSF (F647-8).

\section{Gerência Regional}

Na perspectiva de construção e implementação do projeto de novo modelo de atenção, ... a implantação das gerências foi um processo também fundamental (F649).

Pra nós já parecia meio claro que tinha uma certa região informal caracterizada. ... O processo iniciou, já definidas as regiões. A idéia que apareceu no plano era de construir regiões administrativas mais com caráter de participação popular. Onde, a população se identifica com a sua unidade sanitária na própria região. ... O principal trabalho das gerentes regionais é na comunidade. Apesar de ainda não se ter conseguido muito, isso implicava na região administrativa ter uma gerente, com a possibilidade de ... "arregimentar" a administração de todas as unidades da região. ... A criação do cargo de gerentes regionais foi uma proposta nossa, que foi discutida e foi aprovada no conselho (F650).

Antecedentes da regionalização: Agora, nessa gestão eles dividiram o município em 5 regiões administrativas, e geográficas também, administrativo e geográfico, ou melhor ficou 6 regiões se considerar o centro. $\mathrm{Na}$ gestão anterior a gente dividiu nas mesmas regiões. Só o centro ficava de fora porque não tinha equipe de PSF e a regionalização visava organizar a supervisão e referências do PSF. ... Em cada uma daquelas 5 regiões ficou um responsável. ... Ao mesmo tempo em que se estava tentado fazer um trabalho com as equipes do PSF, a gente estava tentando se organizar como é que ia trabalhar. Então nós sentamos e discutimos como fazer, ... porque era uma confusão total. ... Havia mais ou menos o mesmo tanto de equipes por região ... e uma coordenação geral. Nessa cidade o problema das gerências, isso nunca foi resolvido na saúde (F651). 
Seleção das gerentes regionais via teste psicológico: Houve um processo seletivo, inclusive com uma assessoria de recursos humanos, sendo contatados todos os candidatos em potencial, ou alguns por indicação da própria rede. Os que tinham interesse passaram por esse processo, que definiu algumas pessoas, algumas acabaram não aceitando, houve alguma mudança, mas se chegou ao consenso de um número de 6 gerentes, uma acumulando duas regiões menores. (...) Era preciso selecionar um grupo de gerentes regionais, mesmo que depois prevalecesse a indicação do partido. Nós fomos fazer o teste, era tudo sigilo. Eu ia e você também, mas eu não sabia de você e nem você de mim. Ninguém sabia de ninguém. Mas no fim todo mundo sabia quem foi. (...) Eu estava totalmente a margem disso, não entendia, não sabia o que era aquilo, até que ... me mandaram também ir fazer esse teste ... sem saber para quê. Pensei, ... então essa coisa de gerente pode ser um mito, vão fazer com todo mundo da casa. ... Percebi que não era para fazer muita pergunta, não fiz. (...) Mesmo criada a figura ... das gerentes regionais há quase um ano, ... parece que somente essa última semana (fevereiro 2000), ... as gerentes foram para os ambulatórios, cada uma no de sua região (F652-5).

O teste era feito em outra cidade por uma empresa especializada, um monte de gente.... Eu me submeti a alguns testes, entrevistas de duas horas e meia, uma coisa assim bem grandiosa mesmo, me viraram do avesso. Só faltou perguntar assim olha, que horas que eu tomo banho, o resto perguntaram. É teste visual, o que você vê naquilo, o que você não vê, avaliação e não sei mais o que. (...) Foram 20 pessoas fazer esse teste. Aí vieram os resultados, ... e esses perfis todos foram analisados pelas psicólogas aqui da casa e pelo secretário (F656-7).

Depois ainda demorou bastante tempo até que o secretário formalizou, efetivando mesmo a regionalização na cidade. ... Junto a isso então, logo em seguida da primeira oficina de territorialização começou então a aparecer dentro das regiões a figura do gerente. (...) As gerentes foram escolhidas, junto com as oficinas, ali mesmo, enquanto iam acontecendo as oficinas, elas iam sendo indicadas. (...) Até que colocaram as gerentes regionais, escolhidas também devido a esse teste. ... Ali foi traçado o perfil de várias pessoas e escolheram 6 supostamente mais adequadas para serem os gerentes 
regionais, convidaram as pessoas para assumir as gerências e elas aceitaram. ... Assim as gerências foram concretizadas mesmo e o secretário apresentou as gerentes para a rede $(\mathrm{F} 658-60)$.

Enquanto se falava da territorialização estava acontecendo o processo seletivo das gerências. ... Como eu coordenava a odontologia e ... não havia nenhum dentista como gerente, eu disse numa reunião assim: ... Mas o secretário não confia em nenhum dentista? Aí no outro dia, chega um dentista assim de repente e aterriza como novo superintendente, aterrizou, assim mesmo. E aí começou a acontecer tudo, e agora ... o que eu vou fazer ... ali, se esse é meu superior, entende? ... Enquanto as gerências iam sendo selecionadas eu ia às oficinas porque eu gostava das oficinas de territorialização, até que resolveram também me colocar como gerente, eu acho (F661).

Estava acontecendo todo um processo seletivo, mas não ficava claro. ... Eu até acho que eles me deixaram meio em banho-maria, agora que estou me dando conta, ... que eu fiquei ali meio sobrando na história, ... porque não tinha mais a minha coordenação, onde a gente tinha uma identidade, havia sido extinta em nome da integralidade. ... No momento em que eles estavam fazendo ... o processo seletivo, havia um movimento em que ia acontecendo a territorialização. ... Eu fazia parte então da equipe técnica, se falava da territorialização, falava-se que o secretário estava querendo cargo de confiança para as gerentes e que não era legal e continuava aquela seleção (F662).

Muita gente não foi nas oficinas, no início tentaram esvaziar. ... Só que eu adorei a oficina, foi muito boa, ... então aí comecei a me empolgar. Na oficina ... comecei a ver aquelas coordenadoras ... apresentando seu trabalho e tal, meu deus, ... a gente vê que é por aí o caminho. ... Então eu comprei aquela idéia, me convenci. E foi aí que eu comecei a vender a idéia ... das gerências como cargo de confiança (F663).

Poder técnico-organizacional: Quando foram colocadas em cheque, as equipes do PSF cobravam das gerentes - ou vocês são nossas aliadas, ou vocês defendem o PSF com a gente e a situação que a gente está, ou ... não sei. Por outro lado, essa situação deu uma insegurança muito grande, com as gerentes assumindo uma situação muito delicada 
porque, aо mesmo tempo em que concordam com o PSF, elas também são função de confiança. Então, o que se tentava passar pras equipes lá era lhes ... dar mais confiança. ... E na verdade, eu não acredito que eles vão mexer muito nisso. O que aconteceu ... foi só as enfermeiras da rede que levantaram a questão, claro porque se sentem prejudicadas ... com a diferenciação de salário e sensibilizaram o novo secretário. A mobilização do PSF foi tal que, enfim deu tanto barulho, que o secretário mudou de estratégia, não está falando mais de baixar salário, não vai mais mexer ali e ficou assim, para sossego das gerentes (F664).

\section{Função das gerências}

Era um objetivo, desde o começo tem a proposta de que gerência é pra gerenciar a ponta. E não ficar no nível central. ... Elas tinham como proposta, um período mais aqui dentro, pra poder resolver algumas questões mais estruturais, como estoque de material. ... Todo o final do ano (99) as gerências ficaram praticamente resolvendo questões administrativas, por problemas históricos aqui de dentro. (...) Mas isso havia se prolongado muito. ... Elas sentiam também ... uma pressão, uma certa falta de apoio e estavam também um pouco desmotivadas, ... e tremendamente desgastadas ... aqui no nível central, e não faziam parte lá porque não apareciam lá. Aqui o pessoal metia o pau porque ... incomodavam, ficavam fazendo críticas ... aos setores aqui dentro. Vocês estão se desgastando a toa, eu dizia (F665-6).

A referência das gerentes não é aqui dentro, elas não têm que estar referendadas no nível central, a força delas tem que vir da ponta. Quer dizer, quem tem que falar por elas, ... é toda a ponta que vem junto ... na sua função. Elas têm que estar lá na própria região, pra resolver os problemas lá, que tem um monte de coisas pra fazer lá e não mais aqui. ... São mil problemas, questões internas dentro das unidades, questões de relacionamento, precisa avançar no mapeamento de dados. ... É claro que a gente tem pressa em desencadear esse processo. As gerentes ainda estão muitas presas ao nível central. (...) Em algumas discussões aqui a gente tem acirrado essa crítica com as próprias gerentes, ... por estar muito só resolvendo as questões administrativas. ... Aí acabam não fazendo o papel maior lá dentro da região, que é conhecer a área $\mathrm{e}$ 
possibilitar isso. (...) Então este seu papel mais nobre, que seria a gestão do modelo na região, vai ficando ... para segundo plano (F667-9).

Precisa muito também a presença dos gerentes fazendo ... um trabalho de maior âmbito, na articulação, essa união entre as unidades da rede. ... A gente viu que 'ficou um comprometimento com essa integração' num primeiro momento. (...) Então, o grande desafio do modelo tem sido colocado nas gerências, pretendendo-se que através delas se possa fazer com que o plano saia da teoria e vá pra prática. E todo mundo está envolvido nisso. É preciso conseguir uma mudança principalmente naquelas unidades sempre mais sobrecarregadas pela demanda, que não conseguem avançar no modelo por não conseguir sair da sua condição atual (F670-1).

Elas têm a função de ter a região delas na palma da mão, têm que conhecer tudo da sua região, pra ficar por dentro de tudo. Vai chegar um momento, se acontecer alguma coisa na região, elas vão ter uma responsabilidade não instituída, mas por direito, porque são as verdadeiras conhecedoras de todos esses processos e questões locais e/ou regionais de saúde ... na região. Nisso é que elas têm que se afirmar. ... Essa é a força delas, para se fortalecer a partir desse referencial, desse conhecimento que elas têm que ter. Porque daí elas vão ter nível de discussão e nível de enfrentamento. Junto, apoiadas pelas equipes e pela comunidade. (...) Porque foram elas que tiveram a clareza de definir o que é a região ... numa leitura de território (F672-3).

A gente já tinha construído um mapa do município e a idéia era ir trabalhando localmente estes mapas. Já se tinha definido a questão das gerências, que elas tivessem a formação técnica, que seria através do Projeto GERUS, que ... potencialmente poderia dar conta do processo. Mas em curto prazo não, porque a gente não tem muito tempo (F674). Só se colocar o GERUS com esse objetivo. O Projeto GERUS pode ser o apoio que as gerentes precisam, já era para ter começado no início do ano. Todas elas são monitoras, aí ... elas podem começar a levar pra prática o que estão levando pros alunos. Na verdade, elas começam a ver coisas que não conheciam na própria área, e começaram a fazer reuniões rotineiras, para ir conhecendo a região, as equipes e todo o pessoal das unidades (F675). 
Na gestão do PSF existe alguma dificuldade de explicar suas condições de organização: O PSF, eu particularmente, acho que existe, por ali mesmo, um espaço de mudança do modelo. Só que neste município é preciso ver o custo/benefício, no sentido do financiamento disso. É comum o questionamento - Bom, o que se gasta com o PSF, tem retorno? É que o PSF ainda não conseguiu mostrar isso, que na verdade aí eu acho até que é da função da gerente e eu não acho que foi falha não, porque ainda está num processo de construção. No PSF não estão claros nas suas metas quais os indicadores que seriam, assim, como parâmetros, por exemplo, quantas internações diminuíram? (F676).

Do jeito que é a secretaria, como gerente eu administro oportunidades, quando a secretaria está meio perdida, eu administro oportunidades. E nessa situação, que nós estamos aqui, ... de repente nenhuma das gerentes está fazendo as mesmas coisas, cada uma está fazendo mais ou menos do seu jeito (F677).

Segundo o secretário atual, precisa só de duas ou 3 gerentes, ele diz que não precisa as 6. Então ele vê a gerente bem como supervisora. (...) Aí a última agora, nos vem o gestor dizer assim: Vou fazer um sistema de rodízio com as gerentes (rindo), ... essa é uma prática gerencial moderna, rodízio de gerência. Isso revela que não captou a proposta da territorialização nem da autoridade sanitária descentralizada. Ele não vê a gerente assim como estudando o território, trabalhando a região, os problemas da região, com aquela comunidade, o bairro, identificando as áreas de risco, ... que seria a função da gerente. ... Eu acho que ninguém sabe bem dessa função (F678-9).

Isso tudo pras gerentes ... é uma coisa muito desgastante, porque além de estar tentando, vamos dizer assim, legitimar um cargo ou uma função, não só isso, é uma proposta, ... que também têm que defender e mostrar que são competentes na função. Então isso dá uma sobrecarga muito grande. Então se tu vais conversar com as gerentes, vais ver que estão tudo doente lá (rindo). A gente está tudo meio doente. (...) Essa angústia das gerências, ... essa discussão, ... de acreditar, mas ao mesmo tempo não ficar claro, ... mas é bem isso que está se passando no dia a dia. É inevitável. Se 
fores entrevistar as gerentes tu vais notar essa angústia, assim, elas vão te colocar, todas elas (F680-1).

Relação das gerentes regionais com as chefias de unidades locais: As coordenações de unidade e dos ambulatórios gerais no início tiveram uma certa resistência em relação às gerentes, ... porque viam as gerentes como supervisoras. ... De repente para elas era mais interessante ficar como estava. E o grande questionamento era que a gente não resolvia as coisas básicas. O que é que adianta ter gerente, se não tinha lá o que mais precisava (a máscara, o soro, por exemplo). Inclusive como gerente eu até ... fui lá falar com as coordenadoras de unidades, mas até conseguir conversar com as coordenadoras e entender como é que elas vêem hoje a situação, também é um processo (F682).

A coordenação de um ambulatório geral sob o ponto de vista da gerência regional: Ela trabalha principalmente mais assim dentro da sua unidade, ela coordena a sua unidade. ... Dificilmente uma gerente vai intervir lá em coisas da unidade. ... Claro que o ideal é trabalhar junto com a gerente local para tocar a unidade. Mas hoje está muito assim: ... quando a coordenadora local solicita a presença da gerente, seja por ... um conflito interno lá na unidade, com a equipe, por exemplo, aí a gerente vai, faz reuniões na equipe e não se mete mais diretamente ... na unidade. Ou quando a gerência faz reuniões às vezes com as associações, pra falar do serviço, a coordenação participa, mas é que ela gerencia a unidade (F683).

\section{Relação da gerência com a comunidade}

Uma comunidade lá fez um abaixo-assinado pra comprarem uma geladeira pra ... conservar a vacina. Aí foi toda aquela discussão, porque tem outras necessidades, $o$ exame disso e daquilo. ... Eu não agüentei, levantei e disse assim: Olha, vocês não estão discutindo o que a população quer, porque ... quem pede exame de alguém, quem pede isso tudo que vocês estão discutindo, é médico que pede. ... Aí assim vocês não sabem o que é que a comunidade quer. Se quiserem uma geladeira para armazenar a vacina é porque eles acham que é importante ter a vacina lá no posto. ... Então, assim, 
tu vais vendo que tudo gira em torno disso, não da gerência em si, mas é essa interação com a comunidade. ... Eu faço reunião com a comunidade, faço sempre. A gente tem feito, não sei se todas as gerentes, umas com mais facilidades, outras menos. Também vou praticamente todas reuniões do conselho. ... É hábito já, acho importante (F684).

E pro próprio secretário, se quiser administrar com participação, tem que fazer assim, ... isso é fácil, só que perde poder, aparentemente. ... E mesmo que perca poder, ele tem que confiar nas pessoas. ... E acreditar na territorialização, entender que esse é ... o caminho. Ele precisa então, também acreditar nas suas gerências, ele tem que legitimá-las. Resumindo tudo, a gente está batalhando pra tentar descentralizar as ações, ... pra não ficar tudo no nível central. ... Parece assim que existe uma lacuna, entre o nível central e a prestação de serviços à população (F685). A gerência regional passa a representar este elo.

Na semana passada nós fizemos uma primeira avaliação, ... após as gerentes haverem ficado na região, isso é recente, não tem nem um mês. A avaliação foi ótima, elas estão vendo assim que agora efetivamente estão coordenando a sua região de saúde, por estar mais próximas da comunidade. ... E de qualquer forma, a questão da região em si, é uma questão consolidada. Porque as pessoas já identificam que não tem mais aquela peregrinação aqui na secretaria, de vir gente pra cá o tempo todo, procurando resolver seus problemas locais aqui no nível central. Já existe a identificação de todas as pessoas e da gerência local com suas gerências regionais (F686).

\section{Gerência Local - Coordenação de Unidade}

A coordenação de unidade e dos ambulatórios gerais inclusive, na verdade passa por muitas pressões. Em geral é a enfermeira da unidade que coordena. Então ela fica dentro da parte interna mesmo. ... Antes as coordenadoras de todas as unidades, tinham uma coordenação central, então elas vinham aqui no nível central expor a sua problemática em reuniões periódicas, ... dirigiam-se diretamente à ... superintendente. ... Hoje elas se dirigem à gerente regional, que vai mais no local. ... Tem coordenações que conseguem gerenciar melhor, noutras as unidades já não estão tão bem. (...) A 
chefia de unidades ... geralmente é enfermeira ou assistente social, mas sempre eles persistem em ter um médico numa coordenação geral, ou pelo menos da categoria, como na policlínica, para fazer a relação com os médicos. ... Até a interação com a gerência talvez seja diferente se a gerente local for enfermeira, ou se for dentista ou assistente social, categorias que não entendem a parte específica da enfermagem (F687-8).

É preciso preparo para a função de chefia de UBS: A assistente social em coordenação é experiência única nessa administração, ... tem uma resistência muito grande quanto às assistentes sociais para assumir uma chefia. ... Eles não consideram o assistente social como profissional de saúde, ... e se procurar espaço, então a gente é discriminada. Há uma rejeição muito grande e fica difícil, dá muita insegurança, por mais que se brigue sempre tem uma certa insegurança na chefia de unidade. (...) E fica muito difícil o relacionamento, passei já por uma fase assim, até me aceitarem como coordenadora; mas por ser assistente social e ter tirado uma outra pessoa. ... Pra provocar, as enfermeiras usam muito termos técnicos, então é uma barra muito grande coordenar, sem um curso, ninguém nunca teve formação pra gerenciar uma unidade, então é porque eu sou assistente social e ela enfermeira, acho que ninguém nunca esteve preparado. A gente estava trabalhando da forma ... que achava que deveria ser feito, ... e só agora a gente está tendo uma visão mais ampla do que é coordenar, e tudo que a gente precisa realmente saber dessa unidade pra poder dar uma guinada principalmente ... na área preventiva (F689-90).

Que características tinham que ter as chefias de unidade pra poder abrir mais possibilidade de fazer mais prevenção, mais promoção, mais integralidade: ... Antes de tudo, é preciso ter mais conhecimento da própria realidade. Se você não conhece a sua realidade você nem sabe o que fazer. ... Me parece que é uma coisa meio desvinculada ainda, a unidade aqui e a população lá, e eu não posso dizer que avancei muito não, porque realmente eu vou caminhando aos poucos, gradativamente a gente vai tentando avançar (F691). 
$\mathrm{Na}$ perspectiva da coordenação de unidades, a contribuição da gerência regional: Quanto à gerência regional eu acho que é bastante interessante que às vezes ela vá lá na nossa unidade ou ambulatório, conhecer nossa área, então ela conhecendo melhor a nossa realidade, aí é mais fácil, fica um pouco mais tranqüilo administrar assim (F692).

Gestão com profissionais problemáticos: E também quero te dizer, não sei se isso entra, outro entrave muito grande, que dificultou talvez um avanço maior por uma equipe, ... é que nós temos uma equipe muito problemática. Não sei se a gerente te falou, mas ninguém queria ser gerente daquela região, por problemas daquele ambulatório geral. Tem um profissional ... que acompanha unidades ... básicas, que estava há 9 anos internado no ambulatório e ... tiraram esta pessoa de lá. Então ela não aceita cumprir, ... nunca aceitou, ela sempre disse claramente isso. E faz todo um movimento que realmente às vezes emperra o trabalho da gente. (...) Fica sendo trabalho bobo, jogado assim, por baixo do pano, umas puxadas de tapete ... Então às vezes eu sinto que ... está avançando, porque a equipe está ... trabalhando todas as outras questões. E outras vezes a coisa parece que não anda, então é muito triste isso, é muito ruim. ... E isso complica, ... para os funcionários e para a administração (F693-4).

Na concepção auto-referida, ... já outra categoria que não tem muito jeito de mexer, é o médico mesmo. (...) Os médicos são formadores de opinião. Então, pra qualquer modelo de saúde funcionar, tem que haver alguma forma de acordo, de negociação, com os setores médicos mais tradicionais, para buscar aliados (F695-6). Isso afeta diretamente a gestão das unidades básicas de saúde.

Pela sua inserção com a gerência regional, as unidades podem dispor de um maior acesso ao nível central. Além dessa relação externa e da interação direta com as unidades de sua área de abrangência, um ambulatório geral necessita também da relação inter-regional com seus pares. ... O que a gente notou assim, é que com a regionalização também fragmentou um pouco. Porque agora ... eu tenho a minha região, eu sei dos meus problemas, ... isso é bom porque assim até se tem 'uma integração maior com todas as unidades da região'. ... Mas em relação ao que acontece em outro ambulatório geral, isso aí a gente não sabe, ficando cada um bem isolado. ... A gente deveria 
também se reunir com os outros ambulatórios gerais, para discutir a nossa realidade. Porque as pouquíssimas, raríssimas vezes que a gente se reuniu, a gente trocou algumas coisas e é superinteressante saber como os outros resolvem problemas que são similares aos nossos, se a mensagem ... é a mesma. Ao se reunir, cada um fala das suas experiências, ... essa troca é muito importante (F697).

\section{Planejamento e programação local}

Foi tirado dentro do plano municipal de saúde, que toda unidade tem que fazer o seu planejamento local, algumas até já tiveram alguma experiência de gerência, planejamento e avaliação. (...) Depois da oficina de territorialização ficou só um diagnóstico que identificou os pontos, mas ... com o GERUS a gente está retomando novamente, só que agora ... vai-se tomar uma postura mais administrativa mesmo. Lógico que tem que ser ... retomando os dados da comunidade, revendo onde e como vai ser a vigilância à saúde. ... Com as oficinas de territorialização se abria essa possibilidade. É uma hora em que a gente põe as pessoas de frente pra discutir qual é a relação do trabalho de um e de outro, pra mostrar que as pessoas estão querendo a mesma coisa. ... Aconteceu, mas não está sendo valorizado. E era para ter dado uma seqüência maior, mas ... foi feito muito irregularmente (F698-9). Isto requer a instituição de processos de planejamento local participativo. Haveria que propor trazer todos os profissionais da rede para os próximos movimentos do processo, especialmente o trabalho com os desdobramentos locais da territorialização, sistema local de informação e o planejamento, programação e avaliação local. Mas, no contexto estudado, parou-se na oficina de territorialização.

A primeira oficina foi realizada na ... maior região, com o maior número de unidades, e um ambulatório geral muito grande, com 4 ou 5 equipes de PSF. ... Quem participou daquela oficina junto com a assessora externa foram alguns técnicos da secretaria, representantes das superintendências e de todas as unidades de saúde da região, ... independentemente de ser unidade avançada ou PSF, ambulatório geral ou clínica odontológica (F700). Esse foi um importante preparo para as chefias locais começarem a pensar no planejamento de ações da sua área de abrangência. 
Era fundamental o suporte das gerências regionais: Então, a meu ver, das gerentes e da assessora do processo de territorialização, que a gente discute muito isso, a gerente está dentro da área, fazendo as ligações entre unidades, propiciando ... a possibilidade maior de essas unidades avançarem no processo da territorialização enquanto conceito, no conhecer o seu território e poder planejar, fazer planejamento local com dados mais contundentes, digamos assim. Esse planejamento também foi tirado dentro do plano municipal de saúde, que toda unidade tem que fazer o seu planejamento local, algumas até já tiveram alguma experiência. (...) Enfim, por uma série de coisas ... esse processo atrasou, mas na nossa visão, cada unidade vai ter condição de fazer um planejamento local a partir do momento em que conhecer bem a própria unidade, se tiver dados epidemiológicos da sua área de abrangência, se conhecer a sua região, que tenha uma parceria com a comunidade, para poder fazer uma mudança, porque a comunidade está sempre cobrando. ... Pra gente conseguir fazer a oficina, praticamente parou um monte de unidades (eram 50 pessoas em média, 40 no mínimo), ... ficava só um ambulatório geral de plantão e a comunidade cobra. Então a gente tem que ter a comunidade como parceira, até pra que ela possa entender (F701-2).

Por referência a um processo de planejamento e programação voltado para a mudança do modelo de atenção, constata-se o movimento de algumas estratégias colocadas neste sentido: Agora, com o novo secretário, nós estamos tentando viabilizar as duas oficinas que faltam, para que daí também com a implantação do Projeto GERUS, a gente possa 'ter um avanço maior nesse processo de vigilância à saúde e atenção integral'. ... Tem coisas pra fazer ainda, a gente já queria e/ou podia estar mais avançado (F703).

No ambulatório geral ... nós já fazíamos o nosso planejamento, é lógico, não aquela coisa assim, como propõe a oficina de territorialização, mas ... uma coisa mais simples, com um levantamento da problemática, dos problemas, e tentando ver algumas ações para isso. Também 'solicitamos alguma coisa tipo uma oficina de planejamento e programação local', a gente sente essa necessidade. Só que assim, quando eu procurei o técnico responsável pelo projeto das oficinas, no começo desse ano, ... a gente até já tinha pedido isso também no ano passado, solicitei de novo pra ele esse ano, mas foi justamente no dia da reunião do GERUS e aí ele disse: Não, não precisa fazer isso, 
vocês vão fazer automaticamente (F704). São princípios e metodologia a assimilar. Na construção de um processo participativo e ascendente de planejamento local para mudança da prática sanitária, nada acontece automaticamente. Inclusive mesmo com o Projeto GERUS, que ao preparar o gerente local para a gestão da unidade, o que inclui os demais momentos de um processo de planejamento local em saúde, pressupõe-se que para desencadear um processo desse porte em toda a rede, se exige um esforço coordenado.

Apesar da necessidade sentida por coordenações de unidades, não se observava na equipe técnica central uma maior preocupação com essa visão de conjunto do processo de capacitação de forma comprometida com a instituição de um processo participativo de planejamento e gestão local para mudança do modelo de atenção, envolvendo todas as equipes de agentes do trabalho. Havia somente um grande interesse em fazer as oficinas de territorialização em todas as regiões do município. Supunha-se que uma formação ao nível de especialização, em um projeto de desenvolvimento gerencial, pudesse dar conta da continuidade daquele processo. O problema que se coloca aqui é que não se pode considerar que o preparo das chefias, se todas fizessem a formação, possa garantir uma preparação extensiva aos agentes do trabalho para uma nova prática de saúde comprometida com um modelo de atenção integral e vigilância à saúde, conforme o projeto original no caso.

A captação das necessidades de ação: No PSF, sobre suas programações, gerência e planejamento, para orientar a programação das ações, a equipe se reúne semanalmente para discutir e programar o seu trabalho, mas muito esporadicamente em relação ao total da equipe. Reuniões de planejamento das ações ocorrem na maioria das equipes, teve 13 casos, em duas equipes essa atividade é quinzenal e em 4 não existe regularidade. ... O que orienta a programação das ações desenvolvidas para $90 \%$ são dados do SIAB, de forma associada às orientações da secretaria para $80 \%$, e à realidade local observada em 95\%. Outros não dizem quais. Isso segundo o que as equipes informaram no levantamento realizado pelo serviço. (...) Para programar suas ações, somente $15 \%$ das equipes usam, além dos sistemas de informação implantados, orientações ou dados das associações de moradores da comunidade (F705-6). 
O planejamento local das ações: Os agentes faziam os projetos de suas ações, $e$ enquanto enfermeira supervisora eu pedia pra eles escreverem. Começou assim: $O$ quê que vocês acham que tem de pior na comunidade? Tem muito desmame precoce. Bom, então vamos trabalhar com amamentação. Aí quatro ficaram responsáveis pelo trabalho de estimular a amamentação. Eles ajudavam no diagnóstico do problema, porque eles faziam parte. (...) Tem problema com o lixo, é mais urgente, então vamos trabalhar isso. Aí fizeram o projeto escrito, um projetinho, dentro das condições deles. É legal até para estimular a pesquisa e escrita. É importante também por documentar isso tudo. Depois do lixo e amamentação, na mesma lógica auto-organizativa das ações captadas como problemas de saúde na localidade, trabalharam, escabiose e água (F707-8).

Na sua experiência de planejamento local, as equipes ... sabem localizar os problemas, sabem pontuar, mas na hora de planejar a intervenção é que eles pecam. Mas isso porque nunca foram treinados para isso. ... Por isso que eu acho que o planejamento é um aprendizado e alguns já conseguiram fazer o planejamento junto com a comunidade, mas ainda fica muito pontuado. ... Só que aquela coisa ... de planejar o dia a dia, de modificar o planejamento ... a partir do que aconteceu, analisar os mapas, ver o que modificou no mapa, colocar no mapa os pontos, ainda são poucos que fazem. (...) Eu acho que por aí teria que entrar com uma programação local. ... É, eu acredito que eles vão conseguir fazer isso, porque faz parte do treinamento do GERUS e todas as chefias de todos ambulatórios estão fazendo projetos de prática. O GERUS trabalha esse levar à prática o planejado, ... trabalha bem isso (F709-10). Mas daí a envolver todos os agentes do trabalho nas diversas equipes da rede neste processo é um caminho a percorrer.

\section{A prática de avaliação local dos serviços}

Como antecedentes da avaliação no PSF, no final de 1996 fez-se ... um consolidado da produção das equipes, dos envolvimentos - o vínculo das equipes com sua população de responsabilidade, das visitas domiciliares e outras coisas simples, fizemos uma avaliação e apresentamos pra todas as equipes, sugerindo algumas coisas que 
deveriam ser encaminhadas. (...) A maioria das equipes do PSF diz avaliar o próprio trabalho apenas internamente (95\%). ... Do total, 70 e $75 \%$ avaliam também com a participação da comunidade e da coordenação municipal, respectivamente. Menos da metade delas, $40 \%$, partilha a avaliação com as outras equipes do PSF. Uma das dificuldades identificadas para o desenvolvimento do trabalho em $55 \%$ das equipes foi o desconhecimento pela população da proposta do PSF e 30\% das equipes está deixando de usar o recurso ou a estratégia de avaliar o seu trabalho com a comunidade. Eles dizem que a comunidade não conhece a proposta do PSF, mas não estão avaliando muito o trabalho com a comunidade (F711-2), para entender porque eles não conhecem.

$A$ avaliação sempre tem quer ser do conjunto das ações realizadas (Nemes 1995) e por referência à população da área de responsabilidade da unidade. Na prática, ou se faz $a$ avaliação de procedimento na área, de forma muito técnico-normativo, ou quando tem participação da comunidade tende a ser só reivindicatória. ... Pode-se constatar que a avaliação é informal, pontual (F713).

Avaliação de desempenho no PSF: As gerências fizeram uma avaliação de desempenho ... junto com as psicólogas da secretaria. As psicólogas dizem que foi as gerentes e as gerentes dizem que foram as psicólogas, ... ninguém quer assumir, mas foram essas duas ... instâncias da secretaria. Fizeram uma avaliação não da equipe, mas de cada profissional do PSF. ... E foi uma avaliação pra tirar ... quem não dava. Foi ruim pros profissionais, ... estava todo mundo na corda bamba. E depois dessa avaliação ... começou a aparecer ... muito problema de relacionamento e confronto mesmo, agravos e desagravos entre as pessoas (F714).

E depois da avaliação de desempenho, eles re-arranjaram as equipes, e separaram todo mundo, trocaram os profissionais que constituíam uma equipe, em quase todos os lugares. ... Tipo assim, a avaliação foi boa e eles tiraram essa enfermeira daqui e botaram pra lá e tiraram de lá e botaram aqui. Aparentemente não tem nenhuma lógica. Segundo as gerentes, ... era pra mudar os ares, oxigenar. É uma coisa assim, da linha da psicologia organizacional, ... porque com o tempo vicia. Eles não notaram que estavam trabalhando com equipes do PSF, nem leram o manual que diz que uma coisa 
básica do PSF é o vínculo com a comunidade. ... Porque daí já tinha assim uma ligação muito forte com a comunidade e foram logo mudar a comunidade (um suspiro de tristeza) (F715).

Essa avaliação de desempenho, como foi colocada, ... baixou muito a bola dos profissionais, que diziam - eu quero saber o que estou fazendo de errado. A avaliação foi muito boa, tu és ótima, ... o problema não é contigo, mas tem que mudar de comunidade. A pessoa conhecia cada família, ... tudo. Teve duas ou três equipes que a comunidade gritou demais e pediram pra ficar. Em uma comunidade, ... onde um vereador da oposição pegou junto, ... disseram assim lá na associação de moradores nós não queremos isso, nós gostamos do trabalho dessa equipe, elas estão aqui desde o início, não tem porque trocar, ... daí não trocaram. Teve uma outra, que ... só ficou a enfermeira ... e uma auxiliar, os outros mudaram. Isso ainda porque na associação de moradores também berraram. ... E numa outra equipe ... teve uma médica que ficou, parece que a comunidade fez um abaixo assinado, eles disseram ... ela nos atende em casa e nos conhece, sabe o problema de cada família e é isso que a gente quer. (...) A equipe é super envolvida com a comunidade e quando está envolvida, troca. Então teve esse problema. Inclusive caiu a produtividade deles, foi bem significativo (F716-7).

Da avaliação local tem que se chegar a uma avaliação do cumprimento do plano e a reelaborar novas estratégias emergentes para alcançar a direcionalidade buscada. Baseando-se nas medidas adotadas para retomada do plano, pode-se fazer... indicadores que não deixam dúvidas sobre o cumprimento das metas do plano, a gente teve um norte pra seguir e está seguindo, ainda que não totalmente (F718).

Coerentemente com a metodologia de planejamento assumida e com os fundamentos epidemiológicos de que se reveste a proposta de um modelo de atenção integral e vigilância à saúde, impõe-se a organização do trabalho por operações e problemas, isto é, trabalhar por problemas. A sua operacionalização pode ser processada através de um mecanismo de programação local estratégica articulada ao planejamento participativo ascendente. Dos resultados obtidos nos processos instituídos depreende-se a potencialidade da organização do trabalho por operações e problemas, ou simplesmente a idéia de trabalhar por problemas como importante instrumento tecnológico da 
programação local estratégica, desenvolvida dentro de um processo de planejamento participativo ascendente. A lógica dos problemas de saúde, tomados enquanto tradutores de necessidades da população, é potencialmente capaz de permitir a materialização da integralidade da atenção à saúde.

\subsubsection{Participação Popular na Gestão Local}

A sexta via indicada é democrático-popular, compreendendo aspectos indispensáveis de participação popular na gestão em saúde. Trata-se da população participar na gestão de forma comprometida com a perspectiva da integralidade da atenção à saúde. Embora a temática do controle social, democrático e popular, seja uma idéia reguladora do SUS, nas representações dos trabalhadores entrevistados a sua falta aparece como limite gerador de insucessos nas tentativas de implementar a mudança do modelo e é apontado como condição propulsora de se poder fazer a integralidade. Tal concepção permite pressupor que por essa via se processa também um conteúdo democrático-popular no saber operante da gestão dos serviços locais de saúde.

\section{Referências ao controle social via CMS}

O controle social aqui é enfocado na perspectiva da sua participação na gestão dos serviços de saúde. $O C M S$ (conselho municipal de saúde), logo depois de constituído no município (1972), já marcava um espaço de seu poder. Houve um momento em que ... $o$ secretário de saúde seria ... substituído, e nós pressionamos o prefeito pra mantê-lo, até porque tinha uma postura diferenciada, ... voltada para o social, mesmo dentro de um governo considerado neo liberal ou de direita. Em todas suas decisões, fazia consulta às bases, ... mesmo antes da existência do conselho, havia mensalmente reunião com sindicatos e associação de moradores. Tivemos oportunidade de indicar os superintendentes dos postos de saúde, ... muita gente custa a acreditar que ... se tenha feito isto. Quando terminada aquela gestão, o conselho ainda influenciou o governo pra escolher um membro indicado naquele colegiado para ser o próximo secretário de saúde (F719). 
Vou citar uma experiência, um diálogo entre o gestor e um representante dos sindicatos, que mostra uma concepção reducionista do que significava o secretário trabalhar com os sindicatos. ... Naquela época, uma semana antes do dia $1^{o}$ de dezembro, um conselheiro chega pro secretário e diz: doutor que material nós vamos distribuir ... amanhã, por ser o dia mundial da luta contra a Aids? Não tem nada. Não dá pra multiplicar esse papel aqui? E se faz um levantamento em 3 gráficas, mas só se pode gastar até 8.000 reais. Aí vai, modifica, corre nas gráficas, ... negocia e manda fazer, pode passar lá e faturar. ... Consegue um desconto de $25 \%$ e aí um administrador financeiro conseguiu por $50 \%$ do preço e fechou. O conselheiro considera que fez um trabalho bom, note-se. ... Aí, muda de governo e os caras tiram essas pessoas que têm transparência e moralidade. Isso marca sim (F720). O papel do conselheiro desde sua origem se confundia com funções de gestão dos serviços.

Em certas condições o conselho passa a ser um aliado do secretário. $O$ primeiro secretário que conviveu com um conselho de saúde no município fazia isso muito bem. Eu te confesso que tive dificuldades em alguns momentos. (...) Houve um momento na história deste conselho que as pessoas diziam que era um conselho pelego, que aprovava as coisas de acordo com a cabeça do secretário (F721-2). Essa concepção da participação no processo decisório precisa ser mais bem trabalhada no CMS.

Na gestão atual ... foram eles que não permitiram a democracia, a participação do conselho nas suas decisões (F723). Por trás do conflito atual, expressado pela representação ouvida do CMS e que vinha interferindo negativamente na administração, havia um ressentimento explícito por divergentes alianças na eleição da chapa para a presidência do CMS: Eles vetaram toda participação do conselho a ponto de ... fazerem uma outra chapa pra nos derrubar e perderam. Tentaram dividir o movimento popular, lançando um candidato das associações de moradores contra o representante do sindicato. ... Nem foi preciso campanha, ... na hora da apresentação pra ser votado, o candidato deles disse, olha a secretaria está me lançando numa chapa, mas eu não entendo nada disso; ... e acabou sendo derrubada (F724). O conselho se ressentia muito de participar mais diretamente na gestão da recente administração popular. E não ficava clara a diferença implicada entre ser gestor e conselheiro. Do ponto de vista de 
representações da gestão tem-se: ... Em certas decisões, tem que ouvir o conselho sim, não precisava ter medo (F725).

Quanto à presidência do conselho: Já na nossa segunda conferência municipal (1996), ... quando houve a primeira eleição de conselheiros, tomamos a decisão que o secretário necessariamente não deveria ser o presidente do conselho. Ficamos até 2 horas da manhã, eles procurando esvaziar, nós ficamos lá e aprovamos. (...) Em 98 a terceira conferência teve um clima bem quente, foi quando se abriu a presidência do conselho, mesmo tendo sofrido uma certa reencarnação do grupo que encabeçou essa proposta, mas eu acredito ... que na presidência do conselho é mesmo melhor ... que não seja o secretário (F726-7).

Dinâmica de funcionamento do CMS: Quando tem coisas mais complexas ... convocamos a comissão de saúde. Se tiver coisas específicas pra deliberar, nós não marcamos reuniões do conselho e sim da comissão, que é menor. ... Pode-se fazer duas ou 3 reuniões por semana, ... não nos prendemos muito a essa formalidade de ali estar representativo ou não. (...) As decisões da comissão de saúde ... ou são por consenso ou não tem decisão. ... Nunca houve problemas, ... não que isso seja uma glória, é que as pessoas lá tem maturidade, ... o máximo que pode acontecer é alguém dizer - eu me abstenho. ... Tem uma transparência muito boa. ... O presidente não tem direito a voto, mas opina também, e se não há consenso nem precisa votar (F728-9). Os trabalhos da comissão são submetidos à deliberação do conselho, que tende a aceitar as propostas apresentadas.

Não consigo entender esta distância entre estado e município, como também regional de saúde e município. Na composição do conselho municipal, por ser gestão plena e sede da regional, eles tinham que ter um assento no conselho, independente de que governo é. ... No SUS diz que é representante de governo, ... não só do governo municipal, ... porque a regional também atua dentro do município, ... por esse ser um município-pólo na região. ... No mínimo para dar uma satisfação pros conselheiros e usuários sobre decisões que são do governo estadual (F730). 
A estrutura das nossas entidades sindicais e populares tem ... reflexo aqui. Isso não é brincadeira, nós não construímos ... na base da ética, moral e princípios, não senhora. Vão reproduzir o que são. ... Todas essas pessoas que não têm uma matriz ideológica definida, eles vão lá para se locupletar. ... E por isso levam parente e botam tudo lá. (...) Espero que politicamente esse baile mude (F731-2). Por outro lado, sabe-se que é pela participação política o maior canal para mudar essa realidade. Neste espaço o controle social tem sua importância destacada.

Aqui nós não chegamos ainda a ter no conselho ou comissão de saúde um dia na semana para definir as demandas da secretaria, sobre ... os aspectos econômicos e financeiros. ... E onde fica a Lei? O CMS tem que opinar no econômico e no financeiro. Nisso ainda não chegamos, temos batalhado e brigado muito ... pra que isso aconteça, mas ainda não deu. Numa auditoria que houve saiu que o ordenador do Fundo (FMS) é o secretário, isso não tem problema nenhum, ... mas a Lei também diz que ele tem que ouvir o conselho (F733).

Cumprir e cumprir. ... Quando chegaram aqui os recursos financeiros no início da gestão, ... os caras vieram no conselho dizer, ó, tem que botar este dinheiro lá na fundação hospitalar municipal, começou desta forma. Aí ... a gente questionou, mas como que é isso, espera um pouco, ... nós temos é que viabilizar a proposta da saúde da família, e aí começam os problemas (F734). Com aqueles recursos se pagou a "gratificação de dedicação plena" para o pessoal do PSF e equipe dirigente da secretaria, o que gera reações políticas contrárias: Quando as pessoas começam a se locupletar no poder, ... como é que fica? ... Eu denunciei no Ministério Público, foi registrado, ... isso aí é pra você ver o quê que era o conceito. ... Isso foi em 98, quando eles estavam um ano no governo (F735).

Bancamos recentemente, com dinheiro do conselho a ida do pessoal do PSF a Brasília. ... Dentro desse processo o conselho tem participado da seleção dos médicos candidatos para trabalhar no PSF, ... aonde nós enquanto usuários temos opinado no perfil desse profissional (F736). 
O conselho deliberar sobre o que entraria na Lei de Diretrizes Orçamentárias é o que nós queremos, colocar lá o que se tornará política no próximo ano. Até então nunca tínhamos feito isso. ... Algumas deliberações se tornam realidades, outras ficam só registradas no papel (F737). A expectativa do conselho é de participar mais na gestão.

A diferença é que não estando ... vinculado a nenhum grupo, faço a defesa dos usuários e cobro tanto da esquerda quanto da direita, e isso muitas vezes, se confunde. Pra elogiar alguém ... ou criticar, ... não é porque um governo é da esquerda agora que o conselho vai mudar sua postura. ... Eu acho que a gente conseguiu um movimento da reforma sanitária justamente por isso, esses valores da saúde para a população como responsabilidade do Estado, ficando acima de qualquer vertente (F738).

Foi marcante nesse caminho a última avaliação ... que se elaborou no conselho sobre o que tinha sido feito do plano. Isso foi ... importante. Você poder influenciar a lei do município, a partir de um planejamento da saúde discutido com o conselho, bota democracia nisso. As pessoas acham muito normal, ... no momento que você discute com o conselho, sentam os técnicos, algumas propostas são discutidas, todo o mundo aprova, e se leva pra fazer a lei correspondente no município, eu acho bárbaro (F739).

Como o SUS é descentralizado e exige participação, a hora que a população acordar que só vem dinheiro pro município, porque tem conselho e esse conselho é composto em $50 \%$ de representantes da população, eu acho que esses governantes, eles tinham que se re-situar e ... vão pedir pelo amor de deus, não é? (F740).

Com relação ao Boletim Informativo: Isso aqui era pra ser ... um jornal da secretaria e conselho - o SUS no município. Pode ser que não está ainda como era para ser. Mas pelo menos está circulando. ... E chegaram dizendo ... isso aqui não pode ficar assim, é para cortar isso aí. Quem é que vai cortar? Então nós vamos publicar, ... o conselho tem verba e faz a edição, ... não botava logotipo da marca do governo, nem nada. ... A cara da secretaria é essa, então que se expresse isso aí. Só que o jornal que era pra ser mensal, passou a ser trimestral. ... Então tem umas coisas que não deveriam acontecer e por incrível que pareça acontece num governo democrático popular. (...) No CISAT- 
comitê intersindical de saúde dos trabalhadores, sempre aparece alguém fazendo denúncias. Tem algumas dificuldades, como por exemplo, um posto aonde os profissionais chegam atrasados, ... hoje já fui cobrado sobre esta questão, a gente está toda vida interferindo neste processo (F741-2).

O SUS está legal no município, principalmente no sentido de estar crescendo a abertura. Pra quem acompanha todo o processo, ... inclusive, eu disse pro secretário que nós somos referência e nós não podemos retroceder no modelo, ... nós temos é que

efetivar mesmo o controle social porque é isso que vai ser a nossa referência. ... É tão difícil um governo democrático popular se eleger e depois de se eleger deveria fazer tudo que tem que ser feito (F743).

Ninguém sabe o que é que vai acontecer aqui. Mas tem uma coisa, ... aqui aquilo que tem ninguém tira. ... O nosso conselho tem uma presença de participantes maior do que as reuniões da câmara de vereadores. As pessoas descem o morro mesmo, como teve outro dia uma presidente de associação de moradores, e nós damos voz, não tem direito a voto mas tem direito de se expressar e manifestar a sua opinião na platéia. (...) Quando o secretário era presidente, as pessoas não se manifestavam e ninguém ia lá. ... Todos entenderam que ... ter um presidente que não é o secretário foi muito positivo. ... Assim, quando atrasaram o pagamento do pessoal do PSF, nós cobramos do secretário, porque ... o dinheiro estava aí. Assim se pode interferir. Eles, por outro lado sentem que têm alguém pra cobrar, que é da comunidade, são das organizações, ... então isso é importante, como é importante os funcionários também poder sentir-se representados, isso é fundamental (F744-5).

\section{Participação popular na gestão via conferência municipal de saúde}

A participação está aqui enfocada basicamente em duas dimensões, na apreensão das deliberações das conferências municipais de saúde pela gestão do sistema e na sua representação junto a unidades prestadoras de serviços de saúde à população, via conselhos gestores. 
Na gestão 1989-92 nós fizemos duas conferências de saúde no município - ... a conferência de saúde do trabalhador e uma pré-conferência da etapa estadual da $9^{\mathrm{a}}$ CNS. Quando era pra fazer as conferências, tinha gente na secretaria que queria fazer com 50 pessoas, e aí nós não deixamos e mobilizamos. ... Depois de tanta concentração no sentido de fazer uma conferência mais ampla possível, aí na terceira municipal (1994-96-98) nós esperávamos algo muito mais evoluído e tivemos uma decadência. ... No início estava desanimado, ... todo o mundo quer mais. No conselho ... a gente quer mais SUS e quer participar (F746).

Na gestão passada houve momentos importantes aqui na participação popular. Quando levamos dois ônibus daqui para Brasília em 94, fomos a única delegação do Sul, que num momento em que eles queriam acabar com o SUS nós ... estávamos lá, ... fazendo a defesa do SUS. ... Nós fomos a única cidade que estava com todas as representações populares possíveis, pastoral da saúde, pastoral operária, sindicatos, associação de moradores, representantes de deficientes, portadores de patologias, funcionários públicos, empresários, estavam todos ... lá representados. E como se dá este envolvimento? Dá-se desta forma, ... com 'sanitarista apaixonado pelo modelo' (F747).

Na conferência de saúde de 96 tinha um jornalzinho na parte de trás da convocação da conferência, onde ... escrevemos tudo que a gente tinha feito na gestão anterior. ... Foi a primeira vez para uma conferência municipal que houve um documento escrito por referência (F748).

Cumprir o discurso é o problema: Então o plano vai indo de água a baixo a partir da hora que as pessoas começam a olhar a secretaria com outros olhos, a mentir pra comunidade, dizer que vai fazer isso e não faz, não tem recurso, vão lá prometem e não cumprem as deliberações da conferência municipal. ... Se o que foi deliberado for um erro, ... nós sabemos que foi um erro coletivo e temos consciência que podemos repensar e fazer de uma forma melhor. ... Se você tomar uma decisão e achar que não é nada disso, amanhã o povo vai cobrar. ... Está tudo escrito aqui nos relatórios das conferências, ... você pode rasgar um, mas não vai rasgar todos; e alguém vai cobrar 
porquê não foi feito. (...) Quem briga pelas recomendações da conferência é só o conselho, isso pra nós é uma constante. O grande problema que nós temos, pergunta se ... o relatório foi reconhecido pelo prefeito, no mínimo tinha que ser publicado no Diário Oficial do Município ... reconhecendo as deliberações populares. ... Senão não adianta colocar o nome das autoridades na apresentação. (...) Então o que vamos fazer? É possível que na $4^{a}$ conferência nós vamos repetir tudo que está aqui no relatório da anterior, e vamos repetir tudo na outra conferência, até conseguirmos sensibilizar um secretário da saúde e um prefeito ... a adotar isso como política. ... A gente sabe que isso é um processo, é lento, tem que ter paciência. ... Se nós trabalharmos com a comunidade, aquilo que eles submetem a aprovação da própria comunidade via conferência municipal, pelo menos tem que ser respeitado (F749-51).

$\mathrm{Na} 3^{a}$ Conferência nós trabalhamos essa questão de que todas as entidades têm que fazer sua pré-conferência. ... As pessoas entenderam que a participação tem que ser qualificada ... para poder dar respostas. Assim, se vier um entendido, ... todo mundo não vai aceitar porque o cara disse que era assim. ... Tem muita estrada. (...) As associações de moradores começaram a exigir um espaço maior, nas conferências, esse foi um avanço legal. (...) A $3^{a}$ Conferência foi um momento muito rico, teve uma participação muito rica, muito importante. ... E algumas coisas a respeito do modelo de saúde, ficou muito na teoria, esse é o problema (F752-4).

E tem essa questão da Associação do PSF. ... Porque a gente começou a observar que $o$ profissional está se desmotivando, por todos os problemas, a área é grande, o número de famílias é grande, e os que entravam primeiro, aquele pessoal que batalhou, agora está querendo desistir. ... Então o que a gente faz pra evitar? Porque se sair vai acabar e a gente quer manter esse modelo. ... O objetivo dessa associação é manter o modelo. Manter os profissionais, ter dignidade de trabalho, buscar cursos, fazer um mestrado de forma articulada ao serviço, porque com 8 horas, quando vai se ter tempo de fazer um mestrado em Florianópolis, ou em qualquer outro lugar (F755). 


\section{Conselhos gestores de unidades de saúde}

Como antecedentes, a gente tem uma história dos conselhos gestores de unidades, quem vai ser e tal. Foi o seguinte: Nós tínhamos um clima político-eleitoral (96), em que parecia que ia vencer era um candidato ... que defendia o modelo do PAS de São Paulo. Aí ... e u fui no secretário da saúde e disse: ... o teu candidato não está lá essas coisas, o do PT também não, e parece que nós temos que fazer algum negócio para garantir o SUS aqui no município. Na época o conselho gestor foi pensado como forma de garantir o SUS. Isso se dá num momento de transição e medo. ... Então se discutia que com a vitória do governo popular, o PSF continuaria e então os conselhos gestores seriam implementados para reafirmar e tal. E isso daí o governo da gestão anterior dizia: Se o PT ganhar, nos não vamos ter dificuldade, ... muito pelo contrário. (...) Aí se faz um projeto de lei às pressas, ... é mandado para a Câmara, negociado e aprovado. ... Então tem a "lei do conselho gestor". ... E a unidade que quiser, faz. ... Mas nós não estamos incentivando a fazer o que está na Lei. Por que? Porque nós queremos dizer que o que tem aqui não é ainda um governo popular, nem democrático. ... É preciso que eles reformulem os seus conceitos de ser esquerda e democráticos. Com conselho gestor é preciso ser democrático, ... participativo e ter ... coragem de se expor ... e descentralizar. Essa é a questão (F756-7).

Os representantes do governo iam pra dentro da reunião do CMS dizer que o conselho não era deliberativo. Iam lá fazer essa provocação, nesse governo, e diziam que não dava pra implementar os conselhos gestores porque era uma coisa de cima pra baixo. ... Mas só existe uma Lei, pode-se implementar da forma que quiser, ... ninguém vai questionar como é que está escrito lá. Esse governo tem que fazer, mas quer fazer melhor, alterando a Lei. ... Tem pessoas aqui dizendo assim: tem que implementar os conselhos de gestão, mas na realidade elas não querem porque têm medo. Existe a proposta, ... foi num momento político que oportunizou isso, ... e já passou na conferência. Se outro tivesse sido eleito nós na mesma hora íamos sair correndo, ... para fazer o conselho gestor, íamos na Promotoria Pública e fazer o que fosse pra implementar. ... E por que não faz agora? Pra massacrar esses caras (F758). Desvelam-se conflitos e mágoas da representação ouvida do conselho em relação à atual 
gestão da secretaria. Se a gente ... fica patinando e tudo está bem, existe incoerência. Por quê ainda não implementamos os conselhos gestores? ... Eles também enfraqueceram aquilo que nós queríamos - o Programa de Saúde da Família, que era pra ter ampliado e foi morrendo, morrendo, parecia que ia sumir (F759). Percebe-se que os ressentimentos e um conflito com a gestão atual da secretaria se sobrepõem a tentativas de explicações.

Na composição do conselho gestor é fundamental a participação dos trabalhadores de saúde. Nas experiências relatadas na literatura tanto existem conselhos gestores de unidades de saúde com $50 \%$ de usuários e $50 \%$ dos serviços de saúde, como com um terço de usuários, um terço de trabalhadores de saúde e um terço de governo.

Na regionalização, a idéia é mudar o modelo e com uma base popular forte se metendo dentro do serviço local. ... Ao que tudo indica, ... não mudando as cabeças aqui dentro, não vai existir conselho local de jeito nenhum. (...) Antes não tinha como. Só ... esse ano que a secretaria começou a fazer mesmo um trabalho de sensibilização para o sistema único, ... porque as pessoas que estão aqui não conhecem isso aí. Então por exemplo, o que adianta querermos sufocar aqueles ... trabalhadores das unidades, o que nós vamos exigir deles se eles não sabem o que vão fazer e daí o nosso trabalho foi trabalhar aqui com os recursos humanos e discutir ideologia e o que é essa quebra de modelo (F760-1). A partir daí vai fazer mais sentido a proposta de conselhos gestores.

A idéia é que cada unidade do PSF tenha um conselho gestor. ... Cada PSF um, também nas unidades da rede e mais o conselho da região. ... Por exemplo, eu sei da importância que tem o nosso conselho intersindical. As pessoas sempre perguntavam Sim e por que vocês não montaram uma comissão local? E essa é uma coisa que a própria lei cita - comissão local, conselho não. Vamos ter que sempre estar discutindo ... essa oportunidade pra interferir (F762). A principal diferença é que a idéia do conselho local seria como um desmembramento do conselho municipal na perspectiva do controle social em sua expressão local e não gestão participativa de unidades de saúde, como é o caso dos conselhos gestores. 
Nos primeiros passos da comunidade na direção de conselhos gestores ou comissões locais, essas duas idéias não se diferenciam claramente, no sentido do primeiro ser um instrumento de participação popular e dos profissionais de saúde na gestão local dos serviços de saúde e o segundo, de acordo com a Lei 8142 (1990), ser uma representação da comunidade para organização local do controle social mais direto sobre o SUS, reforçando as representações populares no conselho municipal de saúde.

No início do ano (2000) começou esse movimento na comunidade tal. Até porque lá tem um profissional muito invocado com essas coisas de conselhos. ... Ele encontrou um ... mestre de obras que veio de Joinville e tem um envolvimento no movimento popular e eles conseguiram mobilizar aquela região, fazendo reuniões com a secretaria e nos questionando porque não foi implementada a proposta dos conselhos gestores. Então ali começou o primeiro, está iniciando. (...) Eles exigem que tenha participação de gente da unidade. Eles estão se reunindo e estudando todas as leis do SUS, do próprio conselho municipal e ... querem avançar mais dentro deste processo. ... Aí eu disse pro médico que também é uma espécie de líder lá, vai um pouquinho devagar que tem uma conferência por acontecer (2000) e dentro da conferência se discute melhor essa proposta (F763-4).

Em outra comunidade também, eles reuniram umas associações de moradores, o pessoal da igreja, e ... estão sentando 8 ou 10 pessoas, estudando e discutindo isto. ... Quando nos chamaram para uma reunião, ... falando de cidadania eu disse: a melhor coisa que vocês podem fazer é reunir a comunidade e formar um conselho local. ... Aí já tinha a enfermeira da unidade ... e dali já partiu pra outra reunião. Agora estão programando reunir lá mais ou menos 500 pessoas e estão chamando o secretário pra resolver problemas da unidade. (...) Tem também outro bairro em que ... o pessoal já está se movimentando pra criar seu próprio conselho. O legal é que eles estejam sempre abertos pra qualquer pessoa poder exercer o controle social, aí o conselho local ... passa a ser a representação de toda uma comunidade (F765-6).

Apesar de já ter uma lei municipal, ... o bom desses conselhos é que está vindo espontâneo da comunidade. ... Não foi algo assim que alguém foi lá fazer a cabeça não, 
as pessoas estão começando a entender que se eles querem conseguir mudar sua situação de saúde e o modelo de atenção, eles têm que discutir mesmo a sua realidade e organização com ... muito mais autonomia e mais liberdade pra se constituir enquanto cidadãos e não em cima de leis. É evidente que neste processo nós vamos ter de definir até quais são as pessoas dessas regiões que vão participar do conselho municipal e isto é muito importante, talvez até vai ter que estar na lei, pra garantir isso, mas a organização popular não depende de ficar preso ... em lei, a pessoa assume isso como uma coisa boa e faz (F767).

É esperado ... que nos conselhos gestores eles façam a gerência de cada unidade, sendo deliberativo pra valer, e que eles discutam todas as questões administrativas do dia a dia, porque na verdade nem precisa ter chefe, eu acho que a chefia pode ser o próprio conselho gestor, vai ter um chefe mas subordinado ao conselho gestor, entende? (...) Um dos primeiros resultados na gestão vindo desses embriões de conselho, ... embrião porque está se formando, ... foi conseguir acabar com a vinda das pessoas às 4 da manhã pra sua unidade de saúde. ... Um desses médicos foi na reunião lá e disse: "Se vocês tiverem de vir pra cá de madrugada pra marcar consulta, eu vou embora, ... isso é desumano". Aí eles começaram a discutir isso e definiram que os médicos só iam atender durante a tarde e de manhã faz visita e atende só se eventualmente tiver uma necessidade. E ... pronto, resolveu o problema. É só terem a confiança que vão ser atendidos, a garantia de atendimento estabiliza. (...) E aí esse profissional, na verdade ele não tinha nem perfil, mas ele tinha paixão e dizia assim: "Eu sou socialista, acho que tem que fazer uma coisa diferente, nem que eu tenha de estudar tudo de novo”. E agora ele está mais feliz que todos (F768-70).

A gente deu uns passos bonitos, mas tem outros ... que são frágeis, para ... vir alguém aqui e puxar o tapete é dois toques. ... Só a participação popular segura (mantém) os avanços. Na época do secretário anterior, todos os convênios e contratos passavam pelo conselho, todo mundo tinha uma folhinha dizendo como seria o contrato e quanto íamos pagar nisso ou aquilo. Nesse governo não tem mais isso. (...) Então aqui estamos falhando. ... Nós queremos que amanhã quando apareça um secretário aqui, ele vai ter que se enquadrar de acordo com o que está andando, porque ninguém vai aceitar mais "canetada", os caras ficam meio assustados e com razão. ... Eu acho que é 
insegurança, ... eles não gostam de se expor. Me parece ... ignorância o medo de um Estado participativo comandado pelo povo, que em diferentes âmbitos pode se conciliar articuladamente com o Estado representativo que temos. Às vezes também é medo de perder a cadeira (F771-2).

Com os conselhos gestores funcionando modifica-se o conselho municipal: Não pode ser mais algo onde as pessoas tenham dificuldade de participar. ... Muda a cara completamente (F773). Porque ao amadurecer a participação na base social a sua representação amadurece. Inclusive aí se poderá ter um fórum dos conselhos gestores antes do conselho municipal.

Como ainda não tem os conselhos locais, e como ... no início essa idéia assustava algumas equipes, porque as equipes e unidades não trabalhavam assim, outras começaram a gostar. Começaram a ver que era legal ... poder dividir a responsabilidade, ... e decidir junto com a comunidade. ... E, vamos dizer assim, até pra se legitimar, ... isso ajuda. Vou ser bem franca assim, pra legitimar a função de gerência, precisa trabalhar bastante com a comunidade (F774).

A entrada da secretaria naquele processo popular: Agora a gente está desenvolvendo a questão da formação dos conselhos locais de saúde, estamos com essa discussão no ar. Só tem um que já ... funciona extra-oficialmente, digamos, ... porque as pessoas da comunidade já se reúnem mensalmente. ... Inclusive eu estou a frente desse processo, já tenho uma proposta pronta de regimento, nós entramos em contato com outros lugares que tem um trabalho assim, conseguimos algum material e disponibilizamos isso (F775). Na relação profissional de saúde e comunidade os agentes do trabalho precisam ser preparados para participar de forma mais democrática e menos burocrática, ao menos em processos desta natureza, sem estar reproduzindo velhas práticas de uma pretensa condução do encaminhamento de ações de participação democrático-popular na gestão em saúde. Ainda esse ano a gente vai ter implantado os conselhos locais. (...) A gente adiou em um determinado momento por causa das oficinas, por causa do GERUS. Pra que isso viesse depois das oficinas. ... Por que? Por essa coisa de não parar, não ter tido dado ainda a oportunidade de fazer. ... Então, eu acho assim, a gente não pode "tratar" a comunidade nessas horas. A gente tem que ser parceiro. E 
por isso que eu falo e estou insistindo nesse negócio de romper com o autoritarismo que algumas posturas mantém (F776-7).

A gente observa que se o contato com a comunidade ainda é pouco, é por falta de profissionais mesmo. Na época eu entrei no núcleo de associação de moradores do bairro, para 'ter uma integração maior entre a comunidade e o ambulatório' e também pra implantação dos conselhos locais, já que por duas vezes a criação de conselhos locais foi colocada na conferência e até agora não saiu do papel. Nós tivemos algumas reuniões com o pessoal da secretaria, mas não houve avanço, ... e aquele núcleo da associação de moradores se desfez por questões políticas. (...) Lá eram representadas várias associações, 28 na nossa região que tem quatro bairros. O núcleo existe mas está desativado no momento porque várias pessoas estão ligadas a questões políticas partidárias. ... Esse ano eu me preocupei em estar retomando isso porque, senão, vão querer entrar pessoas só por querer aparecer politicamente e ... não sei se vão estar preocupados com saúde. Isto é meio delicado na atual conjuntura, e por enquanto está assim (F778-9). É também nesses núcleos que se tem colocado a perspectiva de um conselho regional de saúde.

\subsubsection{A via Pedagógica}

Por essa via se processa o saber pedagógico operante nos serviços locais de saúde. Trata-se dos fundamentos pedagógicos expressados nas práticas organizacionais em serviços de saúde. Primeiramente são discutidos os processos de capacitação havidos e suas articulações, em cujo contexto foram realizadas as capacitações do PSF, oficinas de sensibilização para o SUS, de territorialização e a capacitação em desenvolvimento gerencial. Como uma segunda subdimensão dessa via, é discutida a metodologia da problematização enquanto fundamento dos processos de capacitação e educação continuada e das capacitações pedagógicas para o exercício da prática profissional dos agentes de saúde, com o que se pode relacionar o referencial das organizações em aprendizagem (Senge 2000). 


\section{Processos de sensibilização e capacitação para o SUS}

Com as oficinas de sensibilização para o SUS, aumentou muito o conhecimento a respeito do SUS e os princípios da universalidade, equidade, integralidade $e$ participação vão sendo assimilados. (...) Naquele final de 1996 ... nós fizemos as primeiras oficinas ... de sensibilização com todos os funcionários - PSF e rede tudo junto. ... A gente ficou, uma semana e meia direto só nisso. Cada grupo ... de profissionais, ficava 2 dias na oficina, onde era trabalhado ... o SUS. É que antes se havia trabalhado muito só com as equipes do PSF, ... e na rede existia a mesma necessidade. Até pra começar a entender o ... PSF, que não era um bicho papão diferente, era nada mais nada menos que tentar fazer o SUS funcionar. (...) Aquela série de sensibilizações ... fez milagres, mexeu com todos. (...) A oficina de sensibilização sobre o SUS é uma base ... sobre o modelo na nossa prática. (...) $O$ pessoal discute e agora sabe o que é ... o sistema único (F780-4).

Conteúdos trabalhados no treinamento introdutório de médicos e enfermeiros do PSF: Fizemos um treinamento de 30 dias, um pouco mais, porque tinha também a questão pedagógica, que é introdutória, como trabalhar com grupos, a questão dos vários tipos de saberes e que não somos donos do saber científico que temos, valorizando o saber popular, como se processa a aprendizagem, e isso tudo partindo do processo saúde e doença, pra chegar na vigilância à saúde. (...) E ainda ... um pouco de informação, pra tomada de decisão, pra agir em cima da epidemiologia, ... que tipo de informação, o que seria, como se buscava, como é que ia processar, trabalhar, e como é que se ia tomar decisões em cima disso. O enfoque de risco é mais ou menos por aí. (...) Depois eles foram fazer visita, uma vivência em uma das comunidades. (...) Fizemos o treinamento dos médicos e enfermeiros juntos, e nas visitas eles fizeram o mapeamento da comunidade, como exercício do que seria cadastro, a visita e tudo o mais. (...) $\mathrm{Na}$ dinâmica do treinamento introdutório ainda fizeram um rodízio passando nas duas equipes que já estavam funcionando. Foram lá e ficaram 2 dias cada um, vendo como é que eles trabalhavam, as visitas, vendo como o médico atendia todo mundo. ... Alguns médicos descobriram que tinha enfermeiro que fazia atendimento e pré-natal. E interessante que ... quem assim fazia essa observação, ... eram os médicos vindos da 
residência em saúde geral e comunitária, porque ... já estavam acostumados a trabalhar com o enfermeiro, os outros não (F785-9).

Utilizando da monitoria de ... uma enfermeira que já tinha uma prática no PSF, ... pois pelo menos ela sabia do que se estava falando, porque já estava fazendo na prática (...), outra coisa que também foi legal, ... naquele primeiro treinamento do enfermeiro e do médico, é que ... eles começaram a trabalhar e ao mesmo tempo iam fazendo o cadastro, enquanto as enfermeiras começaram a treinar os agentes de saúde (F790-1). Foi uma dinâmica que envolveu toda a equipe em um processo coletivo de aprendizagem dentro do PSF.

Depois dos treinamentos introdutórios do PSF (1996) a gente fez uma nova oficina, que era uma forma de territorialização, como já se sabia o que fazer com o diabético, com o hipertenso, com o tuberculoso, ... o que eles têm de problemas aqui, como lidar com as diarréias por exemplo, pra ser tratada, daí a gente teve como planejar o que era de risco aqui. ... Essas oficinas era pra organizar ... a demanda, começando a tentar fazer alguma coisa de planejamento em cima de risco, ... e fazer um diagnóstico mais lá do seu local, até começamos, só que dividimos e não demos conta de continuar. (...) Era uma versão mais simplificada das oficinas de territorialização, era ali mesmo em cada regional, pra discutir o risco, e se chegava a eleger problemas para trabalhar. Acho que ficou uma região destas sem fazer, não deu pra terminar. Em 2000 a história se repete. Mas a gente tentava correr contra o tempo, pra pelo menos não ficar ... a coisa tão solta. ... Algumas equipes chegaram a revisar todo o cadastro na primeira oficina, fazer o diagnóstico da sua comunidade e selecionar um problema pra trabalhar e descrever as ações que trabalhariam em cima daquele problema (F792-3). Os momentos de um processo de distritalização (Mendes 1993) estavam contemplados, embora muito rapidamente.

Havia uma reunião semanal de todas as equipes juntas, ... porque tinha de continuar aquele processo, era uma proposta de educação continuada. Tudo isso não tem nada escrito, a gente pensava cada encontro ... e ia fazendo. Na primeira reunião com todos se construiu a proposta. ... As equipes escolheram quais ... temas técnicos específicos queriam trabalhar, eram 11 (como hipertensão, IRA, diarréias, tuberculose e DST 
entre outros). ... A idéia era fazer alguns protocolos. ... Era assim: tinha um problema, por exemplo ... o papel do agente, se discutia a situação e as ações e pra cada ação o papel de cada profissional da equipe - agente, enfermeiro, médico e auxiliar. Então tinha lá, digamos o pré-natal - vacina anti-tetânica ... ia o agente buscar a gestante e o enfermeiro fazer orientação, o auxiliar a aplicação e o médico a consulta; e por aí. (...) Em cada encontro, uma equipe era responsável por preparar o tema, apresentava-o e os técnicos do nível central ajudavam. ... Eles se atualizavam para pensar no papel de cada profissional naquela atividade ou ação. Às vezes se chamava um especialista pra trabalhar com a equipe nessa perspectiva, ... isso atualizava, mas com um enfoque assim, o quê que uma equipe lá na unidade do PSF ... pode ou deve fazer, para onde ... encaminhar as situações. ... E foi muito legal aquele processo, porque a gente valorizava alguns profissionais que ... eram da rede $e$ outros de fora, então teve um reconhecimento deste profissional como "expert" na área, e que passou a conhecer o tanto que aquela equipe poderia atuar, porque não é fácil. Assim, vinha o cardiologista dizer - vocês podem e devem tratar hipertensão lá, ... só vão encaminhar pro cardiologista depois de ... socializado o uso da medicação e o tratamento adequado. ... Isso tudo foi bem legal e teve resultados visíveis, por exemplo, começou a cair a mortalidade por AVC e a internação por infecções respiratórias, assim como o índice de amamentação exclusiva subiu. (...) Na medida que a gente trabalhava o tema, a gente organizava a atividade lá, isso de uma forma geral funcionou e deu uma melhorada na atenção básica. ... São aquelas coisas que deveriam funcionar na rede do SUS e não funcionavam e aí dá pra ver bem porque no PSF funciona. Não é porque é o PSF, é porque paga melhor, o profissional está sempre presente e são treinados, assim como ... ia funcionar se fizesse isso no SUS ou rede, sem dar nomes diferentes. (...) Com a leitura do tempo e também com a falta de recursos humanos do nível central preparados ... para continuar a fazer isso, daí a coisa foi parando (F794-7).

Nesse meio tempo a gente teve mais duas capacitações - de amamentação e de infecção respiratória, era um treinamento da OMS, que trouxe uma maior qualidade na atenção. (...) Mais recentemente, no PSF a gente acabou de fazer um treinamento com o pessoal lá da UFSC, sobre como fazer grupo terapêutico (F798-9). 
Os auxiliares de enfermagem não tiveram treinamento, ficaram aí no meio, ... a gente não tinha como. Até que foi feita muita coisa, pro tempo que se tinha. (...) O auxiliar de enfermagem está se sentindo cada vez ... mais distante porque o médico e o enfermeiro sempre batalham mais e participam dos cursos, e o auxiliar que já tem uma formação mais limitada, tem ficado mais isolado (F800-1). E isso não é só no PSF, mas ainda é mais grave nas demais unidades da rede.

Na preparação do pessoal da rede como ação estratégica, sabia-se que essa era uma questão chave pra uma mudança de modelo. É importante, mas não é tudo. ... Nós tínhamos muito pessoal não capacitado. ... Mas se nós criarmos uma cultura de modelo de saúde, essa idéia da cabeça ninguém vai arrancar (F802).

Não é só nível superior, tem que capacitar ... THDs (técnicos de higiene dental), ACDs (auxiliares de consultório dentário), os agentes (...), fazer formação de auxiliar de enfermagem, formação de técnicos, essas coisas. Porque na equipe, se você for contar só com o médico, você está lascado. ... Não é só o modelo, a gente trabalha sempre com o novo modelo pensando nas necessidades da população. E o cara ali do balcão não tem informação nenhuma. Tem que formar é gente de nível médio, isso que vai fazer virar. A gente discutiu bastante sobre isso. (...) Se investiu na formação dos recursos humanos da vigilância sanitária. Porque eles têm uma formação de caráter policial, ainda como polícia sanitária, ... que tem lá o seu papel, ... sempre tem que ter uma inspeção. É como uma certa equação branca, você tem que estar sempre ali, e as pessoas têm que saber que você existe, para elas andarem na linha. A postura é diferente da vigilância epidemiológica. Apesar de que, tem aquela história lá que o CDC (Center for Desease Control) surgiu por causa da guerra fria. É uma coisa paranóica assim, que vai acontecer alguma coisa em qualquer momento. ... Mas então enfim, para formar esse pessoal, ... a gente investiu no curso de técnico em vigilância sanitária. Agora, para o próximo ano vai ter o técnico em registro de saúde, que vai formar o pessoal do ponto de vista administrativo, e isso no Brasil (F803-5). Era uma área que quase nunca se fazia capacitação, pelo menos no setor saúde. 
A educação continuada ... qualifica; se você quer produzir tem que estudar mais. Então, tem muitos profissionais de nível médio, fazendo cursos e ... o nível superior estimulado a estudar dentro da própria rede. Porque não tem como fazer enxoval de olho fechado. Não tem como fazer ... mudança de modelo, se o pessoal também não mudar a cabeça. ... Você tem que ter gente preparada para fazer isso. Você não muda um modelo de saúde, com um nível médio estacionário. ... Porque na verdade a maior parte da produção ... dos serviços de saúde está no nível médio. A produção do nível superior deve ser metade de um terço do que o nível médio produz por dia (F806).

Eu tenho essa visão ... do trabalho preventivo, pela minha profissão, mas também ... eu sinto muita necessidade de uma pós-graduação em saúde pública. (...) Para ampliar o leque de serviços básicos é preciso ... ter equipe preparada para discussões. O médico, com raras exceções, é muito despreparado para a discussão, a nossa enfermeira, mais despreparada ainda, a maioria sem nenhuma especialização. (...) Então, recurso humano é fundamental. Essencialmente porque agora ele vai ter que trabalhar lado a lado com a comunidade, vai ter que sentar pra discutir mesmo (F807-9).

Estratégias de formação de conselheiros: Uma vez por mês, a gente está fazendo um grupo de estudo pra discutir a história da saúde ... com o pessoal do conselho. Então estamos aprendendo como é que se dá essa questão de incorporar a saúde no Estado, a saúde tem de ser responsabilidade do Estado, como é que isso começa, ... como se processa e como ... estão hoje as posições da Organização Mundial da Saúde. ... Fizemos no mês de junho (1999) mais uma atividade de "preparação para conselheiros", foi um encontro muito bom, tinha 110 pessoas, entre conselheiros, suplentes e outras pessoas (F810).

\section{Formação em desenvolvimento gerencial}

Um relato referido ao preparo para a função de chefia: Pedi para o chefe anterior para eu grudar um pouco nele para aprender. Nisso fui apresentada para as gerentes que eu ia coordenar, e fiz uma reunião com o grupo, ... pedindo que elas me ensinassem - todo 
o processo de regionalização que havia acontecido, do qual eu não participei, como que elas construíam o trabalho delas, como ... foi a dinâmica e o método de trabalho. ... Não tem receita de bolo, mas era uma visão necessária para eu me introduzir na equipe, que afinal de contas ... já estava formada. Aí me ensinaram o que quer dizer região e iam falando dia após dia, o que elas encontravam em cada região. Eu também fui estudar e peguei um material para ler (F811).

Nessa gestão foram as oficinas de territorialização que deram um suporte inicial no preparo das gerências regionais. A formação das gerentes começou com o que elas aprenderam nas oficinas, somando ao que elas tinham de visão própria também, pela prática delas. (...) As gerentes regionais assumiram mesmo estando, num primeiro momento, ainda um pouco sem conhecimento, sem estar preparadas, porque não havia sido feita a capacitação. (...) O GERUS é muito importante em termos de melhorar a qualidade gerencial. ... Pra mim o GERUS ... não está perdido (F812-4).

Com o GERUS entrava uma proposta estratégica em recursos humanos. A demora do curso não tem problema, seus resultados poderiam ser utilizados em outra administração. Como o gerente regional, outras pessoas também poderiam fazer. Aí duplicava e não ficaria só em 6 pessoas, sendo que todas essas pessoas poderiam somar. ... Mas as ações foram um pouco limitadas neste sentido de críticas dizendo que era ... bobagem, uma perda de tempo, porque quando acabar ... a gente vai ter saído. $\mathrm{E}$ nunca ia avante essa proposta. Eu acho que a equipe vai sentir na carne, ... efetivamente, as conseqüências por esta proposta ainda não ter sido levada à frente (F815).

No final do ano passado (1999) finalmente se ... conseguiu que esses gerentes fizessem o Curso de Monitores do Projeto GERUS (do Ministério da Saúde). Foi então já o início de uma capacitação diferenciada pra eles. (...) O GERUS é desenvolvimento gerencial de unidades básicas de saúde, no distrito sanitário do SUS, para as regiões. (...) Está sendo importante porque com esse projeto a gente está retomando tudo isso, a proposta do novo modelo de atenção (F816-8). 
Depois da formação dos monitores a questão é viabilizar a realização do curso mesmo, que é a continuação disso, nós ainda estamos em briga para conseguir verba ... pra poder fazer. Precisa ... um convênio com alguma universidade, já tem esse projeto pronto, pra poder ter ... um apoio pra conseguir executar ... o GERUS com as gerências locais mesmo, as coordenações de unidades de saúde e ambulatórios. ... Mas então com a presença dos gerentes formados como monitores do GERUS, a gente esperava já num primeiro momento, poder ... tocar a proposta do modelo. (...) A oficina em si é um processo e dá uma capacitação teórico-prática, mas tem muito mais coisa a ser feita aí na sua reprodução e implementação. (...) A secretaria agora está nos proporcionando o GERUS, pra nós foi uma conquista. Um enfermeiro estar fazendo uma especialização no seu local de trabalho, e assim com tudo aquilo que a gente trabalha, exatamente com aquilo que a gente trabalha, isso é uma coisa muito boa (F819-21).

\section{Gestão humana estratégica}

Existe uma construção que está vindo num processo, não está caindo do céu: ... na administração anterior tivemos a fundamentação teórica, e agora teve a $\ldots$ territorialização, preparando o trabalho com a comunidade em cada território-processo, e como ser mais resolutivo nos problemas. ... Tanto que uma das propostas que eu fiz, ainda no tempo do primeiro secretário nessa administração, ... eu reuni as gerentes, para se encontrar uma forma de não ficar dependendo de papelzinho pra mandar pro secretário, ... que na verdade ... aqui tu ficas meses esperando, ... dá pra tomar uma porção de iniciativas para fazer ... render, se começar a administrar cada espaço. ... Assim as pessoas começam a se responsabilizar mais. E a idéia da descentralização é essa. Por outro lado, eu acho que se o nível central é o condutor de políticas, ele tem que estar puxando isso. Primeiro fez o PES, e agora desenvolve uma proposta de administração estratégica voltada à gestão humana (F822).

Em todas as discussões a gente sempre estava defendendo ... recursos humanos. Essa área cresceu graças ao trabalho que se desenvolveu em conjunto. Com essa opção, vamos fazer uma coisa importante para a próxima geração, ... a formação de pessoas. A gente defendia o recurso humano pra ele poder crescer ... e hoje está bem, 
desenvolveu bastante, e está combinado com as políticas, tem um direcionamento mais claro, a gente trabalhou pra isso. E quando a gente conseguiu que as pessoas crescessem, ... mudaram a equipe de condução da secretaria. ... Sim, tem que voltar um pouco nesta questão, é que havia muita dificuldade em recursos humanos, então a gente começou a tentar juntar forças ... desde o início deste processo, no plano (F823).

Na prática, o que a gente conseguiu reservar de recursos pra capacitação, pra apostar em recursos humanos, foi muito pouco. Criou-se na estrutura uma superintendência de $R H$, com sub-áreas de qualificação, desenvolvimento, educação e informação em saúde, mas, na prática foi bem pouco o recurso que a gente conseguiu guardar pra isso. ... Também houve falta de habilidade nossa em tentar fechar alguns projetos para áreas estratégicas. ... Tem um espaço grande entre o querer fazer, fazer o projeto e chegar na execução. (...) Qualquer planta tem que tratar e hidratar, eu não estou mais conseguindo liderar isso. É um processo difícil fazer essa ponte, que é necessária ... para transformar essas visões particulares e fragmentadas. Eu não estou nem falando da política de saúde em geral. Mas só de ... uma política específica qualquer dentro do nosso SUS municipal (F824-5). Cada vez mais se reafirma a necessidade de compartilhar as visões.

Com o trabalho na área de qualificação hoje tem que jogar com várias modalidades de capacitação, esse é o grande objetivo, especialmente ... que a gente consiga incluir programas de educação continuada, ... a partir das necessidades que vão sendo identificadas pela equipe do desenvolvimento. Essa é a diferença, porque até hoje a capacitação, ainda tem sido muito na forma de demanda espontânea. (...) A gente faz oficinas pra construir com a educação continuada, como a gente fez com o PSF, ... a gente quer é que isso saia das equipes mesmo, e seja feito em toda a rede, ano a ano. ... A nossa meta é assim: ter sempre ... um programa estruturado, com cronograma, que todos tenham claro, mês a mês, que capacitações vai ter, em quais projetos ... podem se inscrever, ... qual capacitação que eles precisam, ... seja atualização por doença, política de saúde, ou sobre o SUS. (...) A gente está regionalizando o trabalho da equipe do desenvolvimento para estar em contato direto com as equipes de saúde e trazer as necessidades pra equipe de qualificação, tipo um sensor das carências existentes, na visão do gerente, da equipe, e até da comunidade. ... A idéia, ao nível 
interno na superintendência de $R H$ hoje, é construir o máximo possível a partir da demanda das equipes. (F826-8). Efetivamente já é tempo que a expressão "equipes" passe a ser usada para todos os grupos de trabalho e não uma idéia vinculada somente às equipes do PSF.

E há ainda as capacitações do ... ministério, quando baixa lá, capacitação em AIDS, vem tudo programado. Ou então vem o Estado com as capacitações em cólera, dengue, que tem que cumprir, tem que mandar gente (F829). Precisa criatividade para avançar a partir da própria história, das condições limites e oportunidades ali contidas.

Já na época da gestão anterior não se dava mais conta de tanto problema de funcionário, ... teve que trazer uma psicóloga pra ajudar a resolver. Isso se ampliou, ... agora elas trabalham mais com os gerentes, mas também escutam os funcionários, às vezes quando a coisa está muito grave elas inclusive participam de reunião de equipe. (...) Pela via do apoio ao gerente regional, ao gerente local e aos profissionais, tem o psicólogo de RH que atende, às vezes, ... o funcionário e daí depois tem de chamar a chefia, enfim, acaba fazendo assim um trabalho que é muito de escuta. Precisa, está todo o mundo angustiado (F830-1).

De alguma forma aquele governo valorizou muitos profissionais em que visualizou algum potencial, algum comprometimento. Assim, eles tiveram um olhar, que eu não entendo. ... eu nem achava que o nosso trabalho estava sendo ... tão visto e valorizado. Para ser chamada de repente para participar de um planejamento estratégico, ou para uma gerência (F832).

A gestão humana informada pela estratégia organizacional de mudança do modelo de atenção implica ter a parte técnica de como desenvolver isso e ter alguém da administração central mais preparado reforçando isso aí. Aí eu acho que vai funcionar. 'Tem tudo pra funcionar a integralidade'. Eu acho que já avançou muito, pelo menos ela já é consciente no discurso, isso já é uma coisa boa (F833). 


\section{Fundamento pedagógico da problematização}

As capacitações têm mudando muito o seu caráter, desde palestras e textos, até a metodologia da problematização. (...) Há uma recomendação que define esses parâmetros de formação de recursos humanos, este trabalho foi iniciado na nossa Escola Técnica de Saúde. Na perspectiva da mudança de prática profissional a questão principal é metodológica. Depois que se conhece a metodologia baseada em prática/reflexão/ação os processos educativos passam a fazer mais sentido. Assim podese dizer que ... a qualificação atua na perspectiva da demanda organizada, ao problematizar as demandas espontâneas (F834-5).

Já desde quando a gente fez a primeira oficina do PSF, que era o treinamento introdutório, ... aí se problematizava: $O$ que estamos fazendo aqui? E o que vamos fazer? ... Assim se discutiu o processo de saúde e doença, ... mas não chegamos a instrumentalizar para o planejamento local. Trabalhamos sobre o que era usar a epidemiologia e chegar na vigilância à saúde como orientação do trabalho, ... mas não foi instrumental. Foi instrumental só pra eles começar a fazer o cadastro, pra chegar lá e começar a atender, mulher, criança e homem adulto, e ... para trabalhar com a comunidade, via associação de moradores. ... Entre esses profissionais, o discurso era e ainda é, muito na linha preventivista, ... até um pouco reducionista. Na prevenção mesmo, ... agora é que talvez se está direcionando mesmo para a vigilância à saúde, e a questão coletiva sendo ... um pouco mais bem trabalhada (F836).

Em 96 a gente estava fazendo uma ... oficina de sensibilização para o SUS, foi muito interessante. A educadora, especialista na metodologia da problematização, trabalhava de uma forma completamente atípica, ... com teatro (dramatização). Foi uma coisa que mexeu bastante comigo. Ela captava o fundo das pessoas, ... tinha muita habilidade para um grupo grande. Então ela trabalhou muito com auto-reflexão e isso me impressionou. Fiquei muito convicto, achando que já era suficiente, ... percebi que tinha algumas carências. Se eu trabalhava numa cidade diferente, eu tinha que melhorar algumas situações. Então a gente começou (F837). 
Mas entre fazer o treinamento e colocar na prática, existe uma dileta diferença (F838). Daí a importância da fundamentação pedagógica dos processos de capacitação visando mudar a prática de profissionais de saúde, espaço em que a experiência do setor tem confirmado a potencialidade da metodologia da problematização.

O preparo para trabalhar com grupos: No ambulatório como não houve capacitação ... pra atividade de grupos, por isso a gente vem fazendo uma reflexão em serviço com os profissionais, informados pelo referencial da problematização. ... Sempre foi discutido, todo mundo falava a mesma coisa, ... isso é uma coisa que a gente vai aprendendo. (...) No começo o médico só vinha fazer a consulta, e às vezes sua palestrinha. ... E depois trabalhando com o médico conseguiu-se aquela coisa dele não falar e deixar que o usuário fale e fazer haver uma troca. ... A gente está conseguindo avançar na reflexão sobre a importância ... da problematização, de deixar o usuário se colocar para discutir a partir do seu entendimento. O profissional tem que ser realmente um suporte e não ... dominar a situação. ... Só com o tempo se aprende (F839-40).

\section{Autonomia do profissional de saúde e equipes autodirigidas}

Havia que buscar alternativas para trabalhar com uma realidade assim: Quanto mais especialistas, mais resistentes os profissionais são, devido ao modelo do corporativismo nosso, associado a uma questão de responsabilidade. Enquanto o médico é responsável só por um número de atendimentos, que ele chega lá, atende e vai embora, é muito diferente de ele ser responsável por uma comunidade, por uma família, pela saúde da população de sua área de abrangência (...) Isso é muito forte Ruth, é muito forte assim, essa coisa de corporação. Eu não gosto muito dessa palavra, mas, não tem outra, talvez segmentação profissional. Isso é forte até, dentro da própria secretaria, que tentou mexer nisso e sofreu as conseqüências e eu estou sofrendo hoje. ... E aí o cara vai ficando corporativo. Não era isso que eu queria. A gente acaba se influenciando pelo meio, impressionante! (F841-2). Naquele contexto havia que construir uma nova lógica como forma de sobrepor as dificuldades, aprender a trabalhar com mudança de forma incremental e aprender a aprender em equipe. 
Tendo uma equipe completa, e com uma equipe que tenha a mesma visão, fica muito mais fácil de trabalhar e organizar. ... No trabalho em conjunto com o médico, ... é importante poder chegar e ter pra quem perguntar: Olha, eu estou em dúvida nisso aqui, como é que eu vou fazer? (...) Na saúde nota-se como a gente depende de cada profissional. ... E é muito diferente a prática de um e de outro. Como é que se vai botar uma linha nessa prática? (...) Essa questão da autonomia tem que ser mais trabalhada na formação do profissional em saúde, por causa da decisão autônoma que ele tem na frente de cada problema. ... É a tua postura que marca a diferença numa ação. Porque enquanto profissional, ali no atendimento tu estás sozinho e depende muito de ti se o caráter da ação vai ser esse ou aquele (F843-5).

A enfermeira também fica muito sozinha, porque muda muito médico no PSF, essas coisas atrapalham um pouco. ... A questão da supervisão do agente de saúde também deixou bem claro essa questão da autonomia, porque ali era eu que coordenava e orientava as ações. E na relação com o paciente, o que te dá segurança é justamente essa inter-relação - 'a interação com o usuário do serviço'. (...) Tu tens que saber por onde caminhar, pra chegar onde tu queres. Não é chegar lá dizendo: Oh, agora só vai ter grupo, não é isso. Tu vais atender a parte curativa, e dentro dessa parte tu vais observar os problemas, e em cima desses problemas pensando também nas suas causas, tu vais planejar ações para reduzir o que dá, o que depende da gente. Muita coisa não depende (F846-7). Aí se pode demandar soluções ou encaminhar para outras instâncias.

Também dá segurança ... ter a autonomia de poder buscar e direcionar a própria formação profissional. Tu tens que ter uma visão maior da coisa, e clareza de objetivo; o meu objetivo é promover saúde. Não vou deixar de lado o curativo, não vou deixar de lado nada. A clareza da visão também (F848). É a visão compartilhada que dá a direcionalidade das práticas frente à autonomia do profissional de saúde, como também das equipes autodirigidas. Essa dinâmica, fundamentada em prática/reflexão/ação, pode ser contraponto à autonomia profissional.

As coordenadoras de unidades de PSF em 96 tiveram um preparo para treinamento dos agentes comunitários de saúde. ... Só que conta muito, a tua formação profissional, 
porque a partir ... daquele treinamento, como profissional uns se direcionam pra um tipo de atendimento e de postura, até no próprio treinamento do agente de saúde, teve diferenças - pessoas que não fizeram, ... que deram o livro pro agente ler, ... assim no grupo, a gente ouvia a forma de conversar e comentários. Então eu acho muito importante isso, não sei se é só a formação profissional, eu acredito assim que tem toda ... uma formação de vida (F849).

E assim, a gente vê, eu trabalho também com supervisão de auxiliar de enfermagem, supervisão de estagiário da Escola Técnica, ... todo ano vai um grupo ... trabalhar conosco. Então a gente vê assim, tem aquelas que têm o perfil pra auxiliar, mas não têm experiência de vida. E eles não têm informação. Então tem muita coisa que envolve ... a gente, mas tem que ver é a população (F850).

\section{Organizações que aprendem saúde}

As equipes de trabalho começaram a surgir na cidade com as equipes do PSF. Porque o PSF obriga você a 'trabalhar em equipe de forma integral'. Então antes, na gestão anterior isso só acontecia dentro da equipe que fazia o PSF (F851). Atualmente já existem outras equipes de trabalho, em vários níveis, sobretudo de gerenciamento.

Isso é fundamental. ... Eu considero que se eu tive a oportunidade de aprender, é porque existia um grupo. Senão, eu não ia aprender tanto quanto eu aprendi. Hoje eu não ia conseguir produzir não, porque eu ia ter que me virar sozinha, ou fazer do jeito que eu bem entender. E ia ser um horror, ia ser um fracasso, uma catástrofe (F852). Havia que recuperar naquele momento específico, o aprender em equipe, uma das cinco disciplinas das organizações em aprendizagem (Senge 2000).

Outra daquelas disciplinas que neste caso insiste em reaparecer é a visão compartilhada mais referida à prevenção na perspectiva da mudança do modelo: Os profissionais do ambulatório têm uma visão mais para a prevenção, não é que só trabalha isso, mas é assistência mais prevenção. Aqueles profissionais sempre estavam abertos para trabalhar prevenção. Isso é muito importante, porque se você comparar, vai ter 
diferença. ... Com o tempo a gente avança e quem sabe outros profissionais também tenham essa consciência da importância do trabalho preventivo (F853).

Coloca-se a questão de como construir um saber operatório das práticas dos profissionais: Quando... eu comecei a ouvir falar em descentralização, territorialização, eu não entendia direito o que era. Aí a gente teve um curso ... de capacitação técnica, depois ... a gente fez a oficina do planejamento estratégico, onde a gente falou muito nisso e ia clareando na minha cabeça. ... Assim, o que é mesmo ficava muito ... n' água, eu tinha o meu pedaço, eu via que era fragmentado, sabia ... que era uma parte da saúde assim, mas era ... muito corporativa aquela situação. Daí tu faz o $q u \hat{e} ?$ Faz reunião, ... até um ponto, faz planejamento até um ponto. ... Então, isso foi acontecendo assim devagarinho na minha cabeça. ... Não houve divergência, vai agregando e agrega (F854).

Aquela parte da supervisão ... eu via que não funcionava. Então, cada vez ... estava mais claro que tinha que fazer a descentralização. E, dentro dos conceitos que eu aprendi, ... se aquilo que eu aprendi no curso de saúde pública e introjetou em mim, se eu posso colocar em prática a única forma é via descentralização. ... Foi essa a maneira que eu achei. Bem, existem várias maneiras, de colocar em prática o que você aprende num curso de saúde pública, ... dentro do meu saber, essa foi a minha maneira de colocar em prática ... aquela concepção ampliada de saúde, e aquela visão de inversão de modelo. ... Então se eu for pensar naquilo que eu aprendi lá e juntando com meu tipo de ser, vou dizer assim, eu achei essa maneira, entendi que a forma de fazer seria essa - a forma de construir um saber operante. ... Tem gente que, não, que não consegue (F855).

Importante ter as gerências que cuidam da saúde num todo, pra mudança de modelo. Tudo que a gente queria, eu via que era através disso. Só que não estava claro mesmo. Pra mim, até hoje, ... eu estou ainda aprendendo. Eu acredito na idéia, depois então das oficinas de territorialização ficou mais claro ainda. O GERUS, aí ficou caindo de maduro. (...) Já naquela época do curso de saúde pública a gente falava, eu me lembro, falava em fazer uma gestão para a mudança do modelo. ... A gente discutia que ... a gestão local e o planejamento local era o motor ... do modelo assistencial (F856-7). 
Havia uma consciência assim: Gente, nós não temos que produzir muito. Se nós temos uma estabilidade, o pessoal da ponta vai continuar trabalhando nessa estabilidade. Agora eles querem confiança. Então, assim, nós aumentamos muito a produção (F858). Shon (1971) demonstra o quanto alguma referência de estabilidade é necessária nos espaços de produção de mudanças planejadas.

O processo de mudança é incremental: A gente pode avançar muito mais, mas ao mesmo tempo a gente já fez uma caminhada suficiente pra ter paciência e saber que as coisas não acontecem na velocidade que a gente gostaria. ... Um dia vai mais rápido outro dia retrocede, mas todo dia tem coisa nova. (...) Pela forma que está estruturada a nossa cidade, não tem volta, essa questão do PSF, essa questão do SUS da forma como foi implementado, as unidades de saúde e tal, não tem mais volta (F859-60).

O compromisso de co-responsabilidade da participação da população nesse processo de vida, doença e morte na gestão dos serviços, é uma diretriz operacional da estratégia do (programa de) saúde da família. ... Mas, assim, acho que eu não cheguei lá. ... Porque as gerentes são gerentes daquela região, não só do PSF (F861). Esse compromisso na realidade é de toda a rede. A capacitação em problematização viabiliza uma prática pedagógica no cotidiano da interação entre profissionais de saúde e usuários do serviço. Assim se abre uma direcionalidade conseqüente nos processos de transformação organizacional para mudança do modelo de atenção na perspectiva da integralidade da atenção à saúde.

A via pedagógica então se constitui na possibilidade de um saber operatório das práticas de gestão, colocadas como instrumentos tecnológicos, para a transformação organizacional do modelo de atenção à saúde. 


\section{Capítulo 5}

\section{CONSIDERAÇÕES FINAIS}

A recuperação histórico-conceitual realizada revelou aspectos particulares da integralidade em saúde, que se relacionam com o surgimento das noções mais aproximadas a essa noção na história das práticas de saúde no ocidente, seus modos de existência e diferentes configurações, suas "desaparições" parciais e reaparições em formas novas. Após apropriar-se do objeto, analisando suas formas de desenvolvimento e rastreando suas configurações e nexos internos, pôde-se captar e expor seu movimento apresentado na síntese do quadro teórico que, agregando aportes da moderna teoria organizacional, iluminou a apreensão empírica.

Esta apreensão foi fundada na concepção de que a integralidade em saúde não é apenas um conceito em elaboração, é uma prática ao mesmo tempo eticamente pautada no campo filosófico, politicamente normatizada na sociedade, tecnologicamente operada nas ações de saúde e organizacionalmente construída nos serviços correspondentes. Seus modos de existência no movimento histórico situado na vida real do Sistema Único de Saúde brasileiro, redesenham constantemente sua origem conceitual e suas proposições práticas no diálogo com a re-produção de necessidades sociais de saúde.

Mas, embora a idéia da integralidade possa ser tomada como uma proposição éticonormativa a qual muitos aspiram e embora muitos municípios estejam seriamente envolvidos na realização deste e de outros princípios éticos do SUS, suas objetivações não têm tido impacto socialmente reconhecido, salvo poucas exceções. O presente estudo sugere que as potencialidades colocam-se como forma de superar os limites.

O estudo confirmou que este impacto depende da efetiva objetivação do princípio da integralidade nas três dimensões do modelo de atenção à saúde: sua formulação e 
viabilização política, o sistema de saúde e seu correspondente espaço organizacional dos serviços e, finalmente, no âmbito das próprias práticas de saúde cujos objetos, finalidades, processos de trabalho e instrumentos compõem o seu conteúdo propriamente tecnológico.

Ainda que pautada em uma pergunta inicial sobre como se operacionaliza a integralidade, esta não é uma tese sobre "como fazer" ou sobre "como organizações de êxito chegam lá". Entretanto, a apreensão sistematizada de mecanismos, que têm sustentado a objetivação da integralidade na história recente, pode contribuir para a ampliação destas objetivações. Foi esta a principal motivação que manteve e mantém este estudo. Sabe-se, entretanto, que este objeto é carregado de determinações sociais e históricas e ainda conjunturalmente envolvido em um cenário de profundas e rápidas mudanças setoriais. Por isto, não é possível estabelecer uma fórmula para vencer os desafios. A ancoragem em mecanismos utilizados por sistemas municipais de saúde bem sucedidos pode apenas iluminar o caminho, mas não o fará igual ou menos desafiador. Cada sistema municipal precisa encontrar seu próprio caminho na saúde.

Por outro lado, enquanto proposição ético-normativa, a integralidade se objetiva - em algum grau e de alguma forma - em cada momento do trabalho, realizando neste movimento, ao mesmo tempo, suas conformações históricas e as potencialidades da sua construção no presente em direção ao futuro. Esta potencialidade - seu devir - será, evidentemente, tão mais presente quanto mais já tiver sido objetivado em práticas concretas. Por essa razão, não parece possível encerrar esta fase do estudo sem enfatizar, para além das contribuições presentes na análise dos dados, o importante papel da dimensão organizacional.

O estudo constatou a pequena exploração, por parte das equipes dirigentes, de princípios e mecanismos organizacionais que poderiam contribuir para uma condução gerencial mais sinérgica com as dimensões políticas e tecnológicas e, neste sentido, mais potencialmente efetivas na objetivação da integralidade. 
À guisa de conclusão, salientam-se, pela importância, alguns destes mecanismos:

- o diálogo entre a ética da responsabilidade na prestação dos serviços com a ética fundada em valores mediante processos que tornem públicas as concordâncias e conflitos entre ambos;

- a articulação entre a ação setorial e a intersetorial mediante o planejamento e organização das operações por problemas que minimamente respondam a componentes de ambas as dimensões;

- o fundamento pedagógico da ação exercido pela metodologia da prática/reflexão/ação, mediante processos de aprendizagem que contemplem equipes inter-disciplinares auto-dirigidas e constroem visões compartilhadas;

- o reconhecimento dos trabalhadores de saúde enquanto sujeitos na realização de valores como o da integralidade, mediante a consideração na operação gerencial de dimensões do ser humano esquecidas nas organizações.

A elaboração de um quadro de características que possa configurar um modelo de transformação organizacional referido à mudança do modelo de atenção à saúde na perspectiva da integralidade pode servir de referência para pensar a realidade. A compreensão dos possíveis e dos princípios implicados em sua caracterização não pode ser confundida com a pura prescrição por se revestir de uma base teórica.

Assim como Morin e Kem (2000, p.10) consideram a complexidade, pode-se também considerar a integralidade como "uma palavra problema e não uma palavra solução". Os estudos referidos a esse objeto não se concluem, implicando sempre sua continuidade. 
Capítulo 6

\section{REFERÊNCIAS BIBLIOGRÁFICAS}

ABRASCO. Reforma Sanitária e a Constituinte. Mesa Redonda. Brasília: UnB, 1988. [Coord. Coelho JGL, Diretor do Centro de Acompanhamento da Constituinte da UnB]. (MIMEO).

Almeida C. Saúde e equidade nas reformas contemporâneas. Rev Saúde em Debate 2000 jan/abr; 54: 08-20.

Almeida MJ de. As constituições estaduais e a reforma sanitária. Rev Saúde em Debate 1988 dez; 23: 13-16.

Anais $8^{\text {a }}$ CNS - Anais da $8^{\text {a }}$ Conferência Nacional de Saúde; 1986 mar 17-21; Brasília. Brasil: Ministério da Saúde, 1986.

Anais do 5o Congresso Brasileiro de Saúde Coletiva / 5o Congresso Paulista de Saúde Pública; 1997 ago 25-29; Águas de Lindóia/SP. Rio de Janeiro: Abrasco, 1997.

Ansoff HI, Decclerck RP, Hayes R. Do planejamento estratégico à administração estratégica. $4^{\text {a }}$ ed. São Paulo: Atlas, 1990.

Argyris C, Shon DA. Organization learning: a theory of action perspective. Massachusetts: Addison-Wesley, 1978.

Arouca S. Saúde na Constituinte: a defesa da emenda popular. Rev Saúde em Debate 1988 abr; 20: 39-42. [Apresentado no Plenário da Constituinte, 1987 ago 28; Brasília].

Assis MMA, Pereira MJB, Mishima SM, Villa TC. O processo de gestão nas unidades básicas: limites e possibilidades de um novo agir em saúde. Rev Saúde em Debate 1996 set; 52 (1): 58-66.

Barbosa PR. Gerência de serviços de saúde: competência política ou capacidade administrativa? Rev Saúde em Debate 1988 dez; 23: 79-81.

Berlinguer G. Medicina e política. Rev Saúde em Debate 1988 dez; 23: 62-65. [Conferência proferida durante a 39 ${ }^{\mathrm{a}}$ Reunião Anual da SBPC, 1988 jul 11; São Paulo].

. Entrevista. Rev Saúde em Debate 1988 dez; 23: 66-67. [Concedida durante a Reunião Anual da SBPC; 1988 jul; São Paulo].

As tarefas das unidades locais de saúde (1). Rev Saúde em Debate 1989 jun; 25: 69-79. 
Bertuol C, Campos FCB, Silveira LT. Criança e adolescente: atenção integral e trabalho intaegrado. In: Anais do 5o Congresso Brasileiro de Saúde Coletiva / 5o Congresso Paulista de Saúde Pública; 1997 ago 25-29; Águas de Lindóia/SP. Rio de Janeiro: Abrasco, 1997. (p.138-144).

Bertussi DC, Fekete MC, Petris SM, Lafoz SE. Enfocando o GERUS: elementos para análise. Espaço para a Saúde 1996 set; 5(5): 23-27.

Bertussi DC, Scucato R, Moysés SJ, Petris SM, Martins VL. Implantação do Projeto GERUS na Secretaria Municipal de Saúde de Curitiba - Paraná. Espaço para a Saúde 1996 set; 5(5): 48-56.

Bobbio N. Direita e esquerda: razões e significados de uma distinção política. São Paulo: UNESP, 1995.

Brandão CR, organizador. Pesquisa participante. $5^{\text {a }}$ ed. São Paulo: Brasiliense, 1985.

Brasil. Lei do Sistema Nacional de Saúde, n. 6229. Brasília, 1975.

Constituição da República Federativa do Brasil. Brasília: Gráfica Oficial do Senado Federal, 1988.

Lei Orgânica da Saúde, Lei n. 8080 de 19 de setembro de 1990. [Diário Oficial da União, Brasília, 20 set 1990]. Brasília: Gráfica Oficial do Congresso Nacional, 1990.

Lei Orgânica da Saúde, Lei n. 8142 de 03 de dezembro de 1990. Brasília: Gráfica Oficial do Congresso Nacional, 1990.

Ministério da Saúde. Projeto de Desenvolvimento Gerencial de Unidades Básicas de Saúde do Distrito Sanitário (Projeto GERUS). Brasília: Ministério da Saúde, 1995.

Bueno WS. Betim: Construindo um gestor único pleno. In: Merhy EE e Onocko R. Agir em saúde: um desafio para o público. São Paulo: Hucitec, 1997. (p.169198).

Campos E. Sociologia da burocracia. Rio de Janeiro: Zahar, 1978.

Campos FCB, Henriques CMP. Contra a maré à beira-mar: a experiência do SUS em Santos. $2^{a}$ ed. São Paulo: Hucitec, 1997.

Campos FE de, Girardi SN. Nota sobre a proposta de co-gestão entre os hospitais universitários e as secretarias estaduais de saúde. Rev Saúde em Debate 1989 jun, 25: 09-15.

Campos GW de S. Tréplica - O debate necessário à construção de uma teoria sobre a Reforma Sanitária. Rev Saúde em Debate 1988 dez; 23: 07-12. 
. A política de financiamento e de gestão do SUDS - considerações para debate. Rev Saúde em Debate 1989 jun; 25: 25-27.

. Resenha de: Silva, SF da. A construção do SUS a partir do município. [São Paulo: Hucitec, 1996]. Rev Saúde em Debate 1996; 51: 98.

. Considerações sobre a arte e a ciência da mudança: revolução das coisas e reforma das pessoas - o caso da saúde. In: Cecilio LC de O, organizador. Inventando a mudança na saúde. $2^{\text {a }}$ ed. São Paulo: Hucitec, 1997. (p.29-87).

. Subjetividade e administração de pessoal: considerações sobre modos de gerenciar trabalho em equipes de saúde. In: Merhy EE e Onocko R. Agir em saúde: um desafio para o público. São Paulo: Hucitec, 1997. (p.229-266).

Canguilhem G. O normal e o patológico. $5^{\mathrm{a}} \mathrm{ed}$. Rio de Janeiro: Forense Universitária, 2000.

Capra F. O ponto de mutação: a ciência, a sociedade e a cultura emergente. $10^{\mathrm{a}}$ ed. São Paulo: Cultrix, 1995.

Carlson RH. Revitalización de los esfuerzos federales y estatales para promover sistemas de atención primaria basados en la comunidad. Bol Oficina Sanit Panam 1990 Noviembre/Diciembre; 5-6 (n ${ }^{\circ}$ esp): 552-555.

Castanheira E, Sader N, coordenação. Formação de recursos humanos e organização do trabalho assistencial (Oficina de Trabalho). In: Anais do $5^{\circ}$ Congresso Brasileiro de Saúde Coletiva / $5^{\circ}$ Congresso Paulista de Saúde Pública; 1997 ago 25-29; Águas de Lindóia/SP. Rio de Janeiro: Abrasco, 1997. (p.249-v).

Castellanos P. Proyecto: Sistemas de vigilancia de las desigualdades en situación de salud y condiciones de vida. Washington DC; OPS - Organização Panamericana da Saúde, 1993 (Documento de Trabajo).

Castoriadis C. As encruzilhadas do labirinto. v.1.Rio de Janeiro: Paz e Terra, 1987.

CEBES. Assistência à saúde numa sociedade democrática. Rev Saúde em Debate 1985 jul (2a ed); 17: 8-11. [Documento apresentado no V Simpósio Nacional de Saúde da Câmara dos Deputados. Brasília, Outubro de 1984].

. Editorial. Rev Saúde em Debate 1988 abr; 20: 05.

Plataformas de saúde: confira seus candidatos. Rev Saúde em Debate 1989 set; 26: 07-26.

. Editorial. Rev Saúde em Debate 1996 jun; 51: 03. 
Cecilio LC de O, organizador. Inventando a mudança na saúde. $2^{\mathrm{a}}$ ed. São Paulo: Hucitec, 1997.

. Uma sistematização e discussão de tecnologia leve de planejamento estratégico aplicada ao setor governamental. In: Merhy EE, Onocko R. Agir em saúde: um desafio para o público. São Paulo: Hucitec, 1997a. (p.161-168).

O desafio de qualificar o atendimento prestado pelos hospitais públicos. In: Merhy EE, Onocko R. Agir em saúde: um desafio para o público. São Paulo: Hucitec, 1997b. (p.293-320).

Indicadores de avaliação de desempenho: um instrumento estratégico para a administração gerencial dos hospitais públicos. In: Merhy EE, Onocko R. Agir em saúde: um desafio para o público. São Paulo: Hucitec, 1997c. (p.373$385)$.

Chanlat JF, coordenador. $O$ indivíduo na organização: dimensões esquecidas. $3^{\mathrm{a}} \mathrm{ed}$. v. I e II. São Paulo: Atlas, 1996.

CONASS - Conselho Nacional de Secretários de Saúde. A questão da saúde no Brasil e diretrizes de um programa para um governo democrático. Rev Saúde em Debate 1985 jul ( $\left.2^{\mathrm{a} e d}\right) ; 17: 22$. [Documento aprovado durante a XVIII reunião do CONASS - Belo Horizonte 1984 out 15-17].

Contandriopoulos AP. Reformar o sistema de saúde: uma utopia para sair de um status quo inaceitável. Rev Saúde em Debate 1995 dez - 1996 jan; 49-50: 53-64.

Cordoni Jr L., Martins VL. Uma visão do papel dos Núcleos de Estudos em Saúde Coletiva. Rev Saúde em Debate 1989 set; 26:58-59. [reedição revisada da publicação anterior: Cordoni Jr. L, Martins VL. Uma visão do papel dos núcleos de estudos em saúde coletiva. Rev Saúde em Debate 1989 jun; 25: 57-59].

Corneta VK, Maia C da CA, Costa W da GA. A reorganização dos serviços de saúde no Sistema Único de Saúde e a formação de recursos humanos. Rev Saúde em Debate 1996 jun; 51: 44-49.

Costa AM, coordenação. Políticas de saúde, equidade e gênero: atualizando a agenda (Oficina de Trabalho). In: Anais do $5^{\mathbf{0}}$ Congresso Brasileiro de Saúde Coletiva / $5^{\circ}$ Congresso Paulista de Saúde Pública; 1997 ago 25-29; Águas de Lindóia/SP. Rio de Janeiro: Abrasco, 1997. (p.223-230). 
Costa Filho DC. Sempre vale a pena ser governo? In: Campos FCB, Henriques CMP. Contra a maré à beira-mar: a experiência do SUS em Santos. $2^{\mathrm{a}}$ ed. São Paulo: Hucitec, 1997. (p.17-20).

Costa Filho DC, Pimenta AL, Henriques CMP. O SUS que dá certo. In: Campos FCB, Henriques CMP. Contra a maré à beira-mar: a experiência do SUS em Santos. $2^{\mathrm{a}}$ ed. São Paulo: Hucitec, 1997. (p.21-24).

Cunha OCN da. Política de saúde para o Xingu. Rev Saúde em Debate 1988; edição especial: $45-47$.

Dejours C. A loucura do trabalho: estudo de psicopatologia do trabalho. $5^{\mathrm{a}}$ ed. São Paulo: Cortez-Oboré 1992.

Dever GEA. A epidemiologia na administração dos serviços de saúde. São Paulo: Pioneira, 1988.

Donnangelo MCF, Pereira L. Saúde e sociedade. São Paulo: Duas Cidades, 1976.

Eco U. Como se faz uma tese. $2^{\text {a }}$ ed. São Paulo: Perspectiva, 1985.

Felipe JS. MPAS - o vilão da reforma sanitária? Rev Saúde em Debate 1988 abr; 20: 65-73.

Freire EP, Ghanem E. A gestão municipal e os servidores. In: Campos FCB, Henriques CMP. Contra a maré à beira-mar: a experiência do SUS em Santos. $2^{\mathrm{a}}$ ed. São Paulo: Hucitec, 1997. (p.41-66).

Freire P. Educação e Mudança. Rio de Janeiro: Paz e Terra, 1992.

Frenk MJ. La nueva salud pública. In: OPS - Organização Pan-Americana da Saúde. La crisis de la salud publica: reflexiones para el debate. Washington DC; 1992. (Publicación Científica).

Gadelha PE, Martins R. A política nacional de saúde e a $8^{\text {a }}$ CNS. Rev Saúde em Debate 1988 abr; 20: 79-83.

Garrafa V e Rodriguez Neto E. Editorial: Deixem os municípios trabalharem. Rev Saúde em Debate 1995 dez - 1996 jan; 49-50: 3-4.

Gianini P de T, Manfredini M. Uma nova agenda para a saúde. In: Campos FCB, Henriques CMP. Contra a maré à beira-mar: a experiência do SUS em Santos. $2^{a}$ ed. São Paulo: Hucitec, 1997. (p.107-111).

Giovanella L, Drummont J, Skaba MMF, Oliveira RG de, Sá VM de. Equidade em saúde no Brasil. Rev Saúde em Debate 1995 dez - 1996 jan; 49-50: 13-22. 
Godoy AS. Pesquisa qualitativa: tipos fundamentais. Rev Adm Empresas 1995 mai/jun; 35(3): 20-29.

Gomes R. A análise de dados em pesquisa qualitativa. In: Minayo MC de S, organizadora. Pesquisa social: teoria, método e criatividade. Petrópolis: Vozes, 1994. (p.67-79).

Goulart FA de A. A organização dos serviços no sistema unificado e descentralizado SUDS: a visão do município. Rev Saúde em Debate 1988 abr; 20: 61-64.

Heimann LG. Reforma do Estado e reforma setorial no Brasil: novos modelos de gestão. [Coordenação de Oficina de Trabalho organizada pela Rede de Investigação em Sistemas e Serviços de Saúde no Cone Sul.] In: Anais do 5o Congresso Brasileiro de Saúde Coletiva / 5o Congresso Paulista de Saúde Pública; 1997 ago 25-29; Águas de Lindóia/SP. Rio de Janeiro: Abrasco, 1997. (p.273279).

Heller A. Teoría de las necesidades en Marx. 2ª ed. Madrid: Península, 1986.

O quotidiano e a história. Rio de Janeiro: Paz e Terra, 1985.

Henriques CMP. SUS: qual a novidade? In: Campos FCB, Henriques CMP. Contra a maré à beira-mar: a experiência do SUS em Santos. $2^{a}$ ed. São Paulo: Hucitec, 1997. (p.25-28)

III Encontro de Secretários e Departamentos Municipais de Saúde do Estado de São Paulo; 1989 mar 31; Santos. [Relatório Final publicado na Rev Saúde em Debate 1989 jun; 25: 85-87].

Ishikawa K. Controle de qualidade total: à maneira japonesa. Rio de Janeiro: Campus, 1993.

Jorge E. O Partido dos Trabalhadores e a saúde na Constituinte. Rev Saúde em Debate 1988 abr; 20: 49-53.

Kehrig Acosta RT. Contribución para la operacionalización de la Política de Salud del Estado de Santa Catarina (Brasil), à nível del "Departamento Autônomo de Saúde Pública". Santiago, 1983. [Dissertação de Mestrado em Saúde Pública - Escuela de Salud Pública de la Universidad de Chile].

Kehrig RT. Usos da epidemiologia nos serviços de saúde. Trabalho apresentado no Concurso para Professor Assistente da UFSC, Florianópolis, maio/1993.

Epidemiologia em serviços de saúde. Florianópolis; 1994. [Texto básico do I módulo do Curso Regionalizado de Aperfeiçoamento em Epidemiologia a nível de Planejamento Municipal e/ou Microrregional - Projeto de Capacitação em Epidemiologia - Diretoria de Vigilância Epidemiológica da Secretaria de Estado da Saúde de Santa Catarina]. 
Klein DA. Gestão estratégica do capital intelectual. Rio de Janeiro: Qualitymark, 1998.

Krenak A, Oliveira AG de, Costa AM, Ferreira MJC de MP, Pinto NR da S, Serra O. Encontro aponta soluções para proteção da saúde do índio. [Conclusões nda Conferência Nacional de Proteção à Saúde do Índio; 1986 nov 29; Brasília.] Rev Saúde em Debate 1988 dez; edição especial: 59-64.

Labra ME. Chile: A contra-reforma sanitária do regime autoritário. Rev Saúde em Debate 1988 dez; 23: 19-24.

Lafoz SE. Editorial. Espaço para a Saúde 1996 set; 5(5): 2.

Laurell AC, organizadora. Estado e políticas sociais no neoliberalismo. São Paulo: Cortez, 1995.

Laurell AC. La globalizacióm y las políticas de salud. In: Anais do 5o Congresso Brasileiro de Saúde Coletiva / 5o Congresso Paulista de Saúde Pública; 1997 ago 25-29; Águas de Lindóia/SP. Rio de Janeiro: Abrasco, 1997. (p.25-41).

L'Abbate S. Comunicação e educação: uma prática de saúde. In: Merhy EE, Onocko R. Agir em Saúde: um desafio para o público. São Paulo: Hucitec, 1997. (p.267292).

Leavell HR, Clark EG. Medicina preventiva. Rio de Janeiro: McGraw-Hill, 1976.

Lefèvre F, Lefèvre AMC, Teixeira JJV. O discurso do sujeito coletivo: uma nova abordagem metodológica em pesquisa qualitativa. Caxias do Sul: EDUC, 2000 .

Lucas Coelho JG, coordenador. Reforma Sanitária: estratégias políticas para a Constituinte. [Mesa Redonda realizada dia 22 de setembro de 1987 em Brasília]. Rev Saúde em Debate 1988 abr; 20: 18-31.

Mantilla FL. Las organizaciones no gubernamentales y los sistemas locales de salud. Bol Oficina Sanit Panam 1990 Noviembre/Diciembre; 109(5-6) (n ${ }^{\text {o }} \mathrm{esp}$ ): 512520.

Mantilla FL, Sangueza ER de. Experiencia de un sistema local de salud en Santa Cruz, Bolivia. Bol Oficina Sanit Panam 1990 Noviembre/Diciembre; 109(5-6) (n ${ }^{\circ}$ esp): p.521-528.

MARE - Ministério da Administração e Reforma de Estado. Plano diretor de reforma do aparelho de Estado. Brasília: MARE, 1995.

Martins CL, Oliveira LS de S, Rodrigues MA, Watanabe HAW, Jacomo YA. Agentes Comunitários nos Serviços de Saúde Pública: elementos para uma discussão. Rev Saúde em Debate 1996; 51: 38-43. 
Matus C. Política, planificação e governo. V.1 e 2. Brasília: IPEA, 1993.

Mendes EV, organizador. Distrito sanitário: o processo social de mudança das práticas de saúde. São Paulo: Hucitec/Abrasco, 1993.

Mendes EV. A construção social da vigilância à saúde no distrito sanitário. In: OPS Organização Panamericana da Saúde. A vigilância à saúde no distrito sanitário. Série Desenvolvimento de Serviços de Saúde n.10. Brasília; 1993a: 7-20. [Representação OPS do Brasil].

Uma agenda para a saúde. São Paulo: Hucitec/Abrasco, 1996.

Mendes-Gonçalves RB, Schraiber LB, Nemes MIB. Seis teses sobre ação programática em saúde. In: Schraiber LB. et alli. Programação em saúde hoje. $2^{a}$ ed. São Paulo: Hucitec, 1993. (p.37-64).

Mendes-Gonçalves RB. Processo de Trabalho em Saúde. Cadernos CEFOR 1992; 2. [Secretaria Municipal de Saúde de São Paulo].

Tecnologia e organização social das práticas de saúde: características tecnológicas do processo de trabalho na rede estadual de centros de saúde de São Paulo. São Paulo: Hucitec/Abrasco, 1994.

Menegasso MS. "O conceito de empregabilidade aplicado em organizações bancárias”. [Título aproximado] Florianópolis/SC, 1998. [Tese de Doutorado em Engenharia da Produção e Sistemas - Universidade Federal de Santa Catarina].

Merhy EE. Planejamento como tecnologia de gestão: tendências e debates do planejamento em saúde. In: Gallo E, organizador. Razão e planejamento: reflexão sobre política, estratégia e liberdade. São Paulo/Rio de Janeiro: Hucitec/Abrasco, 1995.

Em busca do tempo perdido: a micropolítica do trabalho vivo em saúde. In: Merhy EE, Onocko R. Agir em saúde: um desafio para o público. São Paulo: Hucitec, 1997a. (p.71-112).

A rede básica como uma construção da saúde pública e seus dilemas. In: Merhy EE, Onocko R. Agir em saúde: um desafio para o público. São Paulo: Hucitec, 1997b. (p.197-228).

Em busca da qualidade dos serviços de saúde: os serviços de porta aberta para a saúde e o modelo tecno-assistencial em defesa da vida (ou como aproveitar os ruídos do cotidiano dos serviços de saúde e colegiadamente reorganizar o processo de trabalho na busca da qualidade das ações de saúde. In: Cecilio LC de $\mathrm{O}$, organizador. Inventando a mudança na saúde. $2^{\mathrm{a}}$ ed. São Paulo: Hucitec, 1997c. (p.117-160). 
Merhy EE, Chakkkour $\mathrm{M}$ e outros. Em busca de ferramentas analisadoras das tecnologias em saúde: a informação e o dia a dia de um serviço, interrogando e gerindo o trabalho em saúde. In: Merhy EE, Onocko R. Agir em saúde: um desafio para o público. São Paulo: Hucitec, 1997. (p.113-160).

Merhy EE, Onocko R. Agir em saúde: um desafio para o público. São Paulo: Hucitec, 1997.

Merrian SB. Qualitative research and case study applications in education. San Francisco: Jossey-Bass Publishers, 1998.

Minayo MC de S, organizadora. Pesquisa social: teoria, método e criatividade. Petrópolis/RJ: Vozes, 1994.

Minayo MC de S. Interdisciplinariedade ou utopia? Saúde e Sociedade; 1994a; 3(2): 42-64.

O desafio do conhecimento: pesquisa qualitativa em saúde, $4^{\mathrm{a}}$ ed. São Paulo-Rio de Janeiro: Hucitec, 1996.

Mintzberg H. Strategy - making in three modes. California Management Review, Winter 1973; XVI (2).

A criação artesanal da estratégia. In: Porter ME, Montgomery CA. Estratégia: a busca da vantagem competitiva. Rio de Janeiro: Campus, 1998.

Mintzberg H, Waters JA. Of strategies, deliberate and emergen strategic. Management Journal 1985; 6: 257-272.

Mintzberg H, Ahlstrand B, Lampel J. Safári de estratégia: um roteiro pela selva do planejamento estratégico. Porto Alegre: Bookman, 2000.

Morgan G. Imagens da organização. São Paulo: Atlas, 1996.

Morin E, Kern AB. Terra-Pátria. Porto Alegre: Sulina, 2000.

Motta PR. Transformação organizacional. Rio de Janeiro: Qualitymark, 1997.

Nemes MIB. Avaliação do trabalho programático na atenção primária à saúde. São Paulo, 1995. [Tese de Doutorado em Medicina Preventiva - Faculdade de Medicina da USP].

NESCOM - Núcleo de Pesquisa em Saúde Coletiva e Nutrição da UFMG. Apoio Acadêmico à Reforma Sanitária. Rev Saúde em Debate 1988 dez; 23: 40-41.

Nicz LF. Pesquisa em serviço e implantação do SUDS. Rev Saúde em Debate 1989 set; 26: 54-55. 
NOB - Norma Operacional Básica do Sistema Único de Saúde. Ministério da Saúde. Brasília 1996; 1.

Nogueira RP. Metáforas da qualidade. Rev Saúde em Debate 1995; 47: 36-40.

Novaes RL. Sobre a Homeopatia. Rev Saúde em Debate 1988 dez; 23: 85-94.

Noronha JC, Pereira TR, Levcovitz E. Estratégias para a construção de sistemas locais de saúde no Estado do Rio de Janeiro, Brasil. Bol Oficina Sanit Panam 1990 Noviembre/Diciembre; 109(5-6) ( $\left.{ }^{\circ}{ }^{\mathrm{e}} \mathrm{esp}\right):$ 529-534.

Noronha R. Prevenção da cegueira no Brasil: uma contribuição à sua história. Rev Saúde em Debate 1996 jun; 51: 89-97.

Nunes ED. Saúde coletiva: história de uma idéia e de um conceito. Saúde e Sociedade 1994; 3(2): 5-21.

Nunes EO, organizador. A aventura sociológica: objetividade, paixão, improviso e método na pesquisa social. Rio de Janeiro: Zahar, 1978.

Oliveira R da C. Assistência hospitalar pública em Betim: mais um passo em defesa da vida. In: Merhy EE, Onocko R. Agir em saúde: um desafio para o público. São Paulo: Hucitec, 1997. (p.339-352).

Onocko R, Amaral M. Cândido Ferreira: experimentando uma mudança institucional. In: Merhy EE, Onocko R. Agir em saúde: um desafio para o público. São Paulo: Hucitec, 1997. (p.353-372).

OPS - Organização Pan-Americana da Saúde. Sistemas Locales de Salud (SILOS). Washington DC, Bol Oficina Sanit Panam 1990 Noviembre/Diciembre; 109(56) ( ${ }^{\circ}$ esp).

. SILOS - Sistemas Locales de Salud: conceptos, métodos, experiências. Washington DC; 1990a. (OPS/OMS, Publicación Científica, 519).

La crisis de la salud publica: reflexiones para el debate. Washington DC; 1992. (OPS/OMS, Publicación Científica).

Promoción de la salud: una antologia. Washington DC; 1996. (OPS, Publicación Científica, 557).

Ortiga AMB. Efeitos da municipalização no acesso e na integralidade dos serviços de saúde, Blumenau/SC. Florianópolis; 1999. [Dissertação de Mestrado em Saúde Pública na UFSC].

Paim JS. A democratização da Saúde e o SUDS: o caso da Bahia. Rev Saúde em Debate 1988 jun; 21:39-44. 
Palma E, Rufián D. La deconcentración administrativa y las prestaciones sociales. Bol Oficina Sanit Panam 1990 Noviembre/Diciembre; 109(5-6) ( ${ }^{\circ}$ esp): 449-461.

Paganini JM, Chorny AH. SILOS: Presentación del Número Especial. Bol Oficina Sanit Panam 1990 Noviembre/Diciembre; 109(5-6) (n $\left.{ }^{\circ} \mathrm{esp}\right)$ : 421-423.

Paganini JM, Chorny AH. Los sistemas locales de salud: desafios para la década de los 90. Bol Oficina Sanit Panam 1990 Noviembre/Diciembre; 109(5-6) (n ${ }^{\circ}$ esp): 424-448.

Patton M. Qualitative evaluation methods. Beverly Hills: Sage Publ, 1986.

Pedrosa JI dos S. Dilemas e perspectivas do SUS no Estado do Piauí: uma conversa com conselheiros. Rev Saúde em Debate 1995 dez - 1996 jan; 49-50: 28-32.

Pettigrew AM et.al. Shaping strategic change. London: Sage, 1992.

Pinchot G, Pinchot E. O poder das pessoas. Rio de Janeiro: Campus, 1995.

Pupo Filho R do A. Uma breve história do controle social do Sistema Único de Saúde em Santos e dos seis anos de Conselho Municipal de Saúde. In: Campos FCB, Henriques CMP. Contra a maré à beira-mar: a experiência do SUS em Santos. $2^{\mathrm{a}}$ ed. São Paulo: Hucitec, 1997. (p.88-99).

Quivy R, Campenhoudt LV. Manual de investigação em ciências sociais. Lisboa: Gradiva, 1992.

Ramos AG. Modelos de homem e teoria administrativa. Rev Adm Pública, Rio de Janeiro 1984 abr/jun; 18(2):3-12.

A nova ciência das organizações: uma reconceitualização da riqueza das nações. $2^{\mathrm{a}}$ ed. Rio de Janeiro: FGV, 1989.

Rodriguez Neto E. Subsídios para definição de uma política de atenção à saúde para um governo de transição democrática. Saúde em Debate 1985 jul (2ªed); 17:12-17.

. Reunião da ABRASCO em Cachoeira, Bahia, 1987. Rev Saúde em Debate 1988 abr; 20: 33-38.

A Saúde na nova Constituição: uma avaliação. Rev Saúde em Debate 1988 jun; 21: 34-35.

SUS: quem são os verdadeiros vilões. Rev Saúde em Debate 1995 dez - 1996 jan; 49-50: 11-12.

Rollo A, Oliveira RC. É possível construir novas práticas assistenciais no hospital público? In: Merhy EE, Onocko R. Agir em Saúde: um desafio para o público. São Paulo: Hucitec, 1997. (p.321-352). 
Rosas EJ. Alguns comentários sobre a nova proposta de saúde em Cuba. Rev Saúde em Debate $1988 \mathrm{dez} ; 23: 85-94$.

Rosen G. Una história da saúde pública. São Paulo/Rio de Janeiro: Hucitec/Abrasco, 1994.

Sá EM de C, Simioni AMC, Ramos CRS, Costa MGTO, Silva ZP da. Êxodo forçado: efeitos do PAS. In: Anais do $5^{\circ}$ Congresso Brasileiro de Saúde Coletiva $/ 5^{\circ}$ Congresso Paulista de Saúde Pública; 1997 ago 25-29; Águas de Lindóia/SP. Rio de Janeiro: Abrasco, 1997.

Samaja J. Epistemologia y metodologia: elementos para uma teoria de la investigación científica. Edición ampliada. Buenos Aires: Editorial Universitaria, 1993.

Scalco E. Sistema Único de Saúde: compromisso a saldar. Rev Saúde em Debate 1988 abr; 20: 47-48.

Schcraiber LB et alli. Programação em saúde hoje. São Paulo: Hucitec, 1993.

Schraiber LB. Políticas públicas e planejamento nas práticas de saúde. Rev Saúde em Debate 1995; 47:28-35.

Integralidade: possibilidade ou utopia na construção dos model;os assistenciais no SUS. In: Costa AM (coordenação da Oficina - Políticas de saúde, equidade e gênero). Anais do 5o Congresso Brasileiro de Saúde Coletiva / 5o Congresso Paulista de Saúde Pública; 1997 ago 25-29; Águas de Lindóia/SP. Rio de Janeiro: Abrasco, 1997. (p.223-229).

Schraiber LB, Nemes MIB, Mendes-Gonçalves RB. Saúde do Adulto: programas e ações na Unidade Básica. São Paulo: Hucitec, 1996.

Schraiber LB et alli. Planejamento, gestão e avaliação em saúde: identificando problemas. Ciência \& Saúde Coletiva 1999; 4(2).

Schramm FR. Equidade na alocação de recursos e vigência da cultura dos limites: um dilema moral para a saúde pública. - Palestra. In: Anais do 5o Congresso Brasileiro de Saúde Coletiva / 5o Congresso Paulista de Saúde Pública; 1997 ago 25-29; Águas de Lindóia/SP. Rio de Janeiro: Abrasco, 1997. (p.45-58).

Schramm FR e Schramm JM de A . Vigilância e qualidade em saúde: uma questão de bioética em epidemiologia. Rev Saúde em Debate 47; 1995;47:50-56.

SEMUS - Secretaria Municipal de Saúde de Blumenau. Plano Municipal de Saúde 1997-2000. Blumenau/SC,1997. 
Senge PM. A quinta disciplina: arte e prática da organização que aprende. $6^{\mathrm{a}}$ ed. São Paulo: Best Seller - Círculo do Livro, 2000.

Seravalle L, BOOG MCF. Introdução à discussão sobre o ensino de práticas alternativas em saúde. Rev Saúde em Debate 1996; 51: 82-88.

Shon DA. Beyond the stable state. New York: The Norton Library, 1971.

Silva GGA da, Egydio MVRM, Souza MC de. Algumas considerações sobre o controle social no SUS: usuários ou consumidores. Rev Saúde em Debate 1999 set/dez; 53: $37-42$.

Silva Jr AG da. Modelos tecnoassistenciais em saúde: o debate no campo da saúde coletiva. São Paulo: Hucitec, 1998.

Silveira LT. Integralidade na saúde. São Paulo 1996. (MIMEO - circulação restrita).

Solla JJSP, Medina MGE, Dantas MBP. O PACS na Bahia: avaliação do trabalho dos agentes comunitários de saúde. Rev Saúde em Debate 1996; 51:04-15.

Tarride MI. La complejidad en salud. Rio de Janeiro, 1995. [Tese de Doutorado em Saúde Pública - Escola Nacional de Saúde Pública, FIOCRUZ].

FIOCRUZ, 1998.

Tealdi JC. Silos y bioética: racionalidade moral de las decisiones comunitaria. Bol Oficina Sanit Panam 1990 Noviembre/Diciembre; 109(5-6) (n ${ }^{\circ}$ esp): 462-473.

Teixeira SMF. Política de saúde na transição conservadora. Rev Saúde em Debate 1989 set; 26: 42-53.

Teixeira CF, Melo C. (orgs). Construindo distritos sanitários: a experiência da cooperação italiana no município de São Paulo. São Paulo/Salvador: Hucitec/Cooperação Italiana em Saúde, 1995.

Testa M. Pensamento estratégico e lógica de programação: o caso da saúde. São Paulo: Hucitec/Abrasco, 1995.

Análisis de instituciones hipercomplejas. In: Merhy EE, Onocko R. Agir em saúde: um desafio para o público. São Paulo: Hucitec, 1997. (p.17-70).

Terris M. Conceptos sobre promoción de la salud: dualidades en la teoria de la salud pública. OPS, Programa Promoción de la Salud, 1994.

Unglert C. Territorialização em saúde. In: Mendes EV, organizador. Distrito sanitário: o processo social de mudança das práticas de saúde. São Paulo: Hucitec/Abrasco, 1993. 
Uribe FJU. Agir comunicativo e planejamento social: uma crítica ao enfoque estratégico. Rio de Janeiro: FIOCRUZ, 1995.

Valente FLS. Repensando a área dentro da perspectiva da Conferência Nacional de Alimentação e Nutrição. Rev Saúde em Debate 1988 dez; 23: 50-57.

Vasconcelos EM. A medicina e o pobre. (Resenha) Rev Saúde em Debate 1989 jun; 25: 81.

O taylorismo e a construção da medicina das classes populares. Rev Saúde em Debate 25; Junho1989a, 25: 47-55.

A priorização da família nas políticas de saúde. Rev Saúde em Debate 1999 set/dez; 53: 06-19.

Vasconcelos MM. Epidemiologia e planejamento: a perspectiva do planejamento. Rev Saúde em Debate 1988 dez; 23:71-78.

Westphal MF, coordenação (Oficina de Trabalho). Cidades/Municípios Saudáveis. In: Anais do 5o Congresso Brasileiro de Saúde Coletiva / 5o Congresso Paulista de Saúde Pública; 1997 ago 25-29; Águas de Lindóia/SP. Rio de Janeiro: Abrasco, 1997. (p.257-64). 